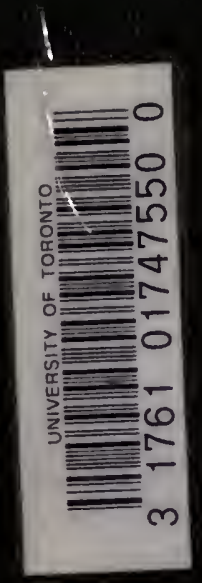

$$
\begin{gathered}
\text { THE } \\
\text { INSECT BOOK } \\
\text { LELAND O. HOWARD }
\end{gathered}
$$






Digitized by the Internet Archive in 2007 with funding from Microsoft Corporation 
THE INSECT BOOK 




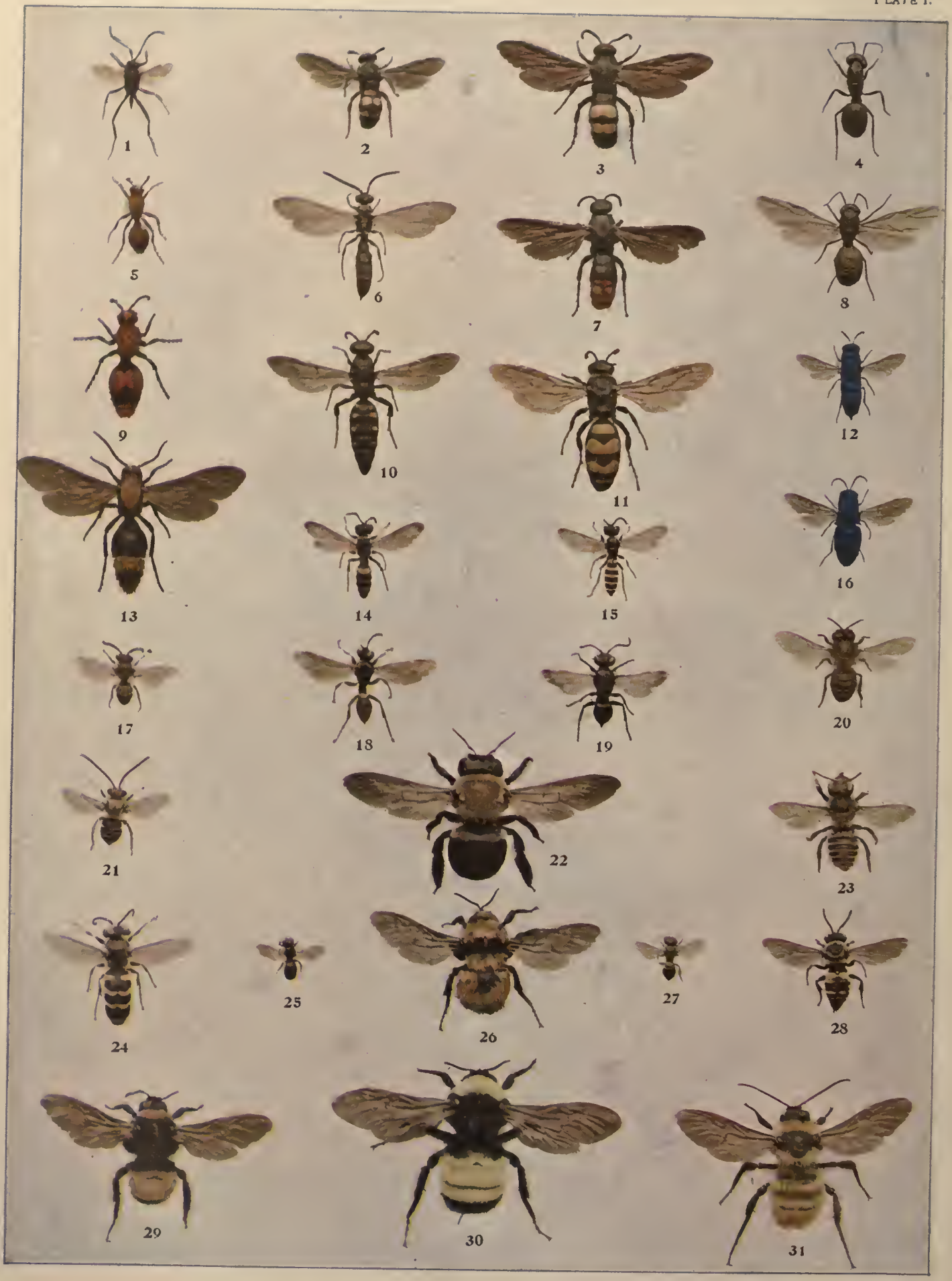




\section{THE INSICOT 1 BOOH A POPULAR ACGO \\ WABPS, ANTS. \\ AND OTHER \\ INSECTG LXCLUSINP WF THE

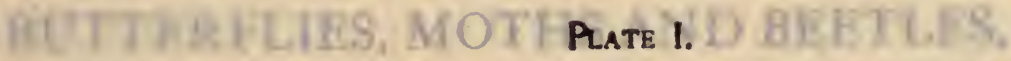 1.11 WWI. LIFF BEES AND ANTS}

FIG.

1. Evania appendigaster

2. Discolia nobilitata

3. Discolia bicincta

4. Camponotus pennsylvanicus

5. Sphærophthalma ferruginea

6. Myzine sexcincta $\delta$

7. Discolia dubia

8. Camponotus pennsylvanicus

9. Sphærophthalma occidentalis ?

10. Myzine sexcincta $q$

11. Dielis plumipes

12. Chrysis parvula

13. Sphærophthalma occidentalis of

14. Cerceris clypeatus

15. Cerceris nigrescens
FIG.

16. Chrysis smaragdula

17. Colletes hyalinata

18. Pseudoplisus phaleratus

19. Astatus sayi

20. Apis mellifica

21. Melissodes urine

22. Xylocopa virginica

23. Megachile latimanus

24. Bembex spinolæ

25. Ceratina dupla

26. Bombus ternarius

27. Halictus navipes

28. Epeolus remigatus

29. Bombus pennsylvanicus

30. Bombus americana 9

31. Bombus americana $\delta$ 


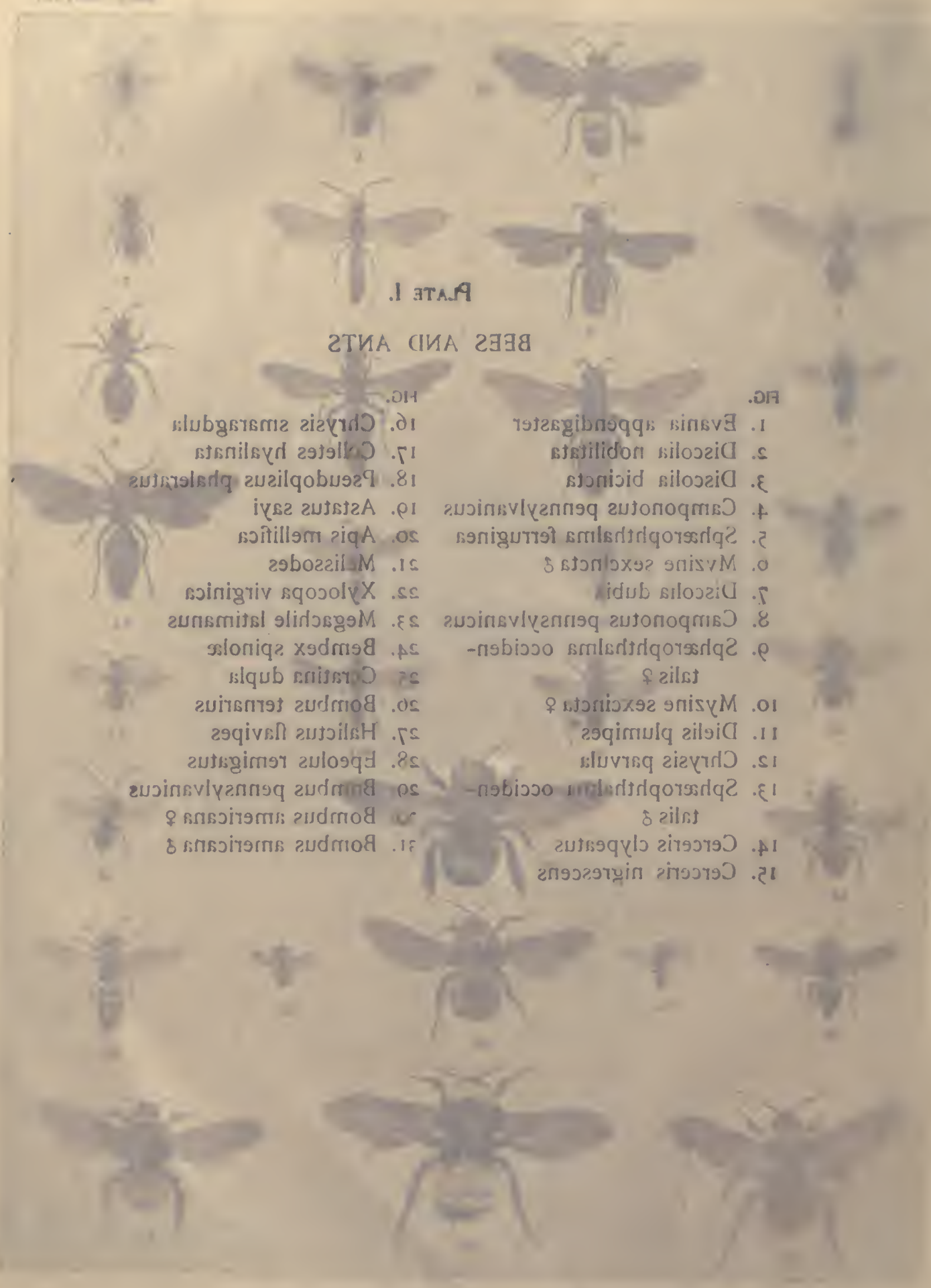




\section{THE INSECT BOOK}

A POPULAR ACCOUNT OF THE BEES, WASPS, ANTS, GRASSHOPPERS, FLIES AND OTHER NORTH AMERICAN INSECTS EXCLUSIVE OF THE BUTTERFLIES, MOTHS AND BEETLES, WITH FULL LIFE HISTORIES, TABLES AND BIBLIOGRAPHIES

LELAND O. HOWARD, PH. D.

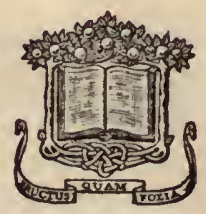

GARden City New York DOUBLEDAY, PAGE \& COMPANY I9I6.

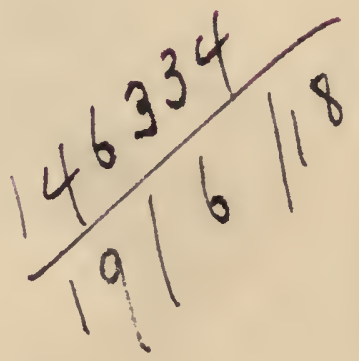





\section{INTRODUCTION.}

Persons who love nature are apt to be long-lived and their lives are apt to be happy ones. In this country until quite recently few people have realized this fact, and while notably with the Germans, and to a lesser extent with other European nations, we find a love of nature fostered through early childhood, and while there are people of all countries and all occupations who know much about the animals and plants which surround them, and many who make collections and study certain groups as a fad or pastime and as a relief from the daily drudgery of life, in the United States little attention has been paid to nature study in the school and in the family until within the past few years. It is true that there have been Americans who were born naturalists and who have pursued their studies in spite of uncongenial surroundings. It is true, too, that almost every country boy is a close observer in his own untrained way, and that he picks up many interesting facts about his natural history environment. But even the youngster of decided tastes has been too often discouraged by his parents, and, further than that, he has few books to help him and stimulate him in the occupation to which his tastes direct him.

Recently, however, a great nature study movement has sprung up amongst us and in this movement the study of insects must play an important part. They are the most easily observed of living creatures. They abound everywhere-in the fields and woods, in the door-yards, and, unfortunately, even in the household. Subjects for observation are never lacking, and although some prejudice exists against them as insignificant crawling creatures and in large part nuisances and pests from a human standpoint, yet their structure is wonderful, their life histories are most interesting, and among them may be found a wealth of material for the study of broad life problems of the utmost biological importance. I know a stock broker, an insurance agent, a commercial traveler, a hotel clerk, a minister of the Gospel, a keeper of a beer saloon, a portrait painter, a hardware merchant, a stonecutter, an iron founder, a carpenter and builder, 


\section{Introduction}

a wholesale wine merchant, a lawyer, a chemist, an undertaker, a librarian, an army officer, a navy officer, and any number of physicians and teachers who take the greatest delight in the study and collection of insects. Heaven will bless the oldfashioned country doctor for his self-sacrificing life and the good he has done to humanity. That will everywhere be granted, but he deserves an additional star in his immortal crown for the fact that he was the original naturalist in this country. Very many of our early workers were country doctors. and it has been through their influence that many naturalists have been made.

The principal aim of this book is to encourage the study of a rather neglected aspect of nature. The groups of insects which it considers are of very great extent. The wealth of material is so great that it has been only with the greatest difficulty that the book has been held within reasonable bounds. We have other books on insects, many of them much better from several points of view than this can hope to be, yet there has been a distinct object in writing this one, and if 1 had not thought that it was needed I should never have written it. One of the main desires in my mind in planning the method of treatment has been to encourage the study of life histories of insects. Where possible a typical life history has been given in each family treated. Some of these are moderately complete as to main facts, while others leave gaps in the life-round of the species. Such gaps can in many instances be easily filled by careful study. In a number of important and interesting groups, however, no typical life history can be given for the simple reason that no one has ever devoted sufficient care and time to the subject. The army of nature workers now springing up should not devote their whole time to the well-trodden paths of long known and clearly ascertained truths when they might just as easily, if they knew just where to look and what to do, study some unknown life-round and learn exact facts which would be contributions to knowledge. Professor L. C. Miall, of England, who has written several most interesting books on insects, has been a leader in this kind of work, but in this country very few perfectly complete life histories have been worked out. Most of these have been done by economic entomologists, and hence nearly all that we know are of insects of economic importance. Very many others, however, of which we are more or less ignorant, offer 
fields of study of fascinating interest and through such study will undoubtedly come discoveries of much biological importance. Most books tell what is known, but here we shall try also to point out what is not known but which, nevertheless, can be more or less easily found out.

Something more is necessary, however, than life history study alone. One must know the relations of the creature he is studying and, moreover, he must know exactly what it is. Therefore synoptic tables of the larger groups have been given, and, in addition to this, full title references have been given to all works and papers which will assist in the determination of exact species in each of the larger groups. In this way an attempt has been made in the first place to foster the study of life histories; in the second place to write in popular style an account of these insects which will interest perhaps those who know little about insects and who wish to find out something about them in the easiest way; and, thirdly, to put those who have an earnest wish to go deeply into the study in possession of information which will enable them to follow their studies much further than this book or any other one book can take them.

The choice of the groups of insects treated in the volume may seem odd, but there are good reasons for it. The majority of collectors of insects confine their attention to butterflies, moths, and beetles. The butterflies and moths are most attractive from several points of view and the beetles are compact, easily preserved and easily collected insects, whose classification is most exact and more available than that of almost any other group. The butterflies of the United States have already been admirably treated in a volume of this series- "The Butterfly Book"-by the eminent naturalist, Dr. W. J. Holland, and the same author is preparing a moth book. The beetles need a book by themselves, and such a volume will eventually be prepared. The insects of the other orders have been more neglected and since nevertheless their study is quite as interesting and perhaps even more so than that of the beetles, butterflies and moths, a special book may well be given to them.

It has been the endeavor of the author and publishers to illustrate the present volume as profusely as possible. The plates are all original, having been photographed from insects either collected especially for the purpose or taken from the collection 
of the United States National Museum. The text figures for the most part are printed from electrotypes made from blocks which are the property of the United States Department of Agriculture, and many of them have illustrated previously published articles by the writer.

A word must be said in regard to the literature references which follow the consideration of most of the groups. Nearly all of the papers mentioned have been published either by Government institutions or by learned societies and scientific periodicals. Very few of them have been published as separate books, but such as have been published in this way, if of comparatively recent date, may be obtained from book dealers. The periodicals and transactions of scientific societies may be obtained through the societies which publish them and through the publishers but in the case of Transactions and Proceedings, single volumes, and more especially single papers, are seldom sold, and the older ones are liable to be out of print. Moreover, the expense of purchasing all of the periodicals containing the publications on the different groups of insects will be so great that few workers can afford it. But there is a custom among writers on these topics of securing a certain number of separate copies of their papers, and these are freely distributed, so that it often happens that a person interested can obtain a copy of a scientific paper by writing to the author. The American Entomological Society, of Philadelphia, has published a little directory containing the names and addresses of those interested in the study of insect life in the United States and Canada, and from this directory the addresses of all living writers on insects in North America can be obtained. Many of these "author's separates" can be purchased from dealers in second-hand books, and the American Entomological Society, of Philadelphia, and a few other societies here and in Europe offer many of these author's extras for sale, and in some cases publish lists. Moreover, there are certain establishments through which the student can buy nearly all of the works and separates which he needs. These are dealers in natural history books and papers, and many of them publish catalogues which are sent free on application. Bulletin 24, new series of the Division of Entomology, United States Department of Agriculture, contains a list of these dealers which publish catalogues, and this bulletin is sent freely to all applicants. viii 
Many systematic papers have been published by the United States Government through the Smithsonian Institution, the National Museum, the Department of Agriculture, and the Geological and Geographical Surveys. Many of these publications are distributed free of cost to applicants, while others are sold at a moderate price to cover the cost of publication. There is a Government institution known as the Office of the Superintendent of Documents, Union Building, Washington, which publishes lists of Government publications and sends them free of charge to applicants. From these lists one can see what has been published and what is still on hand for distribution, and what price must be paid for the available ones. Many of them are out of print, but these can be obtained through dealers in second-hand books. There are two large firms of such dealers in Washington, and these make a specialty of Government publications. They are: W. H. Lowdermilk \& Company, Corcoran Building, and Lewis S. Hayden, 1212 F street, N. W.

The subject. of how to collect and preserve the different kinds of insects mentioned in this book is treated in a separate section at the end of the volume.

The writer owes warm thanks to several of his associates in Washington, all of whom are specialists in certain groups of insects, for advice and suggestions. These are Mr. W. H. Ashmead, the results of whose labors in the Hymenoptera have been so largely used, and who has read the section relating to this important order; Mr. D. W. Coquillett, a well-known writer on Diptera, who has prepared the table of the higher groups of this order which is given in this volume and who has read the manuscript of the Diptera; Mr. O. Heidemann, to whom the writer is indebted for information concerning the Heteroptera, and who has loaned specimens for illustration from his private collection; Mr. Nathan Banks and Mr. Rolla P. Currie, who have helped with advice regarding the portions of the book which relate to the insects of the Neuropteroid series; Mr. F. H. Chittenden, who has loaned for illustration insects from his private collection; Mr. F. C. Pratt, whose excellent work in the resetting of the insects illustrated on the plates and in the arrangement and mounting of the plates, a most difficult and laborious task, will, 1 trust, be appreciated by the reader.

I wish especially to thank Dr. E. P. Felt, State Entomologist 


\section{Introduction}

of New York, for allowing me to examine the manuscript of an admirable report on aquatic insects, prepared by Dr. J. G. Needham, and which will be published in Bulletin 48 of the New York State Museum. 


\section{TABLE OF CONTENTS}

Introduction

List of Plates . . . . . . . . . . . . $\quad$.

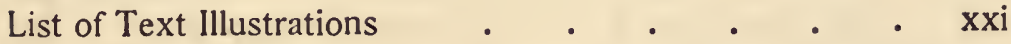

Order Hymenoptera $\quad$. . . . . . .

Table of Suborders and Superfamilies . . . . 2

The True Bees (Superfamily Apoidea) . . . 4

Life History of a Bumble Bee (Bombus fervidus). $\quad 12$

Wasps • • • • • • • • • 18

The Solitary Wasps (Superfamily Sphecoidea) . . . 18

Life History of a Digger Wasp (Sphecius speciosus Say.) • . . . . . 22

The Social Wasps and Their Allies (Superfamily Vespoidea) . . . • . . . 25

Typical Life History . . . . . . 33

Life History of a Parasitic Wasp (Lelius trogodermatis) . . . . . . . 34

The Ants (Superfamily Formicoidea) . . $\quad 37$

Typical Life History . . . . . . 48

The Proctotrypoid Parasites (Superfamily Proctotrypoidea) . . . . . . . . 49

The Gall-Flies (Superfamily Cynipoidea) . . $\quad 53$

The Chalcis Flies (Superfamily Chalcidoidea) . $\quad 56$

Life History of a Chalcis Fly (Euplectrus comstocki How.)

The Ichneumon Flies (Superfamily Ichneumonoidea)

Life History of an Ichneumon Fly (Pimpla inquisitor). . . . . . . . 64

The Horn-Tails (Superfamily Siricoidea) . . $\quad$. 69

Life History of a Horn-Tail (Phylloecus integer). $\quad 71$

The Saw-Flies (Superfamily Tenthredinoidea) . . 73

Life History of the Pear Slug (Eriocampoides limacina) . . . . . $\quad . \quad 76$

The True Flies (Order Diptera) $\quad$ • $\quad$ • $\quad$ • $\quad$. $\quad$ • 79 
Table of the Higher Groups .

The Crane Flies (Family Tipulida). . . . . . 94

Life History of a Crane Fly (Bittacomorpha clavipes) • • . . • • • 95

Families Dixida and Stenoxenida . . . . $\quad$. 97

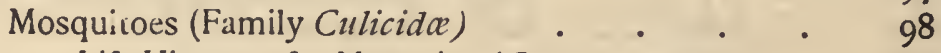

Life History of a Mosquito (Culex pungens) . 104

The Moth Flies (Family Psychodida) . . . 108

The Midges (Family Chironomida) . . . 110

Life History of a Midge (Chironomus minutus) III

The Gall-Gnats (Family Cecidomyiida) . . . II $_{3}$

Life History of a Gall-Gnat (Cecidomyia leguminicola) . . . . . . 115

Fungus Gnats (Family Mycetophilida) . . $\quad 117$

The March Flies (Family Bibionida) . . . 119

The Black Flies and Buffalo Gnats (Family Simuliida) . . . . . . . . . 120

Life History of a Black Fly (Similium pictipes). $\quad$ 121

Families Orphnephilida, Blepharocerida and Rhyphida . . . . . . . . 124

The Snipe Flies (Family Leptida) . . . $\quad$. 126

Soldier Flies (Family Stratiomyiida) • . $\quad 128$

Family Acanthomerida . . . . . . 130

The Gad-Flies or Horse-Flies (Family Tabanida) . 131

Life History of a Gad-Fly (Tabanus atratus) . 132

The Small-Headed Flies and the Tangle-Veined Flies (Families Acrocerida and Nemestrinida). . 134

Families Mydaida and Apiocerida . . . . 136

The Bee-Flies.(Family Bombyliida). . . . 137

Life History of a Bee-Fly (Systoechus oreas) . 138

The Window-Flies and Stiletto Flies (Families Scenopinida and Therevida) . . . . 139

The Robber Flies (Family Asilida). . . . 141

The Dance Flies and the Long-Legged Flies (Families Empidida and Dolichopodida) . . . 144

The Spear-Winged Flies (Family Lonchopterida) . 146

The Hump-Backed Flies (Family Phorida) . . 147

Life History of the Ant-Decapitating Fly (Apocephalus pergandei) . . . . 
The Flat-Footed Flies and the Big-Eyed Flies (Families Platypezidae and Pipunculida) . 149

The Syrphus-Flies (Family Syrphidae) . . . 150

The Thick-Headed Flies (Family Conopida) . . 154

The Bot-Flies (Estrida) . . . . . 155

Life History of a Bot-Fly (Hypoderma lineata) $\quad 155$

The Tachina Flies (Family Tachinida) . . . 158

The Nimble Flies (Family Dexiida) . . . 162

The Flesh Flies (Family Sarcophagida) . . . 163

The House Fly and Its Near Relations (Family Muscida). . . . . . . . 166

Life History of the House Fly (Musca domestica). . . . . . . 167

The Anthomyia Flies (Family Anthomyiida) . . 17!

The Dung Flies (Families Scatophagidae and Heteroneurida) . . . . . . . 173

Families Helomyzida, Phycodromida and Sciomyzida) . . . . . . . . 174

Families Sapromyzida, Lonchceida and Ortalidae . 175

The Fruit and Gall Flies (Family Trypetidae) . $\quad 177$

Families Micropezida, Sepsida, Psilida and Diopsidae.

The Salt Water Flies (Family Ephydrida)

The Grass-Stem Flies (Family Oscinidae) • . 183

The Little Fruit Flies (Family Drosophilida) . $\quad 185$

Families Geomyzida, Agromyzida and Borboridae . $\quad 187$

The Bird-Ticks (Family Hippoboscidae) . . . 188

The Bat-Ticks (Family Nycteribiida) . . . 190

Fleas (Order Siphonaptera) . • • . . . 191

Life History of the Cat and Dog Flea (Pulex serraticeps)

The Caddis-Flies (Order Trichoptera)

Table of Families

$\bullet \quad \bullet \quad \bullet \quad \cdot 197$

Family Phryganeidae . • • • • . 198

Family Limnephilidac • • • • • • 199

Family Rhyacophilida . • • • • • 200

Family Hydroptilida $\quad$ • . . . . . 201

Family Sericostomatida . • • • • • 202

Family Leploceridae . • • • • . 203

Family Hydropsychida ${ }_{\text {xiii }} \cdot$ • • • 204 
The Scorpion Flies (Order Mecoptera) . . . . ${ }^{206}$

Family Panorpidae. . . . . . . 207

Life History of a Scorpion Fly (Panorpa rufescens). • . . . . . 207

The Lace-Winged lnsects (Order Neuroptera) . . 209

Table of Families . . . . . . . . 210

The Dobson and Its Family (Family Sialida). . 211

Life History of the Dobson (Corydalis cornuta) 212

The Snake-Flies (Family Raphidiida) . . . 216

The False Rearhorses (Family Mantispida) . $\quad 217$

The Dusty-Wings (Family Coniopterygida) . . 218

The Ant-Lions (Family Myrmeleonida) . . . 219

The Aphis-Lions (Family Hemerobiida) . . . 221

The Golden-Eyed Lace-Winged Flies (Family Chrysopida) • • • • • • • • 222

Life History of the Golden-Eye (Chrysopa oculata) . . . . . . $\cdot 224$

Plant-Lice, Scale Insects, True Bugs, Etc. (Order Hemiptera)

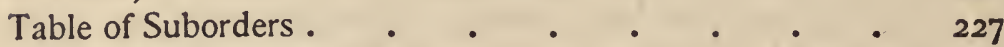

Suborder Homoptera • $\quad$ • $\quad$ • $\quad$ • 228

Table of Families . $\quad$ • $\quad$ • $\quad$ • $\quad$ • $\quad$ • 229

The Harvest Flies or Cicadas (Family Cicadida) . 231

Life History of the Seventeen-Year Locust (Cicada septendecim)

The Lantern Flies and Their Allies (Family Fulgori-

$d a$ ) .

Life History of the Frosted Lightning Hopper (Ormenis pruinosa).

The Tree Hoppers (Family Membracida)

Life History of the Buffalo Tree Hopper (Ceresa bubalus) . . . . . .

The Frog-Hoppers or Spittle Insects (Family Cerco236 237

239 pida)

The Leaf-Hoppers (Family Jassida) . . .

Life History of a Leaf-Hopper (Deltocephalus inimicus)

The White Flies or Aleyrodids (Family Aleyrodida)

Life History of a White Fly (Aleyrodes citri) .

Scale Insects (Family Coccida) 
Life History of the Oyster-Shell Bark-Louse of the Apple (Mytilaspis pomorum) • • 255

The Jumping Plant-Lice or Flea-Lice (Family Psyllida 259

Life History of the Pear Tree Psylla (Psylla pyricola) . . . . . . . 260

Plant-Lice (Family Aphidida) 。 . . . 262

Life History of the Hop Plant-Louse (Phorodon hnmuli) • • • . • . . 265

The True Bugs (Suborder Heteroptera) • • • . 269

Table of Families . $\quad$ • . . . . 270

The Water Boatman (Family Corixida) • • . 273

The Back Swimmers (Family Notonectida) . . 275

The Water Scorpions (Family Nepida) • • $\quad 276$

The Giant Water Bugs (Family Belostomatida) . $\quad 278$

The Creeping Water Bugs (Family Naucorida) . $\quad 280$

The Toad Bugs (Family Galgulida) . . . 28I

The Marsh Treaders (Family Limnobatida) . 282

The Water Striders (Family Hydrometrida) . $\quad 283$

Life History of a Water Strider (Hydrometra lineata) . . . . . . . 285

The Flower Bugs (Family Anthocorida) . . $\quad 287$

The Bed-Bug Family (Family Cimicida) . $\quad 288$

Life History of the Bed-Bug (Cimex lectularius) $\quad 289$

The Shore Bugs (Family Saldida) . . . . 291

The Thin-Winged Bugs (Family Henicophalida) . 292

The Assassin Bugs (Family Reduviida) . • . 293

Life History of the Wheel-Bug (Arilus cristatus) 294

The Ambush Bugs (Family Phymatida) • • . 297

The Flat Bark-Bugs (Family Aradida) . . . 298

The Lace Bugs (Family Tingitida) • • • . 299

Life History of the Hawthorn Lace-Bug (Corythuca arcuata) . . . . . . 300

The Leaf-Bugs (Family Capsida) . • . . 301

Life History of a Leaf-Bug (Pecilocapsus lineatus) • • • • • • 302

The Squash-Bug and Its Allies (Family Coreida) · 304

Life History of the Squash-Bug (Anasa tristis) 305

The Cotton Stainer and Its Allies (Family Pyrrhocorida) 
Life History of the Cotton Stainer (Dysdercus suturellus) . • • • • • . 308

The Stilt Bugs (Family Berytida) . . . . 309

The Chinch Bug Family (Family Lygaida) . • 310

Life History of the Chinch Bug (Blissus leucopterus). • . . . . . . 311

The Stink-Bugs and Their Allies (Family Pentatomida)

Life History of a Stink-Bug (Podisus cyaneiventris) • • • • • • . . 314

The True Lice (Suborder Anoplura) • • • • . 316

Thrips (Order Physopoda) . . . . . . 318

Grasshoppers, Katydids, Crickets, Etc. (Order Orthoptera) .

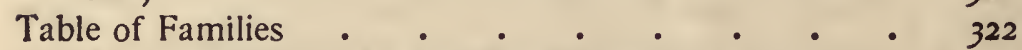

The Walking Sticks (Family Phasmida) . . 323

Life History of a Walking Stick (Diapheromera femorata) . • • • • • • 323

Rear-Horses or Praying Mantids (Family Mantida) 326

Life History of a Rear-Horse (Stagmomantis carolina) . . • . • • . 327

Cockroaches (Family Blattida) . . . . 329

Short-Horned Locusts or True Grasshoppers (Family Acridiida)

Life History of a Grasshopper (Melanoplus atlanis).

Long-Horned Grasshoppers (Family Locustida)

Life History of a Katydid (Microcentrum retinervis) . . . . . . . .

The Crickets (Family Gryllida)

334

336

339

341

Earwigs (Order Euplexoptera) • • • • • • 345

Bird Lice (Order Mallophaga) • • • • • • 347

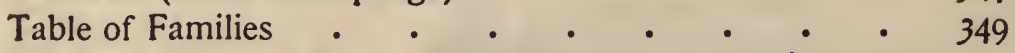

The Book-Lice and Their Allies (Order Corrodentia) - 350

White Ants (Order Isoptera) • • • • • • 353

The Stone Flies (Order Plecoptera) • • • • • 361

Dragon Flies (Order Odonata) • • • • • • 363

Table of Families : $\quad . \quad \cdot \quad \cdot \quad \cdot \quad \cdot \quad \cdot \quad \cdot 369$

Damsel Flies • • • • • • • • 370

Family Calopterygida. • • • • • • 370 
Table of Contents

PAGR

Family Agrionidac . • . • • • 371

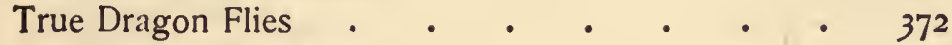

Family Gomphidce . . . . . . . . $\quad$ • 372

Family Cordulegastrida . . . . . . 373

Family Aschnidae . . . . . . • • 374

Family Cordulida . . . . . . . 375

Family Libellulidia . • • . • • 376

May Flies or Shad Flies (Order Ephemerida) • • • 377

Spring-Tails and Fish-Moths (Order Thysanura) • . 380

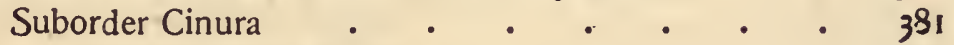

Family Lepismatidae • • • • • • 382

Family Japygidac • • • • • • • $\quad 384$

Family Campodeida . . . . . . . 384

Suborder Collembola • • • • • • • 385

Family Aphoruridae . . . • . . 386

Family Poduridae . • • • . . 386

Family Entomobryidae . • • . . . 387

Family Symnthuridae • • • • • 388

Family Papiriidac . . . . . . 388

Collecting and Preserving Insects . . . . . 389

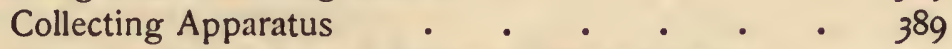

Points on Methods of Collecting Different Orders . 394

Collecting Aquatic Insects . $\quad$ • $\quad$ • . $\quad$ • 395

Rejaring Different kinds of Insects . . . . 396

Killing and Preserving lnsects . . . . . $40 \mathrm{I}$

Preparing Insects for the Cabinet . . . . 401

Bibliography • • • • • • • • • 405 



\section{LIST OF PLATES}

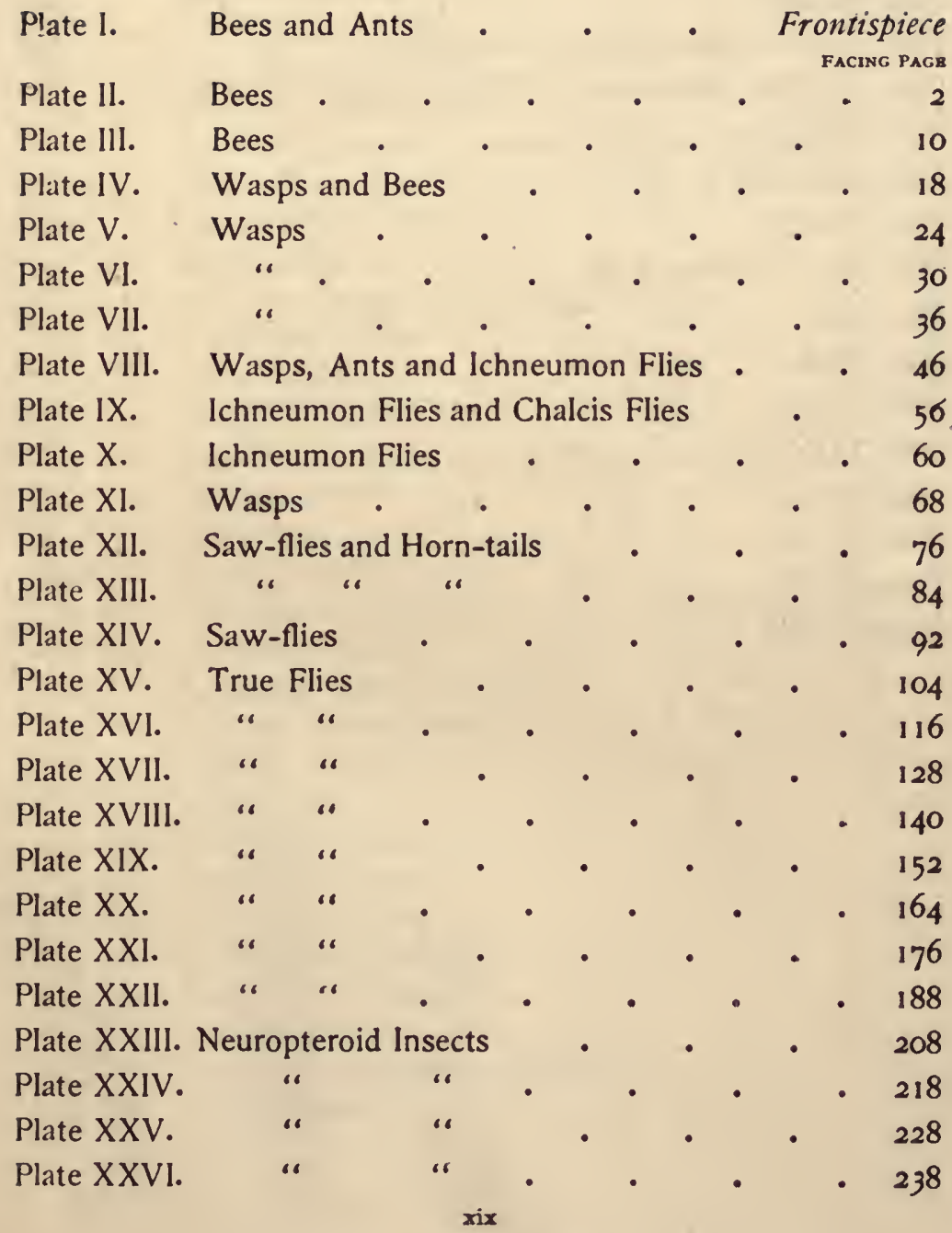


Plate XXVII. Bugs, Leaf-hoppers and Cicades

Plate XXVIII. Cicadas and Leaf-hoppers • . . 256

Plate XXIX. True Bugs . . . . 266

Plate XXX. “ " $\quad$. $\quad . \quad$. $\quad . \quad 278$

Plate XXXI. " " $\quad$. $\quad$. $\quad 280$

Plate XXXII. Miscellaneous Orthoptera • • • 288

Plate XXXIII. Long-horned and Short-horned Grasshoppers 296

PIate XXXIV. " " " " 328

Plate XXXV. Miscellaneous Orthoptera • • 336

Plate XXXVI. Short-horned Grasshoppers or True Locusts 342

Plate XXXVII. " " " " " "

Plate XXXVIII. " " " " " " "

Plate XXXIX. " " " "

Plate XL. Dragon flies • • . • 364

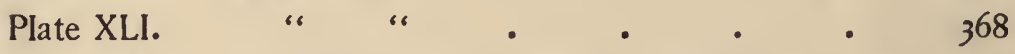

Plate XLII. " "

Plate XLIII. “ “ $\quad$ “ $\quad$ • • • • 374

Plate XLIV. " "

Plate XLV. “ "

Plate XLVI. “ " " $\quad$ c • • • 380

Plate XLVII. “ "

Plate XLVIII. “ “ $\quad$ “ $\quad$ • • 388 


\section{LIST OF TEXT ILLUSTRATIONS}

Fig. 1. Head and tongue of worker bee . . . 4

Fig. 2. Heads of queen and drone . . . . 5

Fig. 3. Queen cells and worker brood of honey bee . 7

Fig. 4. Queen of the common honey bee . . . 7

Fig. 5. Legs of different bees . . . . . 8

Fig. 6. Legs of different bees $\quad . \quad \ldots \quad . \quad . \quad . \quad 9$

Fig. 7. Sphecius speciosus carrying Cicada to its burrow 23

Fig. 8. Adult Cicada bearing eggs of Sphecius . . 23

Fig. 9. Larva of digger wasp in Cicada burrow . . 24

Fig. 10. Same, spinning its cocoon ‘. . . . 24

Fig. 11. Immature stages of the digger wasp . . . 24

Fig. 12. Cocoon of same . . . . • . 25

Fig. 13. Polistes pallipes . . . . . . 25

Fig. 14. Polistes rubiginosus . . . . . . 26

Fig. 15. Odynerus flavipes and its nest in a spool . . 31

Fig. 16. Tiphia inornata . . . . . . 31

Fig. 17. Chrysis sp. . . . . . . . 31

Fig. 18. Lælius trogodermatis . . . . . 35

Fig. 19. Goniozus sp. parasitic on larvæ of codling moth 36

Fig. 20. Solenopsis xyloni . . • . • . 37

Fig. 21. Crematogaster lineolata . • . . . 38

Fig. 22. Monomorium minutum . . . . . 39

Fig. 23. Tetramorium cæspitum . . . . . 40

Fig. 24. Ants at play . . . . . . . 46

Fig. 25. Pelecinus polyturator . . . . . 50

Fig. 26. Bæus americanus . . . . . . 51

Fig. 27. Cynips spongifica . . . . . . 53

Fig. 28. Diastrophus nebulosus . . . • • 54

Fig. 29. Pachyneuron micans . . . . . 56

Fig. 30. Chalcis ovata . . . . . . . 57

Fig. 32. Larvæ of Euplectrus comstockii . . - 58

Fig. 33. Pupæ of same . . . . . . 58 
Fig. 34. Adult of same

Fig. 35. Thalessa lunator . . . . . . 62

Fig. 36. Same . . . . . . . . 663

Fig. 37. Polysphincta dictynæ . . . . . 63

Fig. 38. Pimpla inquisitor . . . . . . 64

Fig. 39. Same, early stages . . . . . . 65

Fig. 40. Same, cocoons . . . . . . 67

Fig. 4I. Tremex columba . . . . . . 70

Fig. 42. Cephus pygmæus . . . . . . 70

Fig. 43. Phyllœcus integer . . • . . . 71

Fig. 44. Cimbex americana . . . . . . 74

Fig. 45. Nematus similaris . • • • • . 75

Fig. 46. Nematus marylandicus . . • . . 75

Fig. 47. Eriocampoides limacina (Pear Slug) . . . 76

Fig. 48. " " " . . 77

Fig. 49.

Fig. 50. " "

Fig. 51. Pachyrrhina sp. • • • • • • . 94

Fig. 52. Anopheles punctipennis . . . . . 98

Fig. 53. Culex sollicitans • • • • • • 99

Fig. 54. Anopheles maculipennis . . . . . 100

Fig. 55. " " . . . . IOr

Fig. 56. " larva and Culex larva . . . 102

Fig. 57. " pupa and Culex pupa . . . 103

Fig. 58. Psorophora ciliata . . . . . . 104

Fig. 59. Culex pungens _. • . • . . 105

Fig. 60. " $" . \quad . \quad . \quad . \quad . \quad 106$

Fig. 61. Chironomus larva $: \quad \cdot \quad \cdot \quad \cdot \quad 110$

Fig. 62. " . plumosus . . . . III

Fig. 63. Cecidomyia trifolii . . . . . . 113

Fig. 64. Diplosis resinicola . • . . • . II4

Fig. 65. " pyrivora . . . . . . I14

Fig. 66. Cecidomyia leguminicola . • . . 115

Fig. 67. Sciara tritici . . . . . . . II7

Fig. 68. Bibio albipennis . . • . . . II9

Fig. 69. Simulium meridionale . . . . . 120

Fig. 70. " invenustum . . . . . I2I

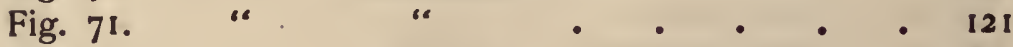

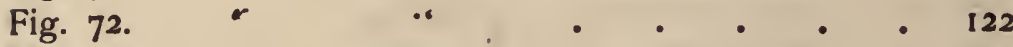

Fig. 73. " ornatum : $. \quad . \quad . \quad 123$ 
Fig. 74. Chrysops fugax . . . . . . 131

Fig. 75. Tabanus atratus $\bullet \quad . \quad . \quad . \quad 132$

Fig. 76. Anthrax hypomelas . . . . . . 137

Fig. 77. Systœchus oreas . . . . . . 138

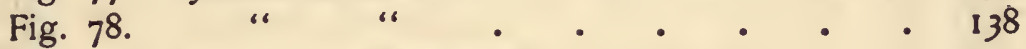

Fig. 79. Scenopinus fenestralis . • • . 139

Fig. 80. Erax bastardi . . . . . . . 141

Fig. 81. " apicalis . . . . . . . 142

Fig. 82. Mesograpta polita . . . . . . 150

Fig. 83. Eristalis tenax . . . . . . . 151

Fig. 84. Rat-tailed maggot . . . . . . 152

Fig. 85. CEstrus ovis . . . . . . . 155

Fig. 86. Hypoderma lineata . . . . . . 156

Fig. 87. Winthemia quadri-pustulata . . . . 158

Fig. 88. Euphorocera claripennis . • . . . 159

Fig. 89. Compsomyia macellaria . . . . . 163

Fig. 90. Lucilia cæsar . . . . . . . 163

Fig. 91. Calliphora erythrocephala . . . . 164

Fig. 92. Sarcophaga sarraceniæ . . . . . 165

Fig. 93. Hæmatobia serrata . . • . . . 166

Fig. 94. Morellia micans . . • • . 167

Fig. 95. Stomoxys calcitrans . . . . . 167

Fig. 96. Musca domestica : . . . . . 168

Fig. 97. Homalomyia brevis . . . . . . 171

Fig. 98. Pegomyia vicina . . . . . . 172

Fig. 99. Scatophaga furcata . • • • . . 173

Fig. 100. Chætopsis ænea . . • . . . 175

Fig. 101. Trypeta signalis . . . . . 177

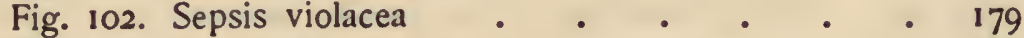

Fig. 103. Piophila casei . . . . . . . 180

Fig. 104. Nemopoda minuta . . . . . . 180

Fig. 105. Hippelates plebejus . • . . . . 183

Fig. 106. Gaurax anchora . . . . . . 184

Fig. 107. Drosophila ampelophila . . . . . 185

Fig. 108. Sphærocera subsultans • • • • • 187

Fig. 109. Olfersia americana . . . . . . 188

Fig. 110. Melophagus ovinus . . . . . . 189

Fig. 111. Nycteribia sp. . • • • • • • 190

Fig. 112. Pulex serraticeps . • • . • . 191

Fig. 113. Sarcopsylla gallinacea . . . • . 192 
Fig. 114. Caddis fly and larva.

Fig. 115. Nest of Hydropsyche . . . . . 204

Fig. 116. Hydropsyche sp. (larva) . . . . . 204

Fig. 117. Corydalis cornuta . . . . . . 213

Fig. 118. " " . . . . . . 214

Fig. 119. Chrysopa plorabunda . . . . . 222

Fig. 120. " oculata . . . . . . 223

Fig. 121. “ “ . . . . . . 225

Fig. 122. Cicada septendecim . . . . . 231

Fig. 123. " " " . . . 231

Fig. 124. “ “ $"$ (eggs) • . . . 232

Fig. 125. " “ (work) • . . . 233

Fig. 126. " “ (larva) . . . . 234

Fig. 127. Helicoptera sp. • • • • • . 235

Fig. 128. Scolops sulcipes . . . . . . 235

Fig. 129. Otiocerus coqueberti . • • . . 235

Fig. 130. Ceresa taurina . . . . . . 237

Fig. 131. " " . . . . . . 238

Fig. 132. Enchenopa binotata . . . . . 238

Fig. 133. Archasia galeata . . . . . . 239

Fig. 134. Ceresa bubalus . . . . . . 239

Fig. 135. " " . . . . . . 240

Fig. 136. Monecophora bicincta . . . . . 241

Fig. 137. Proconia undata . . . . . . 243

Fig. 138. Thamnotettix clittelerius . . . . 243

Fig. 139. Erythroneura vitis . . . . . . 244

Fig. 140. Aleyrodes citri . . . . . . 246

Fig. 141. " " . . . . . . 248

Fig. 142. Diaspis pentagona . . . . . . 250

Fig. 143. “ " . . . . . . 251

Fig. 144. " “ . . . . . . . 251

Fig. 145. “

Fig. 146. Lecanium nigrofasciatum . . . . 252

Fig. 147. Dactylopius citri . . . . . . 253

Fig. 148. " longifilis . . . . 253

Fig. 149. Pulvinaria innumerabilis . . . . . 254

Fig. 150. Mytilaspis pomorum . . • . . 255

Fig. 151. " " . . . . 256

Fig. 152. Chionaspis furfurus . . . . . 257

Fig. 153. Pachypsylla venusta O. S. . . . 259 
Fig. 154. Pear tree Psylla . . . . . . 260

Fig. 155. " " "

Fig. 156. " " " . . . . . . 261

Fig. 157. Nectarophora (destructor) pisum : . . 262

Fig. 158. Phylloxera vastatrix . . . . . 263

Fig. 159. " "

Fig. 160. $\quad$.

Fig. 161. " " . . . . . 264

Fig. 162. Phorodon humuli . . . . . 266

Fig. 163. “ " . . . . . . . 266

Fig. 164. “ “

Fig. 165. “ “

Fig. 166. “ “ . • • . . . 268

Fig. 167. Corixa interrupta Say . . . . . 273

Fig. 168. Notonecta undulata . • . • • 275

Fig. 169. Nepa cinerea . . • • • • 276

Fig. 170. Ranatra fusca . • . • . . 277

Fig. 171. Ambrysus signoreti . . . . . 280

Fig. 172. Galgulus oculatus . • • . • . 281

Fig. 173. Hydrometra lineata . . . . . 282

Fig. 174. Gerris (Hygrotrechus) remigis Say • . 283

Fig. 175. Rheumatobates rileyi • • . • . 284

Fig. 176. Triphleps insidiosus . . . . . 287

Fig. 177. Æciacus hirundinis . • . . . 288

Fig. 178. Cimex lectularius (young) • • • . 289

Fig. 179. " " . . • . . . 290

Fig. 179a. Henicocephalus culicis . • . . . 292

Fig. 180. Conorhinus sanguisuga . . . . . 293

Fig. 181. Reduvius personatus . . . . . 293

Fig. 182. Rasahus biguttatus . • . • . 294

Fig. 183. Melanolestes abdominalis . . . . 294

Fig. 184. Milyas cinctus . . . . . . 294

Fig. 185. Emesa longipes . • • . • . 295

Fig. 186. Arilus cristatus . . . . . : 296

Fig. 187. Phymata wolffi . . . . . . 297

Fig. 188. Aradus robustus . • . • . . 298

Fig. 189. Gargaphia angulata . • . . . 299

Fig. 190. Corythuca arcuata . . • . . . 299

Fig. 191. " " (eggs) . . 300

Fig. 192. Piesma cinerea . . . . . . 300 
Fig. 193. Halticus uhleri . $\quad$ • . . . 302

Fig. 194. Pœcilocapsus lineatus . . . . $\quad 303$

Fig. 195. Leptoglossus phyllopus . . . . . 304

Fig. 196. Metapodius femoratus . . . . . 304

Fig. 197. Corizus hyalinus . . . . . . 305

Fig. 198. Leptocoris trivittatus . . . . . 305

Fig. 199. Anasa armigera . . . . . . 306

Fig. 200. Largus succinctus . . . . . . 307

Fig. 201. Dysdercus suturellus ‘ . • . . 308

Fig. 202. Myodocha serripes . . . . . . 310

Fig. 203. Nysius angustatus . . . . . 311

Fig. 204. Blissus leucopterus . . . . . 311

Fig. 205. " " " . . . . . 312

Fig. 206. " " . . . . 312

Fig. 207. Murgantia histrionica . . . . . 313

Fig. 208. Euschistus variolarius . . . . .313

Fig. 209. Corimelæna pulicaria . . $\quad . \quad$. 314

Fig. 2 10. Brochymena annulata . . $. \quad . \quad 314$

Fig. 211. Stiretrus anchorago . . . . . 315

Fig. 212. Pediculus capitis . . . . . . 316

Fig. 213. Thrips tritici . . . . . . . 318

Fig. 214. Diapheromera femorata . , , . . 324

Fig. 215. Stagmomantis carolina . . . . . 326

Fig. 216. " " (eggs) . . . . 328

Fig. 217. Periplaneta americana . . . , . 329

Fig. 218. Ectobia germanica, different stages . . 330

Fig. 219. Periplaneta orientalis " " . . 331

Fig. 220. Melanoplus devastator . . . • • 332

Fig. 221. Schistocerca americana . . . . . 332

Fig. 222. Romalea microptera -. . . . . 333

Fig. 223. Melanoplus spretus, laying eggs . • . 334

Fig. 224. Orchelimum vulgare, and eggs . • . 336

Fig. 225. Song note of Cyrtophyllum concavum . $\quad 337$

Fig. 226. Microcentrum retinervis . • • • • 338

Fig. 227. Day song of Scudderia angustifolia . $\quad .339$

Fig. 227a. Night " " " • 339

Fig. 228. Gryllus assimilis . • • • • . 341

Fig. 229. " " . . . . 341

Fig. 230. Anabrus simplex . . . . . . 342

Fig. 231. Song note of the mole cricket . • $\quad 342$ xxvi 
Fig. 232. Song note of the field cricket

Fig. 233. Day song of the snowy tree cricket . . 343

Fig. 234. Night " " " • 343

Fig. 235. Song of the cave cricket . . . . 344

Fig. 236. Forficula sp. . • • • • . 345

Fig. 237. Menopon biseriatum • . • . • 347

Fig. 238. Goniocotes abdominalis . . . . 348

Fig. 239. " d dissimilis • • • • • 349

Fig. 240. Atropos divinatoria . . . . . 350

Fig. 241. Termes flavipes, male and female . . . 353

Fig. 242. “ " " false queen, workers and soldiers 354

Fig. 243. Plathemis lydia . • • • • • 363

Fig. 244. Lepisma domestica . . . . . 382

Fig. 245. " saccharina . • . . . 383

Fig. 246. Lepidocyrtus americanus . • • . 386

Fig. 247. " " side view and enlarged parts 387

Fig. 248. The hand net frame . . . . . 390

Fig. 249. The Sanborn net frame . . . . . 390

Fig. 250. Beating net or sweeping net . . . . 390

Fig. 251. A good hand net . . . . . . 391

Fig. 252. Small water dip net . . . . . 391

Fig. 253. A fumigator . . . . . . . 392

Fig. 254. A good haversack • • • • • . 393

Fig. 255. The umbrella and its mode of use . . . 393

Fig. 256. The Riley breeding cage . • . . 396

Fig. 257. The Comstock improved base for breeding case 397

Fig. 258. A good simple aquarium . . . . 400

Fig. 259. Pocket cyanide bottle . . . . . 401

Fig. 260. Spreading board for Lepidoptera . . . 402

Fig. 261. Insect mounted on cardboard triangle . 402

Fig. 262. Triangle punch . . . . . . 402

Fig. 263. Points for mounting insects . . . . 403

Fig. 264. The Marx tray for alcohol specimens . . 403 

THE INSECT BOOK 


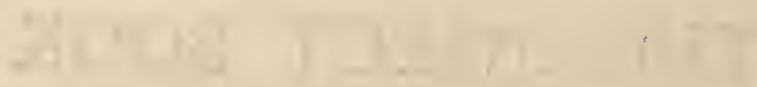




\section{ORDER HYMENOPTERA}

THIS great order of insects, which contains the bees, wasps, ants, gall-flies, saw-flies, ichneumon-flies and related forms is unsurpassed in interest by any other group of animals. It is a very large order, and comprises nearly 30,000 described species; but the enormous number of undescribed species, particularly of the smaller parasitic forms inhabiting tropical regions and other out-of-the-way localities would probably swell this number to more than 300,000. To indicate the work still to be done in this order it is safe to say that a day's collecting in Central Park, New York, almost under the windows of the great American Museum of Natural History, or in Logan Square, Philadelphia, within 200 yards of the Academy of Natural Sciences, would result in the capture of a number of species new to science. But the size of the order is its least important and interesting feature. The very great variation in habits and life history, the wonderful social organization of the bees, ants and some wasps, the seeming marvellous intelligence of these creatures, the remarkable adaptations of structure to environment, the extraordinary interrelations and interdependencies of species seen with the members of the parasitic families, the strange vital phenomena of sex-abortion, of virgin birth or parthenogenesis, and the wonderful plant deformations brought about by the gall-makers, unite to render the Hymenoptera a field of study of never-ending interest.

As a group the Hymenoptera are distinguished from other insects by the following points: Their metamorphoses are complete, their mouth parts are mandibulate, and in most families formed for biting, although in the bees they are so modified as to form a sort or proboscis, and the females are furnished with an extensile sting or ovipositor. All have four wings, of which the hind pair is smaller. The wings are membranous, usually transparent, bear no scales, and are divided by veins or nervures, as they are inappropriately and misleadingly called, into a comparatively small number of cells.

On account of the great diversity of form and structure which exists within these limits, the Hymenoptera have long 
been divided into many families and subfamilies. Mr. W. H. Ashmead of the United States National Museum, whose great work on this order has placed him at the head of all living authorities on the Hymenoptera, has recently given us as the result of his prolonged studies an arrangement of this enormous complex of forms into ten super-families, and for the sake of simplicity our consideration of the order will follow his classification at the risk of some slight temporary confusion in the minds of those familiar with other general works on insects. The correspondence between physical structure and habits and mode of life, however, is so marked in the Hymenoptera, that these structural super-families are really habit super-families as well.

Economically considered the Hymenoptera as a whole is a beneficial group in its relation to man. Aside from the honey industry dependent upon the honey bee, thousands of the parasitic forms destroy noxious insects, very many forms are of the utmost importance as cross fertilizers of trees and plants, and certain galls have a distinct value in commerce.

In the different aspects of the study of this great group there is room for a small army of workers.

\section{TABLE OF SUBORDERS AND SUPER-FAMILIES.}

Suborder HETEROPHAGA, AshmeAd. Abdomen. much narrowed at its attachment to the thorax. Larvæ legless.

Suborder PHYTOPHAGA, LATREILlE. Abdomen broad at its attachment to the thorax. Larvæ with legs.

\section{Heterophaga.}

Underside of last segment of the abdomen not divided longitudinally; the sting or ovipositor, when present, always issuing from the tip of the abdomen.........

Underside of last segment of the abdomen divided; ovipositor issuing some distance before the tip of abdomen; trochanters always two-jointed............... 5

1-Pronotum not extending back to the tegulæ........... 2

Pronotum extending back to tegulæ, or the latter are absent. 3 


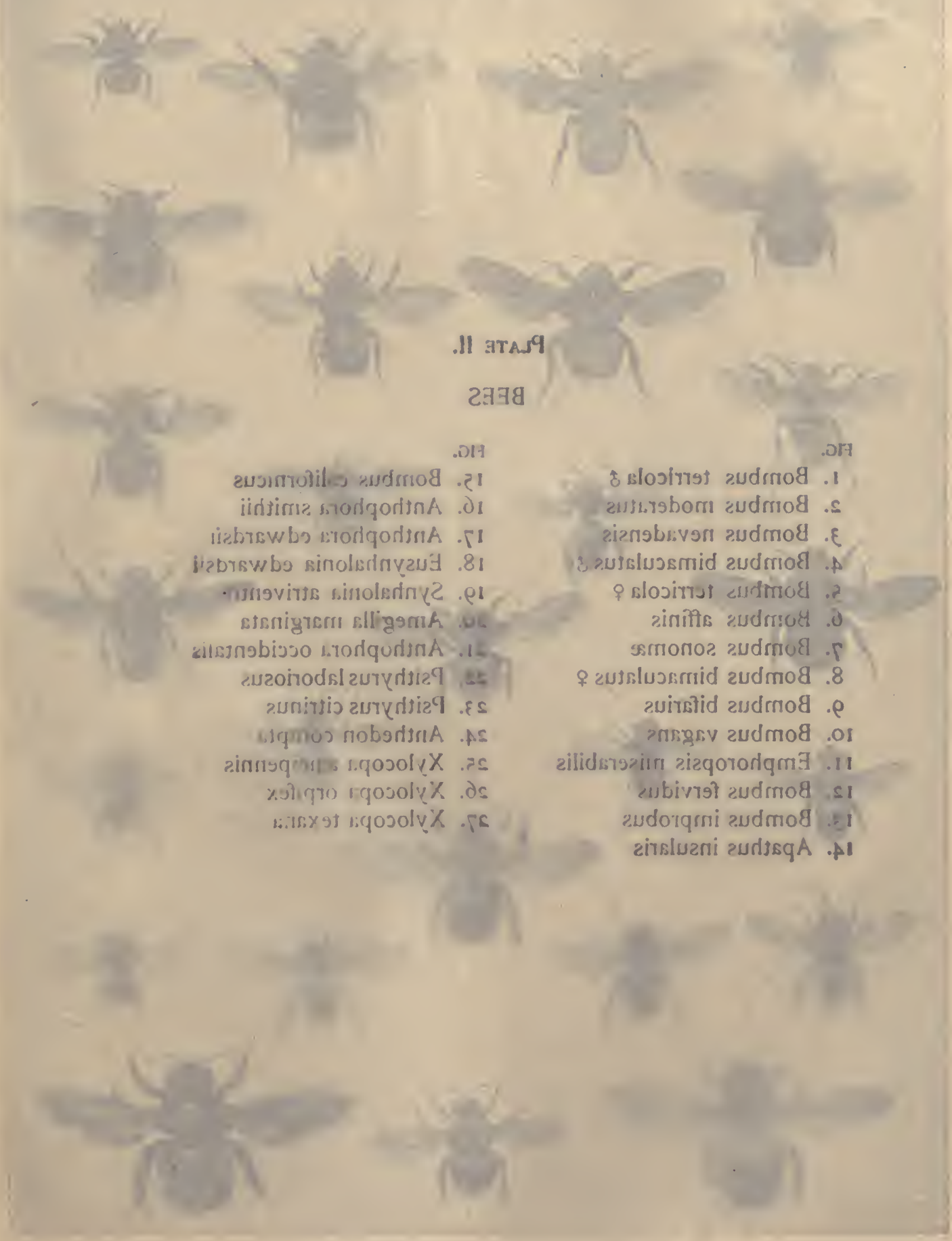




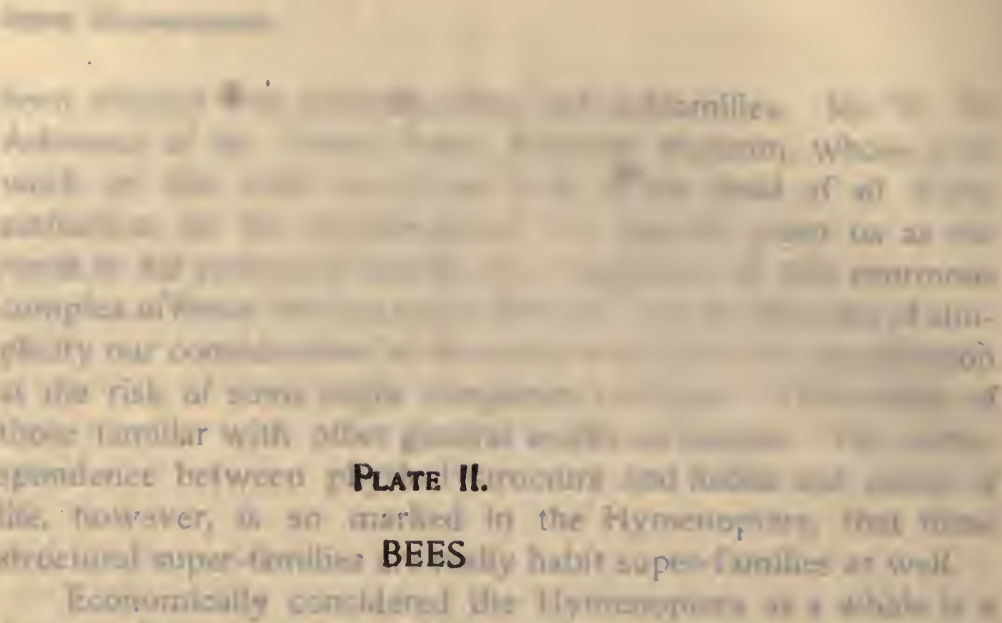

FIG.

I. Bombus terricola $\delta$

2. Bombus moderatus

3. Bombus nevadensis

4. Bombus bimaculatus $\delta$

5. Bombus terricola 9

6. Bombus affinis

7. Bombus sonomæ

8. Bombus bimaculatus 우

9. Bombus bifarius

10. Bombus vagans

11. Emphoropsis miserabilis

12. Bombus fervidus

13. Bombus improbus

14. Apathus insularis
FIG.

15. Bombus californicus

16. Anthophora smithii

17. Anthophora edwardsil

18. Eusynhalonia edwardsii

19. Synhalonia atriventris

20. Amegilla marginata

2I. Anthophora occidentalis

22. Psithyrus laboriosus

23. Psithyrus citrinus

24. Anthedon compta

25. Xylocopa æneipennis

26. Xylocopa orpifex mu-1/ $\pi \cdot 4$

27. Xylocopa texaria

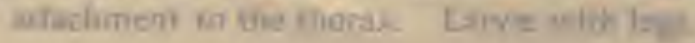

\section{Becansinhera-}

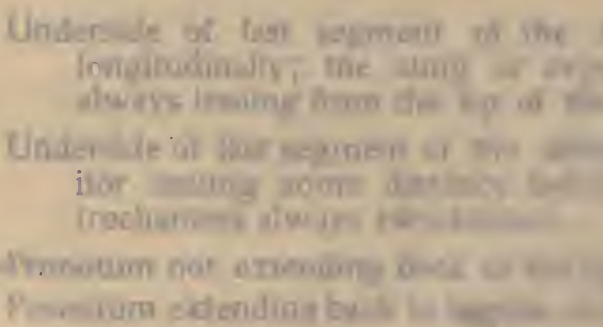




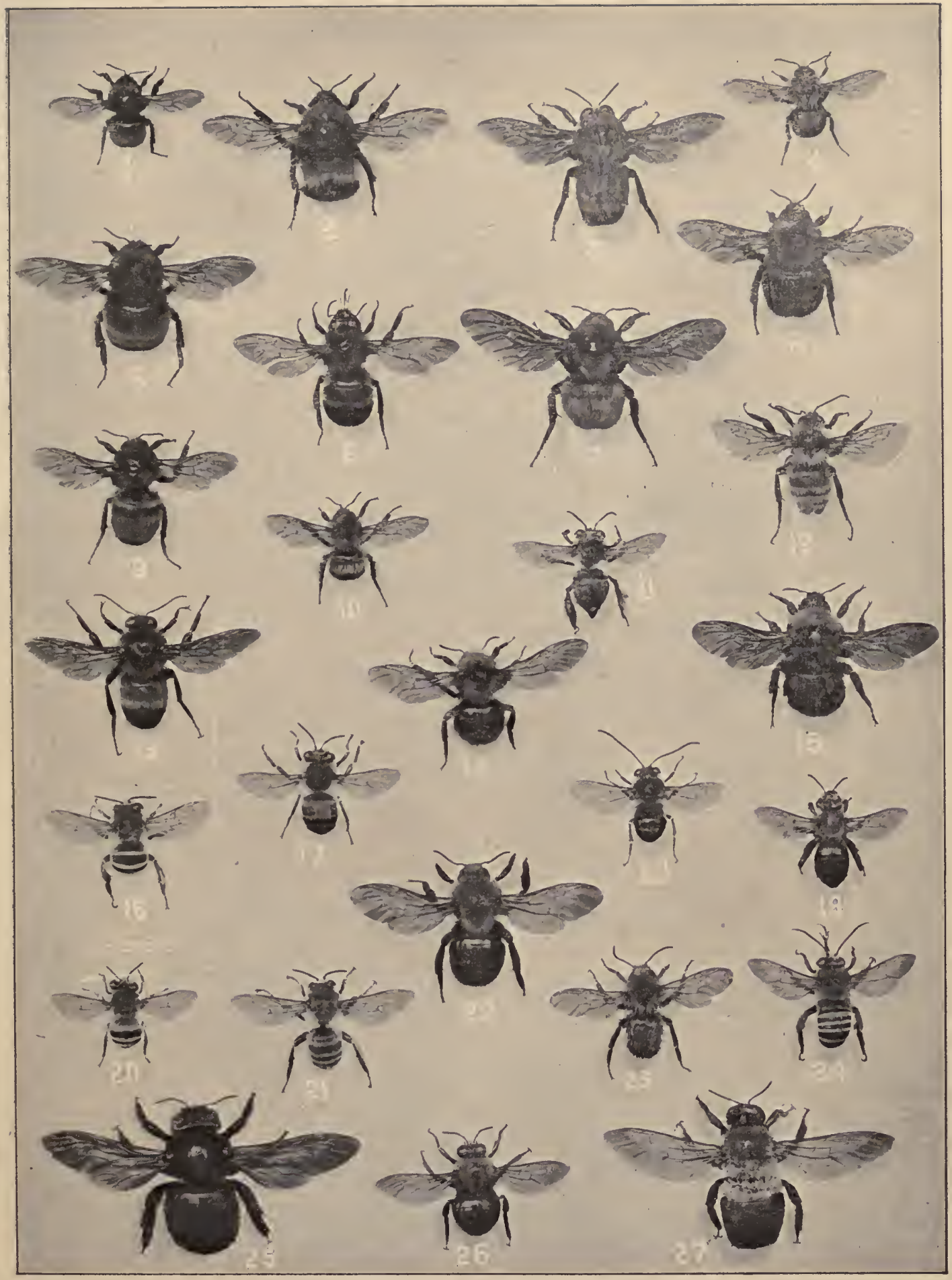



2-Tarsi dilated or thickened; hairs of head and thorax feathery ...................... Super-family Apoidea

Tarsi slender; hairs on head and thorax simple...........

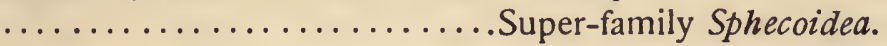

3-Trochanters always one-jointed, (except in the family

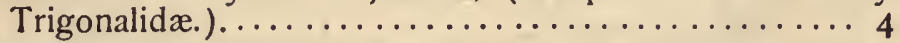

Trochanters two-jointed (except in the family Pelecinidx,) .................... Super-family Proctotrypoidea.

4-Petiole, or first segment of abdomen simple, without swellings; winged forms with well-developed tegulæ...... ..................... Super-family Vespoidea.

Petiole with one or two swellings; winged forms without or with imperfectly formed tegulæ..Super-family Formicoidea.

5-Front wings with the marginal vein, if present, linear, never large or stigmated....................... 6

Front wings with a stigma; the marginal vein usually large and stigmated .......... Super-family Ichneumonoidea,

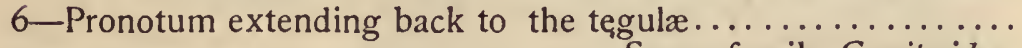

Pronotum not extending back to the tegulæ............. ........................ Super-family Chalcidoidea.

\section{Phytophaga.}

Tibiæ of forelegs with one apical spur................ Tibiæ of forelegs with two apical spurs................... ..................... Super-family Tenthredinoidea. 


\section{THE TRUE BEES \\ (Superfamily Apoidea)}

This great group, comprising about five thousand species, includes all of the true bees, both the honey-gatherers which have social communities and live a strict community life, and the

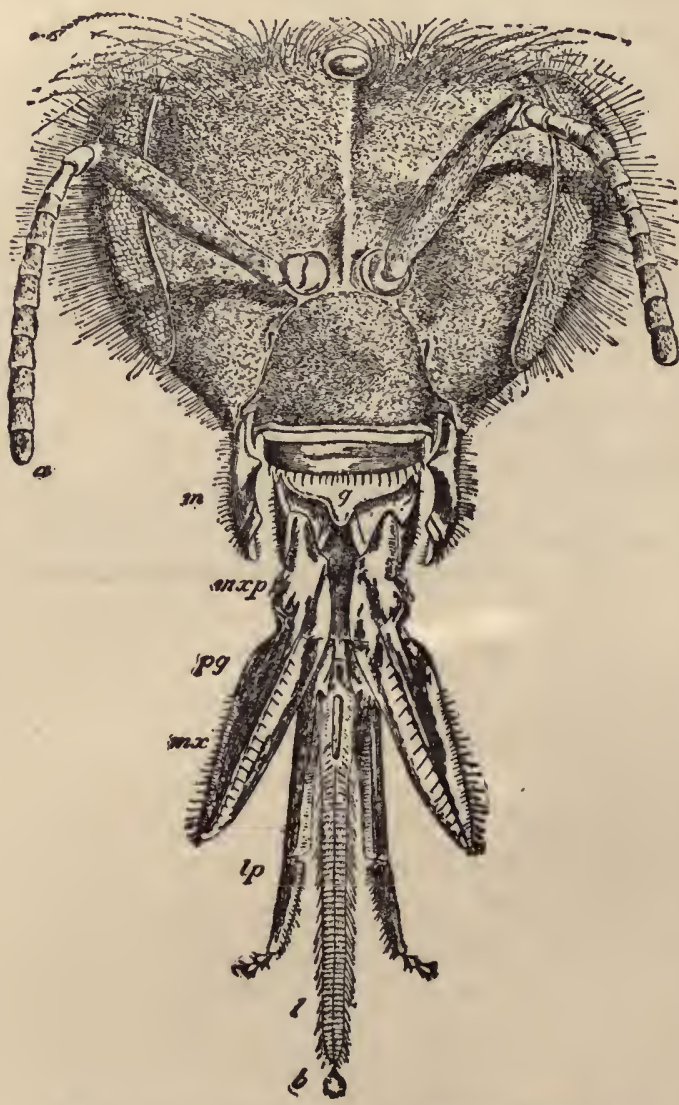

Fig. 1,-Head and tongue of worker honey bee. (Redrawn from Cheshire.) solitary bees. We have already seen in the table of superfamilies that the hind feet of these insects are dilated or thickened, and that the hairs of the head and thorax are feathery. These peculiar feathery hairs are found only in the true bees, which also differ from other Hymenoptera by the peculiar modification of the mouth-parts which are lengthened into a structure which is almost like a proboscis. It is a very conspicuous organ and is fitted in many of them for probing deep flowers and for gathering nectar. The mandibles or upper jaws 
play no part in this proboscis-like structure, which is composed entirely of lower lip and lower jaws, both greatly lengthened.

The eggs of all bees are laid in cells of one kind or another in which the larvæ develop. Sometimes they are fed by the adult
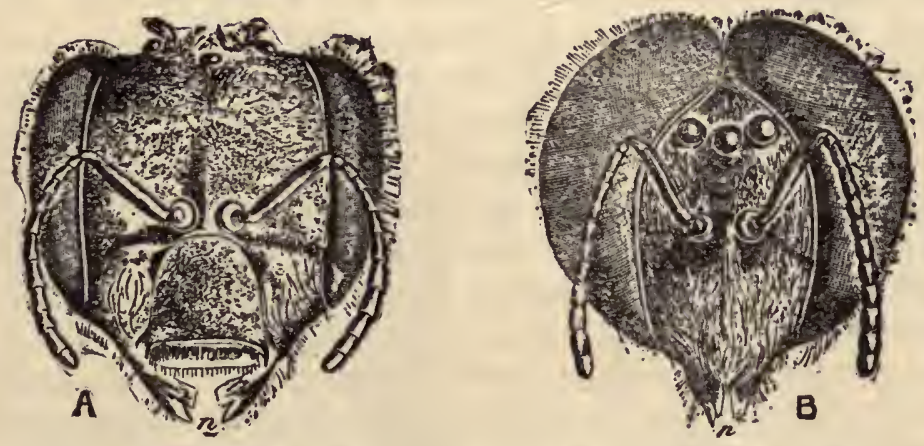

Fig. 2.-Head of A, queen; B, drone of honey bee (From Cheshire.)

bees and sometimes a supply of food is stored in the cell so that after the egg is laid and the cell is completely closed the mother has no more responsibilty for the growth and development of her offspring.

It is among the higher and more specialized bees that we see for the first time the extraordinary community life which is developed among them and certain other Hymenoptera, such as certain social wasps and ants, and practically nowhere else, except among the so-called white ants or Termites, which belong to quite a different order. With the social bees we find a most perfect communism; each individual works for the good of the community, and thus only indirectly for its own ends.

In the evolution of this community life strange things have happened. There has come to be a class of individuals which are practically sexless, and are called neuters or workers. These individuals do the mechanical work of the community. They are really structurally females in which the development of the sexual organs has ceased at a certain point. They are undeveloped and infertile females. The other two sexes are represented, but the number of true females, or queens as they are called, is small, only a sufficient number being found to supply eggs for the perpetuation of the community. The males are aptly termed drones, since they are drones in comparison with the active and 
hard-working neuters or workers. Their function in the community is simply to fertilize the queens at the proper time, and then they are of no further use in the world.

The Apoidea are now subdivided into no less than fourteen fullfledged families. These include the Apidx, or true honey bees, the Bombidæ, or bumblebees, the solitary bees of the Anthophoridæ, the cuckoo bees of the family Nomadidx, the small carpenter bees of the family Ceratinidæ, the large carpenter bees of the family Xylocopidæ, the mason, leaf-cutting and potter bees of the family Megachilidx, the parasitic bees of the family Stelidæ, the sharp-tongued burrowing bees of the family Andrenidx; the blunt-tongued burrowing bees of the family Colletidæ, and others.

The habits of the bees of these diverse families vary greatly, and most of the characteristics which they have in common have already been referred to. All, from their flower-visiting habits, are of great importance in the cross fertilization of plants, and without their aid the health of the plant world would suffer and its infinite variety would hardly have been achieved.

The most famous of all bees is naturally the common honey bee, an importation from Europe, not a native, which by the hand of man has become a true domesticated animal. The life history of this creature has been so often written about and may so easily be learned by consulting any encyclopedia or standard general work of reference that it does not seem necessary to describe it in detail here. The methods of bee culture in use admit of ready study of its economy.* In this brief summary of the general characteristics of bees we shall, therefore, confine ourselves to the wild and less known forms. A bumblebee has been selected for the typical life history, and little need therefore be said of the large and important family to which that species belongs, except to state that bumblebees now occur in most parts of the world, and that they are especially abundant in temperate and even boreal regions, large numbers inhabiting far northern localities where they abound in the brief artic summer, and where they live a short but extremely busy life on account of the crowding together of the flowering periods of sub-polar plants.

*One of the strongest bits of descriptive writing known to me is Tolstoi's description of a queenless bee hive, in "War and Peace," where he likens Moscow on the approach of the French army to a hive deserted by the queen bee. 
The solitary bees of the family Anthophoridx are in general thickly clothed with hair, and many of them burrow into the earth, forming tunnels in which they form earthern cells, storing

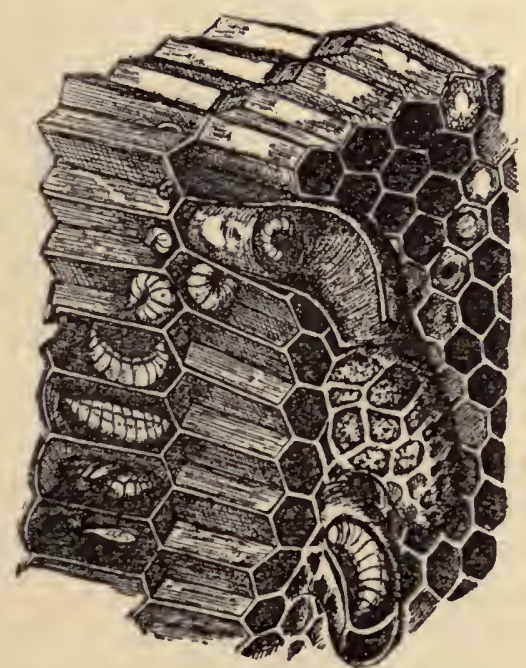

Fig. 3.-Queen cells and worker brood of honey bees. (From Beriton.) them with a supply of pollen and honey upon which the egg is laid and the cell is then closed.

Much good work can be done in the way of accurate observation upon the members of this group; the length of the larval life, duration of the egg stage, and other points have not been accurately followed out, although some of the European species are fairly well known. Certain species bore into wood instead of entering the earth, or they occupy old burrows of some carpenter bee. There are certain curious parasites of these bees, and the life of one of them has been studied by the English observer Newport.

The cuckoo bees of the family Nomadidx without exception live parasitically in the nest of other bees, and have undoubtedly originated from other bees through different lines of descent-probably from those of the group just mentioned. As their parasitic habits would prepare us to learn, their legs are without the scopa for the carriage of pollen, and their life is practically that of the cuckoo, the female laying her eggs in cells already prepared by some more industrious and conscientious bee, and her larvæ living at the expense of the offspring of the cellmaker.

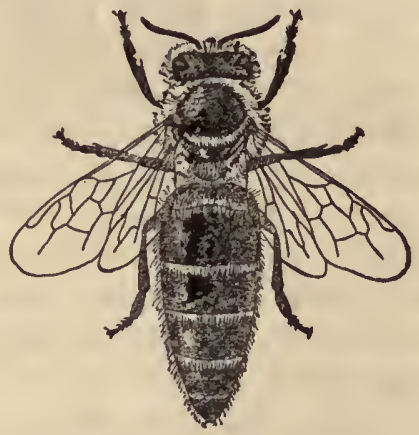

Fig. 4.-Queen of the common honey bee. (From Benton.) 
Curiously enough, these bees seem to be on perfectly good terms with their hosts, visiting flowers in their company and visiting their burrows as unconcernedly as though they were the result of their own labors. Emerton has observed that there is frequently enough food for the larva of the cell-maker and the
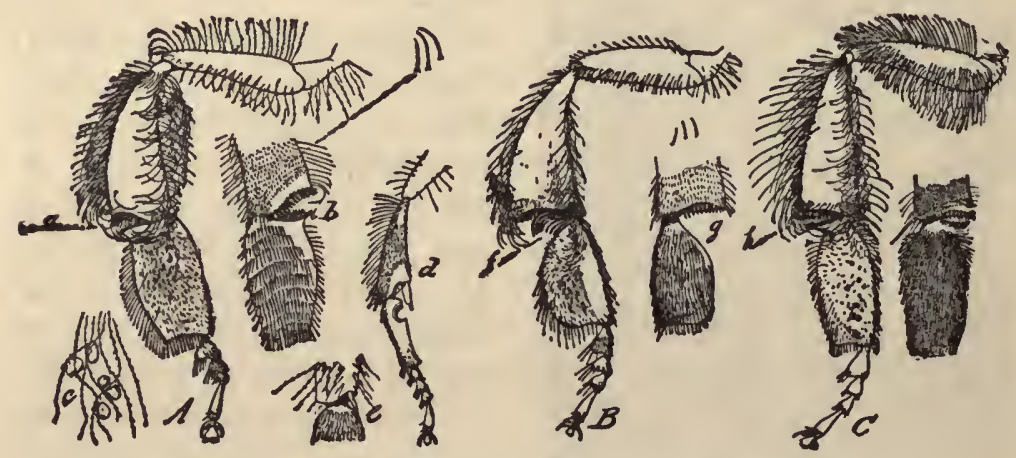

Fig. 5.-Legs of different bees: A; A pis; B, Melipona; C, Bombus. (From Insect Life.)

larva of the cuckoo bee, and that they both thrive and issue as adults simultaneously. This cuckoo life is found with bees of certain other groups, and will be referred to later.

The rather smooth and active little bees of the family Ceratinidx, which have been termed small carpenter bees, are extremely interesting creatures, and are generally metallic blue, blue-black or bright green four-winged flies, not hairy, and are very active in the summer time. They bore tunnels into the stems of pithy plants and form their cells in these burrows. They are very commonly found in brambles. The cells are lined with a delicate silky membrane and are separated from one another by mud partitions. The common Ceratina ciupla is a familiar example. With this bee the cells are filled with a paste of honey and pollen upon which the larvæ feed. The transformation to imago occurs in the latter part of July or during August

From the cells of this bee two very remarkable parasites have been reared by the Rev. J. L. Zabriskie, namely Diamorus zabriskii, Cres., and Axima zabriskii, How. 
The large carpenter bees, however, do not confine themselves to the stems of plants. Their burrows are so large that they are frequently made in the dead trunks of old trees and commonly in lumber, and even in the joists of kuildings. The commonest of the large carpenter bees in this country is Xyloco$p a$ virginica. This large black-bodied bee, as big as the biggest bumblebee, but with a flatter and less hairy abdomen, bores symmetrical tunnels into solid wood, choosing in civilized regions fence posts and boards. The burrow is a half-inch in diameter, and runs horizontally across the grain for about the length of the insect's body, and is then turned downward at right angles and runs with the grain from twelve to eighteen inches. In this boring the bee progresses at the average rate of about half an inch a day, occupying at least two days in digging the first portion against the grain of the wood. After the burrow is once commenced, their persistence in returning to continue the work, in spite of all obstacles, is very remarkable. One of these indefatigable bees

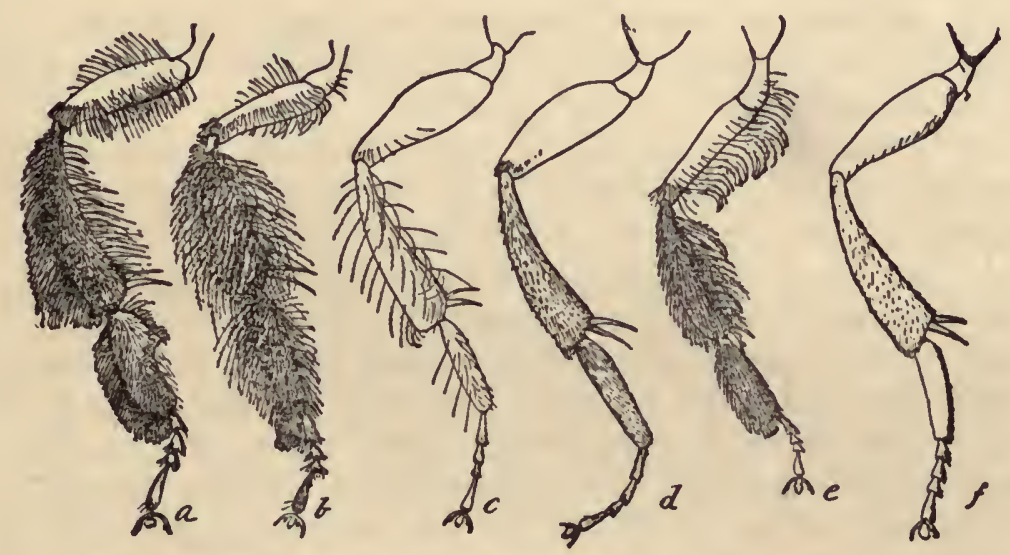

Fig. 6.-Legs of different bees: a, Anthophora; b, Melissodes; c, Perdita; d, Nomada; e, Agapostemon; f, Nomia. (From Insect Life.)

once started a burrow in a lintel over the front door of the writer's house in Georgetown. She was repeatedly driven away, was struck with a broom a number of times, and finally ceased from her labors only because kerosene was squirted at her through a syringe with accurate aim. It was the hand of death alone which released her from her work. 
The tunnels generally run in opposite directions from the opening, and sometimes other galleries are made, one parallel with the other, using a common opening.

While we may admire the industry of the carpenter bee in doing all this hard work for its young, it is not averse to an easy thing, and will use the same burrow over again, and if an old deserted burrow can be found which was made the previous summer, or even several years previously, it is preferred to the drudgery of making a new one. Moreover, there are other bees which will pre-empt the deserted burrows of the carpenter bees.

After the tunnels are prepared the cells are made and supplied with pollen. With the species under consideration the cells are about seven-tenths of an inch long, and are separated from each other by partitions which are made up of a single flattened band of sawdust and fine chips glued together and rolled up into a flat partition about four layers deep. The side forming the bottom of the cell is concave and smooth, while the other side is flat and rough.

Even about the common carpenter bee there is much yet to be learned, and a careful series of studies carried through an entire season cannot fail to show novel facts.

The mason bees of the family Megachilidæ (sub-family Osmiinæ) derive their name from the manner in which they construct small earthen cells under stones, in the burrows of other bees, in decaying wood, in deserted snail shells, in old galls, and elsewhere. These bees show a great diversity of habit. Their cells are constructed of sand, earth or clay mixed with pebbles and wood scrapings, but glued together so firmly that they are smooth inside. Ten to twenty of them are usually found together, and each one contains a store of honey and pollen, for the larvæ, of which only one is found in each cell.

One of these bees (Ceratosmia (Osmia) lignivora Packard) has been shown by Dr. Packard to be a true wood-borer. He saw it make a tunnel three inches long in maple wood, the tunnel containing five cells and the partitions being made of wood chippings.

The leaf-cutting bees of the same family are common creatures whose habits are extremely interesting. They derive their name from the fact that they cut pieces out of the tender leaves of various trees with which to form their cells. The leaf-cutters 


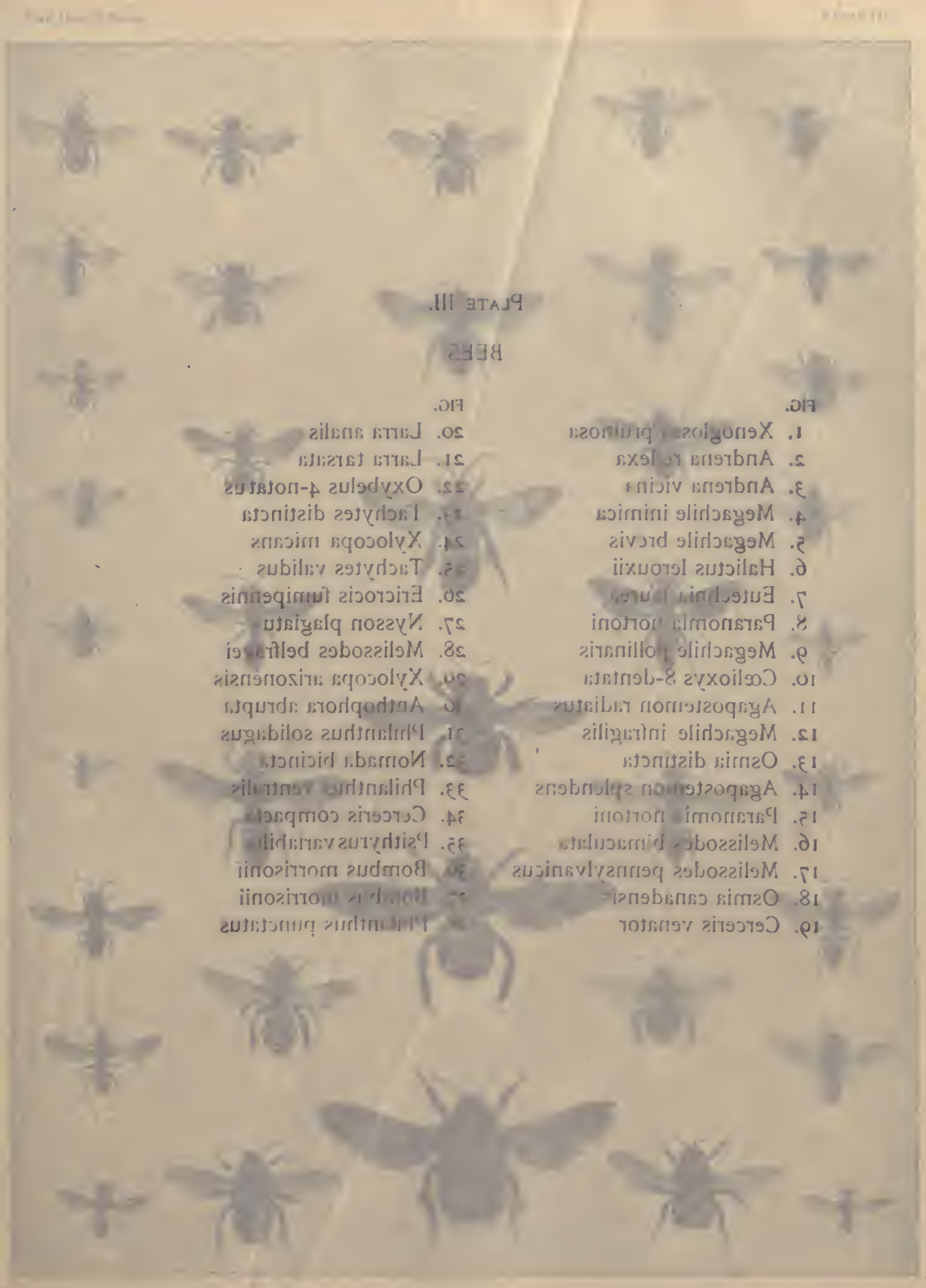




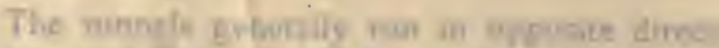

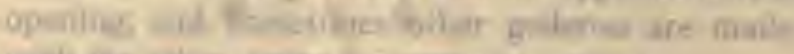

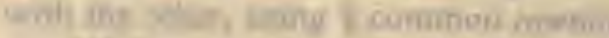

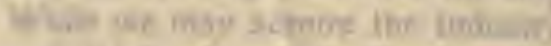

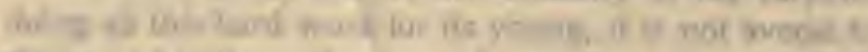

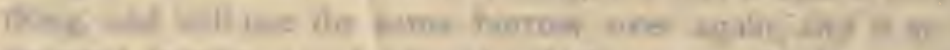

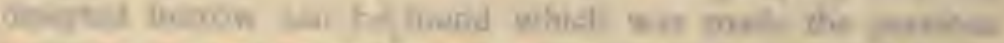

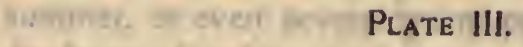

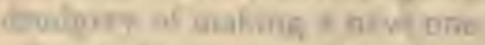

whit th whll pre smbet in BEES

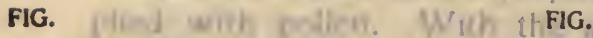

I. Xenoglossa pruinosa

2. Andrena reflexa

3. Andrena vicina

4. Megachile inimica

5. Megachile brevis

6. Halictus lerouxii

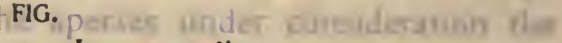

20. Larra analis

21. Larra tarsata

22. Oxybelus 4-notat us

23. Tachytes distincta

24. Xylocopa micans

7. Eutechnia taurea

25. Tachytes validus

8. Paranomia nortoni

26. Ericrocis fumipennis

9. Megachile pollinaris

27. Nysson plagiatus

10. Cœlioxys 8-dentata

28. Melissodes belfragei

11. Agapostemon radiatus

29. Xylocopa arizonensis

12. Megachile infragilis

30. Anthophora abrupta

13. Osmia distincta

31. Philanthus solidagus

14. Agapostemon splendens

32. Nomada bicincta

15. Paranomia nortoni

33. Philanthus ventralis

16. Melissodes bimaculata

34. Cerceris compacta

17. Melissodes pennsylvanicus

35. Psithyrus variabilis

18. Osmia canadensis

36. Bombus morrisonii

19. Cerceris venator

37. Bombus morrisonii

38. Philanthus punctatus

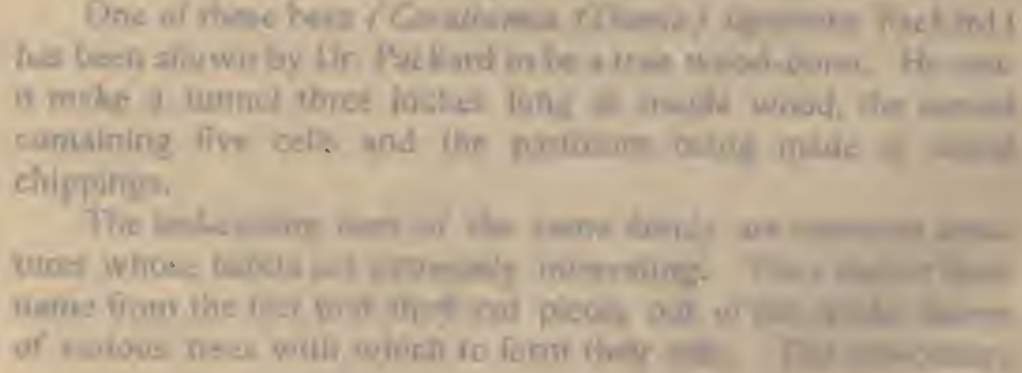




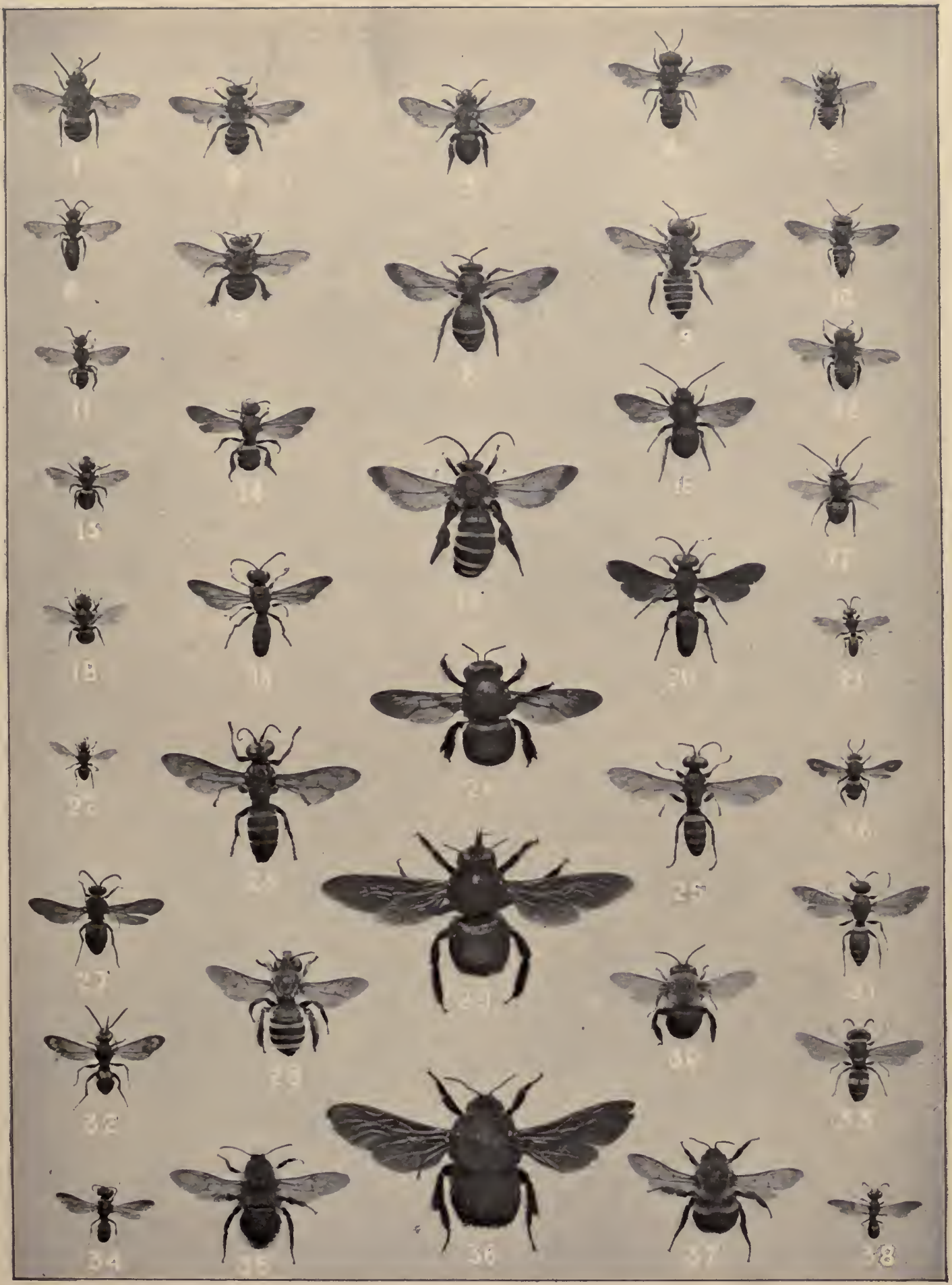



are found in all parts of the world and look much like bumblebees. The pieces of leaf which they cut out very neatly are either oblong or circular, the former being used for the sides and the latter to cover the end of the cell. The burrows which they use vary greatly in situation. Some burrow into the ground, others into soft wood, while others make use of chance tunnels. I have seen them in accidental auger holes, and in lead pipe, and once knew the nozzle of an old pump to be packed full of cells. According to Professor Putnam, a single female observed by him took twenty days to complete and provision a series of cells under a board. He found there were thirty cells in nine rows of varying numbers. An estimate of the number of bits of leaf used in the construction of these thirty cells amounted to more than a thousand.

The potter bees of this same family construct small globular cells of earth and attach them to the stem of a plant.

The parasitic bees of the family Stelidx live, like the Nomadidæ, in the nests of other bees, choosing indifferently the cell of almost any kind of bee, no matter what its situation. No observations on any of the American species have been recorded, and here is an interesting field of study.

The habits of the European species Stelis minuta have been observed with some care. It was found to be parasitic in the nest of one of the mason bees, a female having laid her egg in the cell after it was partly filled by the mason bee. Unaware of the presence of the parasitic egg, the mason bee continued her work, and after nearly filling the cell deposited her own egg on the top of the food mass, closing the cell with a partition, and beginning another one above. The Stelis larva hatched a little earlier than that of the mason bee, and both began to feed, the parasite larva from below and the mason bee larva from above. Unfortunately for those who are interested in the triumph of right and justice, the latter grows very slowly while the parasite larva grows more rapidly, and gradually worked its way upward through the food mass, thus approaching the mason bee larva. In the words of Riley's summary of this tragic performance " the crisis finally comes-the Stelis larva encounters the Osmia larva ; a short but deadly combat ensues; the Osmia larva is easily overpowered and killed by the much larger and stronger parasite, and its body is devoured by the latter within one or two days." 
The sharp-tongued burrowing bees form a very large group, with many common species which fly actively through the summer. The cells as a rule are made in burrows or tunnels in the ground or in hard clay banks. Andrena vicina, according to Emerton, digs a straight tunnel into the ground for a depth of several inches or more with short oblique galleries branching off from it. The earthen cells lined with mucus are filled with pollen and honey. This is all done in the latter part of April and early in May. The larvæ are full grown in less than five weeks, and the adult bees issue all through July and August. To this group belong the beautiful little bees of the genus Halictus, which are often metallic in color. They dig branched tunnels to a depth of from six to ten inches and are semi-gregarious in habit, a great many of the burrows often being found close together. Emerton has studied the habits of $H$. parallelus, and states that this bee has two generations each year.

The blunt-tongued burrowing bees live much like those bees which we have just mentioned, constructing their burrows in hard clay soil or in the cracks in stone walls, but the bees of the allied tamily Prosopidæ which have been called by Ashmead the obtuse-tongued carpenter bees, burrow into the twigs of bramble, elder and other shrubs, in which after extracting the pith, they construct their cells filled with pollen and honey. The Prosopi$\mathrm{d} æ$ used to be considered parasitic, but the English observer, Frederick Smith, discovered their true habits a good many years ago. Mr. R. C. L. Perkins has recently stated, however, that some of the Hawaiian bees belonging to his genus Neoprosopis are genuine parasites.

\section{Life History of a Bumblebee}

\section{(Bombus fervidus Fabr.)}

In our generalization on the habits of the true bees we said little about the bumblebees, preferring to let this typical life history speak for itself. The bumblebees belong to the group of social bees, although their communities are by no means as large or as perfect as those of the domesticated honey bee, nor in fact is the differentiation of the worker class so marked as with the honey bee. The workers, in fact, more nearly resemble the 
females and have few of the structural peculiarities which are so evident with the workers of the honey bee. The bumblebee worker stings severely and this fact makes the close study of their community life rather difficult. It is comparatively easy, however, to study a bumblebee's nest. Marlatt, in the Proceedings of the Entomological Society of Washington, tells how the boys in Kansas avoid the stings and gather the honey. He said that they (and he was one of them) were led to rob these nests more from the excitement caused by the danger of being stung than to secure the honey, which, in fact, was not only rank and unpalatable but in the early fall, during the haying season, was small in quantity. The method followed was to take a one-or-two-gallon jug, such as is commonly used to carry water to haymakers, fill it partly with water and place it, with the cork removed, within two or three feet of the nest. The bees were then thoroughly aroused by beating the nest, immediately after which the brave boys removed themselves hurriedly to a safe distance. The enraged bees would swarm out and begin flying about in widening circles to discover the enemy. The jug would at once attract their attention and numbers would fly about it and over its open mouth, which, by reason of the air set in motion by their wings, would give an answering roar to their angry humming. Excited beyond measure by this noise, the bees would fly at the mouth of the jug and one after another would pop into it - the noise produced by those within still further attracting those without-until all had entered. A second disturbance of the nest would serve to draw out and dispose of any of the remaining fighting worker-bees, after which the robbing of the nest was easy. After robbing the nest the water and bees in the jug were emptied out on the ground and the bees, although apparently drowned, would soon recover and start off to found new colonies which other boys would probably rob. In later years when Mr. Marlatt became interested in the collection and study of insects this method was employed with unvarying success in the examination of bumblebees' nests in order to secure parasites and the guest insects which inhabit these nests. This method seems to be a discovery of the western farm-boys, since the writer, although he robbed bumblebees' nests in central New York when a boy was never ingenious enough to invent such a capital method of avoiding stings. 
Bombus fervidus, also called Bombus borealis, is a species which is common in Canada and the northeastern United States with something of a southern and western range and is a fairly typical bumblebee. At the approach of winter the old colonies fail, the workers and the drones, or males, die and only a few fertilized females remain alive. These hide themselves away in protected places, pass the winter in a torpid condition and when spring comes each one starts out to found a new colony. She collects moss or grass and pollen, seeks some depression in the field and begins a waxen cell under the grass or moss. Old nests of field mice are frequently used for this purpose. In this cell, which is stored with honey intermingled with a small quantity of pollen, is laid an egg and the formation of another cell begins at once. Along in July the nest will be found to contain a queen with a large number of workers of various sizes, as well as eggs and larvæ in all stages of development. Interesting observations upon this species have been made by Mr. F. V. Coville, who, although a famous botanist, ought to have been an entomologist, judging from his study of this insect. The precise duties of the different sized workers, according to this observer, are not evident but in general the larger ones attend to the mending of the covering of the nest and to the bringing in of honey, while the smaller ones for the most part do the inside housework, the wax patching and the nursing of the young. He never saw this nursing, as a matter of fact, done by a large or even a mediumsized bee. The eggs are laid several together in cavities in a mass of wax in which, however, are many pollen grains. The larvæ after hatching remain encased in a shell of wax and soon become separated each from the other by a waxen wall. Here they are fed by a mixture of pollen and honey supplied them by a worker. One of the smaller workers, which Coville has called the nurse bees, collects nectar and then pollen, preparing the mixture, and then goes to one of the larvæ, which lie in circular form in their chambers, and injects the brownish, fluid mixture through a small opening previously made, usually by another worker. This is greedily eaten by the larvæ. Whether the larvæ of both females and workers are fed in the same manner and with the same mixture could not be decided, but it is known that in the honey bee the different kind of food influences the size and the function of the bees, a special food being used to develop queens. 
The larvæ when full grown spin a silk cocoon and transform to pupae, in which stage they remain from two to three weeks and then transform to perfect bumblebees. The bees emerge from the cocoon after gnawing a lid about its apex. As soon as the bee has left, the other workers cut away the upper half of the cell and remove the debris, and the part which is left furnishes a receptacle for nectar and honey as it is brought into the nest.

In early August, all the bees up to this time having been workers with the exception of the original queen, females, or queens, and males, or drones, begin to emerge. Within a few days both sexes leave the old nest and do not return.

The method adopted by Coville for the study of this species is an easy and convenient one and is worthy of description. A box about three inches deep and large enough to contain a nest (a good-sized cigar-box will do) was provided with a glass cover and a small hole was cut in the side. In this box in the early summer a nest taken from the field was placed and the aperture was closed for a day. The box was then fitted in below a window-sash so that the bees could come and go on the outside without annoying the observer, who remained in the room. In collecting the nest, which had been found during the day, the observer started for the field just before dark, after all the bees were in, provided with a cigar-box, a bottle of chloroform, a pair of forceps and a gauze-covered, wide-mouthed bottle. He approached the nest, poured a little chloroform over it, waited until the humming had ceased, opened the top of the nest, picked out the bees with the forceps and put them in the bottle, the nest with the "comb" being placed in the cigar-box. The bees revive after being placed in the permanent box, and the chloroform, if used moderately, does not kill the larvæ.

The study of the life of a.colony of bumblebees will be found to be a very interesting one, especially if observations are made upon the parasites and guest insects, or inquilines, which are frequently found in these nests. Many interesting points as to unimportant habits, especially as they bear upon the question of inherited instinct or intelligence, may be observed in this way. For example, these bees are very cleanly in their habits. Their fæces are always deposited in a particular place outside the nest.

Some of the guest bees frequently found in bumblebee nests belong to the genus Apathus, or Psithyrus, as it is now called. 
These bees resemble bumblebees so closely that it is difficult to distinguish between them and they live apparently in perfect harmony with bumblebees, but are lazy and use the food of the industrious bumblebees, both when adult and when in the larval condition. Bumblebees resent the introduction of one of these guest bees into their nest, but the intruder seems to have very pleasant manners for the alarm and resentment occasioned by his or her presence soon dies away and an amicable relationship succeeds. Whether the guest bee and its larvæ consume so much food (they undoubtedly bring in some themselves) that they endanger the health of the colony of bumblebees is a disputed point. The old idea was that they ate so much that the young bumblebees were starved to death, and it was upon this supposition that the writer in his youth wrote the following lines which perhaps will be accepted rather on account of their aptness to the present topic than on account of their rhythmical merit:

Oh! an Apathus sat on a Chrysanthemum A-cleaning her antennæ,

And she little thought of the Pyrethrum That would take her life away!

And there she sat, a-taking a rest, And smiled in a satisfied waý,

For she'd laid ten eggs in a Bombus nest And there'd soon be the de'il to pay.

For her offspring dear, her very first brood, Would hatch in a very short time,

And no trouble she'd have a storing up food, For she worked on the Cuckoo line.

Her young would hatch ere the young bumblebees, And the young bumblebees would die,

When the young Apathi would live at their ease And fatten like pigs in a sty!

So she sat in the sun, this wicked old bee, And scratched her tibiæ,

And chuckled inside in lazy glee At the business she'd done that day.

But the Chrysanthemum on which she sat Belonged to a neat old maid,

Whose plants were her pride (next to her cat), And that day she was out on a raid 
Against Aphids and slugs, with a Buhach-gun

Filled with Peters \& Milco's best,

And seeing the Apathus, just for fun,

She dusted her yellow vest.

How the cheat kicked as she fell on the ground!

And how she did buzz and hum!

But she never got well-she never "came round"-

Her fraudulent life was done.

From this little tale can a moral be drawnHow the bumblebee loafs not a bit;

But works all day from the earliest dawn, And thus 'scaped the death dealing hit?

This moral is good, but please don't forget Those eggs that the Apathus hid!

The Bombus is working and slaving yet, But it's all for the other one's kid! 


\section{WASPS.}

\section{The Solitary Wasps. (Super-family Sphecoidea.)}

To this group belong nearly all of those insects which are known as the solitary wasps, in contradistinction to the social wasps which form communities and live in nests, usually constructed of a paper-like substance, and lead very much the same socialistic life which we see in the social bees. The solitary wasps, in the main, form burrows, just as do the solitary bees, construct cells within their burrows and in the cells provide food for their larvæ. This food, however, is not the pollen and honey mixture which is found in the cells of the solitary bees, but it is other insects which have been stung and paralyzed by the mother wasp. To this super-family belongs a large assemblage of forms which comprise twelve large families, the habits of all being rather similar.

Nothing can be more fascinating than the study of the habits of the solitary wasps and no more readable book on a natural history topic was ever prepared, not even excepting the famous Natural History of Selbourne or the general volume of Kirby and Spence's Introduction, than that entitled, "On the Instincts and Habits of the Solitary Wasps," by George W. and Elizabeth G. Peckham, of Milwaukee, published as Bulletin No. 2 of the Wisconsin Geological and Natural History Survey. The Peckhams, already noted for their interesting work on the habits of spiders, and attracted to the study of solitary wasps probably through observing these creatures carry off spiders to stow away in their cells for their young have spent many summer days in close observation of these industrious, active and most intelligent creatures and have described their observations in the most charming style. They have entered into the lives of the solitary wasps and have shown them to be as interesting in their way as the much-more- 

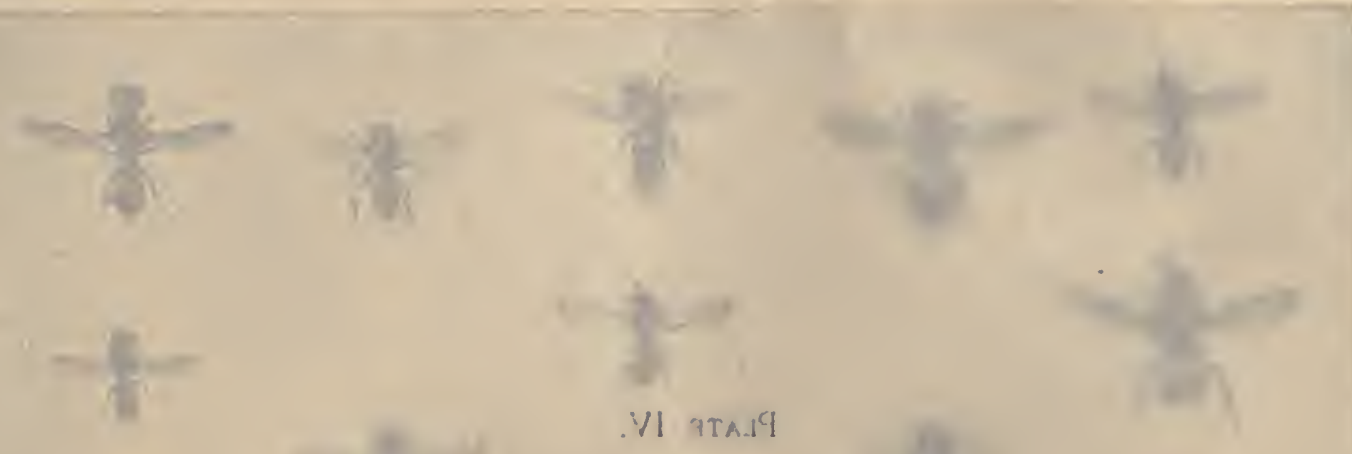

\section{I.A3G IIMA IUEAW}

asbiogusolex stiduggem or

\section{.14 4} गysinlad sibsmoh . Is supsint zobozzilsM .ss bortsts esbosoriqe .E musqunsssi muibinın .\& moilsrigm alingega pibritig s.bsrroh ds

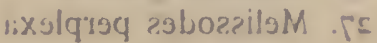

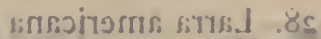

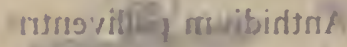
k. .05

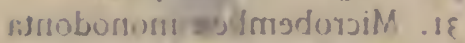

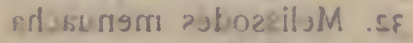
rmutyides rrubibitinh if siros,q̨s furials -

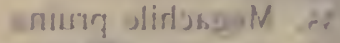

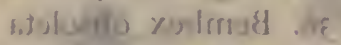

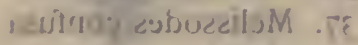
bLoqorsgrl sirnall .8f

is

$s$

$+1$

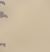




\section{Plate IV. \\ WASPS AND BEES}

FIG.

1. Crabro singularis

2. Agapostemon texanus

3. Andrena melliventris

4. Colletes thoracica

5. Epeolus lectus

6. Crabro interruptus .

7. Andrena texana

8. Epeolus concavus

9. Solenius scaber

10. Coelioxys dubitata

11. Nomada modesta

12. Melissodes rustica

13. Epeolus donatus

14. Xestocrabro 6-maculatus

15. Megachile frigida

16. Nomada maculata

17. Melissodes suffusa

18. Epeolus lunatus

19. Pseudocrabro chrysarginus
FIG.

20. Megachile xylocopoides

21. Nomada belfrayei

22. Melissodes obliqua

23. Sphecodes dichroa

24. Anthidium interruptum

25. Megachile mendica

26. Nomada grandis

27. Melissodes perplexa

28. Larra americana

29. Anthidium palliventris

30. Megachile bucephala

31. Microbembex monodonta

32. Melissodes menuacha

33. Anthidium zebratum

34. Monia apacha

35. Megachile pruina

36. Bembex obsoleta

37. Melissodes confusa

38. Monia heteropoda

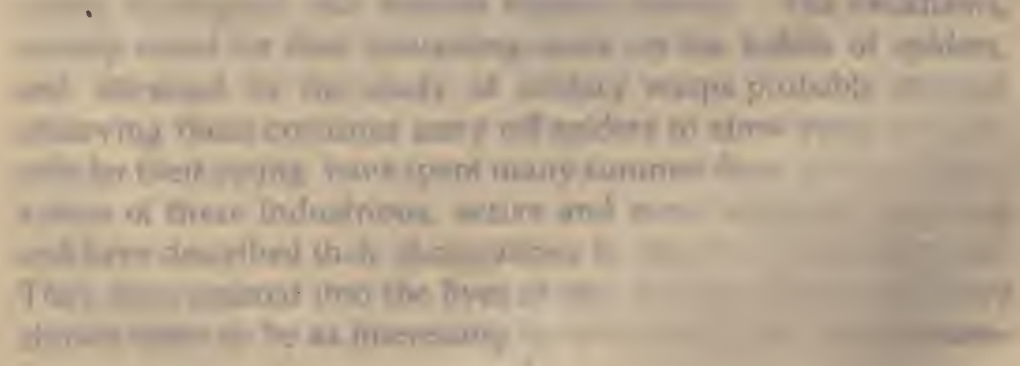




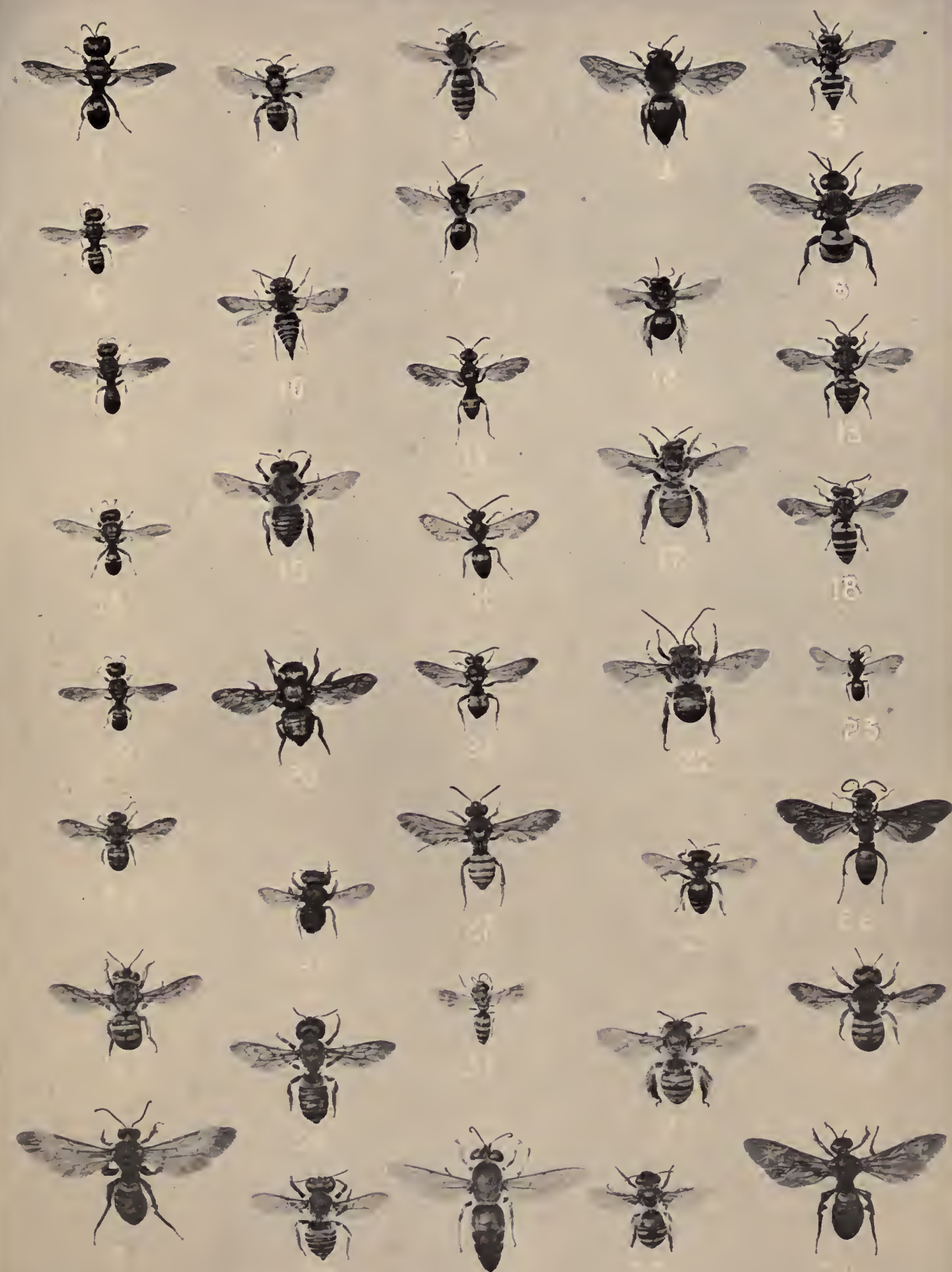


written-about bees and ants. Their ingenuity in capturing their prey, the care with which they conceal their burrows, the different individuality among members of the same species, and more astonishing than all, the actual use of improvised tools by these creatures, and many other points which the Peckhams have brought out and described make one wish to drop all other occupations and immediately begin the study of the solitary wasps.

The active little wasps of the family Oxybelidæ are known in Europe to burrow in the sand and to provision their nests with flies. European writers state that they do not paralyze the flies by stinging as with most other digger wasps, but that they crush the thorax just beneath the wings so as to destroy the great nerve ganglia at that spot. The Peckhams found one of our American species, Oxybelus quadrinotatus, burrowing in the sand and storing flies after the burrow was completed. There were sometimes a dozen flies in the same nest and all had the thorax crushed. This little wasp carries its prey by clasping the head of the victim with the third pair of legs, and flying thus, with the whole body of the fly sticking out behind her, she presents a remarkable appearance.

The wasps of the family Crabronidæ are usually larger, but still are rather small insects. They burrow in sand and clay and many of them make their burrows in wood-in palings, posts, stumps and decaying logs. They store in their cells a great variety of insects. Xylocrabro (Crabro) stirpicola was found by the Peckhams to fill its cells with different kinds of flies. Others store spiders and plant lice. The interesting observation was made by the Peckhams on the species just mentioned that it works at night and that "her manners were an agreeable contrast to those of the wasps that we had been watching through the day. The feverish excitement of their ways seemed quite in keeping with the burning heat of noon, while Crabro's slow and gentle movements harmonized perfectly with the long shadows of evening." One specimen was seen to work industriously for forty-two hours, toiling from three in the afternoon on July 27 , through that night and the day and night following until nine o'clock on the morning of the 29th. " "Surely," say the Peckhams, "she takes the palm for industry, not only from other wasps but from the ant and bee as well." Her burrow was thirty-nine centimeters in length and was made in the stalk of a raspberry or 
blackberry. The species which belong to the genus Trypoxylon and its close allies as a rule make use of the burrows of other insects. They sometimes store the insects which they collect in the deserted cells of a mud-dauber, and sometimes in the small round holes made by wood-boring beetles in old trees. Many of the species seem to store up plant lice but others capture and paralyze different kinds of spiders. There is a very important wasp which belongs to this group which does not occur in the United States but which I am trying to introduce. This is the Ampulex which preys upon cockroaches. A correspondent in Mauritius, D'Emmerez de Charmoy, of the museum at Port Louis, has promised to send me some of these creatures alive. He states that they enter the houses and prey upon the domestic cockroach. Perkins, quoted by Sharp, says that in West Africa cockroaches are stung by these wasps and placed in confinement in some such spot as a keyhole and in one case one was apparently prevented from afterward escaping by the wasp carrying some heavy nails into the keyhole. Rothney, also quoted by Sharp, says, "I saw two or three of these wasps ( $A$ ruficornis) collar a peculiar cockroach by the antennæ and lead it off into a crack in the bark, but as the cockroach reappeared smiling each time I don't know what was up." .

Numbers of other most interesting forms occur here, but those interested must go to the Peckhams' book and to Ashmead's interesting paper entitled, "The Habits of the Aculeate Hymenoptera," published in Psyche, January to May, 1894, and to the papers referred to by the latter author.

The genus Ammophila contains some of the most interesting forms in this family, and the habits of one or more species have been described in the most interesting way by the Peckhams, by the late William Hamilton Gibson, and Dr. S. W. Williston, and by Mr. Theodore Pergande. These are the insects which use tools. Their burrows are deep in the earth and are carefully concealed by the insertion of a stone, over which dry earth is scraped. When the female returns with a caterpillar, (and she travels unerringly to this concealed burrow for a long distance,) the earth and stone are removed, the caterpillar is carried down into the burrow and the mouth is once more concealed until another caterpillar is brought. The solicitude exhibited by the maternal wasp for fear her burrow may be discovered has been vividly 
described by all of the authors above mentioned. When the burrow is complete the female wasp has been observed to use a stone as a tamping iron to pack the earth into the mouth of the burrow. This is the tool use referred to. Dr. Williston states that he feared to publish his observation at first, since he might not be believed. Pergande noticed that after the burrow was completed and filled the mother wasp revisited the spot occasionally to satisfy herself that everything was secure against intruders and to make surety doubly sure by placing additional disguising objects over the already disguised burrow mouth.

It was in their study. of one of the Ammophilas that the Peckhams noticed a very distinct personality among the females which they watched at work. This personality was not of individual appearance but of such mental attributes as careful painstaking or carelessness and industry or laziness. One seemed to hurry tremendously and spent no time on non-essentials. Another was an artist, working for a long time on the closing of her burrow, arranging the surface with scrupulous care and sweeping away every particle of dust to a distance. Still another went to the extreme in carelessness, carrying the caterpillar in a very careless way and making a nest which was a very poor affair. Still a fourth was "the most fastidious and perfect little worker of the whole season, so nice was she in her adaptation of means to ends. so busy and contented in her labor of love, and so pretty in her pride of her completed work." In fact, they seem to have almost as much individuality as human beings and the result of these observations has a strong bearing on the discussion of instinct. Fabre, the French entomologist, who studied the same insects, considered that they were inspired by automatically perfect instincts which can never have varied to any appreciable extent from the beginning of time. Deviation from the regular rule, he thought, would mean extinction. The Milwaukee authorities, however, found that variability was the one unmistakable and ever present fact, and this variability existed in every particular, in the shape of the nest and in the manner of digging it, whether it is left closed or open, in the manner of stinging the prey and of crushing it, in the manner of carrying the victim, in the way of closing the nest and in the condition produced in the victim by the stinging, some dying and others living for a long time, though nearly motionless. All this varia- 
bility the Peckhams got from the study of nine wasps and fifteen caterpillars!

The mud-daubers of the genus Sceliphron (formerly and in most books placed in the genus Pelopæus) are among the most interesting members of this super-family. They build their nests of plain mud in sheltered places under the eaves of barns or even in the attics of houses. The food supply with which the cells are stored consists almost invariably of spiders, as many spiders being packed into one cell as the cell will hold. A single egg is laid upon the last spider packed in and the larva eats rapidly, consuming the abdomen of the spiders first and subsequently the rest of their bodies, eating both dead and living spiders. After the egg is laid and the nest closed up new cells are constructed by the same female.

A curious observation has been made by Schwarz in the Washington parks and gardens. He found that one of the Sphegid wasps-Chalybion coruleum-was engaged in capturing a certain kind of spider which hid itself so carefully that it was most difficult to find. Instead of spending her time in fruitless searching the wasp would entangle herself in the web of the spider when the latter would immediately dart out from her hiding place, thus exposing herself to the wasp who would easily free herself from the web and chase the spider to its retreat.

\section{Life History of a Digger Wasp}

\section{(Sphecius speciosus Say.)}

This large and ferocious wasp, which is in fact the largest wasp in what may be termed the eastern central states, that is to say, from southern New Jersey southward, is very abundant in Maryland, and Virginia and the mid-western states in the month of July, digging great burrows, usually in clayey soils, and storing in them for food the large dog-day Cicada, harvest-fly or lyre-man, or annual Cicada (Tibicen pruinosa Say). During the latter half of July, when the note of the Cicada is filling the air with its vibrations, this big wasp is often seen flying about the trees from which the song comes. Suddenly the regular note of the harvest-fly ceases and in its stead a distressing, discordant cry will 
be emitted. The wasp has caught its victim and with a quick sting has paralyzed it and thrown it into a comatose condition

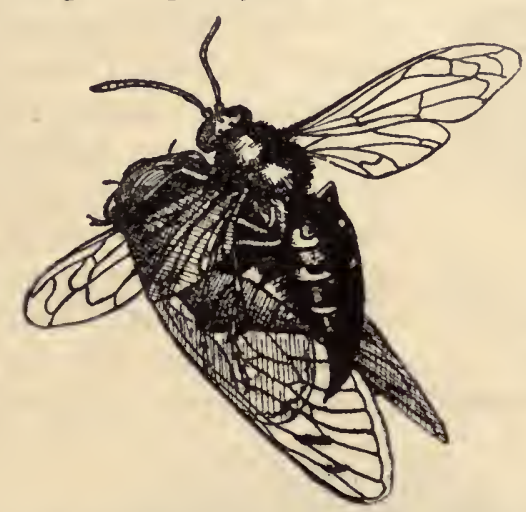

Fig. 7.-Sphecius speciosus Say carrying a Cicada to her burrow. (From Insect Life.)

from which it never recovers. In this preliminary struggle often both the wasp and its victim fall to the ground and then the wasp begins the laborious task of dragging its prey back up the tree straddling it with its long legs, although the Cicada is bigger than the wasp, and working sometimes for an hour or more until it reaches a height from which it can fly obliquely down to its nest at some distance away. In Washington,

the dryer and more elevated portions of the lawns, especially slight terraces along the sides of roadways, are preferred by this wasp for its burrows. Damp earth causes the Cicadas to mould after they have been stored in the burrow. The burrow itself consists of a gently sloping entrance extending for about six inches, when ordinarily a turn is made at right angles and the excavation is continued for six or eight inches farther, ending in a globular cell an inch and a half in diameter. Frequently a number of branches leave the main burrow at about the same point, each terminating in a round cell. Each of these cells contains, along in August, one or two Cicadas, and in those cells which contain two the larva of the wasp acquires a larger size, and, as the female wasp is a

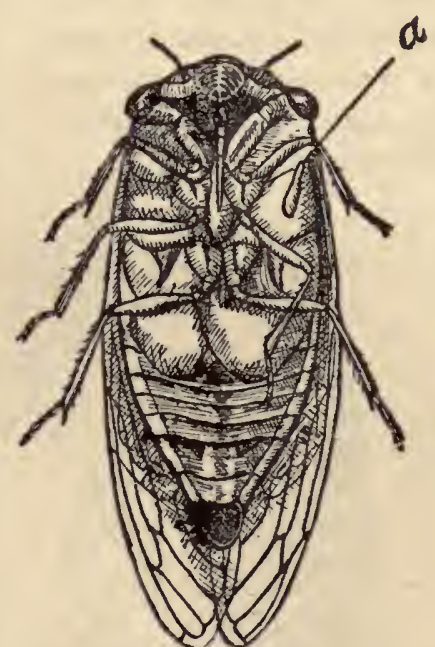

Fig. 8.-Adult Cicada bearing egg of the digger wasp, at $a$. (From Insect Life.) great deal larger than the male, Riley thought that one Cicada is required as food to develop a male and two to develop a female. 


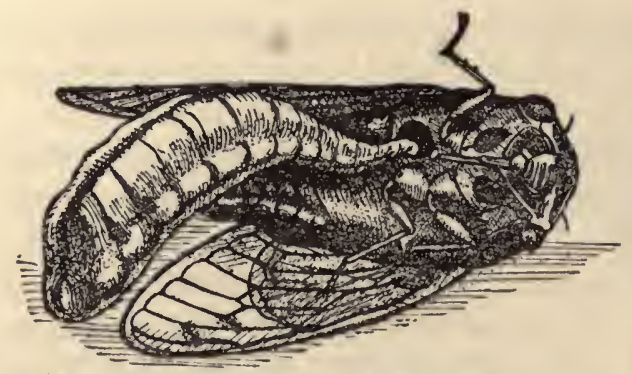

Fig. 9.-Cicada in burrow of Sphecius, with full grown larva of digger wasp feeding. (From Insect Life.)

The delicate, white, elongate egg of the wasp is laid under the middle leg of the Cicada and when it hatches the larva sticks out its head and begins at once to draw nourishment from between the segments of its victim. The egg hatches in two or three days and the

larva attains full growth in a week, or a little more. It feeds entirely from the outside and when full grown spins a white silken cocoon which is finished at the expiration of two days. The word silken is somewhat misleading, since it is mixed with much earth. When it is finished, about a dozen curious, porelike openings are seen in the side of the cocoon, the function of

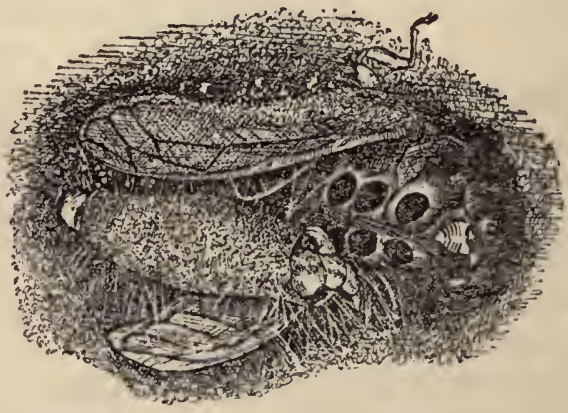

Fig. 10.-Larva of digger wasp spinning its cocoon. (From Insect Life.)

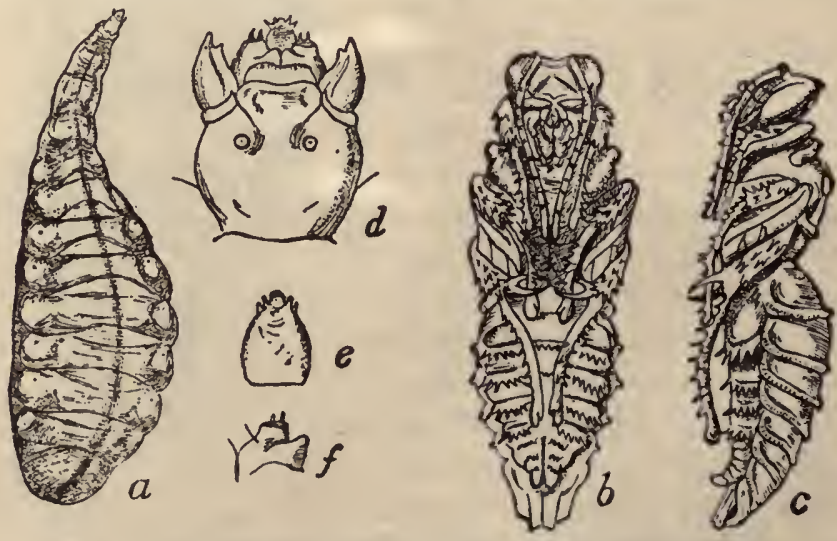

Fig. 11.-Sphecius speciosus: $a$, larva; $b$, pupa from below; $c$, same, from side-natural size; $d$, head of larva; $e$, labium of same; $f$, maxilla of sameenlarged. (From Insect Life.) 

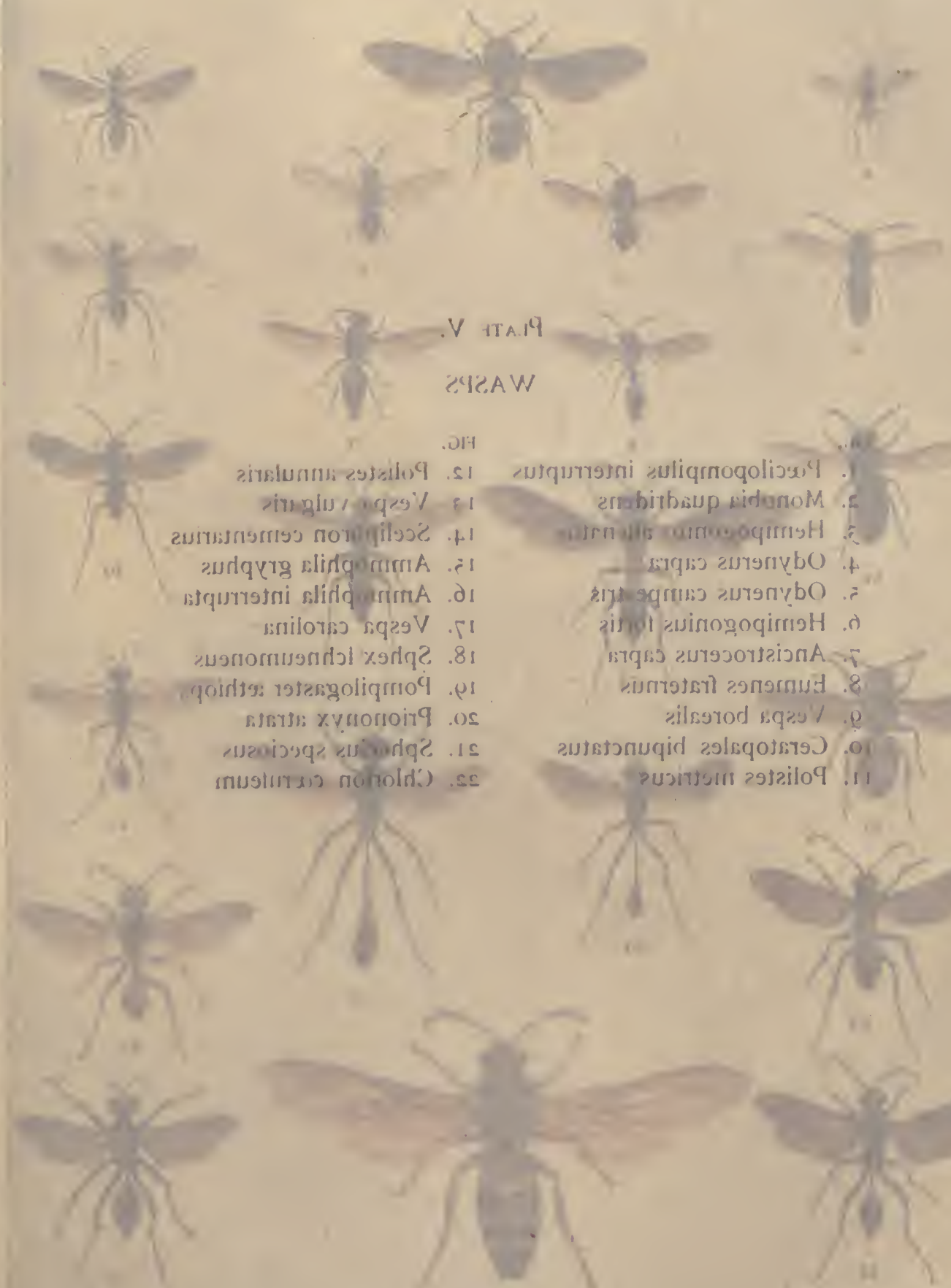

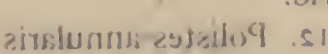
>irngles ongegy \&1

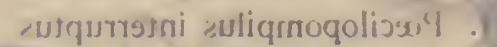

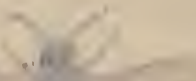
endqug colingonsma is

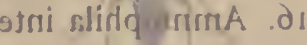

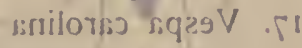
arabithsup sirfanoM if wisnalis rammogrmst

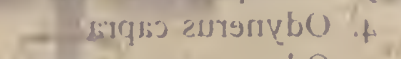

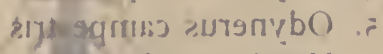
zisตl zusinoģoqirrioH . त

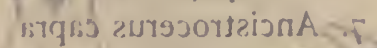

Lismatay zongrous \&

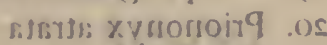

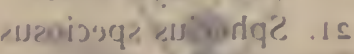
(nustursis numoldi) .s शilssyod sques/.p

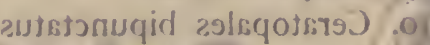
pusms
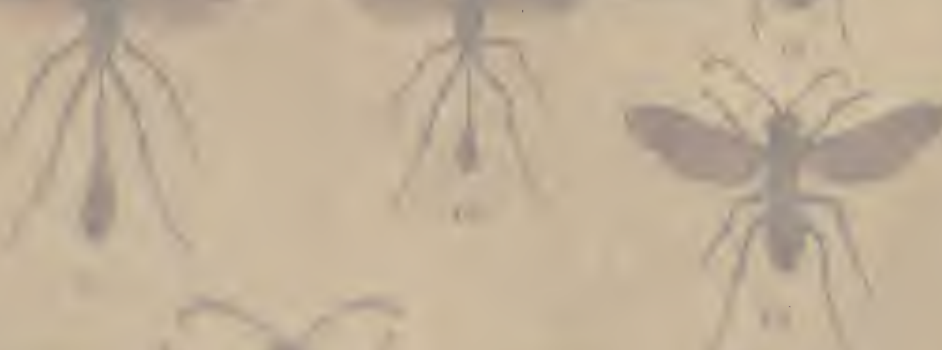


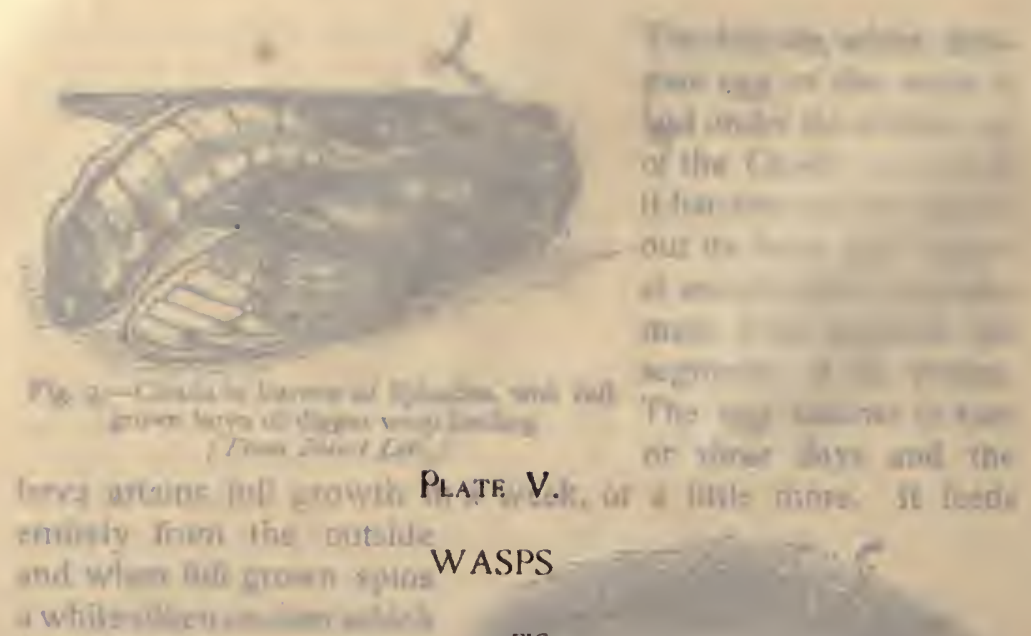

FIG.

1. Poecilopompilus interruptus

2. Monobia quadridens

3. Hemipogonius alienatus

4. Odynerus capra

5. Odynerus campestris

6. Hemipogonius fortis

7. Ancistrocerus capra

8. Eumenes fraternus

9. Vespa borealis

10. Ceratopales bipunctatus

11. Polistes metricus
FIG.

12. Polistes annularis

13. Vespa vulgaris

14. Sceliphron cementarius

15. Ammophila gryphus

16. Ammophila interrupta

17. Vespa carolina

18. Sphex ichneumoneus

19. Pompilogaster athiops

20. Priononyx atrata

21. Sphecius speciosus

22. Chlorion cœruleum
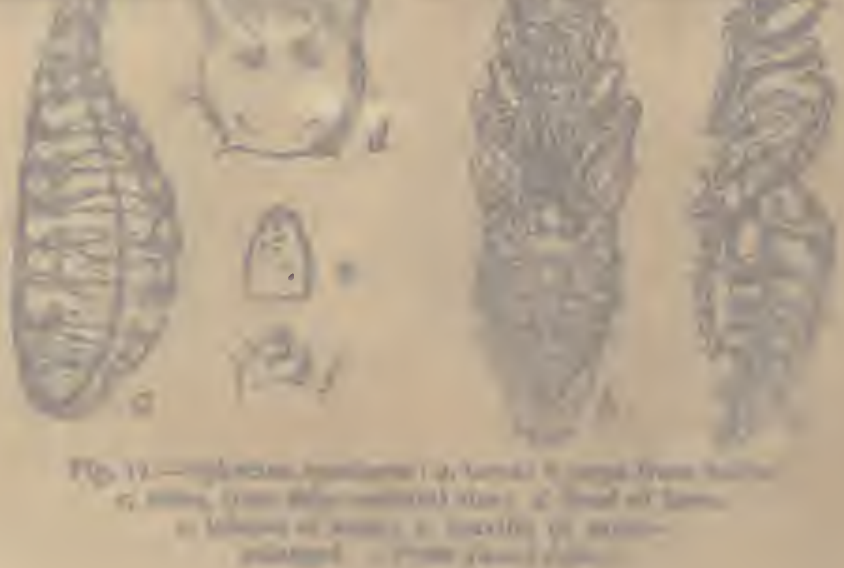


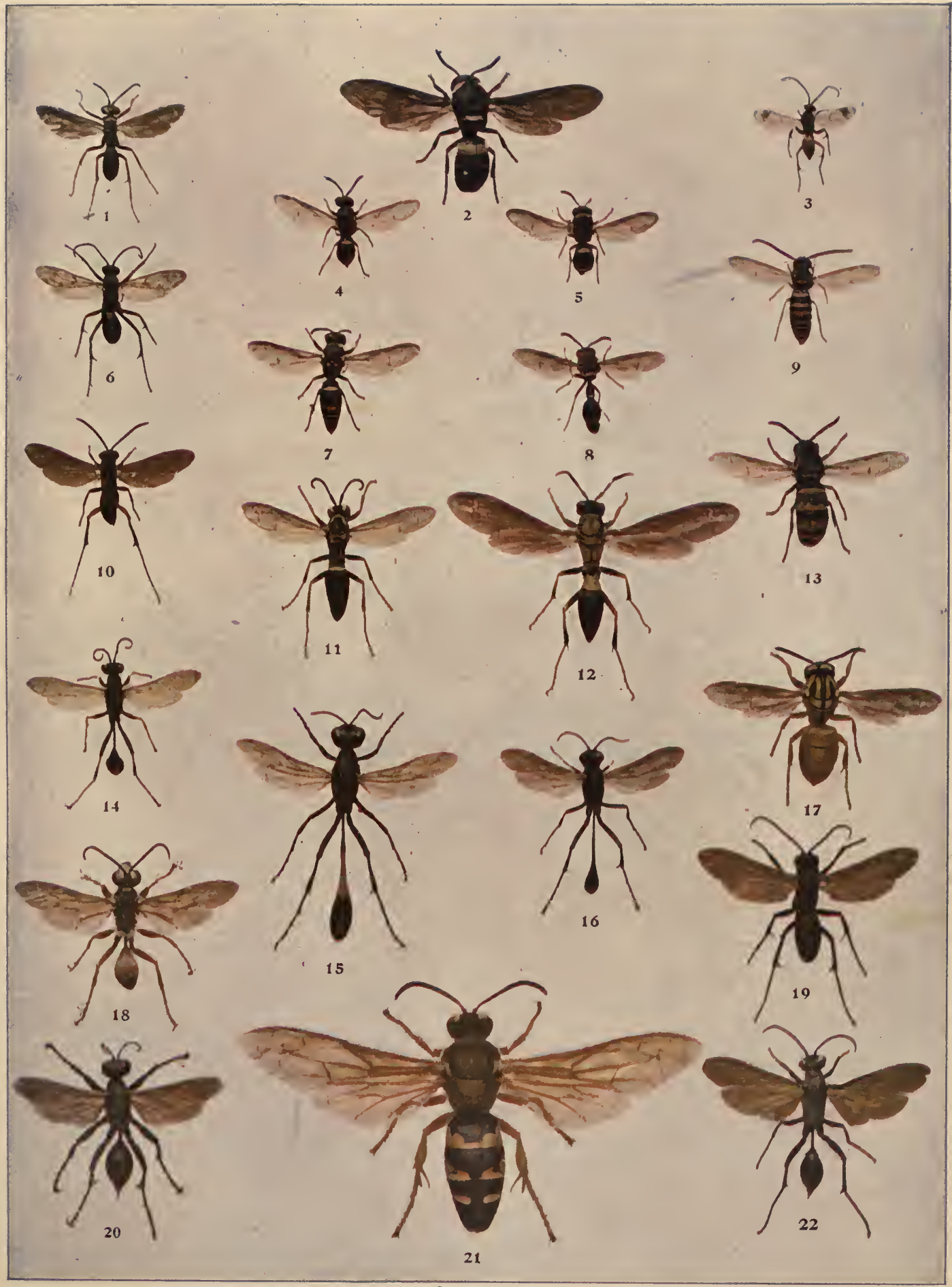





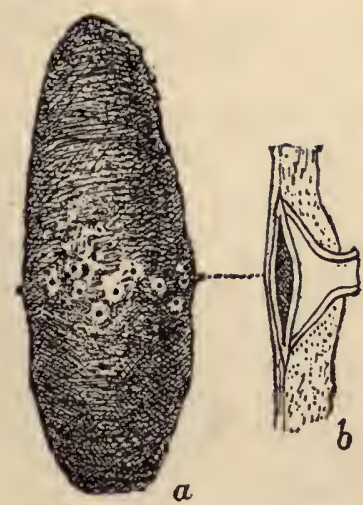

Fig. 12.- $a$, cocoon of Sphecius-natural size; $b$, enlarged section of pore. (From Insect Life.) which can only be surmised. Possibly they are for the respiration of the larva before it transforms to pupa and it remains in the cocoon unchanged through the winter, transforming to pupa only the following spring and shortly before the appearance of the true insect. When the adult hatches it gnaws its way out of the cocoon and so on up through the burrow to the surface of the ground, thus accomplishing its life-round in a full year. This big digger wasp is very abundant in mid-summer throughout the southern states. It stings severely, and, it is perhaps needless to say, should be avoided.

\section{The Social Wasps and their Allies. (Superfamily Vespoidea.)}

All of the social wasps belong to this super-family, and there are also brought into it a number of solitary wasps, as well as the so-called cuckoo flies of the old family Chrysididæ, and some strange insects that were formerly placed in the parasitic family Proctotrypidæ, but which are now made a family by themselves under the name Bethylidx. There are other parasitic groups in this superfamily, and it also contains the curious creatures known as cow-killers, cow-ants, solitary ants, or velvet ants of the family Mutillidæ, which have solitary habits, but closely re-

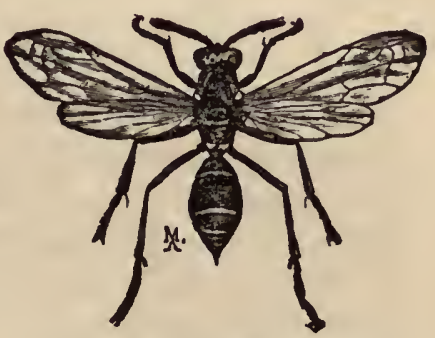

Fig. I3. Polistes pallipes. (After Comstock.) semble the true ants. All these forms, differing however widely in habit, feed for the most part in their early stages upon other insects or upon the remains of other insects. The only exception is a small group found mainly in tropical regions, which may be termed the honey wasps, of which the old Polistes mellifica of Say, which comes from Mexico, is an example. All of these 
honey wasps are now brought together into one genus, which is called Nectarinia.

The true social wasps, nearly all of which in the United States belong to the Genera Vespa and Polistes, form communities much like those of the social bees. Their communities, however, are not so perfect and are not so persistent as are those of the true honey bee or of the ants, but resemble more nearly those of the bumblebee. There is a form known as the worker, just as with the social bees, and the workers here, as in the other cases, are undeveloped females. Here also, as with the social bees, these undeveloped females or workers may lay' eggs which invariably produce males or drones.

Most of our social wasps make paper combs and nests. They are in fact the original paper-makers, and it is quite within the possibilities that the paper-making idea in the human species

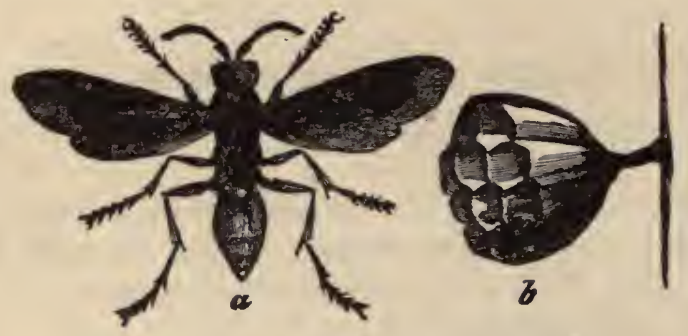

Fig. 14.-Spring nest of Polistes rubiginosus. (After Riley.) was gained from the observation of these insects. Their paper, however, is made from wood pulp-a late development in the human scale of ingenuity. They are particularly fond of scraping the frayed wood fibre from old weather-beaten fence boards and from the sides of old unpainted buildings. These wood fibres are macerated with their saliva, and a pasty wood pulp is thus formed with which the nests are constructed.

In our consideration of the preceding group of wasps, we said something about individuality among, these creatures and its influence upon theories of instinct. In the social wasp also at least one observation seems to show that individuals in the face of an emergency previously unknown to the species readily adapt themselves to new conditions. This observation was made by Miss Mary E. Murtfeldt, of Kirkwood, Mo., who found that in a vineyard where the grape clusters were inclosed in paper bags to prevent destruction by insects the social wasps found that the damp and rotting paper bags were perfectly adapted to their nest- 
building operations, and they thus used this paper already prepared rather than to take the trouble of manufacturing their own wood-pulp paper. This was a good thing for the wasps, but unfortunate for the vineyardist.

It is more difficult to study the economy of the social wasps than that of either the hive bee or ants. As most of the species are very irritable and possessed of venomous stings, it requires considerable tact and courage to investigate their habits closely.

The size of the communities varies at the season when they are largest, and according to the species, from a few individuals to many hundreds. In one large nest I counted 1,135 cells, and since, as will be shown, the worker cells are used two or three times in the summer, the colonies become very strong. This count was made with the large bald-faced hornet (Vespa maculata) but in some of the smaller wasps or yellow-jackets, like $V e s p a$ germanica, the cells are even more numerous. In one nest of the latter species, Mr. Marlatt tells me that he carefully estimated that it contained about fourteen thousand cells.

These communities of the social wasps, unlike those of the hive bee and of ants, but like those of the bumblebees, have only a temporary existence. On the approach of winter the males and workers perish and the fertile females crawl into such protected situations as crevices in walls or under the bark of trees and there pass the winter in a dormant state. At the opening of spring each surviving female founds a new colony. At first she performs the duties of both queen and worker; a small nest is made, eggs are laid in it, and when the larvæ hatch they are fed and cared for by the queen until they reach maturity. This first generation is composed entirely of workers. They relieve the queen of the duties which belong to them and from this time forth her only duty is to lay eggs. Sometimes she assists in the care of the young but not in the construction of the nests.

The essential part of a wasp's nest consists of a comb formed of hexagonal cells similar in form to the cells of a honey-comb. It differs, however, in several important respects from that of the hive bee: The material of which it is made is paper instead of wax; the comb consists of a single layer of cells instead of two, and the cells are usually vertical instead of horizontal. In some species the nest consists of a single comb with one or more stems 
holding it in place. In others the comb is enclosed in a spherical envelope of paper with a small opening at the bottom. In the more complicated nests there is a series of combs placed one below the other, and the whole is enclosed in a case made of many thicknesses of paper. The nests are enlarged by adding cells to the edges of the combs, and room is made for these new cells by rem Jving the inner layers of the envelope; the portion removed, however, not being wasted, but chewed up again by the wasps and added to the outside. The nests are suspended from branches of shrubs and trees or from fences and roofs. Some of the smaller species build their nests in the ground and under stumps. In each cell of the comb an egg is laid. Owing to the position of the ccinb, when the larva hatches it is suspended head downwards in each cell and holds its place while young by means of a glue and when old by its enlarged head end, which completely fills the open part of the cell. They are constantly nursed by the females and workers, and are fed with a brownish fluid which is prepared by the workers or females and consists of the juices of fruits and the remains of other insects which have been chewed up. When it gets full grown the larva spins a silken cocoon, the lower end of which serves as a cap to the cell, and then it transforms to a pupa. After the adult wasp issues the cell is cleaned out by the workers, and is used again by the queen, and, as the whole period from the laying of the egg to the emerging of the full-grown wasp is about a month in the northern states, a comb made early in the season serves for several successive generations.

As a rule the males and queens are not developed until toward autumn. At this time larger cells are made for the reception of the eggs which are to produce these forms. Thus if a large wasp nest be examined it will be seen that the top combs contain smaller cells and all of the same size, while the lower combs contain larger cells. This habit which the social wasps have of beginning at the top and building downward was what suggested to Gulliver's Laputan philosopher that they should begin by building the garrets of every house first of all and then gradually working down to the lower stories and the cellars.

The most notable of the social wasps in the United States is the bald-faced hornet ( $V$ espa maculata) above referred to. It builds the enormous paper nests commonly seen attached to the 
branches of the trees. The great Vespa crabro or hornet of England and Europe, which is the species most commonly referred to in English books of reference, was accidentally imported into this country many years ago and established itself in the vicinity of New York City. I believe it was first discovered there by Mr. James Angus. It has since spread and multiplied very slowly, and is not known to occur very far from the place where it was originally discovered. It is rarely found in parts of Long Island and New Jersey. There is also an unconfirmed report of its establishment near Charleston, S. C. This wasp, which is more yellow in color, builds preferably in the trunks of old trees.

The smaller yellow-jackets (Vespa germanica and $V$.cuneata) build their nests above ground, in or beneath stumps or stones, and in excavations in the open ground. The underground nests are frequently very large, sometimes more than the size of a halfbushel basket. Access to these nests is gained by a single (rarely two) small opening which leads directly from the center of the nests. The loose paper covering is not as tough and thick as that with the big hornet.

These large underground nests may be exterminated, when their location is discovered, by pouring in a little bisulphide of carbon. The time of the application, however, should be chosen, and it should be after dusk; otherwise, there is great danger of being stung. The colonies in the large hornets' nests are rather easily destroyed about nightfall by drenching them with a bucket of kerosene. This should be done late rather than early, because just at dusk a few late-returning workers will "raise Cain" over the destruction of their home.

The other common social wasps found in this country belong to the genus Polistes. They are the long-bodied, black wasps with folded wings and slender abdomens. They are frequently found in houses in the autumn looking for places to pass the winter.

The nest of the Polistes wasps consists of a single comb without any envelope. They are found commonly in country barns, and are also attached to bushes and to the lower surfaces of stones which are slightly raised from the ground. They are generally horizontal in this country, but European species build their combs vertically. Polistes feeds upon caterpillars and also vegetable material as well, and its habits in other respects are very much like those of the other social wasps. 
Mr. F. H. Chittenden tells me that he thinks one of these Polistes wasps was responsible for the destruction of the cabbage caterpillars in the center of a large cabbage field near Washington last summer. The wasps would hover about a plant and then alight and walk about it, but finding nothing would continue to the next plant, and so on to the next. In the sunny center part of the field the cabbage caterpillars were exterminated, but in the shady portions next a patch of woods they were present in great numbers. Wasps do not see well. They find their prey more by a sense of touch than by a sense of sight, and as they prefer the sunshine they unconsciously ignored the abundant caterpillars in the shade.

There are tropical social wasps, most of them belonging to the genus Polybia, which build enormous nests. It is said that the nest of a Ceylonese wasp reaches a length of six feet, and with a common South American form the paper is so thick and hard that it resembles thick pasteboard, while the outer layer is so fine in texture that one can readily write upon it with ink and a fine pen.

The solitary wasps of this super-family, although differing in structure, resemble greatly in habits the solitary wasps of the super-family Sphegoidea. There is one large family known as Pompilidæ, of which we have many representatives in this country. All of these wasps whose habits are known prey upon spiders. More than a hundred species occur in the United States, and most of them dig burrows in the ground, some of them, however, using readily natural burrows and those of other insects. Some of them dig their burrows before they catch their spiders, and others catch the spiders first; and one species has been seen to carefully hang its spider on the branch of a plant where it would not be disturbed by ants while the burrow was being made, occasionally visiting it in the intervals of work to find out whether it was safe. The habits of several Pompilids have been studied by Mr. and Mrs. Peckham. There is a famous wasp of this family which in the Southwest is known as the tarantula-killer.

The wasps or the family Eumenidæ are known as potterwasps, and store up caterpillars, saw-fly larvæ, and the larvæ of beetles. They form globular cells of clay or sand which are attached by a small pedestal to some twig. They are filled full 


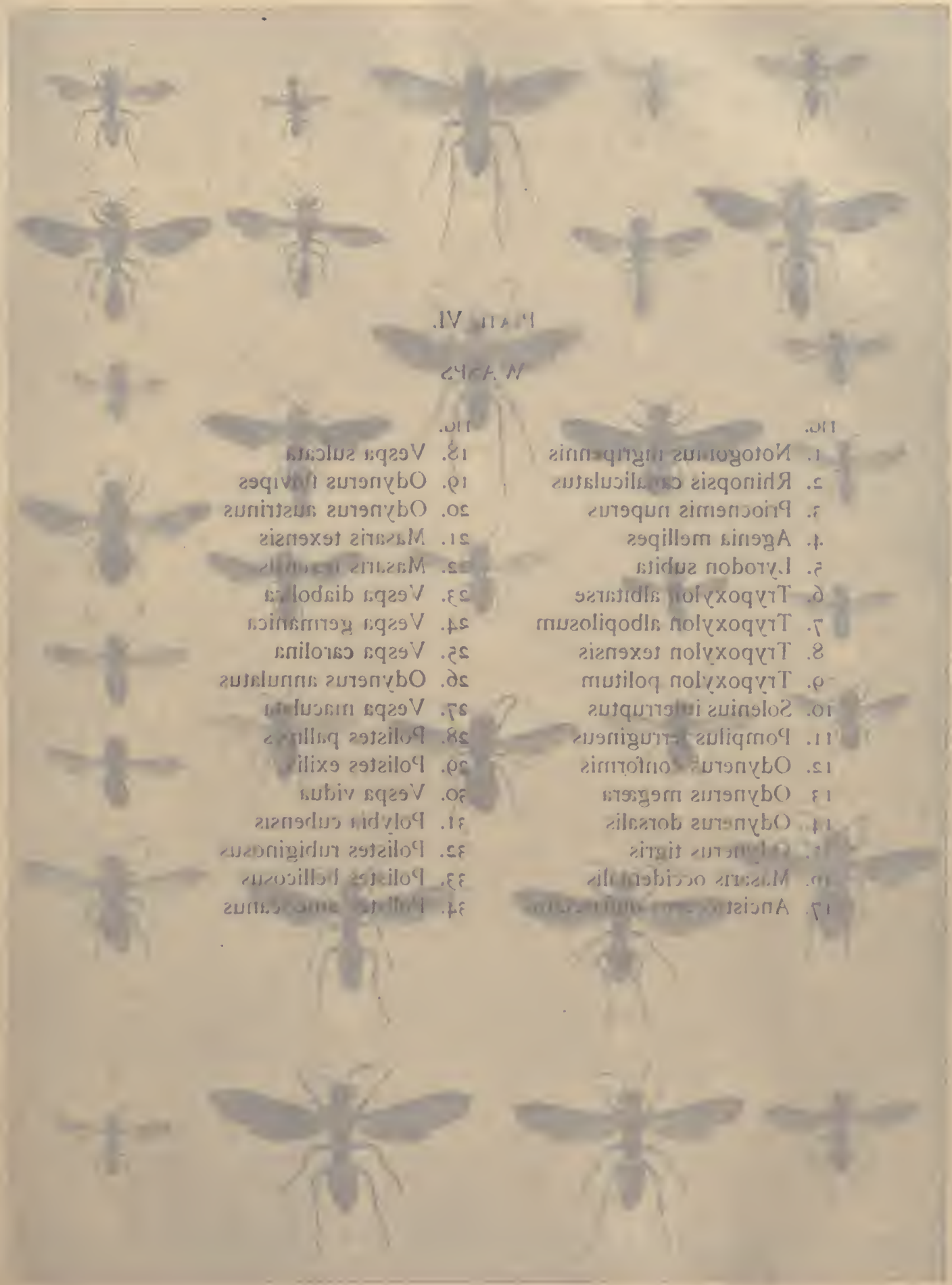


FIG.

1. Notogonius nigripennis

2. Rhinopsis canaliculatus

3. Priocnemis nuperus

4. Agenia mellipes

5. Lyrodon subita

6. Trypoxylon albitarse

7. Trypoxylon albopilosum

8. Trypoxylon texensis

9. Trypoxylon politum

10. Solenius interruptus

11. Pompilus ferrugineus

12. Odynerus conformis

13. Odynerus megæra

14. Odynerus dorsalis

15. Odynerus tigris

16. Masaris occidentalis

17. Ancistrocerus unifasciatus
FIG.

18. Vespa sulcata

19. Odynerus fulvipes

20. Odynerus austrinus

21. Masaris texensis

22. Masaris texensis

23. Vespa diabolica

24. Vespa germanica

25. Vespa carolina

26. Odynerus annulatus

27. Vespa inaculata

28. Polistes pallipes

29. Polistes exilis

30. Vespa vidua

31. Polybia cubensis

32. Polistes rubiginosus

33. Polistes bellicosus

34. Polistes americanus 


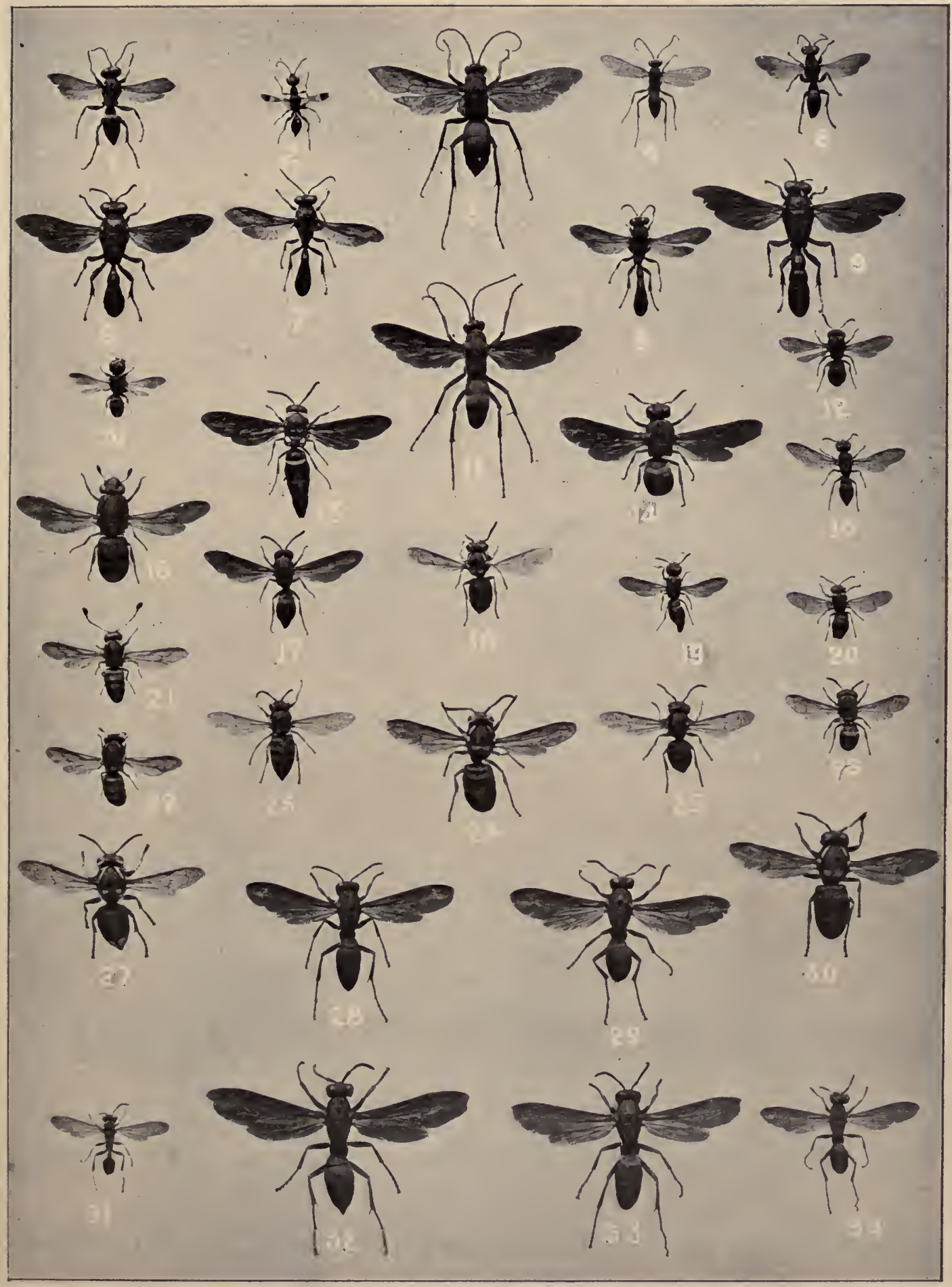



of caterpillars in just the same way that the mud-daubers fill their cells with spiders, and a single egg is placed in each cell. Prof. O. T. Mason says that certain beautifully shaped Indian vessels and baskets have precisely the form of these cells, and he thinks the observant aborigines may have deliberately copied the insect design.

There is an interesting genus in this group known as Odynerus. These are

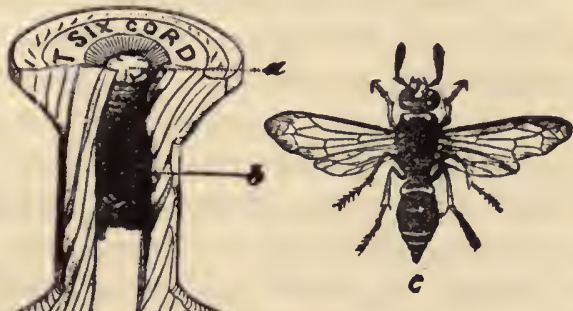
small active wasps, usually with one or more yellow bands. They were probably originally borers, but are most adaptive
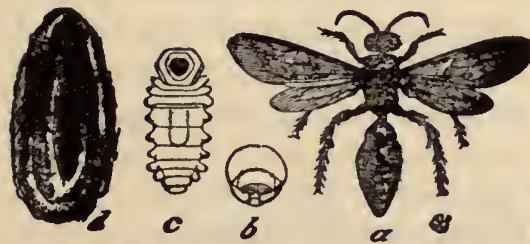

Fig. 16. -Tiphia inornata. (After Riley.) in their selection of places in which to make their cells. They use the old burrows of different bees and wasps, and are fond of using old muddaubers' cells. Ashmead found one species in Florida making its cells in the lock of his front door, and in old holes in a board fence and in old oak galls. Walsh found one building its cell in the cavity of a discarded spool. These wasps also sting caterpillars and store them in their cells.

The insects of several of the families, although resembling in general appearance the other wasps, are probably parasitic in their habits. These are the Sapygidx, the Scoliidæ, the Myzinidæ, the Tiphiidæ, all well represented in this country, and the

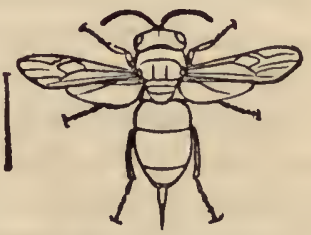

Fig. 17.-Chrysis sp. (After Packard.) curious Thynnidæ of Australia, South America and Africa. By parasitic we mean that their larvæ feed upon or within the living insects instead of such as have been paralyzed by the sting of the parent, or which are already dead. The Tiphia wasps are parasitic upon the big white underground grubs which are the larvæ of the May beetles or June beetles, and the larva of Scolia has been found in Europe within the body of another beetle, and 
Ashmead has found an American Scolia preying upon the larva of still a third beetle.

The so-called solitary ants, of the family Mutillidæ, are very common in portions of the United States. Most of them are clothed with hair, which is frequently bright-colored-in some of them being bright red-and on account of the velvety appearance which this hair gives them they are sometimes called velvet ants. In this group there is admirable opportunity for the study of life histories, since comparatively little is known about the way these insects live. They are no doubt parasitic in the nests of bees, and in Europe one species is known to live in the larval state feeding upon the larvx of a bumblebee. Schwarz, in this country, reared one of them from the cells of a burrowing bee, Riley another from the cells of another burrowing bee, and Davidson from an anthophorid bee.

Many strikingly beautiful insects belong to the family Chrysididæ. They are called cuckoo flies by the English writers, and goldwespen, or gold wasps, by the Germans. The colors are usually brilliant metallic green or blue, and the abdomen is frequently tipped with red. The larger species reach the length of half an inch or more, but the commoner forms in the United States are small insects, seldom reaching three-eighths of an inch in length. They are rather stout-bodied insects, and are readily distinguished from the slender wasps of the preceding groups.

Careful studies of the economy of any of our North American species are greatly needed. Walsh reared Chrysis carulans from the cells of one of the potter wasps (Eumenes fraterna), and Ashmead has seen one of them entering the burrows of a Trypoxylon, while he reared two species from the cells of a mud-dauber and one from the cells of an Odynerus. They are, therefore, either parasites or guests in the nests of wild bees and wasps, and are probably parasites rather than inquilines. In Europe some species of the genus Cleptes are true parasites on saw-fly larvæ. There is a curious confusion sometimes in an Odynerus cell, for a Trypoxylon will enter one carrying its own store of food with it, and closing the entrance against the return of the female Odynerus; then comes along a Chrysis and lays an egg, from which hatches a larva which devours the stores of the Trypoxylon. The larva of the cuckoo fly is said to transform without cocoon to a pupa, and in this state to pass the winter. 
The parasitic family Bethylidæ, which Ashmead has transferred from the Proctotrypoidea to the Vespoidea, is a group of small insects. The family Trigonalidx, now placed here, but formerly placed near the lchneumon flies, is also parasitic; they live parasitically in the nests of Polistes and Vespa, agreeing in habits with the Sapygidx.

The Bethylids are all, so far as we at present know, parasitic upon caterpillars and upon beetle larvæ, usually upon very small larvæ. Haliday, the Irish entomologist, many years ago, wrote an interesting account of the parasitism of some little Tineid larvæ by a species of Bethylus; but in this case the parasite was observed to drag its little caterpillar victim into a hole in a reed. Possibly this fact had much to do with the original suggestion, which came from Haliday, that the Bethylidx should be placed nearer the wasps than with the true parasitic Hymenoptera. In the typical life history which follows, however, we will see that members of this family are true parasites.

\section{Typical Life History}

As has just been shown, the habits of the insects of this great group are so diverse that no one life history could be considered as in any way typical of the whole group. As a matter of fact, the proper and complete study of no one American species has as yet been made. Many of these insects are everywhere to be found, and life histories of surpassing interest and of much novelty await the first careful person who will care to devote the necessary time to this study. Of course a great deal is known about the general economy of our social wasps and interesting studies have been made by the Peckhams and others on some of the solitary wasps which belong to this super-family, as well as to the Sphecoidea; but it is the parasitic forms, especially of the Scoliidæ, Myzinidæ and Tiphiidæ, which offer great opportunities. So do especially the Mutillidæ and the Chrysididæ. Of one of the Bethylidæ, 1 am fortunately able to give some account, since it has been studied with care in my laboratory by Mr. August Busck, from whose unpublished notes the following interesting story is drawn. 


\section{Life History of a Parasitic Wasp (Lalius trogodermatis Ashm.)}

When Mr. Busck was making some studies for me in the summer of 1897 , on the life history of the tussock moth, he made the interesting discovery that the egg masses of this famous shadetree defoliator were sometimes eaten by the larvæ of certain dermestid beetles which are ordinarily known as museum pests, feeding upon skins and furs, stuffed birds and pinned insects, and which, although known to feed upon dead and dry animal matter, were hardly to be suspected of eating living animal matter. But we found (and this is by the way) that these museum pests were really destroying the sound eggs of the tussock moth. This interested us so much that egg masses with dermestid larvæ were brought into the insectary for most careful observation. Then it was found that with the dermestids had also been brought in a most interesting parasite which proved to be Lalius trogodermatis-a Bethylid. The Lælius is a little, black, slender, active, fourwinged fly; and the female, when it finds one of these dermestid larvæ, at once jumps upon its back and clings firmly, in spite of the struggles of the victim. As soon as the poor beetle larva quiets down a bit, Lælius places herself crosswise over the thorax and, curling her abdomen around under the side, inserts her sting just behind the second or third pair of legs, paralyzing the dermestid instantly, the sting apparently having entered one of the large thoracic nerve ganglia. Then the parasite relaxes its hold and begins pulling the legs and hairs of its victim with its mandibles, its antennæ vibrating in a contented manner. The pulling of the legs is evidently an attempt on the part of the parasitè to see if the stinging has done its work with perfect effect. Having satisfied herself by all sorts of tests that the paralysis is complete, she proceeds to lay an egg, attaching it to the skin of the dermestid on the under side of the body, first pulling out the hairs carefully so that the egg can be firmly attached to the skin. If in the course of this operation, or even before the egg is laid, another dermestid larva comes within her range of perception, she leaves the first victim, mounts and stings the second, or even a third or a fourth, each time testing the completeness of the paralysis with the utmost care. Before attaching the egg she thrusts her sting into the spot several times, apparently making an orifice through 
which the larva, after hatching, can thrust its head, or which it can at least enlarge easily so as to insert its head. The egg is oval, soft, translucent, about a third of a millimeter long, apparently has no peduncle, and is not very firmly attached to the skin of the dermestid. From one to six eggs are laid upon a single victim. In a few days the larvæ hatch, yellow in color and very indistinctly jointed. Immediately on hatching, their mouths are closely applied to the skin of the paralyzed dermestid and they begin to grow, not so rapidly as the somewhat similar Euplectrus, which will be described in a succeedingchapter, but still rather rapidly, reaching full growth in from ten to fourteen days. When full grown, a group of these larvæ with their heads inserted at

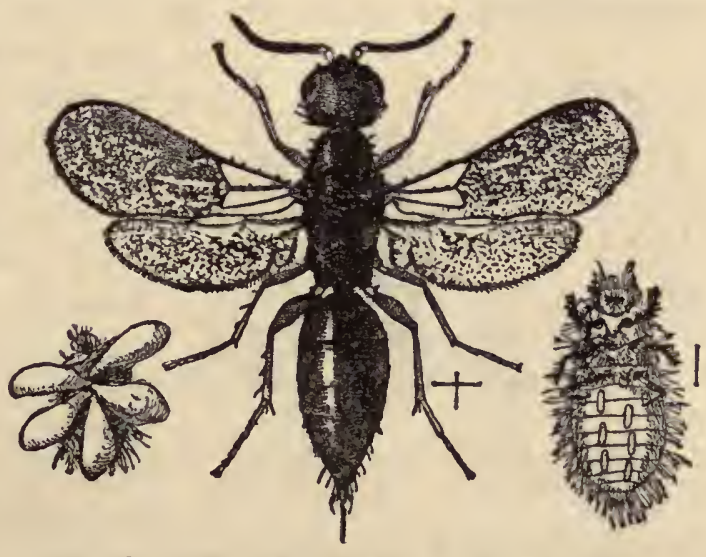

Fig. 18.-Lalius trogodermatis: dermestid larva at right, showing eggs of parasite; fullgrown parasite larvæ at left; adult parasite in centre (original).

a central point, look not unlike the petals of a curious flower growing out of the shriveled dermestid larva. When only one Lælius larva occurs upon a host it sometimes enters the sucked-dry skin and spins its cocoon within it, but generally the white, rather loose, silken cocoons are spun outside the skin of the dermestid, which shows large holes where the parasitic larvæ have been at work. After the cocoon is formed the larva remains within it, motionless, for ten days or more, finally transforming to a white pupa with red eyes. This white color changes gradually to black and in eight to ten days further the adult fly issues from the end of the cocoon through a ragged hole. The entire life duration of a generation, in the summer-time, is from thirty to thirty-five days and the insect passes the winter as a larva in its cocoon, the cocoons of the winter generation being firmer than those of the summer brood and darker in color. Mr. Busck observed that a female will paralyze all dermestid larvæ with which it comes in 
contact, but it does not use them all for egg-laying. The sting does not kill the dermestid larva but simply paralyzes its motor nerves. It remains alive, as is evident from the fact that its alimentary canal continues to work and excreta are emitted from the anus. In spite of all the precautions taken by the mother Lælius to assure herself of the complete paralyzing of her victim, occasionally this is not complete and after a few days the dermestid larva molts. In such cases, of course, the eggs of the parasite perish. Mr.

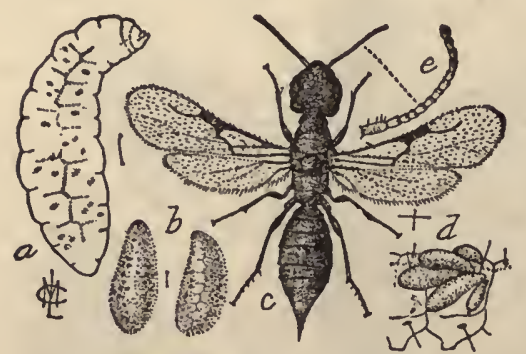

Fig. 19.-Goniozus sp., a parasite of the Codling moth. (After Marlatt.)

Busck found the phenomenon of parthenogenesis to occur with this insect, a virgin female in one instance having laid eggs which hatched and the larvæ were reared to the adult condition, all of the individuals, as was quite to be expected, being males. The volume of the eggs laid by a single female is surprising. It lays more than twice its bulk in eggs. The female drinks water greedily and possibly takes other food. In confinement it will perish if left without water.

An undescribed Bethylid of the genus Goniozus in Kansas has a similar life history, according to Popenoe and Marlatt, but this one is of greater economic importance since it attacks the larvæ of the codling moth-the worm so commonly found in apples. Just such a cluster of parasitic larvæ as is described above was found by Marlatt upon an apple-worm in the interior of an apple. 


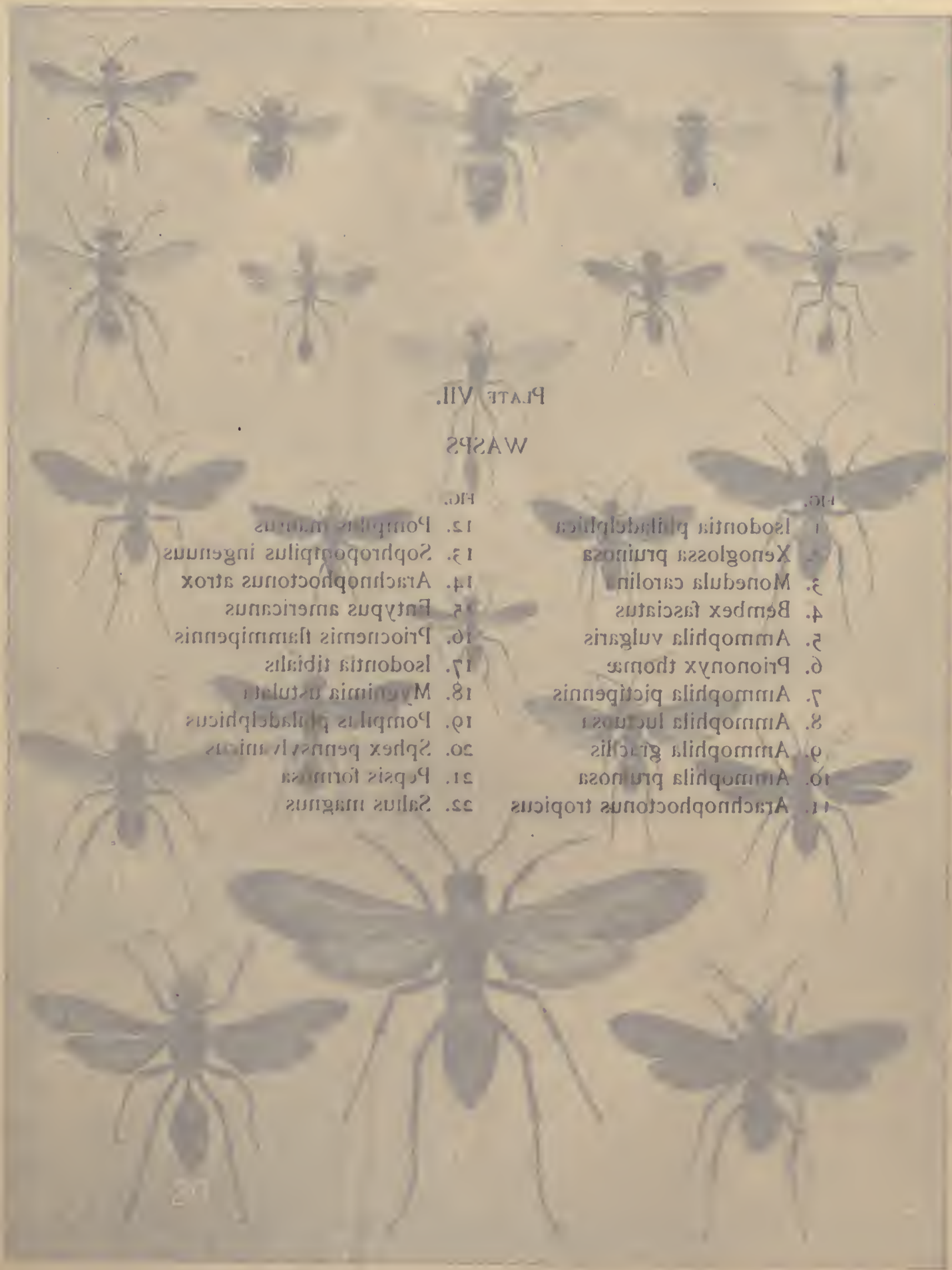




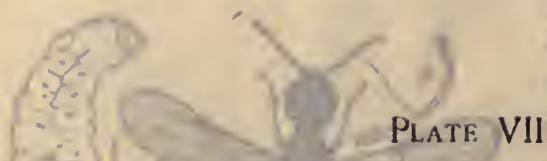

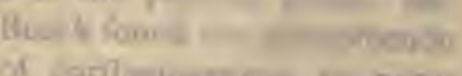

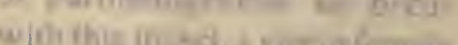
$\therefore=$ WASPS

FIG.

1. Isodontia philadelphica

2. Xenoglossa pruinosa

3. Monedula carolina

4. Bembex fasciatus

5. Ammophila vulgaris

6. Priononyx thomæ

7. Ammophila pictipennis

8. Ammophila luctuosa

9. Ammophila gracilis

10. Ammophila pruinosa

11. Arachnophoctonus tropicus
FIG.

12. Pompilus maurus

13. Sophropompilus ingenuus

14. Arachnophoctonus atrox

15. Entypus americanus

16. Priocnemis flammipennis

17. Isodontia tibialis

18. Mygnimia ustulata

19. Pompilus philadelphicus

20. Sphex pennsylvanicus

2I. Pepsis formosil

22. Salius magnus 


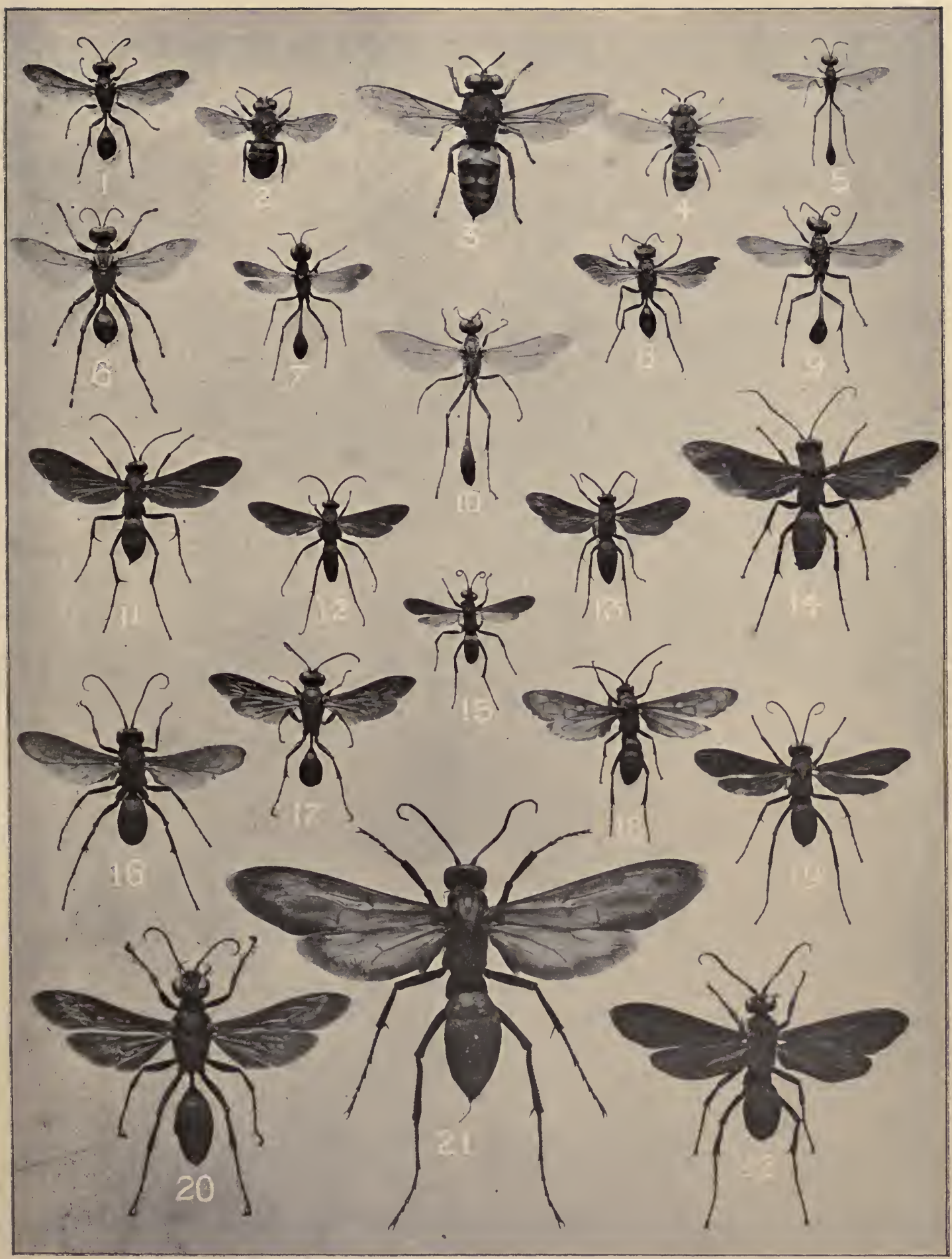





\section{THE ANTS}

\section{(Super-family Formicoidea.)}

All of the true ants belong to this group. They are all very characteristic in appearance and there are very few other insects which can be mistaken for them, except possibly the so-called cow-ants, or velvet ants, of the family Mutillidæ (super-family Vespoidea), or the so-called white ants, which belong to an entirely different order and which really should not be called ants, if popular names are to coincide at all with scientific classification. The true ants, however, as shown in the synoptic table, are readily distinguished from all other Hymenoptera, aside from their general and more characteristic appearance, by the one or two swellings on the petiole of the abdomen.

We have seen with the bees and with the wasps that while some species are social and live in communities, others are solitary in their habits. With the ants, however, it is different; all species

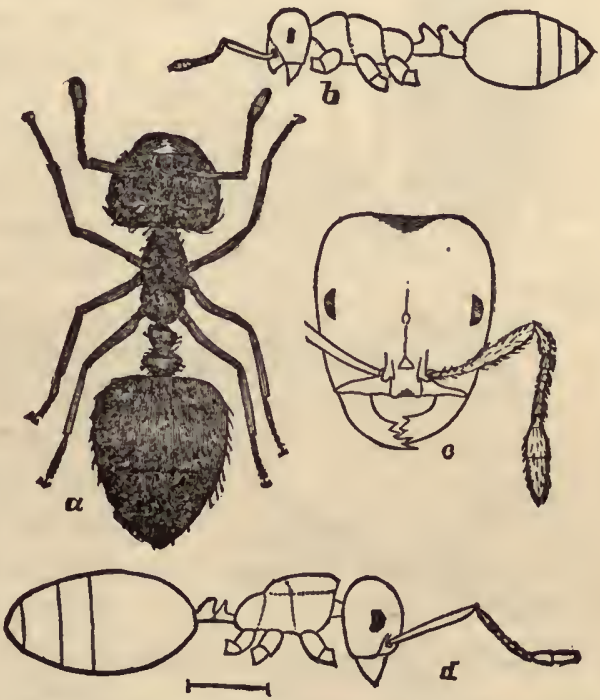

Fig. 20.-Solenopsis xyloni. (After McCook.) live in communities and are social insects. Social life with certain of the ants is carried to the greatest extreme known in nature. The differentiation into different castes or forms of individuals of the same species is carried to a much higher extent than with the bees and the wasps. We have seen, with the bumblebees; the beginning of a separation into two classes of workers, that is to 
say, there are large workers and small workers which have ditferent functions in the community. With the ants this becomes almost the rule and when we consider all ants we find that there may be eight distinct castes, not all in the same individual species, though five may occur in the same species. There are not only the ordinary winged males and the ordinary winged females, the large workers and the small workers (workers major and workers

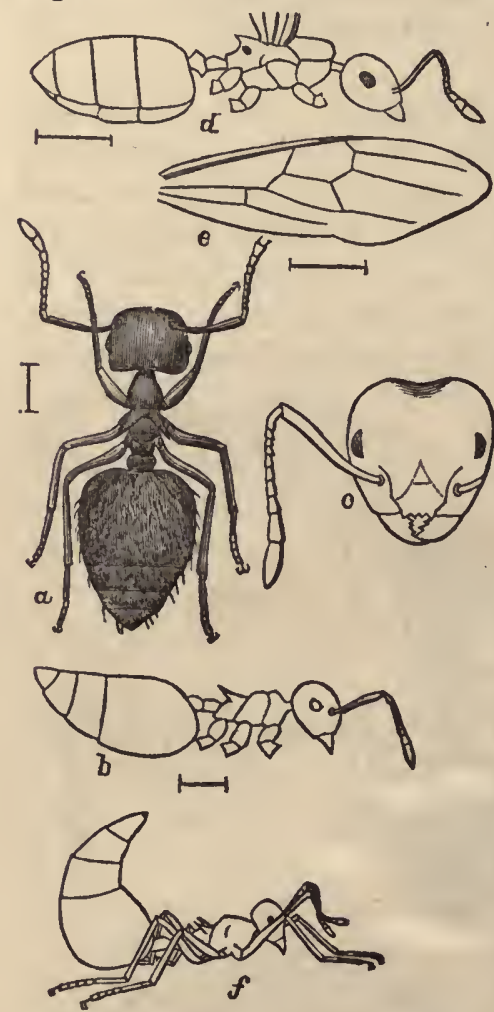
minor, as they are termed), but with certain species there is a well developed and well adapted caste which does the principal fighting for the community and which is known as the soldier. The workers, as with the bees, are simply infertile and undeveloped females. They never have wings. The true females have wings, but after the nuptial flight they are discarded and only at certain times in the year are winged individuals seen in an ant community. The true workers, when examined as to their internal anatomy, seem to differ principally from the true females in that they lack the receptaculum seminis. There are, however, with certain ants forms which never have wings and which in the female sex possesses a receptaculum seminis, and there are correspond-

Fig. 21.-Cremastogaster lineolata (After McCook.) ing wingless males, that is, males which never develop wings. These are, then, sexually competent males and females, neither of which ever develop wings. This adds two more structural forms to the possible number of forms in a community, and they are called ergatoids. This is a term which will come more frequently into use and should be mentioned. It applies to both sexes, but the females are said to be ergatogynous and the males are said to be ergatandrous. The eighth possible form occurs. 
exceptionally and seems to be intermediate between female and worker.

The community life of ants and their industry, thrift and supposed foresight have been the subject of observation and comment since the earliest times. The biblical references are familiar to all and the old ideas are well formulated in part in La Fontaine's charming fable of the Grasshopper and the Ant. Milton, Prior and many other poets have sung praises of the ant, and it is safe to use the trite expression and say that it is "fabled in song and story." In "The Royal Dream Book," an English north-country chapbook, it is said that "to dream of ants denotes that you will live in a great town or city, or in a large family, and that you will be industrious, happy, well-married and have a large family." .

The ants form a very largegroup. More than two thousand species have been described. Sharp estimates that there are probably five thousand species in existence. There is a marked uniformity of structure as well as of

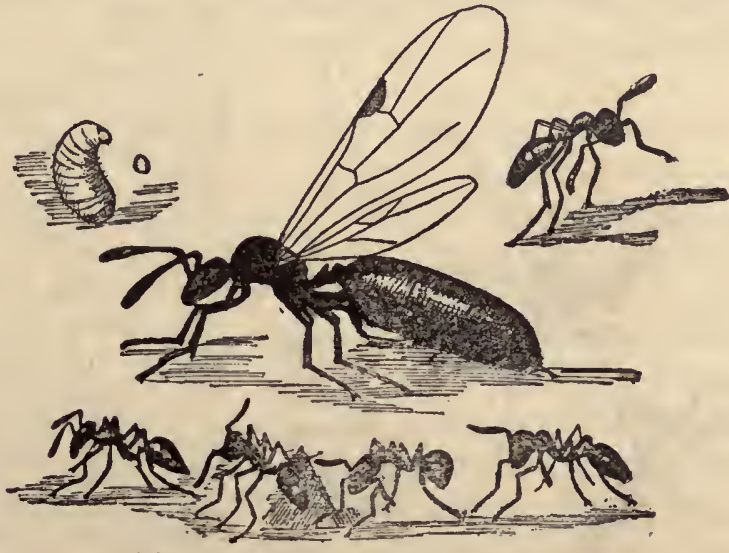

Fig.-22. Monomorium minutum. habits in this great group and the systematic workers have so far made only eight families, of which the Camponotidæ, or common stingless ants, and the Myrmicidæ, or stinging ants, are the most familiar examples to persons living in the more northern United States. Representatives of the curious ants of the family Poneridx occur in the Southern States.

Many stories have been told of the supposed intelligence of ants, but perhaps it will not be out of place to tell one more which has not been published. In one of the greenhouses of the Department of Agriculture at Washington, a medium-sized black ant occurred in considerable numbers, attracted by the presence of plant lice and mealy bugs upon the hothouse plants. As is well known, ants are especially fond of the nectar secreted by these 
insects. A number of years ago some Liberian coffee-trees were started in the greenhouse. On the under side of the leaves of these coffee-trees, there exist at the bases of certain of the leaf ribs some very minute, nectar-secreting glands. The ants soon found this out and sipped the nectar. Then the idea occurred to some clever ant that these nectar glands would be the best places in the world for mealy bugs to live and grow fat and they would in consequence secrete a great deal more nectar then they would if they lived on other parts of the leaf. But the nectar glands were too small to accommodate even one good-sized mealy bug. So, the word was passed around and the ants gnawed the edges of the gland and enlarged it so that it would accommodate a good-sized mealy bug, which was carried to it. Doubtless to the delight of

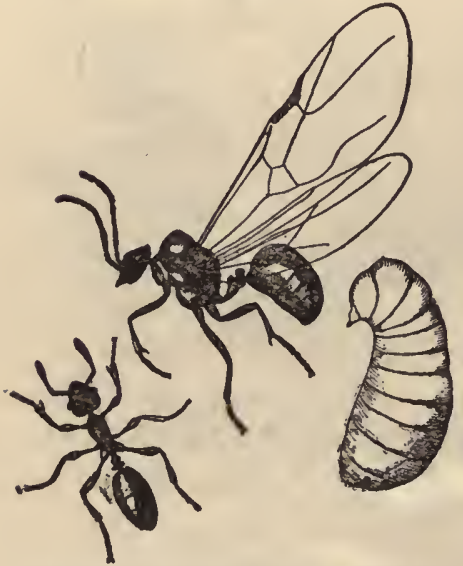

Fig. 23.-Tetramorium cæspitum. the ants, the result was as we may imagine it to have been anticipated. The mealy bug thrived exceedingly. The gland was enlarged still further and a whole family of mealy bugs was raised in the same hole. Thus a custom grew up and many such greatly enlarged glands were found after a few months. Here was an ant, then, apparently taking advantage of an opportunity which was new not only to the experience of the individual, but new to the experience of the race, and if we adopt the most reasonable of the definitions of instinct here seems to have been displayed positive intelligence of a high order.

In all of these stories of the seeming intelligence of ants and of bees, and of other insects as well, it must be remembered that we are running a great risk in our interpretations for the reason that we make them from a human standpoint, that is to say, that we consider these insects as though they had human personalities. The observer and the narrator inject their own persunalities into the subjects investigated and in fact they use words which carry with them meanings which may not be warranted by the facts. This fact is brought out strongly by the German 
writer Bethe, who wrote, in 1898 , on the psychological qualities of ants and bees. He shows, for example, that while we see, all we know about bees and other insects is that they are influenced by the light and that it would be most unscientific to say that they do anything as highly psychical as seeing until it is proved. Some of the peculiar and apparently highly intelligent things which ants do, such as recognizing the enormous number of members of the same colony and fighting instantly members of other colonies, and such as finding their way to their own nests and to food supplies and communicating intelligence of the location of food supplies from one to the other, have been carefully tested by this author who concludes that he can find nothing in the phenomena exhibited by bees or ants to prove the existence of any psychical quality. "They learn nothing, but act mechanically in whatever they do, their complicated reflexes being set off by simple physiological stimuli." *

It is interesting to note in passing that Bethe's conclusions were anticipated for a number of years by the famous American naturalist, Samuel L. Clemens (Mark Twain). If any reader does not believe this let him consult Chapter XXIl of a "Tramp Abroad".

No one who has read Bethe's account of how ants find their way by. ant-traveled paths and how easily they are lost when but a very short distance from the path, can help thinking of Mark Twain's inimitable "chapter in natural history" which also wakes a responsive chord in the mind of every one who has attempted to see intelligence and design in the movements of the isolated ant. "During many summers, now, 1 have watched him," says Twain, "when I ought to have been in better business, and I have not yet come across a living ant that seemed to have any more sense than a dead one. $* * * 1$ admit his industry, of course ; he is the hardest working creature in the world, - when anybody is looking,- - but his leatherheadedness is the point I make against him. He goes out foraging, he makes a capture, and then what does he do? Go home? No,-he goes anywhere but home. He doesn't know where home is. His home may be only three feet away, - no matter, he can't find it. He makes his capture, as I have said; it is generally something which can be of no sort of use to himself or anybody else; it is usually seven times

* Albrecht Bethe, Archiv. f. d. Ges. Phys. LXX. I 5. Ioo. January, I 898. A Review by Caswell Grave, American Naturalist, Vol. XXXII, pp. 437-439. 
bigger than it ought to be; he hunts out the awkwardest place to take hold of it; he lifts it bodily up into the air by main force, and starts; not toward home, but in the opposite direction; not calmly and wisely, but with a frantic haste which is wasteful of his strength; he fetches up against a pebble, and instead of going around it, he climbs over it backwards dragging his booty after him, tumbles down on the other side, jumps up in a passion, kicks the dust off his clothes, moistens his hands, grabs his property viciously, yanks it this way, then that, shoves it ahead of him a moment, turns tail and lugs it after him a moment, gets madder, then presently hoists it into the air and goes tearing away in an entirely new direction; comes to a weed; it never occurs to him to go around it, he must climb it; and he does climb it, dragging his worthless property to the top-which is as bright a thing to do as it would be for me to carry a sack of flour from Heidelburg to Paris by way of Strasburg steeple; when he gets up there he finds that is not the place; takes a cursory glance at the scenery and either climbs down again or tumbles down, and starts off once more-as usual in a new direction. At the end of half an hour he fetches up within six inches of the place he started from and lays his burden down ***." After continuing this charmingly aimless work for some time and meeting another ant and fighting him about nothing, "each starts off in a different direction to see if he can't find an old nail or something else that is heavy enough to afford entertainment and at the same time valueless enough to make an ant want to own it."

Wasmann has just published some important observations in which he shows that ants of the genus Lasius appear to determine direction only by paths previously traveled by members of the same community and which they distinguish by the sense of smell located in the antennæ, but that certain ants of the genus Formica proceed directly to the desired point without following paths, using apparently sight as the directing influence. Some little understood sense of orientation, however, may lead to this result and such a sense of course would be instinctive.

The community life of ants seems almost perfect. It has been likened to a perfect republic where each works for the good of the whole community, each having his appointed work, laboring constantly for the good of all, and each ready to sacrifice himselt for the good of all. Most of the writings on the habits of ants 
deal with European species. Little is known of an exact nature about the full details of the life history of any one species which inhabits the northern half of the United States. Random notes and occasional observations have been published, but a thorough, conscientious study of all of the aspects of the life of one of our commoner forms is still to be made. Even the little red ant of households (Monomorium pharaonis), or the pavement ant (Tetramorium cospitum), or the common black carpenter ant (Camponotus pennsylvanicus), or any of the common species of Lasius or Formica, afford subjects for investigation which may everywhere be found and which should be studied through one or two years by some careful observer willing to record all that he sees.

There need be no great interruption from the weather, since colonies of ants can be studied to advantage indoors. Sir John Lubbock, in his charming book entitled, "Ants, Bees and Wasps," carried such colonies along for several years. He kept in captivity, in fact, about half of the British species of ants, as well as a considerable number of foreign forms, and for several years he had generally from thirty to forty communities under observation. He found that the most convenient method was to keep them in nests consisting of two plates of common windowglass about ten inches square, and at a distance apart of one-tenth to one-fourth of an inch, in fact, just sufficiently deep to allow the ants freedom of motion, with slips of wood around the edges, the intermediate space being filled up with fine earth. The nests were kept covered over, except when under actual observation, since ants very much dislike light in their nests. On one side a small door was left. These glass nests were either kept in shallow boxes with loose glass covers, resting on baize, which admitted enough air, or on stands surrounded either by water or by fur with the hairs pointing downward. Some of the nests were arranged upon stands. Comstock tells how the habits of ants can be studied in a school-room by establishing a colony in an artificial nest. His arrangement practically follows that of Sir John Lubbock. He takes two pieces of windowglass ten inches square, a sheet of tin eleven inches square and a piece of plank one and one-fourth inches thick, twenty inches long and at least sixteen inches wide. He cuts a triangular piece, about an inch long on its two short sides, from one corner of one of the panes of glass. From the sheet of tin he makes a tray 
three-eighths of an inch in depth. On the upper surface of the plank, a short distance from the edge, he cuts a deep furrow. This furrow is kept filled with water in order to prevent the escape of the ants. The tin tray is placed on the plank, within the furrow, the square pane of glass is laid in the tray, and along the edges of the glass are litid fuur strips of wood about a half an inch wide and a little thicker than the height of the ants to be kept, then a layer of fine earth is placed in, and the pane of glass of which one corner has been cut off is laid on the strips of wood, and the whole is covered with something which will keep the nest dark.

The general features of the community life of ants of the commoner genera may be briefly summarized as follows: A community is supposed to be founded by a single queen which lays white or yellowish, elongate eggs, which hatch in two weeks or more. The larvæ are white, legless, helpless creatures which, in the beginning of the colony, are attended by the queen and which develop into workers. As the community grows, egg-laying is continuous, new queens are born and these pair with the males and lay eggs, the workers, as soon as they begin to make their appearance, taking care of the larvæ, feeding them and carrying them about from chamber to chamber in order to secure the suitable warmth and moisture. In different parts of the community will be found larvæ of comparatively similar size, the smallest ones in one place, larger ones in another, and still larger in another. These larvæ have to be fed for a month or more, according to the species, and when full grown transform to pupæ, sometimes naked, sometimes covered with a silken cocoon. The cocoon is usually white, and is also carried about to suitable places by the workers. When an ant colony is disturbed the workers are seen scurrying about, carrying these cocoons, endeavoring to carry them to a place of safety, and the common idea is that these cocoons are eggs, but they are a great deal larger than eggs. In three to four weeks the pupæ emerge, and in emerging from the cocoons they are helped by the workers, which are said to take the greatest care of them, unfolding their legs and helping them expand their wings. The males die very soon as a rule, but the females and the workers are very long-lived. Lubbock kept two queens for more than seven years, and certain workers more than six. 
The life of an ant community is practically perpetual, thus differing greatly from the community life of wasps and bumblebees. The nests vary greatly in form. Some ants occupy galleries and chambers in the ground. Others make extensive galleries and chambers in decaying wood. Others build mounds. Still others construct nests of a paste-like substance, and in tropical regions there are extraordinary variations in the manner in which nests are built and in the material which composes the nests. The ants themselves feed upon a great variety of substances. Under natural conditions they are both carnivorous and vegetable feeders, eating various plant substances, fruit, and other insects, as well as the dead bodies of higher animals. They are especially fond of the sweet sap of certain trees, and of the secretions of plant lice, of scale insects, and of certain leaf hoppers and tree hoppers. In an old community the number of ants may be very great, extending high into the hundreds of thousands, and it is a matter of common observation that while the ants of one community are perfectly able to recognize other members of the same community, no matter how great their number, they also recognize at once and either resent or have nothing to do with members of other communities, even of the same species.

The battles of ants, the slave-making habits of certain species, the extraordinary variety of the guest insects which are found in ants' nests and their diverse functions in the community, the relations of ants with plant lice and other insects which afford them one of their articles of diet, have so often been described in other works that it would be a vain repetition to dilate upon them here. The strange facts connected with their agricultural pursuits, with the occupation of mushroom-growing which is cultivated by certain species, the remarkable features of the lives of the honey ants and, in fact, everything connected with ant economy offers most fascinating reading, even to persons not especially interested in nature.

The honey ants deserve more than passing mention, even though they are found in this country only in the far West and at high elevations. The peculiarity of these creatures is that one form has the abdomen distended the size of a currant and entirely filled with grape sugar, or "honey." The nest is a low, gravelcovered mound about six inches in diameter and two or three 
inches high. The honey-bearers are found clinging to the roofs of the chambers, a few inches under the ground, and seem to act simply as cells for the storing of the sweet substance which is collected by the active workers from the exudations of a gall which is found upon a dwarf oak. In times of famine and in seasons when the exudation is not forthcoming the honey-bearer regurgitates the honey, drop by drop, and it is transferred to the stomachs of the individuals in waiting. In other respects the economy of the colony does not differ materially from other species. There is practically with this insect a new caste of workers which probably are not gradually transformed by the distension of the crop and the expansion of the abdomen, but which have some peculiar structure or form of the intestine and abdominal walls which gives them a tendency to this change.

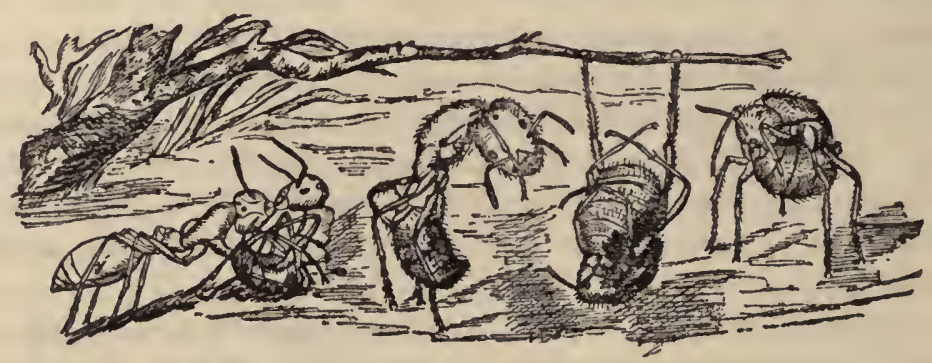

Fig. 24.-Ants at play. (Redrawn from McCook.)

They become simply animated pantries for the use of the others in time of want. Dr. H. C. McCook has written a charming book upon this subject, which is entitled, "The Honey Ants and the Occident Ants," and the same distinguished entomologist and divine has written another book, entitled, "The Agricultural Ant of Texas," which gives a most interesting account of the most interesting ants found in this country, and which includes at the same time many observations, scattered here and there throughout the volume, on other ants to be found in the United States.

A word may well be said of the household ants. The little red ant (Monomorium pharaonis) has become thoroughly domesticated, passing its entire existence in houses and having its nests in the walls or beneath the flooring. The little black ant, (Monomorium minutum), and the pavement ant of the Eastern States (Tetramorium caspitum) are also frequently found in 


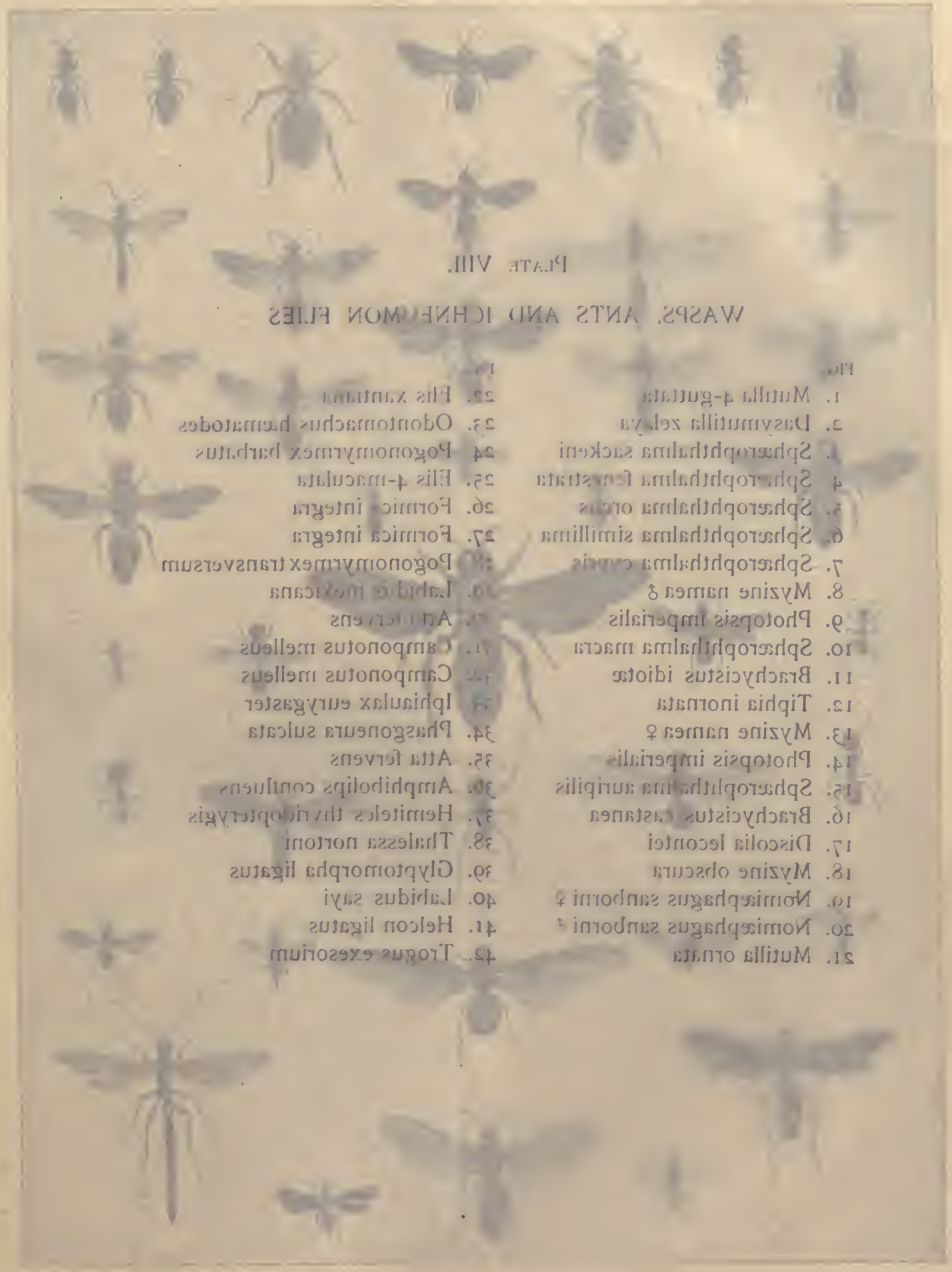


Woches high

bi the chamive

umply as adils far the Hown

collertod by

which is inund upon a dimes.

kectors whetishe cowdia

regungitutes the hency,

stomiche of tis insivi PLATE VIII.

WASPS, ANTS AND ICHNEUMON FLIES

FIG.

worker whic l probulily is: act

1. Mutilla 4-guttata

2. Dasymutilla zelaya

3. Sphærophthalma sackeni

4. Sphærophthalmal fenestrata

5. Sphærophthalma orcus

6. Sphærophthalma simillima

7. Sphærophthalma cypris

8. Myzine namea $f$

9. Photopsis imperialis

I0. Sphærophthalma macra

II. Brachycistus idiotæ

12. Tiphia inornata

13. Myzine namea $q$

14. Photopsis imperialis

15. Sphærophthalma auripilis

16. Brachycistus castanea

17. Discolia lecontei

18. Myzine obscura

19. Nomiæphagus sanborni 우

20. Nomiæphagus sanborni $\delta$

21. Mutilla ornata
22. Elis xantiana

23. Odontomachus hæmatodes

24. Pogonomyrmex barbatus

25. Elis 4-maculata

26. Formica integra

27. Formica integra

28. Pogonomyrmex transversum

29. Labidus mexicana

30. Atta fervens

31. Camponotus melleus

32. Camponotus melleus

33. Iphiaulax eurygaster

34. Phasgoneura sulcata

35. Atta fervens

36. Amphibolips confluens

37. Hemiteles thyridopterygis

38. Thalessa nortoni

39. Glyptomorpha ligatus

40. Labidus sayi

41. Helcon ligatus

42. Trogus exesorium

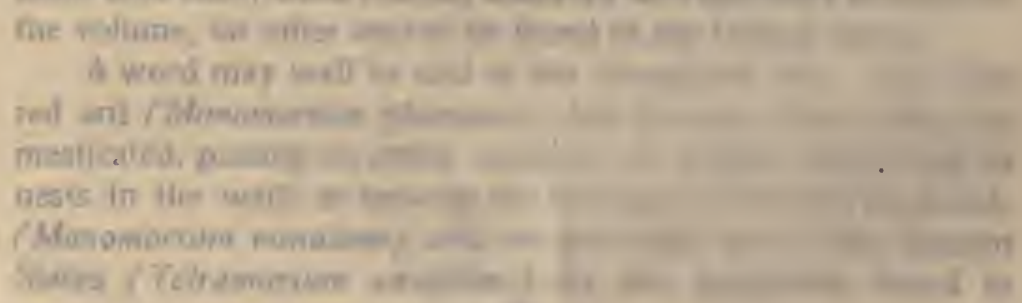




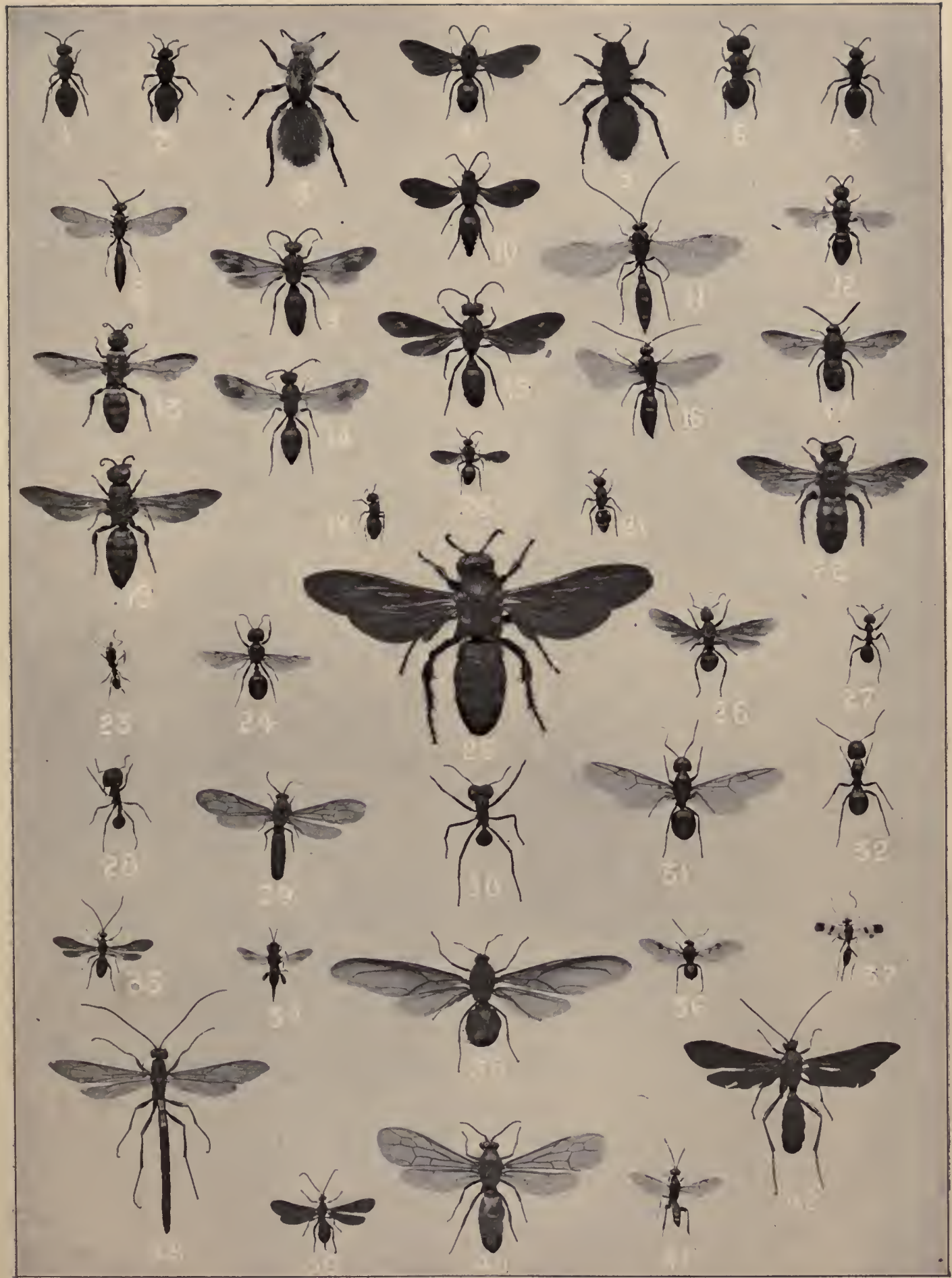




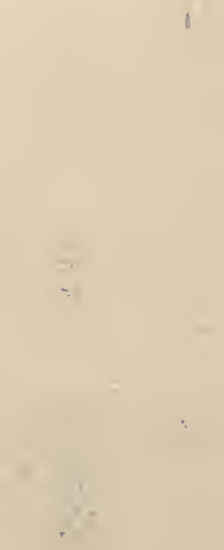


houses. They are not so destructive to household effects as they are annoying through their presence on articles of food. A friend once told me a beautiful story of how he once bought a piece of blackberry pie one night, in a dimly lighted railroad eating house in a western town. He began to eat it and discovered an acid flavor which he did not expect, and, carrying it to the light, found it swarming with Monomorium pharaonis. This is not an uncommon experience and simply indicates the countless numbers in which these little creatures occur sometimes in houses. How to get rid of these ants is a difficult and serious question. Their nests, occurring usually in walls, are hard to locate. Trapping them with sweetened sponges afterwards soaked in hot water is apparently sometimes almost hopeless on account of their infinite number. Careful watching, however, will usually show the crack through which most of them enter the pantry or the dining room, and then squirting in kerosene with a large syringe through this crack will often stop the incursions; or, the crack may be packed with cotton soaked in kerosene, driving it in with a table knife.

Dr. William $M$. Wheeler has recently published some very important studies of the peculiar ants of the family Poneridæ, as they occur in Texas (Biological Bulletin, Vol. 11., No. 1, October, 1900). These ants make rather primitive nests and they seem to be generalized creatures from a socialistic standpoint. They do not seem to feed one another like the specialized ants, but they have the same habits regarding the cleanliness of the individuals and of the nests. Their larvæ differ from those of other ants, as do their eggs. They are not nearly so prolific as are other ants and the feeding habits of the larvæ are very remarkable. The workers capture another insect, cut it into pieces and scatter the pieces among the larvæ, which insert their long necks through the cut surfaces, feeding upon the juices of the recently killed insect. Dr. Wheeler found that there is no such sharp distinction between the sterile and the fertile female with the Poneridx as with the more specialized ants 2 He finds an irregular,polymorphism in both sexes. The workers have the same habit of opening the cocoons and drawing out the pupæ which are ready to transform. Ten or a dozen workers were observed to gather around a prematurely extracted pupa and lick it for hours.

One of the most interesting features of the study of ant colo- 
nies is the wonderful diversity of guest insects which are found in them. Insects of several different orders may be found, including beetles, grasshoppers, plant lice, bark lice and Thysanurans as well as mites. All these creatures play some part or another in the economy of the community. Several are cared for by the ants and furnish food through their secretions. Others live at the expense of the ants, either as true parasites or as partakers of ant food. Wasmann has long made a study of these ant guests and his papers afford such fascinating reading that they should be generally translated into English for the benefit of persons engaged in nature study.

\section{Typical Life History.}

From the observations or Dr. McCook on the agricultural ant of Texas a nearly complete typical life history could be drawn up, but the geographic range of this ant is so uncharacteristic of the greater part of the United States that it does not seem wise to devote the necessary space to such a treatment. The absence, therefore, of a typical life history in such an abundant and common group as the ants will serve to emphasize, as strongly as anything which has been said, the ease with which novel and important observations can be made upon insects. It is the earnest hope of the writer that some student will take up, for example, the large carpenter ant, Camponotus pennsylvanicus, study it most carefully and compare his observations with those of European writers upon congeneric forms, although, as a matter of fact, representatives of this particular genus are not abundant in Europe. Whoever begins the careful study of this large carpenter ant must first read Dr. H. C. McCook's interesting paper entitled "Notes on the Architecture and Habits of the Pennsylvania Carpenter Ant" published in Vol. V. of the Transactions of the American Entomological Society, pp. 277-289. 


\section{THE PROCTOTRYPOID PARASITES}

\section{(Super-family Proctotrypoidea.)}

With the consideration of the insects of this group we first meet with forms which were formerly grouped together in a section called the Hymenoptera parasitica, the true parasitic Hymenoptera. In the old system this included the families lchneumonidx, Braconidæ, Chalcididæ and Proctotrypidæ. Other groups have been added since, and entomologists now, following Ashmead, consider the Proctotrypoidea, in spite of their invariably parasitic habits, to be more closely allied to the Vespoidea and Cynipoidea than to the Ichneumon flies and the Chalcis flies. This is undoubtedly true as to structure, and it will be remembered some of the Vespoidea which we have just been considering are parasitic in their habits, while, as will be seen when we take up the Cynipoidea, some of these insects too, although most of them are gall-makers, are truly parasitic in their life.

How internal parasites live.-The development of the larvæ of those parasitic insects which live within the bodies of other insects has been the subject of much speculation and some investigation. How these. creatures breathe, nourish themselves, move, cast their skins, and pass their excrement have been mooted points. Cuvier thought that these larvæ breathe by placing their spiracles in relation with those of the insect in which they live. Ratzeburg showed that.. some of them have a curious caudal appendage with very thin walls, and this he thought acted as a blood gill, oxygen being gained through its walls from the purified blood of the host insect. Boisduval concluded that they do not take nourishment through the mouth; that they do not breathe, and that they void no excrement, the larvæ being analogous to the fotus in mammals, which lives the life of the mother. Newport described the larvæ of certain Ichneumon flies as having no anus, the rectum and its orifice being rapidly developed at the final molt of the larvæ. The older authors thought that these 
larvæ attack only the fatty tissues of the host, or that they nourish themselves exclusively on the lymph.

Through the work of a recent French author, Seurat, we now understand better how these internal parasites live. They have very sharp jaws, and use them in order to pierce the tissue of the host. The digestive tube has a very voluminous stomach which is closed behind, and which serves as a storehouse for food which is digested later. A small quantity of food digested at once suffices for the immediate wants of the larvæ. The voiding of the excrement takes place only in the interior of the cocoon, the stomach not opening until the larva changes to pupa. The parasite larva feeds upon the fat and blood and the lymph, and in most cases devours everything except the skin and the air vessels. It respects the viscera up to the last limit, and only sacrifices them at the end. In the youngest of these

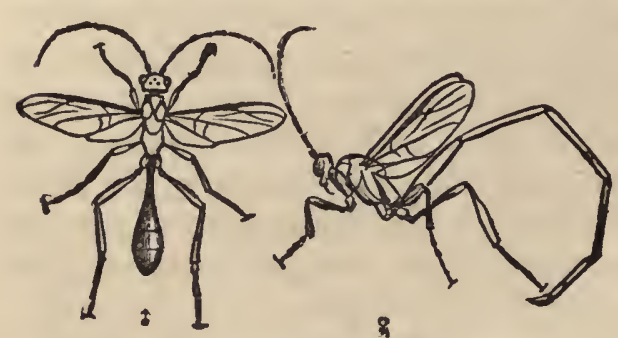

Fig. 25.-Pelecinus polyturator. (After Packard.) internal parasites the air vessels have not appeared, and they breathe by absorbing oxygen through the skin from the blood of the insect in which they live. The skin is very delicate and the oxygen passes through by osmosis. A little later the air vessels begin to appear and become very complicated, branching all through the skin. The skin in fact appears as if carpeted with an extremely rich network of fine breathing tubes. In no place do these breathing tubes open through the skin but the oxygen is absorbed into them through the skin from the blood of the host. When the parasite leaves its host its spiracles or breathing holes open, and the outside air enters through them into the air vessels. Contrary to the old idea, these internal parasites sometimes molt, and the cast skin slips from the anal end of the body into the open space behind it. A remarkable observation has been made by Marchal, who states that a single egg of Encyrtus laid in the egg of a little Tineid moth divides up into a great number of embryos which develop into individual larvæ in the larva of the host.

These remarks are general, and apply in a way to all of the 
parasitic Hymenoptera. In the Proctotrypoidea a curious hypermetamorphosis occurs in certain egg parasites in which there are three distinct forms of the larva of the same species, one form resembling the little aquatic animals of the genus Cyclops.

The eggs of the Proctotrypoids are ovate, with a peduncle at the end. Nearly all of the larvæ live within other insects. Very many of them live in insect eggs, undergoing their transformations within these eggs, sometimes a half-dozen or more being found within a single egg-shell. Still others live within the larvæ or the pupæ of insects, in which case they gnaw their way out before spinning cocoons, or sometimes transform within the body of the host, in which case there is usually no cocoon, the skin of the host giving ample protection. The insects of one genus, Trichacis, develop in the nervous system of the larvæ of one of the little gall midges, while the larvæ of another genus, Polygnotus, develop in the digestive tract of the same insect.

As just stated, many of them develop in the eggs of other insects, such as butterflies, moths and true bugs, as well as grasshoppers. Many times students interested in rearing butterflies from the egg will be disappointed, instead of hatching out caterpillars to find numbers of the extremely minute black fourwinged flies of the Proctotrypoid genus Telenomus, which make their appearance through minute perforations in the egg-shell. The eggs

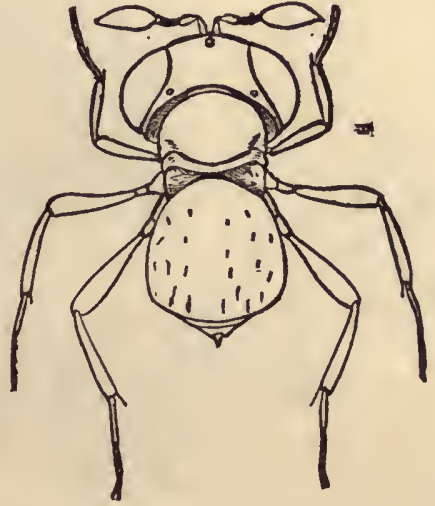

Fig. 26.-Bæus americanus.

(Author's illustration.) of the mourning-cloak butterfly (Euvanessa antiopa) are especially apt to suffer in this way.

Other Proctotrypoids live in the larvæ of gall-flies, gall-gnats, of many kinds of flies, of butterflies and moths and beetles, and in plant-lice, and the eggs of spiders, as well as of bugs, butterflies and moths. Some of the species (of the genus Baus) which live in spider eggs are very curious, wingless creatures of simple form.

The curious family Pelecinidæ is placed in this super-family by Ashmead, and it forms an exception to the remainder of the 
insects with which it is thus associated from the fact that the trochanters are not divided; that is to say, they appear to be formed of but one segment. They are very curious creatures with an extremely long and slender abdomen, and look like Ichneumon flies. This elongation of the abdomen occurs only in the female sex. The male has a more normal abdomen. In their early stages they are probably parasitic upon the larvæ of beetles. Pelecinus polyturator is our commonest species, and Professor Forbes states that he has bred it from May beetle larvæ. 


\section{THE GALL-FLIES}

\section{(Super-family Cynipoidea.)}

To this group belong the true gall-flies, as well as certain insects which are inquilines, or gall-fly guests, and also certain forms which are true parasites. Although we call the Cynipoids the true gall-flies, there are many other insects which make galls, such as some of the two-winged flies of the families Cecidomyiidæ and Trypetidæ, certain caterpillars, a few Chalcis flies, and a few beetles, as well as certain mites and scale insects. Certain of the oak galls formed by Cynipoids were early used in the manufacture of ink, and later for tannin, so that when one speaks of gallflies these creatures are always thought of. They are small dark

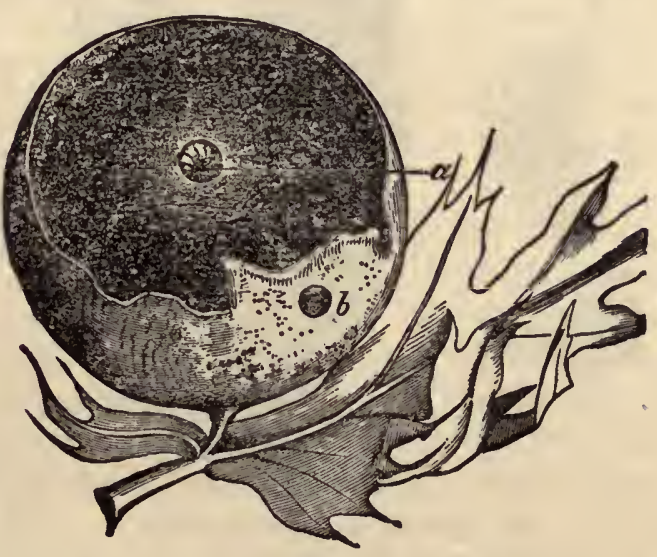

Fig. 27-Cynips spongifica. (After Riley.) colored four-winged flies, at once distinguished from their close allies by the venation of the wings and the structure of the thorax, as pointed out in the analytical table.

Those which make galls lay their eggs in the tissues of the growing plant, and the larvæ when hatched feed upon the plant cells and their contents. A very slight gall deformation may result, but in the majority of cases there is a rapid growth of plant-cells and a curious enlargement of variable shape which is called a gall.

The nature of the gall has long been a disputed point. It was at first thought that it was a purely vegetable growth and 
that the little grubs found within it were the result of spontaneous generation. Later it was supposed that galls were caused by the punctures of insects and the injection of a poisonous liquid.
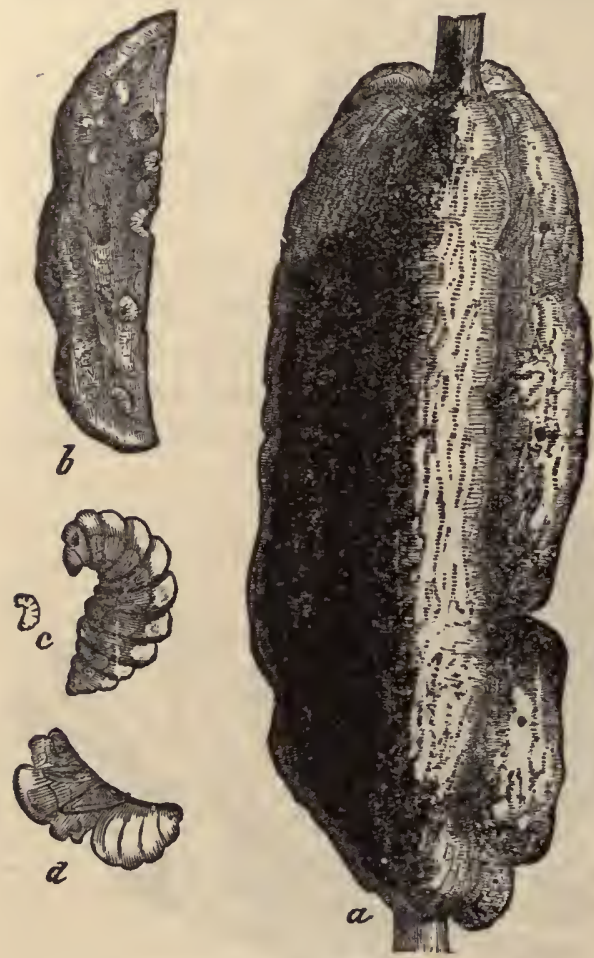

Fig. 28.-Diastrophus nebulosus. (After Riley.)

With the true gall-flies, however, the gall apparently does not commence to form until after the egg hatches. It is supposed that the larva secretes a liquid which causes the abnormal growth of the plant, the plant cells which are most active in growth and subdivision being directly affected.

The egg of the gallfly is slender, and has a very long petiole which is six to ten times the length of the egg body, and this is inserted by means of a very long curiously formed ovipositor. A good account of the method of oviposition reported by Riley fiom observations made by Pergande will be found in the Proceedings of the Entomological Society of Washington (Vol. Ill. pp. 260-263).

Most of the Cynipoids make galls upon oak. Others, however, are found upon rose bushes. All parts of the plant are affected-roots, stems, twigs and leaves, as well as leaf petioles. In some galls but a single larva develops, while in others very many develop. The oak galls of commerce are European galls, but some of our native galls would undoubtedly be found to possess commercial value through the quantities of tannin they possess.

The origin of tannin in galls has been the subject of investi- 
gation by Kraemer. He finds that gallic acid is formed at the expense of the starch during the chrysalis stage of the insect. With the maturing of the winged insect, the gallic acid is changed to tannic acid. The transformation of gallic acid into tannin is accomplished by the condensation of two molecules of the former with the loss of one molecule of water.

Most of these insects are single-brooded and develop but one generation in the year. Under unfavorable circumstances, however, this period may be greatly lengthened, and circumstances are on record where the flies have emerged only after two or three years. Certain moisture conditions favor the proper issuing, and when these are lacking the development is retarded.

Some very curious alternations of generations occur among these insects. Of certain species, and indeed of certain genera, for years only the female sex was known, and it was afterward discovered, first by Riley and afterward by Adler, that what had been considered two entirely distinct forms were really the same species, but that one generation included both sexes while the alternate generation comprised only females which reproduced parthenogenetically.

One of the most peculiar facts connected with the gall-flies is that a particular part of the plant is always affected by the same species, and that each species of the same generation always produces a deformation or gall of exactly the same character, so that the gall alone identifies the species of insect, and in fact for a long time generic and specific names were given to the galls before the insects were named, the name subsequently being applied to the insect itself.

-The full development of none of the American gall-making Cynipoids has been studied with the care which this subject should have and doubtless there are many interesting and important facts yet to be discovered.

The guest gall-flies closely resemble the true gall-flies, but lay their eggs in galls already formed by the true gall-flies, their larvæ living upon the plant growth produced by the true gallfly larvæ.

The parasitic gall-flies live as true internal parasites in other insects, mainly plant lice and the larvæ of dipterous insects.

About fifteen hundred species of this super-family have been described. 


\section{THE CHALCIS FLIES}

\section{(Super-family Chalcidoidea.)}

This group of parasitic Hymenoptera is probably the largest in number of species of any of the corresponding Hymenopterous groups. It is a well defined and well limited group structurally speaking and comprises undoubtedly many thousands of species. Only a small proportion of the species have as yet been described. As a rule the insects are so small that they attract no attention from the average collector and the paucity of our specific knowledge of the group possibly arises from this fact. The writer was the first entomologist in America to undertake the systematic study of the Chalcidoidea and he and his colleague, Mr. Ashmead, have

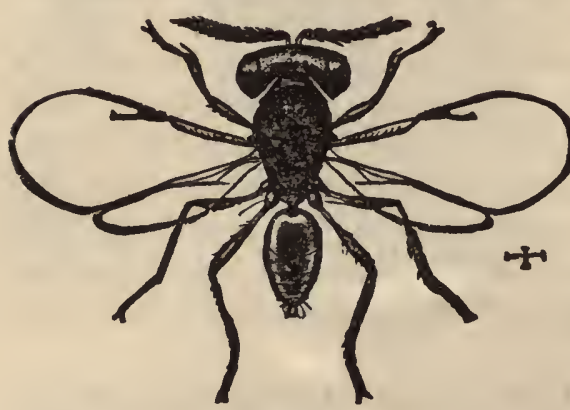

Fig. 29.-Pachyneuron micans, How. (Author's illustration.) had the field practically to themselves for the past 20 years. In the course of this time, however, we have described many hundreds of species and have learned many interesting facts about the strange life histories and relationships with other insects, many more of which remain to be noted by careful observers. Almost all of the forms are truly parasitic, the exceptions being certain gallmaking species belonging to the genus Isosoma and its allies and possibly the seed inhabiting species of the genus Megastigmus. Nowhere in nature is there a more marked example of the corelation between structure and habits than occurs in this family. This co-relation descends to the relation between the parasites and their hosts so that it is possible for an experienced person on seeing a new species of Chalcis fly to tell precisely what kind of an insect it will be found to be parasitic upon. For example, the 


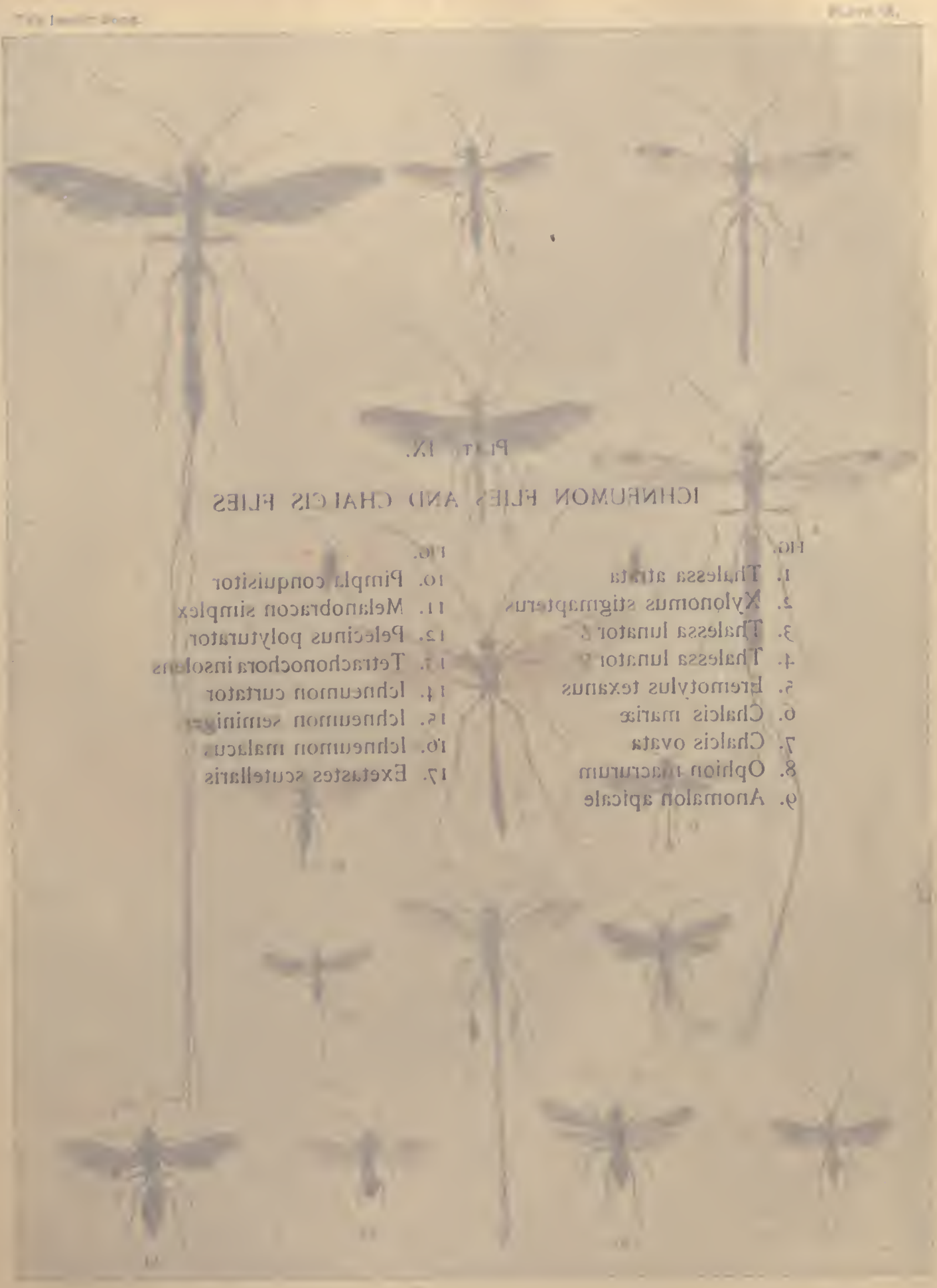




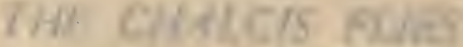

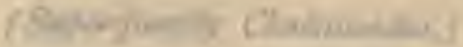

The group af parelus Wytazsupers is projeles xie Lecon.

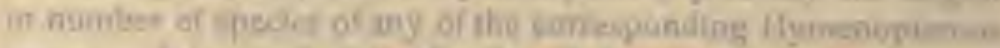

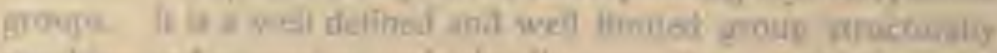

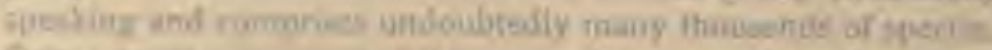

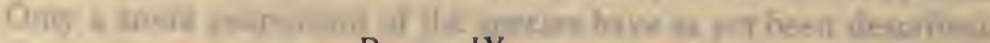

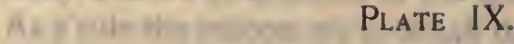

\section{ICHNEUMON FLIES AND CHALCIS FLIES}

FIG.

1. Thalessa atrata

2. Xylonomus stigmapterus

3. Thalessa lunator $\hat{z}$

4. Thalessa lunator $q$

5. Eremotylus texanus

6. Chalcis mariæ

7. Chalcis ovata

8. Ophion macrurum

9. Anomalon apicale
F1G.

10. Pimpla conquisitor

11. Melanobracon simplex

12. Pelecinus polyturator

13. Tetrachonochora insolens

14. Ichneumon curtator

15. Ichneumon seminiger

16. Ichneumon malacus

17. Exetastes scutellaris

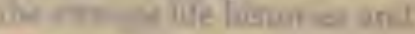
mamolipgs will overe ortide mene more of w

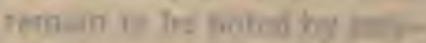
fd sonecress

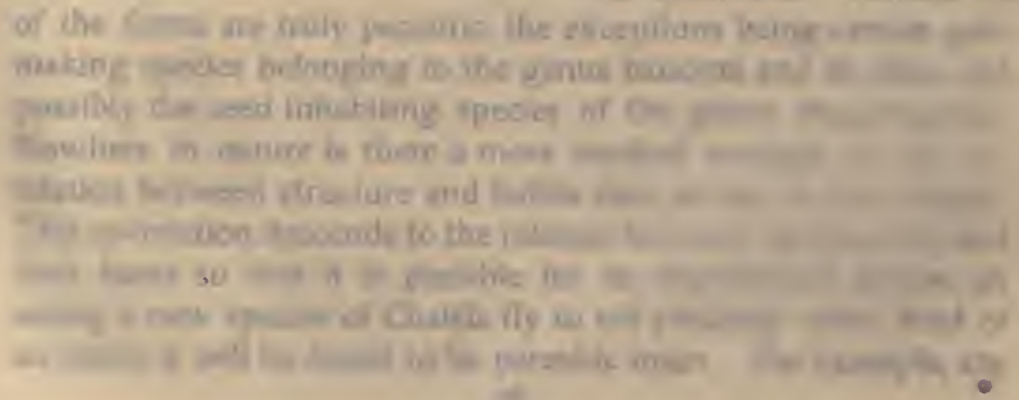




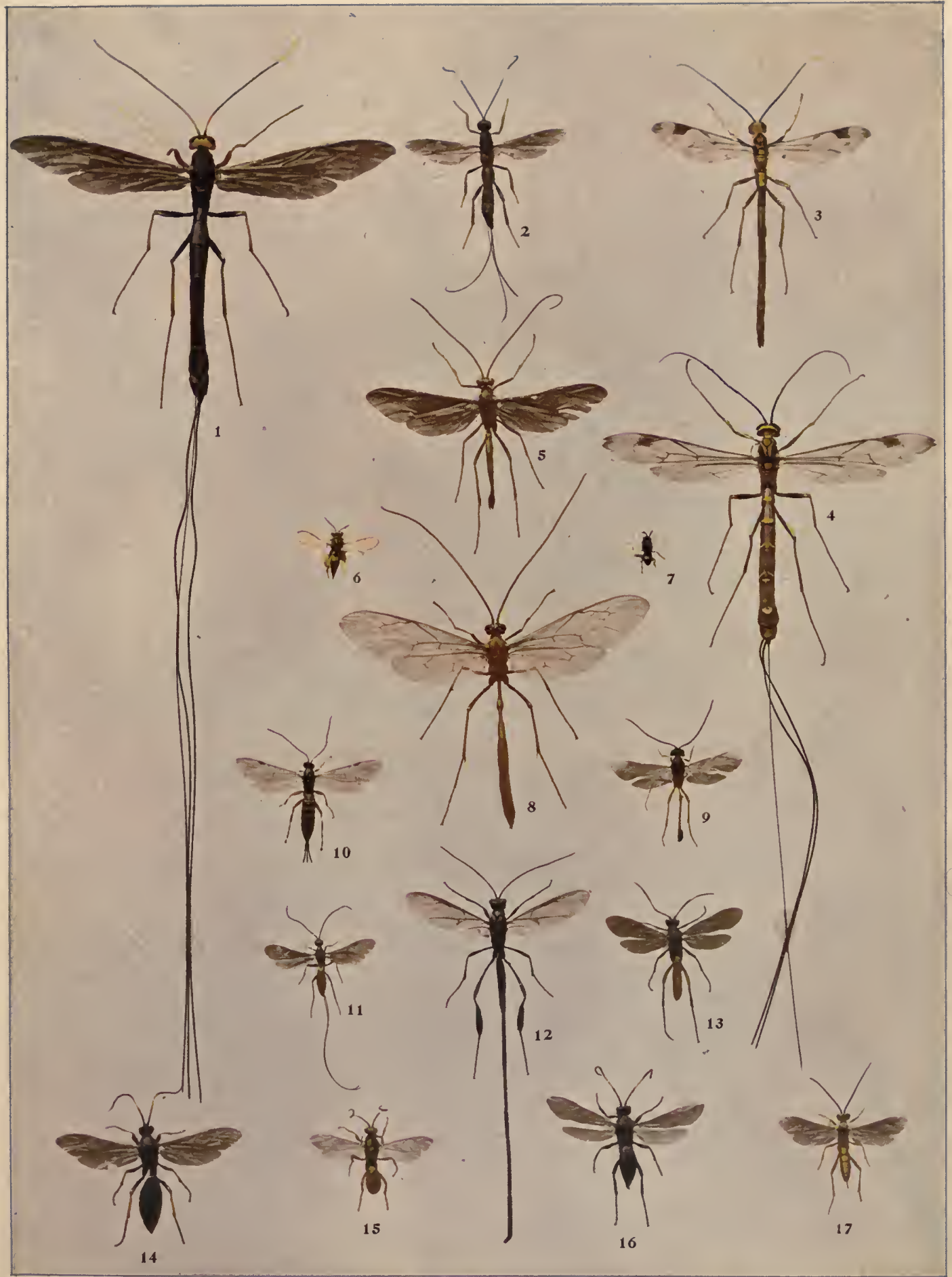



species of the genus Copidosoma are always parasitic within naked caterpillars. Those of the genus Bothriothorax are always parasitic in small dipterous larvæ. The economic importance of the group is great. They are the most effective parasites of many of our most injurious insects. For example, in a certain year in the

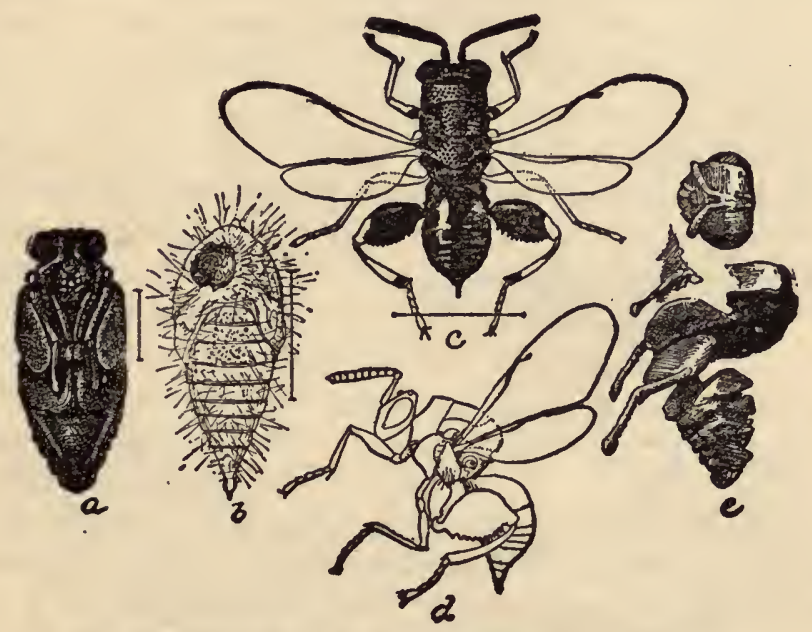

Fig. 30.-Chalcis ovata, Say. (Author's illustration.)

cotton fields of Northern Florida 95 per cent. of the eggs from which would have hatched the voracious cotton caterpillar were killed by the minute Chalcidid parasite,Trichogramma pretiosa.

\section{Life History of a Chalcis Fly (Euplectrus comstockii, How.)}

It goes without saying that the full life of the internal-feeding parasites of this group is very difficult and practically impossible to follow so long as they are within the body of the host insect. In our earlier consideration of the super-family Proctotrypoidea we have given some general remarks upon the development of all internal-feeding parasitic Hymenopterous larvæ, and those remarks will apply in general to the Chalcis flies. There are some of them, however, whose larvæ do not feed internally. These are especially those which are parasitic upon the larvæ of gall-making insects. If a gall be cut open, it is quite likely that there will be found within it the larva of a Torymus (one of the Chalcis flies) 
feeding externally upon the gall making larva, and there is a quite large group known as the Elachistinæ which are parasitic upon caterpillars, the larvæ of which feed also outside the skin of the host insect. It is one of these which has been selected for our typical life history. It was studied in the summer of 1878 in the cotton fields of Alabama by Mr. E. A. Schwarz, but it has a northward spread and is parasitic upon caterpillars of certain Geometrid moths-measuring worms.

The adult parasite, which is a little black, shiny, four-winged fly and which, when seen under a strong lens has a number of

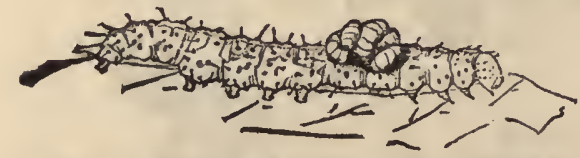

Fig. 32.-Larvæ of Euplectrus comstockii, on cotton caterpillar.

(Fourth Report U. S. Ent. Com.) strong, dark colored bristles upon its back, lays its eggs to the number of from three to fifteen in a group upon the middle of the back of the wriggling caterpillar. Each egg is brown in color, almost black before hatching, is elongate oval, strongly convex above, and somewhat flattened beneath. The individual eggs although laid in a group are sufficiently separated from each other to allow for the development of the larvæ. They hatch about two days after being laid. The delicate egg shell splits longitudinally in the middle of the back and discloses the white, grub-like parasite larva, which gradually works the egg shell more and more down the sides of its body where it remains visible as a black line for some hours. As soon as the grub has freed its head from the egg shell it pierces the skin of the victim, and thereafter remains stationary with its head buried. As soon as it has fairly begun to feed, the white color changes to a bright bluish green, and the spiracles and the constrictions between the segments are readily seen. The growth of this larva is extremly rapid. In fact, we know of no insect larva which has a more rapid development. In midsummer it reached full growth in three days from the time of hatching. In September

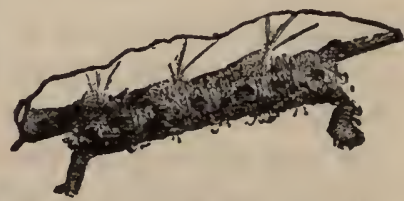

Fig. 33.-Pupæ of Euplectrus comstockii. (From Fourth Report U.S. Ent. Com.) this larval growth took four days. When full grown the parasitic grubs crowd each other, and if there are five or more of them on a caterpillar they form a semi-globular lump of very striking 
appearance. Usually their growth is uniform. A retardation in the development of individuals in the group results in death. When full grown they turn white and relax their hold.

The poor caterpillar, which up to this time has shown no signs of being affected, except by its sickly yellowish color and by its very slow growth, collapses and dies as soon as a single one of the parasitic larvæ withdraws, and the same fate overtakes those parasitic maggots which are at the time less advanced in their development. If one of the larvæ be removed by hand, Schwarz found, both the victimized worm and the remaining parasites quickly dry up. After the larva turns yellowish white and relaxes its hold on the caterpillar, it works its way around underneath the

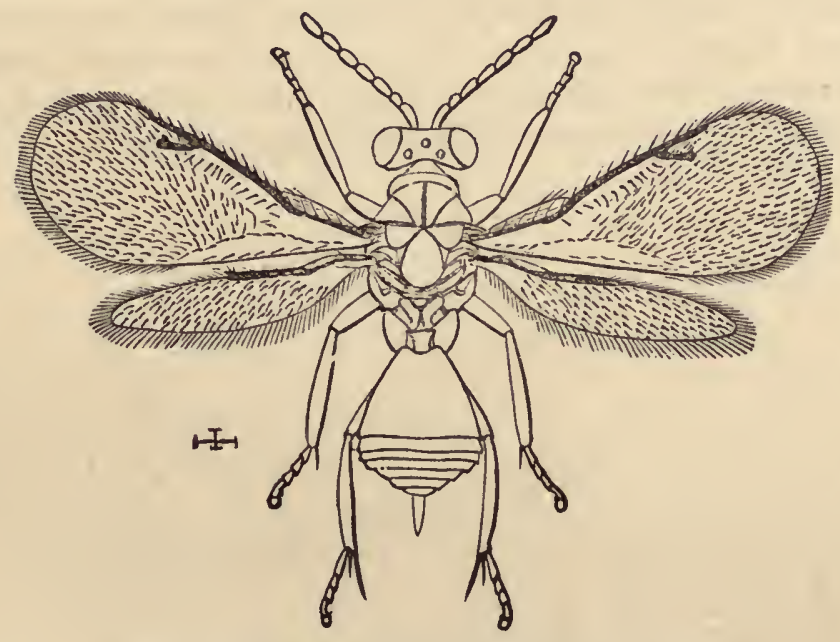

Fig. 34.-Euplectrus comstockii, How. Adult. (From Fourth Report U. S. Ent.Com.)

belly of the host and spins a series of silk threads attaching the caterpillar, which is now a mere empty skin, to the leaf. Then the parasitic larvæ take their places side by side across the under side of the caterpillar skin, fasten it for nearly its whole length to the leaf, spin a little more loose silk of yellowish white color, and transform to pupæ. This silken web does not form a series of cocoons since it is so loose that the black pupæ can plainly be seen between its strands. The caterpillar skin protects these pupæ just as a roof would do. After first transforming, the pupa is 
dark yellow, but soon becomes black, especially on the head and abdomen. In from three to eight days the adult parasite emerges.

Just think what a speedy development this means!- two days for the egg stage, three days for the larval stage, and three days for the pupal stage-an entire generation in eight days. Even the prolific and rapid-breeding house fly cannot beat this. It is altogether the shortest development of any Hymenopterous parasite that has been studied, and it is due to this great rapidity of development of this parasite, together with the abundance of certain other parasites, that the famous cotton caterpillar of the South, an insect which used to damage the cotton crop annually to the amount of fifteen millions of dollars, is periodical in its attacks and while very abundant some years is very scarce in other years. During the summer when Mr. Schwarz studied the species in Central Alabama he found that there was an almost complete destruction of the caterpillars in the early part of October, and that this destruction was principally due to this parasite. 


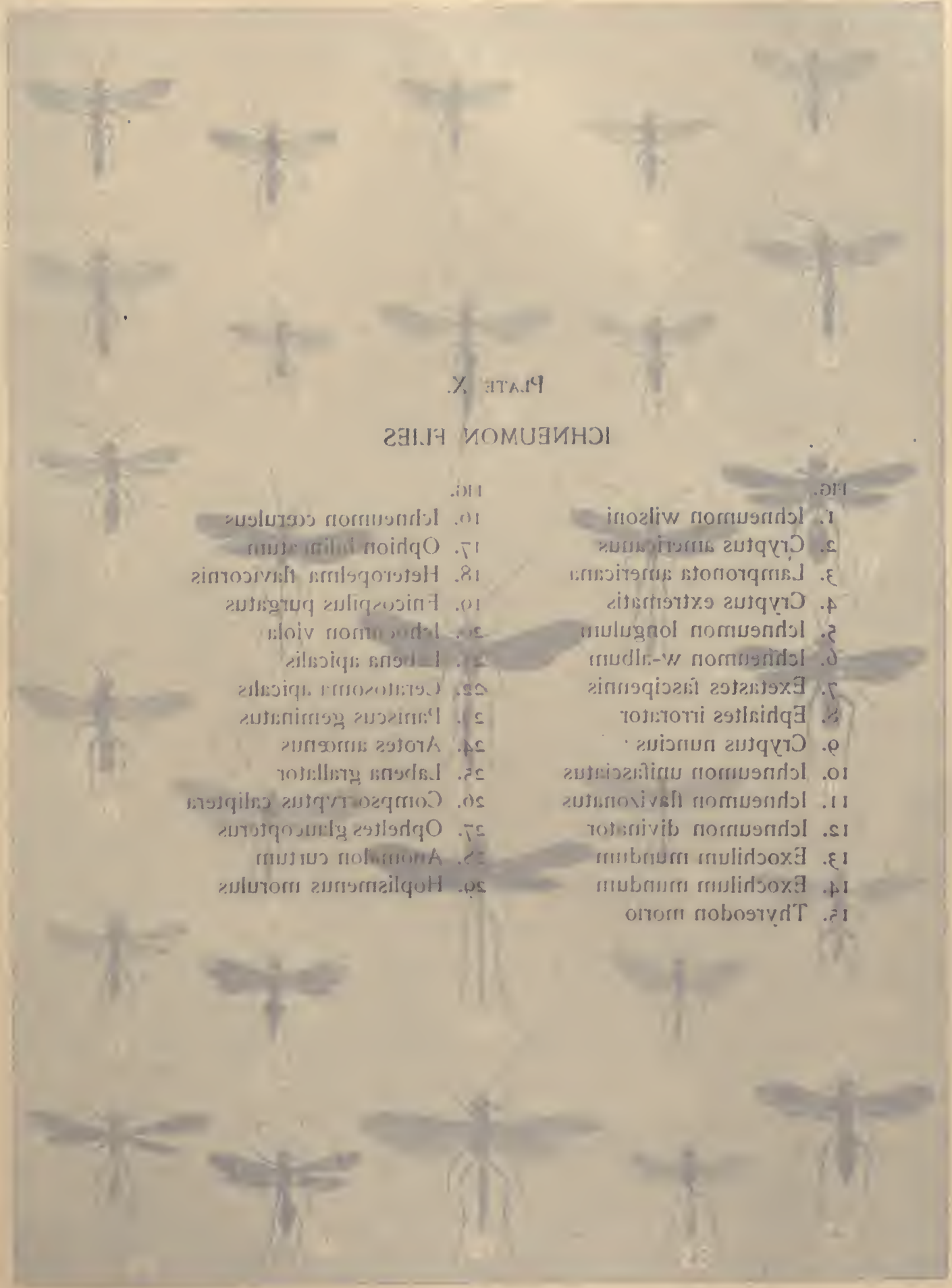




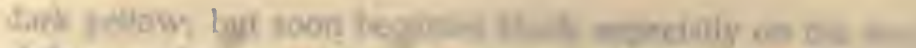
whomen. in iman Hitien

Jus dink what:

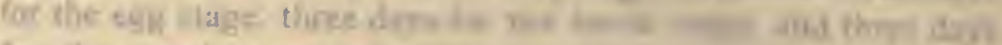

for the pupat stige $-\mathrm{m}$

the provilic amil rayid Nerentore

alleyr ther the iheresy de

affe that bas leen stvalid, are

development of lins

cerlain odier pualtel, flist the fam

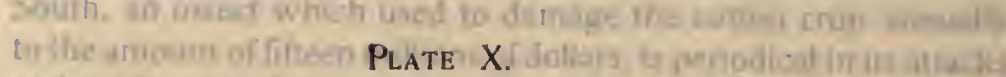

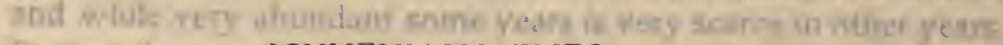

During the win ICHNEUMON FLIES

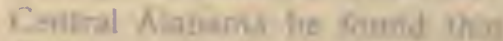

FIG. Jequacion orkhe Gievp:Il \& FIG.

1. Ichneumon wilsoni

2. Cryptus americanus

16. Ichneumon cœruleus

3. Lampronota americana

17. Ophion bilineatum

4. Cryptus extrematis

18. Heteropelma tlavicornis

5. Ichneumon longulum

19. Enicospilus purgatus

6. Ichneumon w-album

20. Ichneumon viola

7. Exetastes fascipennis

21. Labena apicalis

8. Ephialtes irrorator

22. Ceratosoma apicalis

9. Cryptus nuncius

23. Paniscus geminatus

10. Ichneumon unifasciatus

24. Arotes amœnus

11. Ichneumon flavizonatus

25. Labena grallator

12. Ichneumon divinator

26. Compsocryptus caliptera

13. Exochilum mundum

27. Opheltes glaucopterus

14. Exochilum mundum

28. Anomalon curtum

15. Thyreodon morio

29. Hoplismenus morulus 


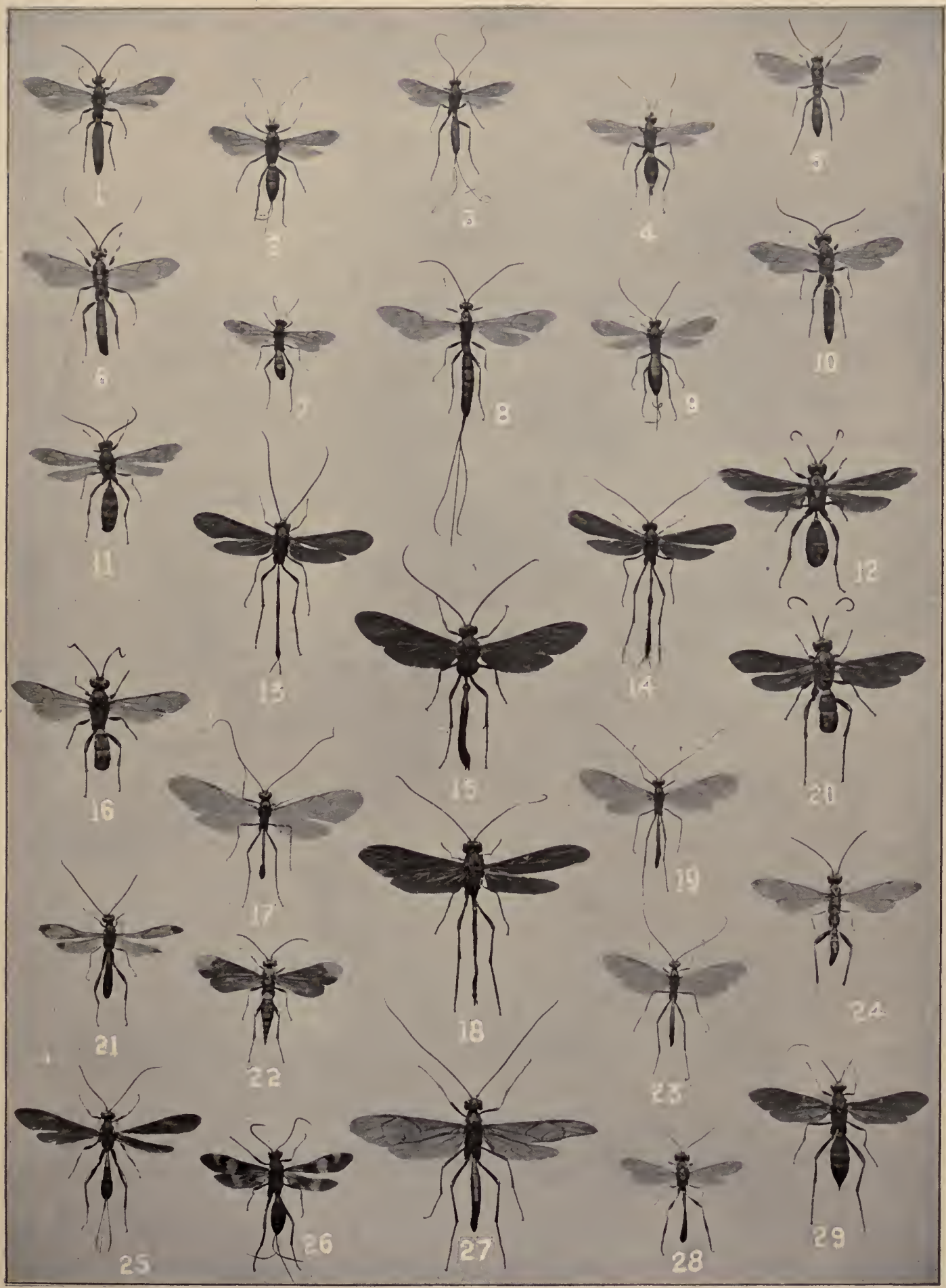





\section{THE ICHNEUMON FLIES}

\section{(Super-family Ichneumonoidea.)}

Until quite recently this great group comprising what are popularly known as the Ichneumon flies* was considered by entomologists to form but a single family-the Ichneumonidx, but Ashmead has justly decided that the group is of super-family rank, and in a recent paper has carefully worked out the genera of the world, recognizing no less than 1,140 distinct genera, very many of which inhabit the United States. The species of the Ichneumonoidea are without exception parasitic upon other insects, and for the most part upon insects which are injurious to vegetation. Caterpillars are especially subject to the attacks of the Ichneumon flies. In his paper upon the Hymenopterous parasites of North American butterflies, published as a chapter in Mr. Scudder's great work "The Butterflies of the Eastern United States and Canada," the writer has described a large number of Ichneumon flies which lay their eggs in butterfly larvæ, and which issue as adults either from the caterpillars or from the chrysalids. One of the most frequent disappointments met with by collectors of butterflies in trying to rear to the adult condition the larva of some interesting or rare species is the ultimate realization of the fact that some lchneumon fly has laid her eggs in the rare specimen before it was captured. Not only do larvæ of butterflies and moths suffer from the attacks of members of this group, but also beetle and fly larvæ and more rarely the larvæ of other orders. They are on the whole distinctly beneficial insects, and as will be shown in the detailed life history which follows, they may be responsible for the absolute saving of great damage to the shade trees of our cities as well as to agricultural crops by their widespread destruction of injurious insects.

* Both the scientific and the popular names of this group were derived from the name of the so-called Egyptian Ichneumon or Pharaoh's rat, which devours the eggs and young of the crocodile and was held sacred by the ancient Egyptians. The applicability of this title to the group under consideration is due to the parasitic habits of the Ichneumon flies. 


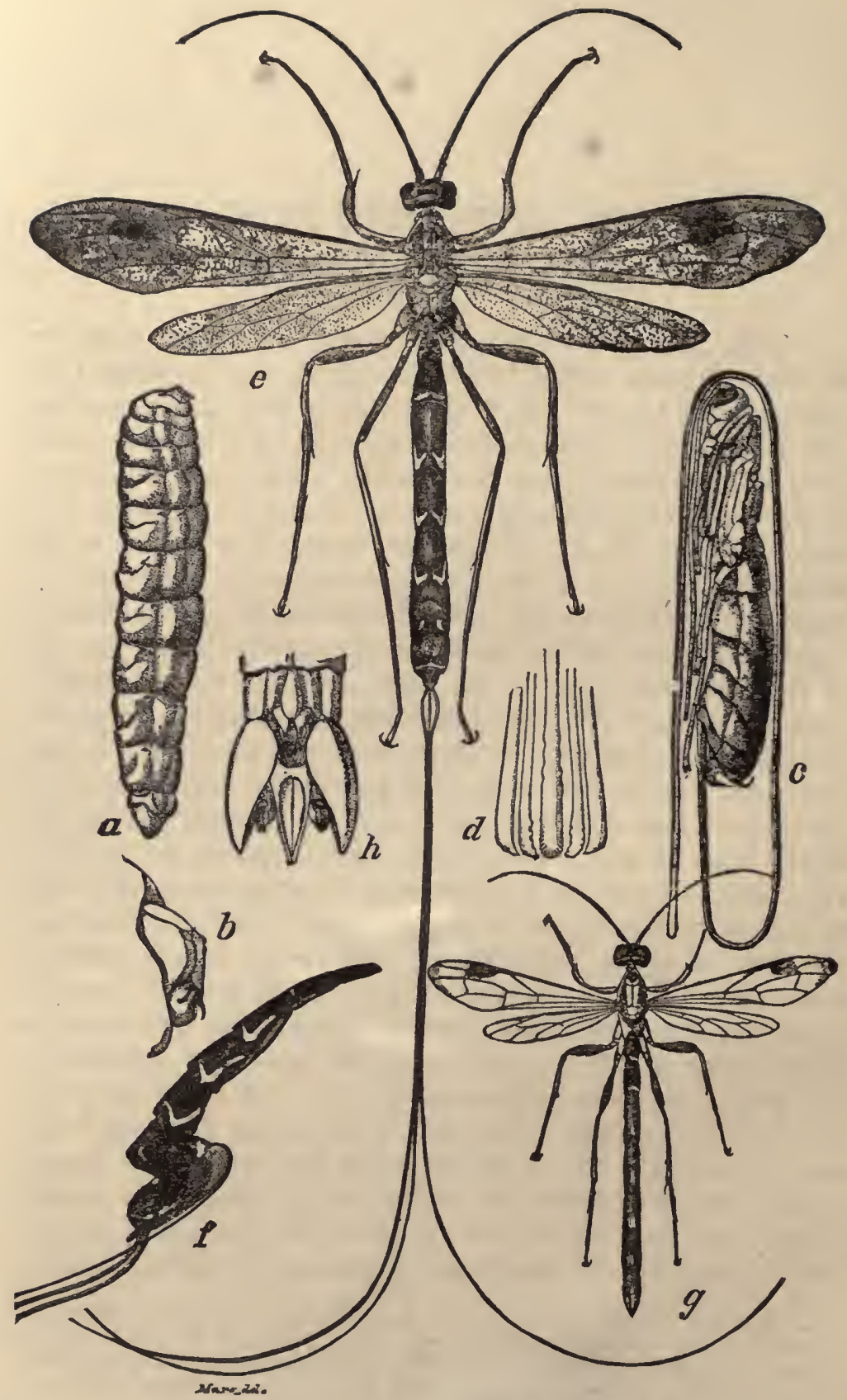

Fig. 35-Thalessa lunator. (From Insect Life.) 


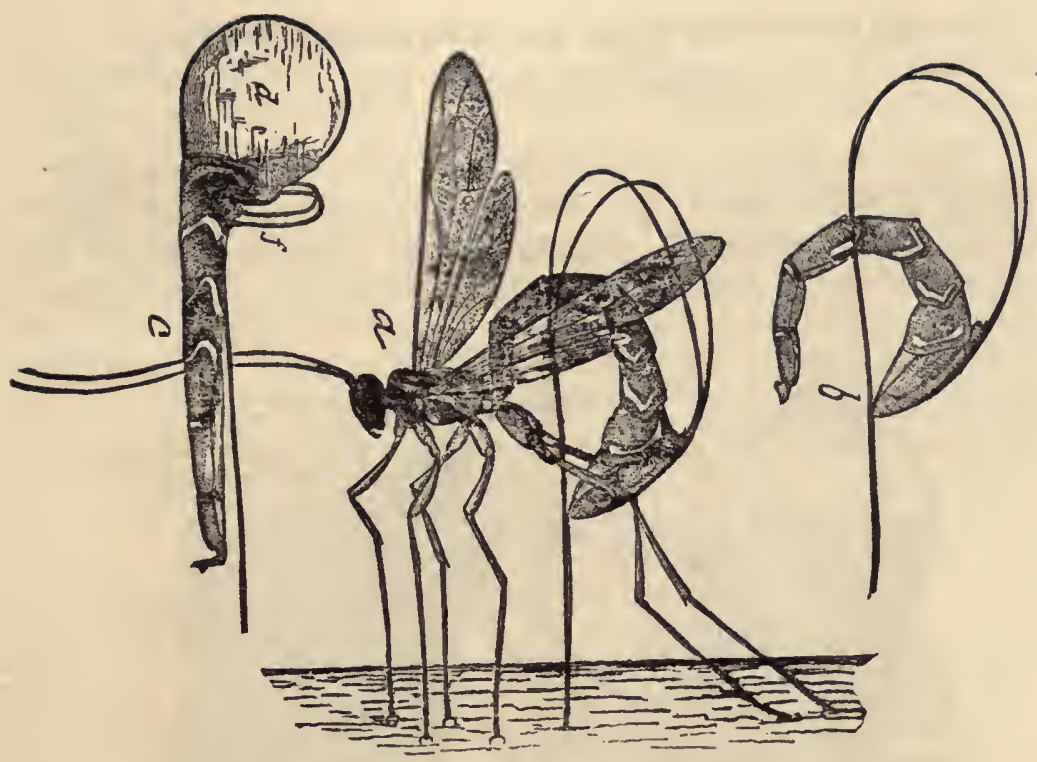

Fig. 36.-Thalessa lunator. (From Insect Life.)

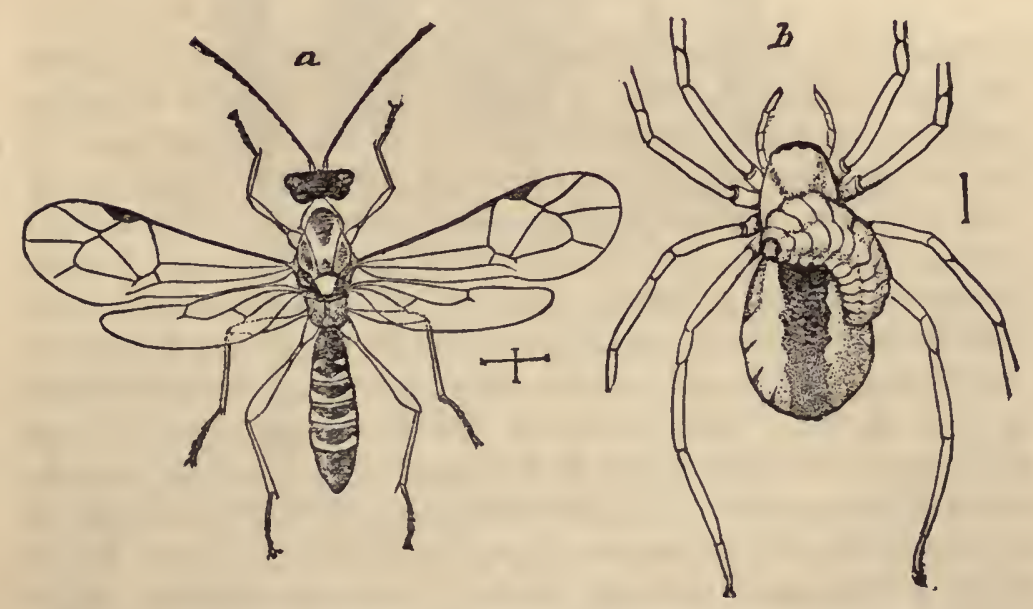

Fig. 37.-Polysphincta dictynæ, a parasite of spiders. (Author's illustration.) 
The Ichneumon Flies

\section{Life History of an Ichneumon Fly (Pimpla inquisitor, Say.)}

This important but widespread parasite of caterpillars occurs in California, Texas, lowa, lllinois, Missouri, Ohio, New York, New Hampshire, Massachusetts, Virginia, District of Columbia, and is probably to be found in all parts of the United

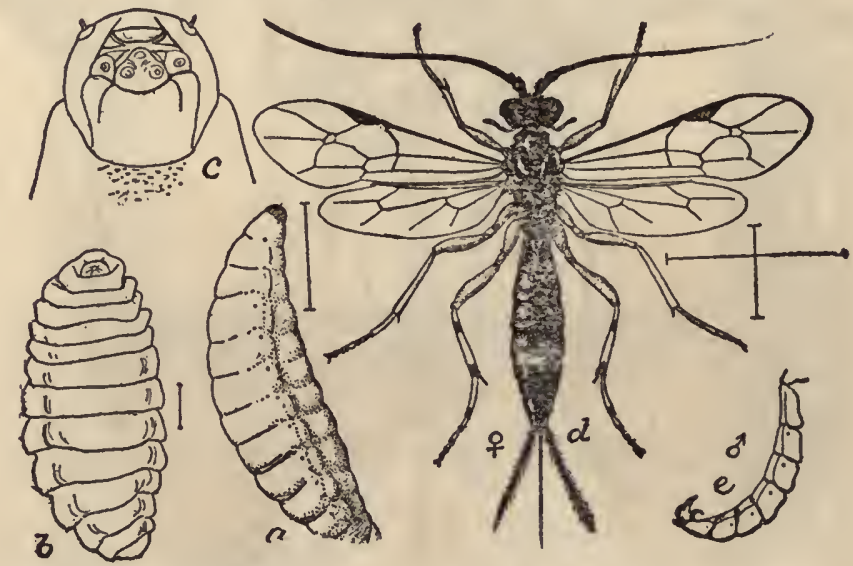

Fig. 38.-Pimpla inquisitor; $a, b, c$, larvæ at left; $e$, male abdomen. (Author's illustration.)

States except possibly in the very coldest portions. It is parasitic upon a large number of different kinds of larvæ of moths feeding upon such concealed spinners as the tent caterpillar of the orchard and the army worm of the forest (Clisiocampa americana and $C$. disstria) and upon certain stalk borers and gall makers, leaf folders and certain of the larger leaf miners. It is by far the most abundant of the parasites of the white marked tussock moth (Orgyia leucostigma), a famous shade tree enemy of the northeastern United States. The adult Pimpla is shiny black in color and has a wing spread of, on the average, three-quarters of an inch, the length of its body being about one-half an inch, but it varies greatly in size, the adults issuing from well fed larvæ exceeding these measurements and under-fed specimens transforming into much smaller adults. Upon the tussock moth caterpillar and upon the army worm of the forest the female Pimpla will lay her eggs when the larvæ are full grown or just after 
they have spun their cocoons, the latter time being seemingly preferable. When either species is abundant their newly spun cocoons are the rallying points of large numbers of these Pimplas. One of the females after running about for a few seconds will suddenly thrust its ovipositor through the cocoon into the body of the caterpillar which will writhe with pain. The Pimpla, however, will remain apparently undisturbed and push its ovipositor in to its full extent, remaining motionless in this position for about five minutes during which time the abdomen is slightly moved in a peristaltic manner as if forcing the eggs out and down through the ovipositor. She will then turn round, take a step or

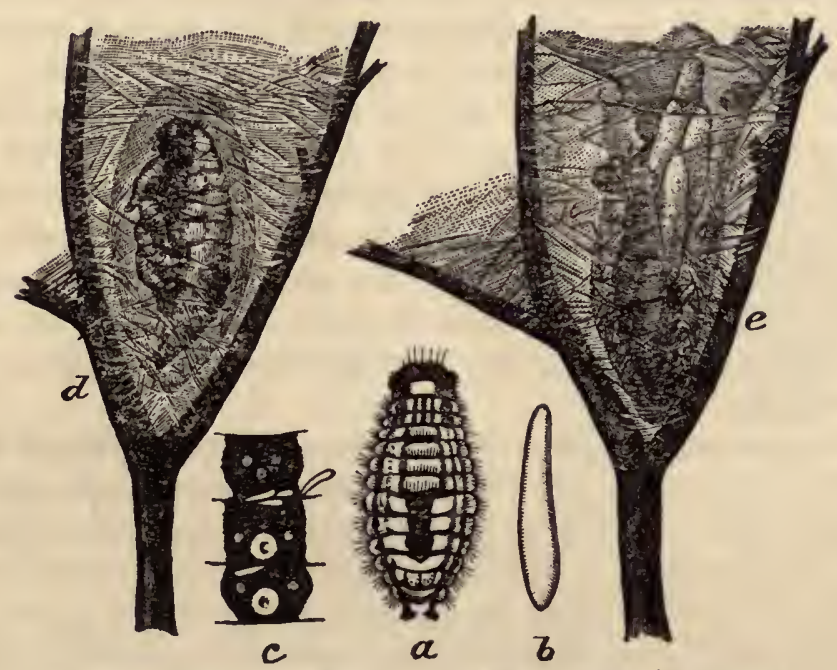

Fig. 39.-Pimpla inquisitor; $b, c$, eggs; $d$, larvæ; e, cocoons. (Author's illustration.)

two, and finally give the caterpillar what is apparently a coup de grace with two or three thrusts in quick succession. Sometimes the same operation is repeated. The eggs are not thrust into the body of the caterpillar when the latter is enclosed in its cocoon but sometimes are to be found loose between the cocoon and the caterpillar and sometimes not firmly attached to the skin of the caterpillar standing upright on end. The eggs are elongate, somewhat wider at one end than the other, pure white in color and perfectly smooth appearing highly polished. The average length is one mm., and the greatest width about one 
and eight-tenths $\mathrm{mm}$. The duration of the egg state must be very short and is probably only a matter of but a few hours. After hatching the Pimpla larvæ when at work upon a just spun up tussock moth caterpillar feed externally upon the body of the caterpillar, the mouth-parts closely applied to the skin and in fact obviously sucking blood through a minute orifice. Their growth is rapid and there is no perceptible casting of the skin. In midsummer the larvæ will become full grown in four days, when they are nearly ten $\mathrm{mm}$. long, by three $\mathrm{mm}$. in greatest diameter, fusiform in shape, and slightly curved. The color is yellowish white. They soon begin spinning cocoons. These cocoons, at first white and afterward turning gradually to a pale yellow brown, becoming much the same color as the cocoon of the tussock moth, are denser in structure and are composed of a considerably finer quality of silk. They are long oval in shape and are closely applied together adhering so firmly that it takes some little force to separate them. They are applied side by side and so closely that their oval outline becomes more or less angular at the point of application. Two days after the spinning of the cocoon in midsummer the larva changes to pupa and adults issue sometimes as early as six days later, making the entire life round of the species about fifteen days.

It sometimes happens that a tussock moth caterpillar is stung when it is just on the point of transforming, but in such a case the transformation to pupa is occasionally accomplished. The recently formed pupa is also occasionally stung. Contrary to the general rule holding when caterpillars are eaten out by the Pimpla larvæ the latter seem to feed within such pupæ and evidently to spin their cocoons within the caterpillar's pupa skin so that one will frequently find an apparently perfect pupa of the tussock moth within its cocoon which, however, contains four or five cocoons of the Pimpla packed close together and completely filling it.

The number of Pimpla larvæ nourished by a single tussock moth caterpillar varies from one to ten, with perhaps an average of three or four. This is the case in the summer time, but in the autumn more are found. Ten or fifteen in a single cocoon are not unusual at this time of the year, while in one case the writer has seen twenty-three male Pimpla cocoons in a single cocoon of the tussock moth. This particular cocoon mass was 
cross-sectioned and is shown at $c$ in the accompanying figure. When fall comes and the feeding and breeding season is past, all living individuals of this particular parasite will be found snugly packed away in the larval state within the bodies of some host insect and the winter is passed by them mainly in the larval condition in their cocoons. With the approach of spring, however, they transform to pupæ and about the time when the young host caterpillarș begin to hatch from their eggs the adult parasites emerge ready for the summer's campaign.

In this act of emerging it is interesting to notice that as with many other parasitic Hymenoptera and in fact with many other insects the males as a rule issue before the females and wait with impatience for the companionship of the fair sex. From one lot of cocoons studied by the writer in the spring of 1896 , forty-nine males issued between March 3d and 11 th before a single female put in an appearance. On March 1 $3^{\text {th }}$ and 14th a single female issued each day; on the 17th eight more; on the 18 th three more; on the 19th fourteen more, and on the 2oth twenty more. In the meantime the number of

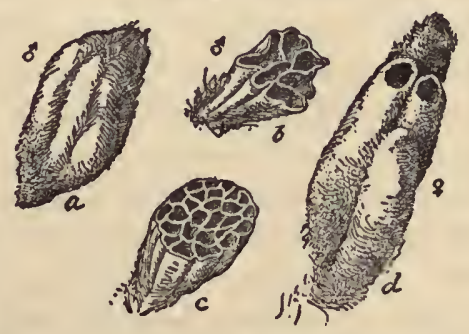
males issuing had rapidly fallen Fig. 40.-Cocoons of Pimpla inquisitor. off and they eventually ceased

(Author's illustration.) to make their appearance. The number of members of both sexes was approximately equal.

A curious fact may be noticed concerning the cocoons from which these early spring individuals issued, that is to say, the over-wintering cocoons. We have seen that an entire generation may be produced in a space of fifteen days in midsummer, but, of course, in colder weather the development is slow and the time may be much extended. Again, in the absence of proper host insects the females may live for several weeks without having opportunity to deposit their eggs. The midsummer cocoons are rather fluffy and although more closely spun than are the cocoons of the tussock moth caterpillar, they are still rather loose and the outer silk in particular is loosely spun. With the over-wintering cocoons, however, it is at once noticed that they are of a closer, tougher and more parchment-like consistency. There is less of 
the loosely spun silk with the individual although more of this loose silk surrounding the whole mass in any given host cocoon. Thus it seems as though the parasitic larvæ in preparing for the winter appreciated the degree of cold which they would have to experience and wisely prepared for it by making their habitations thicker and tighter against the inclemencies of the weather.

As abundant and hardy as this species seems to be it does not escape the attacks of enemies of its own. Certain soldierbugs have been seen to capture the adult females of the Pimpla when they were engaged so assiduously in egg-laying that they were blind to their surroundings. This is not surprising since one can approach them during this process so closely as to be able to study them well with a small hand lens. Then, too, secondary parasites have been reared from their cocoons, that is to say, internal parasites of their own, and still more strange to relate, Hymenopterous parasites of these secondary or hyperparasites have also been reared from the Pimpla cocoons. An extraordinary chain of links in the development of species is thus brought about and may be studied by any one during almost any summer in one of our northeastern cities. When the tussock moth caterpillars appear in great numbers on our shade trees during a given season, it will almost invariably be found that this Pimpla is present also in great numbers and that the majority of the caterpillars are stung by it. This means that the following season there will be an unusual number of adults of the parasitic insect which is now termed the primary parasite. So great is this abundance that the first generation of tussock moth caterpillars is practically wiped out of existence. Then comes the second curious fact, that the secondary parasites become enormously abundant and kill off the abundant Pimplas. At the end of the same season or at the beginning of the next the tertiary parasites put in their appearance and the secondary parasites are destroyed, thus giving relief again to the primary parasites which once more begin to be abundant and ready for the next case of super-abundance of the host caterpillar. This little chain of species depending upon species offers one of the easiest and most interesting series of observations which may be made by any school class in the part of the country indicated. 


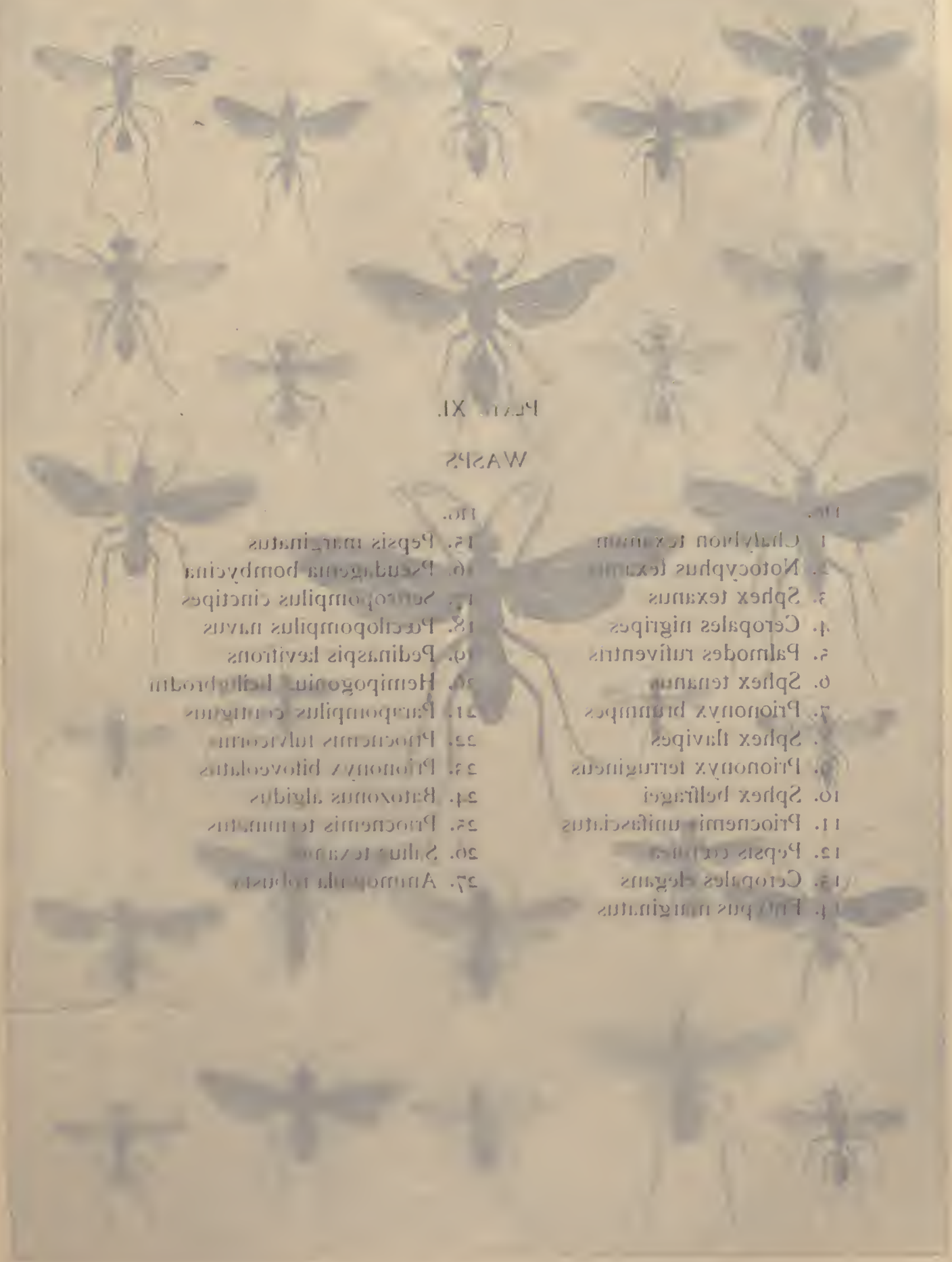




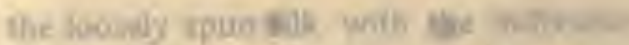

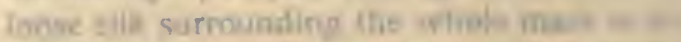

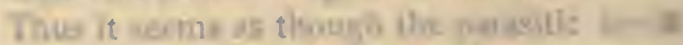

wherer wpyrecialed the deye we of cold

esperience and wiscly urryand tait.

theker and tighifer apans ifie incl

As abundant end binl. as is

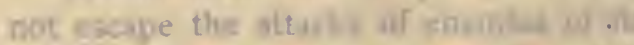

bugs have been iner io coptur our adult

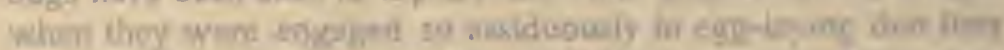

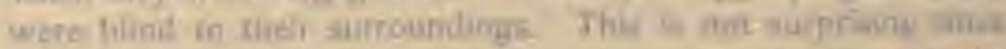

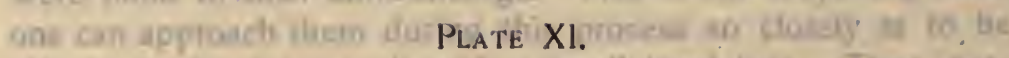

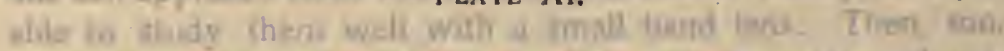

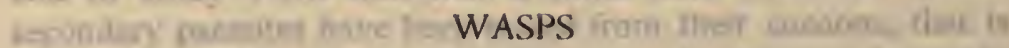

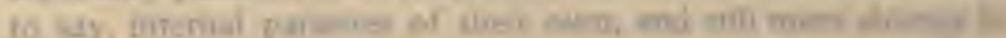

FIG.

1. Chalybion texanum

2. Notocyphus texanus

3. Sphex texanus

4. Ceropales nigripes

5. Palmodes rufiventris

6. Sphex tenanus

7. Priononyx brunnipes

8. Sphex flavipes

9. Priononyx ferrugineus

10. Sphex belfragei

11. Priocnemis unifasciatus

12. Pepsis cøerulea

13. Ceropales elegans

14. Entypus marginatus
FIG.

15. Pepsis marginatus

16. Pseudagenia bombycina

17. Sericopompilus cinctipes

18. Poecilopompilus navus

19. Pedinaspis lævifrons

20. Hemipogonius heiligbrodtii

21. Parapompilus contiguus

22. Priocnemis fulvicornis

23. Prionony $\mathrm{x}$ bifoveolatus

24. Batozonus algidus :

25. Priocnemis terminatus

26. Salius texanus

27. Ammophila robusta

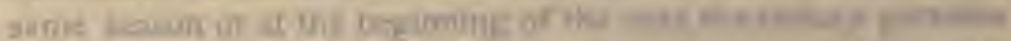

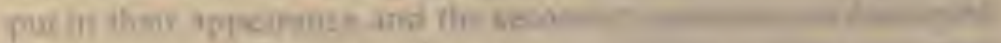

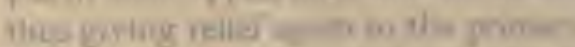

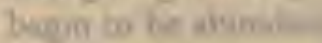

anee of line $\mathrm{k}$

nyoni paced o0e

of unsersangm: *

ferr dit cowery lowet. 


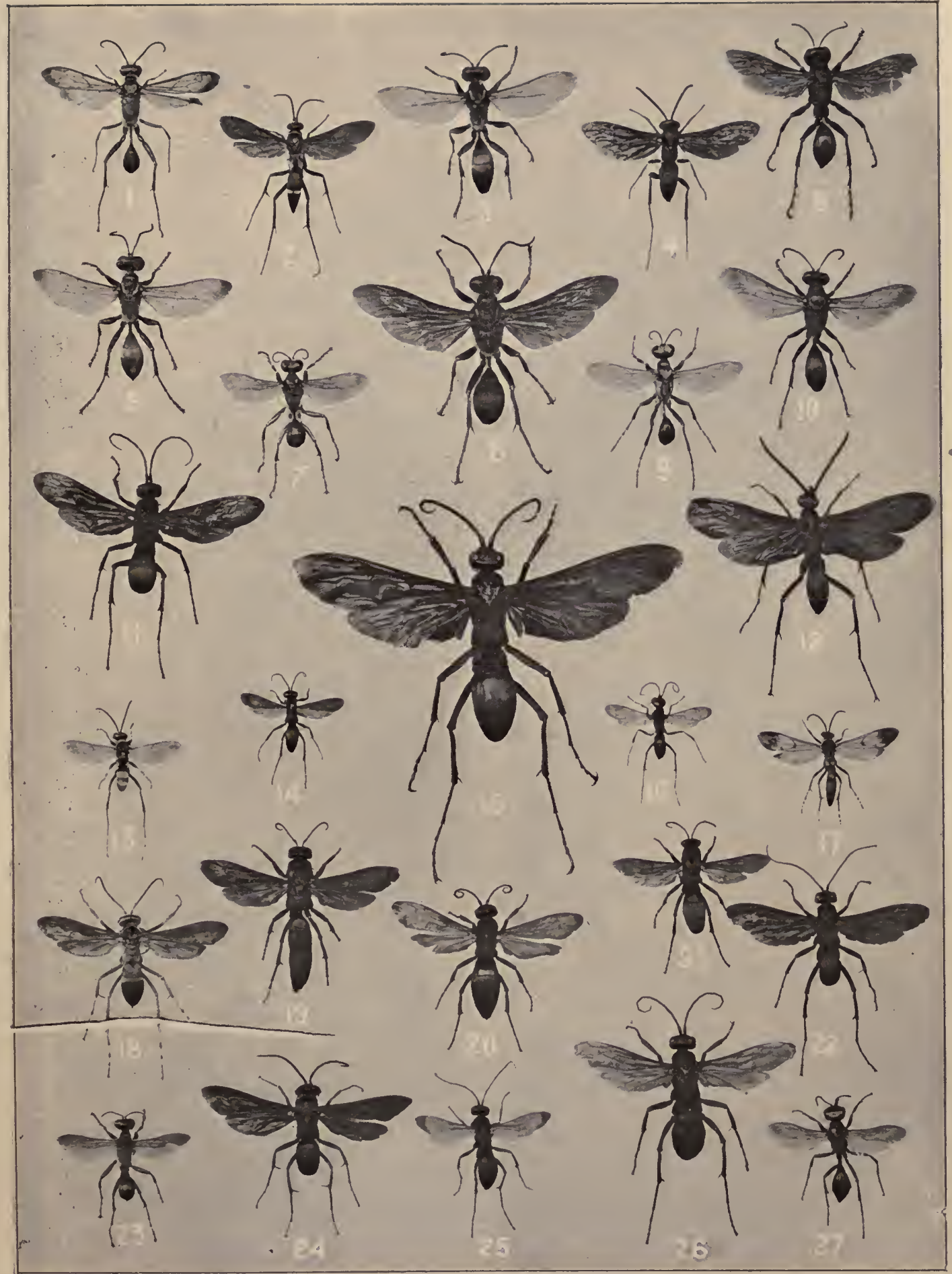





\section{THE HORN-TAILS}

\section{(Super-family Siricoidea.)}

These insects form an old series of Hymenoptera, known as the wood-eaters-Xylophaga. They are distinguished from the true saw-flies by the fact that the foreshanks have only one spur at the tip instead of two. They have the same broad abdomen and broad head and thorax.

The group includes the families Oryssidæ, Siricidæ, Xiphydriidæ and Cephidæ. The larvæ of all of these insects are woodborers, living in the stems of plants, and even in the trunks of trees. The adult flies are called horn-tails, because the end of the body usually bears a spine or horn. The ovipositor is fitted for boring instead of sawing, and with it the female bores into woody tissue and lays her eggs. The group is not a very large or a very important one, although it contains many common species. A noted example is the European Cephus pyginaus, which bores into the stems of wheat. This species was accidentally introduced into this country some years ago, and is now found in portions of Canada and New York State. Its damage, however, has not attracted the attention of farmers of late. The large pigeon Tremex (Tremex columba) is a not uncommon enemy to shade trees in certain of the northern states. It attacks the elm, oak, sycamore, and several varieties of maple. The holes of this borer may be recognized by their regular, evenly-cut shape, about the diameter of a lead pencil. Isolated shade trees along roads and in streets are favorite habitats. The writer, as a boy, saw them in great numbers in the maple trees on the grounds of the old Ithaca Academy, at lthaca, New York. In midsummer a large number of females would be seen boring into the trunk of a single tree, laying their eggs. The female plunges her borer perpendicularly into the trunks, holding it at right angles to the abdomen. The insertion requires eyidently great muscular effort, and the egg is deposited at the bottom 


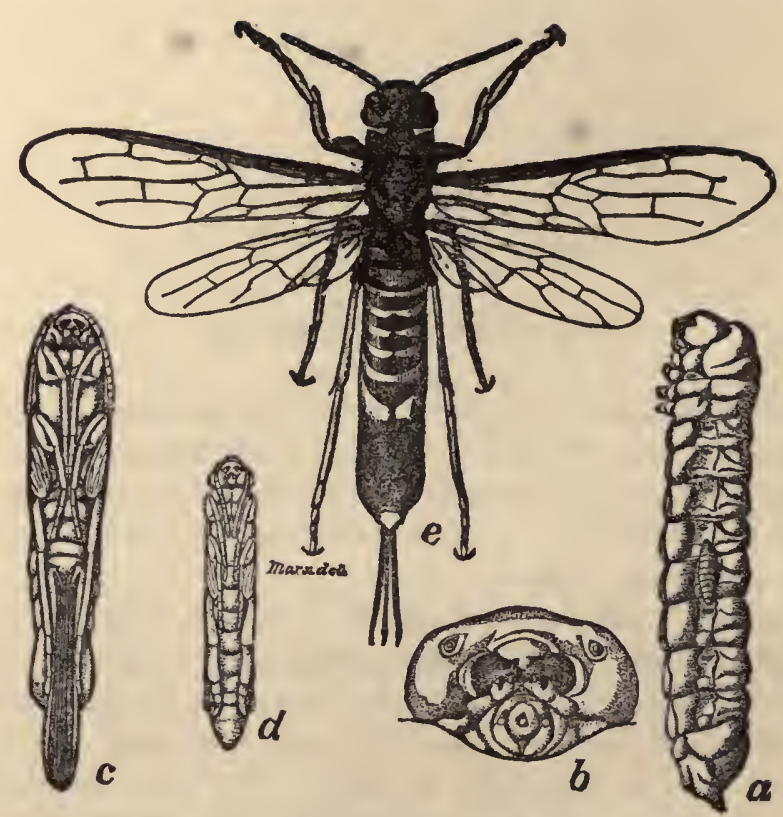

Fig. 41.-Tremex columba. (From Insect Life.)

It was a common sight to see females which, after laying, had been unable to withdraw the ovipositor, so that they had been

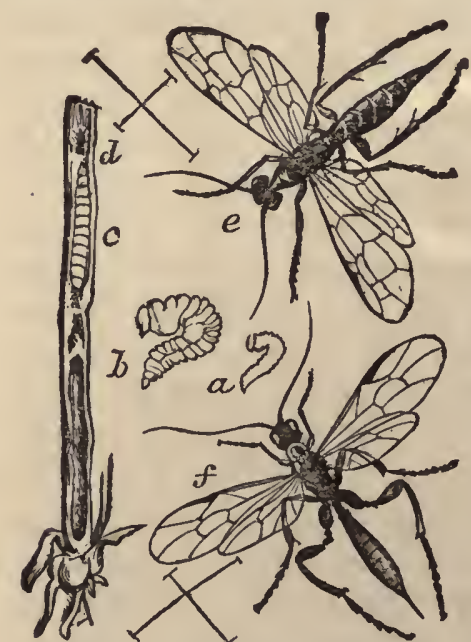

Fig. 42.-Cephus pygmæus. (After Curtis.) held to the trunk until they died. The eggs are oblong-oval and pointed at each end.

The common parasites of the larvæ of these horn-tails are the very large and extremely longtailed Ichneumon flies known as Thalessa lunator and Thalessa atrata. These Ichneumon flies lay their eggs in the burrows of the Tremex, and their larvæ feed upon Tremex larvæ.

The exact facts concerning the life of the Tremex larvæ in trunk of the tree have not been studied, and the species is such a common one that it will be 
an interesting matter for some observer to work out the life history in detail.

\section{Life History of a Horn-Tail \\ (Phyllocus integer, Norton.)}

This insect, which is known as the willow-shoot horn-tail, is found throughout the eastern part of the United States. The female, after boring a hole some inches below the tip of a willow twig, pushes her ovipositor in an oblique direction into the pith of the twig, inserting the eggs at the bottom of the puncture.

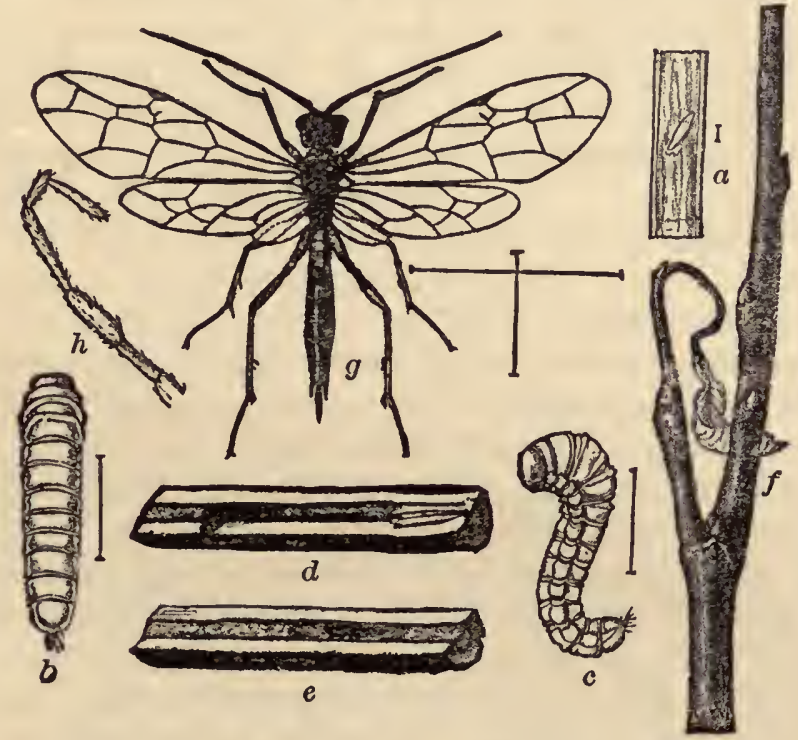

Fig. 43.-Phyllœcus integer. (From Insect Life.)

She then girdles the twig below the eggs to prevent it from growing any farther, obviously to prevent the egg from being crushed by the rapid growth of the plant. After a week the eggs hatch, the young larvæ bore their way down through the pith to a distance sometimes more than two feet, filling the channel behind them with their excrement as they proceed. The eggs having been laid in the spring, the larvæ feed all through the summer and become full-grown in late fall, filling 


\section{The Horn-Tails}

the lower end of the burrow for half an inch with frass. They then eat a passage through the side of the twig about a quarter of an inch above the prospective cocoon, but without cutting through the bark. Then the cocoon is spun in the burrow and the larva remains within it all through the winter, changing to pupa early in the spring.

In young willow groves, the shoots of which are intended for basket-making, the withered tips should be pruned off as soon as noticed in the spring. 


\section{THE SAW-FLIES}

\section{(Super-family Tenthredinoidea.)}

The saw-flies derive their name from the fact that the ovipositor of the female is peculiarly constructed, so as to act like a saw. There are two saws set side by side in a groove underneath the body and can be shoved out and moved up and down. They are used to make the proper aperture in leaves or other vegetable tissues in which the eggs are placed. The head and thorax are wide and the base of the abdomen is not slender. The front shanks bear two spurs.

The eggs are, as just indicated, laid in plant tissues, in apertures made by the female saws.

The larvæ as a rule are remarkable from their resemblance to caterpillars. Some of them look so much like cutworms that one might almost expect to breed moths from them instead of flies. They have, however, from twelve to sixteen prolegs, instead of ten, which is the usual rule with the caterpillar. Many of them also have the habit of curling the body around so as to embrace the twig upon which they may be walking. Many of them feed exposed upon the leaves of plants in much the same way as do caterpillars. Others, however, are covered with slime and look more like slugs than like insect larvæ, while still others are covered with a white, waxy excretion which completely disguises them.

There are a few leaf-miners in this group, while in the family Nematidæ are many gall-makers. A few make cases in which they live. Nearly all descend to the surface of the ground to transform to pupæ, and spin silken cocoons about themselves.

This super-family is particularly well represented in the United States, and its species in fact seem to be more abundant in temperate and cold regions than in the tropics. About two thousand species have been described. 
The Saw-Flies

Many saw-flies are so injurious to vegetation as to possess much economic importance; the larch saw-fly (Nematus erichsonii), in certain years, has destroyed large sections of larch forests in northern New England through the work of its
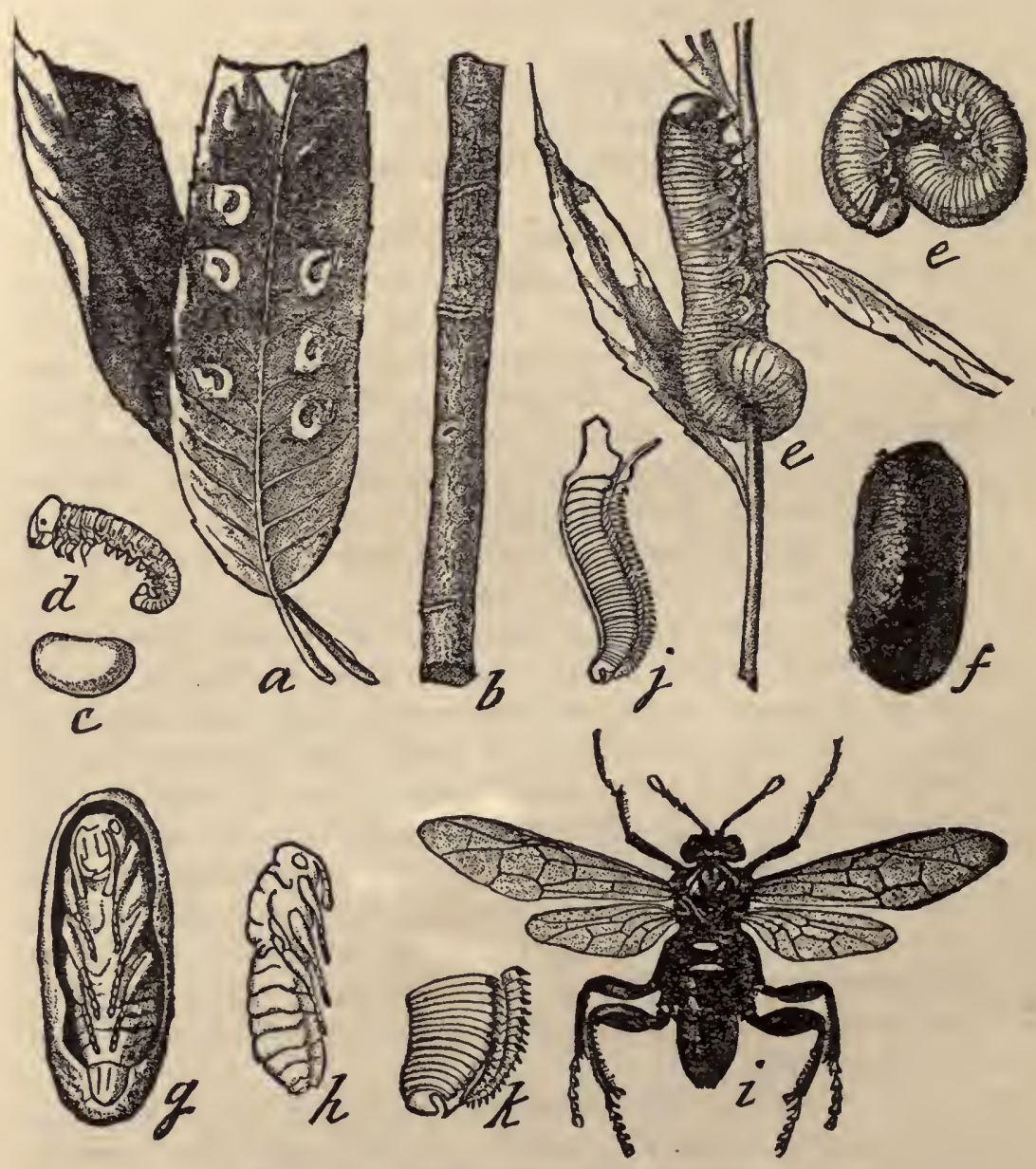

Fig. 44-Cimbex americana. (After Riley.)

larvæ; the imported currant worm (Nematus ribesii) is a famous enemy of currants in most parts of the United States; the common rose slug (Monostegia rosa), next to the so-called green flies and the rose chafer, is the most abundant enemy to rose 
bushes in different parts of the country, while the large and handsome Cimbex americana, known as the American saw-fly, is frequently found upon elms, willows and birches in sufficient numbers to almost entirely defoliate them. The yellow-spotted willow slug (Nematus ventralis, Say) is a common enemy to willows in the United States.

The life histories of all of the species just mentioned are well known, but there are very many forms which need careful study.
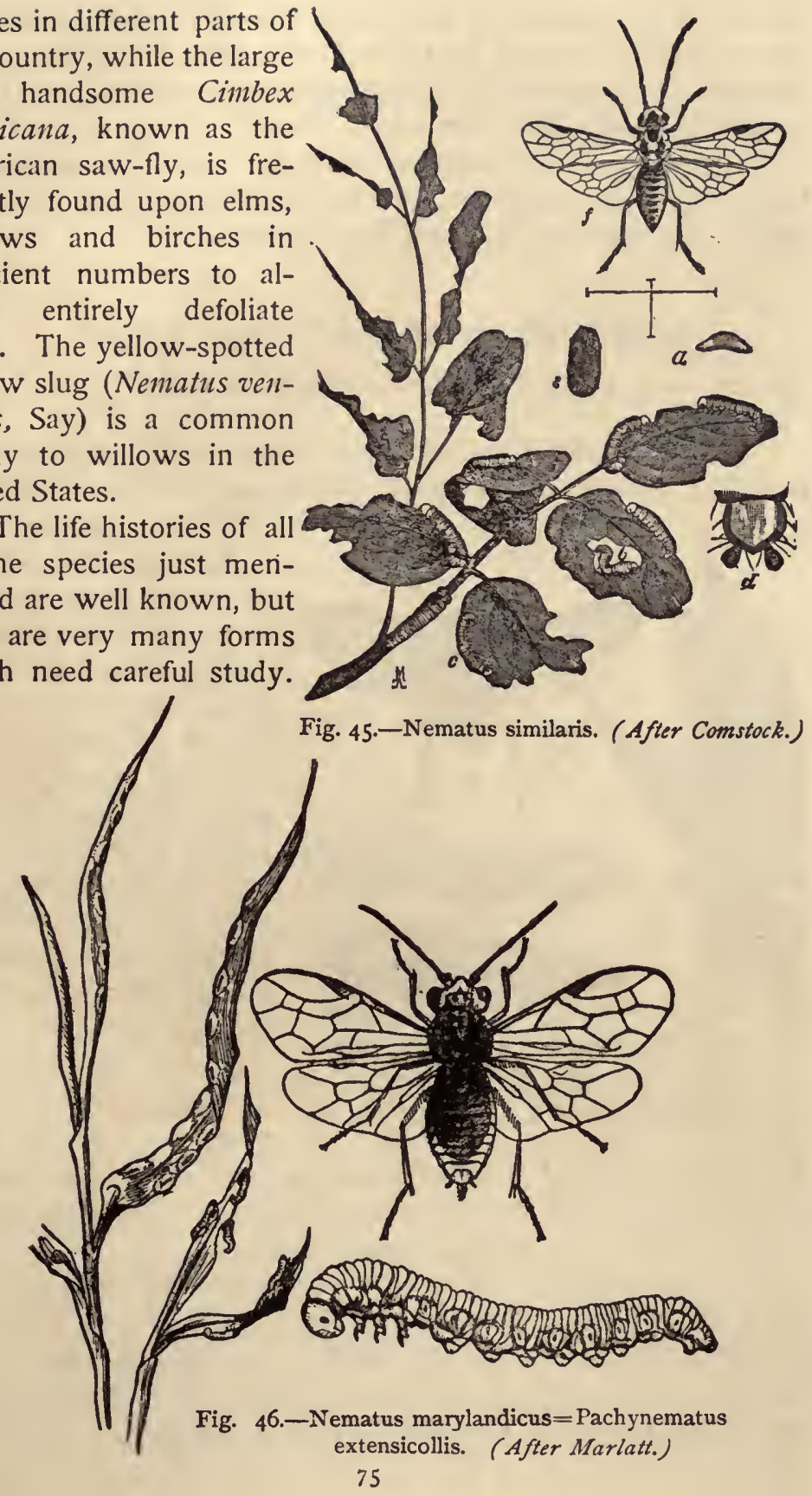
Several of the species of the genus Pontania which make the curious galls on willow leaves are convenient forms for study, and the full and careful life history of any one of them would be a valuable contribution to science.

The super-family Tenthredinoidea was formerly considered a family - the Tenthredinidæ-but it has been justifiably separated by Mr. Ashmead into eleven distinct families.

\section{Life History of the "Pear Slug" (Eriocampoides limacina, Retzius.)}

This insect, the larva of which is commonly known as the pear slug, belongs to the group which has the slimy caterpillars

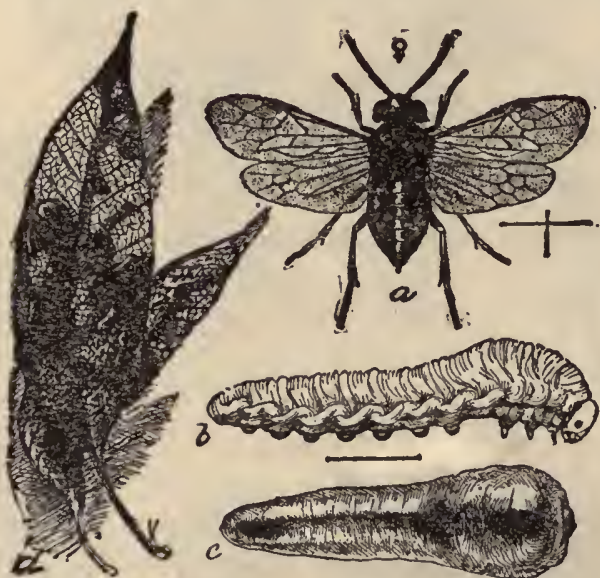

Fig. 47--Pear Slug: $a$, adult saw-fly, female; $b$, larva with slime removed; $c$, same in normal state; $d$, leaves with larvæ natural size; $a, b, c$, much enlarged. (After Marlatt.) referred to above. In fact, its scientific name, limacina, indicates this fact, since Limax is aslug.

This slimy, dark olivegreen, slug-like creature occurs commonly upon the leaves of pear, cherry, plum and allied fruit trees during most of the summer. Frequently itoccurs in such extraordinary numbers with the later broods that the leaves of the tree turn brown, die and fall to the ground in midsummer. Sometimes when the slugs are very abundant, the sound of the eating of myriads of mouths resembles the falling of a fine rain upon the leaves. There are sometimes thirty or more feeding upon a single leaf.

The adult insect is a small glossy black, four-winged fly, about one-fifth of an inch in.length.

The eggs are laid in April and May. The ovipositor of the female is thrust obliquely through the skin of the leaf from below, not reaching through the upper surface, however. The saw 


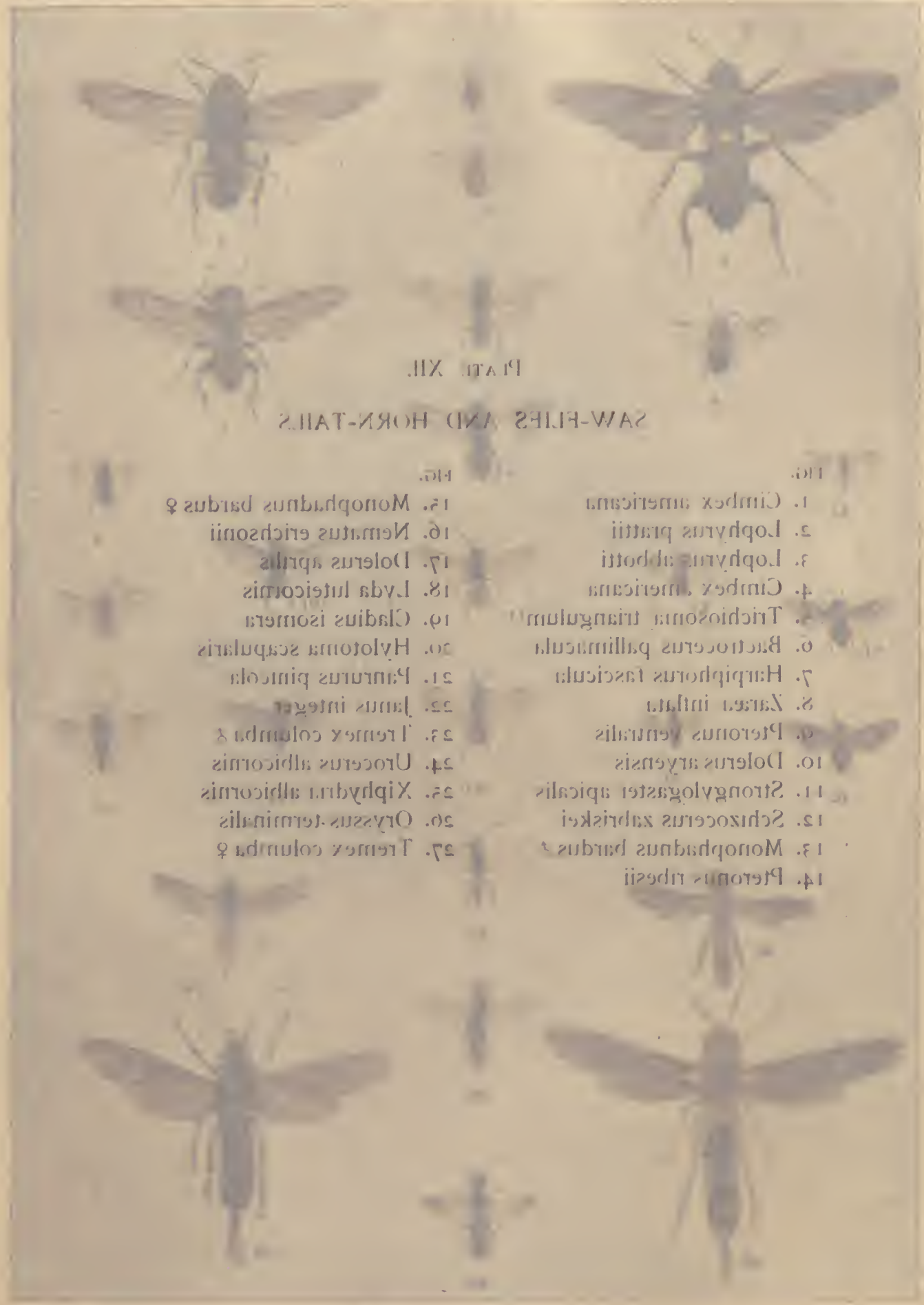




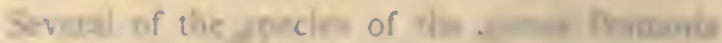

sumous gals on willow Beive

and tho full and carenul tilie foiltory

A valusble canierihudan to seienes.

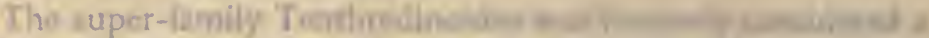

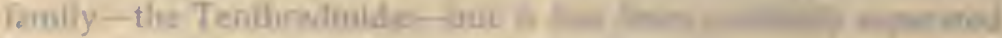

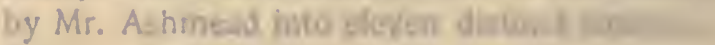

\section{Life History of the "Pear litur.

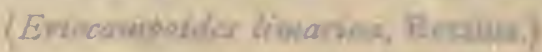

This insed, the lar PLATE XIl., is cannmendy knowun as the pear duE, SAW-FLIES AND HORN-TAILS tim y sterpllan

FIG.

I. Cimbex americana

2. Lophyrus prattii

3. Lophyrus abbotti

4. Cimbex americana

5. Trichiosoma triangulum

6. Bactrocerus pallimacula

7. Harpiphorus fascicula

8. Zaræal intlata

9. Pteronus ventralis

10. Dolerus arvensis

11. Strongylogaster apicalis

12. Schizocerus zabriskei

13. Monophadnus bardus $\delta$

14. Pteronus ribesii
FIG.

15. Monophadnus bardus \&

16. Nematus erichsonii

17. Dolerus aprilis

18. Lyda luteicornis

19. Cladius isomeri

20. Hylotoma scapularis

21. Panrurus pinicola

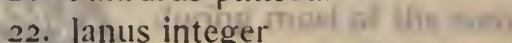

23. Tremex columba os

24. Urocerus albicornis

25. Xiphydria albicornis

26. Oryssus terminalis

27. Tremex columba 9

is

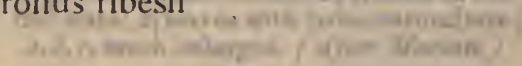

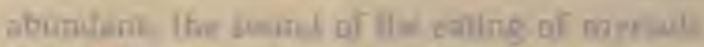

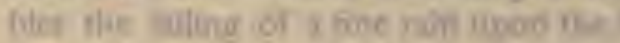

Nimed thitiy at mare for fime no

The soulh bosectes + to.

wbous anz-lifh

The gece bic bata

femals it shrus og: ims

not ceashine torewgh. tis . 


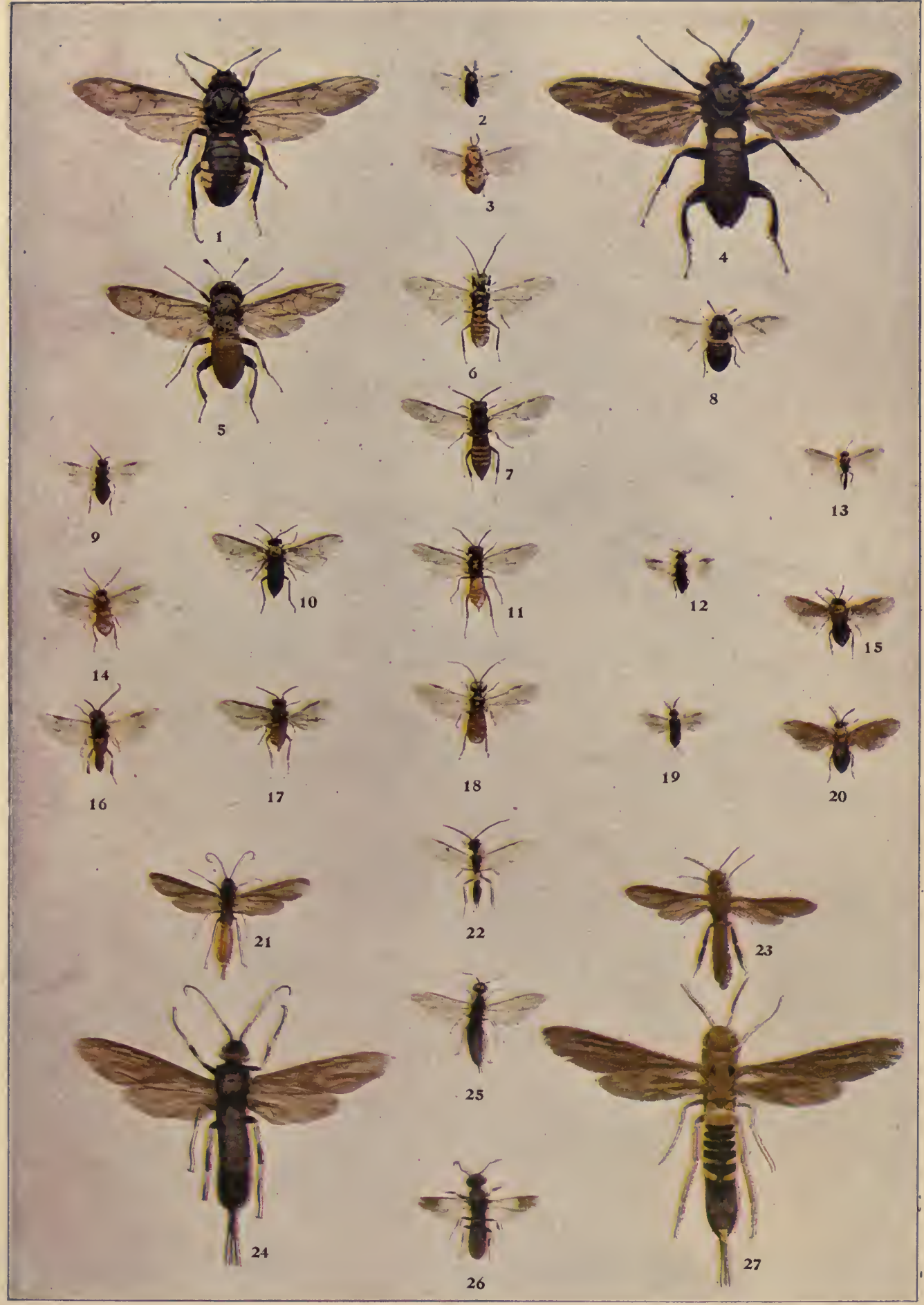



of the female is moved rapidly with a swinging lateral motion from side to side, forming an irregular cell or pocket of an oval outline. The egg is quickly passed down between the plates of

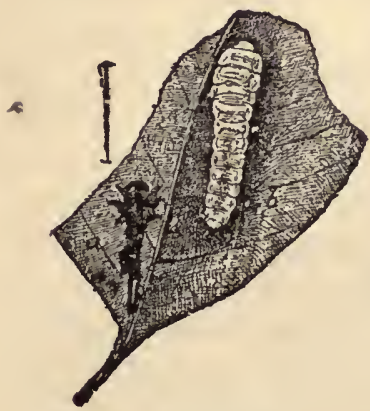

Fig. 48.-Pear Slug: $a$, last moulted larval skin; $b$, larva after casting last skinsomewhat enlarged. (After Marlatt.) the ovipositor, and dropped into the pocket thus made, the time occupying little more than a minute for the operation. A single saw-fly usually deposits only one egg in the same leaf, and after laying the egg she goes around to the upper side of the leaf and examines it carefully, rests awhile, and then flies to another leaf and repeats the operation. The egg is oval, slightly flattened on one side, and remains in the leaf about two weeks. It increases in size apparently by absorbing the plant juices.

The young larva on hatching makes a semi-circular cut through the upper surface and crawls on the top of the leaf. At first it is nearly white in color, with a yellowish brown head. Almost immediately a slimy, olive-colored liquid begins to exude over the whole body; the head appears black under the slime, and the body becomes dark. The anterior segments of the thorax swell out and the head is retracted, so that the little larva appears club-shaped. It begins feeding on the upper surface of the leaf, eating out small holes the size of a pinhead. This work

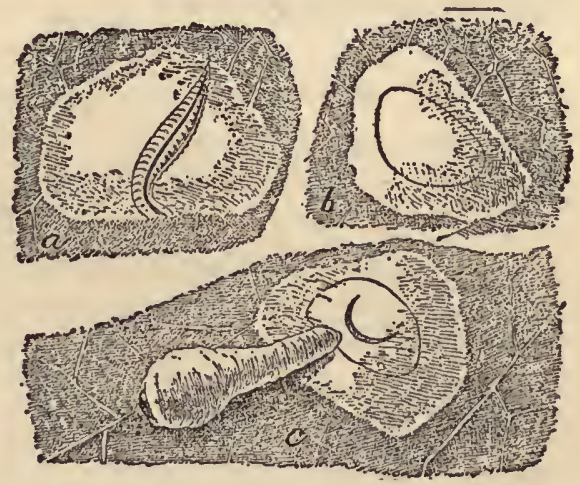

Fig. 49-Pear Slug, illustrating method of oviposition and emergence of larva. $a$, cutting of cell beneath epidermis, with ovipositor; $b$, same after egg has been deposited; $c$, same after escape of larva-enlarged. (After Marlatt.) continues and increases as the larva grows until the leaf becomes entirely skeletonized. Full size is reached in less than a month. The larva casts its skin four times, and usually eats its cast skin 
for its first meal after each molt. When full grown it molts a fifth time, leaving its cast skin as a slender line of slime attached to the leaf. It now appears as a light orange-yellow worm, perfectly clean and dry, with no slime. It then crawls down the plant to the ground, penetrating for half an inch or more and forming a little cell the sides of

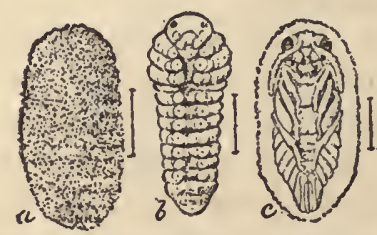

Fig. 50.-Pear Slug: $a$, cocoon; $b$, contracted larva; $c$, pupaall enlarged. (Aftcr MIarlatt.) which it moistens with saliva, thus forming a kind of cocoon of firm texture, more or less impervious to water. Near Washington the first generation of larvæ leaves the trees by the end of June, and a second generation begins to appear soon after; but in New York State many of the individuals of the first generation pass the winter in their cocoons. The insect hibernates below the surface of the ground, and the flies appear the following April or May.

No insect is easier to destroy than the pear slug. All of the insecticide mixtures kill it readily, and even throwing dust over the leaves will destroy it. 


\section{THE TRUE FLIES}

\section{(Order Diptera.)}

All the true flies, that is, those insects which are called flies and have but two wings, belong to the order Diptera. They are the only insects which possess but two wings, with the exception of the males of the scale insects, and a very few May flies (genera Clocon and Conis). Some insects in other orders have one pair of wings so greatly aborted that they appear two-winged as in the genus Psectra, one of the Lacewing flies. The wings are membranous and usually transparent and bear no scales, except in the mosquito family. The hind wings are represented only by two knobbed projections called halteres, or poisers. The metamorphosis is very complete, the larvæ being always footless and usually apparently headless maggots and the pupæ either somewhat resembling those of butterflies and moths, with comparatively free legs and wings, or they are enclosed in the larval skin. Their mouth-parts are formed for sucking. The true flies comprise an enormous number of species. The most numerous of all of the orders of insects are the Coleoptera, or beetles, the Hymenoptera, which we have just discussed, and the Diptera, and for superiority in point of numbers the precedence must probably be given to the Diptera. About forty thousand species are known and it is estimated that the number yet to be described will bring this number fully up to three hundred and fifty thousand, against three hundred thousand which we have estimated for the Hymenoptera. Not only have the true flies a superiority in point of numbers, but entomologists are concludirig that they probably stand at the head of the insect system in point of evolution, that is to say, they are the most highly specialized of insects. While they do not possess the apparent specialization in the way of intelligence and in other respects seen with the bees, wasps and ants, the very completeness of their transformations and the highly specialized organization of the adults of several families support this view. 
The order is not a popular one among entomologists and collectors. Aside from the fact that observations upon their life history are by no means as interesting as some of those which we mentioned in the preceding order, they have none of the beauty which attracts students and collectors to butterflies and moths and they have not the definiteness of structure characteristic of the beetles and they are much more difficult to preserve in collections in perfect condition. The hard-bodied, easily collected, and readily pinned beetles seem much more attractive. But the Diptera in many respects possess a peculiar interest and their study is of enormous importance from many points of view. Even in point of beauty, many of the families possess species of striking color and graceful shape; and; everywhere abundant as they are, they are easy objects to collect. It is true that with some of the delicate species, especially the mosquitoes and crane flies, it is almost impossible to preserve specimens in good condition. Still, with many of the groups they keep well when simply killed and pinned and preserve their colors much better than do the dragon flies, for example.

Very many species, and in fact entire groups, are harmful to man through damage to growing crops and to livestock. One of the most famous crop enemies in the world, the so-called Hessian fly, is a dipterous insect, and most of the insect parasites of livestock belong to this order. As late as 1884 , Dr. S. W. Williston, then of Yale University, an authority upon this order, wrote: "As a whole, the order is a beneficial one to the human economy. While we may resent the troublesome mosquito's and the impertinent house-fly's molestations, and while the black fly and the horse-fly may cause the death of many horses and cattle, yet the larger number are purely parasitic in their habits, either in the larval or adult states, upon other and usually injurious insects. Many others, too, act as beneficial scavengers of unwholesome matters, which would otherwise often bring disease and death." Since Williston wrote these lines, a whole class of baneful work accomplished by flies has been discovered. That is their agency in the spread of disease.

As early as 1864 , Leidy attributed the spread of gangrene in hospitals during the Civil war to the agency of the house-fly, and the terrible disease known as malignant pustule was afterward discovered to be caused by the bite of one of the gad-flies which 
carried the bacillus of anthrax from diseased cattle and by its bite inserted it into the circulatory system of human beings. The carriage of the purulent ophthalmia of the Egyptians by the house-fly was later demonstrated, and the spread of the disease known as "pink-eye" in the South has been shown by Hubbard to be facilitated by little midges of the genus Hippelates. An English army surgeon has ascertained that the tsetse-fly of Africa carries pathogenic germs from diseased cattle and by its bite transfers them to the blood of healthy cattle, and late investigations have shown that certain flies, and especially the common house-fly, are responsible not only for the spread of Asiatic cholera but of the everywhere prevalent and dreaded disease known as typhoid fever. A vital stimulus to this line of investigation has been given by the discovery that certain mosquitoes are responsible for the spread of malarial fevers and a very great interest has been excited and an enormous literature has sprung up within the last few years concerning this line of investigation. This interest has become even more intensified by the experimental proof obtained by the United States Army Yellow Fever Commission of the agency of certain mosquitoes in the spread of yellow fever. The whole subject of the agency of insects in the transmission of disease is one of the most prominent subjects of medical investigation' at the present time and nearly all of the insects concerned in this work belong to this order Diptera; so that, in spite of the benefits to humanity which the parasitic species bring by their destruction of injurious insects and in spite of the beneficial function which many Diptera exercise as scavengers, this incident of the lives of many of them, added to the ravages of many more on crops and domestic animals, makes the order a distinctly and markedly injurious one.

Many strange features in life history occur with the flies. With some no eggs are laid and living larvæ issue from the body of the female. Such flies then become practically viviparous, or "larviparous." With others, although these are few in number, the development within the body of the female goes even farther and when the insect emerges from the body of its mother it is already in the pupal condition. Such forms are called "pupiparous." We have mentioned the wings of the Diptera, but in some forms there are no wings. Such species, and they are also few in number, are usually parasites, and the loss of wings is one of the degradational features consequent upon the parasitic life. 
See the bedbug among the Heteroptera, the true lice (Anoplura) and the bird lice (Mallophaga). With those species which lay eggs the larval development is usually rapid; and with some forms, particularly those which are true scavengers and feeders upon carrion or upon excrement, it becomes very rapid. The possibilities for enormous multiplication are apparently greater in this order than in any other group of insects. It is estimated that the progeny' of a single house-fly, if undisturbed, would in the course of a single summer reach high into the billions in numbers, while an almost equally rapid multiplication takes place with some of the mosquitoes.

There is great variation in habits in the group. Most flies prefer the sunshine and are most numerous in the middle of sunny days. A few, however, such as the mosquitoes, fly at night. These, however, are the great exception. Very many flies frequent flowers, and thus exercise a beneficial function in the cross-fertilization of plants. Many species-comprising, in fact, whole families-are aquatic or sub-aquatic in their early stages, and some possess the faculty of living under what appear to be most disadvantageous conditions. Some of the flies of the peculiar family Ephydridæ, for example, live in the strongly alkaline lakes of the far West where almost nothing else can live.

It is surprising how little of an intimate and exact nature is known concerning the life history of most flies. It is true that maggots are not attractive creatures, but the mode of life is so variable in the different groups of flies and the transformations are so remarkable that a very great interest attaches to many of these life histories. Unfortunately, however, very few observers have done any work in this direction and it results that there is room for an army of workers who will find it especially easy in this order to add to scientific knowledge. It will be noticed in the consideration which follows of the different families that full observations have not yet been recorded in many of them from which typical life histories can be drawn up. This is a sad state of affairs and it is one which observers of nature should endeavor to remedy. As an example, it was not until 1895 that a full account was published of a single one of our common North American mosquitoes and even so ubiquitous an insect as the house-fly was neglected in this country until a comparatively recent date. It is a strange fact, although not impossible to explain, that our com- 
monest forms are neglected by students. One not only does not find them in collections, but when an attempt is made to find what is known about their lives it often results that no information can be gained from books. The reason for this in part is that everyone thinks that everything must be known about these common things.

The classification of the Diptera is complicated. The order has been split up into many families and the determination of species and genera in many of these families is exceptionally difficult. For the following table of the families and higher groups the writer is indebted to Mr. D. W. Coquillett, and it is taken in part from the advance sheets of a paper about to be published by the U. S. National Museum.

\section{TABLE OF THE HIGHER GROUPS}

Antennæ conspicuous, inserted at upper end of the face, sometimes many-jointed, proboscis usually furnished with terminal lips, body rather soft and brittle, legs approximated, wings usually present and frequently furnished with a discal cell ; adults oviparous or larviparous, never in all their stages. living externally on mammals, birds nor honey bees (Suborder PROBOSCIDEA) ........................... I

Antennæ usually inconspicuous, commonly inserted near the middle of the sides of the face, and composed of from one to three joints, the apex furnished with a style or bearing several long bristly hairs, proboscis never furnished with terminal lips, body integument tough and leathery, legs on one side of the body usually widely separated from those on the other side, wings, when present, never furnished with a discal cell ; adults pupiparous, living externally upon mammals, birds or honey bees (Suborder EPROBOSCIDEA) .......6 r

\section{Suborder PROBOSCIDEA Latr.}

1-Discal cell, when present, usually furnished with three veins that extend to the wing-margin; frequently four or five posterior cells are present, the third vein sometimes forked; if the second basal and discal cells are confluent the color 
of the body is usually metallic greenish or the antennal style is usually apical, antennæ sometimes composed of more than three joints; head of the larva of a firm texture and definite shape, pupa not inclosed in the old larval skin, or if inclosed this never forms a hard, cylindrical puparium, the pupa or the imago issuing through a longitudinal and transverse fissure (Section Orthorhapha).. 2

Discal cell, when present, never furnished with more than two veins; never more than three posterior cells are present, the third vein never forked; when the second basal cell is confluent with the discal the color of the body is never metallic green; antennæ never more than three-jointed, the terminal joint usually furnished with a slender arista which is generally dorsal, empodium bristle-like or wanting; head of the larva soft and mobile except the mandibles, the pupa inclosed in the hardened skin of the larva, which is ruptured circularly near the anterior end during the emergence of the imago (Section Cyclorhapha)...30

\section{Section ORTHORHAPHA Brauer.}

2-Joints of antennæ more than three in number; the last one seldom furnished with a slender style or arista; antennæ and legs usually very long and slender; body also usually slender, and rather delicate (Subsection Nemo-

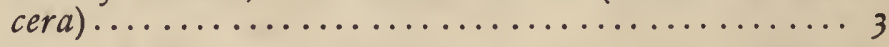

Joints of antennæ never more than three in number; the terminal one much longer than the others and frequently annulate, sometimes furnished with a jointed style or arista; antennæ and legs usually short and robust; body often elongated (Subsection Brachycera)............ I5

\section{Subsection NEMOCERA Latr.}

3-Antennæ usually long and slender, the joints usually longer than broad, and nearly always provided with verticels of bristly hairs, the structure frequently very different in the opposite sexes of the same species; eyes seldom broadly contiguous above the antennæ in either sex, sometimes narrowly contiguous above alid below the antennx, the facets of a uniform size and not separated by a transverse line into an upper and a lower portion; body usually slender and elongate, pulvilli wanting (Super-family Tipuloidea) ............................ 4 


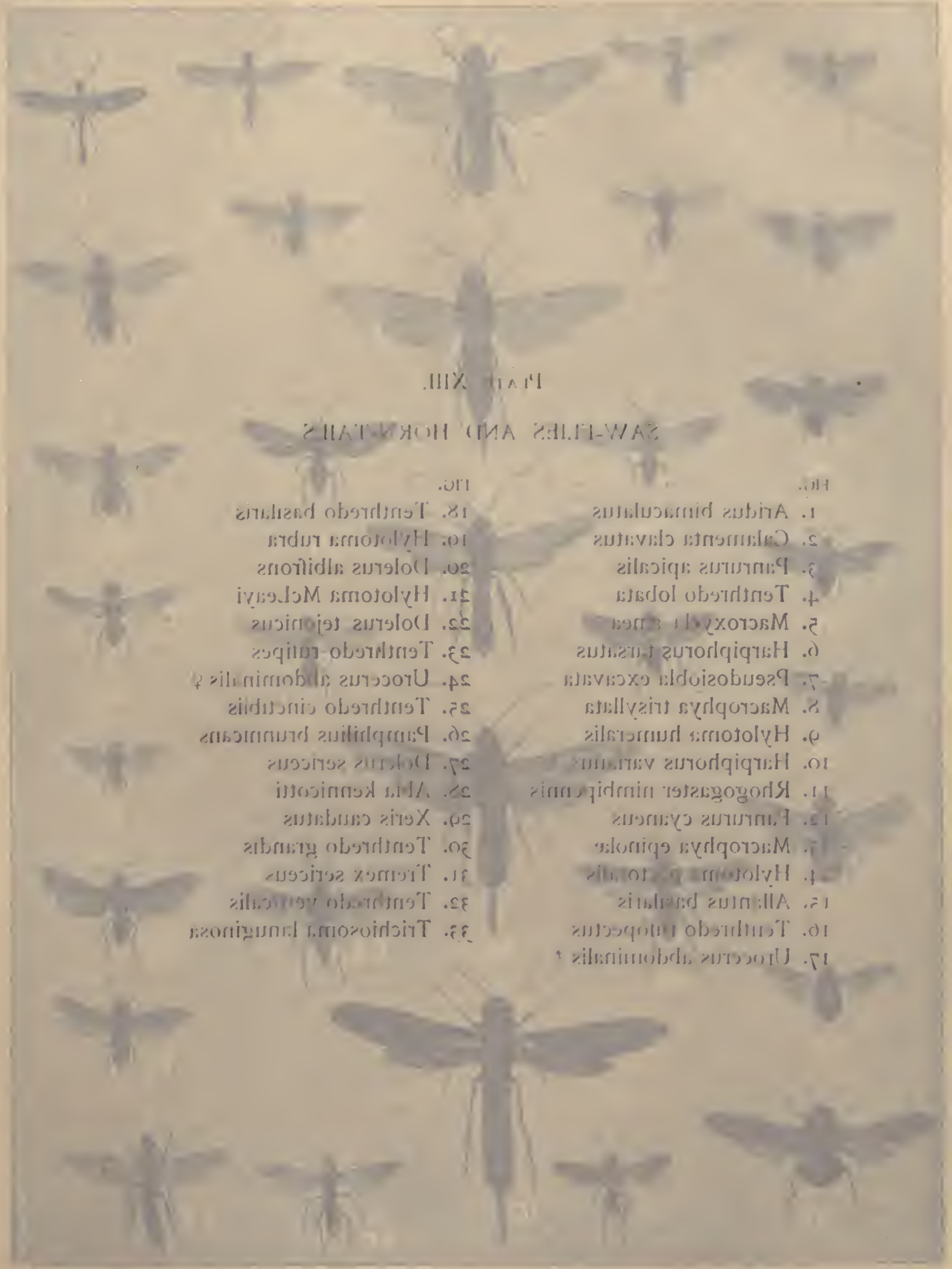


ol the body to uveld aryle is usiaing apaca more than Whee Jamai scad texrure and delinite ther pur

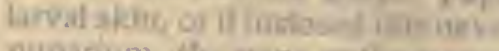
puparian the yope or Q.e mis tudinal ind manse hator

Dic cal cell, wher

yeine: mever in comilus

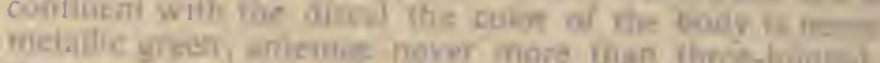

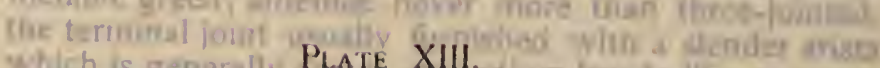
Which is generally PLATE, XIII. Sium Jerible llike or wains

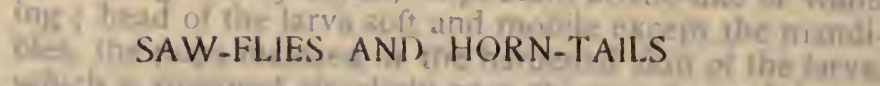

FIG.

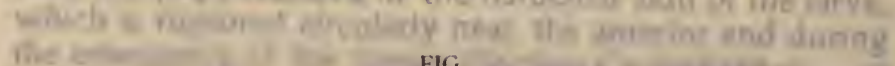

1. Aridus bimaculatus FIG.

2. Calamenta clavatus

18. Tenthredo basilaris

3. Panrurus apicalis

19. Hylotoma rubra

4. Tenthredo lobata

5. Macroxyela æenea

20. Dolerus albifrons

6. Harpiphorus tarsatus

21. Hylotoma McLeayi

7. Pseudosiobla excavata

22. Dolerus tejonicus

8. Macrophya trisyllata

23. Tenthredo rufipes

9. Hylotoma humeralis

24. Urocerus abdominalis of

10. Harpiphorus varianus

25. Tenthredo cinctibiis

11. Rhogogaster nimbipennis

26. Pamphilius brunnicans

27. Dolerus sericeus

12. Panrurus cyaneus

1). Macrophya epinola

8. Abia kennicotti

29. Xeris caudatus

14. Hylotoma pectoralis

30. Tenthredo grandis

15. Allantus basilaris

31. Tremex sericeus

16. Tenthredo rufopectus

32. Tenthredo verticalis

17. Urocerus abdominalis $f$

33. Trichiosoma lanuginosa

thein brued, who itse

irelly wings wae

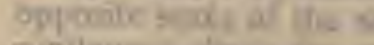

nendias

Iiccelt of

$\operatorname{lime} \ln$

clervoler wis

Fophanifne 


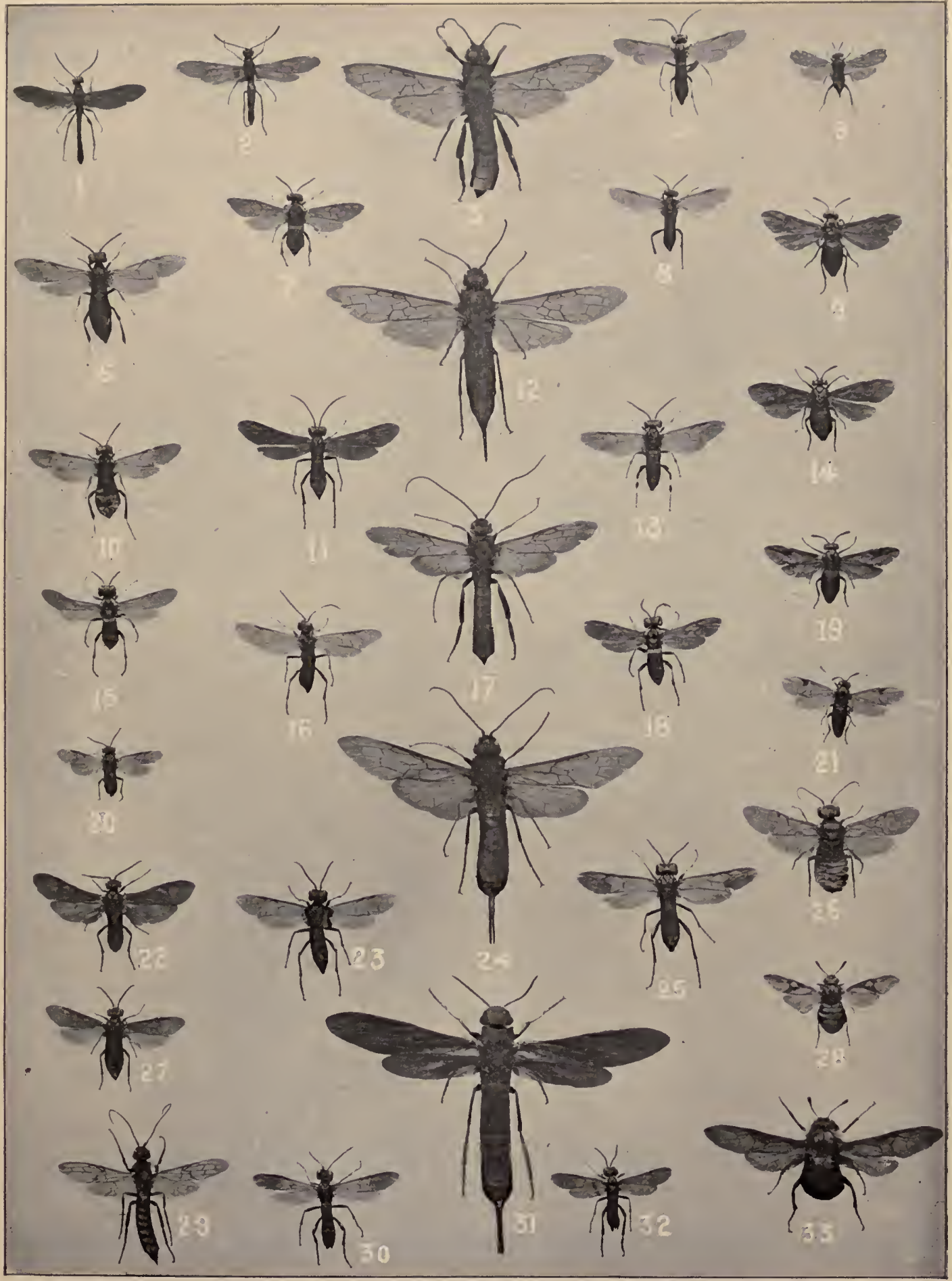



Antennæ rather short, never furnished with verticels of bristly hairs, of the same structure in both sexes, eyes frequently broadly contiguous above the antennæ, but always separated below it, pulvilli, frequently well developed, body rather robust (Super-family Bibionoidea)............ II

\section{Super-family TIPULOIDEA Coq.}

4-Thorax never furnished with a distinct $V$-shaped groove near the middle of the upper side, discal cell always wanting 5

Thorax furnished with such a groove, discal cell usually present, mostly large flies, some of them the largest in this subsection; crane-flies.............. Family Tipulida.

5-Last subdivision of the veins which reach the wing-margin at least nine in number, hind margin of the wings encompassed by a vein, tibiæ never furnished with a pair of spurs at the apex of the inner side.............6 6

Last subdivision of the veins which reach the wing-margin not more than eight in number, tibiæ sometimes furnished with a pair of terminal spurs $\ldots \ldots \ldots \ldots \ldots \ldots \ldots .6$

6 -Veins of the wings bearing long hairs or scales........ 7

Veins bare, in the outer half of the wing three of the veins are forked and there are two cross-veins; rather large and rare flies......................Family Dixidae.

7-Wings long and slender, the veins and body bearing flattened scales; mosquitoes................. Family Culicida.

Wings usually broad, like the body covered with long hairs ; small, moth-like flies.............. Family Psychodida.

8-First two veins never coalescing and then separating into four

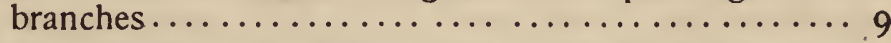

First two veins near their bases coalescing for a considerable distance and then separating into four branches, the remaining vein forked; rather small, very rare flies....... ......................... Family Stenoxenida.

9-Posterior margin of the wings encompassed by a vein, or the tibiæ furnished with a pair of long, apical spurs....... I0

Posterior margin of the wings not encompassed by a vein, tibiæ never furnished with a pair of apical spurs, ocelli wanting, antennæ of the male frequently feather-like or with a pencil of long hairs......... Family Chironomida. 
Io-Tibiæ not furnished with apical spurs, ocelli usually wanting, wings mostly with only three veins of which the last one is forked; small, delicate flies; gall gnats........ ..................... Family Cecidomyiida.

Tibiæ furnished with a pair of spurs at the apex of the inner side, ocelli present............ Family Mycetophilida.

\section{Super-family BIBIONOIDEA Coq.}

I -Ocelli absent, or the wings covered with a net-work of creased lines, or the discal cell present.......... 12

Ocelli present, wings never furnished with a discal cell nor with a net-work of creased lines, the front tibiæ are sometimes greatly swollen, or in some cases are furnished with a circle of short spines. . Family Bibionida.

12-Vertex of head not furnished with ocelli; flies of small size, I 3

Vertex of head furnished with ocelli, wings rather long and

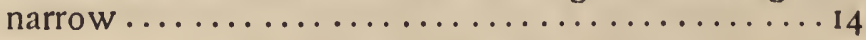

13-Antennæ of nearly an equal thickness, wings unusually broad, the veins on the posterior portion faint; the black-flies ................... Family Simuliida.

Antenna very thick at its base, rapidly tapering to a stylelike, jointed apical portion, the palpi are almost as long as the antennæ; very rare flies.. Family Orphnephilida.

14-Wings furnished with a net-work of creased lines, discal cell never present............ Family Blepharocerida.

Wings never furnished with creased lines, discal cell present; rather large flies............... Family Rhyphida.

\section{Sub-section BRACHYCERA Macq.}

15-Empodium broad, similar to the two pulvilli, third joint of the antennæ frequently annulated, body and legs not provided with stout bristles (Super-family Tabanoidea) 16

Empodium narrow, bristle-like, or wanting, third joint of the antennæ never annulated, body and legs frequently furnished with stout bristles................. I

\section{Super-family TABANOIDEA Coq.}

16-Calypteres very large, or the tibiæ not furnished with terminal spurs ....................... 
Calypteres small or rudimentary, at least one pair of tibiæ provided with distinct spurs at the apex of the inner side..................... Family Leptida.

17-Third joint of the antennæ distinctly annulated...... 8

Third joint not annulated..$\ldots \ldots \ldots \ldots \ldots \ldots$

18-Discal cell lying in the middle of the width of the wing, posterior margin of the wing encompassed by a vein... 19

Discal cell lying between the middle of the width of the wing and the costa, posterior margin of the wing not encompassed by a vein............ Family Stratiomyiidoe.

19-Tibiæ never furnished with terminal spurs, calypteres rudimentary; large flies from Middle and South America... ............................. Acanthomeridoe.

Tibiæ provided with terminal spurs on at least one pair, calypteres very large; horse-flies.... Family Tabanido.

20-Head small, much narrower than the very convex thorax, calypteres very large; hump-backed flies............ ........................ Family Acroceridoe.

Head at least as wide as the depressed thorax, calypteres very small; flies not at all hump-backed. Family Nemestrinidae.

$\mathbf{2} \mathbf{I}$-When five posterior cells are present the fourth vein ends before the extreme apex of the wing; when less than five the anal cell is much longer than the second basal and the third vein ends below the tip of the wing, discal cell always present (Super-family Bombylioidea.)..22

When five posterior cells are present the fourth vein ends below the extreme apex of the wing, when less than five the anal cell is wanting, or, if present, is shorter or scarcely longer than the second basal, or the third vein ends before the extreme apex of the wing, discal cell sometimes coalescing with one of the other cells $\ldots .24$

\section{Super-family BOMBYLIOIDEA Coq.}

22-Wings provided with less than five posterior cells $\ldots \ldots 23$

Wings provided with five posterior cells, fourth vein ending before the wing tip, antennal style much narrower than the third antennal joint; inhabit the southwest........ ........................ Family Apiocerida.

23-Style of the antennæ flat, much wider than the third antennal joint; large, elongate, nearly bare flies.. Family Mydaida. 
Style of antennæ, when present, much narrower than the third antennal joint, fourth vein ending below the wing tip...................... Family Bombyliida.

24-Discal cell wanting or coalescing with one of the other cells, fourth vein coalescing with the fifth for a considerable distance, or the wings having two longitudinal and three or four oblique veins issuing from the second (Super-family Phoroidea).....................29

Discal cell usually present, fourth vein not coalescing with the fifth, wings provided with more than two longitudinal veins (Super-family Asiloidea)...........25

\section{Super-family ASILOIDEA Coq.}

25-Apex of the third vein usually situated below the extreme tip of the wing, body sometimes metallic green or bluish: 26

Apex of the third vein situated at or above the tip of the wing, body never metallic green or bluish, proboscis furnished with terminal lips, anal cell much longer than the second basal, three posterior cells present, third vein forked, antennæ not furnished with a style or arista ....................... Family Scenopinida.

26-With five posterior cells in each wing, anal cell always present and much longer than the second basal, third vein always forked...$\ldots \ldots \ldots \ldots \ldots \ldots \ldots \ldots 27$

With less than five posterior cells, anal cell sometimes wanting; when present it is shorter or only slightly longer than the second basal cell...................28

27-Proboscis furnished with terminal lips, face strongly retreating on its lower part, not bristly.... Family Therevida.

Proboscis sharp-pointed, not provided with terminal lips. face projecting forward or convex on its lower part, provided with strong bristles or long hairs........... ............................ Family Asilida.

28-Second basal cell, when confluent with the discal, the color of the body is never metallic green, anal cell sometimes wanting, third vein sometimes forked.. Family Empida.

Second basal cell confluent with the discal, anal cell always present, third vein never forked, color of body usually metallic green.............. Family Dolichopodida. 


\section{Super-family PHOROIDEA Coq.}

29-Wings furnished with more than two longitudinal veins, fourth vein coalescing with the fifth beyond the apex of the second basal cell, then separating into three branches, axillary lobe and cell wanting, anal cell very narrow... ........................ Family Lonchopterido.

Wings furnished with two longitudinal veins, situated near the costa, the second vein sending three or four indistinct veins obliquely toward the posterior margin of the wing ............................. Family Phorida.

\section{Section CYCLORHAPHA Brauer.}

30-Anal cell present, distinctly longer than the second basal, the discal cell sometimes wanting, both basal cells usually present (Super-family Syrphoidea).............. 31

Anal cell, when present, shorter'than the second basal, but one or both of these cells frequently wanting (Superfamily Muscoidea) ....................... 34

\section{Super-family SYRPHOIDEA Coq.}

31-Proboscis short and robust, no supernumary vein between the third and fourth veins.................... 32

Proboscis slender and elongate or the wings provided with supernumary vein between the third and fourth veins. 33

32-Head less than one-half as long as the thorax, the face and front broad................. Family Platypezido.

Head unusually large, nearly as long as the thorax, except on the occiput almost wholly covered by the eyes..... ........................... Family Pipunculida.

33-With a supernumary vein between the third and fourth veins, crossing the small cross-vein, the proboscis usually short and robust................... Family Syrphida.

With no supernumary vein, the proboscis very slender and elongate........................ Family Conopida.

\section{Super-family MUSCOIDEA Coq.}

34-Lower, or posterior, calypter distinct, usually projecting beyond the upper (Group Calypteratce).............35 
Lower calypter minute or wanting, eyes broadly separated in both sexes (Group Acalypterce)..............40

\section{Group CALYPTERATA Desv.}

35-Oral opening large, the proboscis well developed......36

Oral opening very small, the proboscis and palpi rudimentary, the antennæ very short and somewhat concealed in cavities; rather large, robust flies..... Family CEstrida.

36-Pleura bearing a perpendicular row of bristles above the posterior coxæ........................... 37

Pleura not bearing such a row of bristles, those of the abdomen weak............................ 39

37-Antennal arista hairy or plumose, at least on the basal portion ................................ 38

Antennal arista bare or pubescent....... Family Tachinida.

38-Arista of antennæ hairy nearly or quite to the apex, legs usually very long, abdomen provided with stout bristles Family Dexiida.

Arista bare on its broad apical portion or the bristles of the abdomen weak, legs short and robust............. ..................... Family Sarcophagidde.

39-Fourth vein before its apex strongly curving toward the third .......................... Family Muscida.

Fourth vein not or only slightly curving toward the third... ....................... Family Anthomyiida.

\section{Group ACALYPTERÆ Macq.}

40-Auxiliary vein distinct, separated from the first and terminating in the costa, the anal cell present........... 4 l

Auxiliary vein absent, or confused with the first vein ....52

$4 \mathrm{I}$-Anterior oral margin bearing a distinct bristle on either side 42

Antërior oral margin never bearing such bristles, their places sometimes occupied by several short bristly hairs $\ldots 45$

42 - Costa of the wings bearing numerous spines, or the bristles of the front confined to the upper half............44

Costa of the wings not beset with spines, front usually bristly from the vertex almost to the antennæ..........43 
43-Third joint of the antennæ noticeably longer than broad.... ....................... Family Scatophagido.

Third joint broader than long, the last section of the fourth vein usually much longer than the preceding section... ....................... Family Heteroneurida.

44 -Front edge of the wings not beset with spines (Sepsida, in couplet 51).

Front edge of the wings beset with short spines, thorax convex, third joint of the antennæ nearly circular......... ........................ Family Helomyzida.

45-Tibiæ bearing an erect bristle on the outer side before the apex, anal and basal cells present..............46

Tibiæ not furnished with such a bristle, anal cell present . . 48

$46-$ Body convex, the face and cheeks not unusually bristly $\cdots 47$

Body greatly depressed, the face and cheeks unusually bristly ......................... Family Phycodromida.

47-Sixth vein of the wings prolonged to the wing-margin..... ........................ Family Sciomyzida.

Sixth vein obliterated before reaching the wing-margin.....

48-Legs usually short and robust, abdomen usually ovate and rather short, in the female furnished with a horny ovipositor ...........................49

Legs and body usually very elongate and slender, abdomen of female not furnished with a horny ovipositor, bristles of the front confined to the upper half............. 5 I

49-Basal and anal cells large, the latter usually prolonged at its lower apical angle........................ 50

Basal and anal cells small, the latter not prolonged at its lower apical angle, bristles of the front confined to its upper half................... Family Lonchaida.

50-Auxiliary vein gradually curving to the costa toward its apex, bristles of the front confined to the upper half......... ............................. Family Ortalide.

Auxiliary vein abruptly bent forward near its apex, bristles of the front extending from the vertex almost to its lower end.................. Family Trypetida.

51-Face in profile retreating on its lower part, palpi usually large, third and fourth veins usually strongly converging toward their apices............. Family Micropezide. 
Face perpendicular and somewhat projecting forward on its lower part, palpi minute, third and fourth veins parallel or diverging toward their apices........ Family Sepsida.

52 -Femora and usually the body short and robust...... 54

Femora slender and elongated, body also usually elongated, anal cell present......................

53-Fourth vein parallel with or diverging from the third vein.. ................................ Pamily Psilida.

Fourth vein usually curving toward the third at its apex (Micropezida, in couplet 51).

54-Head nearly hemispherical, not prolonged laterally .... . 55

Head prolonged laterally, the eyes situated at the apices of the prolongations, front femora very robust.......... ............................ Family Diopsida.

55-Anterior oral margin bearing a distinct bristle on either

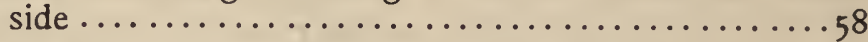

Anterior oral margin not bearing such bristles .......56

56-Anal cell usually wanting, the second basal cell usually confluent with the discal cell...................57

Anal cell distinct, second basal cell usually separated from the discal cell (Agromyzida, in couplet 60).

57-Antennal arista frequently long-pectinate on the upper side, head usually much wider than high, face usually provided with bristles especially on each side, and the oral opening sometimes excessively large ..............

Antennal arista never long-pectinate, head not wider than high, face not bristly, and the oral opening never unusually large........................... Oscinide.

58-Arista of antennæ bare, body short and robust.......6

Arista usually plumose; if bare the lbody is some what slender ........................... 59

59-Hairs of the antennal arista long and few in number, second basal cell usually confluent with the discal cell......... ................................... Drosophilida.

Hairs of the arista short and numerous, sometimes wanting; second basal cell separated from the discal cell......... ....................... Family Geomyzida. 


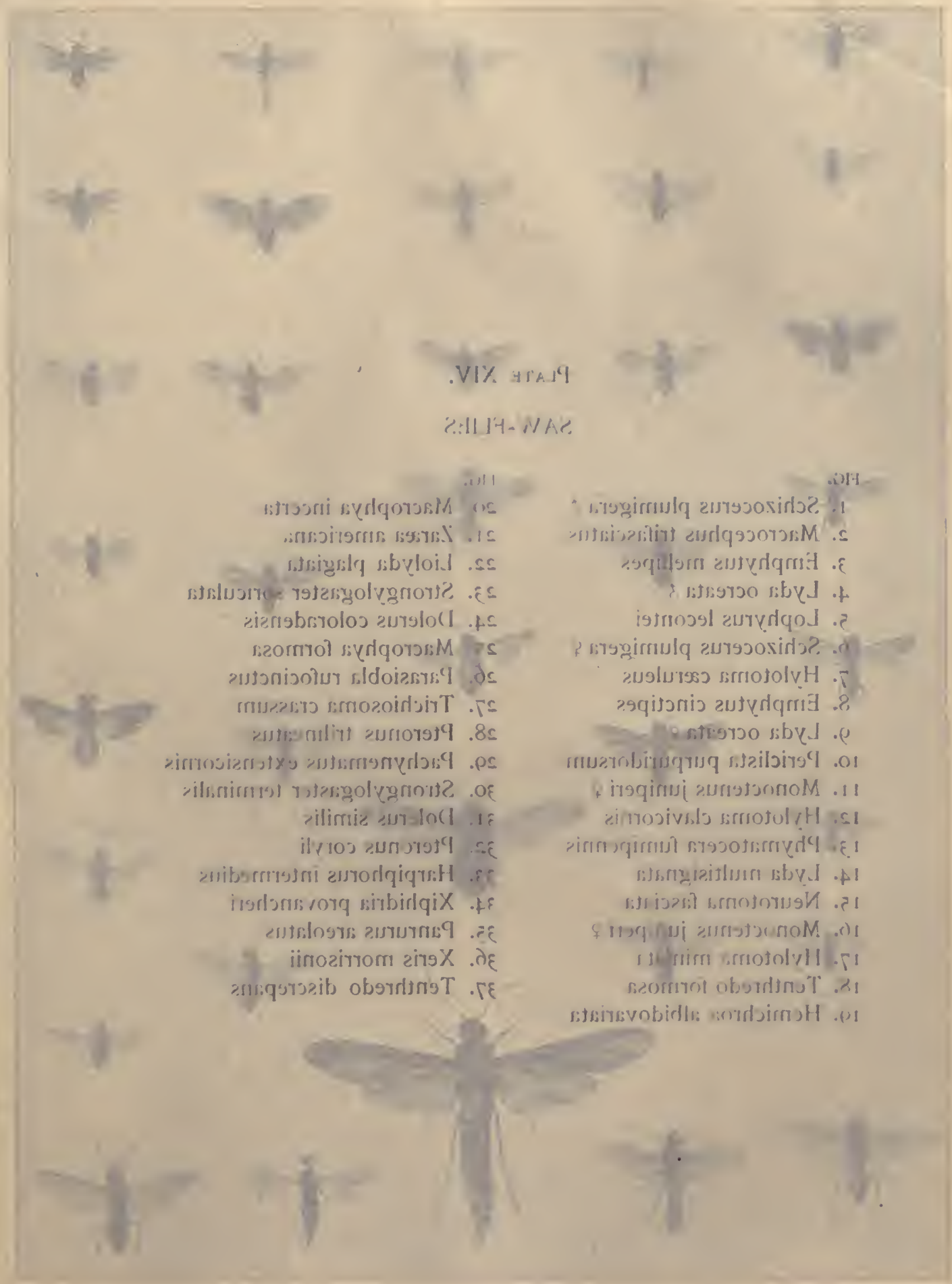


Face perpendiculas and comewhat ph lower pan, peff misuto, thind in or divenging toward their ablows-

53-Femiora and usualy the body atom wal

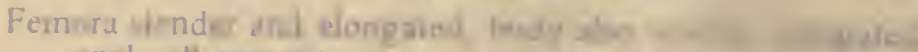
anal cell prasent

53-Fous th velis paodled with ar divengine fires:

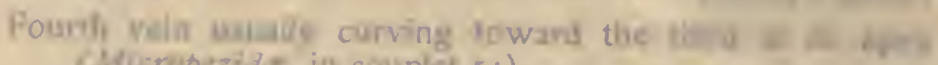
(Mineroperilas, in couples 51).

54-Head nearly hemispheTTE XIV.

Heid prolonged latSAVY-FLIES es artuated of the eplaes of

FIG.

the pradongations, fiont feisogr vert mobuen

1. Schizocerus plumigera $\hat{5}$

2. Macrocephus trifasciatus

3. Emphytus mellipes

4. Lyda ocreata $f$

5. Lophyrus lecontei

6. Schizocerus plumigera ㅇ

7. Hylotoma cæruleus

8. Emphytus cinctipes

9. Lyda ocreata ?

10. Periclista purpuridorsum

11. Monoctenus juniperi of

12. Hylotoma clavicornis

13. Phymatocera fumipennis

14. Lyda multisignata

15. Neurotoma fasciata

16. Monoctenus juniperi $q$

17. Hylotoma miniata

18. Tenthredo formosa

19. Hemichroa albidovariata
20. Macrophya incerta

21. Zaræa american:

22. Liolyda plagiata

23. Strongylogaster soriculata

24. Dolerus coloradensis

25. Macrophya formosa

26. Parasiobla rufocinctus

27. Trichiosoma crassum

28. Pteronus trilineatus

29. Pachynematus extensicornis

30. Strongylogaster terminalis

31. Dolerus similis

32. Pteronus coryli

33. Harpiphorus intermedius

34. Xiphidria provancheri

35. Panrurus areolatus

36. Xeris morrisonii

37. Tenthredo discrepans

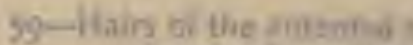

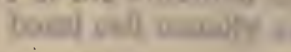

Hisin of une (10son. 


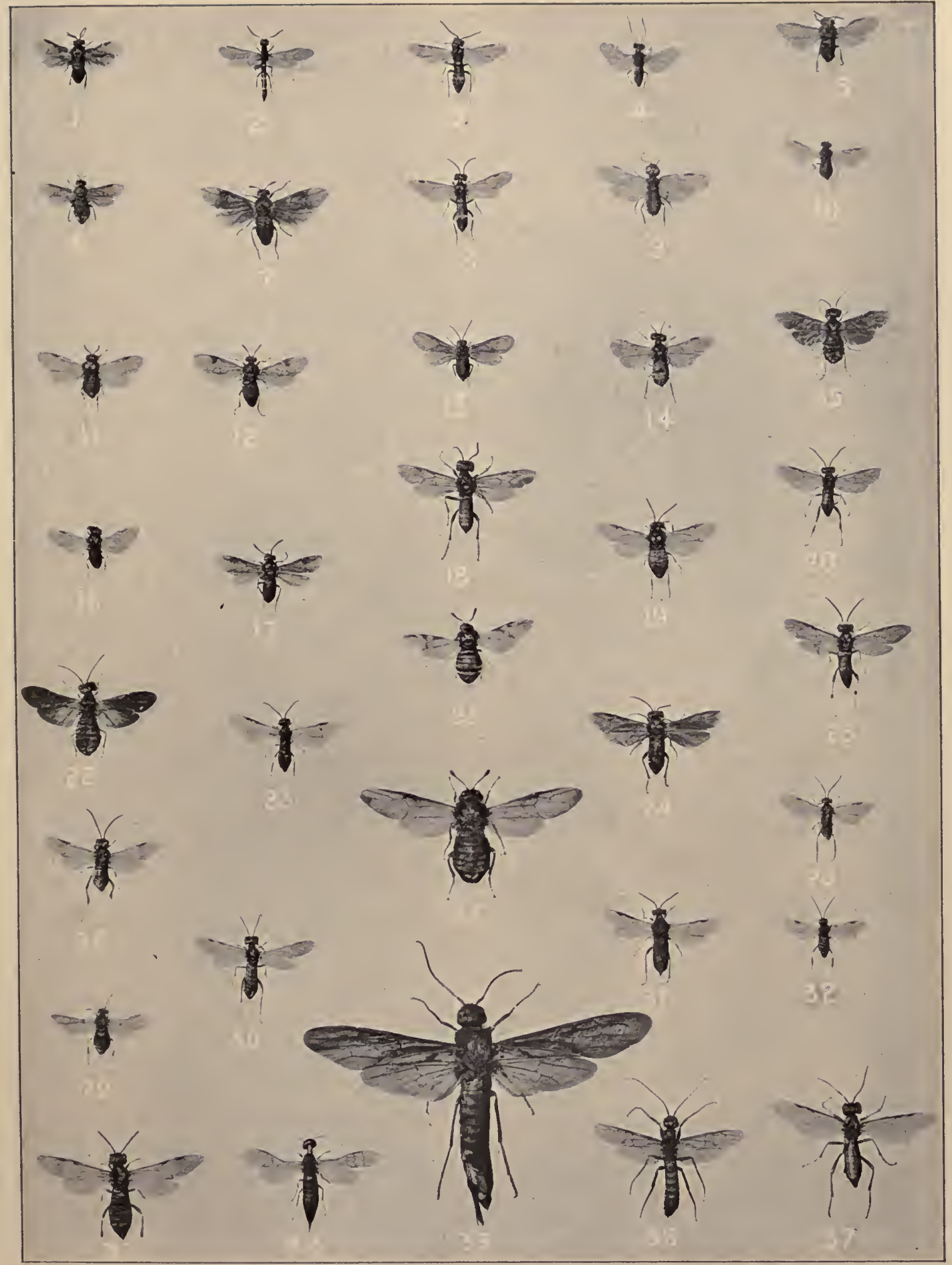



60-First joint of the posterior tarsi slender, longer than the second joint................. Family Agromyzidox.

First joint greatly dilated, shorter than the second......... ................................... Bamily Borborida.

\section{Sub-order EPROBOSCIDEA Latr.}

$6 \mathrm{I}-$ Head greatly depressed, projecting forward or downward, body usually depressed; living on mammals (except bats), birds, or honey bees....... Family Hippoboscida.

Head rounded, projecting backward upside down over the thorax, body usually nearly cylindrical; living upon bats .......................... Family Nycteribiida. 


\section{THE CRANE FLIES}

\section{(Family Tipulida.)}

The big slender long-necked flies, commonly known as "crane flies" in this country and as "daddy-long-legs" in England, * form a distinct and characteristic group of flies. They

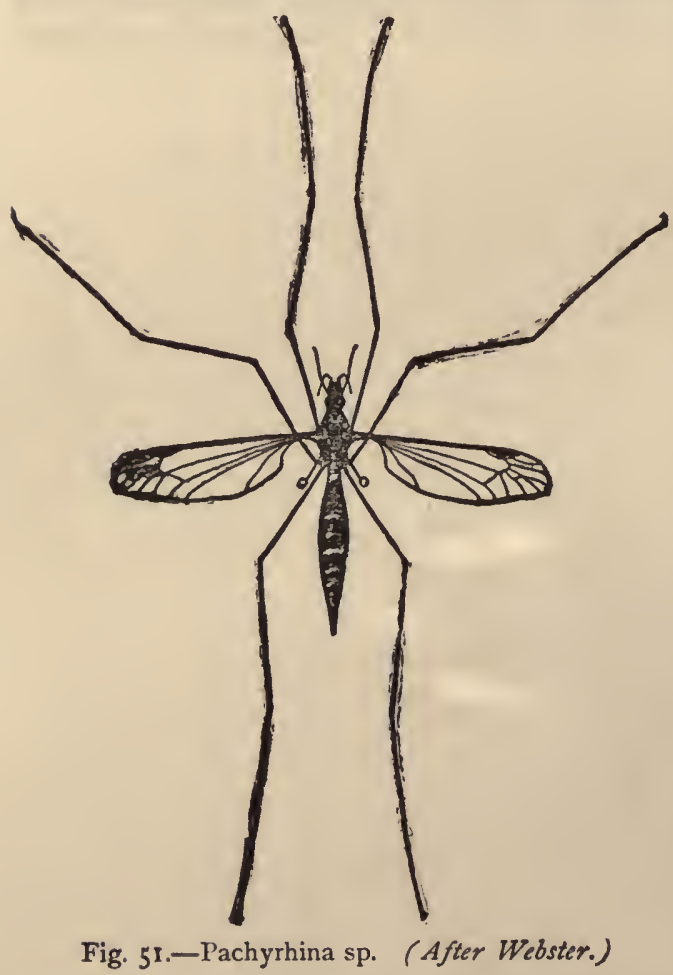

have long antennæ and very long slender legs which are so slightly attached that it is difficult to capture a Tipulid without breaking one or more of them. The thorax has a $V$-shaped suture on the back and the wings contain numerous veins and usually a perfect discal cell.

Crane flies are frequently taken for big mosquitoes, but they differ entirely in habits and do not bite, although those of the genus Elephantomyia have a long proboscis, even longer than that of a mosquito. The larvæ of most species live in the earth but some live in water, in decomposing wood and

* The term "daddy-long-legs" in this country is applied exclusively to the so-called harvest spiders of the family Phalangiidx. 
even upon the leaves of plants. Some of the earth-inhabiting forms destroy grass and grain by injuring the roots. They breathe through two anal spiracles which in aquatic species are placed at the tip of a long process. The pupal stigmatic tube is set anteriorly, the same change from the anal end to the head end taking place in the transformation to pupa as occurs with the mosquitoes. The pupa itself resembles somewhat a Lepidopterous pupa.

The adult flies are commonly seen in the late summer and are found in pastures and woods, sometimes, especially with the smaller species, swarming towards sundown. More than one thousand species are known and about three hundred of them occur in the United States. Certain forms appear in the early spring and there is a curious wingless genus-Chionea-the species of which are found upon the snow.

The wings of the crane flies are generally clear but are sometimes beautifully marked and spotted as in Limnobia and Tipula. The large and beautiful Pedicia albivittata Walk has striking brown bands on a white wing surface. It is found in the White mountains and the Catskill mountains, as well as in the far northwest and in Alaska. Bittacomorpha with its short wings and banded legs and swollen feet is a most striking form. The California genus Holorusia contains the giants of the family and $H$. grandis has a wing spread of more than three inches. The colors of the crane flies are usually dull, but in Ctenophora the body is frequently brilliantly marked with red. In this genus the abdomen is pointed so as to resemble the ovipositor of some Hymenopterous insects and the male abdomen is swollen at the tip almost like that of one of the so-called "Scorpion flies" of the family Panorpidæ (q.v.).

\section{Life History of a Crane Fly}

\section{(Bittacomorpha clavipes Fab.)}

Comparatively few species of this family have been carefully studied, but in his important paper on the "Entomology of the Illinois River and Adjacent Waters," Mr. C. A. Hart records some interesting facts concerning this species. The genus Bittacomorpha is found exclusively in America and the larvæ of the in- 
sect under consideration were found in the early spring in a shallow swampy slough full of rushes and swamp grass. In the mass of dead stems, grass and leaves, through which a broad stream of water ran slowly, were found the cylindrical rustybrown larvæ of Bittacomorpha, which in their appearance look like bits of decaying grass stem. Their stomachs were found to be filled with diatoms, mud and dead vegetable tissue and the larvæ had evidently fed on the diatomaceous growth which coated the decaying stems. At the anal end of the body was a long respiratory tube bearing two pairs of spiracles at the end. About the end of March they showed some swelling and within the loose skin the soft white pupæ were found. The thoracic respiratory tube was rudimentary and the tube was coiled between the larval and pupal skins. On April 6th the first adult flies issued. Later, in September, a number of adults were seen flying, which indicates either an emergence of the same generation both in fall and spring or two generations annually, the offspring of the fall flies remaining in the larval state through the winter and giving forth adults in the spring. The eggs have not been observed and a more careful study of this species is needed. 


\section{FAMILIES DIXIDA AND STENOXENIDAE}

The little midges of the Dixidæ resemble mosquitoes, but they do not bite. They all belong to the single genus Dixa, which is so distinct from the other Diptera as to constitute a group of family rank all by itself. We have less than ten species in this country. The Dixas seem intermediate between the mosquitoes and the crane flies. They are found in damp places in forests, and in the larval state are aquatic. The larva is considerably like that of a mosquito, and might by the careless observer well be taken for the larva of a mosquito of the malariabearing genus Anopheles. The Dixa larva has fringes on the upper jaws like those in mosquito larva, but it differs in having leg-like projections from the first two segments of the abdomen. It is found in shallow water and breathes air as do the mosquito larvæ. The pupa has respiratory siphons on the thorax just as does the pupa of mosquitoes.

Stenoxenida is a family name proposed by Coquillett for a single little fly of curious venational structure-Stenoxenus johnsoni-which is known only from Delaware Water Gap, N. J. 


\section{MOSQUITOES}

\section{(Family Culicida.)}

This group includes the familiar insects known as mosquitoes-not a large group, but a very important one, not only from the fact that mosquitoes abound in so many localities and are great annoyances to man and animals, but also from the fact that

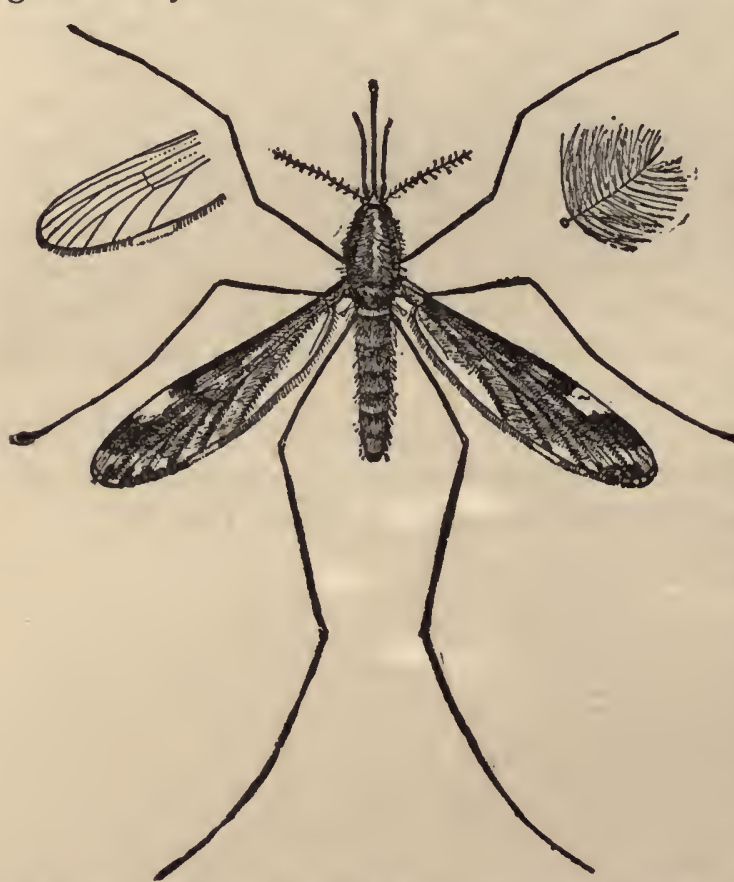

Fig. 52.-Anopheles punctipennis: Female with male antenna at right, and wing-tip showing venation at leftenlarged. (Author's illustration.) they are active agents in the transfer of disease. They are found in great abundance in tropical regions, in temperate regions and even far to the North. Travelers in Alaska state that the abundance and voracity of the Alaskan mosquitoes is beyond description. They occur with equal abundance in Lapland and in Greenland.

So far as definitely known the larvæ of all mosquitoes are aquatic, although they are true air-breathers; that is to say, they must come to the surface of the water to breathe. They are rapid breeders, and pass the pupal 
condition also in the water, but floating normally at the surface. They pass through several generations in the course of a year, and hibernate as adults. Hibernating mosquitoes may often be found during the winter months in barns and in the cellars and cold garrets of houses or in sheltered places like outhouses and under bridges and stone culverts. In the extreme southern states many mosquitoes are active all through the winter, and mosquitobars are almost as necessary at Christmas time as during the summer. Even as far north as Baltimore, mosquitoes sometimes bite in houses in December and January. In places where there are prolonged dry spells, and very heavy rains are only expected at certain seasons of the year, adult mosquitoes live through the dry spells and lay their eggs as soon as the rains come. This is the case in the dry regions of our southwestern country, and it is also the case in tropical countries where the entire year is divided into a wet season and

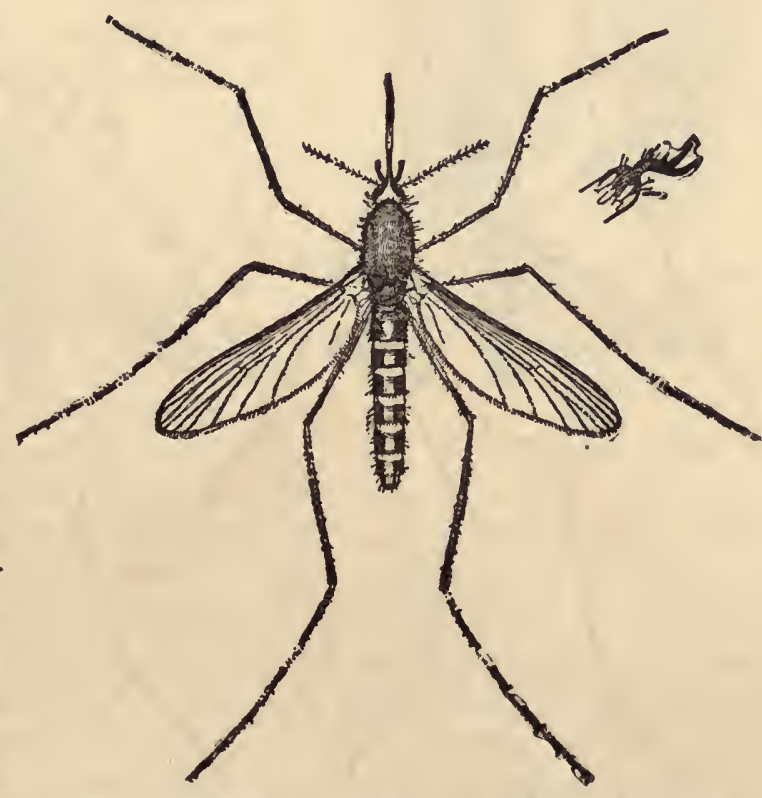

Fig. 53.-Culex sollicitans: Female showing the short palpi which distinguish Culex from Anopheles; toothed front tarsal claw at right-enlarged.

(Author's illustration.)

a dry season.

In those countries the wet season is generally considered as comparable to our winter, yet it is the active breeding season of mosquitoes, while the dry season, which is supposed to be comparable to our summer, is the season when the adult mosquitoes live on and on. With these insects, as with so many others, the life of the adult seems to be dependent only upon 
the opportunity of propagating the species. The main purpose of the adult is propagation.

The adult male mosquito does not necessarily take nourishment and the adult female does not necessarily rely upon the blood of the warm-blooded animals. The mouth-parts of the male are so different from those of the female that it is probable

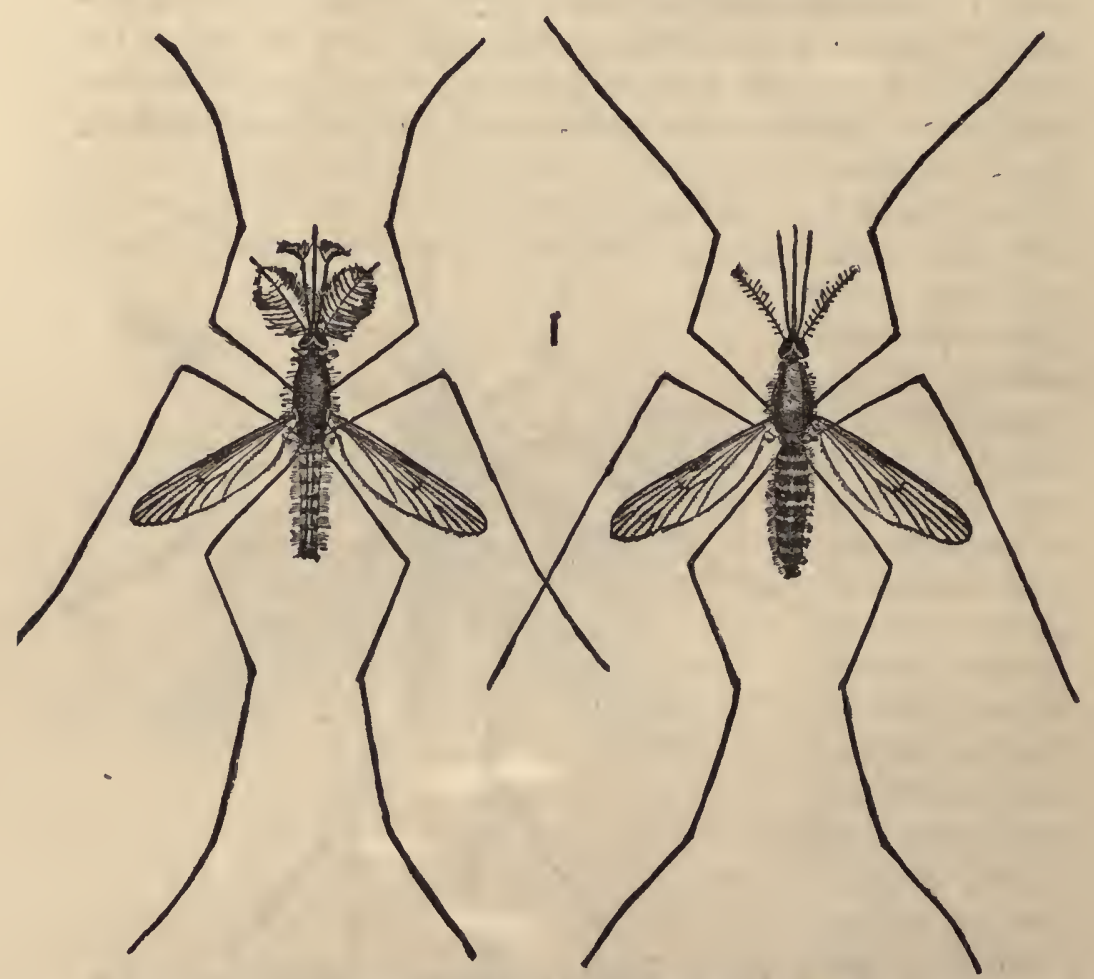

Fig. 54.-Anopheles maculipennis : Adult; male at left, female at rightenlarged. (Author's illustration.)

that if it feeds at all it obtains its food in quite a different manner from the female. They will sip water or any liquid substance, and appear to be especially fond of beer and wine. The females are normally, without much doubt, plant-feeders, and very few of them get an opportunity to taste the blood of a warm-bodied animal. They will feed upon other than warm-blooded animals. They have been seen puncturing the heads of young fish; they 
have been seen puncturing the chrysalis of a butterfly, and they have been seen swarming about turtles when the latter are on land. The larvæ on the contrary, feed upon all sorts of minute organisms floating in the water, such as the spores of algx and minute aquatic animals. They are all furnished with many bristles at the mouth, and these bristles are kept in constant vibration drawing particles floating or in suspension in the water into the mouth cavity.

Five genera of mosquitoes are represented in this country, namely Anopheles, Aedes, Megarhinus, Psorophora and Culex. Most of our species belong to the genus Culex, and one species of this genus has been selected for the typical life history which is given.

The mosquitoes of the genus Anopheles are the ones which are responsible for the transfer of ma-

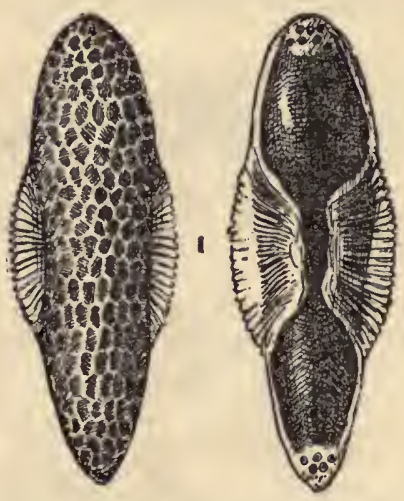

Fig. 55--Anopheles maculipennis: Egg from below at left, from above at right-greatly enlarged. (Author's illustration.) laria. The micro-organism of malaria is a protozoon which in the human being inhabits the red-blood corpuscles. It undergoes a sporulating development in the red-blood corpuscles, the spores being thrown into the blood serum afterward entering other blood corpuscles extracting their red coloring matter and destroying them. The full life round of the malarial parasite, however, is not completed until it has been taken with the blood of a human being into the stomach of a mosquito of the genus Anopheles. Here, and here only, is the sexual generation of the parasite developed. Certain of the parasites which undergo no development in the human body, when they are brought into the stomach of the Anopheles continue a sexual development, unite and give birth to elementary forms, known as blasts, which penetrate the stomach wall of the mosquito, enter the salivary glands, and are thus with the poison directed into the body of the next human being punctured by this mosquito.

We have in the United States three species of mosquitoes of this malarial genus Anopheles, namely $A$. maculipennis= quadrimaculatus=claviger, $A$. punctipennis and $A$. crucians. 
The mosquitoes of the genus Aedes are excessively small. Those of Megarhinus and Psorophora are very large, and include the forms known in various parts of the country as gallinippers. Psorophora is distinguished by possessing upright scales on the legs; Megarhinus by its curved beak. Anopheles is distinguished
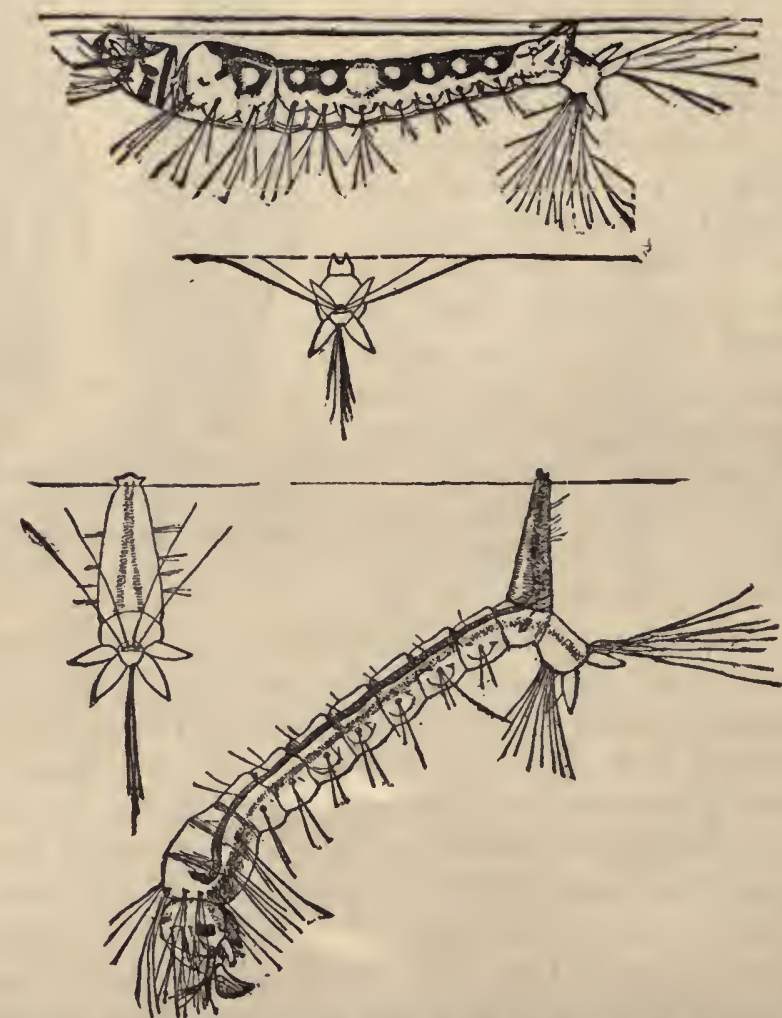

Fig. 56.-Figure at top, half grown larva of Anopheles in feeding position, just beneath surface film. Figure at bottom, half grown larva of Culex in breathing position-greatly enlarged. (Author's illustration.)

from Culex by the fact that the palpi of the female are nearly as long as its beak, while in Culex the female palpi are very short.

Mosquitoes as a rule do not fly very far. Those of the genus Anopheles appear to be of extremely short flight. Those of the genus Culex will not fly far away from their breeding 
places, unless they are carried by light and continued winds. In heavy winds they cling to the nearest point of attachment. They are carried long distances by railroad trains, and many localities where mosquitoes were unknown have become infested by the introduction of railways or improvement of the through train service.

Many localities can be practically rid of mosquitoes by the adoption of any one of three measures: either by the drainage or the swamps or ponds in which they breed, or by the use of kerosene upon the surface of the waters in which they breed, or
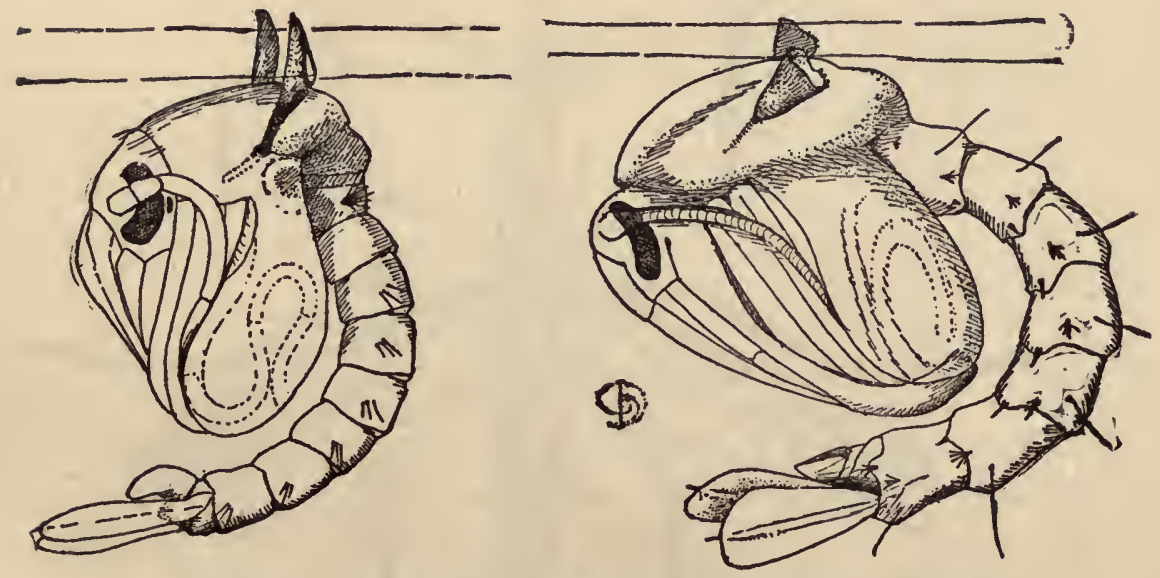

Fig. 57.-Pupa of Culex pungens at left; pupa of Anopheles maculipennis at right-greatly enlarged. (Author's illustration.)

by the introduction of fish into fishless ponds so that they may eat the larvæ of the mosquitoes. In all mosquito-extermination work, however, it must be remembered that they will breed successfully in any transient pool of water or in any receptacle where water is left standing for a week, no matter how small this receptacle may be. They may breed in collections of water in the hollows of old stumps or in old bottles or in old discarded tomato cans. They breed profusely in rain-water barrels, and in rain-water tanks, and in old wells, and even in cess-pools where the adults are able to gain access to such pools. Therefore every possible source of this kind must be hunted for when one is engaged in mosquito extermination. 


\section{Life History of a Mosquito}

(Culex pungens Wiedemann.)

This common and widespread mosquito, which occurs from the White Mountains in New Hampshire to Cuba, and from British Columbia to Mexico, lays its eggs, numbering from 200 to 400 , in a raft-like mass on the surface of the water. The eggs

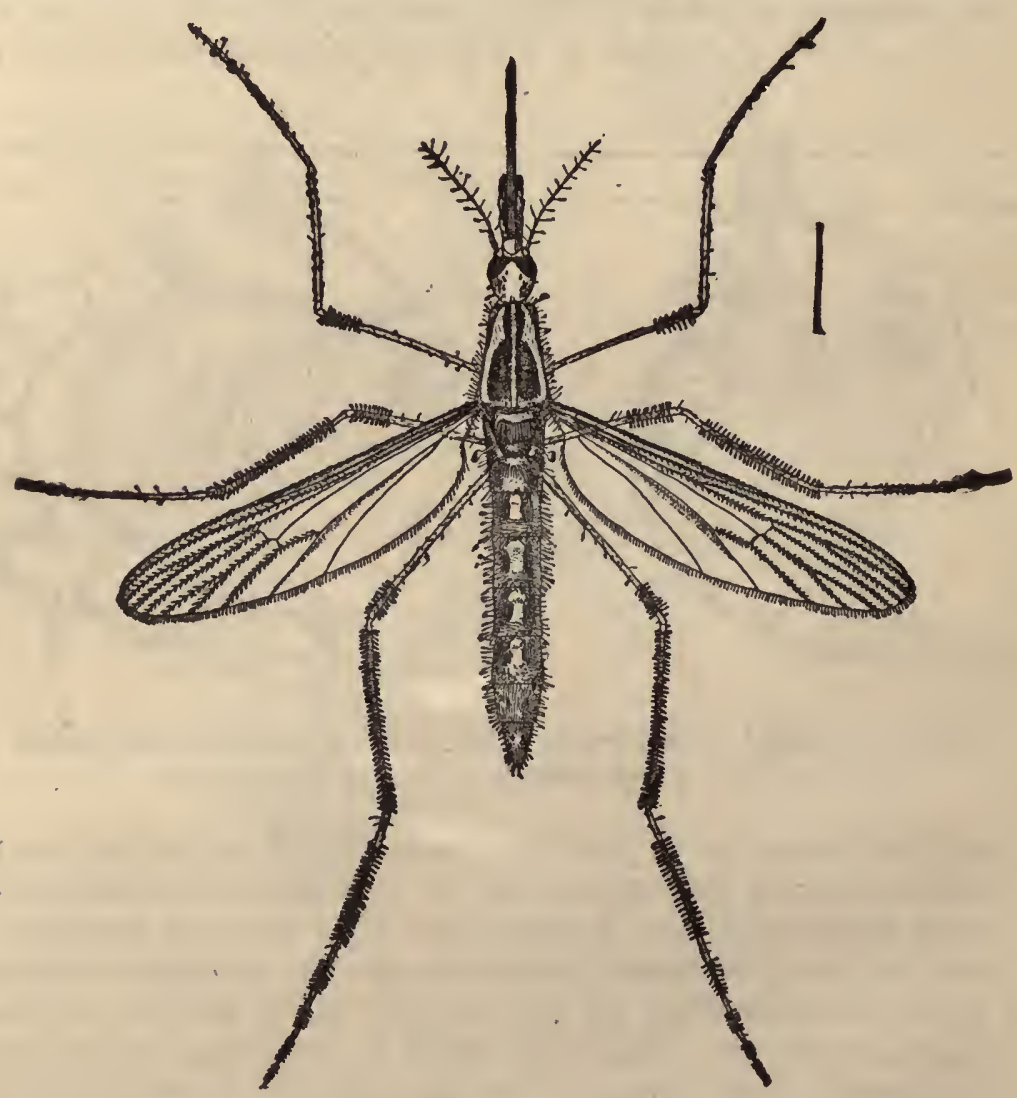

Fig. 58.-Psorophora ciliata: Female-enlarged. (Author's illustration.)

are laid side by side, standing on end and stuck close together in longitudinal rows six to thirteen in number and with from three or four to forty eggs in a row. The egg mass is gray-brown 


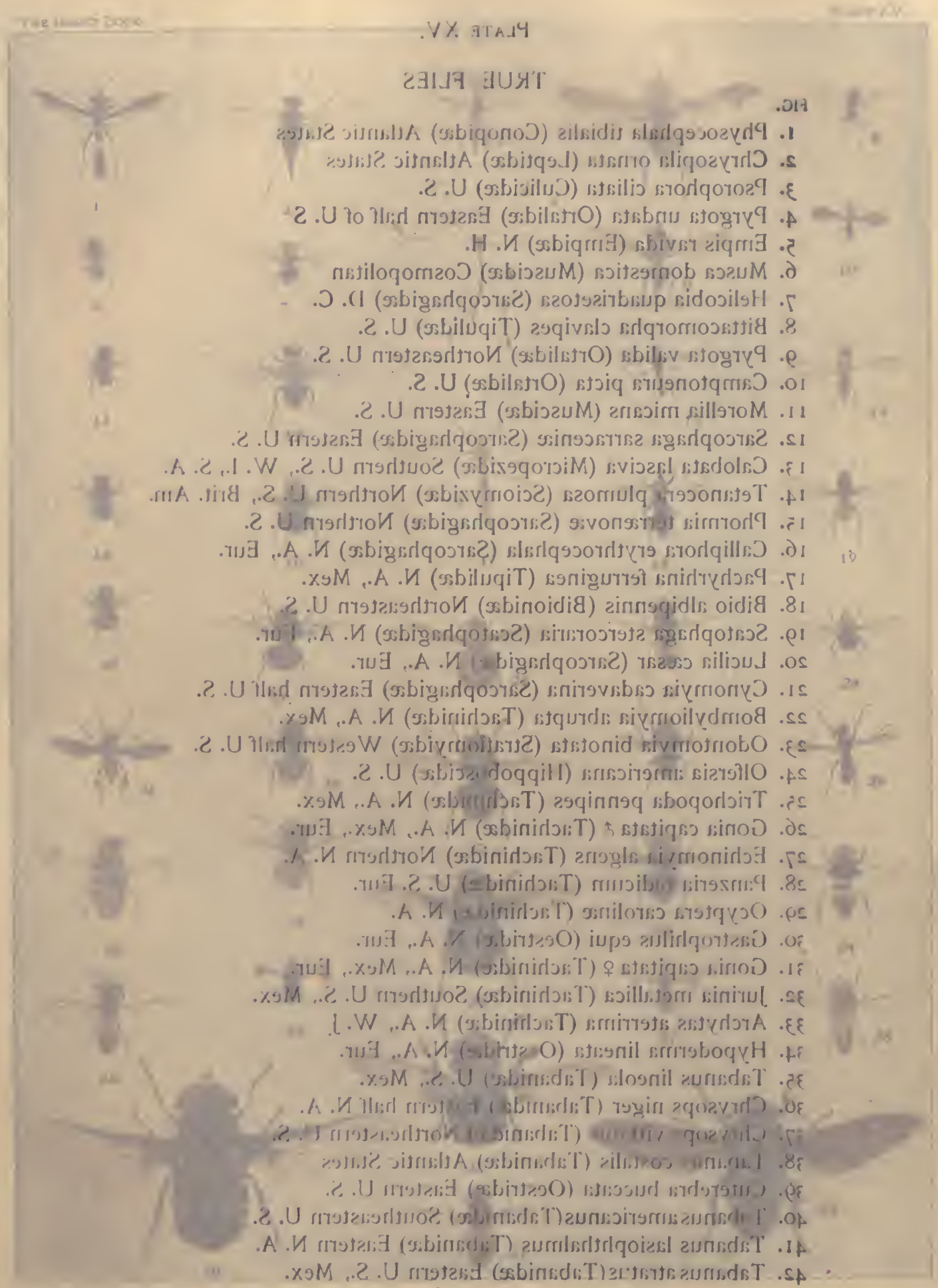


Plate XV.

FIG.

\section{Lifo HITRUE FLIES}

1. Physocephala tibialis (Conopidx) Atlantic States

2. Chrysopila ornata (Leptidæ) Atlantic States

3. Psorophora ciliata (Culicidx) U.S.

4. Pyrgota undata (Ortalidæ) Eastern half of U. S

5. Empis ravida (Empidæ) N. H.

6. Musca domestica (Muscidæ) Cosmopolitan

7. Helicobia quadrisetosa (Sarcophagidæ) D. C.

8. Bittacomorpha clavipes (Tipulidæ) U.S.

9. Pyrgota valida (Ortalidx) Northeastern U.S.

10. Camptoneura picta (Ortalidæ) U.S.

11. Morellia micans (Muscidæ) Eastern U. S.

12. Sarcophaga sarracenix (Sarcophagidx) Eastern U.S.

13. Calobata lasciva (Micropezidæ) Southern U. S., W. l., S. A.

14. Tetanocera plumosa (Sciomyzidæ) Northern U. S., Brit. Am.

15. Phormia terrænovæ (Sarcophagidæ) Northern U.S.

16. Calliphora erythrocephala (Sarcophagidæ) N. A., Eur.

17. Pachyrhina ferruginea (Tipulidx) N. A., Mex.

18. Bibio albipennis (Bibionidæ) Northeastern U.S.

19. Scatophaga stercoraria (Scatophagidæ) N. A., Eur.

20. Lucilia cæsar (Sarcophagidæ) N. A., Eur.

21. Cynomyia cadaverina (Sarcophagidæ) Eastern half U. S.

22. Bombyliomyia abrupta (Tachinidx) N. A., Mex.

23. Odontomyia binotata (Stratiomyidx) Western half U. S.

24. Olfersia americana (Hippoboscidæ) U. S.

25. Trichopoda pennipes (Tachinidx) N. A., Mex.

26. Gonia capitata of (Tachinidx) N. A., Mex., Eur.

27. Echinomyia algens (Tachinidæ) Northern N. A.

28. Panzeria radicum (Tachinidæ) U. S. Eur.

29. Ocyptera carolinæ (Tachinidæ) N. A.

30. Gastrophilus equi (Oestridæ) N. A., Eur.

31. Gonia capitata \& (Tachinidx) N. A., Mex., Eur.

32. Jurinia metallica (Tachinidæ) Southern U. S., Mex.

33. Archytas aterrima (Tachinidæ) N. A., W.J.

34. Hypoderma lineata (Oestridx) N. A., Eur.

35. Tabanus lineola (Tabanidæ) U. S., Mex.

36. Chrysops niger (Tabanidæx) Eastern hall N. A.

37. Chrysops vittatus (Tabanidx) Northeastern U. S.

38. Tabanus costalis (Tabanidie) Atlantic States

39. Cuterebra buccata (Oestridæ) Eastern U.S.

40. Tabanusamericanus(Tabanidx) Southeastern U.S.

41. Tabanus lasiophthalmus (Tabanidæ) Eastern N. A.

42. Tabanus atrat 1 (S (Tabanidæ) Eastern U. S., Mex. 


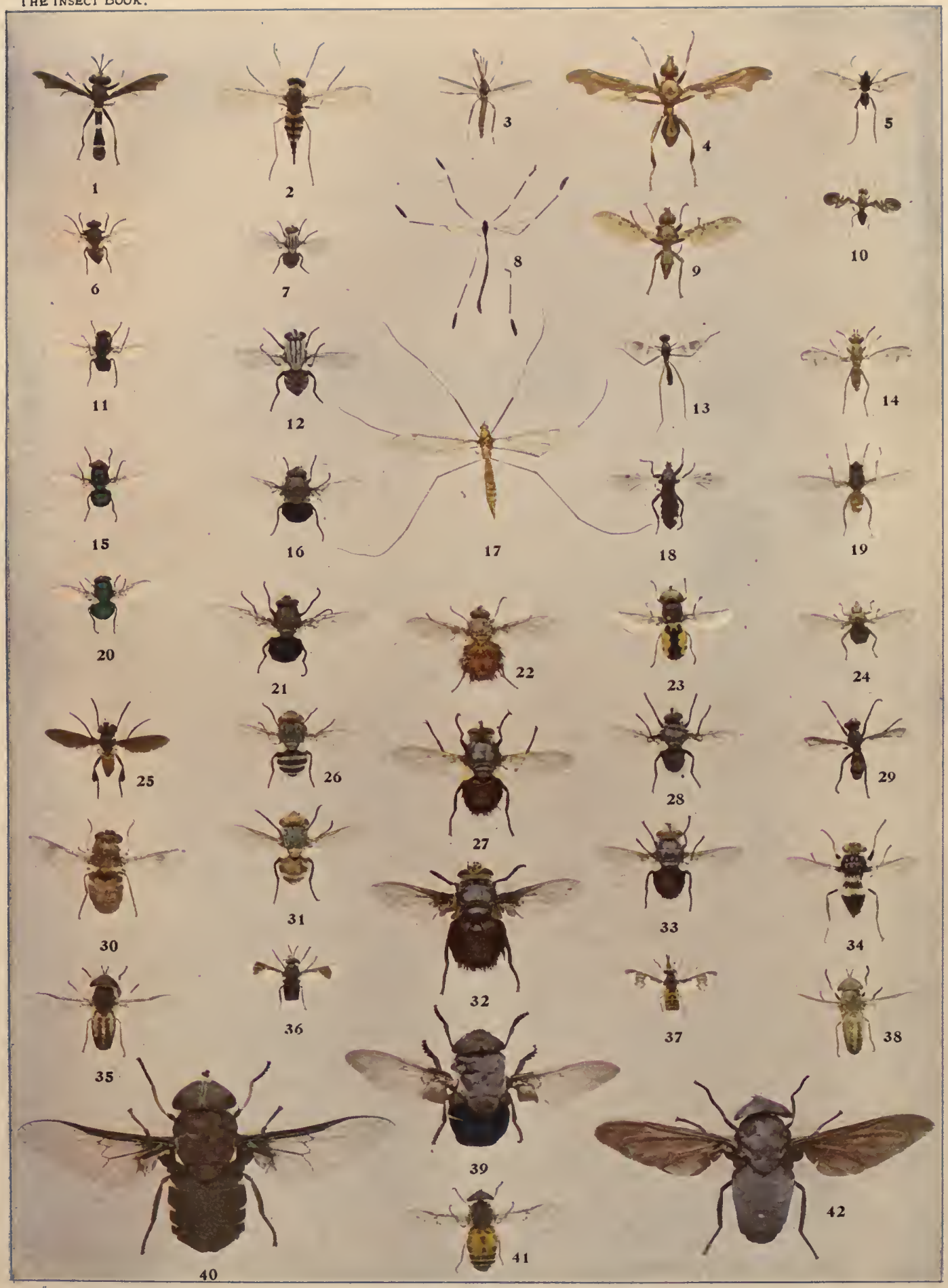


from above and silvery white from below, the latter color being due to the water film. The eggs are laid early in the morning before dawn and in warm weather will hatch by two o'clock on the afternoon of the same day. The larvæ are active little creatures known as wrigglers which are so often to be seen in rainwater barrels and horse troughs. The anal end of the body is provided with a long respiratory tube into which two large air vessels extend quite to its tip, where they have a double orifice which is guarded by four flaps. This tube issues from the eighth

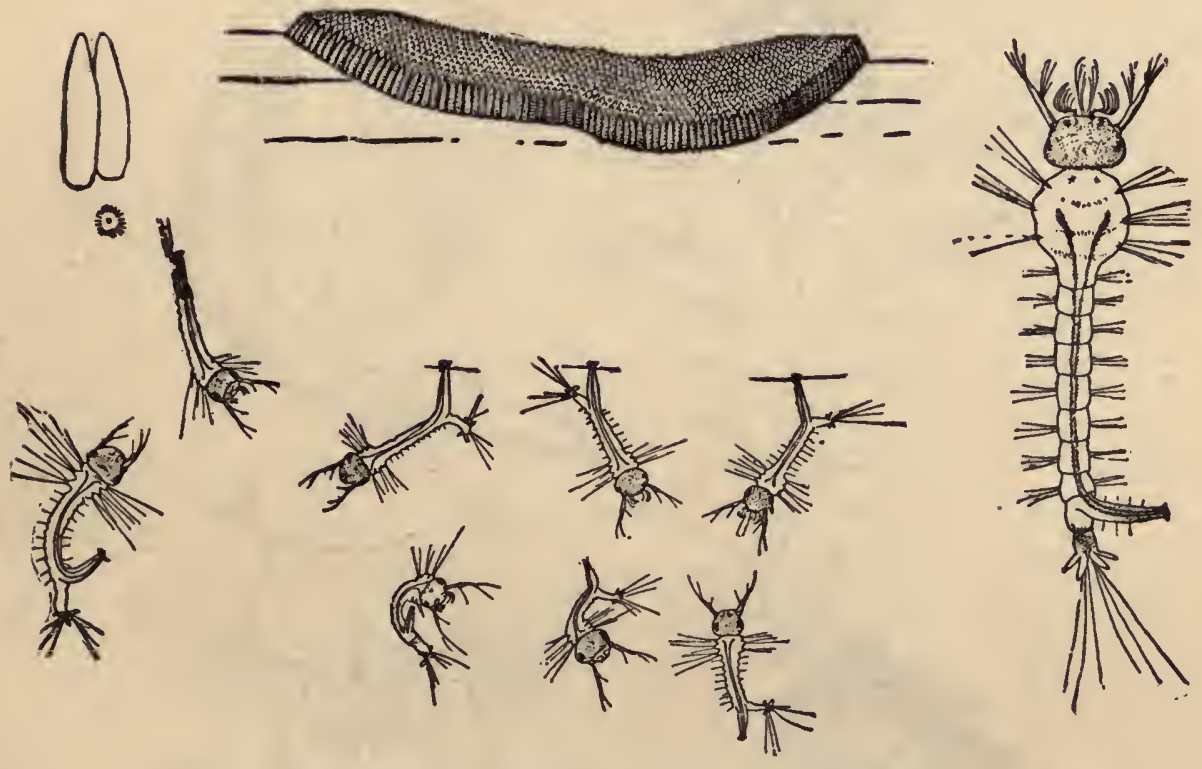

Fig. 59.-Culex pungens: Egg mass, with enlarged eggs at left and young larvæ below-enlarged. (Author's illustration.)

segment of the abdomen. The ninth segment is armed at the tip with four flaps and six hairs. The flaps are gill-like in appearance, though they are probably simply locomotary in function. The mouth parts are curiously modified and are provided with long cilia which are kept constantly in vibration, attracting and directing into the mouth minute particles of animal and vegetable matter which are to be found in the water. The wriggler remains at the surface of the water when breathing through its respiratory tube but descends when seeking for food. It undergoes three 
different molts, reaches maturity and transforms to a pupa in a minimum of seven days in hot summer weather, taking much longer in the early spring or when the weather grows cool in the fall. The pupa is well illustrated in the accompanying figure and differs radically from the larva or wriggler from the fact that it now breathes from the ear-like or trumpet-like organs issuing
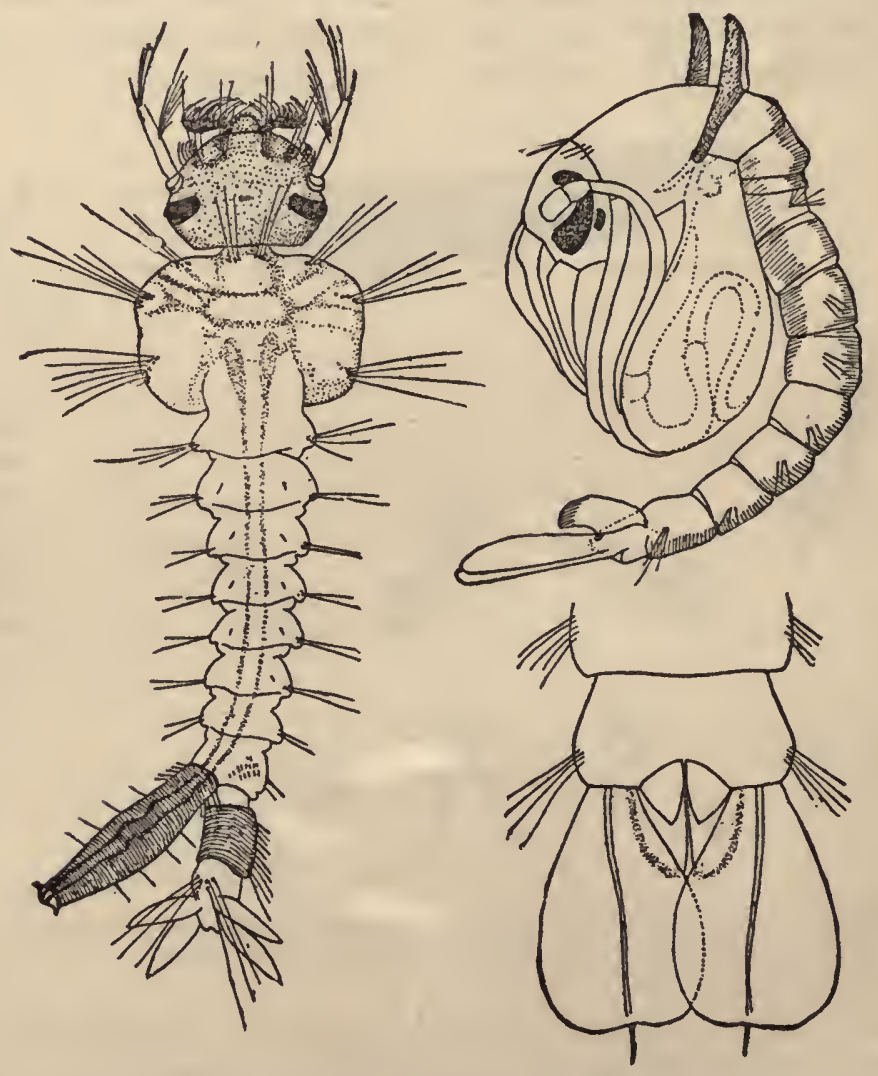

Fig. 60.-Culex pungens: Full-grown larva at left, pupa at right-enlarged. (Author's illustration.)

from the thorax instead of from a respiratory tube at the other end of the body. The pupa remains at the surface of the water in an upright position but when disturbed wriggles actively to the bottom, floating upwards again in a very short time. The pupa stage lasts in warm weather but two days, at the expiration 
of which time the skin splits on the back of the thorax and the adult mosquito works itself out, resting upon the old pupa skin until its wings unfold, and then flies away. The duration of a single generation may be within ten days; say sixteen hours for the egg, seven days for the larva and two days for the pupa. This time, however, may be indefinitely extended if the weather be cool. 


\section{THE MOTH-FLIES}

\section{(Family Psychodida.)}

There are certain very small, weak flies which look like little moths, from which fact they have been termed "moth-flies," which are frequently found upon windows and upon the under surfaces of leaves, and which have broad wings, rather thick antennæ, and which are densely clothed with hairs, even the surface of the wings being hairy. These are the flies of the family Psychodidæ. They are so small and so fragile that they are difficult to preserve, and though there are probably very many species only comparatively few have been described.

The arrangement of the wing veins in these flies differs from that of all other flies, and possibly represents the lowest or most generalized type in the Diptera, although there is good reason to believe that perhaps the Tipulidæ more nearly represent the primordial fly.

In larval habits they are interesting and variable. Some of them live in dry cow dung; others on fallen leaves immersed in the water of pools or small streams, while others live in rapidly running water, and others are found in rotten potatoes. The larvæ are remarkable from the fact that they have both tracheal gills and open spiracles, so that they can theoretically both breathe air and use the oxygen in the water.

One of the European forms (Pericoma canescens) has been carefully studied by Miall and Walker (Trans. Ent. Soc. London, 1895), but the larvæ of none of the American forms were known until very recently, when Kellogg discovered the larvæ of Pericoma californiensis in the streams of the Sierra Morena Mountains near Stanford University, California. With Kellogg's larva no tracheal gills were found but they may have been retracted. On the under side of the larva are curious sucking discs, through which it attaches itself to objects under the water, a structure which seems to be necessary in order to prevent the larva from I08 
being carried down the stream. They were found on the stones of the stream bed, not usually submerged, but always at the very verge of the water, sometimes submerged, sometimes above the water surface, but always wetted by the current or spray. They look something like a sow-bug or pill-bug (Oniscus) in shape, but are narrower. Kellogg's figures and descriptions may be found in Entomological News for February, 1901.

Less than twenty species have been described in the United States. 


\section{THE MIDGES \\ (Family Chironomida.)}

The insects of this family, commonly known as "midges," are small, delicate flies with simple wing venation and no ocelli. The antennæ of the males of most genera are strongly plumose, and the flies themselves are frequently seen flying in swarms with a dancing motion. When at rest the front legs of these

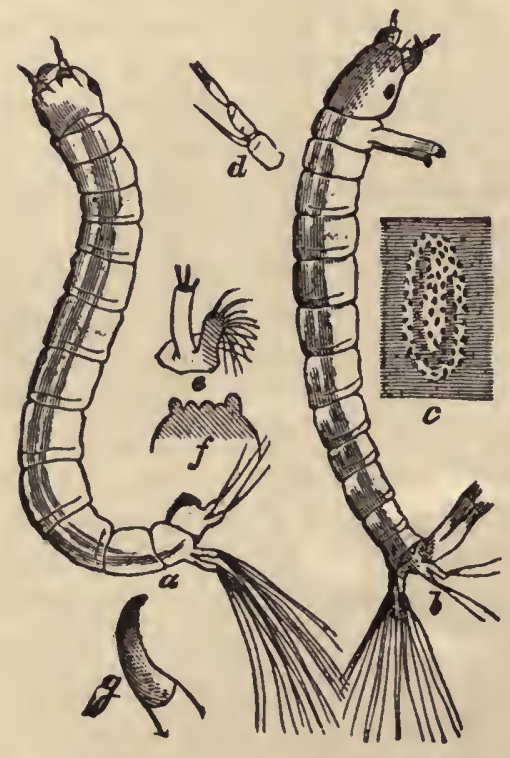

Fig. 61.-Chironomus sp.: $a, b$, larvæ: c, eggs. (After Riley.) flies are lifted and are used as feelers. The larvæ are mainly aquatic, but some live in decomposing matter and in soft earth. They are softskinned and worm-like in form and frequently bloodred in color. The aquatic forms are usually found in shallow pools and streams and make larval cases of silk and mud or decomposing leaves; but some are found at the bottom of lakes of great depth, Professor S. I. Smith having dredged them from the bottom of Lake Superior at a depth of nearly a thousand feet, and Packard has found them living in salt water in Salem harbor. The larva of Chironomus plumosus, figured herewith, abounds in great numbers in the waters of Chautauqua Lake and other fresh water lakes of the United States. These larvæ form an important fish food but the family has no other economic value.

The flies abound in the spring, even before the snow has left the ground. Dr. Williston has seen them in the Rocky 
Mountains rise up from the ground at nightfall in the most incredible numbers, making a humming noise like a distant waterfall. Many species are common to Europe and North America, belonging to the so-called "circumpolar fauna." The eggs of Chironomus are laid in the late evening or early morning in a dark gelatinous mass which swells up on touching the water and which is attached to some object close to the water's edge. The larvæ differ in form and habit, but there are two types. In one there are four long anal tubules which function as blood-gills, as in the fishes, and the pupæ bear bunches of long filamentary tracheal gills. These larvæ are large and red and are called in England "blood-worms." The larvæ of the second type have no anal tubules and the pupa has a pair of short, breathing trumpets, as in the mosquitoes, instead of the thread-like tracheal gills. Larvæ of the first type burrow; those of the second type often live at the surface of the water and

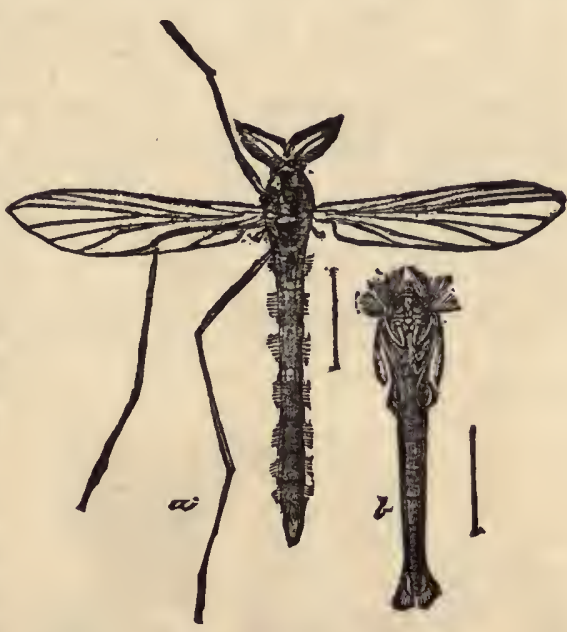

Fig. 62.-Chironomus plumosus : adult and pupa. (After Riley.)

feed on weeds. These generalizations are taken from Miall and Hammond. One European species has been found to lay eggs while yet in the pupal stage. A genus of this family-Ceratopogon-is composed of very minute biting flies. The so-called "punkie" of the north woods, called "no-see-um" by the Maine Indians, belongs to this genus, and other species are found from Canada south to Chili.

\section{Life History of a Midge (Chironomus mimutus.)}

The life history of no American species of this family has been worked out. That which follows is taken from the observations of Mr. L. H. Taylor, of Leeds, England, as given in the 
work on Chironomus by the above mentioned authors. The larvæ are found in gelatinous tubes attached to stones in slow or swift-running streams. When disturbed they leave their cases and crawl like measuring worms or swim with a figure-of-eight motion. The larva is pale green in color and about seven $\mathrm{mm}$. long and has no anal blood-gills. When about to pupate the thorax is much swollen. The pupæ live in gelatinous cases attached to stones, each case having a slightly protruded orifice at either end so that the water flows through impelled by the motion of the body of the pupa. The pupa breathes by means of respiratory trumpets which are so small as to suggest that the insect also breathes cutaneously or in some other way. It is armed with strong hooks on the abdominal segments by means of which, when mature, it tears its way through the case and rises to the surface of the water. In this position the skin of the thorax cracks and the adult fly emerges. 


\section{THE GALL-GNATS}

\section{(Family Cecidomyiida.)}

The minute flies of this family are small delicate flies somewhat resembling mosquitoes, but do not bite. The antennæ are many-jointed, and are furnished with whorls of hair. The wings have only a few longitudinal veins and but a single cross vein in some genera. The legs are not swollen, and the body and wings are clothed with hairs which are easily rubbed off.

In this country these flies have not been systematically studied with great care. There are many species, however, and some of them are known only by the work of their larvæ. About one hundred species have been described in the United States.

The larvæ differ considerably in their habits, but most of them form galls on

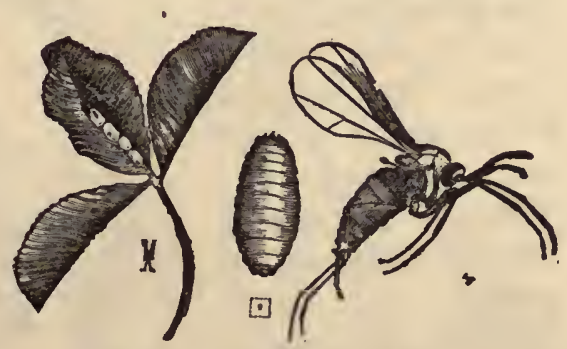

Fig. 63.-Cecidomyia trifolii.

(After Comstock.)

the twigs or leaves of different plants. Some live urder bark and others (of the genus Diplosis) prey upon plant-lice and bark-lice. Others still produce plant deformities of different kinds which cannot strictly be called galls.

The larvæ are small, somewhat flattened maggots, tapering at each end, and frequently brightly colored with some shade of red or yellow.

The pupa is either naked or is enclosed in a delicate silken cocoon.

The most famous member of this group is the so-called Hessian fly (Cecidomyia destructor Say.) This species lives, in 
the larval state, in stems of wheat, and annually damages

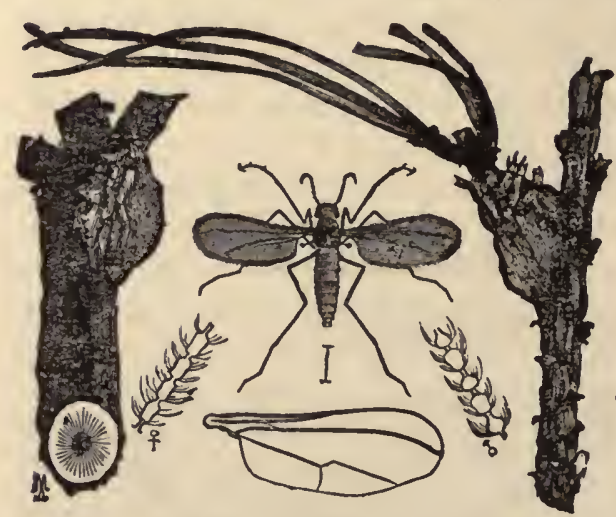
the wheat crop of the United States to the extent of many millions of dollars. It is supposed to have been introduced into the United States in the straw brought over for bedding by the Hessian troops during the War of the Revolution. Hence the popular name. Other American species form Fig. 64.-Diplosis resinicola. (After Comstock.)

resembling a pine cone. Another species lives on the surface of the maple leaves. Still another forms a gall in the stem of Chrysopsis. There are also several Cecidomyiid galls on golden rod, sunflowers and Aster. The species of two genera have been found in Europe to give birth to young while in the larval state. This phenomenon is known as pædogenesis, but has not been observed in curious galls on willow, one of them for example

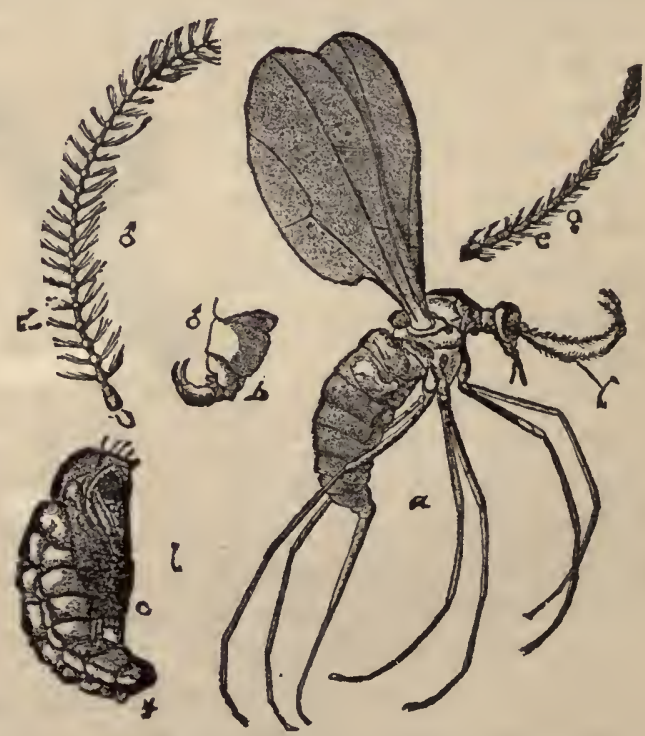

Fig. 65.-Diplosis pyrivora.

(From United States Department Agriculture.) any American forms. 


\section{Life History of a Gall-Gnat}

\section{(Cecidomyia leguminicola Lint.)}

This insect, commonly known as the clover-seed midge, occurs throughout a large part of the United States and breeds in the flower heads of the common red clover. It was first noticed in New York State in 1879, but has since been found in most of the clover-growing regions of the country.

The very minute, long, oval, pale yellowish eggs are pushed down by the female between the hairs which surround the seed capsule of the yet undeveloped florets. They are generally deposited singly, but are sometimes found in clusters of from two to five. After young larvæ hatch they work their way through the mouth of the flower to the seed. They feed upon the seed, usually destroying it, and when full grown work their way out of the closed florets, wriggling violently until they fall to the ground where each forms an oval, compressed, rather tough cocoon of fine silk with particles of the surrounding earth

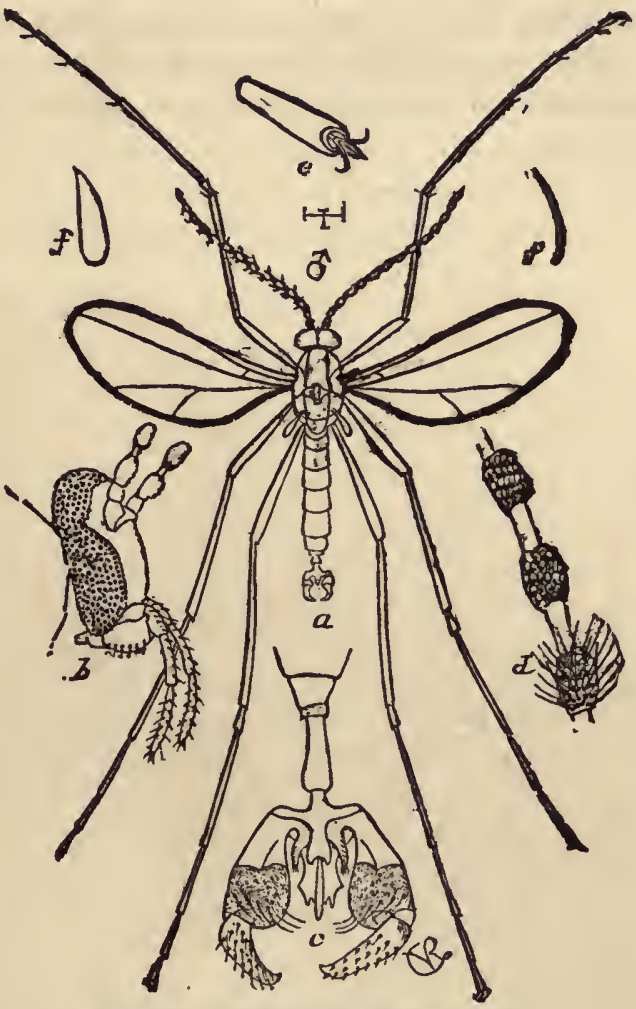

Fig. 66.-Cecidomyia leguminicola. (From United States Department Agriculture.) adhering to the outside and rendering its detection extremely difficult. The pale orange pupa remains within the cocoon about ten days, after which period the adult fly emerges. 
There are two generations annually in New York, and three in the District of Columbia.

The species also breeds in white clover, and is frequently so numerous as to destroy the clover-seed crop over a large section of the country.

The remedy is a simple one, and affords an excellent example of the value of accurate knowledge of the life history of injurious insects. It is the custom in the northern states to cut clover twice in the season, once when the clover is in full bloom, for hay alone, and again in the autumn for seed. If the hay crop be cut from two to three weeks earlier than usual the first generation of the insect will be destroyed and the seed crop in the autumn will not be affected, or at least only to a comparatively slight extent. 


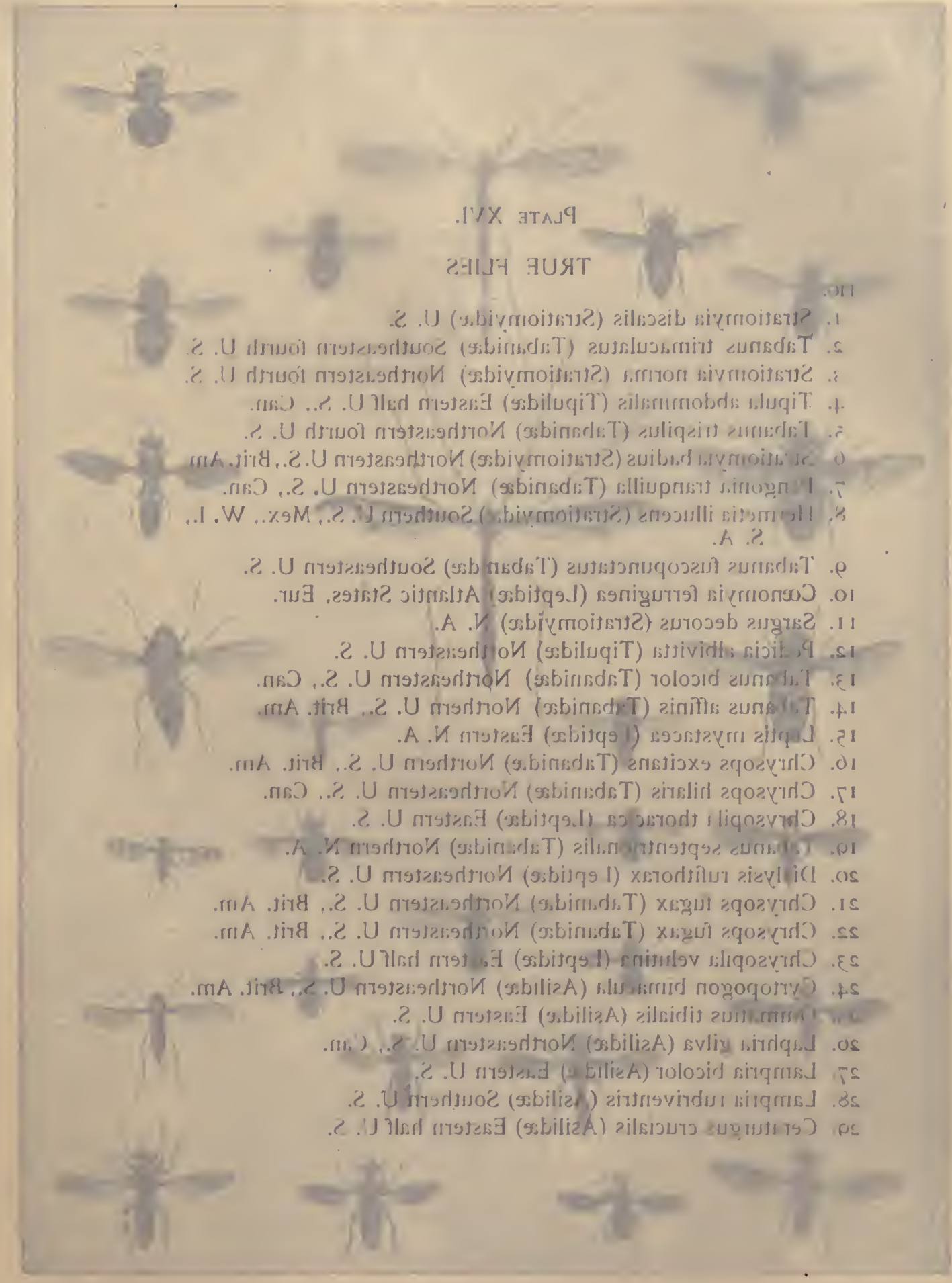




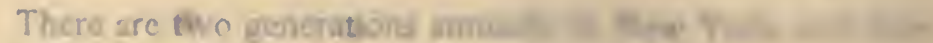
in the District ai Coluinlais.

The spocies dso breeds in whire us o

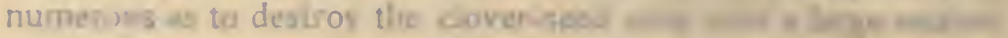
of the country

The ramedu is a PLATE XVI.

\section{of the wulue faccurate Kr TRUE FLIES}

FIG.

t1.- Stratiomyia discalis (Stratiomyidæ) U.S.

2. Tabanus trimaculatus (Tabanidx) Southeastern fourth U. S.

3. Stratiomyia norma (Stratiomyida) Northeastern fourth U. S.

4. Tipula abdominalis (Tipulidæ) Eâstern half U. S., Can.

v. Tabanus trispilus (Tabanidæ) Northeastern fourth U.'S.

6. Stratiomyia badius (Stratiomyidæ) Northeastern U.S., Brit. Am.

7. Pangonia tranquilla (Tabanidæ) Northeastern U. S., Can.

8. Hermetia illucens (Stratiomyidæ) Southern U. S., Mex., W. I., S. A.

9. Tabanus fuscopunctatus (Tabanidæ) Southeastern U. S.

10. Cœnomyia ferruginea (Leptidæ) Atlantic Státes, Eur.

11. Sargus decorus (Stratiomyidæ) N. A.

12. Pedicia albivitta (Tipulidæ) Northeastern U. S.

13. Tabanus bicolor (Tabanidæ) Northeastern U. S., Can.

14. Tabanus affinis (Tabanidæ) Northern U. S., Brit. Am.

15. Leptis mystacea (Leptidæ) Eastern N. A.

16. Chrysops excitans (Tabanidæ) Northern U. S., Brit. Am.

17. Chrysops hilaris (Tabanidæ) Northeastern U. S., Can.

18. Chrysopila thoracica (Leptidæ) Eastern U. S.

19. Tabanus septentrionalis (Tabanidæ) Northern N. A.

20. Dialysis rufithorax (Leptidæ) Northeastern U. S.

21. Chrysops fugax (Tabanidæ) Northeastern U. S., Brit. Am.

22. Chrysops fugax (Tabanidæ) Northeastern U. S., Brit. Am.

23. Chrysopila velutina (Leptidæ) Eastern half U. S.

24. Cyrtopogon bimacula (Asilidx) Northeastern U. S., Brit. Am.

25. Ommatius tibialis (Asilidæ) Eastern U. S.

26. Laphria gilva (Asilidæ) Northeastern U. S., Can.

27. Lampria bicolor (Asilidæ) Eastern U. S.

28. Lampria rubriventris (Asilidæ) Southern U. S.

29. Ceraturgus crucialis (Asilidæ) Eastern half U. S. 


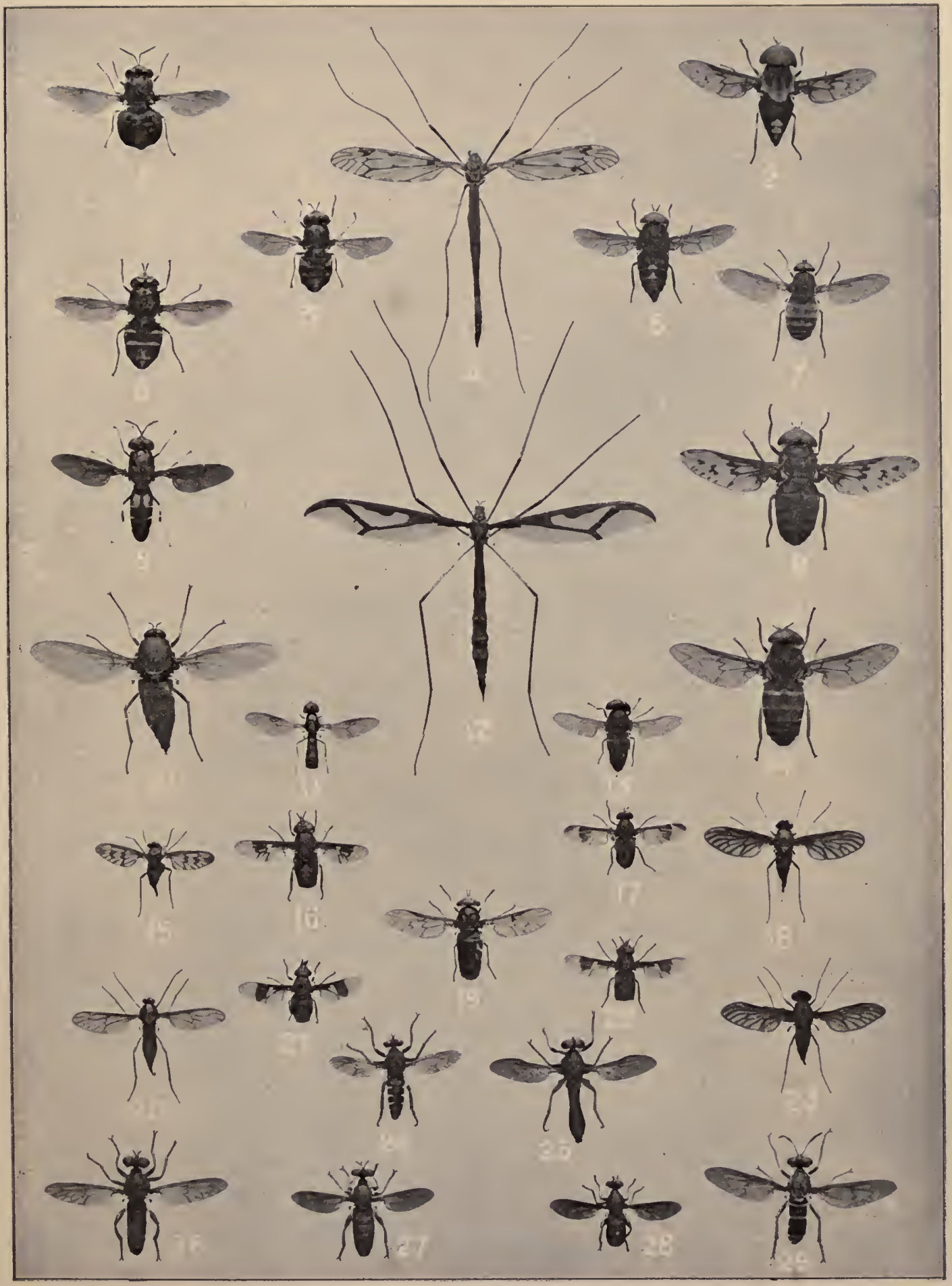


and 


\section{FUNGUS GNATS}

\section{(Family Mycetophilida.)}

The flies which belong to this group are known as the fungus gnats, from the fact that many of them breed in fungi. These insects are so delicate in structure that they are difficult to collect and study and are not so well known as they should be, although nearly a thousand have been described. More than a hundred species have been described from the United States. They are delicate and as a rule rather slender little flies. The wings are generally clear, but sometimes they are smoky or with
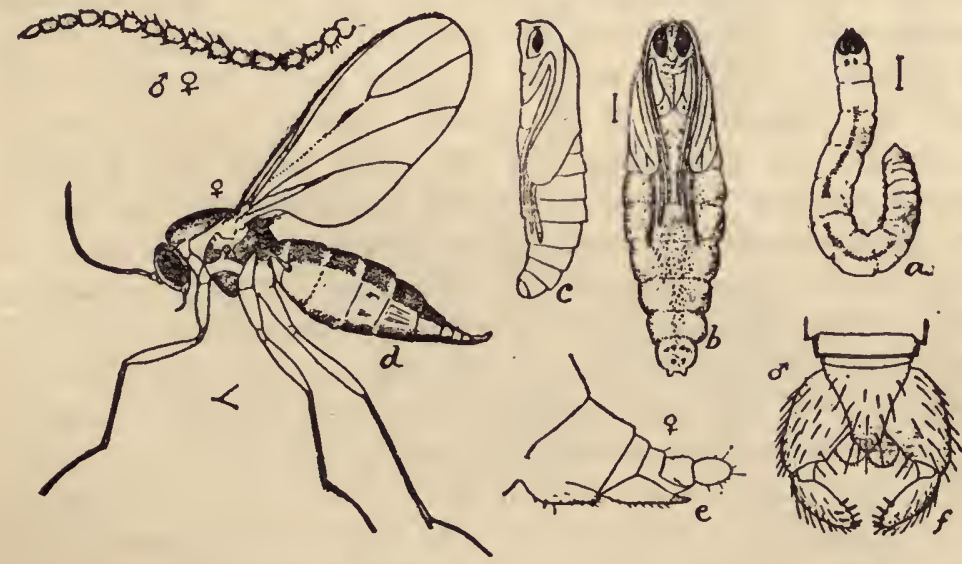

Fig. 67.-Sciara tritici. (After Coquillett.)

large spots as in those which belong to the genera Platyura, Sciophila and Mycetophila. The female abdomen is frequently distended and expanded toward the tip, as in Platyura pectoralis Coq. and Asindulum montanum Röder. With those species whose larvæ live in fungi or decaying wood or other vegetable matter, the larvæ are usually slender, cylindrical maggots, more or less worm-like in appearance. Some of them somewhat resemble 
snails and construct delicate cocoons. It was formerly supposed that with some of the species the larvæ formed galls on leaves, as, for example, one species was supposed to belong to the genus Sciara which makes the beautiful crimson, eye-like spots often seen on the leaves of the silver maple, but the larvæ in these spots are now thought to be Cecidomyian and it is doubted whether any true Mycetophilids ever make galls. Some of the Sciaras also have the curious habit when in the larval state of traveling in great armies so close to each other as to almost form one mass. They have then been called worm-snakes. They travel in a solid column several deep over each other at the rate of about an inch a minute. In Europe they have from this habit been called the army-worm, but in this country the term army-worm is applied to a caterpillar. One of our American species of this habit has been reared by Pratt and proves to be Sciara fraterna. Some species live in the sap of trees, and injury to the bark of a maple or an elm causing the sap to flow in the spring frequently attracts these little midges, which will lay their eggs there and subsequently little maggots will be found. One species, known as Epidapus scabiei, is said by Hopkins to be the cause, or at least the transmitter, of the disease known as scab among potatoes. He also finds that the same insect will breed in healthy potatoes. The use of scabby seed potatoes offers favorable conditions for the attack of these insects as these are attracted to the scabby spots under which they breed and are thus brought into contact with the growing tubers. Another species feeds upon ripe apples. One of the Sciaras has been called the yellowfever fly in the southern United States, since it made its appearance in extraordinary numbers during a yellow fever epidemic. It has, however, no connection with the disease. Certain of these fungus gnats jump actively as well as fly. Sciara tritici Coq., figured herewith, in its larval stage damages young growing wheat plants. 


\section{THE MARCH-FLIES}

\section{(Family Bibionida.)}

The flies of this family are not especially interesting. They are of medium size and are rather thick-bodied and rather hairy but are weak fliers. Their wings are frequently smoky. Some species, as Scatopse, are very small. There seems to be nothing especially interesting about the group, although more than three hundred species are known. The larvæ are cylindrical and have transverse rows of bristles and the head, which is rarely obvious in dipterous larvæ, shows eyes. They feed upon excremental or vegetable substances and are said to attack the roots of growing grass. One of our commonest species is Bibio albipennis. This species sometimes occurs in enormous numbers. In the spring of 1891 , according to Osborn, it abounded in parts of lowa and was erroneously reported as doing much damage to vegetation. In this form the wings are white,

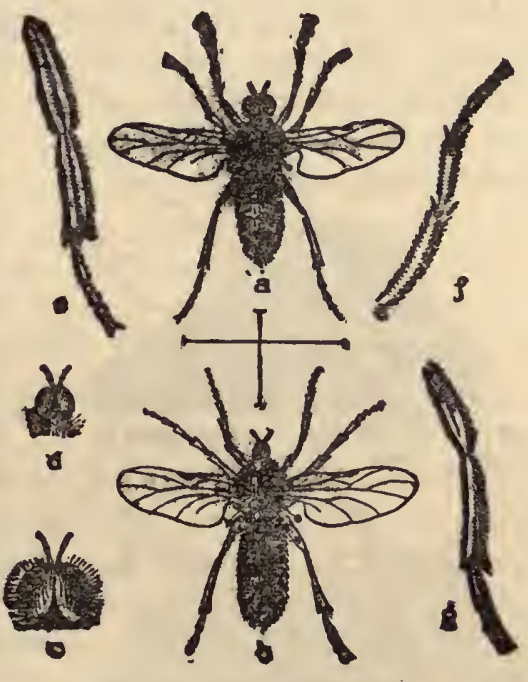

Fig. 68.-Bibio albipennis. (After Lintner.) quite contrary to the general rule in the family. Other species are of a deep red color with dark wings. The larvæ of some species of this family have been found on the surface of snow. The flies of the genus Scatopse breed in decaying vegetable material, in sewers, and in human excreta. Scatopse pulicaria is common on our windows at certain seasons of the year and, as it is an excrement fly, is a dangerous inhabitant of houses. 


\section{THE BLACK FLIES AND BUFFALO GNATS}

\section{(Family Simuliida.)}

These insects, known as black flies, sand flies or buffalo gnats, are small, stout, hump-backed, biting flies with broad wings and rather short legs which are sometimes speckled, and with short, straight, simple antennæ. The eyes of the male are very large

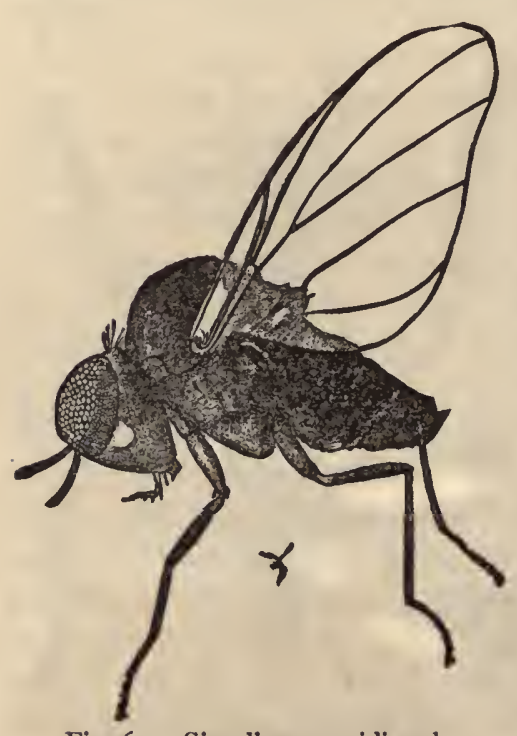

Fig. 69.-Simulium meridionale. (From U.S. Dept: Agr.) and frequently touch each other, and the insect in this sex does not bite. The family contains only the single genus Simulium of which the black flies of the north woods and the buffalo gnat of the Mississippi and Missouri valleys are well known examples. They rival the mosquito in their blood-thirsty tendencies and not only do they attack human-beings, but poultry and domestic animals are frequently killed by them. There is one case on record in which a man was killed by innumerable bites. In certain seasons they multiply enormously, alight in thousands on cattle and produce death through their poisonous bites as well as from loss of blood. Unlike mosquitoes they fly and bite in the day time and are often seen in large numbers flying in bright sunshine. The larvæ are aquatic and unlike mosquitoes again, the larvæ of which live in stagnant water, Simulium larvæ frequent well aerated and frequently swiftly running streams. They are found most abundantly on rocks or logs so near the surface as to cause a rapid ripple. 
On one occasion in the South the buffalo gnat plague was averted

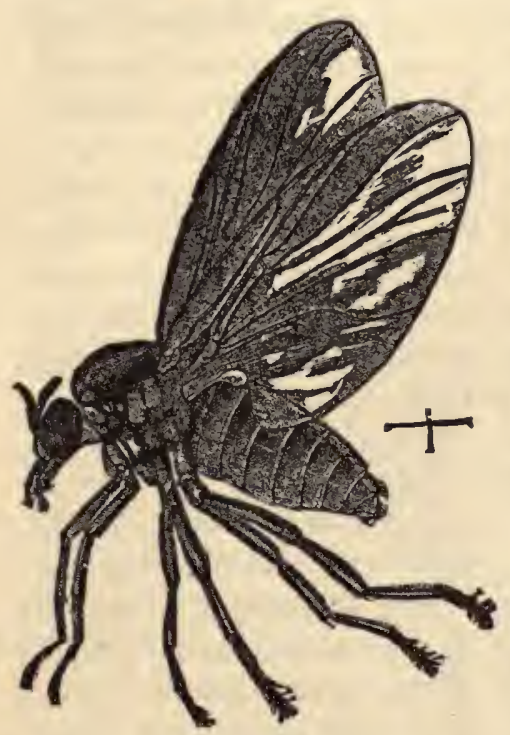

Fig. 70.-Simulium invenustum. (From U. S. Dept. Agr.)

by the removal of a jam of logs in a sluggish bayou cver which the water ran shallowly with sufficient speed to make a perfect breeding place. When the logs were removed and the old sluggish current was resumed the breeding places had been abolished. In the typical life history which follows, the issuing of the fly is mentioned but it should be stated here that with another species in the southwest Mr. H. G. Hubbard while watching the surface of the water saw adults issue in great numbers with such force and velocity that as he expressed it they appeared as if shot out of a gun.

\section{Typical Life History}

\section{(Simulium pictipes Hagen.)}

The larvæ of this species occur abundantly on the rocks in the hillside streams about Ithaca, N. Y., where the writer was familiar with them as a boy. The boys who bathed in the streams in that region feared these larvæ, called them leeches and supposed that they would attach themselves to the skin and suck blood. They are, however, perfectly harmless. The life history of the species has been carefully worked out by Miss R. O. Phillips in an unpublished paper from

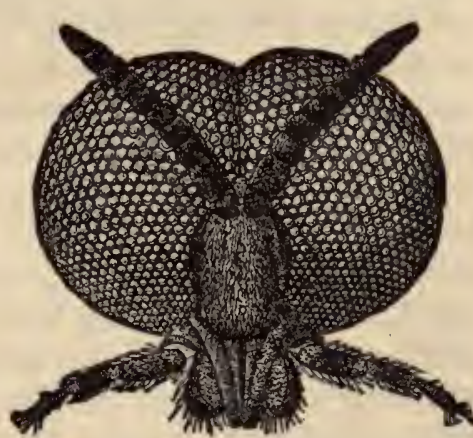

Fig. 71.-Simulium invenustum, male. (From U.S. Dept. Agr.) 
which the following account is condensed. The adults occur in the early part of May or at the beginning of the first continuous warm westher in the spring. The eggs are deposited on rocks over which the water is flowing. The flies hover in little swarms a foot or two above the rock, rapidly flying back and forth, and occasionally darting down and depositing their eggs beneath the water on the flat surface of the rock. The batch of eggs becomes at least a foot $\mathrm{cr}$ more in diameter and is distinctly observable at some distance on account of the light yellowish color. When the water is very shallow and its velocity slight the flies sometimes crawl over the surface of the rock and deposit eggs without flying. Only a small proportion of the eggs produce larvæ. The larvæ hatch about eight days after the eggs are

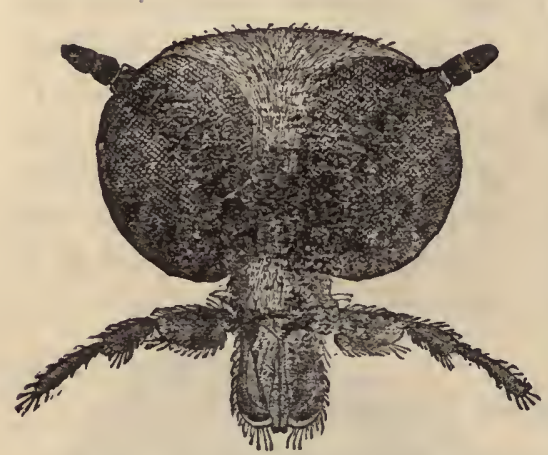

Fig. 72.- Simulium invenustum, female. (From U.S. Dept. Agr.) laid and in this stage the insect may be found at any season of the year, in summer as well as in winter, and it is in this stage that it hibernates. The larvæ die in three or four hours when placed in quiet water. Fastened to the rock by the anal end of the body they assume an erect position and move the head around occasionally with a circling motion.

They may release themselves and as they grow larger they sometimes allow themselves to be washed into deeper water, holding by a thread which they spin as they go. The thread is spun from the mouth but is attached along the side of the body to the different segments. Sometimes a large cluster of larvæ will cling to the same thread which they can ascend in much the same manner as do spiders. Not much food is taken in the winter time. During the summer the length of the larval life is about four weeks, varying with the temperature and the velocity of the water. When full grown the larva spins its cocoon, firmly attaching it to the rock and also to adjacent cocoons. The length of the pupal stage is about three weeks. Over-wintering larvæ transform to pupæ about the 12 th of April, the first flies appearing on the $2 \mathrm{~d}$ of May. The newly issuing fly surrounded by a 
bubble of water quickly arises to the surface of the water and flies away instantly, the silky pubescence keeping it from getting wet. The first generation having appeared in early May, successive generations are produced from this time on during the summer and part of the autumn. All of the flies captured from the first brood in one instance were females and this may be the rule but towards autumn the males began to appear in greater numbers and towards the last of August nearly all of the specimens taken were males. On September 2, 1888, the present writer captured fifty specimens of this fly at lthaca and all were males with the exception of one. Adults were
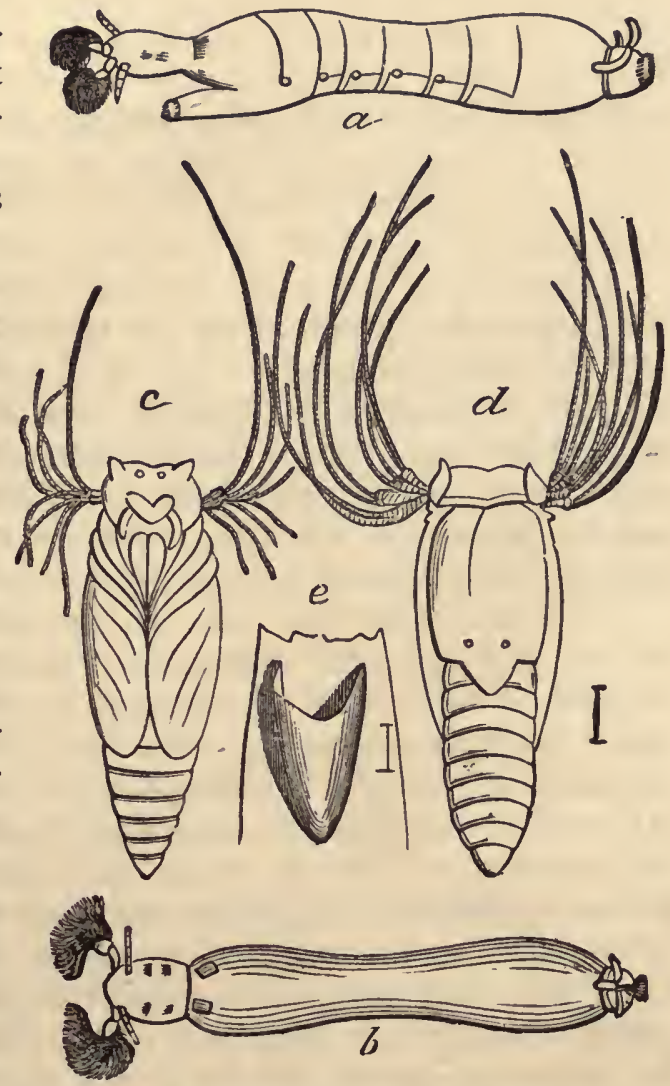

Fig. 73.-Simulium ornatum, early stages. (After Riley.)

observed on the wing as late as the roth of October. 


\section{FAMILIES ORPHNEPHILIDA, BLEPHARO- CERID $A$ AND RHYPHIDA}

These three families are not especially well represented in the fauna of the United States and comparatively little need be said about two of them.

The Orphnephilidæe are small brownish or yellowish flies without bristles or hairs. We have only one described species in this country, viz, Orphnephila testacea Ruthe, common to Europe and North America. Nothing is known about the transformations of any member of this family.

The Blepharoceridx, however, are insects of much greater interest and especially on account of their curious larvæ and on account of an unusual arrangement of the viens in the wings which has been pointed out in the table of families. The adult flies look somewhat like mosquitoes but do not bite. The eyes are divided, the upper half containing large ocelli and the lower half small ones. The larvæ are very peculiar looking objects, having appparently but seven segments and being furnished with conical leg-like structures on most of the segments. On the under side of the body is a row of circular suckers by which they attach themselves to rocks in swift running streams. Each of the suckers is surrounded by a little fringe of tracheal gills or there are tufts of such gills near the sides of the body. The pupa is formed within the last larval skin but subsequently the skin is cast so as to leave the pupa naked. The pupa also clings to the rocks, the skin of the back being hard and making a sort of scale over the body. On the underside, however, it is delicate and soft and furnished with six suckers by which it clings to the rocks so firmly that they can hardly be removed without breaking them. Comstock has watched the flies issue from the pupa skins. The pupæ occur in groups so as to form black patches on the rocks. Each one rests with its head down the stream. The fly emerges through a split in the skin between the thorax and 
abdomen, working its way out slowly and holding itself upright in spite of the swift current. Where only a quarter of an inch of water flowed over their heads flies were able to hold to the pupa skins with their hind legs, the body being free from the water. The wings then expanded and they flew away. Where the water was deeper the flies were carried down the stream and possibly perished. The commonest species of the northeastern states is Blepharocera capitata Loew, which occurs in the District of Columbia, in central New York, in the White Mountains and in Canada.

The family Rhyphidx, the members of which have been called the "false crane flies," is composed in general of small flies with broadly rounded and spotted wings. It is a small farrily and only two genera are represented in this country. The early stages of none of our American species are known but in Europe they are described as long, slender, worm-like creatures which are found in decaying wood, in cow dung, in decaying fruit and even in dirty water. 


\section{THE SNIPE FLIES}

\section{(Family Leptida.)}

These are slender, rather small flies, somewhat resembling the robber flies, on account of their long legs and slender bodies. They have usually smoky wings and velvety bodies, some of them slightly resembling yellow-banded wasps. They are not especially numerous. Some of these flies are predatory and destroy other insects and this may be the habit of all. They are sluggish in their habits and are easily caught. The larvæ are predaceous, and variable in their habitations. Some are found in water, others live in decaying wood, or in the earth, in moss, in dry sand, or in the burrows of wood-boring beetles. There is a curious resemblance between the habits of the species of the genus Vermileo and the well-known ant-lions, the larvæ forming conical pitfalls in the sand in which to catch small insects. Flies of the genus Atherix lay their eggs, as do the females of the Stratiomyiid genus Odontomyia, in masses on dried branches overhanging the water. The masses become very large and pear-shaped from the curious fact that a number of females add their eggs to the same mass, frequently dying after egg laying and leaving their bodies attached to the egg mass. The larvæ are cylindrical and sometimes bristly, and may have fleshy appendages resembling prolegs on the abdomen. Atherix has seven pairs of these prolegs. The larva of one species has been found by Hart in damp earth.

The families Xylophagidæ and Cœnomyiidæ which will be found mentioned in some books are merged with the Leptids. The Xylophagids are rather slender flies with the abdomen pointed in the female sex. The Cœnomyiids on the contraryare stout, rather large flies. The larvæ of some of Xylophagids live under bark and prey on other insects and the larvæ of Cœnomyia live in the earth and are also probably predaceous. 
Nearly three hundred species are known, of which rather more than fifty occur in the United States, but the full life history of none of our American forms is known. Vermileo, the form whose larva resembles that of the ant-lion, does not occur in the United States. 


\section{SOLDIER FLIES}

\section{(Family Stratiomyiida.)}

There are certain rather broad, but rather flat-bodied flies of divers structure, but separated from other flies by the characters given in the table, which are not especially remarkable in their appearance except in some aberrant forms, and which are not especially numerous or notable, which are grouped together in this family. Comstock has called them the "soldier flies," on account of bright colored stripes with which some species are marked. They are also dark colored and metallic and are not hairy or bristly. Some of the brightly marked ones look like Syrphus flies and some of them have a superficial resemblance to some of the solitary wasps. The wings are usually clear, but are sometimes smoky or brown. They are found generally in marshy places on flowers and vegetation, and their larvæ live in the water, in the earth, in moss, in decaying wood, and in ants' nests, and there are observations on record which seem to show that the larvæ of the curious American genus Hermetia may live in bee hives, and in the nests of wild bees. At all events, $H$. illucens has been seen hovering about bee hives and thrusting its eggs through cracks in the hives. The aquatic species are not confined to fresh water, but at least one is known to inhabit salt water, and one form lives in some of the alkaline lakes of the western states.

Some of the larvæ are carnivorous, while others feed upon decaying vegetable matter.

The aquatic forms feed upon very small aquatic organisms. The eggs are laid in overlapping layers upon the under sides of the leaves of aquatic plants, or they are laid upon the surface of the water. The larvæ are elongate pointed and flattened. We hardly know enough about the development of any one North American form to draw up a typical life history, but several of I 28 

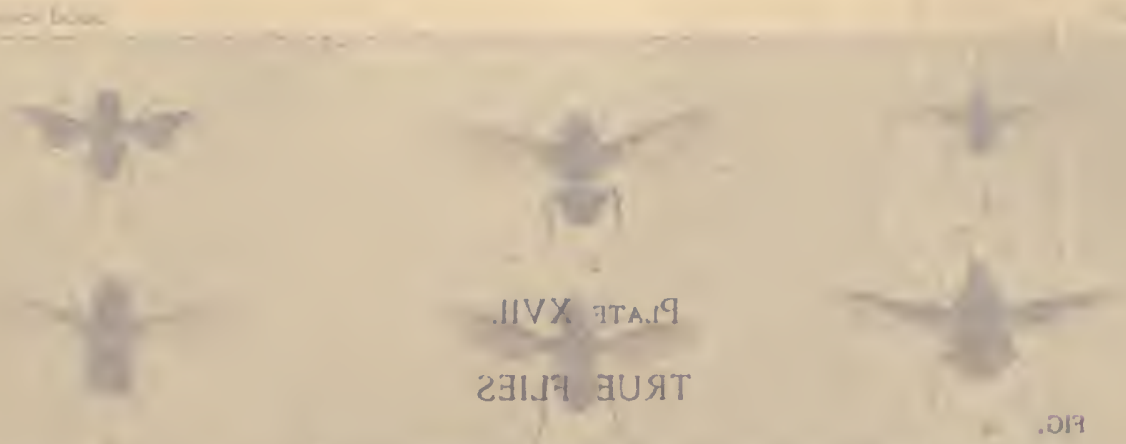

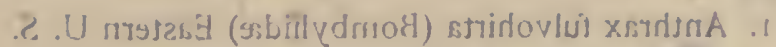

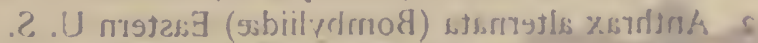

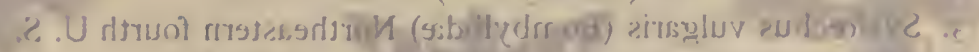

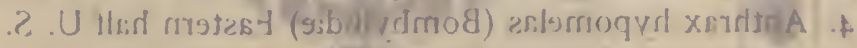

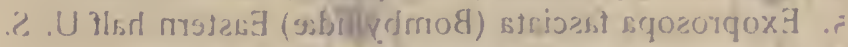

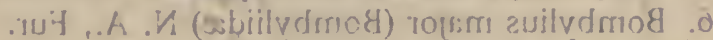

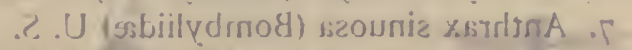

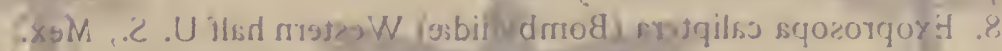

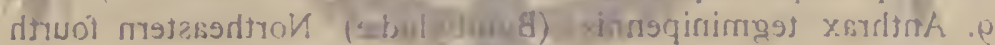

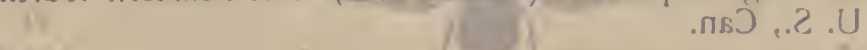

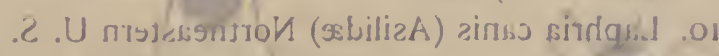

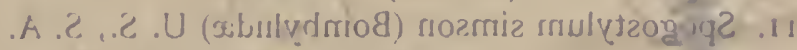

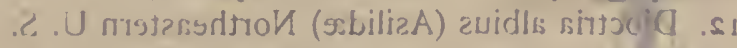

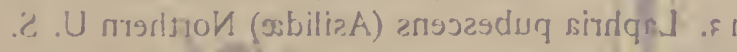

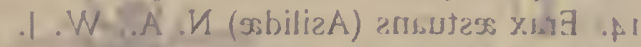
2 U II - ⿰氵

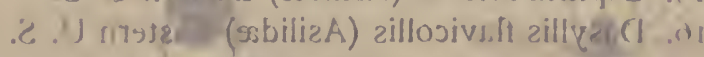

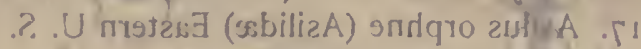
X (sbilisA) .q? siymotod .81

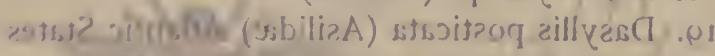

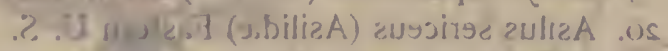

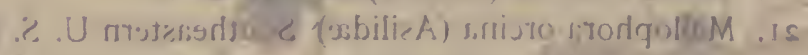

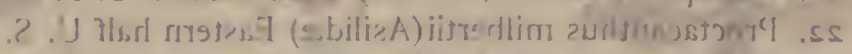

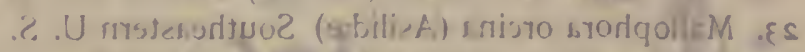

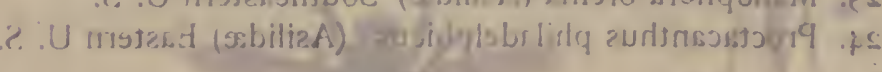




\section{Plate XVII.}

\section{TRUE FLIES}

FIG.

1. Anthrax fulvohirta (Bombyliidæ) Eastern U. S.

2. Anthrax alternata (Bombyliidx) Eastern U. S.

3. Systochus vulgaris (Bombyliidæ) Northeastern fourth U.S.

4. Anthrax hypomelas (Bombyliidæ) Eastern half U.S.

5. Exoprosopa fasciata (Bombyliidæ) Eastern half U.S.

6. Bombylius major (Bombyliidæ) N. A., Eur.

7. Anthrax sinuosa (Bombyliidæ) U.S.

8. Exoprosopa caliptera (Bombyliidæ) Western half U. S., Mex.

9. Anthrax tegminipennis (Bombyliidæ) Northeastern fourth U. S., Can.

10. Laphria canis (Asilidæ) Northeastern U. S.

11. Spogostylum simson (Bombyliidæ) U. S., S. A.

12. Dioctria albius (Asilidæ) Northeastern U. S.

13. Laphria pubescens (Asilidæ) Northern U. S.

14. Erax æstuans (Asilidæ) N. A., W. J.

15. Laphria sericea (Asilidæ) Eastern U. S.

16. Dasyllis flavicollis (Asilidæ) Eastern U. S.

17. Asilus orphne (Asilidx) Eastern U. S.

18. Deromyia sp. (Asilidæ)

19. Dasyllis posticata (Asilidæ) Atlantic States

20. Asilus sericeus (Asilidx) Eastern U. S.

21. Mallophora orcina (Asilidæ) Southeastern U.S.

22. Proctacanthus milbertii(Asilidæ) Eastern half U.S.

23. Mallophora orcina (Asilidæ) Southeastern U. S.

24. Proctacanthus philadelphicus (Asilidæ) Eastern U. S. 


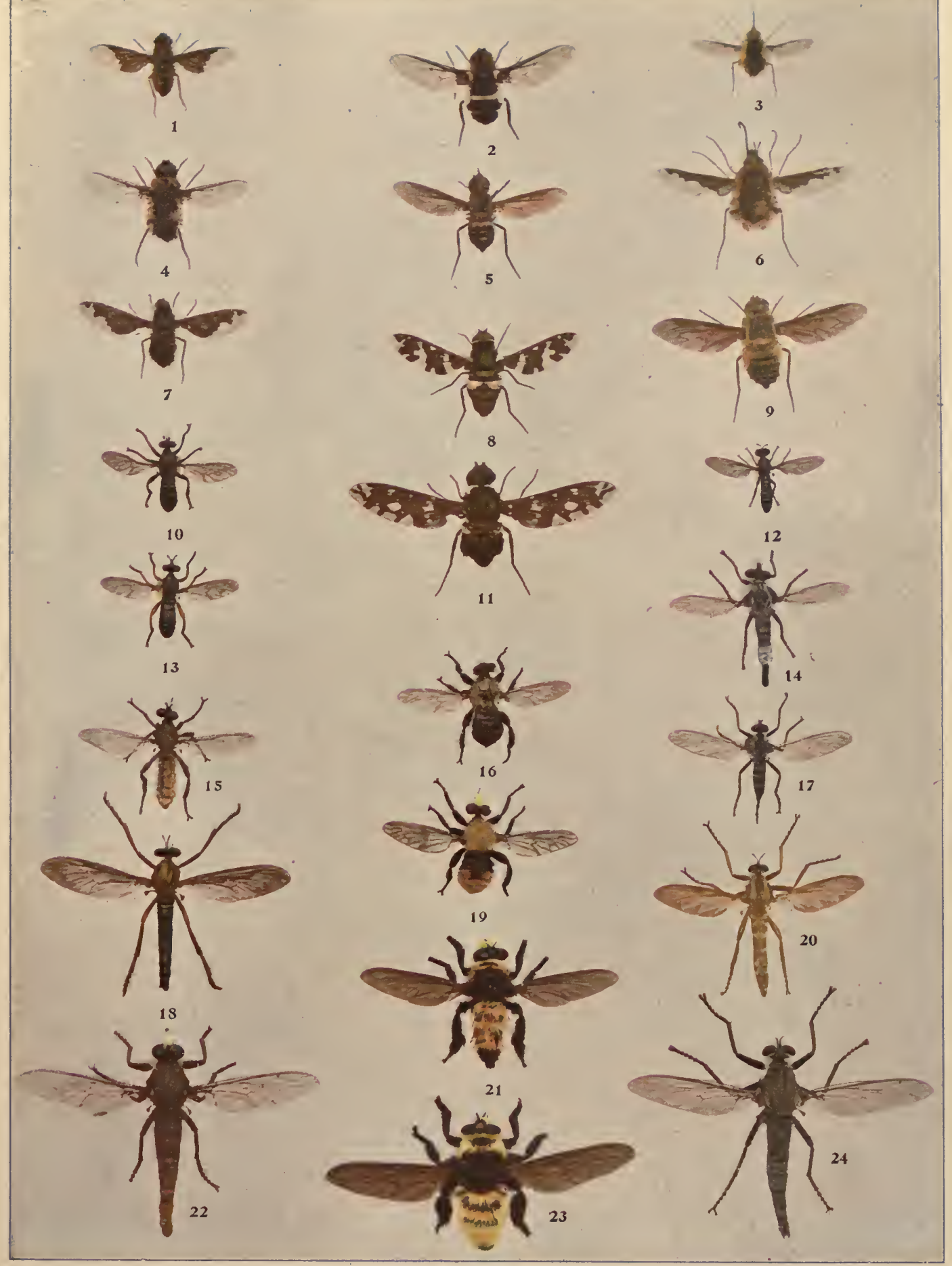



the aquatic and subaquatic species have been studied by Hart in his interesting investigations of the entomology of the Illinois River. He finds that Stratiomyia seems to prefer the shore and Odontomyia the water. The larvæ are large, opaque, greenish brown or gray, obscurely striped, and when in the water are found upon vegetation near the surface or floating about, and when on shore crawling about over the mud and in the green scum so often found on wet banks. The pupa is formed within the larval skin, but occupies only the head-end, the remainder of the skin being filled with air which causes the pupa to float at the surface of the water. When the fly is ready to emerge the Iarval skin splits transversally on the fourth segment and the fly emerges while the case is floating on the water or resting on the shore. Hibernating larvæ and pupæ are found in large numbers on loose drift on the shore, emerging, in Illinois, in early summer. Hart thinks there are two generations annually. $\mathrm{He}$ watched the egg-laying of Odontomyia cincta and O. vertebrata. They chose dead branches in the water, reeds and the stems of various plants. The female generally stood with the head downwards, and the long and narrow eggs were placed in an irregular oval mass to the number of several hundred closely laid with their tapering ends inserted between the ends of those next to them.

The larvæ and pupæ are frequently parasitized by certain Chalcis flies (Smicra rufofemorata and S. microgaster.) Hart made an extremely interesting observation when he found the latter parasite mutilating with its jaws an egg mass of one of these flies. I know of no observation parallel to this. The eggs above referred to were laid June Ist, and hatched in ten days. The stomachs of the larvæ were found to contain mud for the most part, with a little vegetable matter, and here and there a diatom.

About one thousand species of Stratiomyiidx have been described, of which about two hundred are found in North America. 


\section{FAMILY ACANTHOMERIDAE}

This is a small and relatively unimportant family of flies of which but a single genus and half a dozen species are represented in North America and all of these are southern forms. They include some of the largest flies known and resemble the gadflies and bot-flies more than the flies of any other family in general appearance. 


\section{THE GAD-FLIES OR HORSE-FLIES}

\section{(Family Tabanida.)}

The insects of this important family are known as gad-flies, horse-flies or deer-flies. To this group belong the active, strongflying creatures which annoy horses to such an extent when one is driving along a wooded road, especially in pine woods, and also the smaller yellowish or greenish flies which annoy forest animals, and which bite human beings when in the woods. The proboscis of all of the flies of this family is in the female sex adapted for piercing and sucking, the males, as in all of the bloodsucking flies, including the mosquitoes, being harmless, and the proboscis not adapted for piercing the skin of mammals. The bites do not appear to be as painful as those of mosquitoes or of black flies, and apparently no poison is injected, but any one of these flies may be responsible for the transfer of the bacillus of anthrax or "malignant pustule," as it is called. The adults are great water drinkers,

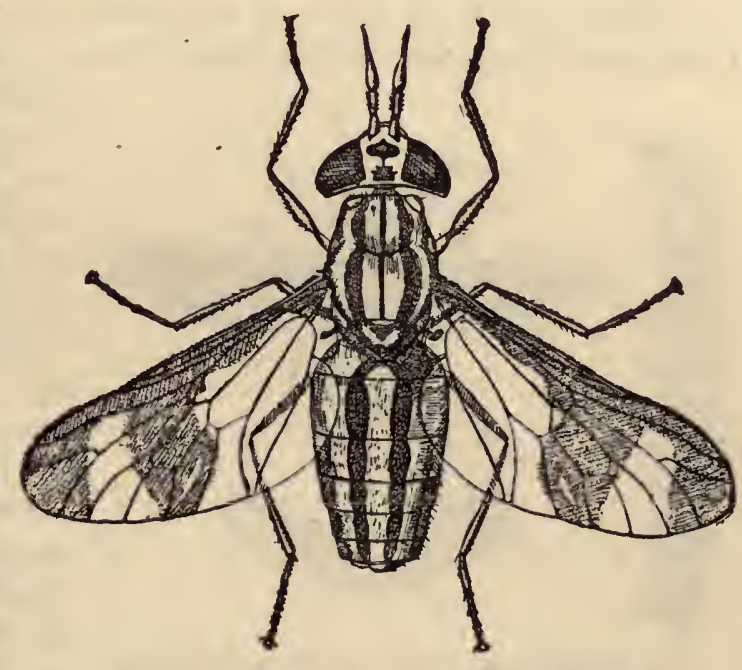

Fig. 74.-Chrysops fugax. (After Osborn.) and are usually most abundant in the vicinity of inland ponds and streams. This has suggested to Porchinsky, the Russian entomologist, the desirability of coating such ponds with kerosene, 
and his experiments resulted in the destruction of great numbers of Tabanids.

The larvæ of the Tabanidæ live in the earth or in water and are carnivorous, feeding upon soft-bodied insects and water snails. The spindle-shaped brown or black eggs are deposited in summer in groups attached to the leaves or stems of herbage. The gad-flies vary greatly in color and size, and the smaller ones of the genus Chrysops, sometimes called "deer flies," are frequently quite small and colored with yellow or green. The larger ones vary through gray and brown to black. Our largest gad-fly is Tabanus americanus Först., which is an inch and a quarter long, and has a wing-spread of two and one-half inches. It inhabits the Southern States. About 1,500 species are known, and perhaps 200 occur in this country.

\section{Typical Life History of a Gad-Fly}

\section{(Tabanus atratus Fab.)}

This is one of the common large black horse-flies which has a very wide distribution in the United States. Its larvæ have been

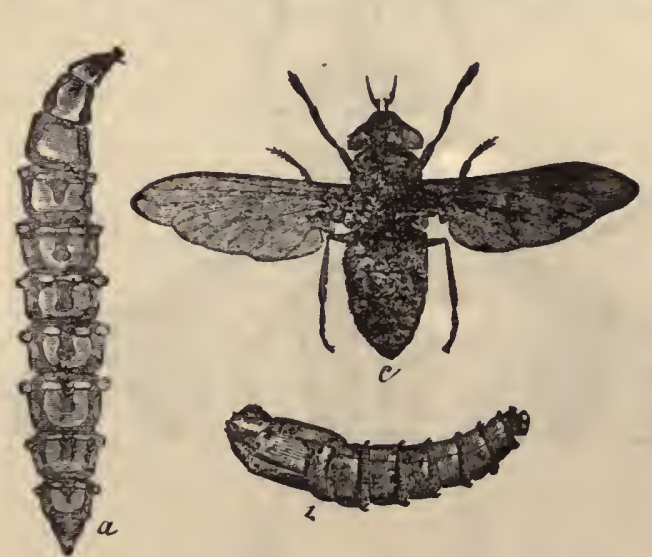

Fig. 75.-Tabanus atratus : $a$, larva; $b$, pupa ; $c$, adult. (After Riley.) studied by Walsh, Riley and Hart. Hart has found the egg masses in July on the dry bark of a stick projecting from the water. From these eggs larvæ hatched August 4th. Larvæ of this species were found commonly in water, among vegetation and in the sand of the sandy shores of the lllinois River. Pupæ may be found in the early summer, and the adults appear from May to July, living all through the summer. The species is apparently single-brooded, that is to say, has but one generation annually, 
and hibernates in the larval stage, the adults mainly emerging in July after a short pupal period, the eggs being laid without delay and producing larvæ a week later. The egg is about $2.5 \mathrm{~mm}$. long, with a diameter of .4 mm., dark-brown, sub-cylindrical, more or less tapering at the end. As they are laid in masses they point obliquely upwards, and are stuck in four or five tiers, one above the other, and all gummed together in a firm mass. The larva is shining and of a transparent, whitish color, with a greenish tinge, marked with conspicuous dark-brown or goldgreen irregular bands. The egg is parasitized by the little Hymenopterous insect known as Phanurus tabanivorus Ashm. 


\section{THE SMALL-HEADED FLIES AND THE TANGLE-VEINED FLIES}

\section{(Families Acrocerida and Nemestrinida.)}

The Acrocerid flies, which have been called the "smallheaded " flies by Comstock and which in some books are known under the family name of Cyrtidx, are of medium size and with a strongly convex thorax so as to appear hump-backed. The head is very small and is composed almost entirely of eyes. Both the flies of this family and of the Nemestrinidæ would be described as little fat flies from their stout bodies. The Acrocerids are sometimes of brilliant metallic colors and are rather well represented in North America since we have representatives of ten genera comprising more than thirty species. The flies of the genus Pterodontia, of which one species ( $P$. analis) occurs in our Southern States, are of very extraordinary form. They look like minute inflated bladders, the head being extremely small. The larvæ of the small-headed flies are chiefly. parasitic, living in spiders or in their cocoons. In Europe one species lives in the body of a spider, leaving it to pupate, while in this country Emerton has found the larva of one of these flies living in the webs of a common spider, presumably having eaten the spider itself.

The flies of the family Nemestrinidæ resemble somewhat in general appearance certain wild bees or the bee-flies of the family Bombyliidæ. Their mouth parts are frequently of great length and they are used in gathering nectar from the flowers. They are rare in the United States, only four species being known to occur here. The life history of none of them has been worked out. One of the European species of the genus Hirmoneura is in its early stages parasitic in a beetle larva. The parent fly lays her eggs in the burrows of some wood-boring insect. When the larvæ hatch they come to the surface of the log in which they 
were born, tilt themselves upwards and are blown away by the wind, falling to the ground and entering the bodies of the white grubs upon which they feed, or they may attach themselves to the bodies of the beetles and so be carried into the ground when the female enters to deposit her eggs. 


\section{FAMILIES MYDAIDAE AND APIOCERIDAE}

The flies of the family Mydaidæ, for which there is no other popular name than the "Mydas-flies," are large and rather slender forms, frequently black with yellow or red bands and with smoky wings. They much resemble the robber-flies of the family Asili$\mathrm{d} x$, to which they are rather closely related. They are quite abundant in this country, though rare elsewhere in the world. The flies are predatory like the robber-flies and feed upon other insects. The early stages are known in only a few species. The larva of Mydas fulvipes Walsh lives in decaying sycamore trees and is probably predatory on other insects living in such locations. This larva is nearly two inches long. Other species are said to be predaceous in the larval stage and on the larvæ of the gigantic long-horned beetles of the genus Prionus, which are generally found in dying or dead trees and usually in the roots. The remarkable species known as Mydas luteipennis Loew, which occurs in Texas and New Mexico, has dark orange-yellow wings of the same shade as those of the so-called tarantula-killer (a very large wasp known as Pepsis formosa). This is obviously a case of aggressive or protective mimicry, and the same phenomenon is seen with some of the siender black and yellow-banded flies of this family, which look like Scoliid wasps.

The flies of the family Apioceridæ also look something like the robber flies, but our species are all western. They are rather large and slender; some rest on the ground and others hover over flowers like humming-birds. The early stages and transformations are not known. 


\section{THE BEE-FLIES}

\section{(Family Bombyliida.)}

The handsome, stout-bodied, active flies of this family are commonly known as "bee-flies" from their superficial resemblance to bees. There are over I,400 species known. They usually have spotted or banded wings and their bodies are clothed with hair. They poise in the air in their flight and are most frequently found in sunny openings in the woods. They are distinguished from allied flies by the characters mentioned, by their venation, slender legs, small, close three-jointed antennæ and rather long proboscis. They are distinctively flower-flies, frequenting blossoms and feeding upon the pollen and nectar which they are able to reach with their long beak. Some of them some-

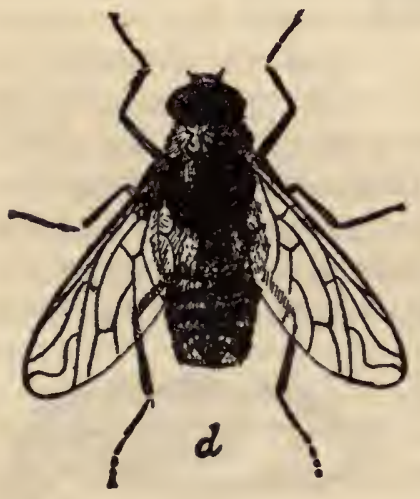

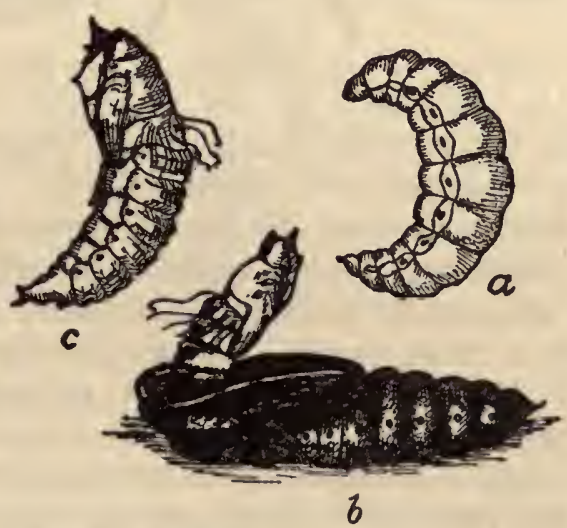

b

Fig. 76.-Anthrax hypomelas.

what resemble the gad-flies of the genus Chrysops, and others, like Systropus, have a slender abdomen swollen towards the tip and look like mud-dauber wasps. Their larval habits are extremely interesting and they are parasitic upon wild bees and in the egg-cases of grasshoppers as well as upon certain caterpillars. On the whole they may be termed beneficial insects. 


\section{Typical Life History of a Bee-Fly (Systoechus oreas O. S.)}

This species is a Western form and is parasitic in the eggcases of the so-called Rocky Mountain Locust or Western Grasshopper. It is unfortunate that the life history of no good representative of the Eastern species in some one of the other genera which may be supposed to live in the nests of wild bees has been

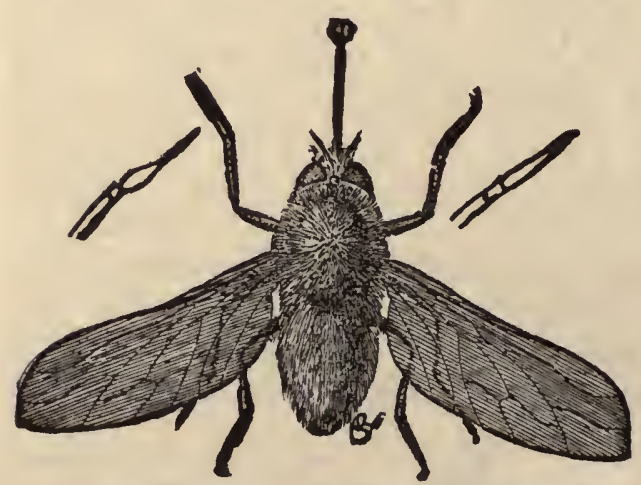

Fig. 77.-Systoechus oreas. (After Riley.) worked out. Here is a field for some intelligent Eastern worker. The eggs of the present species have not been observed but the larvæ are found in the egg-pods of the grasshopper or near them and of different sizes during most of the year. The larvæ begin to transform to the pupa state early in the summer and the pupa pushes itself half-way out of the ground in order to disclose the fly. Flies continue to issue during the summer. Normally there is but one generation annually but there is a great tendency to retardation and sometimes the larvæ remain over unchanged until the second year. The larva is a stout, plump, curved, grub-like looking creature with an opaque whitish color with small dark-brown head. The pupa looks something like the pupa of a Lepidopterous insect but bears many spines on the head and thorax and the dorsal ridges of

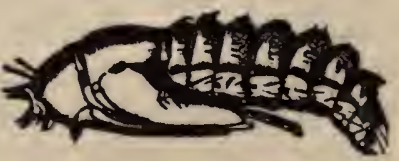

Fig. 78.-S. oreas, pupa. (After Riley.) the abdominal segments also bear rows of spines while other portions of the body carry soft dark hairs. 


\section{THE WINDOW-FLIES AND THE STILETTO-FLIES}

\section{(Families Scenopinidee and Therevide.)}

The Scenopinid flies, which Comstock called the windowflies for the reason that they are quite commonly seen upon the windows of houses, are small, active, shining black flies of which we have a half-dozen species in North America, the commonest being Scenopinus fenestralis Linn., which is common to both Europe and North America. Its specific name, fenestralis, is due to its window-loving habit. The larvæ of these flies resemble those of the following family, and are long and very slender, white in color and with apparently many joints to the body. They are frequently found under carpets and in decaying wood; also in woolen blankets, and Riley has stated that he found one in human expectoration. This, however, was prob-

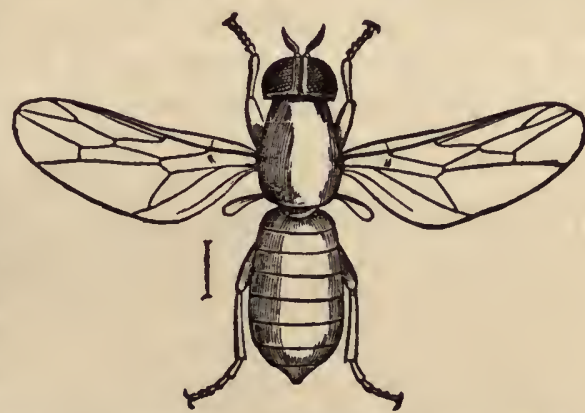

Fig. 79.-Scenopinus fenestralis. (After Smith.) ably accidental. The manager of a storage warehouse noticed many of these slender, white larvæ under carpets sent in by his customers for storage. He was worried at their number since he supposed that their presence might indicate the advent of some new kind of carpet moth. He was assured, however, that they were considered as predatory in habit, and that they feed upon clothes moths and other insects found in such places, such as book-lice. Nowhere, however, does there appear to be any record of any definite observations on this point. One observer tells me that he tried to decide this question, but that the insect intended for 
prey turned out to be more aggressive and ate up the Scenopinus larva. They are apparently always especially abundant, as I am informed by Mr. Chittenden, in the sweepings in feed stores and the flies are always to be found around the windows in such establishments. The probability is very strong that they feed upon such small, soft-bodied insects as flour-mites and book-lice. Mr. Pergande tells me that he has seen them eat the pupx of one of the little stored-grain beetles (Silvanus surinamensis) and also disabled house-flies which he had offered them, as well as their comrades of their own species.

The family Therevidæ comprises a group of rather small and rather slender flies, frequently of variegated color, and looking something like robber-flies. They have been called stiletto-flies. The flies themselves prey upon other insects, principally other flies. They are not as active as the true robber-flies, nor are they as strong, and as a result they choose weaker prey and have the habit of lying in wait upon leaves and bushes and even upon the ground for their prey to come near them instead of flying about actively in search of it as do the robber-flies. Their larvæ are very curious and are found in rotting wood or in earth which is full of vegetable mold, and seem to feed upon both decaying animal and vegetable matter. They have been found feeding upon dead caterpillars and pupæ. They are very long and slender, and have apparently twenty segments to the body including the head. This appearance, however, is deceptive, and is due to a seeming division of the anterior segments. 


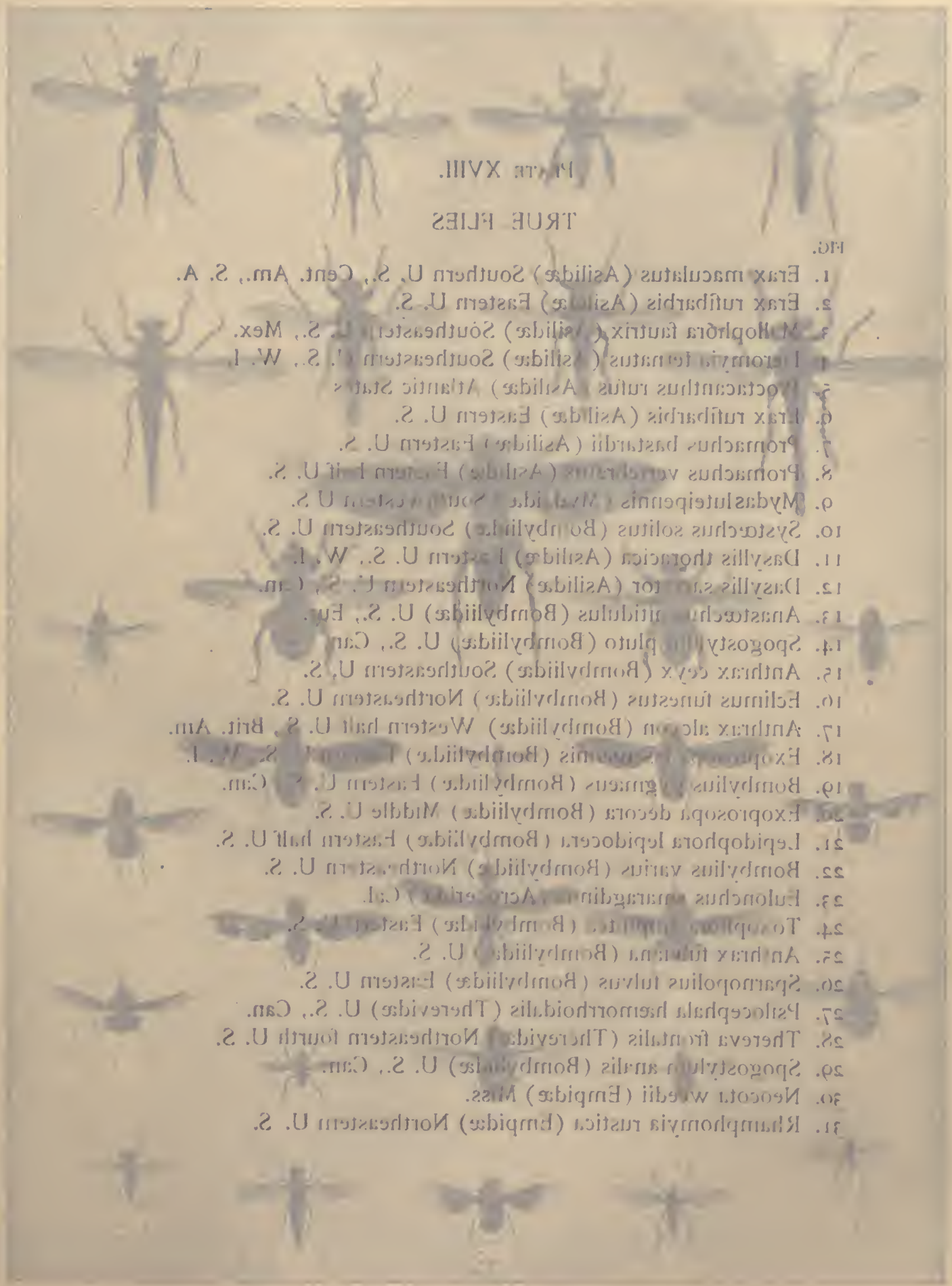


prey tumed nit ti he minti 1 ke

lerva.

Thes we upporenty th

infarmed by Mr. Chittenulern in

the dies are alw its to bu PLATE XVIII.

establishments

FIG.

TRUE FLIES

Mr 1. Erax maculatus (Asilidæ) Southern U. S., Cent. Am., S. A.

of 2. Erax rufibarbis (Asilidæ) Eastern U. S.

3. Mallophora fautrix (Asilidx) Southeastern U. S., Mex.

4. Deromyia ternatus (Asilidx) Southeastern U. S., W. I.

5. Proctacanthus rufus (Asilidæ) Atlantic States

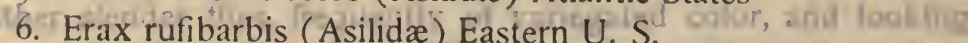

7. Promachus bastardii (Asilidæ) Eastern U.S.

8. Promachus vertebratus (Asilidx) Eastern half U.S.

9. Mydasluteipennis (Mydaidæ) Southwestern U S.

10. Systœchus solitus (Bombyliidæ) Southeastern U. S.

11. Dasyllis thoracica (Asilidæ) Eastern U. S., W. I.

12. Dasyllis sacrator (Asilidæ) Northeastern U. S., Can.

13. Anastœechus nitidulus (Bombyliidæ) U. S., Eur.

14. Spogostylum pluto (Bombyliidæ) U. S., Can.

- 15. Anthrax ceyx (Bombyliidie) Southeastern U. S.

16. Eclimus funestus (Bombyliidie) Northeastern U. S.

17. Anthrax alcyon (Bombyliidæ) Western half U. S., Brit. Am.

18. Exoprosopal fascipennis (Bombyliida) Fastern U. S., W. I.

19. Bombylius pygmaus (Bombyliida) Eastern U. S., Can.

20. Exoprosopa decora (Bombyliidæ) Middle U.S.

21. Lepidophora lepidocera (Bombyliida) Eastern half U. S.

22. Bombylius varius (Bombyliidæ) Northeastern U. S.

23. Eulonchus smaragdinus (Acrocerida) Cal.

24. Toxophora amphitea (Bombyliidæ) Eastern U. S.

25. Anthrax fulviana (Bombyliidæ) U. S.

26. Sparnopolius fulvus (Bombyliidæ) Eastern U. S.

27. Psilocephala hæmorrhoidalis (Therevidæ) U. S., Can.

28. Thereva frontalis (Therevidx) Northeastern fourth U. S.

29. Spogostylum analis (Bombyliidæ) U. S., Can.

30. Neocota weedii (Empidæ) Miss.

31. Rhamphomyia rustica (Empidæ) Northeastern U. S. 


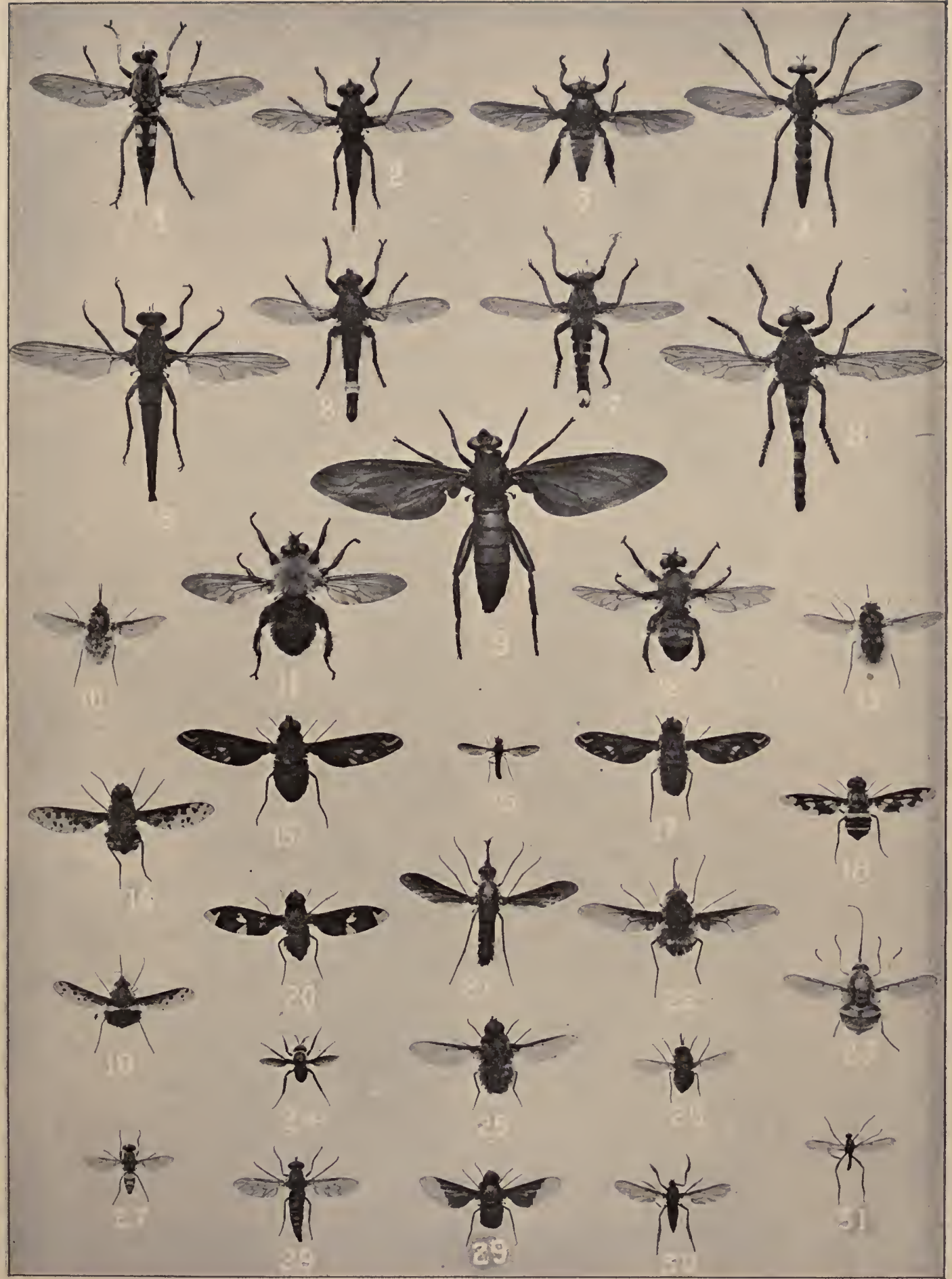





\section{THE ROBBER-FLIES}

\section{(Family .Asilida.)}

The strong, hairy, active, predatory flies, known as robberflies, form this group. They are very numerous and are always conspicuous, flying with a darting motion and preying upon many different kinds of insects. They are, as a rule, rather slender, but extremely strong, and are furnished with a large, tapering, hard beak, enclosing a sharp lancet which is thrust out and cuts a severe wound in the body of the insect captured. The tip of the beak is bearded with stiff bristles which hold it securely in the wound into which it is crowded. Fitch says, "These flies are inhuman murderers. They are savages of the insect world, putting their captives to death with merciless cruelty. Their large eyes, divided into such a multitude of facets, probably give them the most acute and accurate vision for espying and seizing their prey; and their long, stout

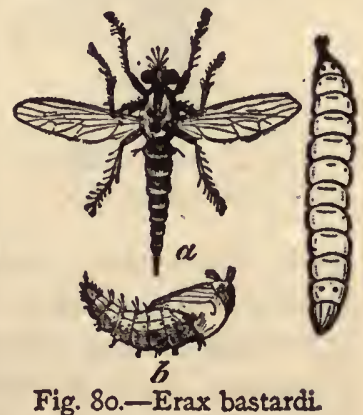

(After Riley.) legs, their bearded and bristly head, their whole aspect indicates them to be of a predatory and ferocious character. Like the hawk, they swoop upon their prey, and grasping it securely between their forefeet they violently bear it away." Nearly all of their victims are captured on the wing, and any flying insect is liable to be caught by them-other flies, bees, beetles, moths. butternies, grasshoppers, and even members of their own species, so that they are true cannibals. Just as with the praying Mantis, or rearhorse, the female frequently resents the caresses of the male, and grasps him and eats him. They will also feed upon caterpillars, but rarely. Persons engaged in bee culture especially fear these robber-flies, which are known rather generally in this country as bee-killers. One of Dr. Fitch's corre- 
spondents sent in an interesting account of the damage done to his apiary. The robber-fly captured bees by making rapid dashes catching them on the wing, then wrapping its legs about the bee, and pressing it tightly to its own body it immediately sought a bush or tall weed upon which to alight and devour its prey, piercing a hole in the body and sucking out the fluids and soft internal viscera, leaving only the hard outer skin. Upon the ground beneath some favorable perch for the fly near the apiary hundreds of these shells of bees were found accumulated in a single day. The correspondent thought that it was through the work of the robber-flies that during certain seasons in a bee rais-

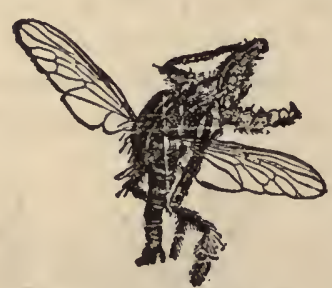

Fig. 81.-Erax apicalis. (After Comstock.) ing region in New York not a single hive threw off a swarm. The beak of a robber-fly is so strong that it can pierce the skin of a human being, but fortunately none of these creatures has yet acquired the habit of feeding upon warm-blooded animals.

Some robber-flies are very delicate and slender, as in Leptogaster, some of them being almost as slender as midges, upon which they probably feed, and looking half starved, in spite of their voracity. The colors of the robber-flies are variable, but nearly all are very hairy or bristly or spiny. In this family some good cases of what is called "aggressive mimicry" are seen, aggressive mimicry meaning a resemblance of a predatory insect to the insects upon which it feeds, thus facilitating the capture of its prey. We should not fear grizzly bears if they looked like harmless, peaceable human beings. Thus the robber-fly known as Deromyia annulata Bigot, looks like the common wasp Polistes metricus Say; while some of the flies of the genera Dasyllis and Mallophora resemble bumblebees. In some of the latter the hind shanks are modified so as to look very much like the pollen-bearing hind legs of the bumblebees. This curious structural modification can be of no service to the fly except in increasing its resemblance to the bees. Then also, as another illustration, one of the robber-flies of the genus Laphria resembles a big wasp of the genus Vespa.

The larvæ of the robber-flies much resemble the larvæ of the gad-flies, although the adults are so widely different. They live 
in the earth, and in decaying wood, and prey upon the larvæ of wood-boring beetles. In the ground they have been known to feed upon the eggs of grasshoppers. Harris has described the early stages of one species (Asilus sericeus) which he thought fed in the larval stage upon the roots of rhubarb. Harris was seldom mistaken, but it is safe to say that as a rule the larvæ are carnivorous. The pupæ are bristly, and have the head and the segments of the abdomen provided with spines which assist them in making their way out of the ground or the decaying logs which they inhabit.

The group is a very large one and comprises about three thousand described species, of which four hundred or more inhabit this country. The detailed life history of some robber-fly is a great desideratum. 


\section{THE DANCE-FLIES AND THE LONG-LEGGED FLIES}

\section{(Families Empida and Dolichopodida.)}

The flies of the family Empidæ are rather slender, sordid, uninteresting-looking creatures, usually of small size. They are sometimes called dance-flies, because they are often seen in swarms in the woods flying up and down with a dance-like movement. By "dance-like" is not meant the slow, gliding movement of modern waltz, but the robust up and down backwoods jig movement. It is a very large family comprising more than eleven hundred species. They resemble the robber-flies somewhat in form and also in habits since they are predatory and capture other insects. Some of them have the curious and as yet unexplained habit of carrying little silken webs with them when they fly, although no one really knows how they spin these webs or where they get them. Their use has also been a mooted point, but it has been suggested that they act as parachutes or aid in the capture of their prey.

Aldrich has studied what is probably this same phenomenon. He finds that the males of an Empis carry little oval masses larger than themselves, which are really not composed of silk, but of bubbles of a viscid substance. The purpose of this structure is to attract the female. Aldrich says, "When numerous males were flying up and down the road it happened several times that a female was seen to approach them from some chokecherry blossoms nearby. The males immediately gathered in their path and she with little hesitation selected for a mate the one with the largest balloon, taking a position upon his back $* * *$ The pair would settle down toward the ground, select a quiet spot $* * *$ here she would continue to hold the male beneath her for a little time. The male meanwhile would be rolling the balloon about in a variety of positions, juggling with it, one might almost say. After the male and female parted company the male immediately 
dropped the balloon upon the ground and it was greedily seized by ants." It seems probable that this observation by Professor Aldrich will explain all of the cases in which dance-flies are seen to carry such structures.

Many of the species do not capture their prey by flight, but run rapidly about on the ground catching other insects with their front legs. The female, as in certain other predatory groups which we have mentioned or will mention, resents the approaches of the male, and if he be incautious seizes him and dispatches him at once. The only time at which he can with safety make his advances is when she is busy eating some other insect.

The larvæ of the dance-flies are cylindrical, and live in the earth under leaves and in decaying vegetation. They are said to be probably carnivorous. One species was reared, however, from human fæces in the course of certain investigations made by the writer on the subject of the flies which may carry the germs of tpyhoid fever, but of course they may have been preying upon other insects which were feeding in this substance. The pupæ are said to be free and to possess two points at the front end.

The Dolichopodid flies are rather small and rather slender species, usually greenish or bluish in color and more or less metallic. Their wings are clear, or they may be dusky or obscurely banded. They possess long legs, from which fact they are called by Comstock "the long-legged flies," which, however, does not seem to be a good popular term, since there are other flies with much longer legs. Just as with the dance-flies, these creatures are predatory and capture small flies of other groups, and even soft-bodied worms. They are found in damp places upon the leaves of aquatic plants, and some of them are able to run rapidly over the water. The proboscis is short and not as strong as with the robber-flies. It is a large group, and about twelve hundred species are known. Many forms occur in this country. With none of the species, however, has a good full life history been studied out. The larvæ live in the earth or in decaying vegetable matter; some are found under the bark of trees or in flowing sap. They form a cocoon and the pupa has two long breathing tubes on the back of the thorax. 


\section{THE SPEAR-WINGED FLIES}

\section{(Family Lonchopterida.)}

The flies which belong to this group have not the slightest general interest, but they are structurally very different from other flies, showing even more differences than are necessary to the establishment of the group as a separate family. They are very minute creatures, some of them being only one-twelfth of an inch in length, and they are also slender. But two species are known in this country, both belonging to the genus Lonchoptera, and both occurring also in Europe. They are common all through the summer in damp, grassy places, as on the banks of wellshaded streams. Their larvæ apparently undergo very interesting transformations, but no studies have been made in this country and in Europe-the knowledge of entomologists dated back to some incomplete observations made by Sir John Lubbock as long ago as 1862-until within the past year de Meijere of Holland has described, with figures, the early stages of Lonchoptera lutea. The larvæ live under leaves and decaying vegetable matter on the surface of the ground, and have the peculiar habit of transforming to what may be termed a semi-pupa or a wingless maggot-like creature within the last larval skin, subsequently transforming to a true pupa. The careful working out of the life history of these flies ought not to be difficult, and such careful work is decidedly needed. 


\section{THE HUMP-BACKED FLIES}

\section{(Family Phorida.)}

The little dark flies of this family have no popular name, unless we adopt that of Comstock, "the hump-backed flies," which is characteristic enough. They may easily be recognized by the two very dark, thick veins on the front margin of the wings. There are not many species, but individuals are excessively common in this country, flying in swarms, and frequently being found upon window panes. Their larval habits are various, but they breed in decaying animal and vegetable matter. The flies lay their eggs on dead chrysalids, on dead snails and in decaying vegetation, and the maggots which hatch develop rapidly. They are slender, and the pupa which is contained in the hardened last larval skin breathes by means of two slender processes issuing from the fourth segment. There has been some discussion as to whether the larvæ of the flies of this family are ever directly parasitic in other insects, but it seems to be accepted that one species is a true parasite in the hives of the honey bee and a most interesting form has recently been discovered which is a true parasite of ants. In other cases, these flies undoubtedly lay their eggs on diseased or dying insects.

\section{Life History of the Ant-Decapitating Fly}

\section{(Apocephalus pergandei Coquillett.)}

It would be rather a misnomer to call this a typical life history since this form seems peculiar in its habits and rather aberrant among the Phoridæ, but the observations which have been made upon it by Dr. W. H. Fox and Mr. Theo. Pergande have been more complete than any which have been made upon other members of the family, so it is here included. A common black ant, Camponotus pennsylvanicus, is the host of this little 
hump-backed fly. In the District of Columbia and in New Hampshire the fly may be found in midsummer darting about the moving ants on tree trunks and elsewhere and finally succeeding in laying its egg, sometimes after a struggle, on the neck of the ant. The egg hatches and the young larva bores directly into the head of the ant. As it enlarges it eats out the whole head cavity, the head breaks off from the body of the ant and moves about independently, propelled by the body of the contained maggot which extrudes partly from the neck hole. The larva of the fly transforms to pupa within the last larval skin in the cut off ant's head and the adult fly issues in the course of from two to three weeks. To see an ant's head walking off by itself is a curious sight, yet it is common enough where this fly abounds. Dr. Fox named it, appropriately enough, "the antdecapitating fly." 


\section{THE FLAT-FOOTED FLIES AND THE $B I G-E Y E D$ FLIES}

\section{(Families Platypezidee and Pipunculide.)}

The flies of both of these families are common looking little creatures and most uninteresting in appearance to the general observer. The flies of the family Platypezidæ have been called "flat-footed flies." It is a small family of little flies which are also found in shady places. The hind feet of many males are very broad and flat from which comes the name of the family, The larvæ live between the gills of toad stools.

The members of the last named group are called by Comstock "the big-eyed flies" for the reason that they have very large heads which seem to be composed almost entirely of eyes. They are found in shady places and their larvæ so far as known are parasitic within the bodies of leaf-hoppers. The pupa is said to resemble that of one of the Syrphus flies. 


\section{THE SYRPHUS FLIES}

\section{(Family Syrphida.)}

The syrphus flies (for they have no other vernacular name), comprise many of the most interesting of the dipterous insects. It is a very large family and more than three hundred species are known to occur in. the United States. As a rule they are rather stout-bodied flies, varying greatly in color. Some are metallic greenish as in Microdon and Psilota, while others are banded with yellow in different ways. As a rule the abdomens are rather broad and are rather apt to be flat, but in some, as in Baccha and its allies, the abdomen is slender. The syrphus flies are flower flies
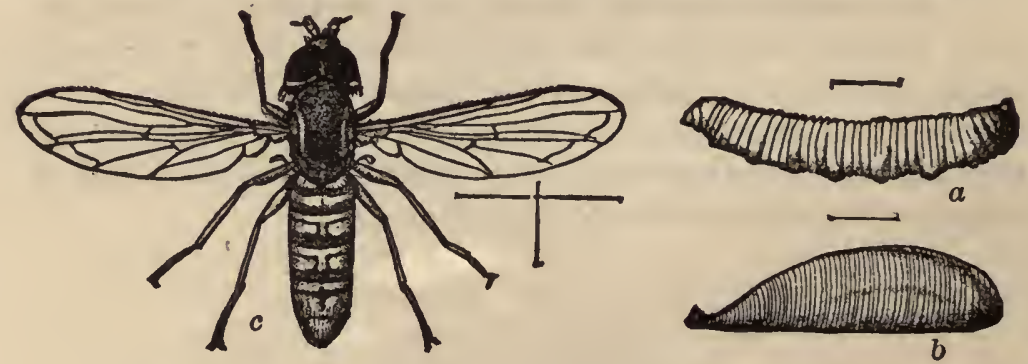

Fig. 82.-Mesograpta polita: $a$, larva; $b$, puparium; $c$, adult.

(From Insect Life.)

par excellence. They fly in the sunlight and are easily taken by sweeping flowering plants. Almost all types of bees and wasps are mimicked by them and so generally does this occur throughout the family that syrphus flies form the most striking instances of protective mimicry. There are syrphus flies like honey bees, bumblebees, social wasps and solitary wasps of several kinds. They are rarely to be seen except in the middle of sunshiny days, some of them resting occasionally upon leaves, but more frequently they are to be found about flowers, while others seem to be almost constantly upon the wing. 
The habits of the syrphus flies in their early stages vary greatly. Very many of them in the larval state feed upon plant lice and other small, soft-bodied insects. 1 have seen currant bushes upon which there was hardly a leaf which did not support a thriving colony of plant lice and which had not become curled and distorted in consequence, and yet within a very few days, while the distortion of the leaves remained, not a plant louse was to be found but under each leaf instead of the flourishing group of lice was a fat, full-grown syrphus larva which had destroyed all of the previous inhabitants and was now ready to transform.

These larvæ do not have a distinctly differentiated head. The external mouth-parts are either entirely lacking or there are two or four usually dark-colored hooklets. The body is smooth and usually glistening. When ready to transform, the last skin of the larva contracts and hardens and assumes an oval shape and a darker color and the pupa is formed within it. When the fly is ready to emerge, the front end of the old skin is pushed out and the perfect fly escapes. The hooklets on the mouth of the larva occur with those syrphus fly larvæ which feed upon

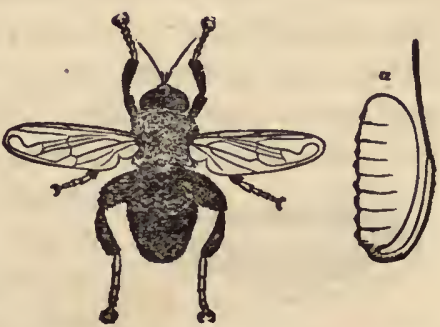

Fig. 83.-Mallota posticata and puparium of same. other insects and they serve to grasp and pierce the body of the prey. Those larvæ which do not have such hooklets have other habits. They may feed in the decaying wood of old trees or logs; they may live in manure or soft mud impregnated with decaying vegetable matter; they may be found in the sap of trees or in the stems of certain tender plants or in fungi. Still others are common in ants' nests and others again are guests in the nests of bumblebees. With such variable habits there must necessarily be considerable variation in structure and as a result of this mode of life those forms which live in soft mud or manure, which may be almost a liquid, and some of those which live in very damp, decaying wood, have long slender projections at the end of the body bearing spiracles or breathing holes at the tip, so that when the body of the larva is buried in the semi-liquid mass in which it is feeding this long tail still protrudes to the air, enabling it to breathe in comfort. These larvæ have been termed 
"rat-tailed maggots" and are very curious objects which are frequently sent to entomologists for name.

Those which live in ants' nests belong to the genus Microdon and are among the strangest insect larvæ known. They do not look like insect larvæ, and, in fact, resemble certain land shells. Curiously enough, they have been described and named as species of mollusks. In fact, certain insects have given shell students a good deal of trouble, for, as will be shown when we study the caddis-flies, certain cases constructed by these insects have also been described as shells. The Microdon larva does not appear to be jointed and the upper surface of its body is covered with a network of bristles which usually hold a coating of dirt. There is no trace of any head and the sides of the body project, forming a sort of fringe around the edge. The soft pupa is formed within the last larval skin and does not alter its shape. Just what these larvæ do in the ants' nests is not well understood. Perhaps the ants gain some secretion from them. As a matter of fact they are sometimes found elsewhere. The adult flies of this genus are

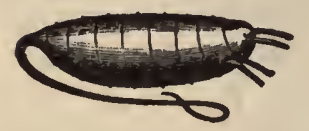

Fig. 84.-Rat-tailed maggot.

(After Smith.) usually dull-colored, are slow fliers and are found on the borders of low-growing woods. The flies have been seen laying their eggs in the ant hills and the ants have been seen to drive them away but they returned again, undiscouraged by the impolite rebuff. This fact would not seem to indicate that the larvæ are of any service to the ants.

Those syrphus flies which live, in their early stages, in the nests of bumblebees belong to the genus Volucella, and the flies of this genus rather closely resemble bumblebees. Their larvæ were for a long time considered to be parasitic upon the young of the bumblebees but later observations have practically disproved this and we are forced to conclude that the Volucella larvæ are simply scavengers, feeding upon the waste or excreta of the bee larvæ and even upon the dead bodies of those which die. The bumblebees seem to realize that the syrphus flies are not inimical to them, since they allow them free access to their nests and do not seem in the least disturbed by their presence.

The most famous of all the syrphus flies is the one which commonly goes by the name of the drone fly. It is Eristalis tenax and its larva is one of the rat-tailed maggots. It is a cosmo, 


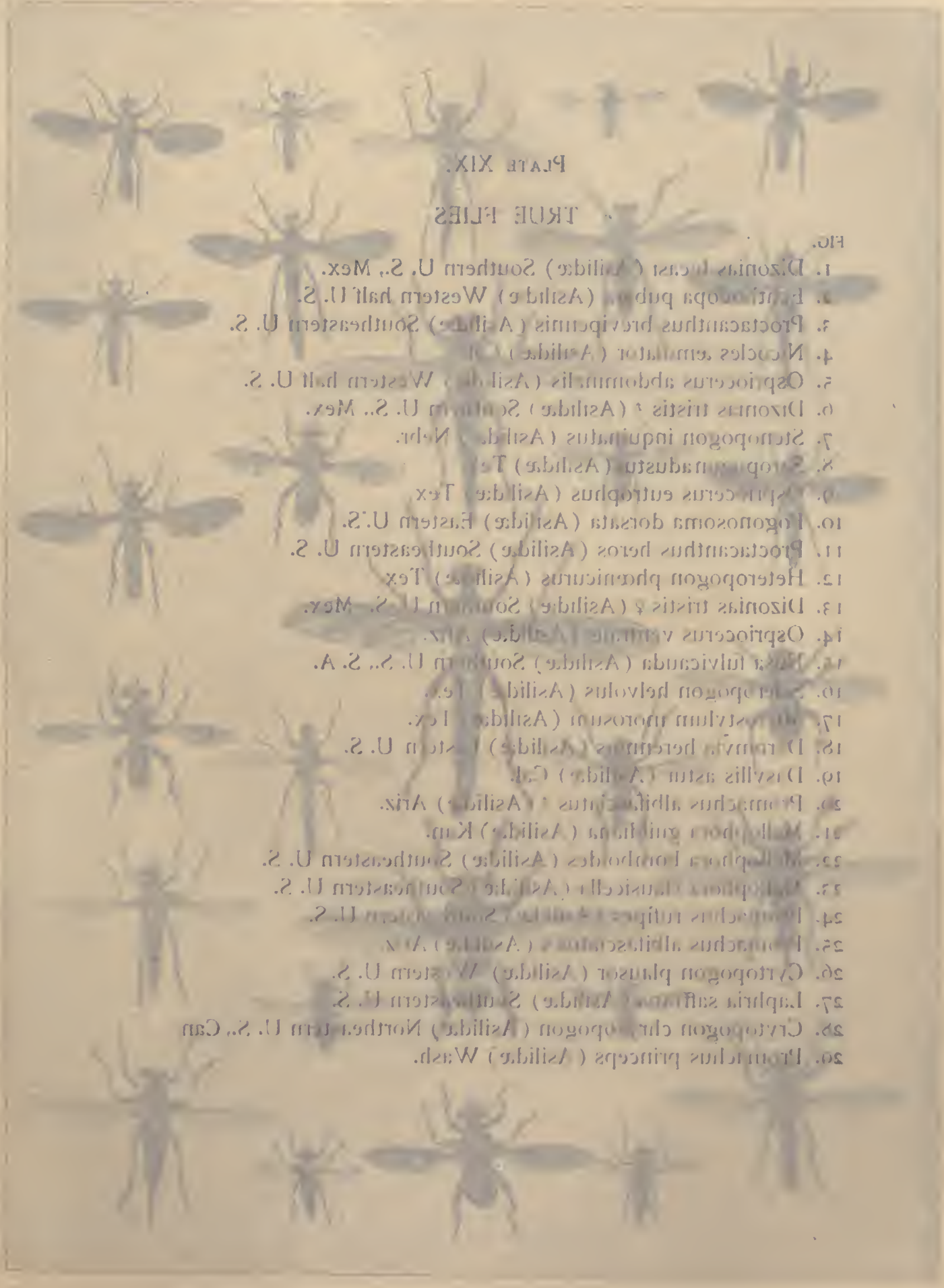




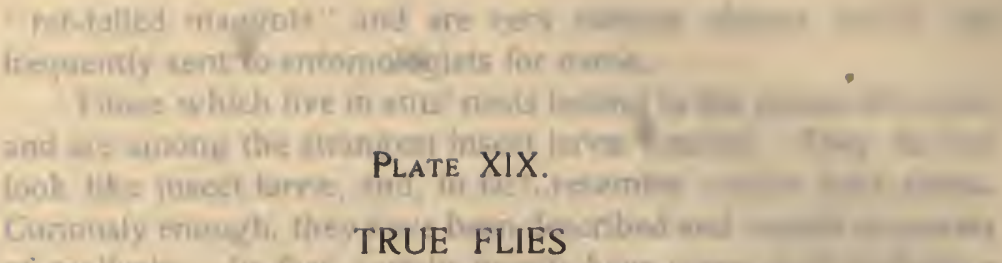
FIG.

\section{TRUE FLIES}

I. Dizonias lucasi (Asilidæ) Southern U. S., Mex.

2. Echthodopa pubera (Asilidæ) Western half U.S.

3. Proctacanthus brevipennis (Asilidæ) Southeastern U. S.

4. Nicocles æmulator (Asilidæ) Cal.

5. Ospriocerus abdominalis (Asilidæ) Western half U.S.

6. Dizonias tristis o (Asilidæ) Southern U. S., Mex.

7. Stenopogon inquinatus (Asilidæ) Nebr. pupga fermes wethit

8. Saropogon adustus (Asilidæ) Tex.

9. Ospriocerus eutrophus (Asilidæ) Tex.

10. Pogonosoma dorsata (Asilidæ) Eastern U.S.

11. Proctacanthus heros (Asilidæ) Southeastern U.S.

12. Heteropogon phœnicurus (Asilidæ) Tex.

13. Dizonias tristis \& (Asilidæ) Southern U.S., Mex.

14. Ospriocerus ventralis (Asilidx) Ari\%.

15. Nusa fulvicauda (Asilidæ) Southern U. S., S. A.

16. Scleropogon helvolus (Asilidæ) Tex.

17. Microstylum morosum (Asilidæ) Tex.

18. Deromyia herennius (Asilidæ) Eastern U.S.

19. Dasyllis astur (Asilidæe) Cal.

20. Promachus albifasciatus $\hat{\delta}$ (Asilidæ) Ariz.

21. Mallophora guildiana (Asilidæ) Kan.

22. Mallophora bomboides (Asilidæ) Southeastern U. S.

23. Mallophora clausicella (Asilidx) Southeastern U. S.

24. Promachus rufipes (Asilidx) Southeastern U.S.

25. Promachus albifasciatus $q$ (Asilid $x$ ) Ariz.

26. Cyrtopogon plausor (Asilidæ) Western U.S.

27. Laphria saffrana (Asilidæ) Southeastern U.S.

28. Crytopogon chrysopogon (Asilidæ) Northeastern U. S., Can.

29. Promachus princeps (Asilidx) Wash.
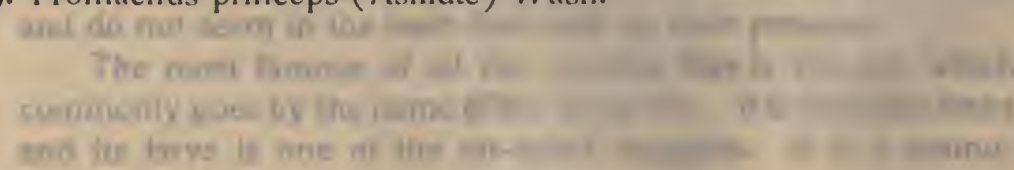


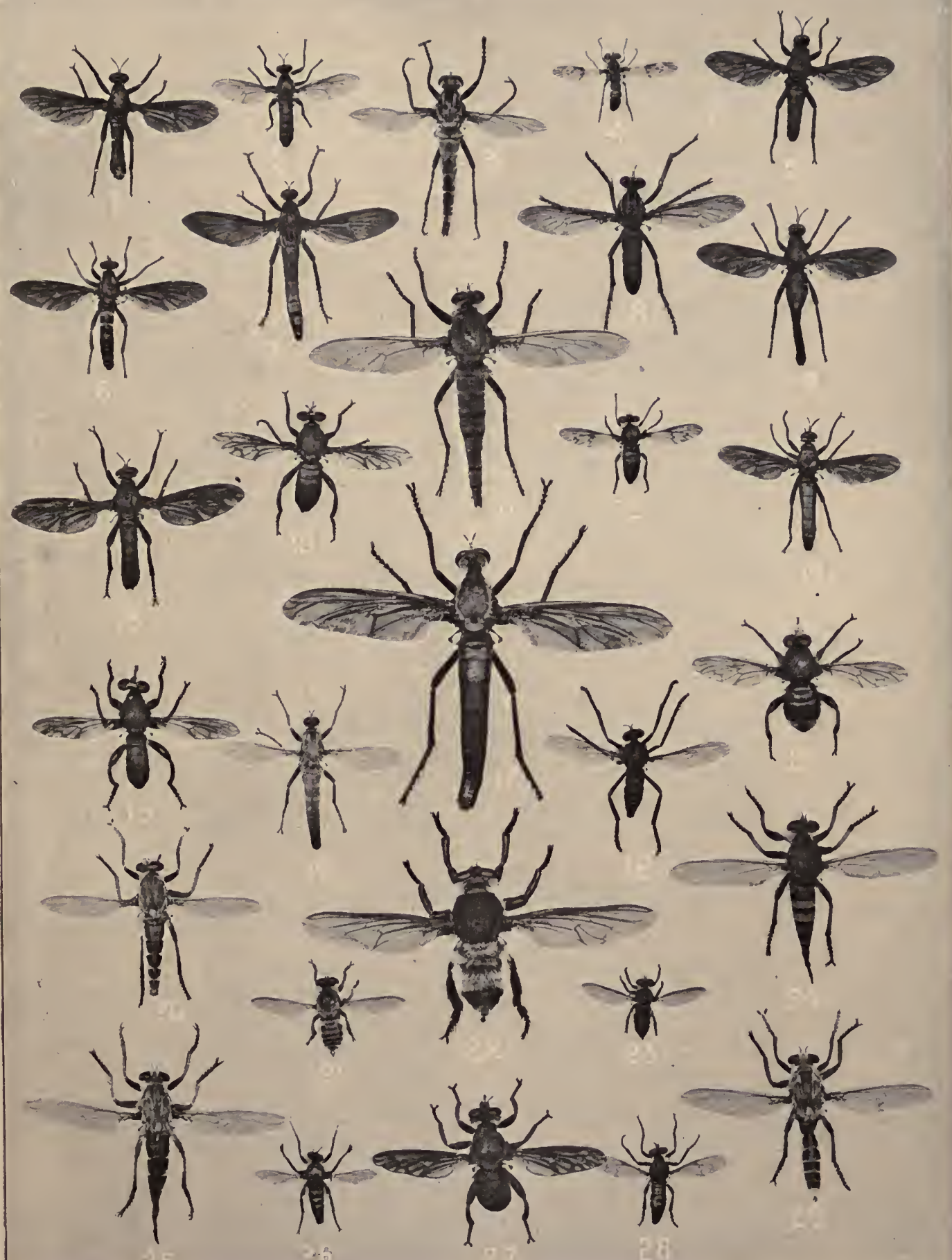


politan species and is rather larger than the honey-bee, which it closely resembles. It frequents flowers and is commonly found in houses on windows late in the autumn. The larvæ are found in soft mud and in privies, where they feed upon decaying animal and vegetable matter, transforming to pupa within the last larval skin. Osten Sacken, in two interesting papers on the so-called "Bugonia myth," shows that this idea, which has been prevalent since ancient times and which is that the carcasses of animals may generate swarms of honey-bees, has probably arisen from the fact that this drone fly, breeding in carcasses, has almost universally been mistaken for the honey-bee. The learned Russian author shows the existence of this myth with many nations, including the Chinese and the Japanese. It is mentioned in many places in ancient literature and even occurs in the story of Sampson, in the book of Judges in the Old Testament.

This family is probably the most attractive group of flies. A collection of specimens is a most interesting one, both from the æsthetic and the scientific point of view. The very frequent instances of protective mimicry referred to above, in themselves should give a great impetus to the study of the group. Moreover, we in this country are most fortunate from the fact that most of our species have been carefully studied and an admirable monograph by Dr. Williston has been published by the National Museum, which is one of the most perfect works of its kind which the entomologist is able to consult. A careful work on the life histories of these insects, however, is almost as greatly needed as in the other families of flies. The statements which have been given above are general, but in searching for specific accounts of individual life histories we find that they are lacking. 


\section{THE THICK-HEAD FLIES}

\section{(Family Conopida.)}

The flies of this group are rather closely related to the syrphus flies. They may be called, after Comstock, "the thickhead flies," because their heads are large and conspicuous. The flies themselves are rather large, but are generally slender and the abdomen is stalked, like those of some wasps. The wings are usually dark and the insects themselves are darkcolored, but some have yellow bands on the abdomen. Those which belong to the genus Myopa are stouter and have hairy legs, almost like those of a robber-fly. The big-head flies are found upon flowers with the syrphus flies and their larvæ are parasitic, chiefly upon bumblebees and wasps, but they have also been found, according to Williston, in the bodies of grasshoppers.

The larvæ of these flies live in the bodies of the full-grown wasps and bees. It has been supposed that the flies enter the bees' nests and place their eggs on the larvæ or pupæ, but the adult flies always issue from the adult bees or wasps, having occupied the interior of the abdomen. When full-grown they frequently completely fill the abdomen. Williston has seen a Conops following a bumblebee and repeatedly flying against it and thinks that the eggs are deposited upon the body of the bee and that after hatching the larvæ bore into the abdominal cavity. In one instance a big-head fly was reared from the body of a bumblebee several months after the latter had been killed and pinned in a collection. There is a peculiar genus in this family, Stylogaster, in which the female has an ovipositor which is longer than the entire body. Rather more than thirty species of thickhead flies, distributed in seven genera, are known to occur in the United States. 


\section{THE BOT-FLIES}

\section{(Family Estrida.)}

This family contains the parasitic creatures known as botflies, several of which are the cause of great suffering and even the death of domestic animals. The bot-fly of the sheep (CEstrus ovis), the bot-fly of the horse (Gastrophilus equi), the bot-fly of the ox which is known in England as the "ox warble" fly (Hypoderma lineata, the European species being $H$. bovis), and certain other forms whose larvæ live under the skin of such wild animals as squirrels and rabbits (genus Cuterebra) and which are sometimes in tropical regions found under the skin of human beings (Dermatobia cyaniventris) belong to this family. The group is not a large one, comprising only about sixty species and the life history of the dif-

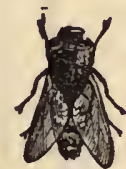

1

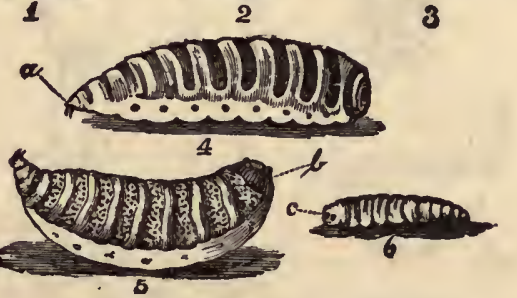

Fig. 85.-CEstrus ovis. (After Riley.)

ferent species is quite variable, comprising many strange and curious phenomena. All, however, are parasitic in vertebrate animals. The flies themselves are rather large, generally rather hairy, and they are as a rule inconspicuous in their coloration. The antennæ are small and inserted in rounded pits.

\section{Typical Life History (Hypoderma lineaia Villers.)}

This fly is the common "ox bot " or "ox warble " of the United States and is known in the southwestern country as the "heel fly." To stock raisers its larva is also known as the "grub." Affected cattle are known as "grubby" cattle. Early in the spring 
the fies appear and are immediately attracted to cattle, laying their eggs upon the legs, especially just above the hoof, which explains the southwestern name "heel fly." The eggs are occasionally laid on other parts of the body but the neighborhood of the hoof is preferred. They are attached to the hair by means of a clasping projection and usually from four to six are laid together. The animal licks its legs and the larva at once hatches and is carried down into the œsophagus, the walls of which it penetrates by means of its strong spines. It then molts and becomes smooth

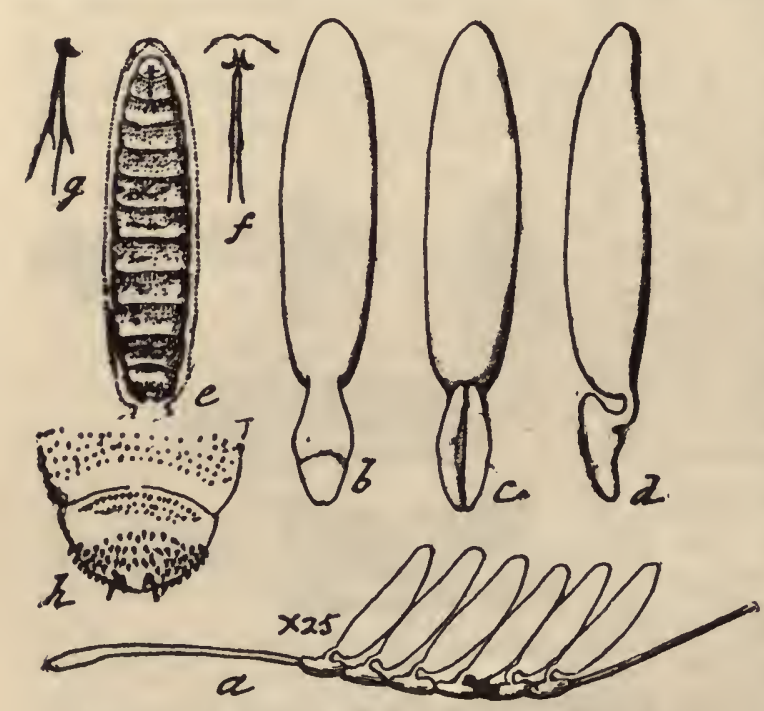

Fig. 86.-Hypoderma lineata, eggs. (After Riley.) and for several months wanders through the connective tissues of the cow, between the skin and the flesh, penetrating gradually along the neck and ultimately reaching a point beneath the skin on the back of the animal. The larva then molts again, becomes more spiny, and bores a hole through the skin, placing its anal spiracle near the orifice in order to get air. During its earlier life it probably breathes by an endosmotic method as do the larvæ of the parasitic Hymenoptera and in fact much as do the aquatic larvæ of certain other insects.

The larva now develops rapidly, living upon the pus and bloody serum which is produced by the irritation of its spiny skin. It molts again and is then more than an inch long and yellowishwhite in color. It works its way out of the minute orifice which it enlarges and drops to the ground where it contracts and hardens, the larval skin becoming the protection for the pupa which is formed within. In three to six weeks the adult fly escapes by pushing off the circular cap at one end of the puparium. 
The life history of this insect was entirely misunderstood until recent years. It was supposed that the eggs were laid upon the back and that the larva immediately penetrated the skin and lived there without wandering. It was not until 1890 that the true life history, as described above, was ascertained by Dr. Cooper Curtice. 


\section{THE TACHINA FLIES}

\section{(Family Tachinida.)}

This is a large and important group of flies, the members of which have no common name except that of "tachina fies," by which they are generally known to everyone who has studied insects, even if his studies have not carried him into the order Diptera, for all or nearly all of these creatures are parasitic upon other insects and a person engaged in rearing caterpillars will often have his ultimate design frustrated through the work of the larvæ of these flies. As a rule they are medium sized or rather large flies of a gray tint, rather unattractive in appearance and perhaps resembling the common house-fly as a rule. In fact, one may say that they belong to the house-fly type. The gray body

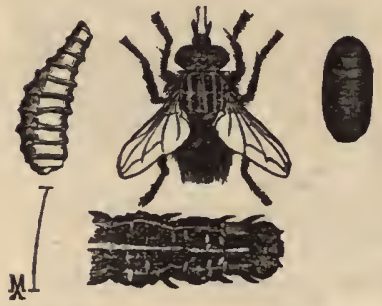

Fig. 87.-Winthemia quadripustulata.

(After Comstock.) color is frequently striped with dark or lighter stripes and there are some marked exceptions to this general colorational scheme as, for example, in the dark-winged, sometimes reddish-bodied Trichopodas, the slender Xanthomelænas and Hemydas, the redbodied Echinomyias and those species of the genus Archylas which look like blue-bottle flies. In general the wings are clear, the bodies are somewhat

bristly and the insects fly with a buzzing sound which is not very pronounced but like that of a house-fly. They are active and fly usually in the sunshine, being much less in evidence on cloudy days.

In their relations with man the tachina flies are beneficialthe most beneficial group of Diptera, with the possible exception of the syrphus flies. With the tachina flies, however, the habits are much more uniform and the larvæ feed only upon living insects. By far the favorite hosts of these flies are the leaf-eating caterpillars and the numbers which are destroyed in a single 158 
season by these parasites is quite beyond computation. I have seen vast armies of the army-worm, comprising unquestionably millions of individuals, and have been unable to find a single specimen which did not bear the characteristic eggs of a tachina fly. These flies were present in such numbers that their buzzing, as they flew over the army of caterpillars, could be heard at some distance and the farmers were unnecessarily alarmed since they conceived the idea that the flies were the parents of the caterpillars and were flying everywhere and laying their eggs in the grass and wheat. As a matter of fact, one great outbreak of the army-worm in northern Alabama, in the early summer of $188 \mathrm{I}$. was completely frustrated by the tachina flies, aided by a few other parasites and predatory insects. They also attack grasshoppers, bugs and beetles, saw-flies and saw-fly larvæ and bumblebees and wasps.

Their eggs are usually white in color, oval in shape and are stuck by some sort of a gummy substance to the surface of the

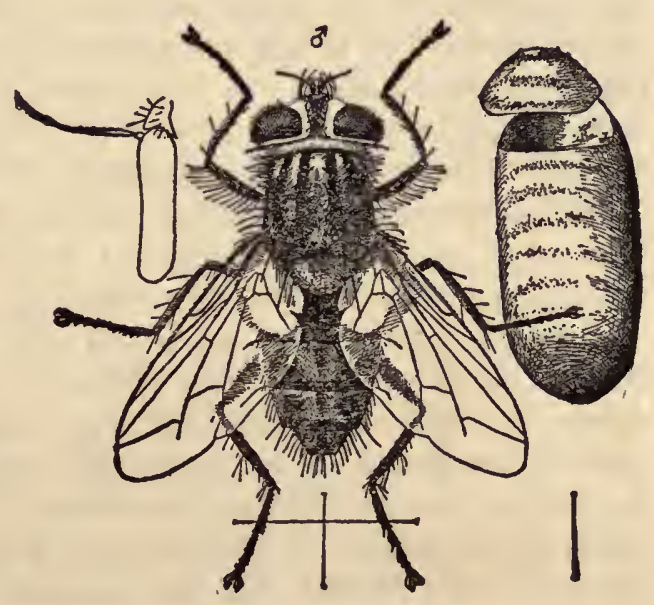

Fig. 88.-Euphorocera claripennis. (Author's illustration.) insect on which the future larvæ are to feed. The small white eggs are frequently seen sticking to the back of some unfortunate caterpillar. From the under side of each egg there hatches a little maggot which bores its way through the skin of the host insect and penetrates into its body, where it lives, nourishing itself upon the fatty matter and lymph, until it reaches full growth, usually if not always destroying before it emerges some vital organ so as to cause the death of the host insect. It almost invariably issues when full grown from the body of the insect attacked and transforms at or near the surface of the ground within the last larval skin, which hardens into a brown, oval puparium. Breeding is rapid and there may be several generations each summer. In 
issuing from the puparium the fly breaks away the entire end of the hardened larval skin.

It used to be thought that every caterpillar upon which these eggs were placed was doomed, but it often happens that the mother tachina fly, with a faulty instinct, places her eggs upon the back of a caterpillar which is about to cast its skin and in such instances it frequently moults before the eggs have had time to hatch, so that when they do hatch the young larvæ find themselves out in the cold world instead of revelling in the interior of a well-fed caterpillar. So frequently does this occur that a very large proportion of tachina eggs are wasted by the mother flies. The observations of Fernald and his assistants in their work upon the gipsy moth in Massachusetts have given us exact figures in regard to this matter. In one instance 250 caterpillars, each bearing eggs of tachina flies, were fed and carried through their transformation without the appearance of a single adult fly. In another instance 235 caterpillars, each bearing from one to thirtythree eggs, were fed and watched and from these, 226 moths were reared and only nine were killed by the tachinas.

An interesting point connected with the life of these flies is brought out when we compare them with the parasitic Hymenoptera, the ichneumon flies and the chalcis flies. In the latter case we are struck by the extremely definite relation between the kind of parasite and the kind of host. The parasites of a particular genus will attack perhaps only insects of a certain family and it is a very definite rule that parasites of a given subfamily will attack only insects of a certain order. With the tachina flies, however, it is quite different. The same species of fly will lay her eggs not only upon insects of several different families but upon insects of two or even three different orders. This would seem to me to indicate that the parasitic mode of life in the tachina flies is one of comparatively recent acquirement and that sufficient time has not elapsed since they began to take on this habit for so great a differentiation, so great a co-relation between the host relation and the structure of the insects, to grow up. The ancestors of the tachina flies were probably flesh-flies and the parasitic mode of life has come from a gradual change from feeding on dead insects to feeding on live ones.

Coquillett has pointed out that in their instincts these flies appear to be much stupider than the ichneumon flies. The latter, 
for example, seem to know by a touch of their antennæ whether or not an insect has already been stung by some other parasite and they only in very rare instances insert an egg in the body of an insect that already contains an egg or larva of another parasite. Moreover, the ichneumon flies seem to grade the number of eggs which they lay in a certain insect to the number of larvæ which can successfully grow within it. But the tachina fly will attach to a caterpillar three or four times as many eggs as the number of larvæ the caterpillar can maintain. Thus many tachinid larvæ perish for want of food while some, which are barely able to exist, produce flies which are dwarfed in size, so that some adult flies are only one-third as large as others.

As above stated, the group is a very large one and fortunately it has been admirably monographed by Mr. D. W. Coquillett, who has also brought together from the records of the U. S. Department of Agriculture an interesting table of these flies in relation to the insects upon which they have been parasitic. 


\section{THE NIMBLE FLIES}

\section{(Family Dexiida.)}

The flies of this group, of which we have nearly fifty species in this country, most of them belonging to the typical genus Dexia, resemble the Tachina flies for the most part, although some are quite handsome, as, for example, Euantha liturata, which has banded wings and a striped thorax. The legs of these flies are usually long and in their early stages they are parasitic in various insects, especially in beetles and also in snails. Some of the exotic species are very handsome, as those of the genus Rutilia. 


\section{THE FLESH-FLIES}

\section{(Family Sarcophagida.)}

This is a large group of flies, comprising very many species, and as the scientific name indicates they are called "flesh-flies"

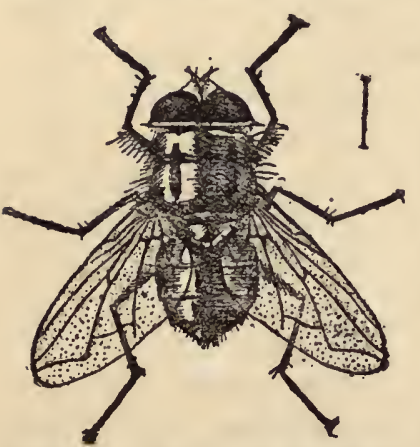

Fig. 89. - Chrysomyia macellaria. (Author's illustration.)

because many of them live in the larval state in the bodies of dead animals. Although, as just stated, many of the so-called flesh-flies are flesh feeders, the group as a whole is a variable one in habit. The larvæ of some live in decaying vegetable matter and fruits, others live in dung and others are practically parasitic upon living insects. One genus (Sarcophila) is a parasite of mammalia and even of human beings, depositing its young in the nostrils where they cause great suffering and even death. Several species of this family are referred to in the medical literature of "myiasis" which means the parasitism of human beings by flies.

The females of the flesh-flies may deposit eggs in large numbers or they may deposit living larvæ, as just indicated, the eggs being hatched before they have left the body of the female. A number of famous insects belong to this group. The insect popularly known as the "screwworm fly" is well known in the

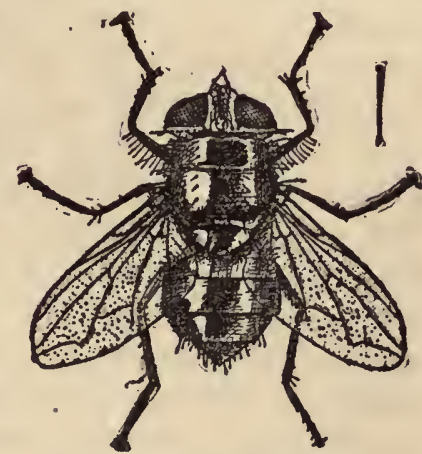

Fig. 90--Lucilia cæsar. (Author's illustration.) west. It is one of the most important of the insects which affect domestic animals and its greatest damage is done in Texas 163 
and adjoining States. The fly lays its eggs on any spot where the skin has been injured either from a scratch by a barbed-wire fence or the puncture of a thorn. The raw or slightly bloody surface attracts the flies which lay their eggs and the larvæ live in the flesh, making a large sore. The fly does not confine its

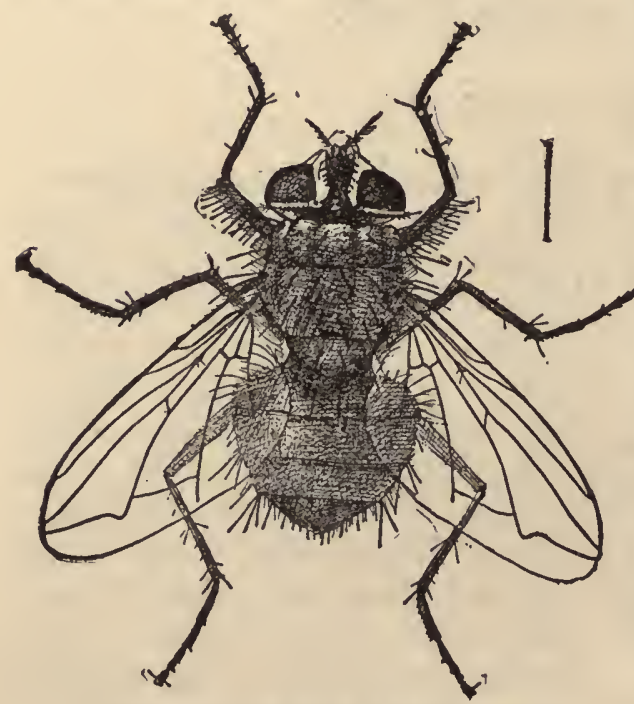

Fig. 91.-Calliphora erythrocephala. (Author's illustration.) attacks to domestic animals but also frequently attacks man. The most common cases are those where the fly has laid its eggs in the nostrils of some one, generally some person with a bad catarrhal trouble. The eggs hatch and the larvæ work their way through the upper nostrils and destroy the tissues. The soft palate is frequently entirely destroyed and fatal cases in men are not rare. The remedy is to syringe out the nasal passages with diluted carbolic acid. This insect also in its larval stage feeds on carrion. Another well known flesh-fly is Lucilia casar, generally known as the greenbottle fly, which is sometimes driven into houses on the approach of a storm. The large blue-bottle fly of rather dull color with black spines on the thorax is known as Calliphora erythrocephala. This is the common "blow-ny" of Europe and is the species treated by Lowne in his classic "Anatomy of the Blow-Fly." Its larvæ are indistinguishable from those of the preceding species except in size and they are to be found on meat and dead animals. Riley states also that it destroys the Rocky Mountain locust or western grasshopper. The flies of the true genus Sarcophaga are very general scavengers, feeding, however, upon animal matter practically exclusively. The common flesh-fly of Europe Sarcophaga carnaria does not seem to occur in this country but we have a closely allied species, $S$. sarracenia, which has been reared from 


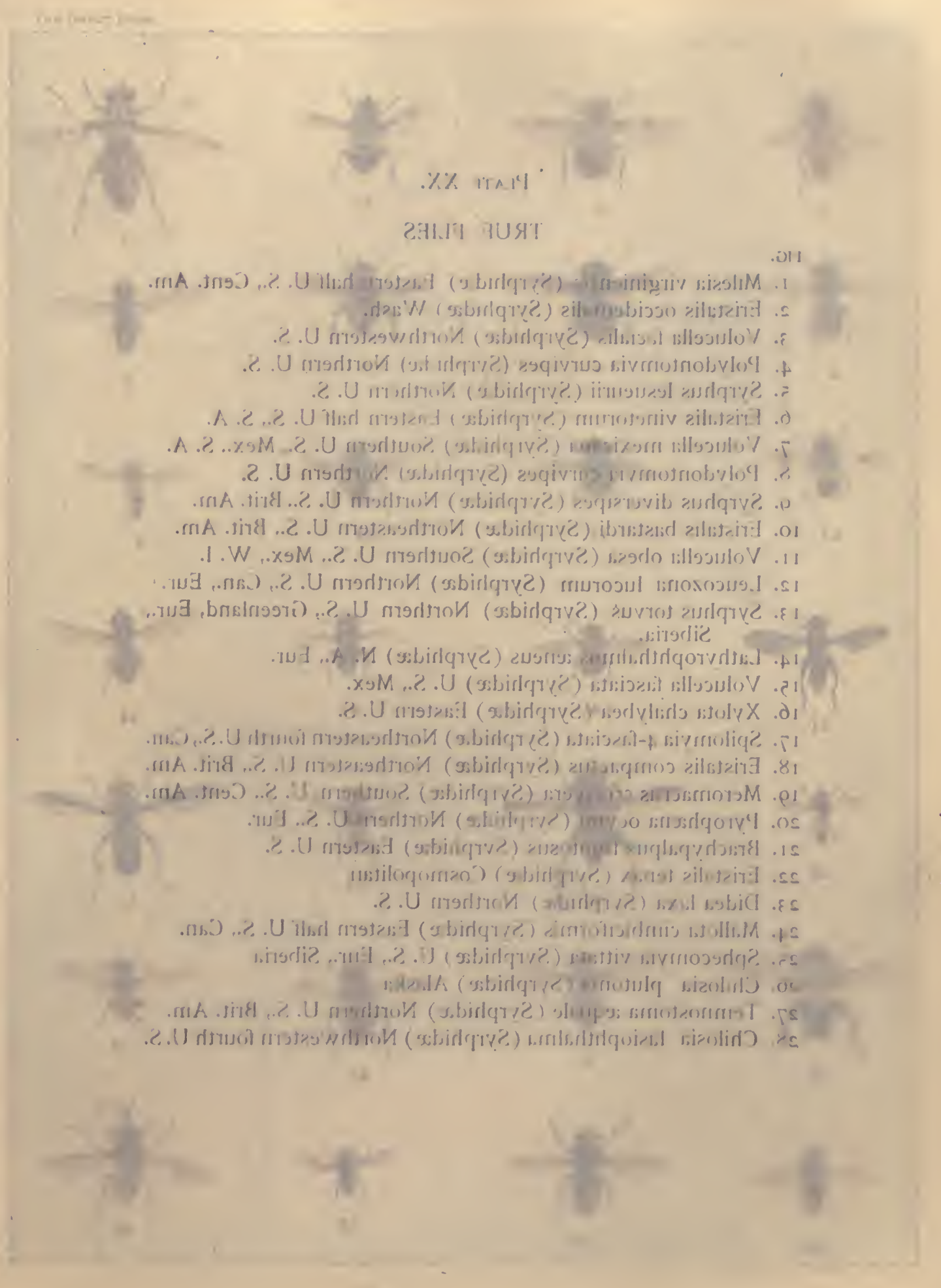


FIG.

\section{TRUE FLIES}

1. Milesia virginiensis (Syrphidæ) Eastern half U. S., Cent. Am.

2. Eristalis occidentalis (Syrphidæ) Wash.

3. Volucella facialis (Syrphidx) Northwestern U.S.

4. Polydontomyia curvipes (Syrphide) Northern U. S,

5. Syrphus lesueurii (Syrphidæ) Northern U.S.

6. Eristalis vinetorum (Syrphidæ) Eastern half U. S., S. A.

7. Volucella mexicana (Syrphidæ) Southern U. S., Mex., S. A.

8. Polydontomyia curvipes (Syrphidx) Northern U. S.

9. Syrphus diversipes (Syrphidæ) Northern U. S.. Brit. Am.

10. Eristalis bastardi (Syrphidæ) Northeastern U. S., Brit. Am.

11. Volucella obesa (Syrphidæ) Southern U. S., Mex., W. I.

12. Leucozona lucorum (Syrphidæ) Northern U. S., Can., Eur.

13. Syrphus torvus (Syrphidx) Northern U. S., Greenland, Eur., Siberia.

14. Lathyrophthalmus æneus (Syrphidæ) N. A., Eur.

15. Volucella fasciata (Syrphidæ) U. S., Mex.

16. Xylotal chalybea (Syrphidx) Eastern U.S.

17. Spilomyia 4-fasciata (Syrphidæ) Northeastern fourth U.S., Can.

18. Eristalis compactus (Syrphidæ) Northeastern U. S., Brit. Am.

19. Meromacrus crucigera (Syrphidx) Southern U. S., Cent. Am.

20. Pyrophæna ocymi (Syrphidæ) Northern U. S., Eur.

21. Brachypalpus frontosus (Syrphidæ) Eastern U.S.

22. Eristalis tenax (Syrphidx) Cosmopolitan

23. Didea laxa (Syrphidæ) Northern U. S.

24. Mallota cimbiciformis (Syrphidx) Eastern half U. S., Can.

25. Sphecomyia vittata (Syrphidæ) U. S., Eur., Siberia

26. Chilosia plutonia (Syrphidæ) Alaska

27. Temnostoma requale (Syrphidæ) Northern U. S., Brit. Am.

28. Chilosia lasiophthalma (Syrphidx) Northwestern fourth U.S. 

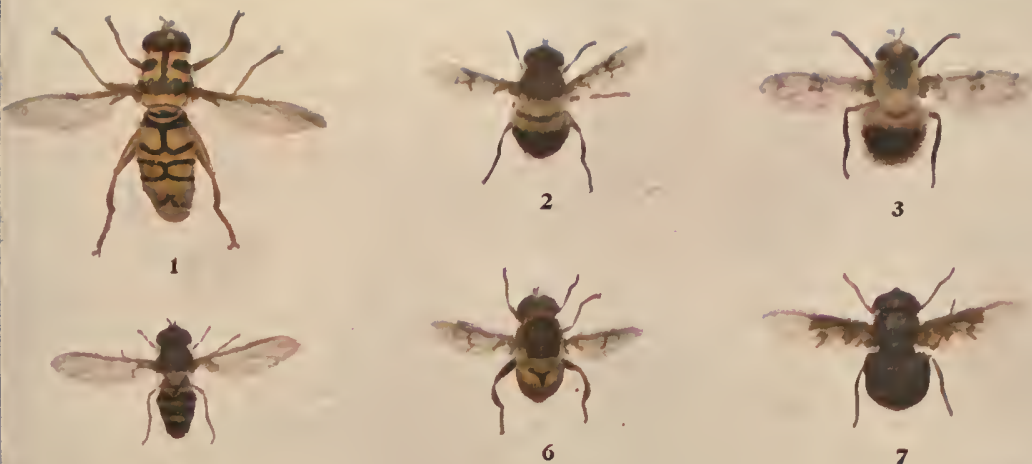

5
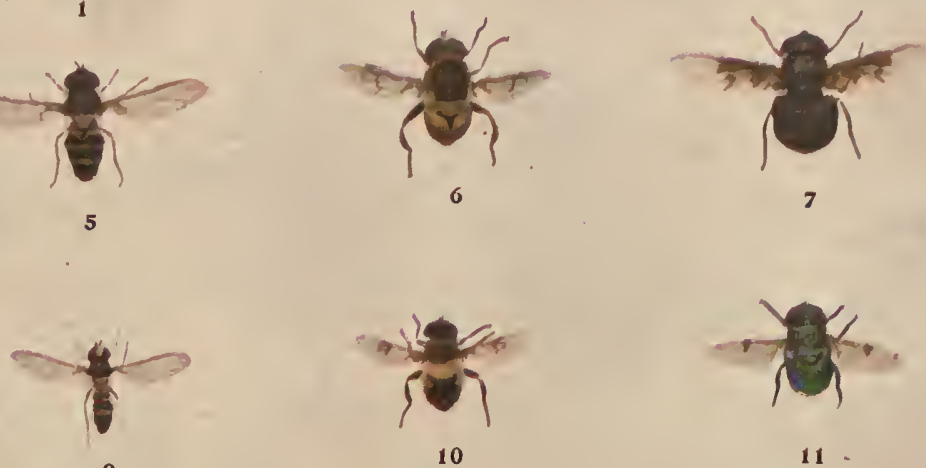

9

10

11.
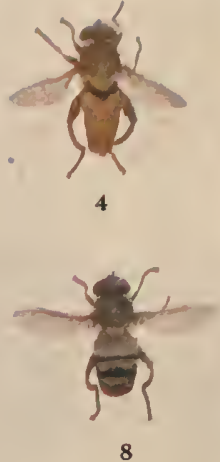

8

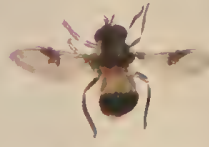

12
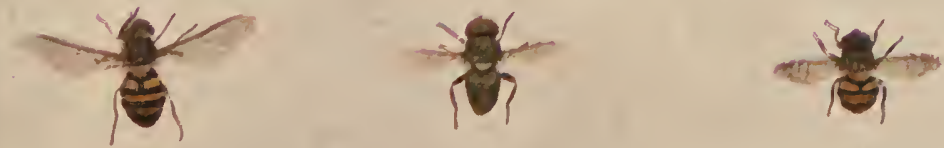

14

15
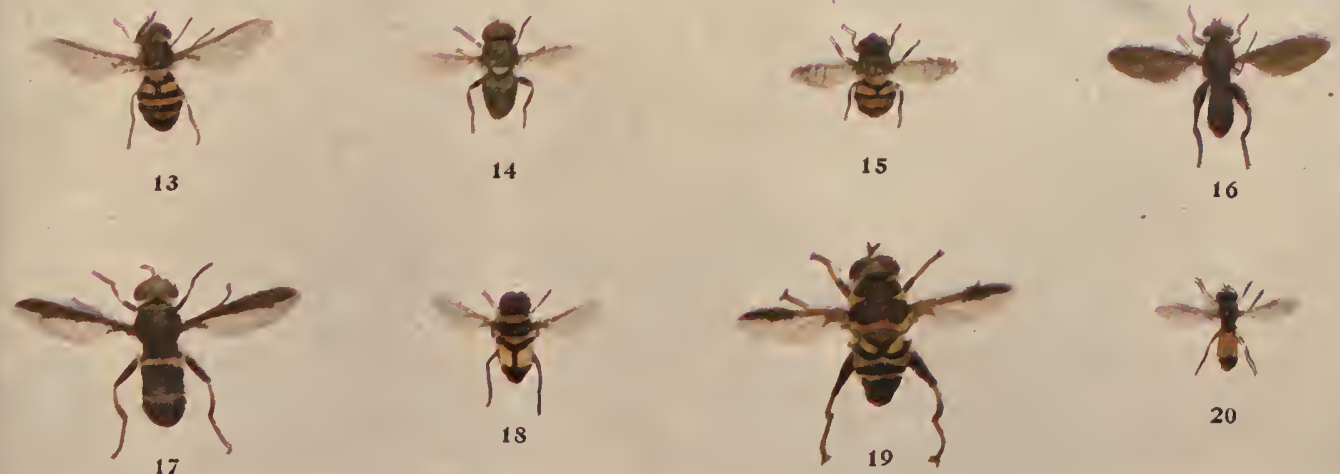

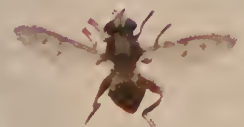

21

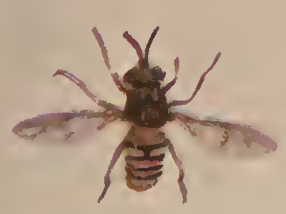

25

5

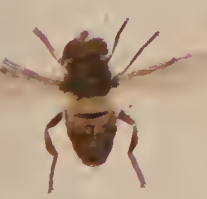

22

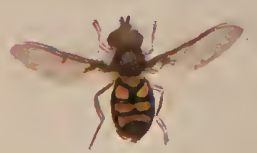

23

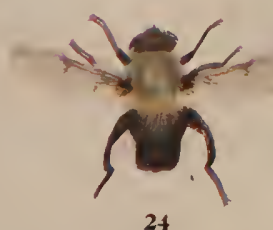

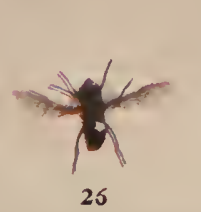
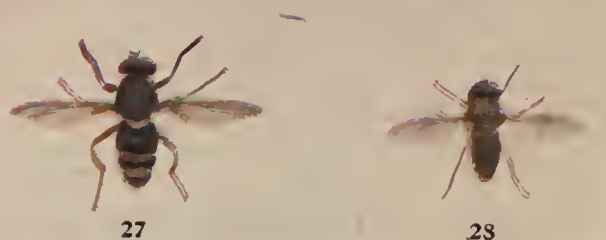

larvæ found feeding upon dead insects in the pitchers of the common pitcher plants and which is often reared from dead insects and from excrement. It is rather a rapid breeder and a

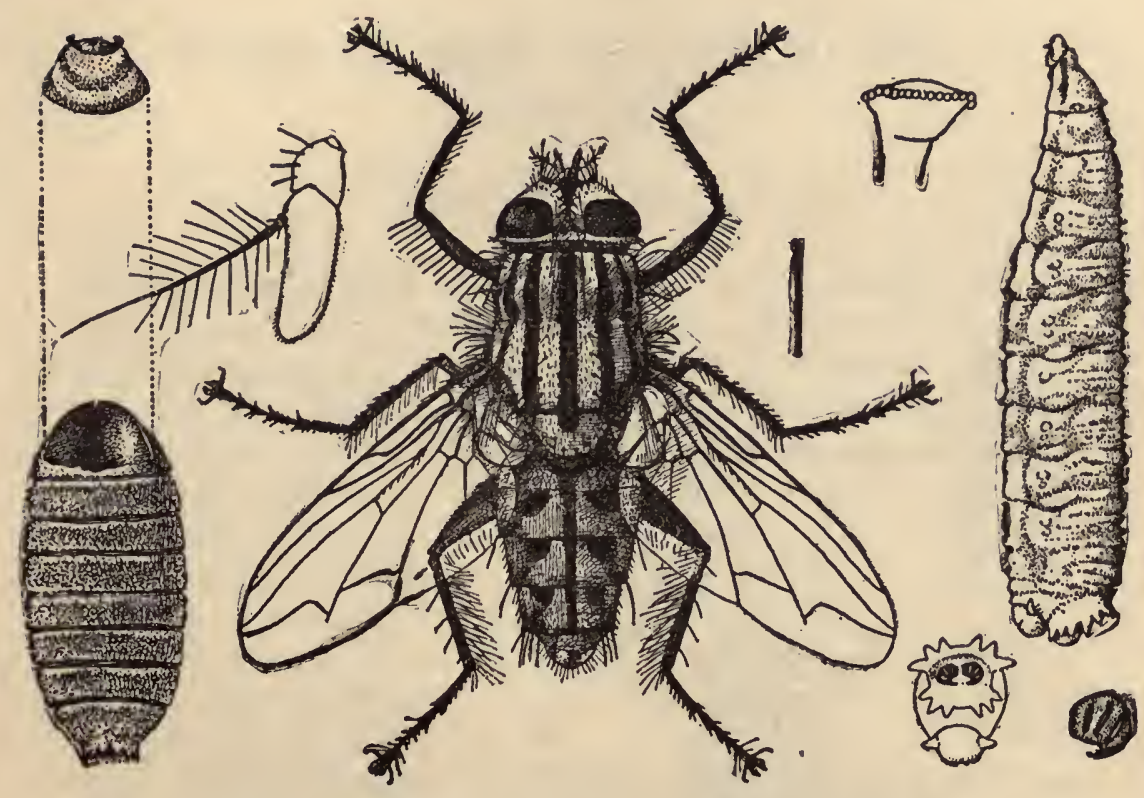

Fig. 92.-Sarcophaga sarraceniæ. (Author's illustration.)

generation will be developed in ten days in the summer time. Among the commonest of the flesh-flies are the small species of the genus Helicobia, originally so named because they were reared from a dead snail. They are very commonly found feeding in the larval stage upon the dead bodies of insects.

A majority of the flesh-flies belong to what may be termed the house-fly type, $i$. e., they are gray flies rather obscurely striped with black, but some of them, as just shown, may become metallic in color. 


\section{THE HOUSE-FLY AND ITS NEAR RELATIONS}

\section{(Family Muscida.)}

The insects of this family comprise what might be known as the typical true flies. The bristle of the antennæ is feathery and the abdomen is smooth except for a certain number of bristles near the tip. The larvæ as a rule feed upon decaying animal or vegetable matter, more abundantly upon animal than

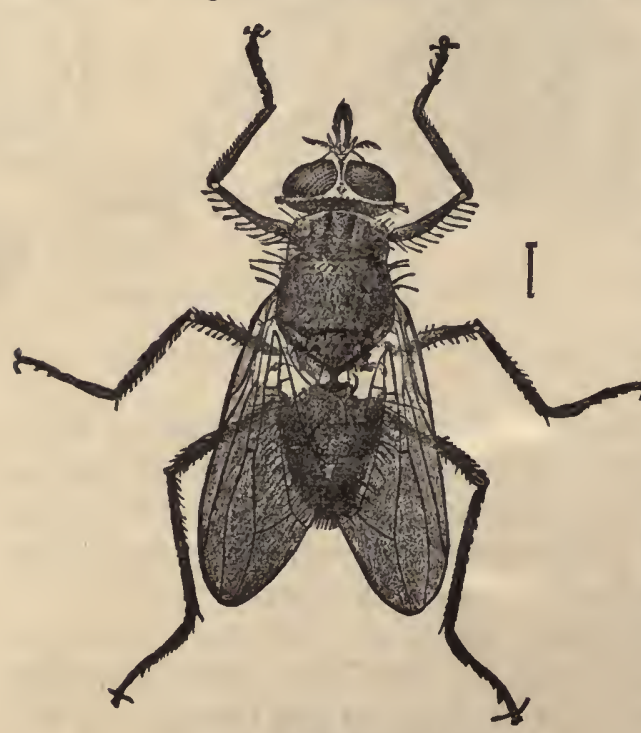

Fig. 93--Hæmatobia serrata.

(From Insect Life.) vegetable. The group comprises many species and includes some of the most common and abundant forms, such as the house-fly (Musca domestica), the horn-fly of cattle ( $\mathrm{Ho}$ matobia serrata), the stable-fly (Stomoxys calcitrans), and some of the so-called "bluebottle" flies. Certain members of this group, such as the horn-fly, and the stable-fly (both species having been introduced from Europe) are very annoying to live stock and produce great loss by their attacks. Many species of this group are of much value as scavengers, destroying, through their great number and quick breeding, quantities of decaying animal matter, but some of them are again injurious as appears from recent investigations by virtue of the fact that they breed in human excrement 
The House-Fly and Its Near Relations

through the carriage and distribution of the germs of diseases of the intestinal tract, such as typhoid fever and Asiatic cholera.

\section{Typical Life History \\ (Musca domestica.)}

This insect, known as the common house-fly, is found all over the world. It lays its eggs by preference in horse manure but in the absence of this substance will oviposit and breed in other excrementitious matter and will lay its eggs in decaying vegetables, although 1 have been unable to rear it in substances of the last named character. It is also difficult and of ten impossible to "- Fig. 94.-Morellia micans. (Autbor's illustration.) rear it from cow dung. In horse manure, however, it flourishes. The eggs are laid freely on horse manure in an undisturbed condition. These

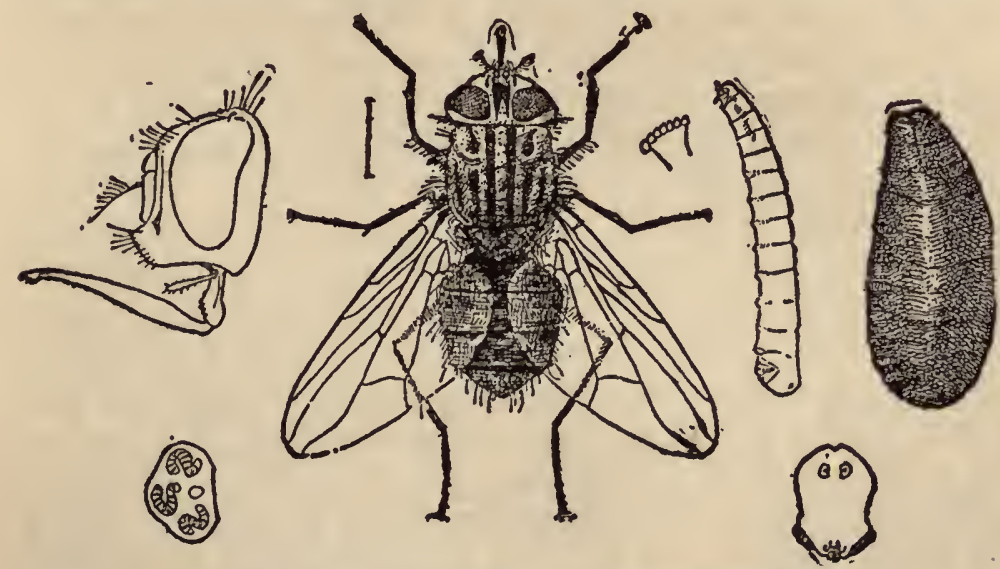

Fig. 95.-Stomoxys calcitrans. (Autbor's illustration.) 
eggs are elongate, white, and hatch very soon after being laid, in six or eight hours. The larvæ, which are white, pointed maggots, as shown in the accompanying figure, grow rapidly, cast their skin twice, and reach full growth under favorable conditions in four or five days. The outer skin then hardens, swells out, turns dark brown in color, and within it the true pupa is formed. In this stage it may live for five days and the adult fly issues at the expiration of this time through a round hole in the anterior end of the pupal covering. This makes the total life round for a.
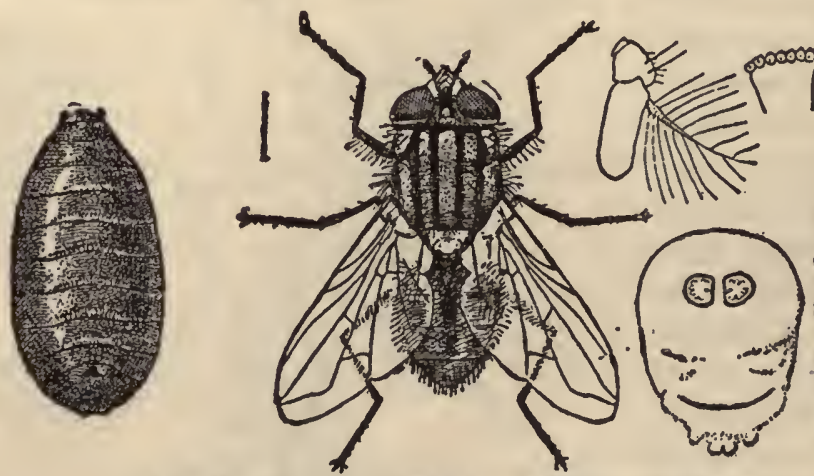

Fig. 96.-Musca domestica. (Autbor's illustration.)

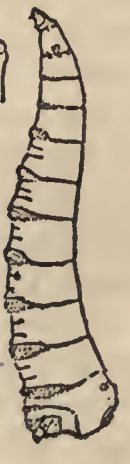

single generation in summer approximately ten days. Thus there is abundance of time for the development of twelve or thirteen generations in the climate of Washington every summer.

The number of eggs laid by an individual fly averages about 120 and the enormous numbers in which the insect occurs is thus plainly accounted for, especially when we consider the abundance and universal occurrence of appropriate larval food. The universal occurrence of uncared for piles of horse manure in cities is therefore not only a source of great discomfort but is inimical to health since the house-fly undoubtedly distributes disease germs. The numbers in which house-fly larvæ occur in horse manure piles may be understood when the statement is made that from a quarter of a pound of manure from the centre of a pile 160 larvæ and 146 puparia of the house-fly were taken. This would make about 1,200 house-flies to the pound of manure. This is not a fair average, but indicates possibilities and is an actual record of an individual case. Experiments conducted by the 168 
writer at Washington indicate that by cleanly measures in stables, by the daily collection of the manure and placing it in a closed pit or closet or by treating it at intervals of a week with chlorid of lime, the house-fly nuisance can be greatly abated and thus the disease danger largely avoided.

There is a general impression that house-flies sometimes bite people, but this is entirely wrong. Their mouth parts are fitted for sucking and lapping up liquids, and not for piercing. The stable-fly mentioned in a previous paragraph is, however, a biting one, and it looks so much like a house-fly that one almost has to let it bite before finding out whether it is a house-fly or not. The stable-fly is seldom found in houses except just before a rain, and then it comes in at the open windows. From this fact arises the old saying, "Flies begin to bite before a rain." It has been asked why flies seem to prefer windows and lookingglasses, but the answer is simple enough: when they are on the windows they want to get out; when they are on lookingglasses they are mistaking them for windows.

Sometimes when a house-fly is examined it will be seen to be fairly covered with little reddish objects which are really living creatures. They are parasitic mites which attach themselves to the bodies of house-flies and certain other insects and inserting their long beaks suck their juices. It is comforting to think that the house-fly has these parasites which torment him so. Such retribution is just. And there is another comforting fact: houseflies die of fungus diseases. Sometimes, especially in the fall, flies will be found behind the picture-frames or in rather dark places, covered with a gray, fur-like substance, which is the manifestation of the fungus disease which has killed it. Then, too, dead flies will be seen with their bodies swollen and appearing more or less striped. These also have been killed by another fungus disease. These epidemic diseases cease in December, and although many thousands of house-flies are killed by them, the remarkable rapidity of development in the early summer months soon more than replaces the thousands thus destroyed.

If we could only get our boards of health in cities to attack the house-fly question and to insist on the proper disposal and treatment of horse manure the insect would soon become scarce, and perhaps its agency in the spread of disease will induce these officials to look into the matter. It is a noticeable fact that 
horses are very much on the decrease in cities; the motor vehicles of different kinds are becoming multiplied, and with this change will come a decrease, and a marked one in the number of house-flies. In the country and in agricultural communities there is not much hope in the near future except through better knowledge on the part of the inhabitants and an effort to do away with the breeding places of this nuisance. 


\section{THE ANTHOMYIA FLIES}

\section{(Family Anthomyiida.)}

The flies of this family also as a rule belong to the house-fly type. They are generally rather small but of unpronounced color. It is a very large family and a most difficult one to study and the flies themselves are singularly unattractive in general appearance. Nevertheless, the habits of many of the species are of interest and they feed not only upon decaying vegetable matter but also upon growing plants and a few prey upon the eggs of grasshoppers. Such a wide variation in habit suggests that structural characters will eventually be found which will split up this large family.

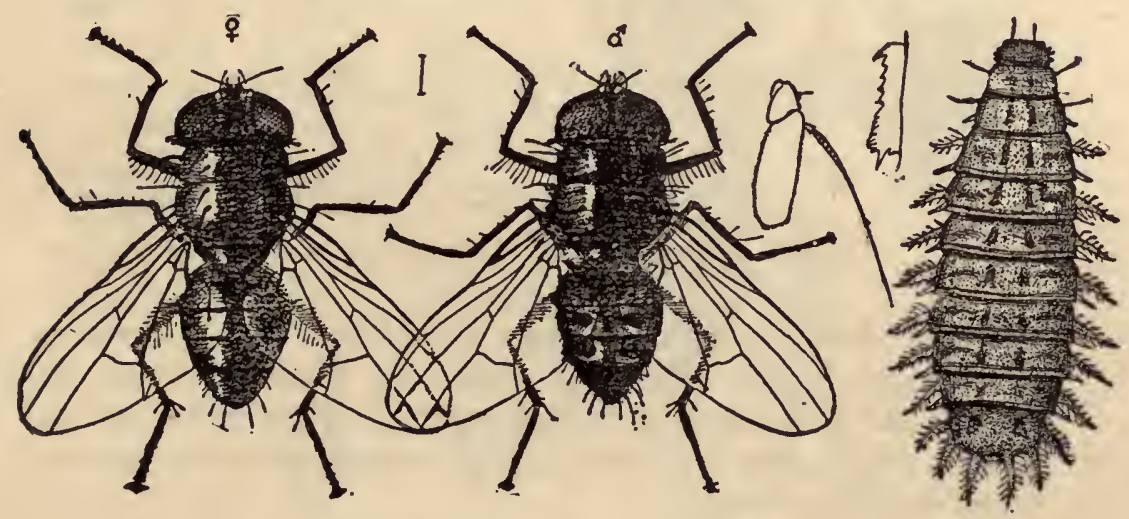

Fig. 97--Homalomyia brevis. (Author's illustration.)

Several species will be found mentioned in medical works under the head of "myiasis interna" and in these cases they have been taken into the stomachs of human beings with spoiled vegetables. They frequently retain their vitality and issue alive with the fæces. The insects commonly known as little house-flies (Homalomyia canicularis and $H$. brevis) frequently seen in houses on windows belong to this family. They breed in decaying vegetable material and dung. The so-called onion-fly (Phorbia ceparum) 
in the larval stage is occasionally very destructive to onions, working into the bulb and destroying it for food. The cabbage maggot ( $P$. brassica) works in the roots of cabbage and sometimes does great damage. Some species in the larval stage mine the leaves of plants. Pegomyia vicina mines the leaves of beets and has become a rather important insect since the cultivation of

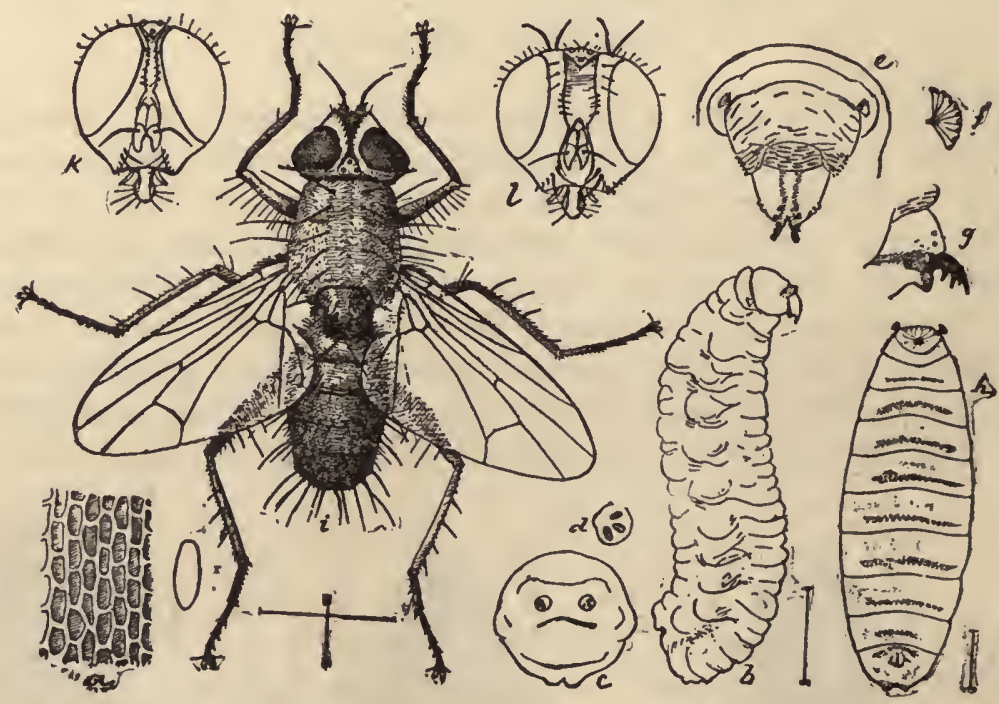

Fig. 98.-Pegomyia vicina. (Author's illustration.)

the sugar beet has assumed large proportions in this country. One species is said to damage seed corn when placed in the ground and others destroy injurious grasshoppers and there are records which show that other forms sometimes live in tumors under the skin of birds. 


\section{THE DUNG FLIES}

\section{(Families Scatopbagida and Heteroneurida.)}

We are coming now to a long series of small families of rather small flies which are not especially interesting or especially remarkable.

The Scatophagidæ are rather slender, medium sized flies, generally smooth, but rarely with some bristles and yellowish hairs. In color they are usually black and shining, but sometimes yellowish or with a broad yellowish stripe on a dark background. The flies of this family are popularly known as dung flies and are attracted to and breed in dung of various animals, and also in decaying vege- Fig. 99.-Scatophaga furcata. (Author's Illustration.) table matter.

The Heteroneuridæ are rather small, slender, yellowish or black species, which are found in foul, damp places, and whose larvæ are found under the bark of trees and in similar situations. 


\section{FA MILIES HELOMYZIDA, PHYCODROMIDAE AND SCIOMYZIDA}

The Helomyzidæ are small, dark-colored flies, looking something like dung-flies. They seem to prefer damp, shady places, and fly in the twilight. In the larval condition they are to be found in fungi and one species in Europe feeds upon truffles. Some of them also lay their eggs in the excrement of dogs and other animals.

The Phycodromidæ are also small, grayish flies in which the abdomen is somewhat darker than the thorax. They are found on ocean beaches, and also on the shores of lakes, upon the different substances, usually vegetable, washed ashore, and they probably breed in such places.

With the Sciomyzidæ, the colors are brown or gray, and they are ordinary-looking, medium sized or small flies. Their wings are usually spotted or slightly clouded. The metamorphoses of most of them are not known. These flies are to be captured on high grasses or upon bushes. 


\section{FAMILIES SAPROMYZIDA, LONCHAIDA AND ORTALIDAE}

The flies of the family Sapromyzidæ much resemble those of the last mentioned group, but the wings are rarely spotted. The abdomen is usually rather broad, and short, and egg-shaped. Their larvæ are found under the bark of trees or in the burrows of wood-boring insects, or in decaying vegetation of almost any kind. The flies are commonly found in damp spots near their breeding places.

The Loncheidæ is a group which was formerly included in the preceding family and which it very much resembles. The
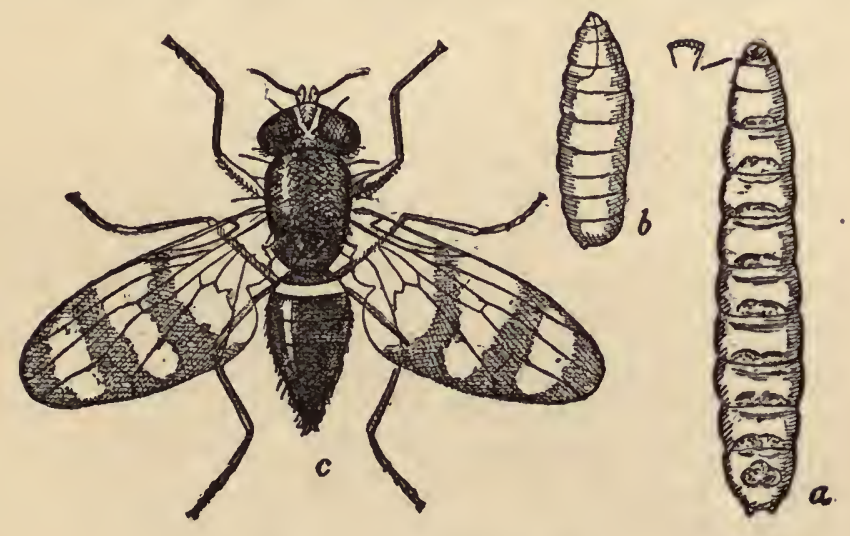

Fig. 100.-Chaetopsis ænea.

metamorphoses are not well known, but the larvæ of one species have been found in Europe in the stems of weedy plants, and of another in the rootlets of wheat. In this country I have bred Loncheea polita from dung.

The Ortalidæ comprises a group of flies with usually spotted or banded wings, and frequently of metallic colors. In the larval state they occur under the bark of pine and poplar and in the burrows of wood-boring insects and also in onions, cotton bolls, 
apples, and the fruit of the Osage orange, probably in all cases, however, following the work of some other insect. Strictly speaking, therefore, these flies are scavengers. The brown winged species of the genus Pyrgota are the largest flies of this family which we have in this country. Camptoneura picta Fabr. is a beautiful little fly with brown wings in which the brown is incised with clear spaces. Chatopsis anea has been reared from corn stalks, which however, as with the other species, had previously been bored by some other insect. 


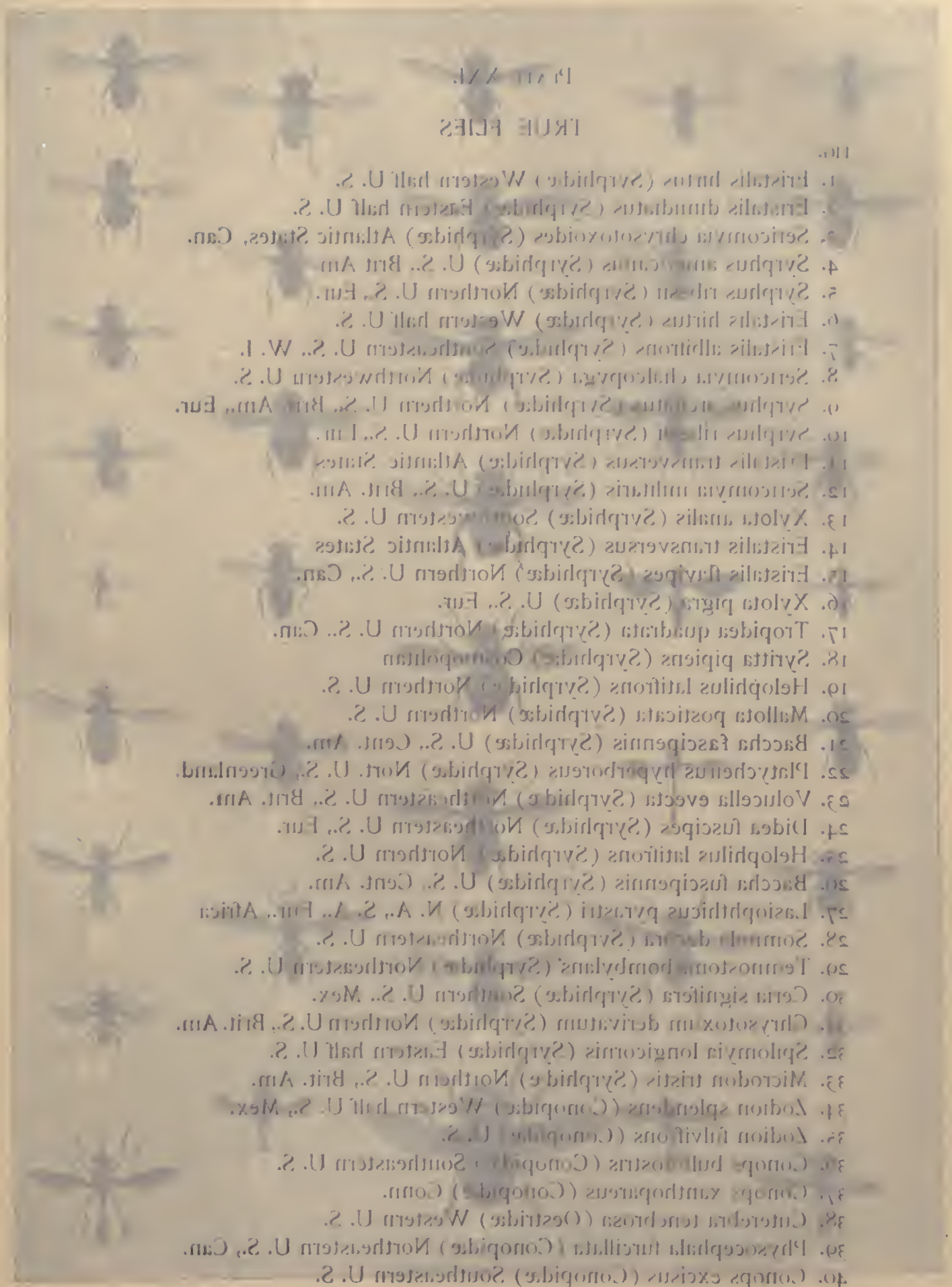




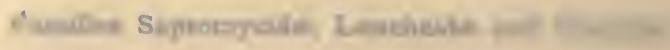

PiAT: XXI.

\section{epples and the irull of the C se.}

\section{nowev $\%$, ollowio, TRUE FLIES}

FIG.

1. Eristalis hirtus (Syrphidæ) Western half U. S.

2. Eristalis dimidiatus (Syrphidæ) Eastern half U.S.

3. Sericomyia chrysotoxoides (Syrphidx) Atlantic States, Can.

4. Syrphus americanus (Syrphidæ) U. S., Brit Am.

5. Syrphus ribesii (Syrphidæ) Northern U. S., Eur.

6. Eristalis hirtus (Syrphidæ) Western half U.S.

7. Eristalis albifrons (Syrphidx) Southeastern U. S., W. I.

8. Sericomyia chalcopyga (Syrphidx) Northwestern U. S.

9. Syrphus arcuatus (Syrphida) Northern U. S., Brit. Am., Eur.

10. Syrphus ribesii (Syrphida) Northern U. S., Fur.

14. Eristalis transversus (Syrphidae) Athantic States

12. Sericomyia militaris (Syrphidx) U. S., Brit. Am.

13. Xylota analis (Syrphidæ) Southwestern U. S.

14. Eristalis transversus (Syrphidre) Atlantic States

15. Eristalis flavipes (Syrphida) Northern U. S., Can.

16. Xylota pigra (Syrphidæ) U. S., Eur.

17. Tropidea quadrata (Syrphida) Northern U. S., Can.

18. Syritta pipiens (Syrphidæ) Cosmopolitan

19. Helophilus latifrons (Syrphidæ) Northern U. S.

20. Mallota posticata (Syrphidx) Northern U. S.

21. Baccha fascipennis (Syrphidæ) U. S., Cent. Am.

22. Platycheirus hyperboreus (Syrphidx) Nort. U. S., Greenland.

23. Volucella evecta (Syrphidæ) Northeastern U. S., Brit. Am.

24. Didea fuscipes (Syrphidæ) Northeastern U. S., Eur.

25. Helophilus latifrons (Syrphidæ) Northern U.S.

26. Baccha fuscipennis (Syrphidæ) U. S., Cent. Am.

27. Lasiophthicus pyrastri (Syrphidæ) N. A., S. A., Eur., Africa

28. Somnula decora (Syrphidx) Northeastern U. S.

29. Temnostoma bombylans (Syrphidæ) Northeastern U. S.

30. Ceria signifera (Syrphidæ) Southern U. S., Mex.

31. Chrysotoxum derivatum (Syrphidæ) Northern U.S., Brit. Am.

32. Spilomyia longicornis (Syrphidæ) Eastern half U. S.

33. Microdon tristis (Syrphidx) Northern U. S., Brit. Am.

34. Zodion splendens (Conopidæ) Western half U. S., Mex.

35. Zodion fulvifrons (Conopidx) U.S.

36. Conops bulbirostris (Conopidæ) Southeastern U. S.

37. Conops xanthopareus (Conopidx) Conn.

38. Cuterebra tenebrosa (Oestridæ) Western U. S.

39. Physocephala furcillata (Conopidæ) Northeastern U. S., Can.

40. Conops excisus (Conopida) Southeastern U. S. 


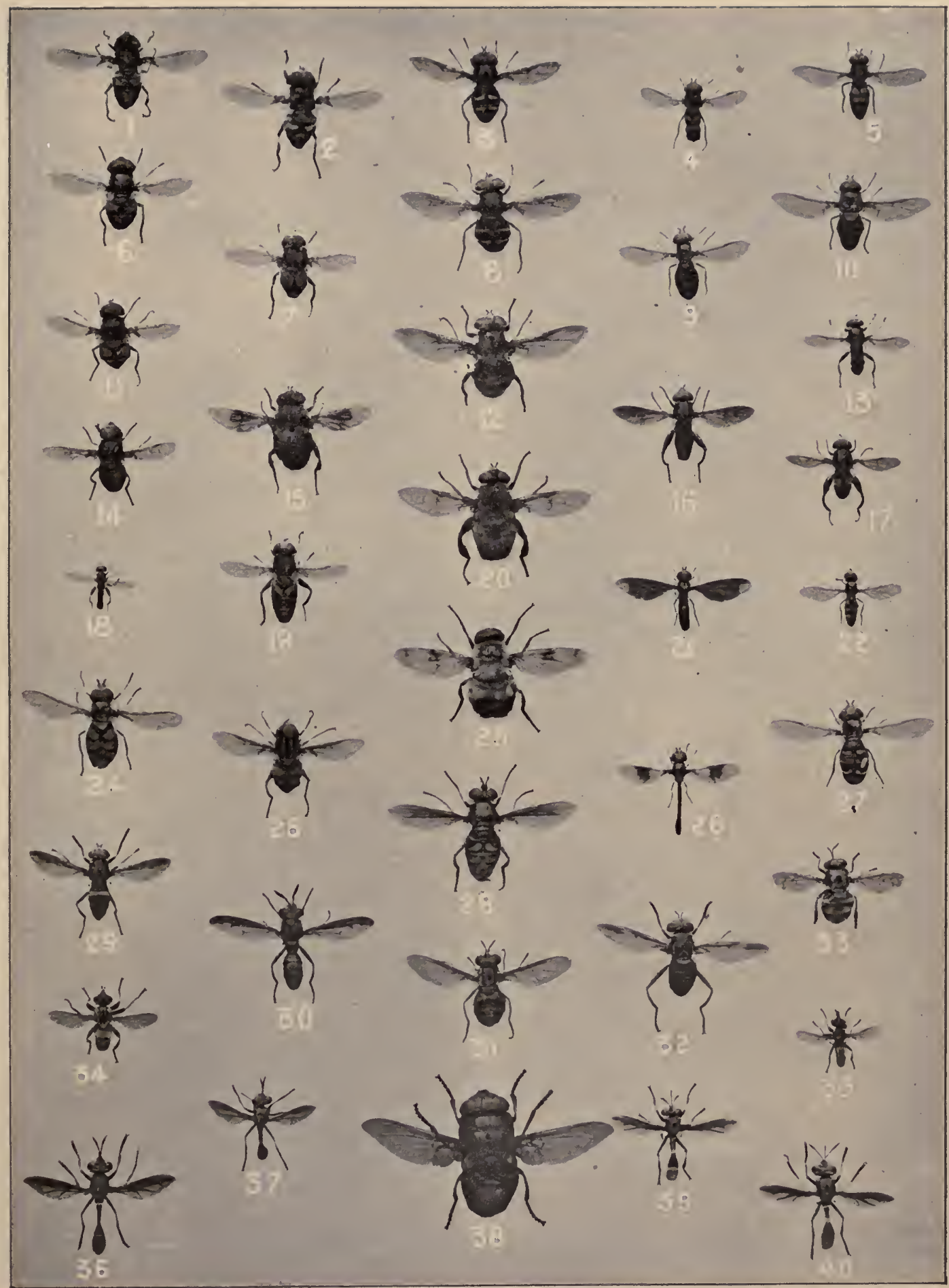





\section{THE FRUIT AND GALL FLIES}

\section{(Family Trypetida.)}

Most of the flies of this family are rather small, although some are above medium size. They are of very striking appearance and interesting habits. They vary from light yellow in color to dark brown or nearly black, and the body is frequently curiously spotted in the lighter specimens. The wings are also beautifully banded and marked. The group is a large one and is well represented in the United States, many genera and species occurring withus.

The Trypetid flies in their early stages live in fruits or in the stems of plants, producing galls. The so-called apple maggot of the Northeastern States, an insect which is especially abundant in Maine and

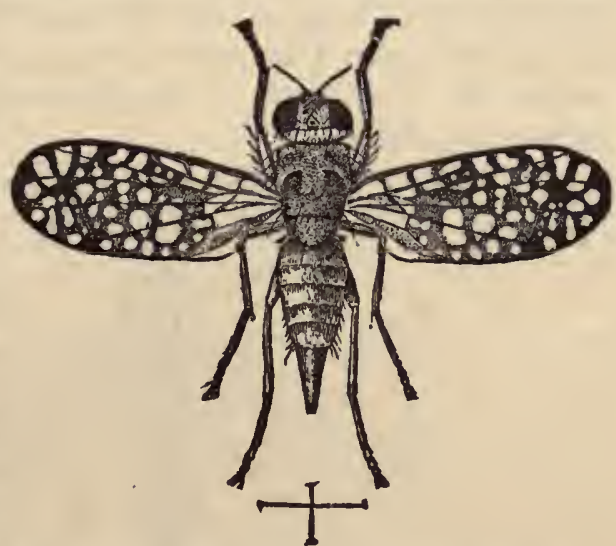

Fig. 101.-Tephritis æqualis. (After Marlatt.) New Hampshire, is the larva of Rhagdetis pomonella. It eats into the pulp of apples, boring tunnels in all directions through the fruit. It is said especially to attack the earlier ripening apples. When full grown it drops to the ground and transforms within the last larval skin. The adult insect is a black and white fly with banded wings. One of the large round galls which occurs upon the stems of goldenrod is made by one of these flies known as Eurosta asteris. There are sometimes two of these galls on the same stalk, and they are most conspicuous in the winter time when there are no leaves on the plant. If one cuts open one of these galls it is found to be full of a pithy solid 
mass, in the center of which is the plump, white maggot of this fly. A famous member of this family is known as Ceratitis capitata, which damages peaches and other fruit in different parts of the world. It is common and injurious in Bermuda, but, fortunately, has not established itself in the United States. Another Trypetid fly which does great damage is Anastrepha ludens, the larva of which is known as the Morelos orange fruit worm. It bores into the pulp of oranges, and renders them unfit for eating purposes. These worms are frequently found in Mexican oranges which are brought into the United States in the early fall before the California oranges come on the market. California orange growers are greatly alarmed at the prospect that this insect may be imported into their orange groves and establish itself there, and they are trying to induce Congress to pass a law by which the Secretary of Agriculture shall be empowered to quarantine against Mexican oranges. This would be by no means the first instance in which insect damage has caused national legislation.

The larva of Trypeta fratria Loew mines the leaves of parsnip in many parts of the country. 


\section{FAMILIES MICROPEZIDA, SEPSIDÆ, PSILIDAE AND DIOPSIDAE.}

The Micropezid flies are slender, dark creatures of a good size, with a few spots on the wings. They are rather awkward in shape, their legs being long, and they are not common. Nothing is known of their metamorphoses, but they are captured upon decaying and foul vegetable and animal matter.

The Sepsidæ comprise a series of small, frequently shining black flies, of rather slender form, which breed, as a rule, in decaying vegetable material or in dung. The little shining black

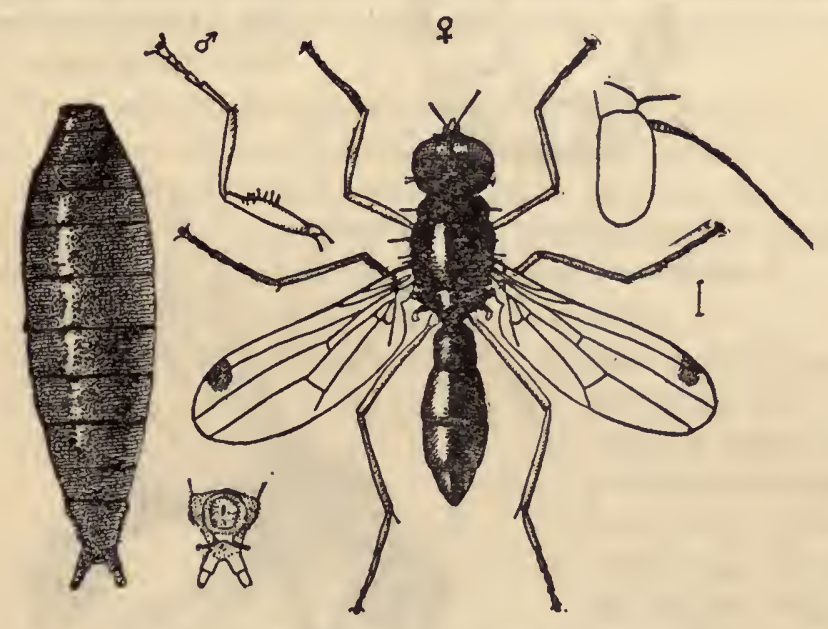

Fig. 102.-Sepsis violacea. (Author's illustration.)

species of the genus Piophila, however, breed in cheese, ham fat, and in other fatty or spoiled and decaying animal matter. The little maggot known as the "cheese skipper" is the larva of Piophila casei Linn. This insect frequently does great damage in packing establishments. The eggs are laid in compact clusters of from five to fifteen, or are scattered singly. Each female lays about thirty eggs. The egg is white, slender, slightly curved, one millimeter long, and hatches in thirty-six hours. The larva 

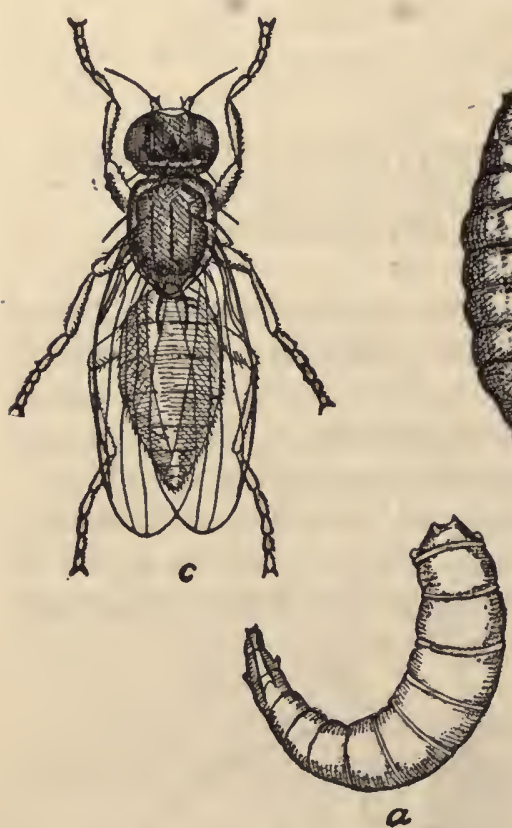

Fig. 103.-Pioplula casei : $a$, larva ;

$b$, puparium; $c$, adult. is cylindrical and tapers toward the anterior end. It completes its growth in from seven to eight days, and if the food supply is sufficient, it does not move much, but when mature it jumps in an extraordinary way, from which it derives its name of cheese skipper.

b The leap is made by bringing the two ends of the body together, and suddenly releasing them like a spring. In this way they sometimes jump

three or four inches. When full grown it moves away to some dry spot, contracts and assumes a yellowish color, the skin hardens, and within the last larval skin the pupa is formed. In ten days the adult fly issues. As a cheese insect in this country this fly does not play as important a part as it does as an enemy to smoked meat. In Europe, it is noted prin-

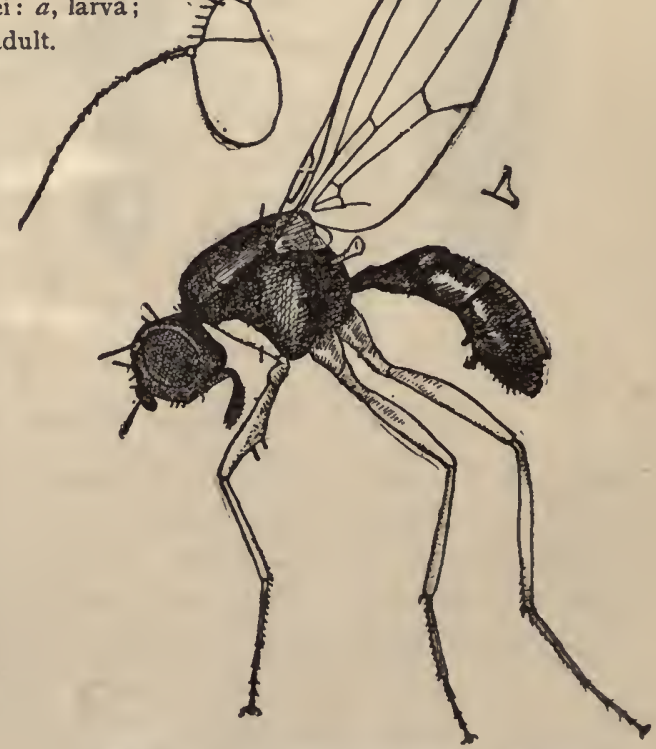
illustration.)
Fig. 104.-Nemopoda minuta. (Author's 
cipally as a cheese pest, and it is a matter of common observation that the mother fly seems to prefer the older and richer cheeses in which to deposit her eggs. Her taste is excellent, and, while it is a fair thing to say that skippery cheese is usually the best, it will hardly do to support the conclusion that it is good because it is skippery, although this conclusion is current among a certain class of cheese-eaters. Readers of this will be reminded of the inimitable scene in the Erasmus Inn, described by Charles Reade in "The Cloister and the Hearth."

The flies of the family Psilidæ are a little stouter and shorter than the Micropezids, and are sometimes light in color, though generally dark. The metamorphoses of very few of them are known. Some occur in the stems of plants; others are found in the roots of carrots and cabbages, and the flies themselves are seen commonly sitting upon the leaves of bushes and lowgrowing plants.

The Diopsidæ are remarkable from their very curious heads. The head is greatly broadened, with the eyes at the extremities, and the eye-portion is swollen. In some tropical species this feature becomes so exaggerated that the insect looks almost as if it carried bicycle handle bars on its head. They are small black flies, usually stouter than those of the groups which we have just mentioned, and they are found in shady wooded places. 


\section{THE SALT-WATER FLIES}

\section{(Family Ephydrida.)}

This family includes a number of insects of curious structure and strange habits. The adults are generally sordid little flies usually with clear wings.

The larvæ, as a rule, are aquatic or subaquatic, and are found in waters strongly impregnated with salt. They occur near salt wells and are found in the strongly alkaline lakes of the West. Some species breed in pools of water strongly impregnated with minerals, and one form is found breeding commonly in the pissoirs of European cities. I have reared Brachydeutera argentata, a handsome little species belonging to this family, from larvæ found in a small pool of water which was strongly impregnated with horse manure from an adjoining manure heap. The numbers in which the Ephydrid flies occur in the alkaline lakes in our western country is something astonishing. They are found in the Great Salt Lake, in Mono Lake, and others of the same character. The waters of Lake Mono are very heavy and have a nauseous taste, and when still the water looks like oil and feels slippery to the touch, and it is said that no fish or reptile lives in it. It swarms, however, with countless millions of these larvæ, which develop into flies which rest upon the surface of the water and cover everything on the shore. The larvæ and the flies drift in heaps on the beaches, and hundreds of bushels can be collected. Professor Brewer, of Yale University, has published an interesting account of them from which these statements are drawn. It seems that at certain times of the year the Indians used to come from far and near to get them for food. . They dried the puparia in the sun and then rubbed off the outer skin. The Indians call this food koo-chah-bee. Prof. Brewer says that it tastes like patent meat biscuit and if one were ignorant of its origin it would make palatable soup. Another species is found in great quantities in Lake Texcoco, near the City of Mexico. 


\section{THE GRASS STEM FLIES}

(Family Oscinida.)

These are little flies, either dark and shining or yellowish in color, and are more or less stout-bodied. The larvæ breed in the stems of grasses or are found in decaying vegetable material; some live in the burrows or cavities in plants made by other insects while a few feed on the egg shells and cast skins of

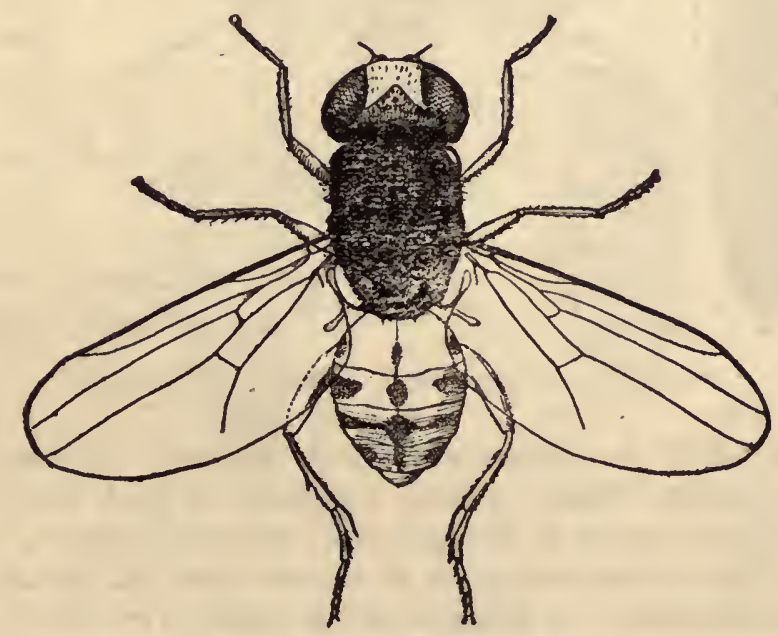

Fig. 105--Hippelates plebejus.

insects. Meromyza americana feeds in the stems of wheat and rye, and sometimes does considerable damage; the larva of Chlorops graminea lives in a gall-like swelling on grass stems, and the larva of Chlorops assimilis mines the leaves of sugar beet. One of the commonest of these flies in this country is a little scavenger known as Gaurax anchora, which feeds upon all sorts of dead animal matter, such as the empty egg shells of other insects, the cast-off skins of caterpillars and chrysalids, and spiders' eggs. The little flies of the genus Hippelates are 
especially noticeable in the summer time, particularly in the Southern States. They are the most minute of flies, and swarm about the eyes of dogs and domestic animals, and in some places are annoying by getting into the eyes of human beings. These are the forms which were considered by Hubbard to be responsible for the spread of the eye disease known as "pink-eye" in Florida, a complaint so prevalent at times, especially among

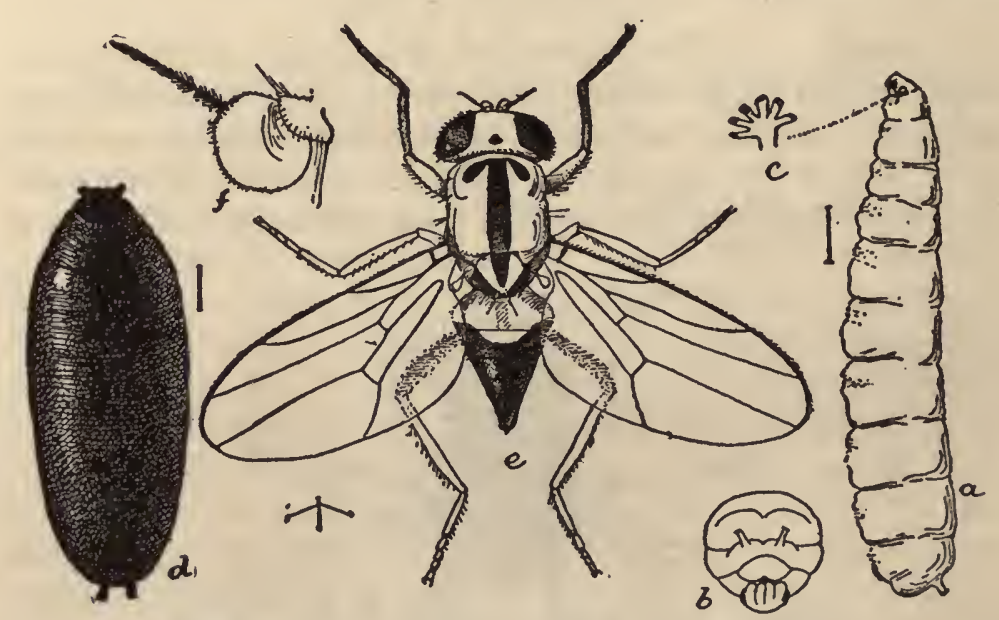

Fig. 106.-Gaurax anchora. (Author's Illustration.)

school children, as to cause the schools to close. The species of the true genus Oscinis almost invariably in their larval stage bore into the stems of living plants, especially grasses, but one species lives in the seed pods of the so-called Indian bean tree (Catalpa speciosa). A member of this family is the famous "frit fly" of Europe, and causes great damage to grain crops, especially in North Europe. 


\section{THE LITTLE FRUIT FLIES}

\section{(Family Drosophilide.)}

This group includes the little fruit flies, or pomace flies, so commonly seen about decaying fruit and also about other decaying vegetation. They are frequently found in houses in the autumn about dishes containing pears, peaches and grapes. They are attracted to fruit both for food and as places for oviposition, since

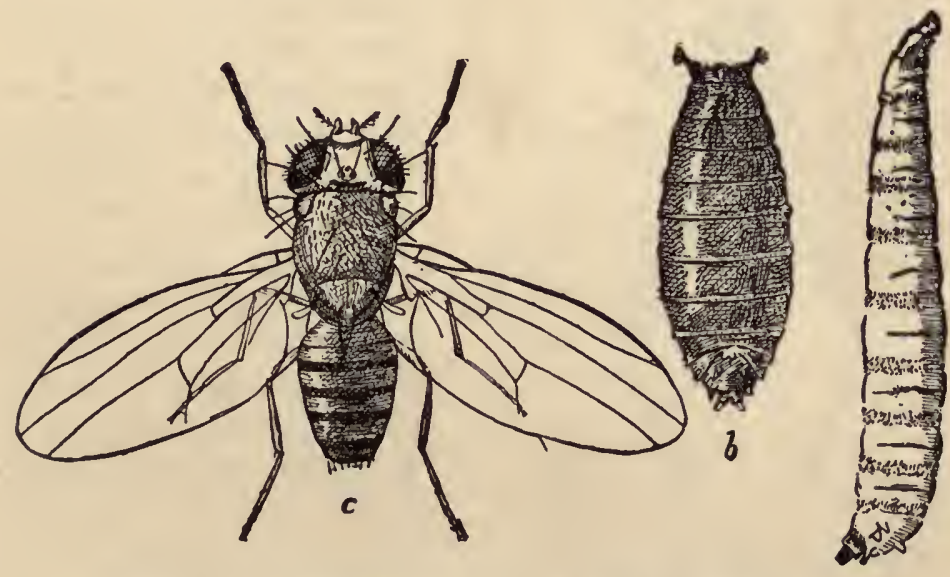

Fig. 10\%-Drosophila ampelophila : $a$, larva ; $b$, pupa; $c$, adult.

their larvæ live in decaying vegetable matter. They are also called "vinegar flies," from the fact that their white, slender larvæ are frequently found in canned fruits and pickles which have been imperfectly sealed, occurring mostly near the top of the jars, but living without inconvenience in the briny or vinegary liquid, and transforming within brown puparia around the edges of the jar.

Drosophila ampelophila seems to be the commonest species all over the United States, and is mainly responsible for the injury to canned fruits and pickles. Drosophilas are found commonly 185 
around the refuse of cider mills and fermenting vats of grape pomace. Forbes has stated that in 1884 they damaged the grape crop at Moline, Ill. They attacked most frequently the grapes which had been mutilated by birds or damaged by rot, but, having once commenced on a cluster, they passed from one berry to another, the flies meanwhile constantly laying eggs.

A brood of these flies may develop in twenty days. I have recently shown that these flies are attracted to dangerously foul substances, and that they may be responsible for the spread of certain diseases.

The larva of Scaptomyza flaveola (Meig.) makes blotch mines in the leaves of radishes 


\section{FAMILIES GEOMYZIDA, AGROMYZIDAE AND BORBORIDAE}

The family Geomyzidæ is a small one, and is composed of very small flies about which there is nothing especially distinctive or especially interesting. They are usually rather slender and of a grayish or yellow color, looking something like the pomace flies. Those of which the metamorphoses are known have larvæ which mine the leaves of grasses and grains.

The Agromyzid flies, as a rule, are small, insignificant creatures of dull colors. The larvae of some of them feed on living plants, forming burrows or mines in various parts, and especially in the leaves, while the larvæ of others (of the genus Leucopis)

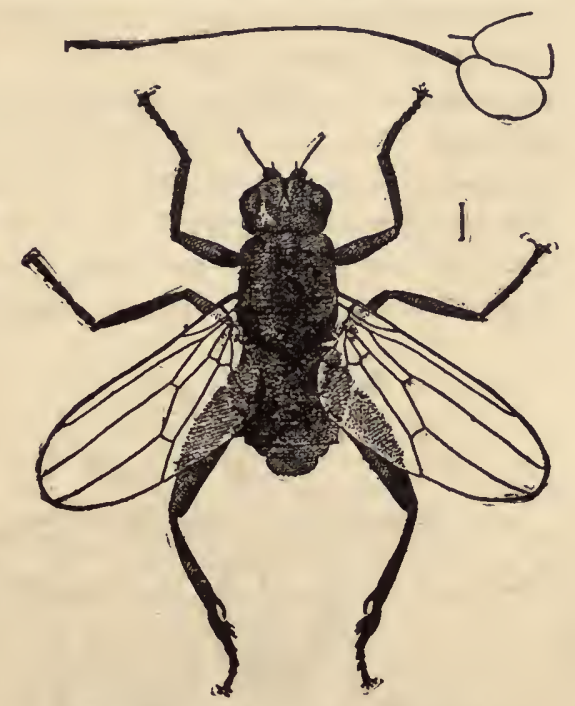

Fig. 108.-Sphærocera subsultans. (Author's illustration.) prey upon plant-lice and scale insects. None of the species, however, appear to have any great economic importance.

The Borboridæ are little flies, usually of dark color, and with clear wings. They are often to be found in great numbers upon dung, and, in fact, appear to breed exclusively in this substance. One of the species of the genus Limosina (L. venalicius) was found abundantly in Cuba by Osten Sacken, and as it is an African species it is very probable that it was brought over in slave ships. The flies of this family have some value on account of their function as scavengers, but they may be responsible for the spread of disease among human beings. 


\section{THE BIRD TICKS.}

\section{(Family Hippoboscida.)}

This group comprises a series of very remarkable flies which are parasitic upon birds and mammals, moving quickly about among the feathers and the hair. Unlike other external insect parasites of vertebrate animals, many of them possess wings although they are modified structurally in many other respects as a result of their parasitic mode of life. One of the most remarkable features of the bird ticks (as they are called), is the fact that they not only do not lay eggs but that they do not lay larvæ. They are pupiparous insects, the eggs having hatched and the larva

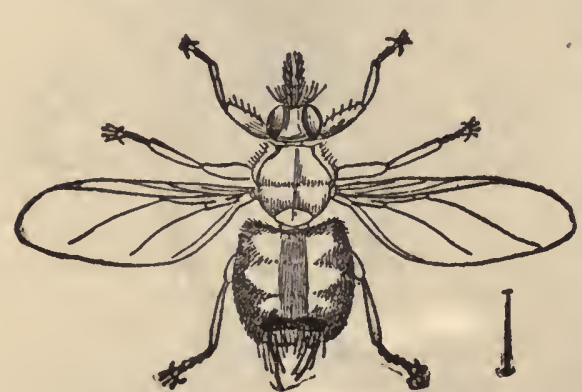

Fig. 109.-Olfersia americana. (After Packard.) developed until the pupa state is nearly reached within the body of the mother. They are extruded by the parent fly only when nearly ready to become pupæ. Bird ticks are not very prolific; only a single young is brought forth at a birth. The proboscis of the adult fly differs from that of other flies, and consists of two hard flaps which spread apart allowing a tube to be thrust out from the head.

Very little is known of the intimate life history of any of them. Hippobosca equina is a winged species which occurs upon the horse and which is known in England as the forest fly. Possibly the best-known species is a wingless form known as the sheep tick (Melophagus ovinus). In this insect the larva has been shown to be nourished by secretions from certain glands of the mother fly. One of the commonest of our North American species is Olfersia americana which is found upon several kinds 

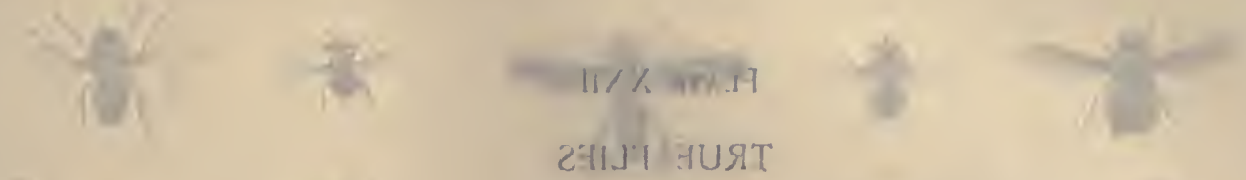

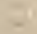

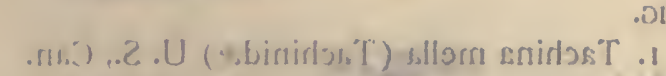
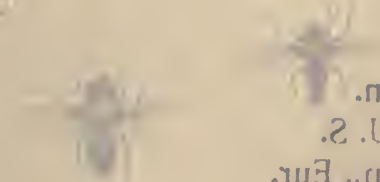

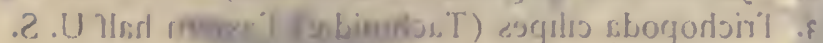

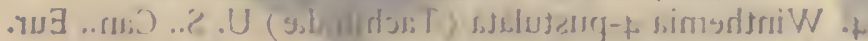

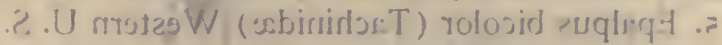

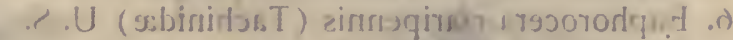

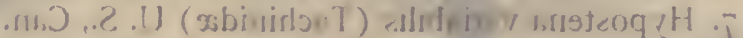

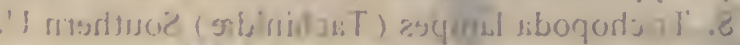

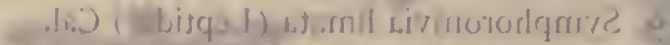

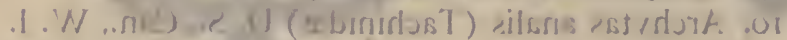
.

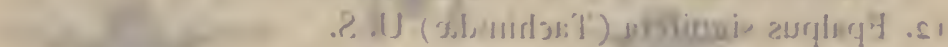

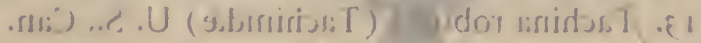
?.U (

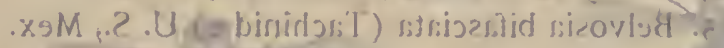

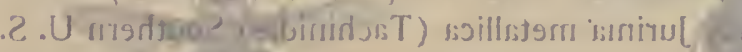

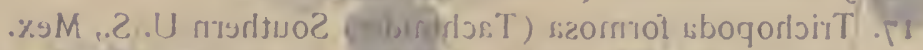

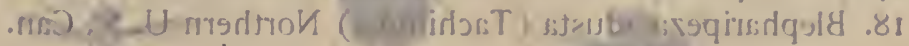

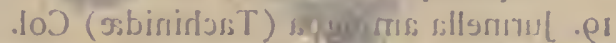

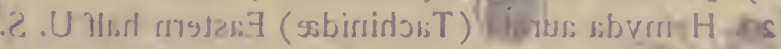

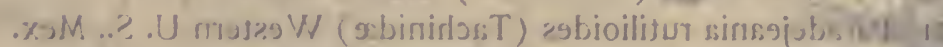

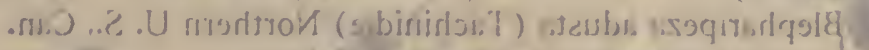

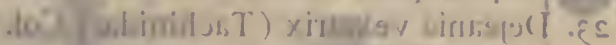

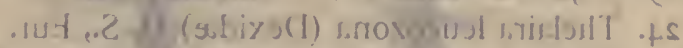

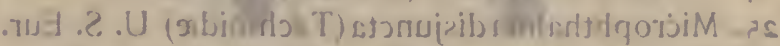

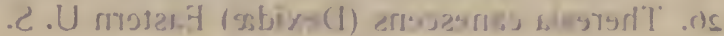

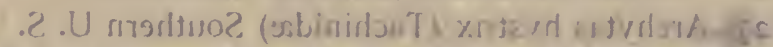

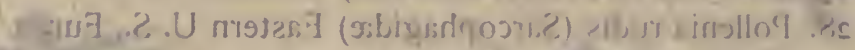

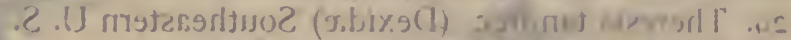

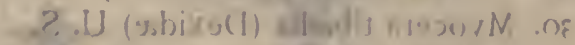

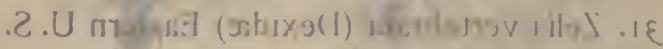

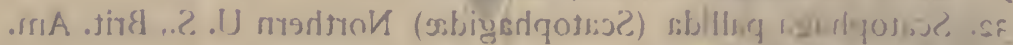

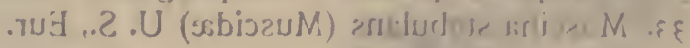

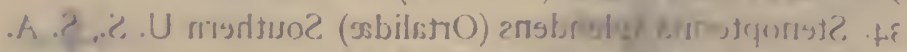

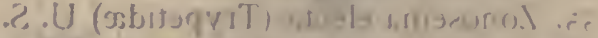

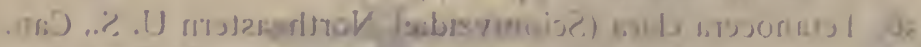

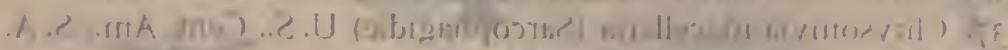
. C.1) (9.3)

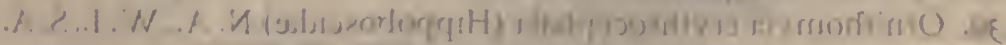

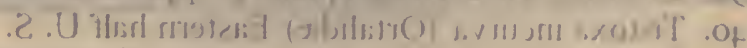

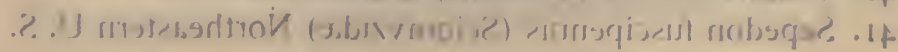


PLATE XXII.

\section{TRUE FLIES}

FIG.

1. Tachina mella (Tachinidæ) U. S., Can.

2. Gymnosoma fuliginosa (Tachinidæ) U. S., Can.

3. Trichopoda cilipes (Tachinidæ) Eastern half U.S.

4. Winthemia 4-pustulata (Tachinidx) U. S., Can., Eur.

5. Epalpus bicolor (Tachinidæ) Western U.S.

6. Euphorocera claripennis (Tachinidx) U.S.

7. Hypostena variabilis (Tachinidx) U. S., Can.

8. Trichopoda lanipes (Tachinidæ) Southern U. S.

9. Symphoromyia limata (Leptidæ) Cal.

10. Archytas analis (Tachinidæ) U. S., Can., W.I.

11. Peleteria tessellata (Tachinidæ) Northern U. S., Can., Eur.

12. Epalpus signifera (Tachinidæ) U. S.

13. Tachina robusta (Tachinidx) U. S., Can.

14. Archytas lateralis (Tachinidæ) U.S.

15. Belvosia bifasciata (Tachinidæ) U. S., Mex.

16. Jurinia metallica (Tachinidæ) Southern U.S.

17. Trichopoda formosa (Tachinidæ) Southern U. S., Mex.

18. Blepharipeza adusta (Tachinidæ) Northern U. S., Can.

19. Jurinella ambigua (Tachinidæ) Col.

20. Hemyda aurata (Tachinidx) Eastern half U.S.

21. Paradejeania rutilioides (Tachinidæ) Western U. S., Mex.

22. Blepharipeza adusta (Tachinidæ) Northern U. S., Can.

23. Dejeania vexatrix (Tachinidæ) Col.

24. Thelaira leucozona (Dexidæ) U. S., Eur.

25. Microphthalma disjuncta(Tachinidæ) U.S. Eur.

26. Theresia canescens (Dexidæ) Eastern U.S.

27. Archytas hystrix (Tachinidx) Southern U. S.

28. Pollenia rudis (Sarcophagidæ) Eastern U. S., Eur.

29. Theresia tandrec (Dexidæ) Southeastern U. S.

30. Myocera tibialis (Dexidx) U.S.

31. Zelia vertebrata (Dexidx) Eastern U.S.

32. Scatophaga pallida (Scatophagidæ) Northern U. S., Brit. Am.

33. Muscina stabulans (Muscidæ) U. S., Eur.

34. Stenopterina splendens (Ortalidæ) Southern U. S., S. A.

35. Zonosema electa (Trypetidx) U. S.

36. Tetanocera clara (Sciomyzidæ) Northeastern U. S., Can.

37. Chrysomyia macellaria (Sarcophagidæ) U.S., Cent. Am., S. A.

38. Strauzia longipennis (Ortalidæ) U.S.

39. Ornithomyia erythrocephala (Hippoboscidx) N. A., W. I., S. A.

40. Tritoxa incurva (Ortalidx) Eastern half U.S.

41. Sepedon fuscipennis (Sciomyzidæ) Northeastern U.S. 


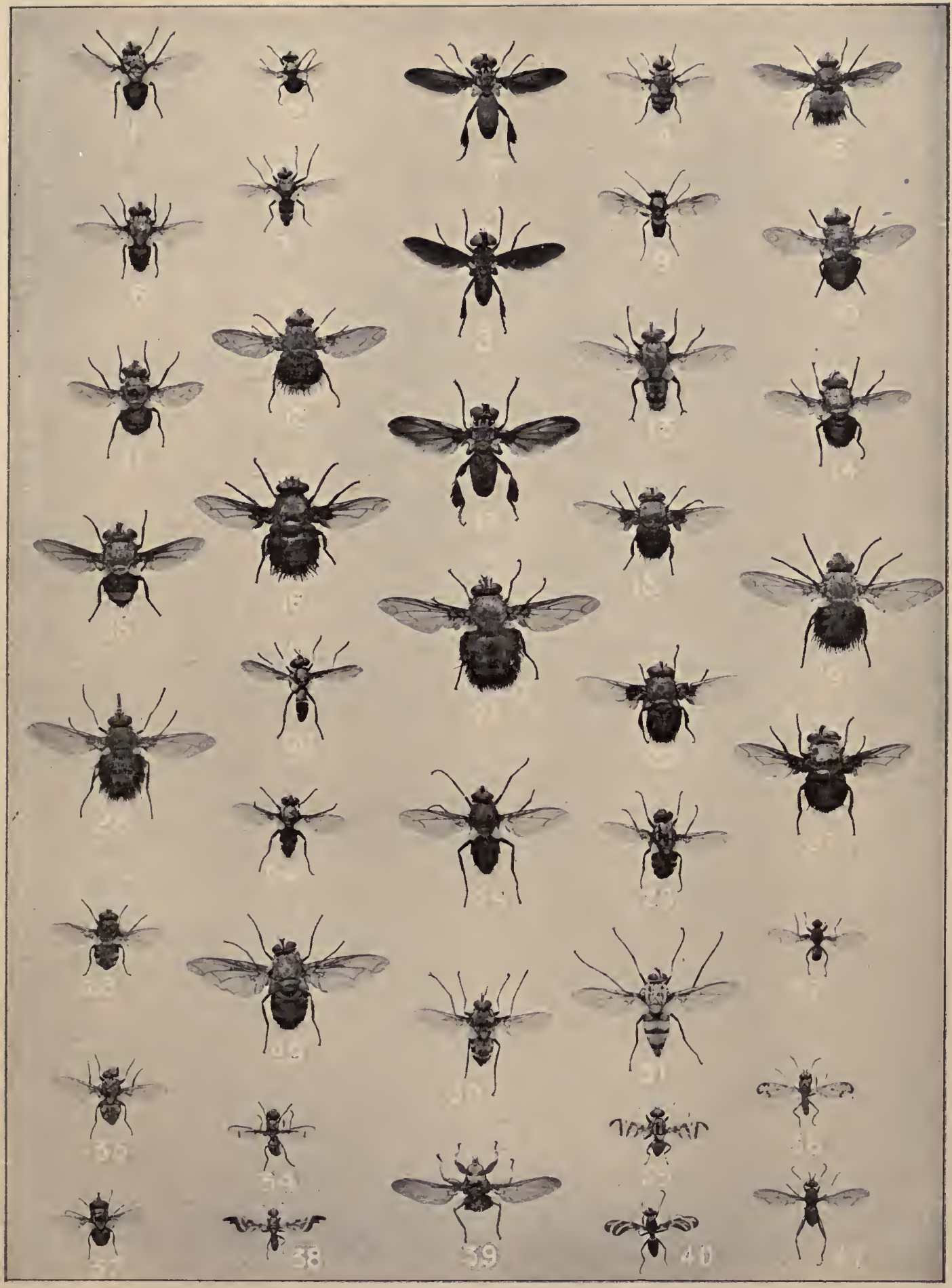



of birds, such as the horned owl, certain hawks, the ruffed grouse or partridge, and which has a hard, smooth, flattened yellow body. The species which belong to the genus Lipoptena live on mammals, and apparently live for a long time. When they first

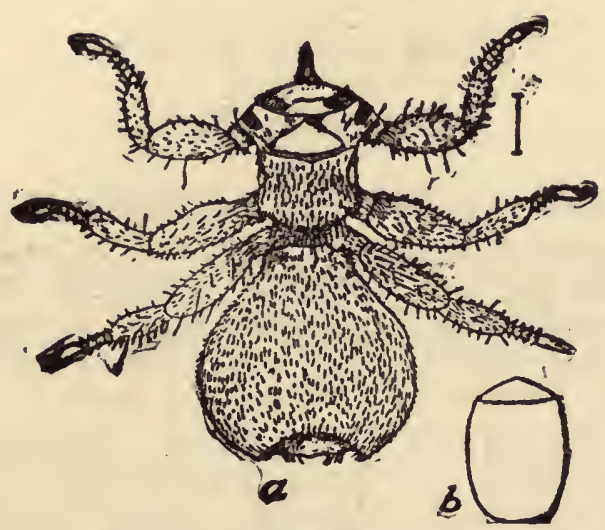

Fig. I 10.--Melophagus ovinus.

(After Packard.)

appear they have wings, but when they have found a satisfactory location on some deer or other animal they lose their wings either by biting them off or casting them. While still winged they may live on birds. In other words, apparently too lazy to fly, they use birds as their means of conveyance until they find themselves in the immediate vicinity of some deer. That the name "bird ticks" should have been applied to these creatures is very unfortunate, since the name tick ought to be restricted to the spider-like parasites of the family lxodidæ, but in the case of the so-called sheep tick, which is really a dipterous insect, it is not surprising that the name tick should have been applied since no one in his senses would think that it is a fly unless he were familiar with the intimate structure of the Diptera and of the true ticks. 


\section{THE BAT TICKS.}

\section{(Family Nycteribiida.)}

These are also wingless, degraded, parasitic flies, which have a similar misnomer in the vernacular, and are called bat ticks. They are quite the most extraordinary of all the flies, the body being small and the legs remarkably long, so that they look

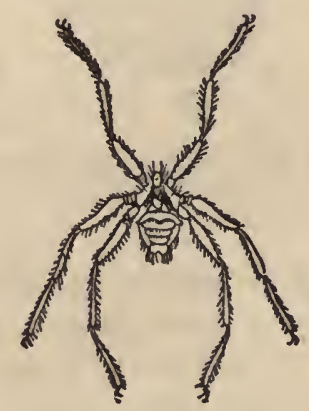

Fig. II I.-Nycteribia sp. (After Packard.)

almost like spiders. The head is very small and the eyes may be entirely lacking. They are rarely more than one-sixth of an inch in length, but the long legs, which are frequently banded with jet black and silvery white, render them quite conspicuous. 


\section{FLEAS}

\section{(Order Siphonaptera.)}

The insects of this order, comprising all of the true fleas, are all contained in a single family, the Pulicidæ. They are all wingless, the mouth-parts are formed for sucking, and the body is compressed from side to side. The antennæ are short and thick, and are placed in depressions behind the simple unfaceted eyes. The metamorphosis is complete. They are the greatest jumpers known in nature. The fleas are like the mosquitoes, comparatively few in number of species, but very abundant in individuals, and well represent in structure the degraded form which is the result of a semiparasitic life. They prey upon nearly all species of warm-blooded animals, some, and in fact most species of fleas, passing readily from one species of animal to another. Very many different kinds of birds are infested by Pulex avium, while Pulex serraticeps occurs all over the world,

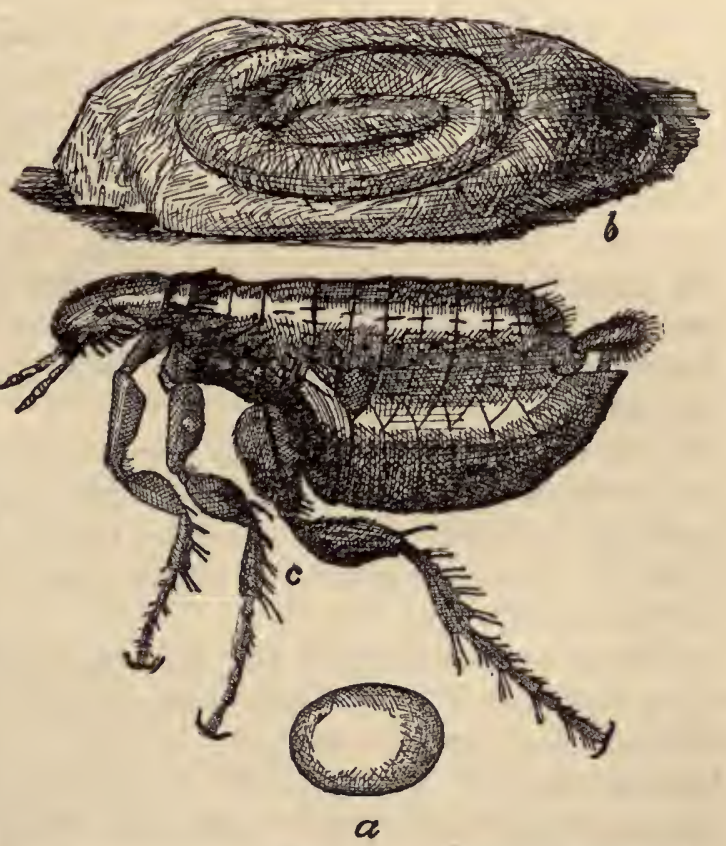

Fig. 112.-Pulex serraticeps. (Author's illustration.) 
infesting cats and dogs, both domestic and wild, upon the Egyptian Ichneumon and the common European pole-cat, the striped hyæna, the common hare, the raccoon, and it also bites human beings. The food of flea larvæ has been the subject of some discussion. The old statement that the female flea disgorges drops of blood upon which her young feed, seems true only to a small degree. Laboulbène, the famous French entomologist, at first believed that blood was necessary for the nourishment of the larvæ, the reddish colored contents of the digestive tract making him think so, but he found that they would flourish and com-

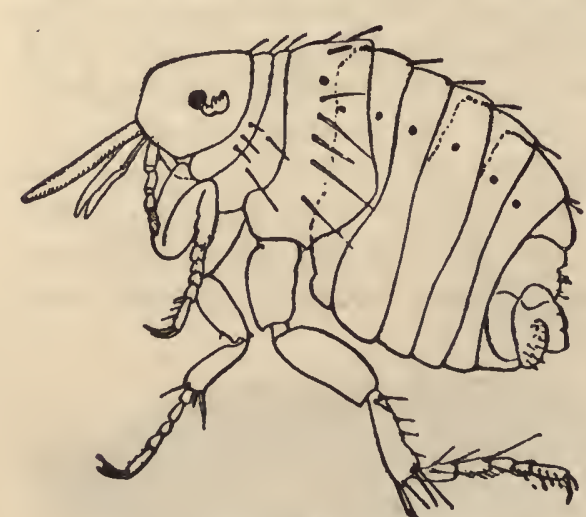

Fig. Ir3.-Sarcopsylla gallinacea. (From Insect Life) plete their metamorphoses in sweepings in which there was no trace of blood. He concluded that all that has been said about $P$. irritans (the human flea of Europe) nourishing its young on dried blood is very problematic. Mr. W. J. Simmons found flea larvæ feeding upon a dust composed of fragments of cuticle, hairs, fibers, and pellets of dried blood, the last being probably the natural excreta of the fleas. The writer has fed them successfully upon moist bread crumbs, and it is reasonably certain that they will feed upon the dust or minute particles of almost any kind of organic matter.

The minute, delicate, whitish eggs hatch into slender, wormlike larvæ, which, when full-grown, spin delicate cocoons, and transform to pupæ, from which issue the adults. Rather more than 100 species are known, of which about 30 have been found in the United States.

In the recent important and alarming indictments of certain species of insects as carriers and transmitters of certain human diseases, fleas have not escaped. Grassi considers that the cat and dog flea ( $P$. serraticeps) is an intermediate host of Tænia (tape-worms), while Simon and others have brought forward some proof that certain fleas convey the germs of the bubonic 
plague from rats to human beings, and from one person to another.

A curious and aberrant flea is the so-called "chigoe" or chigger of tropical America (Sarcopsylla penetrans), not to be confused with the so-called chigger of Virginia and southward, which is the larva of a mite. The female of the chigoe, sometimes found in tropical Florida, and frequently brought to our southern seaports (New Orleans, Savannah and Charleston), buries the forepart of her body in the flesh of human beings, the abdomen becoming greatly distended and discharging a number of eggs. Another species of the same genus (S. gallinacea), sometimes called the chicken flea, buries itself in the eyelids of domestic fowls in our southern states and in other parts of the world.

\section{Life-History of the Cat and Dog Flea (Pulex serraticeps Gervais.)}

This insect, commonly known as the cat and dog flea, as stated above, occurs on a number of different animals, and in the northeastern United States at least is the common flea, which proves a pest in houses. The true human flea, so-called ( $P$. irritans), seems to be very rare in the United States, although common enough in Europe, as travelers and those who have read Mark Twain's account of the "chamois" well know. The eggs of the cat and dog flea are deposited between the hairs of the infested animals, but are not fastened to them, so that when the animal moves about or lies down, large numbers of the eggs will be dislodged and drop to the ground or floor, or wherever the animal may be at the time. An easy way to collect them, therefore, is to lay a strip of cloth for the animal to sleep upon, and afterwards brush the cloth into a receptacle, in which the eggs will be found in numbers. The eggs hatch under favorable circumstances in from two to four days, and the young larvæ, very slender and elongate, white in color, and of the structure shown in the accompanying figure, crawl into the floor cracks and feed upon the accumulated dust. They may be reared under observation, in saucers, between layers of blotting paper, with dust and bread crumbs. Specimens studied by Mr. Pergande, at 
the writer's office in Washington, showed that the larva casts its first skin in from three to seven days, and its second skin in from three to four days. From seven to fourteen days after hatching, they began to spin a delicate silken cocoon, which, when completed, was almost transparent, except where it was covered with dust particles. In the cocoon the pupa, as shown in the accompanying figure, was formed and the insect remained in the pupal condition for four days. Thus an entire generation may be developed in about a fortnight, and since the adult female lays many eggs, it is not surprising that persons having cats or dogs about the house will frequently (and especially where the houses are closed during the summer, and the floors left unswept) find their domiciles overrun with thousands of these active, biting creatures.

The remedies consist in a free use of fresh pyrethrum powder, in spraying the floors and floor coverings with benzine or in thoroughly washing the floors with hot water and soap. On pet animals pyrethrum powder should be freely used. 


\section{THE CADDIS FLIES}

\section{(Order Trichoptera.)}

Almost everyone who likes to watch curious living creatures knows the caddis worms - the strange little larvæ which construct cases of bits of leaves, twigs, small stones, or sand, and which live under the water of permanent streams or ponds. They are very good objects for the aquarium, and are structurally of great interest. While the case-bearing larvæ are so well known, it is quite different with the adult insects, which

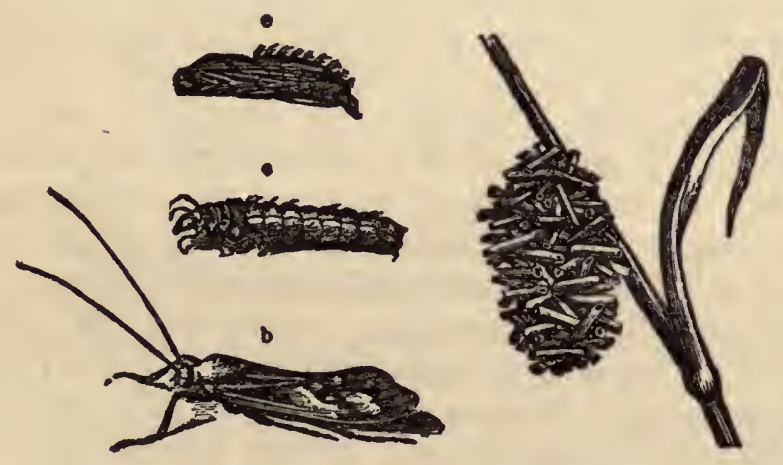

Fig. 1 14.-Caddis fly and larva.

(From Lugger.)

not only are seldom seen in collections, but have been studied to a comparatively slight extent in this country. They have four wings, which are more or less clothed with hairs, so that the caddis flies look very much like moths. The mouth-parts are rudimentary, and the antennæ are thread-like, frequently very long and many-jointed. The pupæ resemble the perfect insects in general appearance, and become active before the last molt. The hind wings of the flies are often broader than the forewings, and may be folded in repose. 
The caddis flies are often seen about the margins of streams and frequent shady places. They seldom fly during the day, but are often attracted to light at night.

The eggs are laid in a double mass, which is gelatinous, and usually green in color. This mass is usually attached to the surface of some water-plant, but it is supposed that certain species creep down the stems of aquatic plants under water for the purpose of laying their eggs. The larvæ are all aquatic, with the exception of one form, which lives in damp moss on land, and they are nearly all protected by a case of some form or another. The cases, as just stated, may be composed of leaves, either attached by their edges or placed longitudinally, or they may be bits of stick arranged in many different ways, or stones, or grains of sand, or even water-snail shells may be used for the purpose, attached to the outside of the case, in such cases sand being the main material. All of these different substances are fastened together by means of silk, spun by the larvæ, and they serve to protect the caddis worms from the predatory insects so often found in streams, and also from fish as well.

In the majority of instances the cases are cylindrical, but sometimes they are curved in a horn-like manner, and in other cases they are very strangely involuted, like a snail-shell. In fact, the case of a caddis worm was once described by a conchologist as a new species of snail-shell. Then there is another form in which the case resembles a bottle with the bottom cut away and the lower part compressed until only a slit is visible. In the majority of instances the cases are free, and the larva crawls or swims about with only its head and thorax protruding from the orifice, but in other instances they are firmly attached to rocks or submerged logs.

The larva itself is elongate and usually cylindrical, and while the head and thorax are tough and horny, the abdomen is thinskinned, delicate, and of a pale color. It breathes by means of tracheal gills, which issue from the sides of the abdomen. It is not known how many times any of them shed the skin and a molt has never been observed to my knowledge. They live several months in the larval stage, and most of them pass the winter in that condition. When ready to transform to pupa, both ends of the case or tube are protected by a silk netting, spun by the larva, which transforms in security, well drawn back 
from either orifice. When ready to transform to the adult stage the pupa works its way through the guarded orifice, swims to the surface of the water, and crawls out, where possible upon a twig or other vegetation, or upon the bank. It may cast its pupal skin while still in the water, the wings remaining unexpanded, but as soon as it leaves the water the wings expand instantly to their full size, and the fly departs through the air. This statement is based upon an interesting observation by Comstock, who states that the instant expansion of the wings is necessitated by the fact that the insects studied by him normally emerge from rapidly flowing streams, which dash over rocks, and if much time were required in this wing-expansion, the water would destroy the wings for purposes of flight, and dash the insect down. The larval food of the caddis flies is mainly vegetable, but there is one group which is carnivorous. The order is not a very large one, but more than one hundred and fifty North American species have been described.

As common as are the caddis worms, and as often as they have been watched in streams and in aquaria, not a single full life history has been recorded in this country, and a fascinating field for original investigation is therefore open to the first comer.

\section{Table of Families}

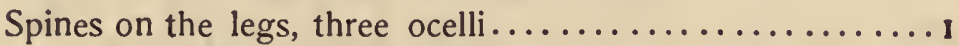

No spines, only hairs and spurs.................

1-Four spurs on middle tibiæ...........Family Phryganeida

Two or three spurs on middle tibix.... Family Limnephilida

2-Last two joints of palpi not elongated, simple not flexible...3

Last joint of palpi, elongate, flexible, palpi hairy ........5

3-Male palpi four-jointed, ocelli absent............

Maie palpi five-jointed, ocelli often present, when absent the spurs $2-4-4 \ldots \ldots \ldots \ldots$......... Family Rhyacophilida

4-No spurs on anterior legs............ Family Hydroptilida

Spurs present on anterior legs........ Family Sericostomatida

5-Basal joint of antenna long and large, wings slender, no ocelli....................... Family Leptocerida

Basal joint of antenna shorter, wings broader, last joint of palpi multi-articulate............ Family Hydropsychida 


\section{FAMILY PHRYGANEIDA}

This family contains the largest of the caddis flies. McLachlan calls them "the giants of the order." They are found only in the northern portions of the globe and some of the most striking species are boreal, or at least inhabit high mountains. They are not very numerous. One of the largest and handsomest, Neuronia semifasciata Say, is shown on the accompanying plate, and has been taken by the writer at night at a light in his cottage in the Catskill Mountains (elevation 2,500 feet). The larvæ live in ponds, swamps, and bogs, and make cylindrical cases of bits of leaves or the fibers of slender-leafed aquatic plants which they arrange in a spiral manner. The cases of the full-grown larvæ are nearly of the same diameter at each end but with the young larvæ it is smaller at the tail-end and that end is cut off by the caddis worm in order to add the remainder to the front end. The cases are open at both ends and the larvæ are probably able to reverse their positions within them. The perfect insects conceal themselves during the day and fly at night. Their flight is lumbering, and they are readily recognized while on the wing. Only two genera are represented in the United States, namely Phryganea and Neuronia, most of our species belonging to the latter genus. 


\section{FAMILY LIMNEPHILIDAE}

The members of this family are smaller than those in the group which we have just discussed but they seem confined very largely to temperate regions. They are common in Canada, Nova Scotia and Labrador, the Northwest Territory and Alaska, but some forms extend down into Louisiana and Georgia. The habits of the larvæ are very variable. Some live in torrents, others in still water. The cases are free, but the materials employed vary in all possible manners. It is some of the members of this group which employ snail-shells, and Comstock has found shells containing living snails securely fastened to the case of one of these larvæ. Thus, he says, "the snail was afforded comparatively rapid transportation whether it desired it or not." It is also to this group that the single form belongs which lives in moss, the only non-aquatic member of the order. The moss which it inhabits may be at the roots of trees far removed from water. In England caddis worms are used very commonly as bait by fishermen, and it is generally the members of this family which are so used. 


\section{FAMILY RHYACOPHILIDAE}

The insects of this group have a broader distribution and more of them extend to the south than any of the preceding families. The flies are small or of medium size. The larvæ are found in rapid streams and, instead of making free cases with which to move about, their cases are formed of small stones fastened with silk to the rocks-a wise provision, considering the rapidly-running character of the streams which they inhabit. These cases are very slight and loosely formed-merely a few pebbles fastened to the lower surface of a large stone by a few threads of silk, but, living on the under surface of rocks as it does, the insect is less liable to be attacked by fish or predatory insects, and does not need so elaborate a case as do the free swimmers or crawlers. When it transforms to pupa a special protection is formed within the case in the shape of a brown cocoon, which is thin but of tough texture. We have a few widely-distributed species in this family, which belong to four genera. 


\section{FAMILY HYDROPTILIDAE}

This group deserves only a word. They are the smallest of the caddis flies, none of them possessing a wing expanse of more than ten millimeters. They look in form much like some of the tineid moths, and possess long fringes to the wings just as do some of these moths. They are attracted by lights in the houses near the water, sometimes in great numbers. The larvæ make very small cases, which are almost seed-like in appearance and are composed of silk dotted with very fine grains of sand. The larvæ are destitute of breathing filaments (probably breathing through the general surface of the skin), and are found amongst water plants or on the surface of stones at the bottom. They have very short legs and a distended abdomen. The cases are provided with a slit at each end, and the larvæ turn around inside the case with facility. 


\section{FAMILY SERICOSTOMATIDAE}

The caddis flies of this group are usually excessively hairy. They vary much in form. Their larvæ usually inhabit streams and not ponds, and the flies are generally found near the breeding places. The larval cases are usually of the ordinary cylindrical form. They are free, and generally made of sand or small stones, but sometimes the cases are broad and flattened and sometimes they are quadrangular, and the most remarkable of all are those which are constructed in the shape of a snail-shell. An almost perfect helix is made by some of them, and it is one of these which, as mentioned above, was described by a conchologist as a new species of snail. That was at a time when shell students described the shells and cared nothing for the animal which inhabits them. We have in the United States a number of species in this family, separated into nine genera, most of the forms being northern, although the two typical Sericostomas inhabit Georgia. 


\section{FAMILY LEPTOCERIDA}

These are caddis flies with very long antennæ, and usually with very hairy wings. It is a large family and widely distributed. About forty species are known from North America, where the genus Setodes is best represented. Some of the caddis flies are very handsome, and also resemble tineid moths, especially the little flies of the genus Adela and its allies. Setodes exquisita Walker well deserves its specific name. The larvæ are found both in ponds and in running streams, but more commonly in the latter. They are not often found in very swiftly running torrents, since their food is largely living vegetation, which does not grow in such streams. The case is free, and is ordinarily composed of sand, nearly cylindrical, but slightly curved, although there are some cases of different shape. 


\section{FAMILY HYDROPSYCHID A}

The caddis flies which should possess the greatest interest for us, because it is a personal interest, belong to this group. Their

- larvæ are the only caddis worms which are carnivorous. They are found both in streams and in ponds, but more commonly in streams. They are elongate and slender, with short legs, and with anal projections which bear strong curved claws with which

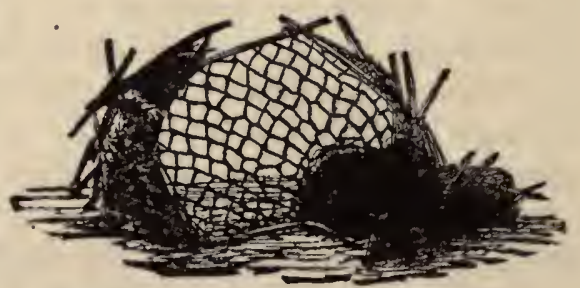

Fig. 11 5--Trap and larval case of Hydropsyche. (Author's illustration.) they hold to the surface of rocks or to their cases. Their cases are fixed and are generally composed of bits of stone fastened to

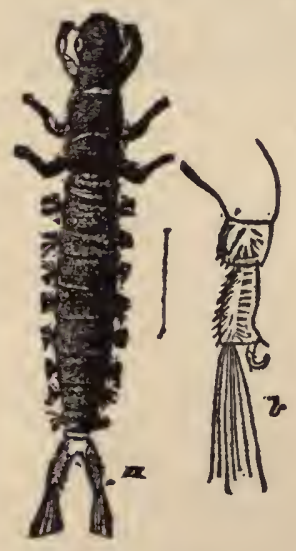

Fig. I 6.-Larva of Hydropsyche, the maker of the trap, figure II 5 .

(Author'sillustration.) large stones or rocks at the bottom of the water. Sometimes several larvæ appear to live in company in a common case, being covered by a sheet of silk, to which minute fragments of leaves and sticks are fastened. There is usually more silk in the construction of the cases of these insects than with the caddis worms of the other families which have stony cases, and although the stones attached to it may be few in number, there is apt to be a pretty dense, silken tube. Sometimes this tube is simply covered with slimy mud and has no other foreign objects attached to it. Some of these larvæ prey upon other aquatic insects and it is probable that this is a general habit of the group. An interesting form which 1 have watched in Rock Creek, near Washington, inhabits a case shaped like a funnel, the tube of the funnel bent nearly at right angles 
with the mouth. The mouth is composed of a network of silk supported by arched bits of twigs. The larva remains hidden in the funnel, watching for its prey to be caught in the open mouth. The cases were preferably placed at the edge of slight depressions in the rocky surface so that the tubular portion was protected from the full force of the current. On the surface of a rock about eighteen inches in diameter 166 of these nets were counted. The larvæ of one of the black flies were very abundant in this stream and were washed into the mouths of these nets and probably formed the principal food of the Hydropsyche larvæ. Therefore, this is one of the few creatures which we know which helps to reduce the number of black flies and it must therefore be considered as very beneficial to mankind. The family is a rather large one and nearly thirty species are known to occur in this country, about half of them belonging to the typical genus Hydropsyche. Macronema zebratum Hagen is one of our handsomest species. Its wings are beautifully spotted and banded with yellowish brown. It occurs from Canada south to Virginia. 


\title{
THE SCORPION FLIES
}

\author{
(Order Mecoptera.)
}

The curious insects of this order are ordinarily called scor. pion flies, although this term applies strictly only to those of the genus Panorpa which have the genital organs of the male adult curiously enlarged and modified so as to resemble the tail of a scorpion. Mecopterous insects have four wings with many veins. The most striking peculiarity is the great prolongation of the head into a stout beak-like organ at the end of which are biting mouth-parts. The metamorphoses are complete. Only one family is contained in this order. 


\section{FAMILY PANORPIDAE}

The representatives of this family in the United States are all contained in the genera Panorpa, Bittacus and Boreus. The true scorpion flies are very common insects in midsummer in most parts of the United States. Some of them have beautiful, spotted wings and are seen flying in the bright sunlight in places where tall herbage abounds. At my country place in the Catskill Mountains they are extremely abundant towards the end of July, flying from one blackberry bush to another and resting frequently upon the golden-rod plants. All Panorpids are carnivorous, but Panorpa has not been observed in this country to capture other insects as does Bittacus. The development of these insects was unknown until the Austrian entomologist, Brauer, in 1863 , succeeded in obtaining eggs and rearing the insect. The larvæ of Panorpa and Bittacus are found near the surface of the ground and feed upon dead animals, including such soft-bodied insects as caterpillars and grubs. The other genus, Boreus, is composed of wingless forms which look something like minute wingless grasshoppers. They occur in winter upon snow in our Northern States.

\section{Life History of a Scorpion Fly (Panorpa mufescens Ramb.)}

This species, which is common in our Northern States, is the first Panorpid to be carefully studied in this country. It was found commonly at lthaca, N. Y., in the summer of 1895 , by Dr. E. P. Felt, flying in moist woods during July and August and especially along streams and where nettles abounded. After confining several females in breeding cages the eggs were obtained. They were laid in an irregular mass, were yellowish white in color, from twenty-four to twenty-nine in each cluster, and from $1 \mathrm{~cm}$. to $2 \mathrm{~cm}$. below the surface of the ground. The earth was moist 
and the larvæ hatched in from six to seven days. The young larva when first hatched is whitish, with a light brown head which becomes darker when the body becomes gray. It looks like a caterpillar but the antennæ and the eyes are unusually prominent. The abdomen bears a row of ringed spines down the back, those toward the anal end of the body being longer. The larvæ pass through several stages of growth within the first two weeks. They burrow into little tunnels under the surface of the ground and remain underground most of the time. They were fed upon raw meat placed upon the surface of the ground. Sometimes they come out of their burrows for feeding. They are cannibalistic and the stronger ones destroy the weaker ones. They wander in search of food and feed upon all sorts of dead flesh. They reach full growth in from three to four weeks, burrow deeper into the ground, excavate another cell, and remain as larvæ for several months before entering the pupa state. There seems to be but one generation annually, the adults issuing in midsummer. 


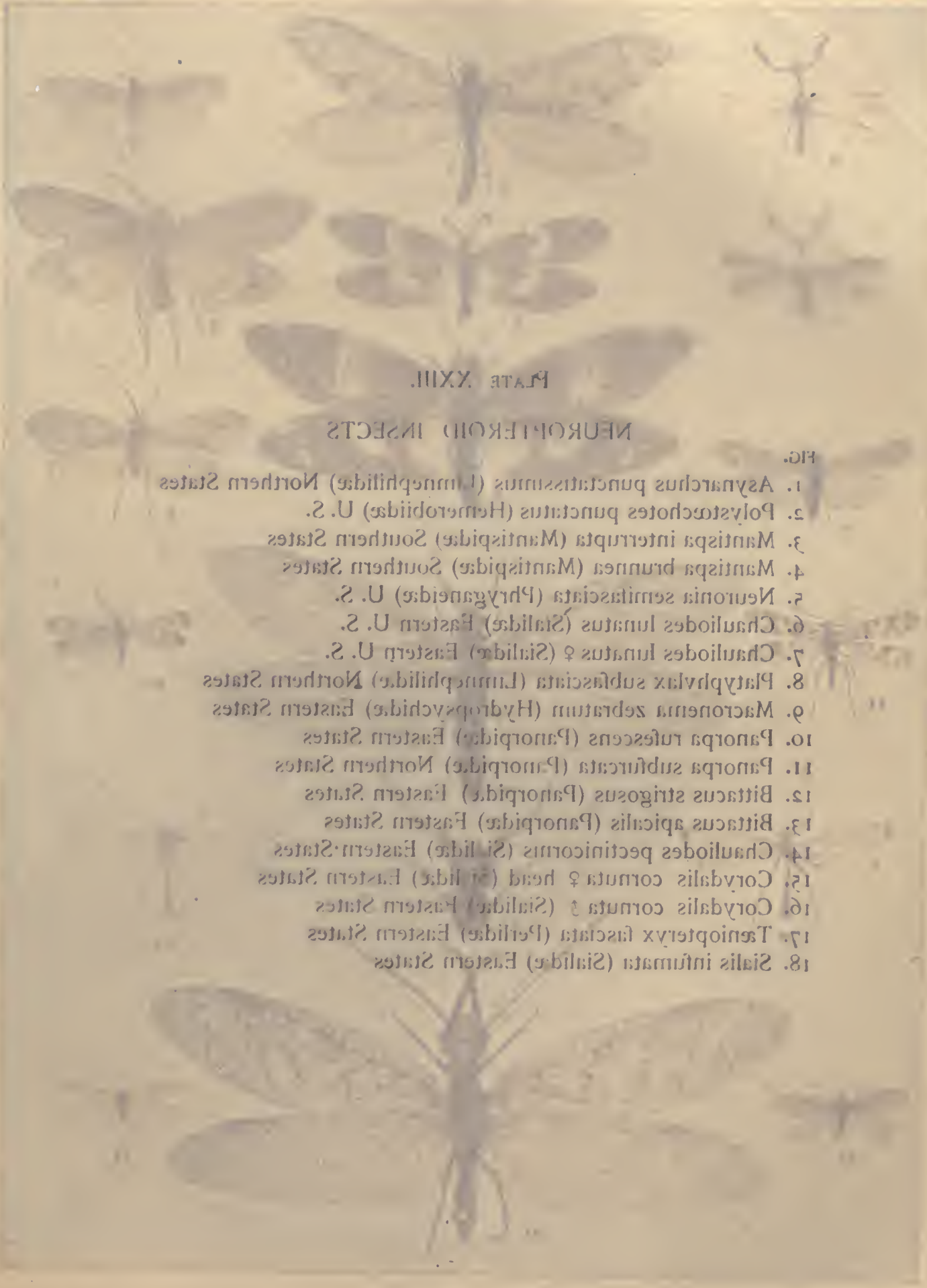




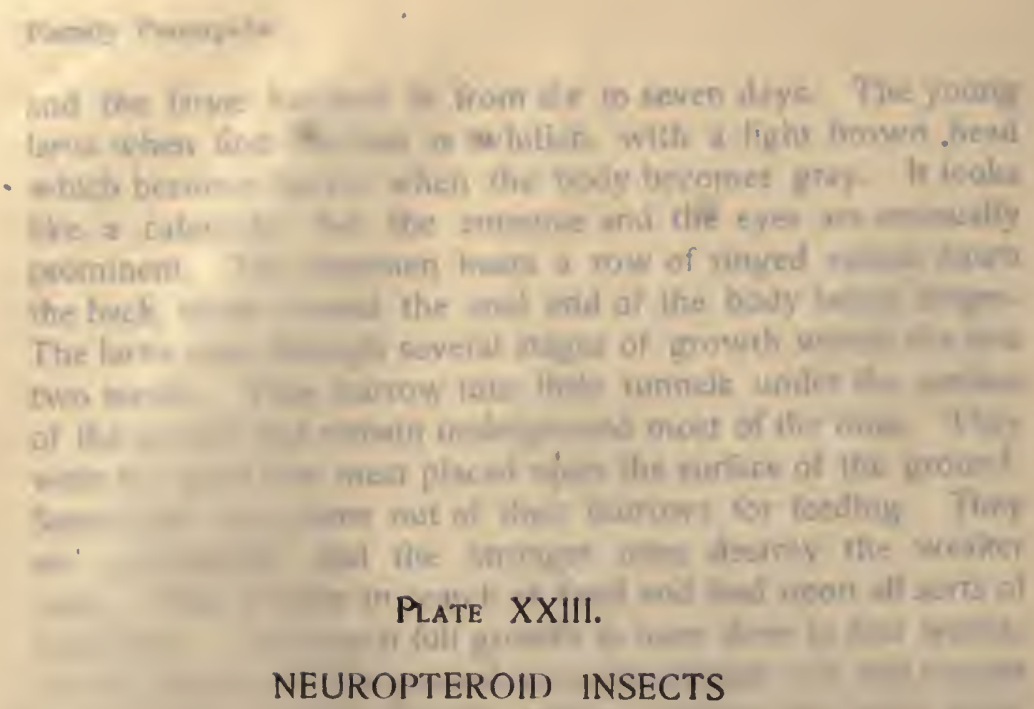

FIG.

1. Asynarchus punctatissimus (Limnephilidæ) Northern States

2. Polystœchotes punctatus (Hemerobiidæ) U.S.

3. Mantispa interrupta (Mantispidæ) Southern States

4. Mantispa brunnea (Mantispida) Southern States

5. Neuronia semifasciata (Phryganeidæ) U. S.

6. Chauliodes lunatus (Sialidæ) Eastern U. S.

7. Chauliodes lunatus $q$ (Sialidæ) Eastern U.S.

8. Platyphylax subfasciata (Limnephilidx) Northern States

9. Macronema zebratum (Hydropsychidæ) Eastern States

ı. Panorpa rufescens (Panorpidæ) Eastern States

II. Panorpa subfurcata (Panorpidx) Northern States

12. Bittacus strigosus (Panorpidæ) Eastern States

13. Bittacus apicalis (Panorpidæ) Eastern States

14. Chauliodes pectinicornis (Sialidæ) Eastern'States

15. Corydalis cornuta $q$ head (Sialidæ) Eastern States

16. Corydalis cornuta of (Sialidæ) Eastern States

17. Tæniopteryx fasciata (Perlidæ) Eastern States

18. Sialis infumata (Sialidæ) Eastern States 


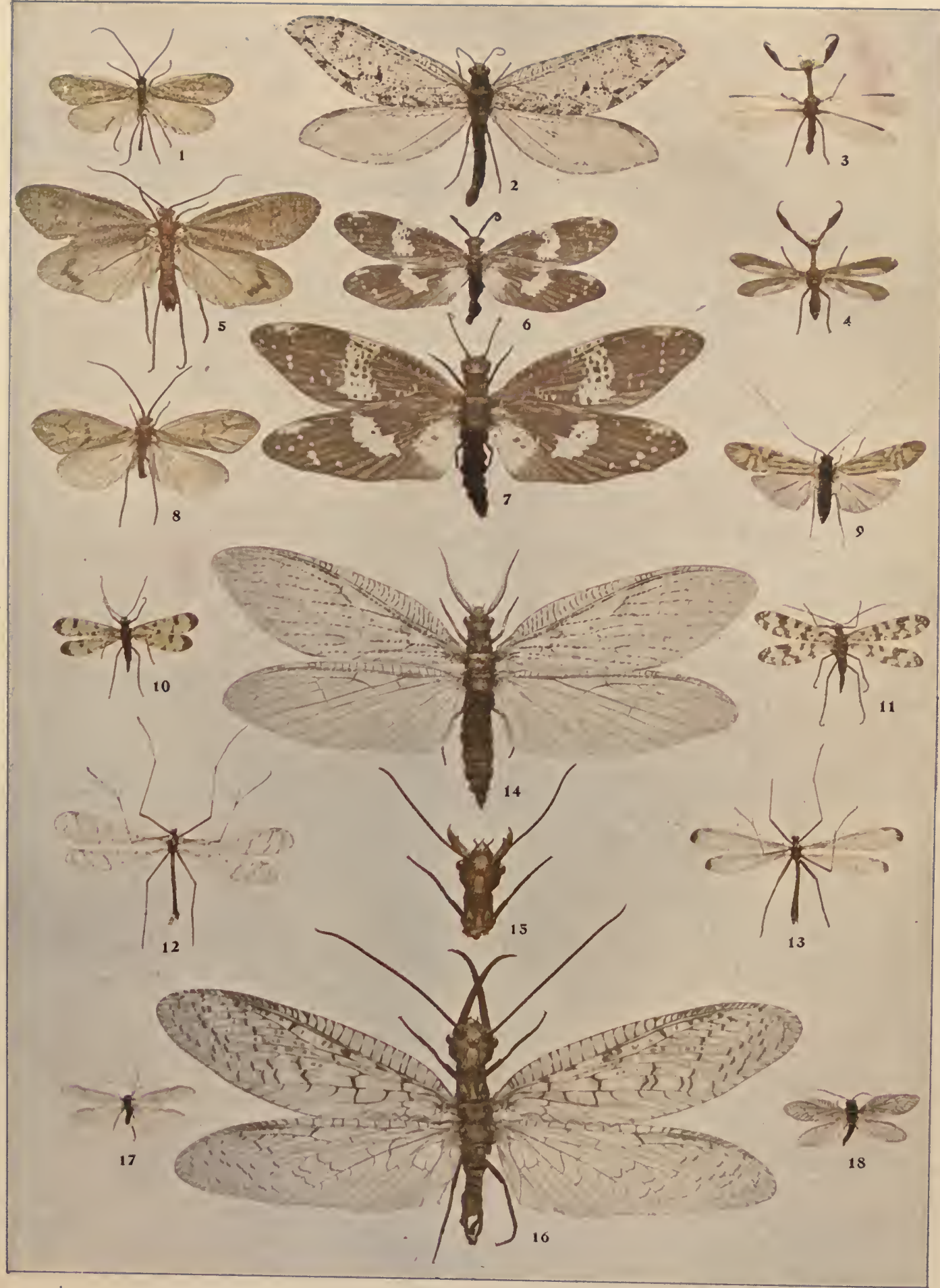


F 


\section{THE LACE-WINGED INSECTS}

\section{(Order Neuroptera.)}

There was a time, and it extended down to comparatively recent years, when all of the insects which would not fit into any of the five principal orders, Hymenoptera, Diptera, Lepidoptera, Orthoptera, or Hemiptera, were placed in the order Neuroptera, but entomologists of late years have changed all that, and the old group Neuroptera, as it was formerly considered, has been divided up into a number of distinct orders.

The first step was to separate those which had a complete metamorphosis from those in which the metamorphosis was incomplete. This resulted in the establishment of only one new order, the so-called Pseudoneuroptera, which included those in which the metamorphosis was incomplete, but the Pseudoneuroptera has again been split up, and we have the Thysanura, the May-flies, the dragon-flies, the white-ants, the Psocids and booklice, the bird-lice, the caddis flies and the scorpion flies, all forming distinct orders, which are treated elsewhere in this work. There remain then those of the old order Neuroptera in which the perfect insect has a biting mouth, two pairs of membranous wings with many veins, and in which there is a complete metamorphosis, the larva being quite dissimilar from the adult, and moreover, in the adults in no case is the head prolonged into a beak-like structure. Even under this restriction of the old order Neuroptera we have still a number of diverse forms in the order, and these are separated into seven well-marked families. It would not be surprising if the old order were still further split up, and as a matter of fact a distinct ordinal name has been suggested for a group of five of these families.

The biting mouth-parts of the Neuroptera as limited at present are not used for the purpose of eating vegetation to any extent, since practically all of the insects in this group are carnivorous and feed upon other insects. Some of them are aquatic, 
but the majority of them live on land, and wherever their prey abounds. Many members of the group are most beneficial in the great number of injurious insects which they destroy, while others are few in number of species and rare in individuals, and some of them prey upon beneficial insects.

\section{Table of Families}

Hind wings with an anal space................. I

Hind wings with no anal space................. 2

1-Prothorax quadrangular when seen from above........... ........................... Family Sialidae

Prothorax long and cylindrical.......... Family Raphidiidae 2-Front legs formed for grasping.......... Family Mantispida Front legs of the ordinary type.................. 3

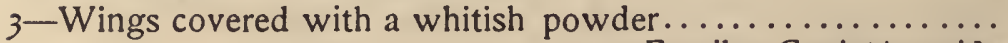
Wings not powdered....................... 4 4-Antennæ clubbed at end............. Family Myrmeleonida Antennæ not clubbed at end.................... 5 5-Antennæ moniliform (beaded).......... Family Hemerobiida 6-Antennæ setiform (bristle shaped)........ Family Chrysopida 


\section{THE DOBSON AND ITS FAMILY}

\section{(Family Sialida.)}

To this group belong the so-called alder flies, fish flies and hellgrammites ; in fact, some of them have many popular names. They have four broad wings, of which the hind ones are wide at the base and capable of being folded behind. The wings have numerous veins, both longitudinal and transverse, forming irregular cells. There is a very complete metamorphosis, the larva having strong-toothed jaws and the pupa being quiescent. It is a small family, with only a few genera, but some of the species are so striking in appearance, so interesting in habits, that the group deserves really more extended mention than can be given it here. All of the forms are aquatic or subaquatic in their earlier stages.

Of the typical genus Sialis we have only two species. They comprise the smaller individuals of the family, and frequent vegetation about the banks of streams. Very many eggs are laid by a single female on the vegetation overhanging streams, from two to three thousand being contained in a single egg mass.

Most of our species belong to the genus Chauliodes, of which the so-called comb-horned fish-fly (Chauliodes pectinicornis L.) is the commonest form throughout the United States east of the Rocky Mountains. The eggs do not seem to be known, but the larvæ are found in the water crawling along weeds and upon the bottom. They are carnivorous, and feed upon other aquatic insects, and when ready to transform to pupæ crawl out upon the bank, and are then found in cavities under stones or even under the bark of trees. The adult insect has a wing spread of three and one-half inches, and is a striking looking creature. Chauliodes lunatus is a large and handsome species with brown wings banded with white. The difference in size between its males and females is very striking.

Needham says that the larvæ of Sialis infumata live in trashy 
places filled with aquatic plants in the border of streams and ponds. They clamber through fallen vegetation with great agility, and push their way readily through sediment fallen upon the bottom. In an aquarium, and probably outside, the long tail is intermittently lashed up and down. This causes a swirl in the water, which is doubtless useful in bringing a fresh supply of well-aërated water into contact with the lateral filaments. When the larvæ are full grown they burrow into the soil for several inches and become pupæ without making a cocoon. The adult fly emerges after two or three weeks.

The eggs of Chauliodes have been found by Needham in the Adirondack region of New York to be very generally parasitized by a very minute egg parasite, a chalcis fly, more than seventy per cent. of the eggs being destroyed in this way.

The most familiar American example of this group is. the so-called hellgrammite fly, some account of which is given in the following paragraphs.

\section{Life History of the Dobson}

(Corydalis comuta L.)

This is one of the most striking and most curious of insects which occur in North America. Its transformations were first described in part by S. S. Haldeman in 1848 . It is interesting to note that at that time, although the insect was well known to most people in the localities where it was found, Dr. Haldeman was never able to discover that it had a vernacular name either in English or German among the so-called Pennsylvania Dutch. Surely this defect must have been speedily remedied, since the great fourwinged fly with its enormous jaws is now generally known as the hellgrammite. while its great, strong, biting, wriggling larvæ are familiar to fishermen in many parts of the United States as Dobsons, or crawlers. In fact, it is likely that not one of our insects has so many vernacular names at the present time. In 1889 Professor W. W. Bailey, of Brown University, collected the names in use in Rhode Island alone for this insect, and they are sufficiently interesting to be repeated. They are : Dobsons, crawlers, amly, conniption bugs, clipper, water grampus, 
goggle goy, bogart, crock, hell devils, flip-flaps, alligators, Ho Jack, snake-doctor, dragon and hell-diver.

It will be very easy to infer from these names alone that the insect is a very extraordinary one and somewhat terrifying in its appearance.

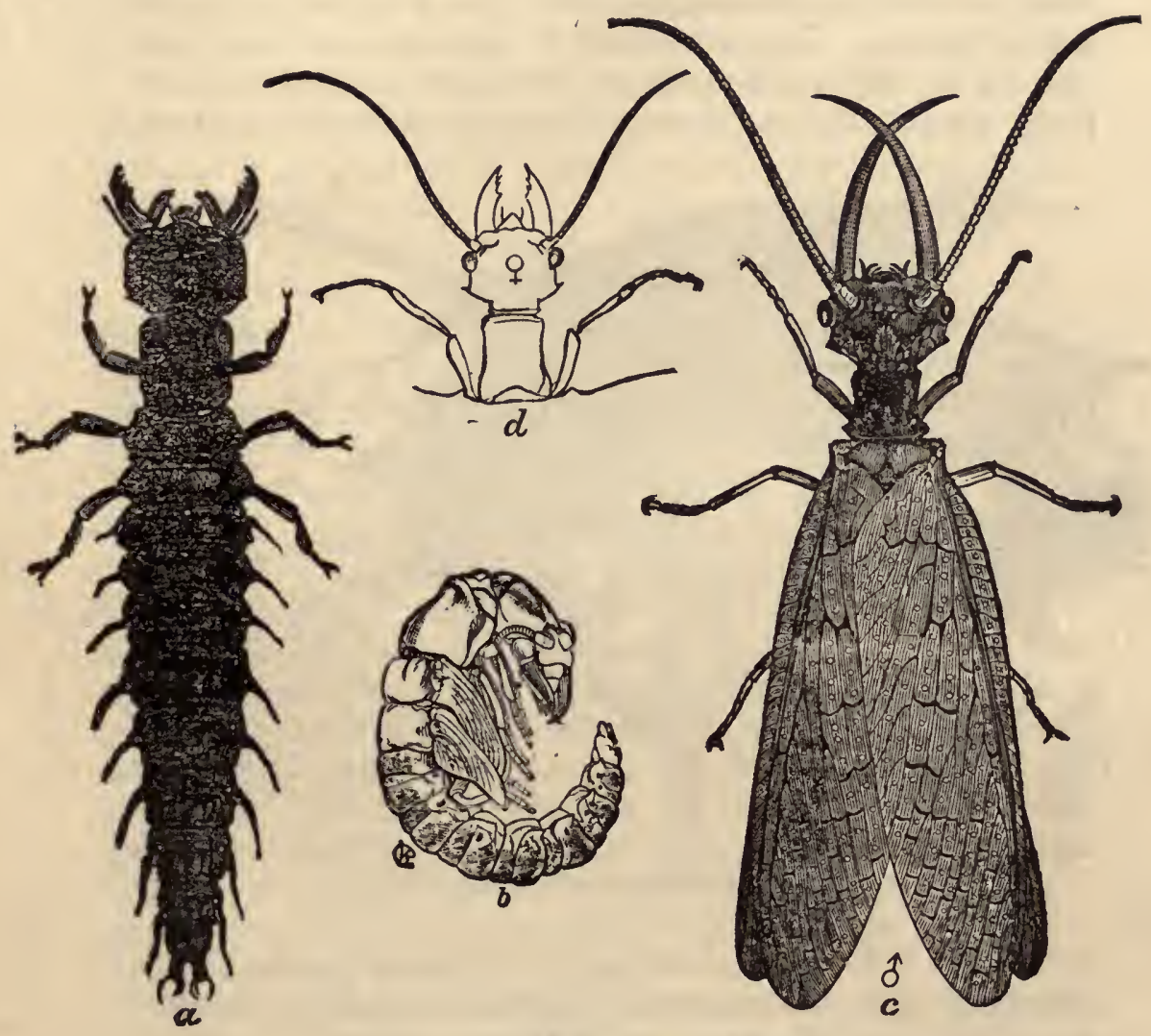

Fig. 117.-Corydalis cornuta (After Riley.)

The adult is a large creature, having a wing spread of more than four inches, and possessed, in the female, of powerful biting jaws, with which it can give a severe pinch to the skin of the person who handles it carelessly. With the male there is a curious modification of the jaws. They are extended into long, curved, piercing organs, which cross when at rest, and which are fully an inch in length. These jaws make the male look particularly 
dangerous, but, fortunately, they do not function as jaws, and are simply used for the purpose of holding the female during marital caresses.

The female lays her eggs in white, chalky-looking masses about the size of a nickel five-cent piece. These masses are somewhat convex, and contain about three thousand very small eggs set on end. They are deposited on the leaves of trees overhanging the water, or on rocks, or the piers of bridges or similar places where the larvæ can readily drop into the stream or pond.

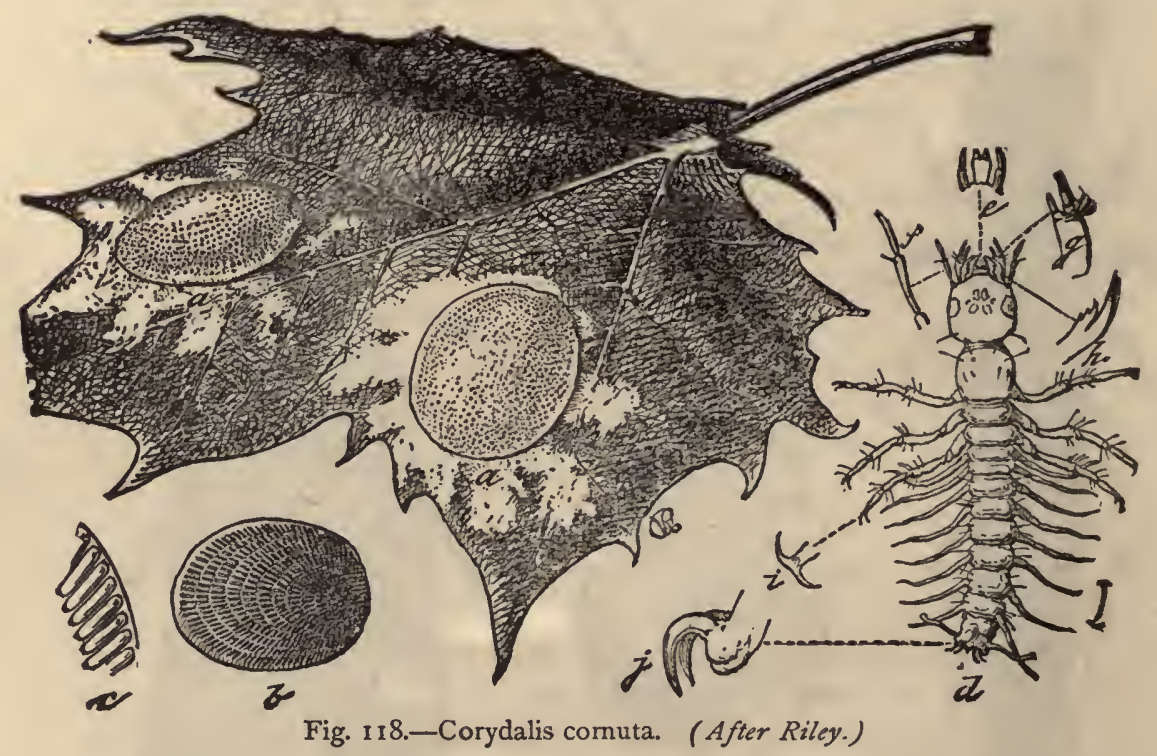

Sometimes they are so abundant as to make the rocks look as though someone had splashed whitewash upon them profusely with a brush.

The young on hatching drop immediately into the water, descend to the bottom, and during the entire larval life, which lasts two years and eleven months, feed upon other aquatic insects, especially the early stages of the May-flies and stone-flies. They hide under stones in swift-running currents, and possess at the anal end of the body two strong tubercles, each provided with two curved claws, with which they hold firmly to one object or another. They breathe through several pairs of tufts of 
breathing filaments situated just beneath each side of the abdomen. They also, when they approach full growth, have spiracles, which are closed, however, until the creature is ready to emerge from the water. The number of molts is not recorded. When full grown (two years and eleven months after its birth), the larva leaves the water and crawls about seeking a suitable place for pupation. It does not travel very far, but it crawls energetically while it is about it, curiously enough, climbing trees occasionally, and on several occasions in lllinois they fell down the chimney of a house occupied by the man who kept the toll bridge over the Rock River. They travel on land only by night, hiding under some stone or log during the day, and it is under stones and logs that they finally pupate.

The larva in color is dark slate-gray, and is remarkably thick-skinned and tough. This fact adds to their value as bait, since one will last a long while. The pupa, however, is light yellow in color, and transforms to the adult fly in about a month. Full grown larvæ begin to emerge from the water in May, and the adults are seen flying a month later.

In rapid, rock-bottomed streams, where these insects abound, the method of catching them is to wade in the streams with a net and lift up the stones in advance, catching the larvæ in the net as they float down with the current.

They bear at the sides of the body, in addition to the respiratory tufts mentioned above, two long filaments on each side, which are furnished with hairs, and may be of some service in swimming. Possibly, also, with the very young larvæ they have a respiratory function. When the larvæ become large, however, dissection shows that the trachex contained in these filaments are insignificant, whereas each element of the branchial tufts possesses a strong branched trachea.

Mr. R. S. Clifton has found an interesting little dark-colored beetle (Anthicus haldemanni) along the Potomac River, feeding upon the egg masses of the hellgrammite fly. The beetle was found to lay its eggs upon the egg masses and its larvæ were found destroying the eggs. Sometimes as many as a dozen of the larvæ were found in a single egg mass. 


\section{THE SNAKE-FLIES}

\section{(Family Raphidiida.)}

Insects of this family are rapacious foes of other insects, and it is a pity that their geographic distribution in the United States is so limited. They are found as a matter of fact practically only on the Pacific Slope, although one species is recorded from Cólorado and another from Arizona.

They are insects of curious structure, the neck being very long and the female bearing a long, curved ovipositor. The larvæ are found under the bark of trees, and Comstock says that in California he has found them commonly under the loose bark of the Eucalyptus.

The codling moth or apple-worm has a habit of spinning its cocoon under the loose bark of apple trees after it leaves the fruit, and many of the codling moth larvæ are destroyed by these Raphidians. In Australia and New Zealand the codling moth is a great scourge, and some years ago an attempt was made to send living Raphidians from California to these English colonies in the hope that they might become acclimated and assist fruitgrowers in their work against the codling moth. Nothing has been heard from them, however, for several years, and the probabilities are that the attempt was a failure. In England these insects are known as snake-flies, from the long neck of the adult.

The larvæ are very voracious and hunt for their prey with great assiduity. They are, like many other carnivorous insects, capable of fasting for a long time. The German entomologist. Stein kept one for eight months without food, but still living.

The pupa is found naked under bark and looks like the adult except that it has not the long neck. It becomes active before giving out the adult, just as do the pupæ of the caddis flies.

Less than ten species inhabit the United States, all of them, as above stated, being far western forms. The full life-history of none of them is known. 


\section{THE FALSE REAR-HORSES}

\section{(Family Mantispida.)}

As the name would indicate, these insects bear some resemblance to the Mantidx, or praying Mantes, or "rear-horses" as they are called in the South. They have a long neck, and the strong, dilated and spined front legs are inserted just behind the head, and are used for capturing their prey.

Very few species inhabit the United States, only two, Mantispa brunnea and $M$. interrupta, having a very wide distribution.

The transformations of these creatures was for a long time a mystery, but Brauer, of Vienna, learned about thirty years ago that they live upon the eggs and young of spiders. Their eggs are very small, and very numerous, and each is placed at the tip of a long stalk, very much the same way as are the eggs of the lace-winged flies which will be described later. The eggs are laid in the fall and the larvæ hatch before winter, but remain hidden without food, until spring. Then they search for the egg cocoons of certain spiders, pierce them, and enter among the eggs. When the eggs are nearly ready to hatch they eat them and the young spiders as well, until they are full grown, molting only twice, and the changing to pupæ or nymphs within the larval skin. Just as in the last family, the pupa is active before giving out the fly, and works its way through the larval skin, through the egg cocoon of the spider, and gives forth the adult.

In the genus Symphasis, which belongs to this family, the transformations of our single native species, which lives in California, have not been studied, but a South American species lives in the nests of a wasp. 


\section{THE DUSTY-WINGS}

\section{(Family Coniopterygida.)}

The insects of this family are the smallest of the Neuroptera. Their wings are covered with whitish powder. In Europe their larvæ have been found to prey upon scale insects and to spin a double cocoon when full grown and ready to transform.

In this country we have only two species, namely Aleuronia westwoodii and Coniopteryx vicina, and the life history of neither has been described. Mr. Banks, however, has found the larvæ of the Aleuronia upon the leaves of maple trees at Washington, where it was probably feeding upon the young of the cottony cushion scale (Pulvinaria innumerabilis) or upon plant-lice found commonly upon the leaves. This larva resembles a small larva of one of the lace-winged flies, but has not the long jaws characteristic of those creatures. 

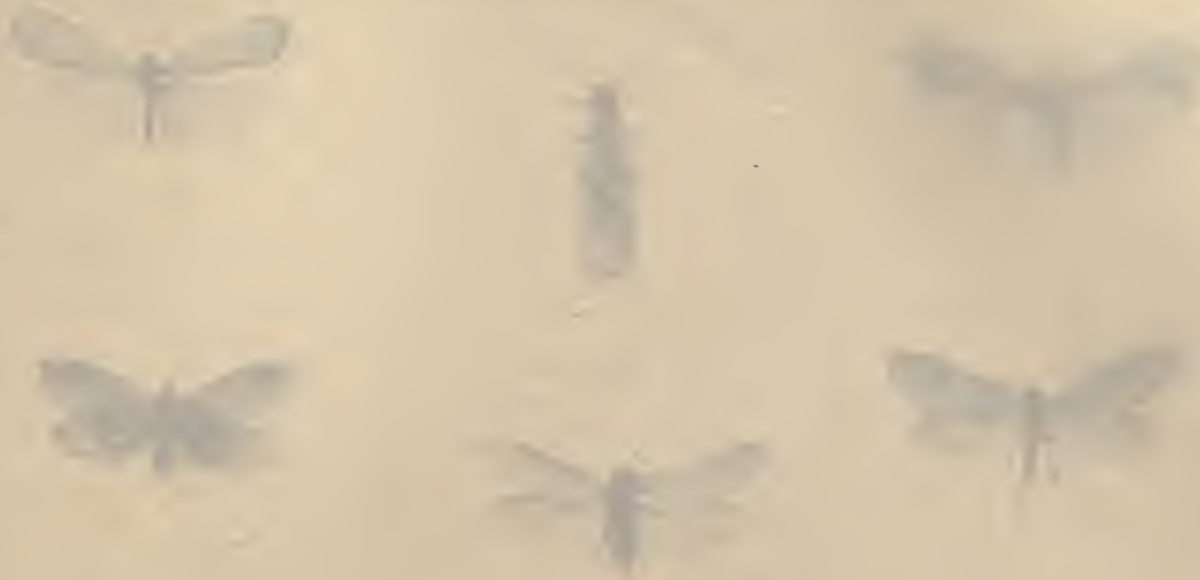

YIX.X. ATA.19

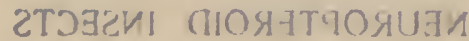

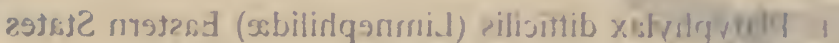

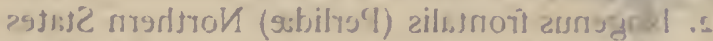

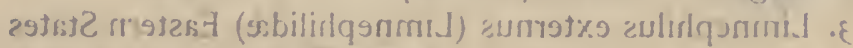

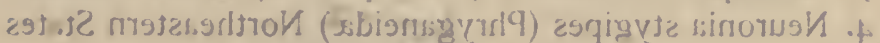

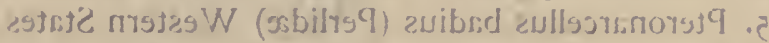

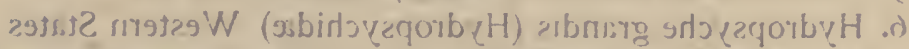

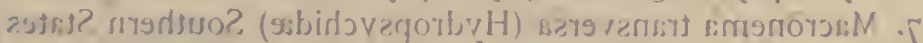

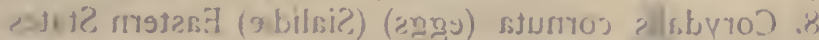

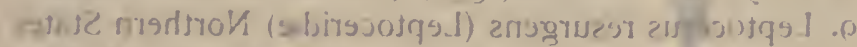

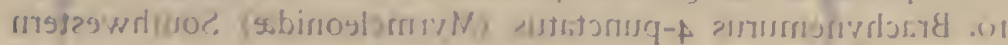
distise.

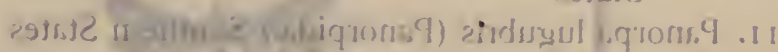

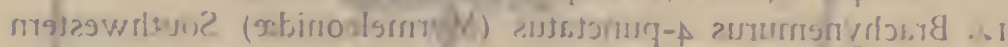
2.96:3?

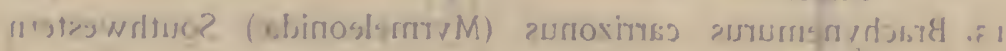
$2975.1 \%$

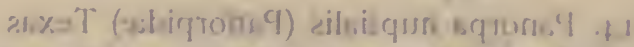

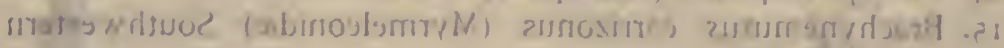
zali,e 


\section{TRIA DUSTY-MINGS}

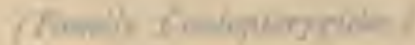

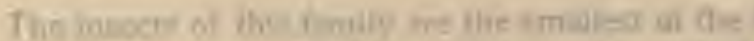

Theiramus wh waress

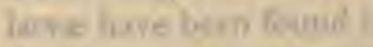

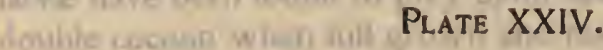

FIG.

\section{Int dith NEUROPTEROID INSECTS}

1. Platyphylax difficilis (Limnephilidæ) Eastern States

2. Isogenus frontalis (Perlidæ) Northern States

3. Limnephilus externus (Limnephilidæ) Eastern States

4. Neuronia stygipes (Phryganeidæ) Northeastern States

5. Pteronarcellus badius (Perlidæ) Western States

6. Hydropsyche grandis (Hydropsychidæ) Western States

7. Macronema transversa (Hydropsychidæ) Southern States

8. Corydalis cornuta (eggs) (Sialidæ) Eastern States

9. Leptocerus resurgens (Leptoceridæ) Northern States

10. Brachynemurus 4-punctatus (Myrmeleonidæ) Southwestern States

11. Panorpa lugubrls (Panorpidæ) Southern States

12. Brachynemurus 4-punctatus (Myrmeleonidæ) Southwestern States

13. Brachynemurus carrizonus (Myrmeleonidæ) Southwestern States

14. Panorpa nuptialis (Panorpidæ) Texas

15. Brachynemurus carrizonus (Myrmeleonidæ) Southwestern States 


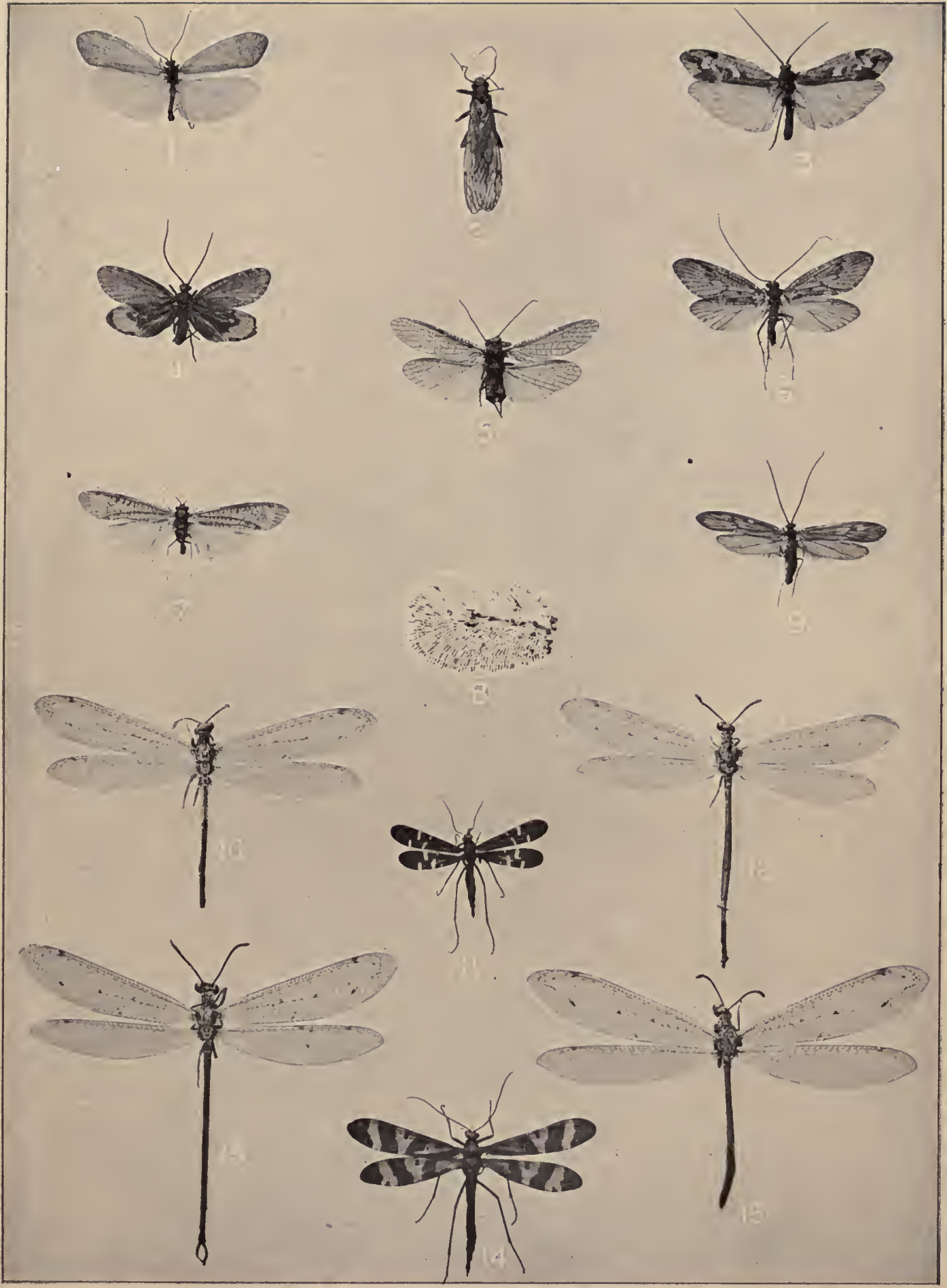





\section{THE ANT-LIONS}

\section{(Family Myrmeleonida.)}

The so-called ant-lions are interesting creatures which have long attracted the attention of naturalists and of nature students. The average American country boy knows the ant-lion pits in the sand about as well as he knows the curious caddis worms in the brooks. It is rather a large group, and about thirty or more species are known in the United States, three hundred or more comprising the number of described species in the entire world.

The adult flies have short clubbed antennæ and four reticulate wings, and are not especially attractive in their personal appearance.

They vary considerably in size, and some of them have a wing expanse of four inches.

The eggs must be laid in the sand, and the larvæ when hatched immediately begin to construct little pits. They have flat heads and long jaws, and scrape a load of sand on the head by means of the front legs, and then jerking the head suddenly upwards and backwards throw the sand to a distance. The future pit is planned as to size, and the larva first excavates a circular groove in the way just described. Then it makes another circle within the first and so on until a conical pit results, at the bottom of which the larva remains in hiding. The sand on the sides lies, when the pit is finished, at such an angle that the least disturbance causes it to slide toward the bottom, and when an ant or some other small insect reaches the verge he is apt to slip rapidly toward the open jaws of the larva waiting to receive him at the bottom. In case, however, by great activity, he seems likely to escape over the margin again, his fall is assisted by the ant-lion at the bottom, which throws little showers of sand upwards, and these showers falling upon the struggling insect hasten its descent.

Any little deposit of sand beneath buildings or at the bottom 
of cliffs along sandy banks in the warm sunshine may be found to contain numbers of these pits. Large collections of them will frequently be found together, which means that one or more females have deposited their eggs in the same general vicinity. The sand must be dry, and hence usually is in a warm, sunny place. When it is damp the larva cannot dig a good pit.

Professor O. Lugger, at a recent meeting of the Entomological Society of Washington, told an interesting story of how a load of sand being carted across a western prairie, far from any stream and miles from any other accumulation of sand, was accidentally spilled through the breaking down of the cart, and how, after a comparatively short time, he found this sand containing many ant-lion pits. This instance indicates that the strong-flying adults are widely distributed and must be in the habit of flying long distances in search of proper places to lay their eggs. There is, of course, also a bare possibility that the eggs were already contained in the sand.

The jaws are enormous and are toothed, and each jaw is grooved deeply on the under side.

After the victim is practically consumed the remains are jerked away by the head just as the sand is jerked up in excavation.

The duration of the life of the ant-lion larva is variable, depending largely upon the abundance of food, just as with some of the other predatory larvæ which we have recently mentioned. They are able to undergo long fasts, in which event the transformation may become indefinitely postponed, but when ants and other food are plentiful they reach full growth in comparatively short time, and spin circular cocoons in the sand, making them of silk, to which, since it is gummy when spun, grains of sand adhere. Within the cocoon the larva usually passes the winter.

There is need of careful study of any one of our common ant-lions. The eggs should be described; the number of molts of the larva should be known, and the duration of the different stages under differing circumstances should be determined. It is probable that with most, if not all of the species, there is one generation annually. 


\section{THE APHIS-LIONS}

\section{(Family Hemerobiida.)}

The insects of this group are medium-sized or large lacewinged flies, the wings being often rather dark colored and spotted with dark spots. There are about thirty species in the United States.

Their larvæ are active, predatory creatures, with long, pointed, sickle-shaped jaws, with which they pierce the bodies of plant-lice and other soft insects, sucking their juices through grooves along the inside of each jaw. Some of these larvæ are furnished with tubercles along the side of the body, the tubercles being clothed with hair, and they have the curious habit of covering themselves with the skins of victims which they have destroyed. The tubercles and the long hairs serve to hold these remains in place. One of these little larvæ will thus disguise itself to such an extent that it cannot be recognized as an insect. The cocoons are spherical.

There are some very interesting forms belonging to this family which are aquatic in their early stages. Needham says that those of the genus Sisyra are very curious-looking objects in the larval stage. They live in or on fresh water sponges, clinging closely to the surface of the sponge or hiding in it, covering themselves with debris. Those of the genus Climacia are also aquatic in the early stages, according to Needham, living in the same places.

A good representative full life history is needed in this family. 


\section{THE GOLDEN-EYED LACE-WINGED FLIES}

\section{(Family Chrysopida.)}

These little insects are known as the golden-eyed lace-winged flies. They are generally green in color, and their eyes, while appearing brown in some lights, have a distinct yellowish, almost phosphorescent or metallic glint in other lights, which accounts for the name golden-eyed. They are sometimes appropriately called stink flies. The uncautious observer, attracted by their beauty, on handling them is at once conscious of a disagreeable and very strong odor which is with difficulty removed from the fingers by soap and water.

The eggs of these little flies are very curious. Each is placed at the extremity of a long slender stalk, which is a most necessary. method of egg-placing, on account of the voracity and omnivorous

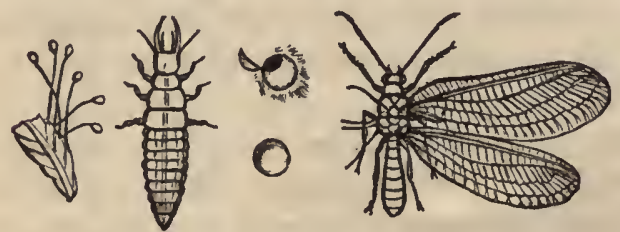

Fig. I19.-Chrysopa plorabunda. (After Riley.) habits of the newly hatched larvæ. If they were laid on the surface of a leaf side by side, as is the case with so many other insects, the first larva which hatched would eat up all of the other eggs, but, issuing as it does from the egg on the top of this long inedible stalk, finding himself on the leaf there is nothing for him to eat unless he searches for plant-lice, of which there is generally an abundance nearby. The eggs are usually deposited on leaves or twigs, and, with wise foresight, customarily in the middle of a colony of plant-lice, and the young larvæ after hatching begin immediately to feed upon the nearest prey. They are most voracious, and insert their long, pointed, sickleshaped jaws (like those of the Hemerobiids) into the body of the nearest soft-bodied insect. It should be stated first, however, that on hatching, the upper end of the egg is cut off by the larval jaws. 
The young larva has an extremely large head, and the sides of its body are armed with immense curved hairs, which give it a very ferocious appearance. It crawls down the egg stalk uniil it reaches the object upon which it is placed. On reaching a young plant-louse it grasps it between its long curved jaws and rolls it one way or the other, the juicy contents being rapidly extracted. It seems always hungry and always to be feeding when it can find anything upon which to feed, and its rapidity of growth is limited only by the abundance of the food supply. It will eat

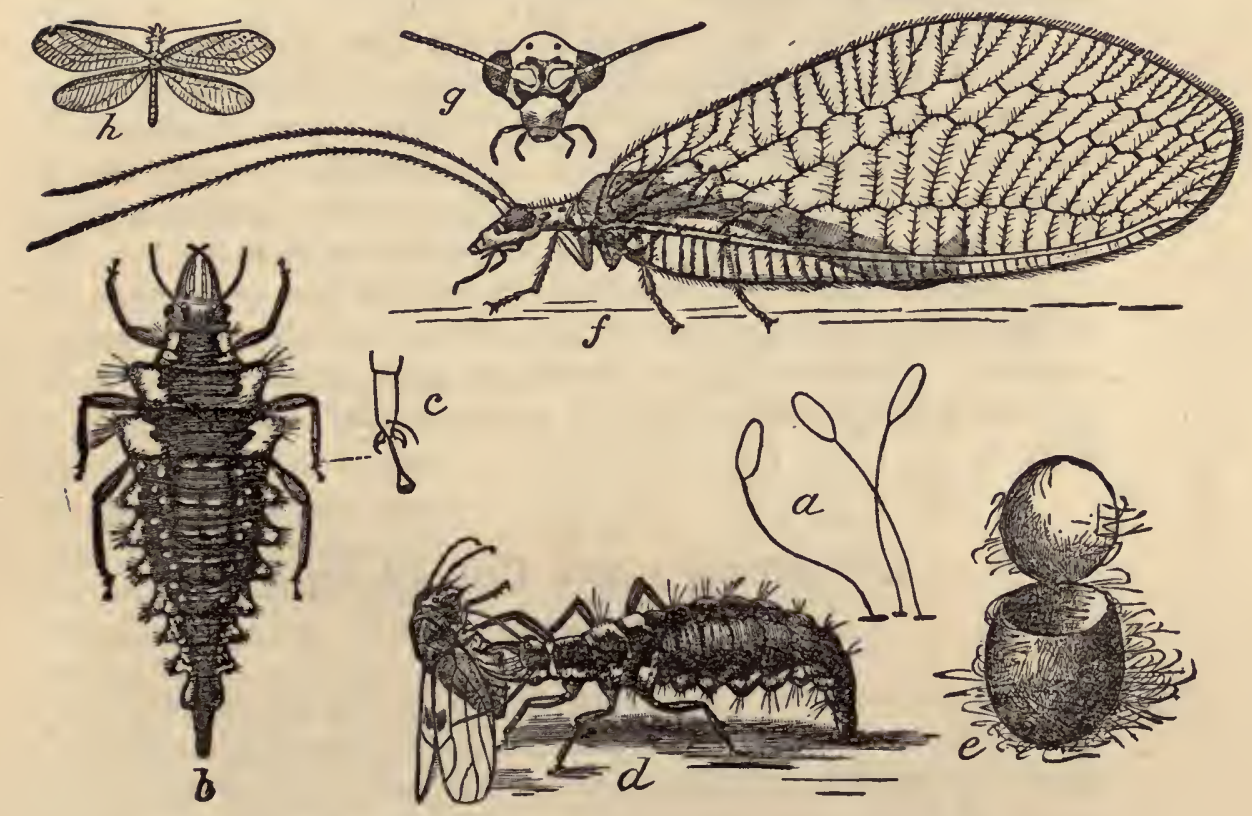

Fig. I20.-Chrysopa oculata : $a$, eggs; $b$, full-grown larva; $c$, foot of same; $d$, same devouring a Psylla; $e$, cocoon; $f$, adult insect: $g$, head of same; $h$, adult, natural size-all enlarged except $h$. (After Marlatt.)

one of its own brothers as quickly as any other insect, and when nearly full grown its jaws are strong enough to pierce the skin of a human being. In Toronto, Canada, 1 once felt a sharp prick on the knuckle of one of my fingers, and on looking down found one of these larvæ with bo.h jaws sticking through the skin and pumping away with its body in an effort to get some nourishment. I watched it for some time under a lens with some interest, and am glad to state that it did not seem satisfied with its meal. 
The insect transforms to pupa within the interior of a white spherical, silken cocoon, which is very characteristic in appearance, and the adult escapes through a circular hole to which the cap remains attached like a lid.

The golden-eyed lace-winged flies are among the most important enemies of the injurious plant-lice which swarm upon many valuable plants especially in the early part of the summer. The mother fly lays her eggs where possible in the midst of colonies of plant-lice, and these are rapidly swept out of existence after the eggs are hatched.

A few of these lace-winged fly larvæ have the same habit which we have described as occurring with the Hemerobiids, of covering themselves with the skins of their victims. Hubbard has studied a species which feeds upon bark-lice, tearing the scales loose from the bark and devouring the soft contents, and then adding a portion of the debris to the load on its back.

Unfortunately, these beneficial lace-winged flies are subject to the attacks of certain parasitic chalcis flies which sting their cocoons. The species of the interesting genus Isodromus seem to confine their attacks exclusively to the cocoons of lace-winged flies.

\section{Life History of a Golden-Eye (Chrysopa oculata Say.)}

This is one of the commonest species in this group, and is often mentioned in books on economic entomology as destroying plant-lice and other injurious insects. The only observer to describe its life history with any detail, however, is Marlatt, from whose observations the following statements are drawn.

The eggs, instead of being deposited in rather large groups, as is the case with other species, are distributed almost invariably singly upon the leaves of trees, and rarely two are found together upon the same stalk. The young larva cuts off the upper end of the egg and on emerging crawls down the stalk and begins its search for food. Approaching the egg of the pear tree Psylla, for example, it immediately grasps it between its long curved mandibles and rapidly extracts the juicy contents. This is done with great celerity, the dry shell is cast aside, and the whole 
operation frequently takes less than a minute. The larva then eats anything in the shape of a living insect which comes its way. It is totally fearless, and attacks with eagerness insects much larger than itself. After ten days it becomes full grown (these observations were made in Maryland in July) and spins up in the curl of a leaf, or in any partial protection, constructing a delicate, slightly oval but nearly spherical silken cocoon, which is attached to the leaf by silken threads. This cocoon is very small in comparison with both the larva which spins it and the adult which emerges from it, and is less than an eighth of an inch long. The adult emerges in from ten to fourteen days, cutting off the upper end of the cocoon in a neat cap. It does not seem to be known whether this cap is partially cut by the larva, or whether, as with other Neuropterous insects, the pupa becomes active before transforming and cuts the cap through which the fly emerges.

The adult insect is peagreen in color, and when alive has brownish eyes with greenish reflections. It is very helpless, does not

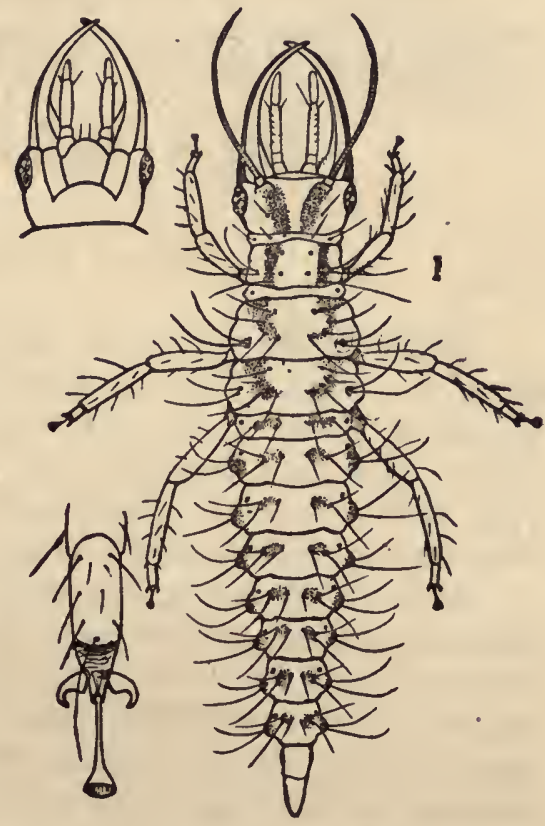

Fig. 121.-Chrysopa oculata: newly hatched larva, with under side of head and claw at side-greatly enlarged. (After Marlatt.) feed, and remains concealed in low grass during the day becoming active in the evening and depositing its eggs at that time. Helpless as it is, the disgusting odor which it emits when handled is probably its chief means of protection from its natural enemies. 


\title{
PLANT-LICE, SCALE INSECTS, TRUE BUGS, ETC.
}

\author{
(Order Hemiptera.)
}

This is another of the old and great orders of insects. It is one of the original Linnean orders and comprises those insects known as the true bugs, true lice and scale insects. Nearly 20,000 species have been described, but, as with the other big orders, very many more yet remain to be studied, probably at least three times as many as are now known.

Although extremely variable in form and structure, all of the Hemiptera have the mouth-parts formed for piercing and sucking (not biting) and their metamorphoses are incomplete, the young bug being active and formed much like the old one. In those which have wings the wings are of two distinct types. In one suborder the forewings are thickened at the base and the thinner end parts lap over on the back. In the other type the forewings are of about the same thickness throughout and are usually held in repose sloping in a roof-shaped manner at the sides of the body.

The order as a whole is a most injurious one in its relations with man. Although some of the true bugs prey upon injurious insects the destruction of plants accomplished by others offsets by far this benefit. In fact Sharp says: "if anything were to exterminate the enemies of Hemiptera, we ourselves should probably be starved in the course of a few months."

The Hemiptera are divided into three suborders which we shall consider separately. They are distinguished as follows: 
Plant-Lice, Scale Insects, True Bugs, Etc.

\section{Table of Suborders}

Beak jointed, hard and horny $\ldots \ldots \ldots \ldots \ldots \ldots \ldots \ldots \ldots$.

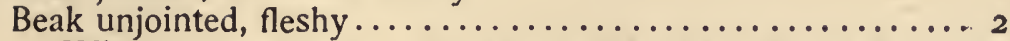

I-Wings when present of the same thickness throughout and held usually in a sloping position at the sides of the body; beak inserted at the hinder part of the head...... Forewings thickened at base, with thinner exorder Homoptera overlap; beak inserted on the front part of the head..... ...................... Suborder Heteroptera

2-Wingless species, parasitic upon man and animals (the true lice) $\ldots \ldots \ldots \ldots \ldots \ldots \ldots$................... Suborder Anoplura 


\section{SUBORDER HOMOPTERA}

A curious and important assemblage of insects belong to the Homoptera. Those creatures which we know as leaf-hoppers, tree-hoppers, cicadas, plant-lice, flea-lice, bark-lice, scale insects, mealy bugs, and white flies all belong here. Their name is legion and they are without exception, destructive to plant life. Their mouth-parts are formed for sucking, and their transformations are incomplete. Their forewings are not modified, as with the Heteroptera, or true bugs, but are more normal and are usually held roof-like over the back when at rest. The front of the head is always bent under so that it touches the base of the front legs. Beyond these points, their structure is very diverse, and beyond the fact that all are plant feeders their habits are also very diverse. In their life histories some of them, particularly the plant-lice, the bark-lice and the periodical cicada (or socalled seventeen-year locust), present some of the most interesting, and, in fact, some of the most astonishing, phenomena in the whole field of biology. The progressive degradation, after birth, of the female of the scale insects; from an active, highly animated creature to a blind, legless, protoplasmic globule, and the contrasting development of the male of the same species, from a minute, crawling mite to a virile, winged, active and highly organized creature whose head is practically all eyes, is one of the most extraordinary life histories among all insects, while the alternate forward and backward development which occurs in the genus Margarodes in this family is even more strange. Then, too, the remarkably adapted parthenogenetic life of the plant-lice, with their alternation of food plants and their relations with ants, make their study one of fascinating interest.

The Homoptera is a large group of insects. No one knows how large. The plant-lice and the scale insects of Europe and North America have been rather well studied. largely on account of the economic interest which attaches to them. Yet, even from North America, many new species are being found, even in these 



\section{SHIPDIDER HOMOPTERA}

FIG.

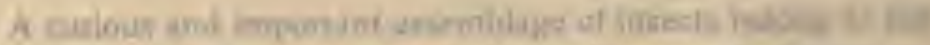

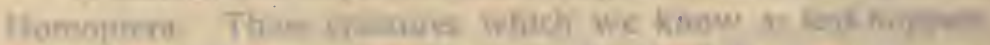

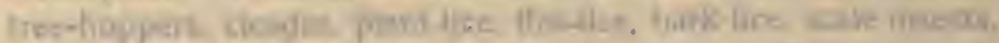

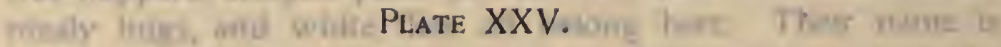

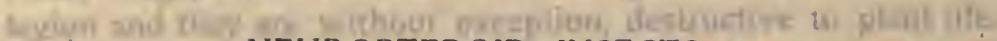
NEUROPTEROID INSECTS

1. Maracanda conspersa (Myrmeleonidæ) Eastern States

2. Myrmeleon immaculatum (Myrmeleonidæ) U. S.

3. Myrmeleon rusticus (Myrmeleonidæ) Southern States

4. Brachynemurus peregrinus $q$ (Myrmeleonidæ) Western States

5. Brachynemurus longipalpis o (Myrmeleonidæ) Southwestern States

6. Brachynemurus nigrilabris $q$ (Myrmeleonidæ) Western States

7. Brachynemurus peregrinus of (Myrmeleonidæ) Western States

8. Brachynemurus longipalpis $\delta$ (Myrmeleonidæ) Southwestern States

9. Brachynemurus nigrilabris of (Myrmeleonidæ) Western States

10. Brachynemurus sackeni of (Myrmeleonidæ) Southwestern States

11. Acanthaclisis congener (Myrmeleonidæ) Western States

12. Brachynemurus sackeni of (Myrmeleonidæ) Southwestern States

13. Acanthaclisis hageni of (Myrmeleonidæ) Southwestern States 14. Acanthaclisis hageni \& (Myrmeleonidx) Southwestern States

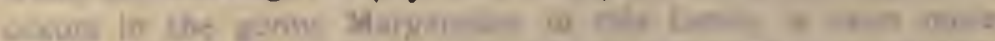

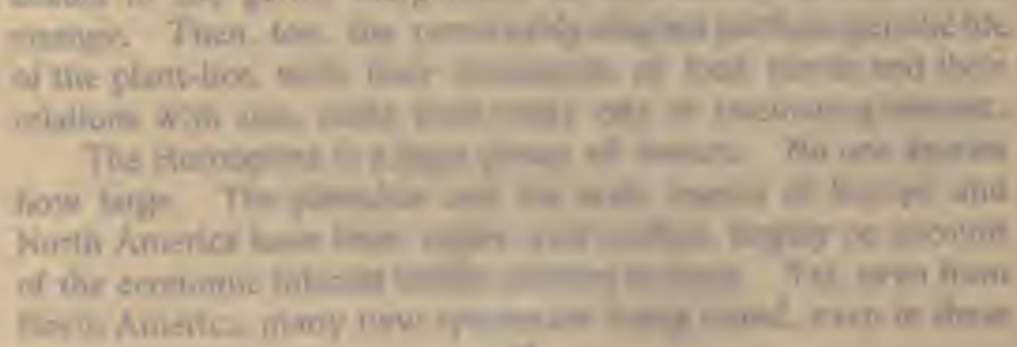




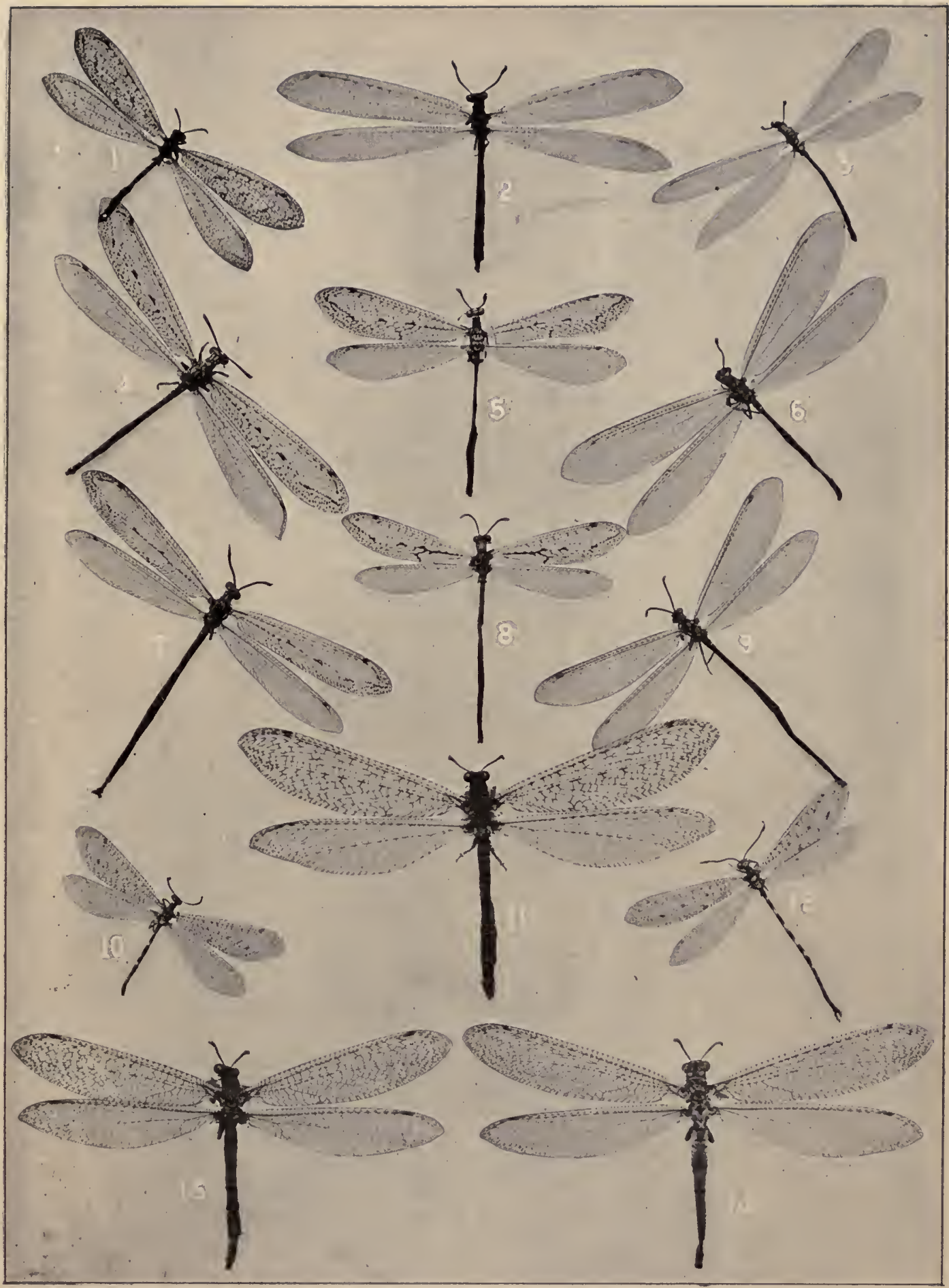



groups, each year. The tree-hoppers and the leaf-hoppers and some of the other groups, however, are very poorly known, and, in fact, the whole suborder, as it is represented in tropical regions, is but slightly known. Collectors in out-of-the-way places have neglected this group, and doubtless very many thousands of species will yet be discovered and described. A small group of American workers, including Messrs. Osborn, Van Duzee, Baker, Gillette and Ball, are doing admirable work upon the leaf-hoppers and tree-hoppers, but there is still room for many more investigators of these interesting insects. They are easily preserved and make an interesting collection. The study of the scale insects may safely be left to the small army of economic workers who have taken up their study during the past ten years, but the plant-lice need many more students. The difficulty of properly preserving the insects of this group, since they must be kept in alcohol or formalin or mounted upon microscope slides, doubtless deters many from entering upon their study. But the life histories of very few of our North American species are known, and many important and most interesting facts are still to be learned about a host of species.

\section{Table of Families}

Beak plainly inserted in the head; feet with three segments; antennæ minute, bristle-like.................. i

Beak apparently inserted between the forelegs; feet with one or two segments; antennæ usually prominent, but sometimes

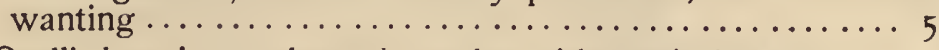

$1-$ Ocelli three in number; the males with musical organs...... .............................. Family Cicadida

Only two ocelli or none; males not musical.......... 2

2-Antennæ inserted in front of and between the eyes....... 3 Antennæ inserted on the sides of the cheeks beneath the eyes

3-Prothorax not prolonged above the abdomen...........

Prothorax prolonged into a horn or point above abdomen.... ......................... Family Membracidae

4-Hind shanks with one or two stout teeth below and at tip with a crown of short, stout spines.... Family Cercopidae Hind shanks with a row of spines below..... Family Jassidae 
Feet usually with two segments; wings when present four in number ............................. 6

5-Wings transparent $\ldots \ldots \ldots \ldots \ldots \ldots \ldots \ldots \ldots \ldots \ldots$

Wings opaque, whitish............. Family Aleyrodida

Feet with only one segment; males without mouth-parts and with two wings only; females wingless and scale-like or gall-like in form, and covered with wax in plates, layers or in powdery form................ Family Coccida

6-Hind thighs swollen; antennæ with nine or ten segments... ....................................... Psyllida

Legs long and slender; antennæ with three to seven segments ........................ Family Aphidida 


\section{THE HARVEST FLIES OR CICADAS \\ (Family Cicadida)}

This is a group of insects commonly known by the popular name of "harvest flies" or cicadas, and frequently in this country by the erroneous term "locust." We have already seen that the term "locusts" should properly be applied to the long-horned grasshoppers of the true family Locustidx, although it is also, especially by British subjects, applied to the short-horned grass-

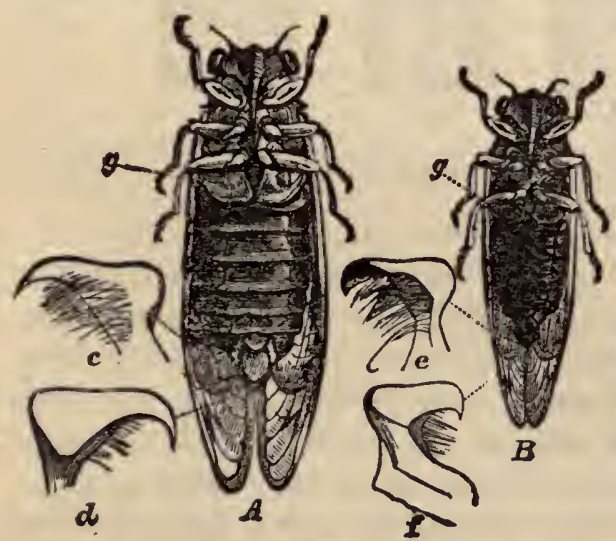

Fig. 122.-Periodical Cicada: $a$, male, of the large form; $b$, male, of the small form. (After Riley.)

hoppers and especially the destructive species. The family Cicadidæ is a group of large insects containing very many tropical species. Their bodies are large, with a wide, blunt head, and with prominent eyes on the outer

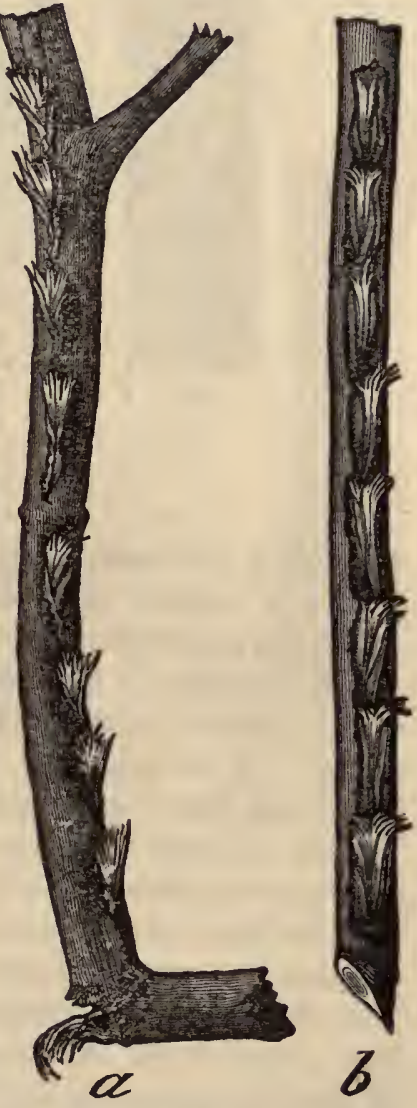

Fig. I 23.-Twigs punctured by Cicadas, illustrating manner of breaking. (After Riley.) 
angles. The head has three ocelli placed triangularly on the summit between the compound eyes and the antennx consist of a short basal joint surmounted by a bristle which is divided into about five segments. The tropical forms are sometimes brightly colored but the species which occur in the United States are usually greenish marked with black.

The commonest form in the more Northern States is the socalled "dog-day harvest fly" or "lyreman"- the insect which every summer, toward the end of July or early in August, begins

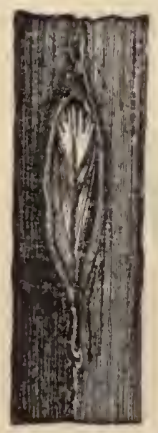

a

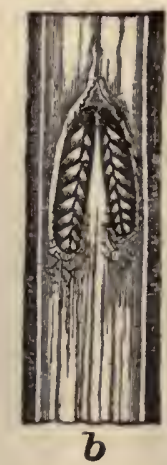

b

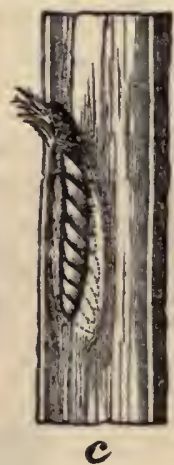

c

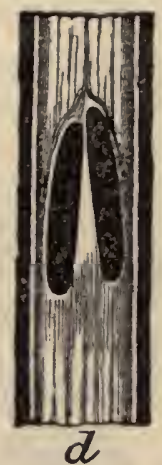

Fig. 124.-Eggs of the Periodical Cicada. (After Riley.)

its doleful but resounding buzzing hum in the tree tops. This sound is iamiliar throughout the hot days of the late summer and is frequently more noticeable in the early morning and about sundown. This, however, may be due to the fact that the day noises of a town or city are less noticeable at such times. It is supposed that this is an annual species, $i$. e., that it has but one generation annually, the larvæ living in the ground through only nine or ten months of the year. It may be, however, that it has a much longer larval period, and that only its great abundance and the intermingling of generations accounts for its annual occurrence in the adult condition. This is a point which should be investigated as its life history has never been thoroughly worked out. There are other cicadas in the Southern and Western States, some of them rather small in size, like Tettigia hieroglyphica, and others large, like the big Cicada emarginata. 


\title{
Life History of the "Seventeen-year Locust"
}

\author{
(Cicada septendecim, L.)
}

This insect, commonly known as the periodical cicada or seventeen-year locust, is taken here because it is the only species of the family whose life history is thoroughly well understood. It is probably not typical in its very extended larval life. In the North this insect remains either as larva or pupa underground for seventeen years. In the South it develops in thirteen years, thus giving rise to two races which are known as the septendecim and tredecim races. The dividing line between the two races corresponds fairly well with the northern margin of the so-called lower austral life zone. In some localities confusion arises from the fact that the insect makes its appearance at shorter intervals than seventeen years. This is accounted for by the fact that the insect appears in distinct broods some of which overlap the territory also inhabited by other broods. There is no reason, however, to suppose that the length of life of any larva is of shorter duration than seventeen years in the North and thirteen in the South. The largest of the Northeastern broods made its last appearance in 1902 , and is due again in 1919. It will then be found in great numbers throughout New Jersey, Delaware, part of Pennsylvania, Maryland, northern Virginia, Ohio, southern Michigan, Indiana, eastern lllinois, Kentucky and down the Appalachian chain of mountains through North Carolina into northern Georgia. It will also appear in a few localities in Vermont, New York, Wisconsin, West Virginia and Tennessee. The eggs are laid in small twigs and branches egg wounds. which are pierced by the ovipositor and in this way

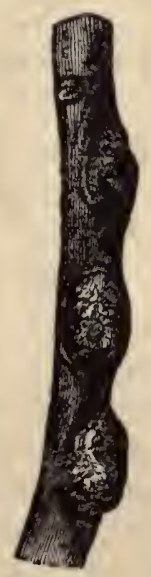

Fig. 125. Healed over (After Riley.) the insect does practically the only damage which it accomplishes. They occur in enormous swarms and the weakening of the twigs, caused by the punctures, causes many of them to be broken off by the wind. The young ant-like larva hatches from the eggs a few weeks after oviposition, escapes from the wounded limb, falls to the ground and burrows quickly out of sight, where it forms for itself a little underground chamber near some rootlet, 
remaining there, isolated from others and moving, probably very slowly, for seventeen or thirteen years. It molts four times, the first time after from one year to eighteen months, the second after two additional years, the third after three years more, and the fourth after another period of three or four years, leaving three or four additional years to elapse before the insect assumes the socalled pupal state. The anterior legs of the larva are curiously enlarged and resemble the cutting jaws of biting insects. They are especially designed for digging and transporting earth. The food which it consumes is obtained probably from the soil humus and

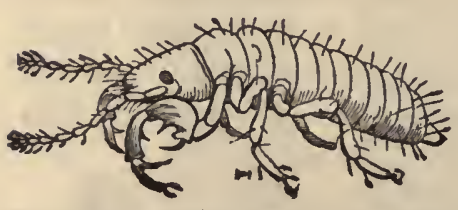

Fig. 126.-Cicada septendecim, young larva. (After Riley.) to some extent from the roots of plants. After the change to the pupal condition the insect burrows to the top of the ground and, emerging, crawls up the trunks of trees where the skin splits and the adult insect issues. Occasionally, in certain kinds of soil or when the pupa has reached the surface too early, it will construct mud chimneys from the summit of which it eventually issues.

In the great cicada year of 1885 , Dr. Riley started an interesting series of experiments in order to determine whether the duration of the larval stage with the thirteen-year race would be prolonged by transporting the eggs north and accelerated by transporting eggs to the south. This was done on a very large scale and at several localities, the exact locations being carefully marked and recorded. No positive results have as yet been obtained; that is to say, no undoubted specimens have issued at either north or south.

The ultimate fate of this interesting species is undoubtedly extinction and its numbers are rapidly growing less. One of the comparatively few insects upon which the English sparrow feeds with avidity is the periodical cicada and many thousands of them are destroyed by sparrows each time they make their appearance and before they lay their eggs. 


\section{THE LANTERN-FLIES AND THEIR ALLIES}

\section{(Family Fulgorida.)}

To this group belong the well-known lantern-flies of the tropics, but it also includes a host of other species of diverse forms which are separated into no less than 13 subfamilies of

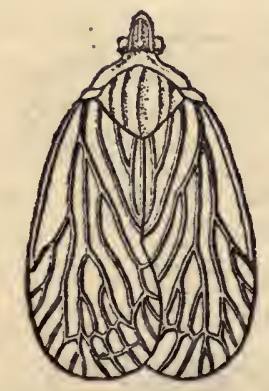

Fig. I 27.-Helicoptera sp. (After Uhler.)

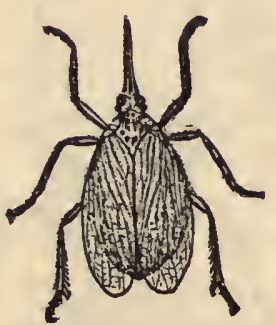

Fig. I 28.-Scolops sulcipes.

(After Uhler.)

which the Delphacinæ and Flatinæ are best represented in the United States. The tropical forms are large and bright-colored and the true lantern-flies are so-called because of the enormous

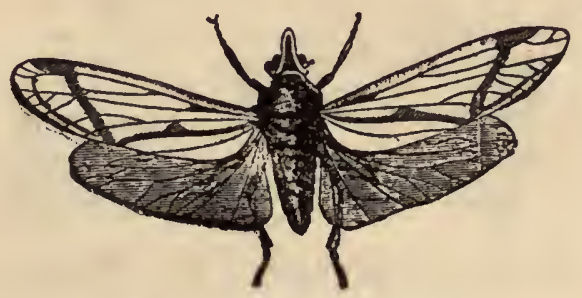

Fig. 129.-Otiocerus coquiberti.

(After Uhler.)

enlargement of the fore-part of the head which was formerly thought to be luminous. All are vegetable feeders. Our Ameri- 


\section{THE TREE-HOPPERS}

\section{(Family Membracidie.)}

These insects comprise some of the most grotesque species which nature has evolved. Comstock offers the apt suggestion that "Nature must have been in a joking mood when tree-hoppers were developed." The antennæ are inserted in front of and

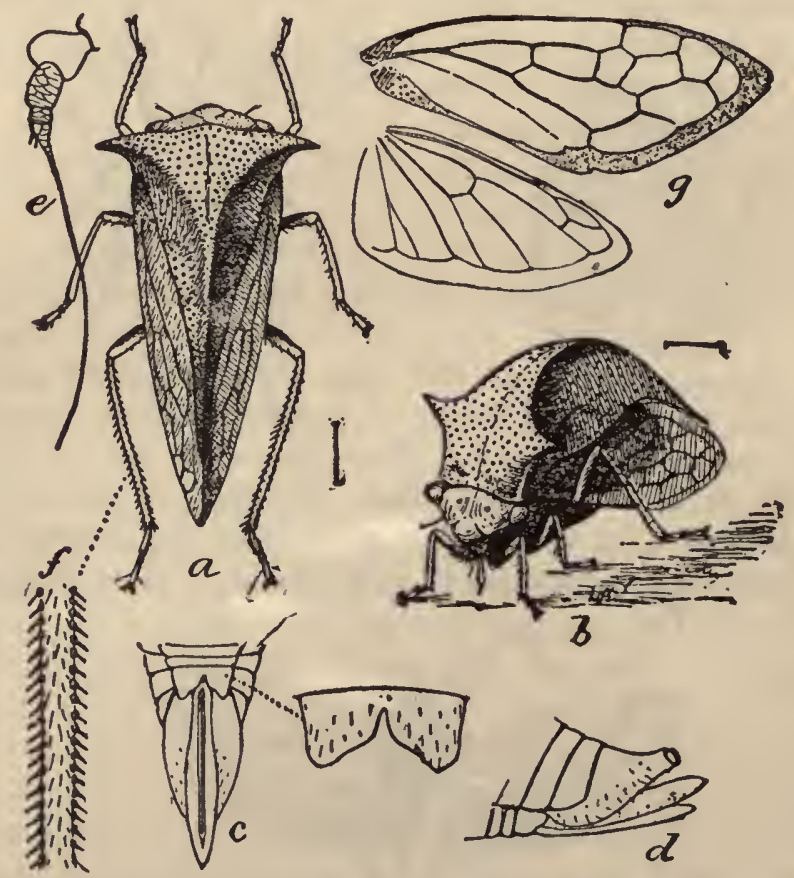

Fig. 130.-Ceresa taurina. (After Marlatt.)

between the eyes and the prothorax is prolonged so that it frequently covers the rest of the body. It is by the curious modifications of this prothorax that the strange, and grotesque forms of the insects are produced. The majority of these modifications 
can forms are all small, some resembling leaf-hoppers and others looking almost like little moths. The green Flata (Chlorochroa conica) feeds on corn and the foliage of the sugar beet in Illinois and elsewhere.

\section{Life History of the Frosted Lightning Hopper}

(Ormenis pruinosa, Say.)

The so-called "frosted lightning hopper," as this little insect is called, belongs to the subfamily Flatinæ, and is one of the moth-like forms. It varies from lead-color to pale green, and is dusted over with a fine white powder, which makes it appear frosted. The eggs are laid in small twigs of sassafras and other trees in a continuous raised slit. They are dirty yellow in color, each $1 \mathrm{~mm}$. long, and are laid on their sides end to end.

$x \quad$ About the middle of May these eggs hatch into delicate little hoppers, which immediately settle on the new growth, insert their beaks and begin to pump up sap. They then copiously secrete a powdery waxy secretion which completely covers them. They grow slowly, molt three times and the adult insect issues from the last nymphal skin about September, soon afterwards commencing to lay the hibernating eggs. 
have been developed in order to bring about protective resemblance since by these modifications the insects are made to look like different plant structures. The thorn-like process on
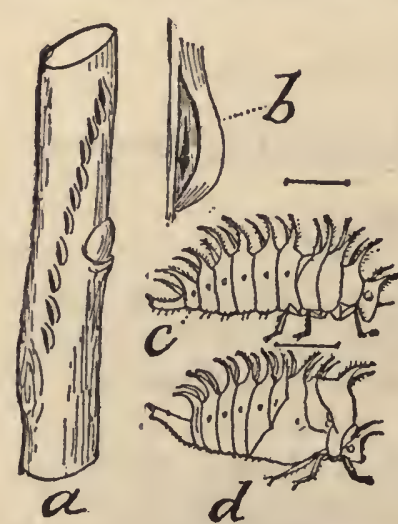

Fig. 131.-Ceresa taurina: eggs and young. (After Marlatt.) the thorax of the common little treehopper of the bitter-sweet (Enchenopa binotata) is a good example. The insects customarily rest in such position along the twig of a vine that they precisely resemble vegetable thorns. This family like so many others reaches its most remarkable development in the tropics but many strange forms occur in the United States. The species just mentioned, when enlarged, bears a fanciful resemblance to the partridge and was once the subject of a charming popular article by the late William Hamilton Gibson, entitled "A Queer Little Family on the Bitter-Sweet," published in the Harper's Monthly for August, 1893. A common form is the little hump-backed species known as Telamona monticola,

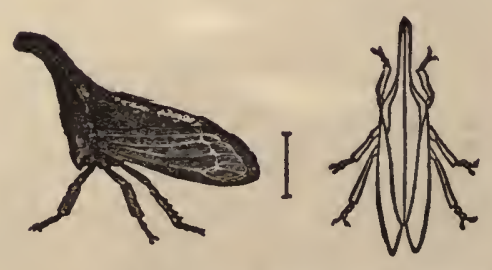

Fig. 132.-Enchenopa binotata

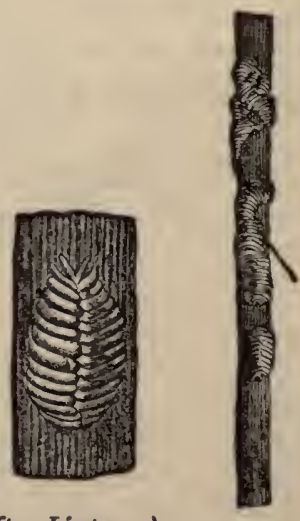

(After Lintner.)

which somtimes swarms upon the branches of the Virginia creeper in June. Another most interesting form is that known as Entilia sinuata, which is found upon the leaves of sun-flower and other annual plants. This species lays its eggs in the mid$\mathrm{r} 1 \mathrm{~b}$ of the upper leaves. The mother insect broods over her eggs 


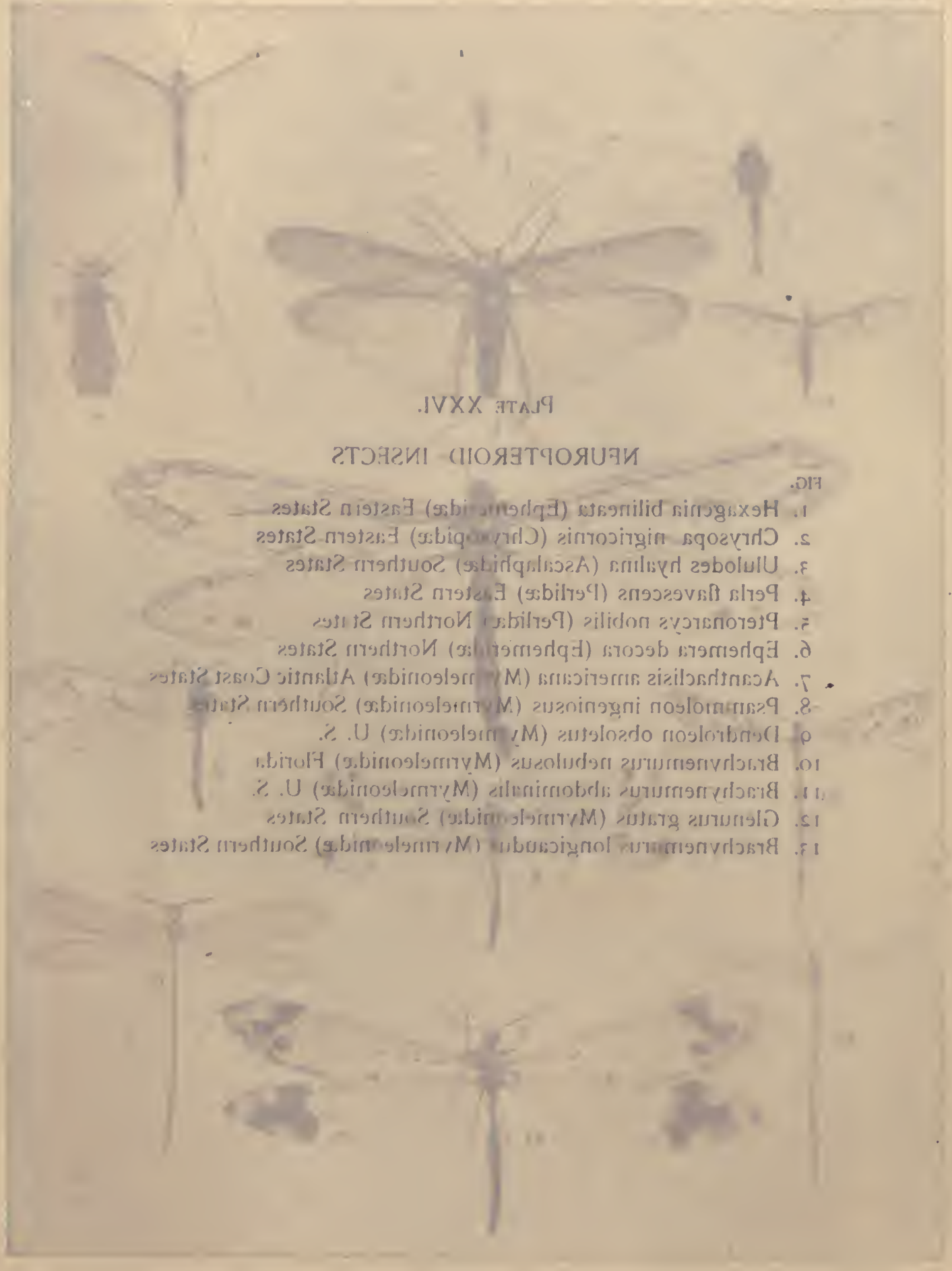




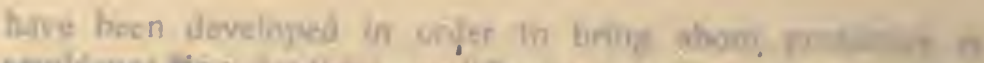

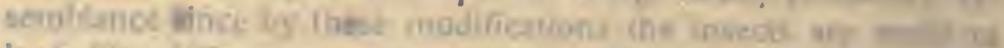

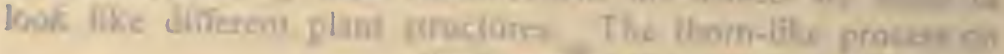
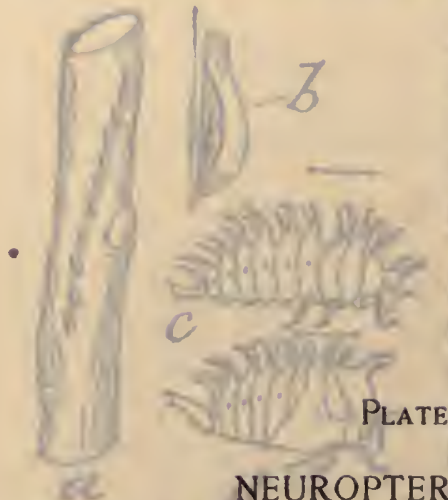
the thumed the sonincus liste was

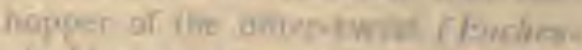

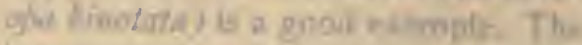

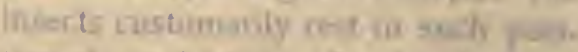

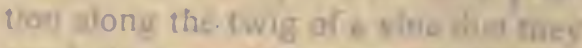

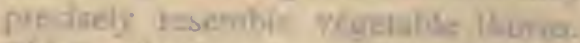

FIG.

\section{NEUROPTEROID INSECTS}

1. Hexagenia bilineata (Ephemeridx) Eastern States

2. Chrysopa nigricornis (Chrysopidæ) Eastern States

3. Ululodes hyalina (Ascalaphidæ) Southern States

4. Perla flavescens (Perlidæ) Eastern States

5. Pteronarcys nobilis (Perlidæ) Northern States

6. Ephemera decora (Ephemeridæ) Northern States

- 7. Acanthaclisis americana (Myrmeleonidæ) Atlantic Coast States

8. Psammoleon ingeniosus (Myrmeleonidæ) Southern States

9. Dendroleon obsoletus (Myrmeleonidæ) U. S.

10. Brachynemurus nebulosus (Myrmeleonidæ) Florida

11. Brachynemurus abdominalis (Myrmeleonidæ) U.S.

12. Glenurus gratus (Myrmeleonidæ) Southern States

13. Brachynemurus longicaudus (Myrmeleonidæ) Southern States
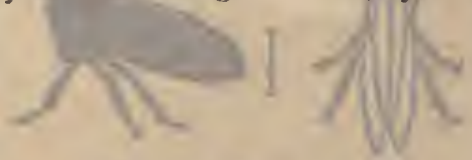

her

whith somirm

as Evilie wisen

and octier anoual pa.so.

nibor the uprep biths

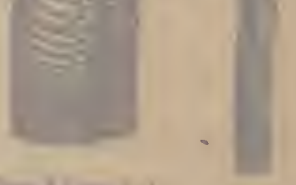

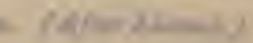




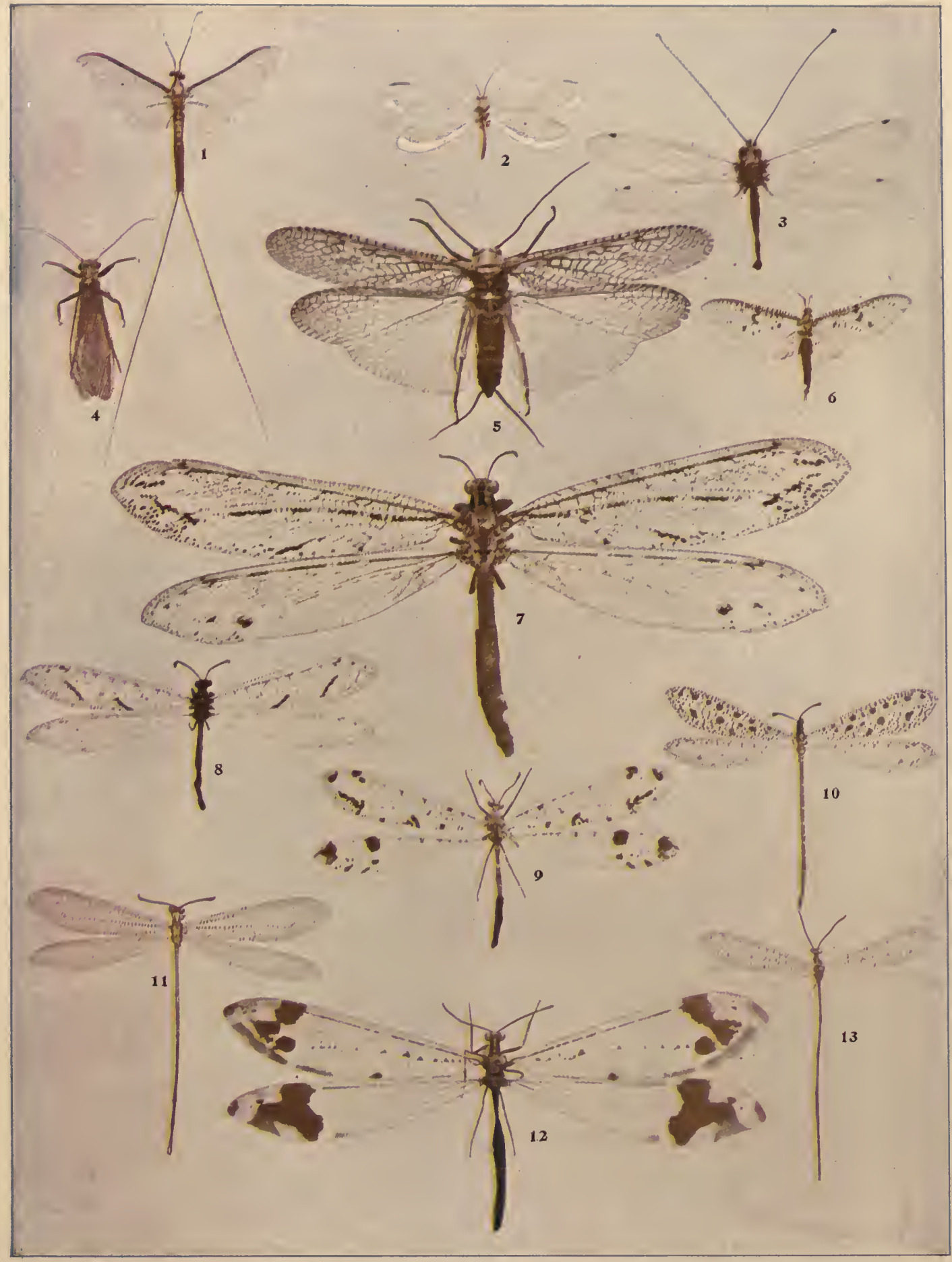



until they are hatched and the young from the time of hatching until full grown are constantly attended by ants which are attracted to the sweet secretion which this insect, together with many others of the same family, just as with certain of the Jassidæ, exudes from its anus.

\section{Life History of the Buffalo Tree-Hopper (Ceresa bubalus.)}

This little insect is probably the species of the greatest economic importance of any of this group of tree-hoppers. It is popularly known by the name of the "buffalo tree-hopper." Its popular name is derived from its supposed similarity in shape to the male bison, the prothorax being greatly enlarged towards the head and projecting at the sides into two strong horns. It

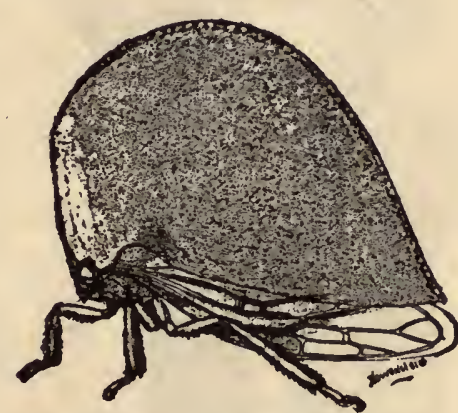

Fig. 133-Archasia galeata. (After Lugger.)

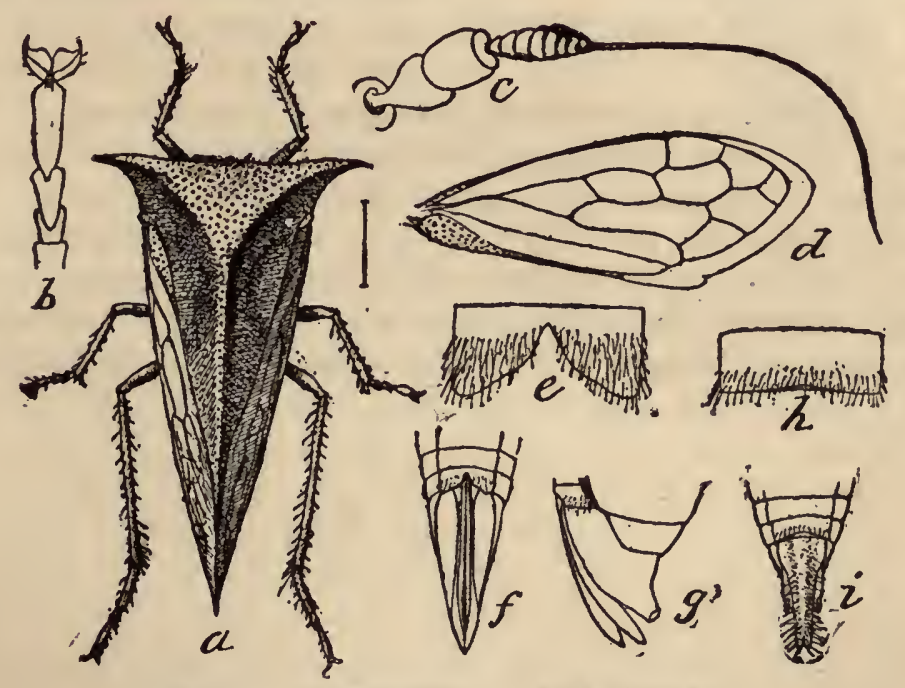

Fig. 134-Ceresa bubalus. (After Marlatt.) 
is common all through the United States, from Missouri northwards into Canada, and is sometimes the cause of considerable damage in orchards, particularly to young trees and nursery stock. The injury is produced by the cutting of the small limbs by the female with her saw-like ovipositor, in which process she

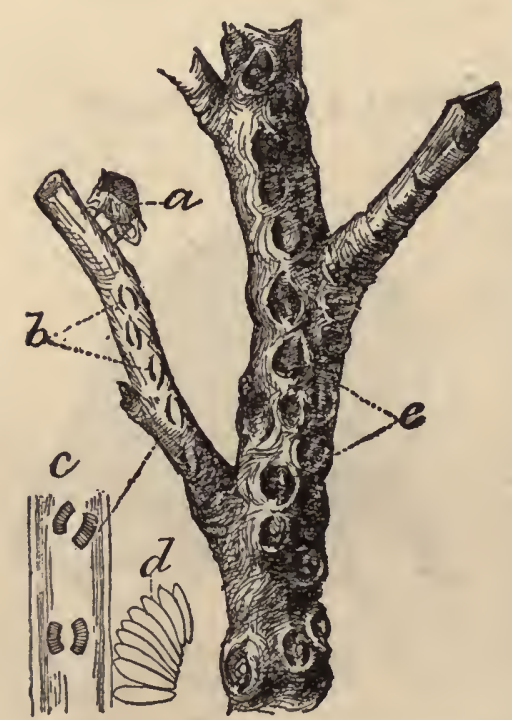

Fig. 135.-Ceresa bubalus, eggs and old egg-scars. (After Marlatt.) makes large holes through the bark in which the eggs are inserted in clusters. The insect flies with a loud buzzing noise from tree to tree and is very shy. The twigs chosen for egg-laying are preferably those of two or three years growth and various kinds of trees are selected. The eggs are placed in small compound groups arranged in two nearly parallel or slightly curved slits. About a minute is required for the insertion of each egg. The wound is made in such a way as to cause a certain cessation of growth between two rows of eggs to prevent their being crushed by the rapid growth of the twig.

Each female lays from one hundred to two hundred eggs. The insect hibernates in the egg condition and the young hatch in the spring. They molt three or four times before becoming fullgrown and during their life feed upon the juices of the tender, twigs and leaves by inserting their beaks and pumping up the sap. The insect in its early stages is wingless and is covered on the upper side along the centre with numerous barbed projections. 


\section{THE FROG-HOPPERS OR SPITTLE INSECTS}

\section{(Family Cercopida.)}

This is a rather large family comprising mostly rather small insects, many of which are known as "frog-hoppers" or "spittle insects." The antennæ are placed between the eyes, there are only two ocelli and the thorax is not strangely modified as with the Membracidæ. Few insects excite more interest among moderately observant people than the true spittle insects which belong to the subfamily Aphrophorinæ. They are small, rather slender, brown, clay-yellow or grayish species, and after hatching from the egg live in little masses of froth resembling spittle on the stems of plants and trees, frequently on grasses and weeds. In some parts of the south, according to Uhler, the negroes think that horse-flies are developed from these froth specks. When abundant they may do considerable damage to pasture-lands. Philonus spumarius and $P$. lineatus are said by Fernald to be common on grass in Massachusetts. The former is abundant in gardens in England and was probably introduced from England Fig. 136.-Monecphora into this country.

The eggs are laid in the stems of plants

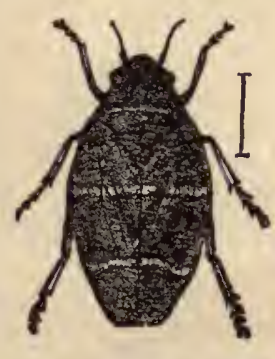

bicincta. (From in the autumn and hatch in the spring. It was formerly thought that the spittle that soon surrounds the young insect was excreted from the anus, but Professor E. S. Morse has recently shown that only a clear liquid containing no bubbles is thus exuded and that the air-bubbles are brought in by a constant thrashing about of the anal end of the body, bringing in air which is retained as bubbles by the viscid quality of the liquid. There are anal appendages which are probably branchial in function, according to Morse.

It is supposed that the purpose of the frothy mass is to protoct the soft-bodied immature insects from their natural enemies 
-in other words that it is a disguise. But it renders them very conspicuous and once their true nature is ascertained they are all the more easily found by their enemies and as a matter of fact they are sought for by certain wasps which drag them out from their froth and carry them off to provision their nests.

No good thorough life history of an American species has been published and here is an interesting and novel field for some observer. 


\section{THE LEAF-HOPPERS}

\section{(Family Jassida.)}

This group of insects, which comprises the forms ordinarily known as leaf-hoppers, is an extensive group, comprising a

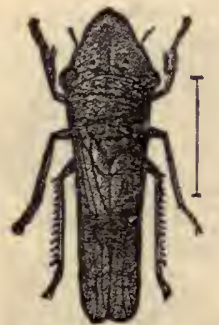

Fig. 137. - Proconia undata. (From U. S. Dept. Agr.)

herbage and have been shown by Professor Herbert Osborn to bring about a very extensive although probably unnoticed injury to forage plants in large grazing ranges in the west as well as in pasture lots in the east. He shows that on an acre of pasture land there frequently exists one million leaf-hoppers and that this million hoppers consume as much grass as a cow if not more. In this restricted sense this family includes the leaf-hoppers now generally placed in the family Tettigonidæ which
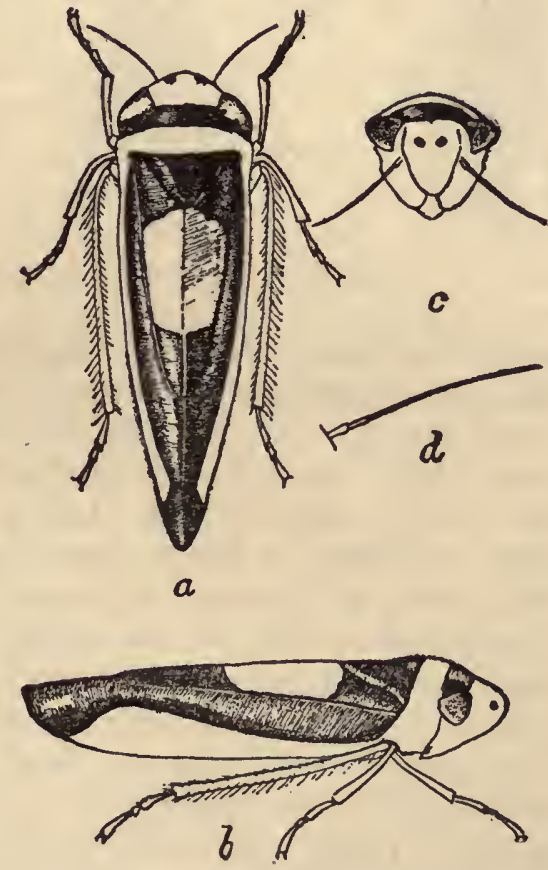

Fig. 138.-Thamnotettix clittelfarius. (After Lugger.) 
are distinguished from the restricted Jassidæ by the position of the ocelli. Among the leaf-hoppers which may be especially mentioned are the green spindle-shaped species of the genus Diedrocephala which are found abundantly in pasture lands, one species (D. mollipes) occurring commonly in the salt marshes of the Atlantic States. The forms belonging to the genus Proconia are rather widely distributed and one of them ( $P$. undata) is responsible for most of the stories of "weeping trees" which

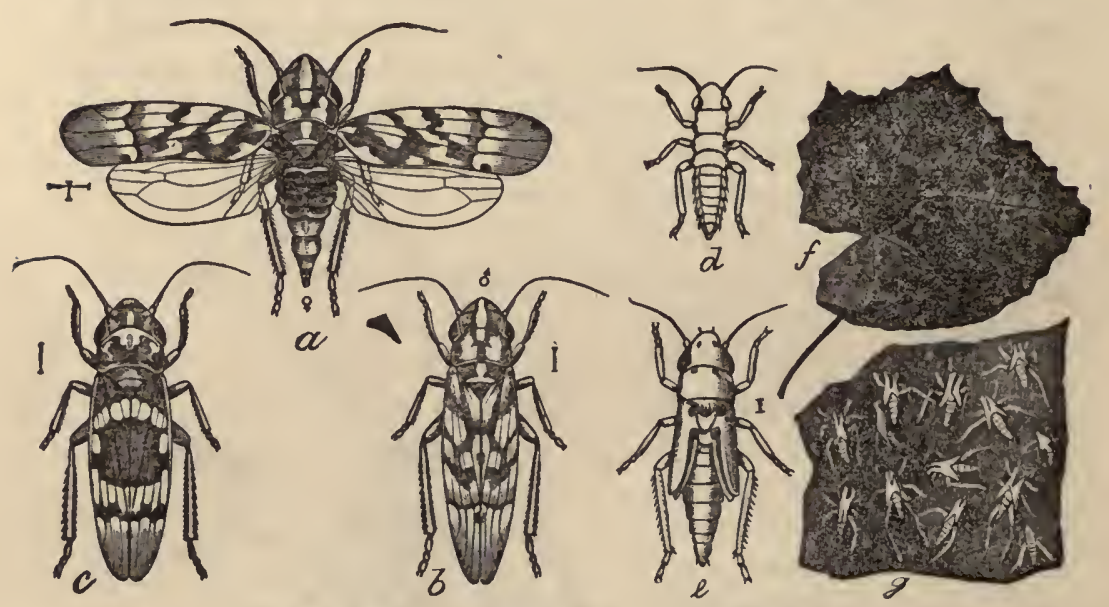

Fig. 139.-Erythroneura vitis. (After Marlatt.)

are seen in the newspapers. These insects in all stages (and the species of several other genera have a similar habit) eject a spray of fluid from the anus when disturbed and, when occurring abundantly upon trees, if the tree be shaken what seems almost like a light shower of rain will fall. One of these "weeping tree mysteries," so-called, in Texas some years ago "set the state agog with various explanations of the phenomenon, ranging from the superstitious credence of the supernaturally inclined to the positive denial and derisive laughter of the constitutionally skeptical." It tcok a brave newspaper reporter to solve the mystery, since he alone dared to climb the tree and investigate. The common leaf-hoppers of the grape-vine, erroneously called by grapegrowers "Thrips," are known as Erythroneura vitis and Typhlocyba vitifex. They frequently cause the leaves of grape-vines to iurn brown and wither. Agallia sanguinolenta prefers open 
sunny places, is destructive to clover and attacks a great variety of useful plants such as cabbage, celery, turnips, strawberry, beets and many weeds.

\section{Typical Life History of a Leaf-Hopper (Deltocephalus inimicus.)}

This little leaf-hopper is one of the species which is commonly found in pastures and meadows. It has been reared upon young wheat plants by Professor F. M. Webster. The females laid their eggs in November in the tissue of the leaves and the young could be seen developing within the eggs without removal. They were especially noticeable just prior to issuing by their jet black eyes. A few days after hatching the young leaf-hoppers molted and they molted again twice thereafter, the full-grown individuals making their appearance December 22d, giving a life period of forty-one days from the egg to the adult. The species seems to hibernate both in the egg state and in the adult condition and to have several generations each year. Osborn found the eggs inserted under the skin of the leaves of blue grass, making little blister-like swellings near the tips and causing them to turn yellow. Those which hibernate in the egg state issue in great numbers in grass lands early in May. There are at least two generations each year, the young being numerous in late May and in August and the adults in June and in the fall. Large numbers have been seen attracted to the electric lights in Illinois. (Forbes \& Hart.) 


\section{THE WHITE FLIES, OR ALEYRODIDS \\ (Family Aleyrodida.)}

This family, more closely allied to the Aphididx and Coccidæ than to any others, and yet widely different in important features, is a puzzling and abnormal assemblage of insects. They

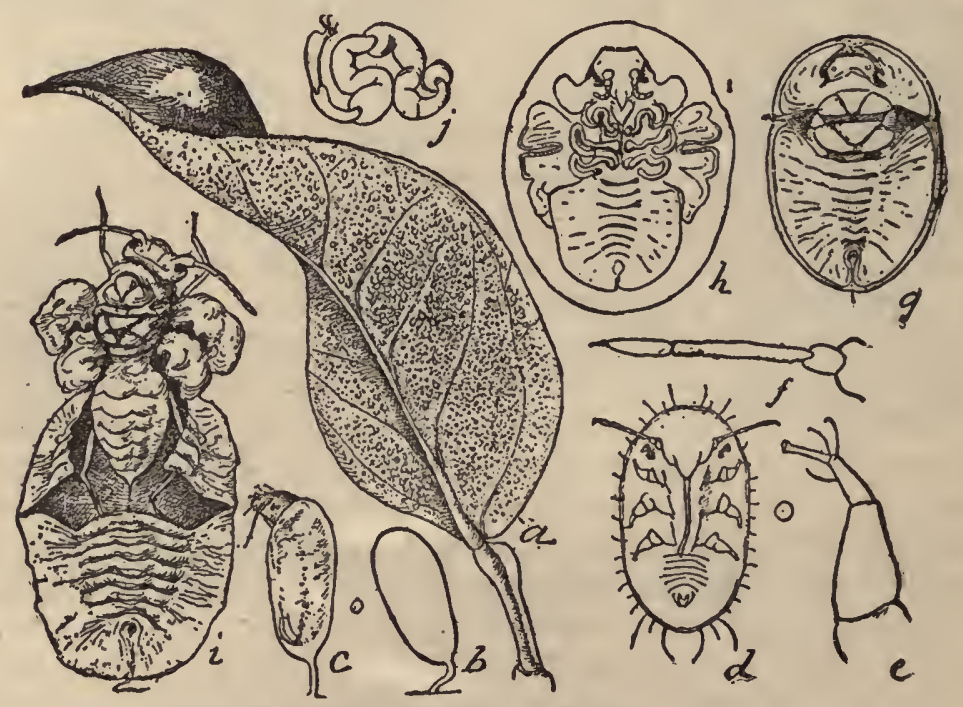

Fig. 140.-Aleyrodes citri. (From Insect Life.)

are very small insects, frequently minute, and infest the leaves of plants, usually on the lower side. In their early stages they are scale-like, and much resemble some of the Coccidx. Unlike the Coccidæ, however, the development of the two sexes is practically parallel, and both males and females are active and winged. Differing again from the scale insects, there are two pairs of wings instead of one pair. All four wings are covered or dusted with a whitish, meal-like secretion, which has given to the group the popular name of white flies. In the immature stages the 
body may be more or less covered by a secretion of wax, but the most distinctive character is the presence of an opening on the dorsum of the last abdominal segment which is known as the vasiform orifice. In the adults the antennæ are sevenjointed, and the eyes are usually somewhat constricted near the middle, and may be even completely divided. The wings when at rest are nearly horizontal, and are broad and well rounded. The wings may be unspotted, or variously spotted or banded. The Aleyrodidx do not constitute a large group, and but two genera and not more than 150 species are known. Of these both genera (Aleyrodes and Aleyrodicus) are known in the United States, and rather more than fifty species occur within our geographic borders. Doubtless many of these are imported, since they occur more commonly upon greenhouse plants than upon wild indigenous plants. They are found upon both herbaceous plants and upon forest trees. They are very seldom serious enemies to vegetation, although the species occurring commonly upon the orange does considerable damage, which arises not alone from the actual loss of sap and consequent withering of the leaves from the sucking of the insect, but also from the profuse quantity of smut fungus, the spores of which find their nidi in the honey dew secreted by the insects. Their natural enemies are practically the same as those of the scale insects, but the very minute Hymenopterous parasites of the family Mymaridæ seem to be their specific internal parasites. In fact, they are too small to harbor any other true internal parasites except the members of this family, which, as a matter of fact, includes the smallest true insects known.

\section{Typical Life History of a White Fly (Aleyrodes citri, Riley \& Howard.)}

This species, which is the only form of any great economic importance in the group and the one to which we have just referred, occurs abundantly in some of the orange groves in Florida and in northern greenhouses and made its appearance about 1890 in the orange groves of Louisiana. It is not known whether it is an indigenous or imported species. It will probably be found 
in any northern greenhouse in which orange or lemon trees occur. It is found in the south also upon the china-berry tree, upon viburnum, cape jessamine and the water oak. The following life history account is drawn up from observations made in greenhouses in the city of Washington. The insect passes the winter in the full-grown larval condition. The adult insects issue during April and begin to lay their eggs about or before the middle of the month. About twenty-five eggs are laid by each female. The eggs are very delicate, pellucid, and each possesses a slender petiole or foot-stalk about one-third the length of the

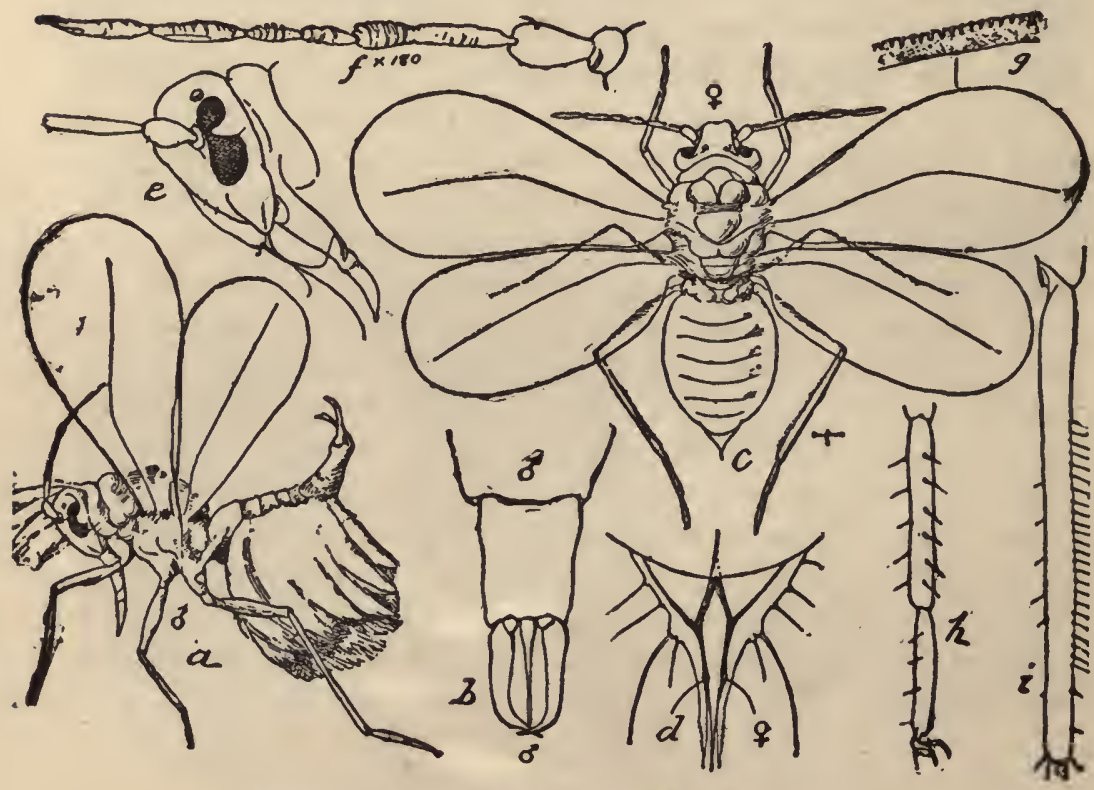

Fig. 141.-Aleyrodes citri. (From Insect Life.)

egg proper. In two weeks the young larva hatches. It is comparatively active and crawls a short distance from the egg-shell before beginning to feed. In from two to four weeks it molts and by the middle of June three skins have been cast. In molting the insect curves the abdomen upwards at more than rightangles, moving it occasionally up and down. It shrinks away from the side margin until it occupies only about one-third of the original lateral space. The skin then splits at the anterior end or underneath the head. Then the head and prothorax are pushed 


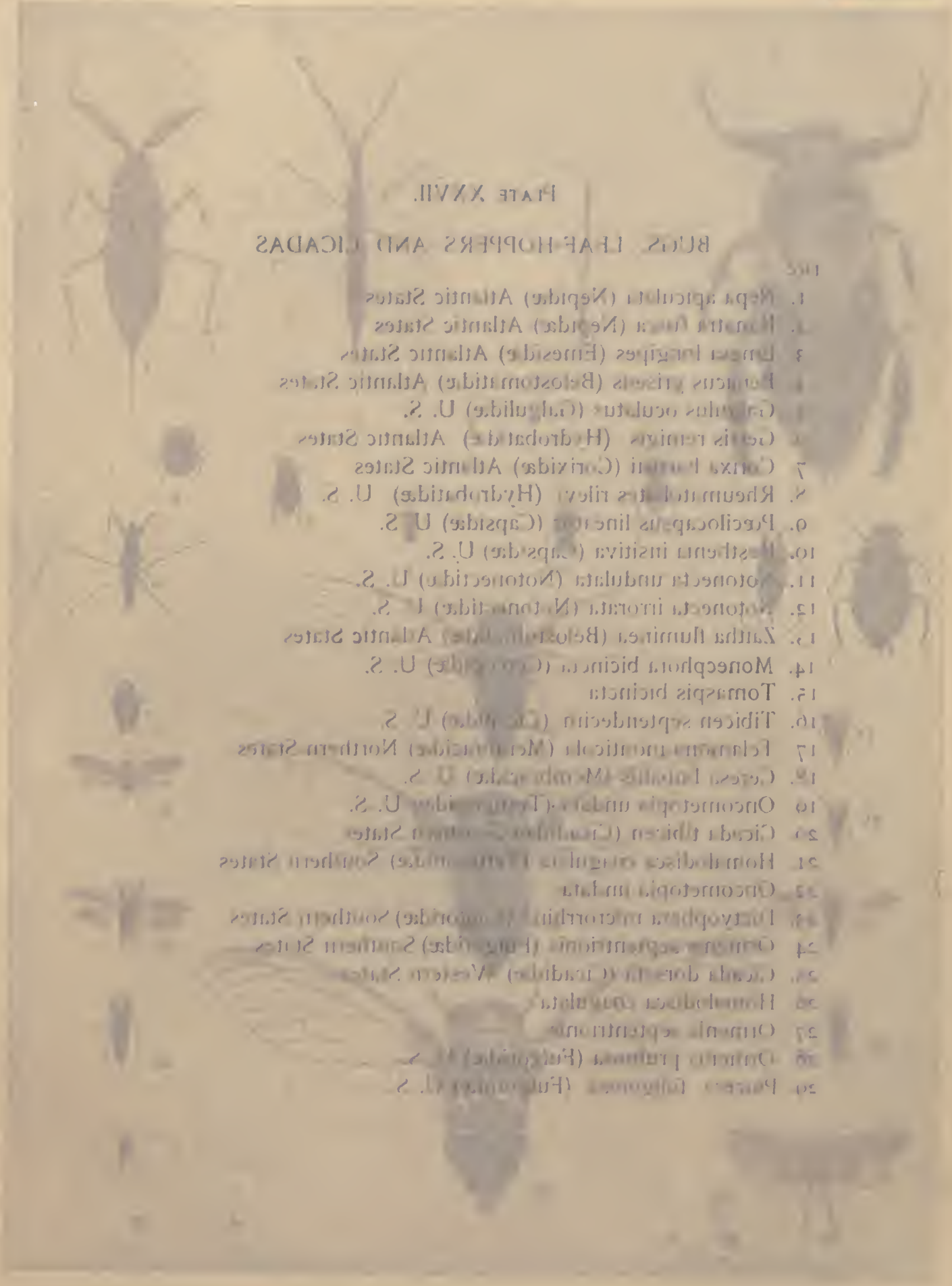




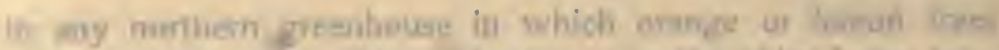

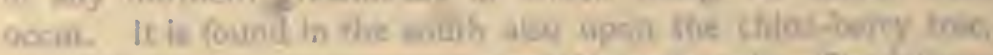

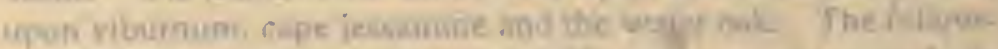

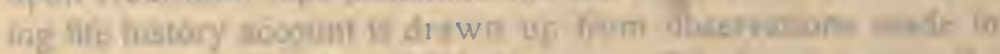

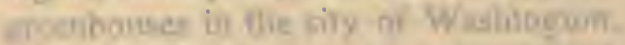

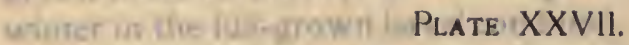

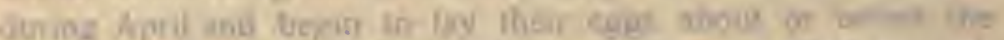
FIG.

BUGS, LEAF-HOPPERS AND CICADAS

I. Nepa apiculata (Nepidx) Atlantic States in the Iny ar thit

2. Ranatra fusca (Nepidæ) Atlantic States

3. Emesa longipes (Emesidæ) Atlantic States

4. Benacus griseus (Belostomatidæ) Atlantic States

5. Galgulus oculatus (Galgulidæ) U. S.

6. Gerris remigis (Hydrobatidæ) Atlantic States

7. Corixa harrisii (Corixidæ) Atlantic States

8. Rheumatobates rileyi (Hydrobatidæ) U. S.

9. Pocilocapsus lineatus (Capsidæ) U. S.

10. Resthenia insitiva (Capsidæ) U.S.

I1. Notonecta undulata (Notonectidæ) U. S.

12. Notonecta irrorata (Notonectidæ) U. S.

1). Zaitha fluminea (Belostomatidæ) Atlantic States

14. Monecphora bicincta (Cercopidi) U. S.

15. Tomaspis bicincta

16. Tibicen septendecim (Cicadidæ) U. S.

17. Telamona monticola (Membracidæe) Northern States

18. Ceresa bubalus (Membracidæ) U. S.

19. Oncometopia undata (Tettigonidæ) U.S.

20. Cicada tibicen (Cicadidæ) Southern States

2I. Homalodisca coagulata (Tettigonidæ) Southern States

22. Oncometopia undata

23. Dictyophara microrrhina (Fulgoridæ) Southern States

24. Ormenis septentrionis (Fulgoridæ) Southern Stites

25. Cicada dorsata (Cicadida) Western States

26. Homalodisca coagulata

27. Ormenis septentrionis

28. Ormenis pruinosa (Fulgoridæ) U. S.

29. Piocera fuliginosa (Fulgoridæ) U. S. 


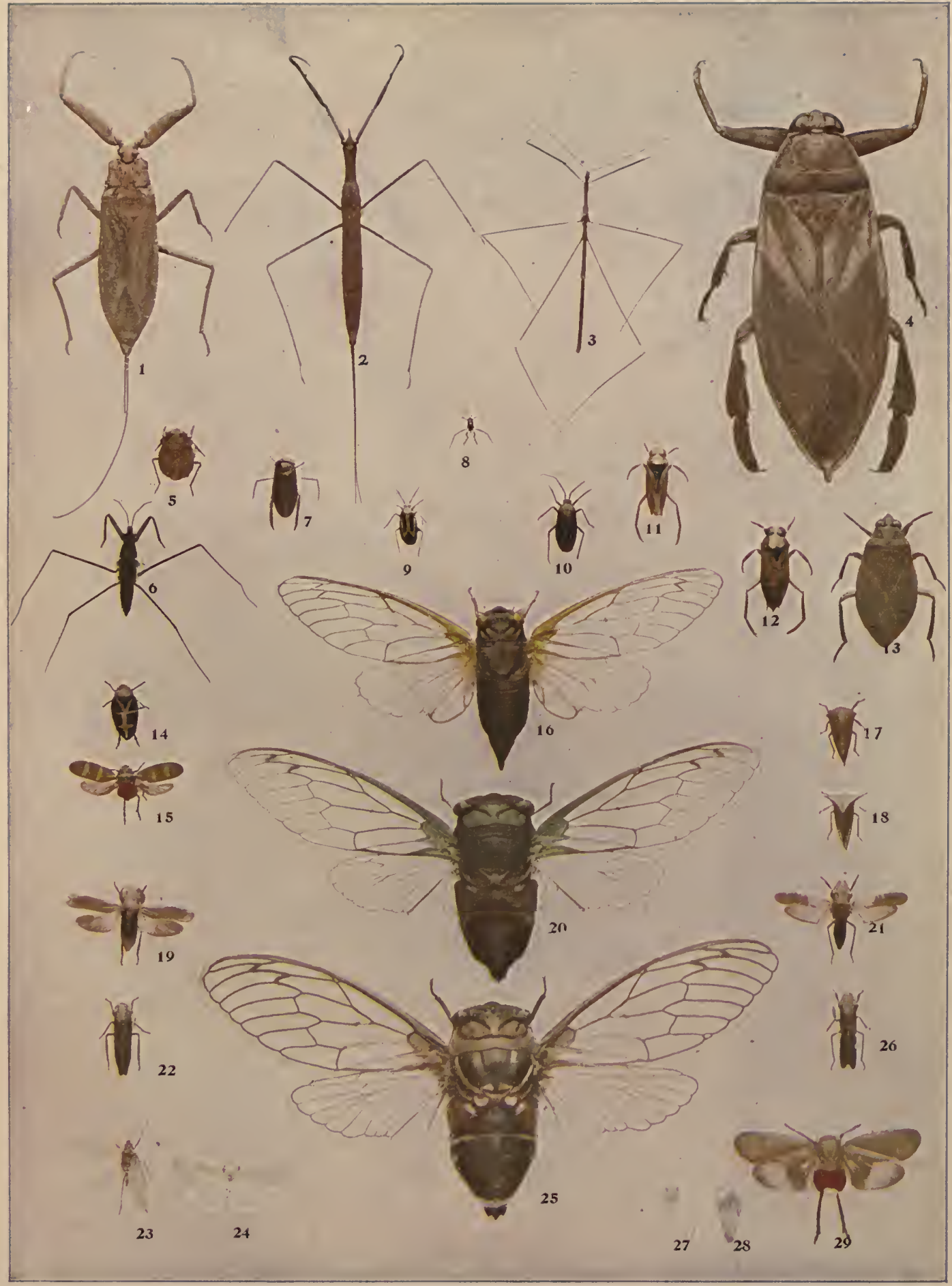




\section{-}


out and the skin is gradually worked backwards. At the end of June the adults begin to issue again in numbers, remaining alive for about twenty days. There are three generations annually. When the perfect insect issues from what may be termed the pupa shell, the wings are rolled up and make their appearance with extreme slowness. Just before the adult is ready to issue the pupa shell becomes transparent so that the contained insect, shrunken away from the skin, is plainly seen in all of its stages. The adult just after issuing is at first milk-white except for bright lemon-yellow thoracic lobes. The adult male is readily distinguished from the female by the anal claspers and by the waxy tufts issuing from the head and from the abdomen. All stages are well represented in the accompanying figures. 


\section{THE SCALE INSECTS \\ (Family Coccida.)}

The insects of this family, popularly known as scale insects or bark-lice, include forms of great morphological interest as well as very many of great economic importance. In the latter respect they form very injurious enemies to most fruit trees as well as to

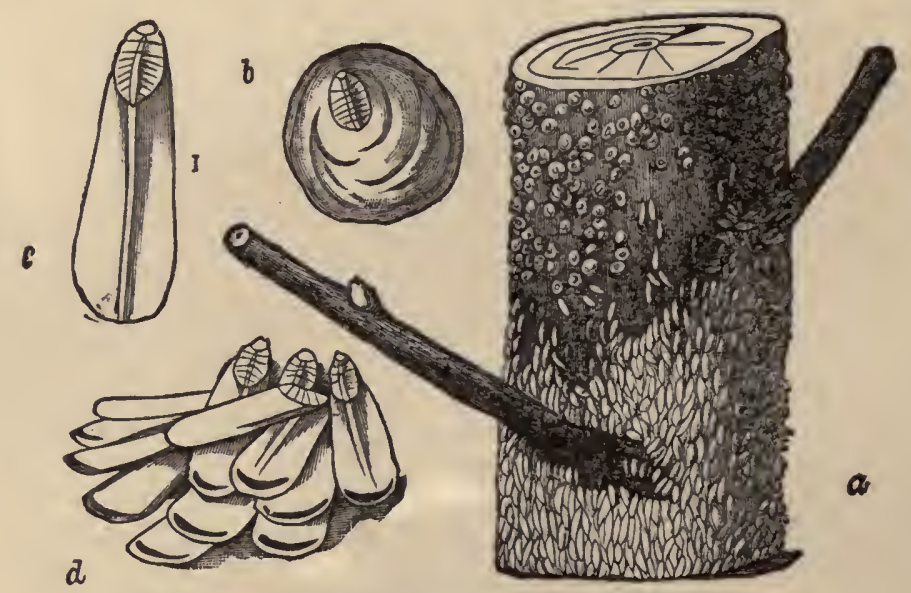

Fig. 142.-Diaspis pentagona. (Author's illustration.)

many other shade and ornamental trees. They occur upon bushes and vines as well and are even in some instances found upon grasses. The group as a whole is a most abnormal one in its life history. In general terms it may be stated that the eggs are laid by the adult female either immediately below her own body or at its posterior extremity. Certain species do not lay eggs but give birth to living young as do the plant-lice. This abnormal habit is not characteristic of any particular group of forms but is found with individual species in one or more genera. The young on hatching from the eggs are six-legged, mite-like 


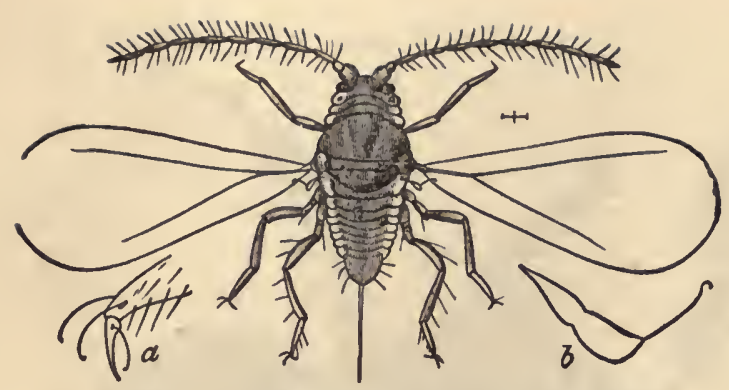

Fig. 143-Diaspis pentagona: adult male. (Author's illustration.)

creatures, which crawl rapidly away from the body of the mother, wander out upon the new and tender growth of the plant or tree, and there settle, pushing their beaks through the outer tissue of the leaf or twig and feeding upon the sap. Even at this early stage the male insect can be distinguished from the female by certain differences in structure. As a general rule the female casts its skin from three to five times before reaching the adult condition and beginning to lay eggs or to give birth to young. With each successive molt the insect increases, in size and becomes more convex in form. Its legs and antennæ become proportionally reduced, its eyes become smaller and are finally lost. As a general rule it is incapable of moving itself from the spot upon which it has once become fixed after the second molt, although certain species crawl through-

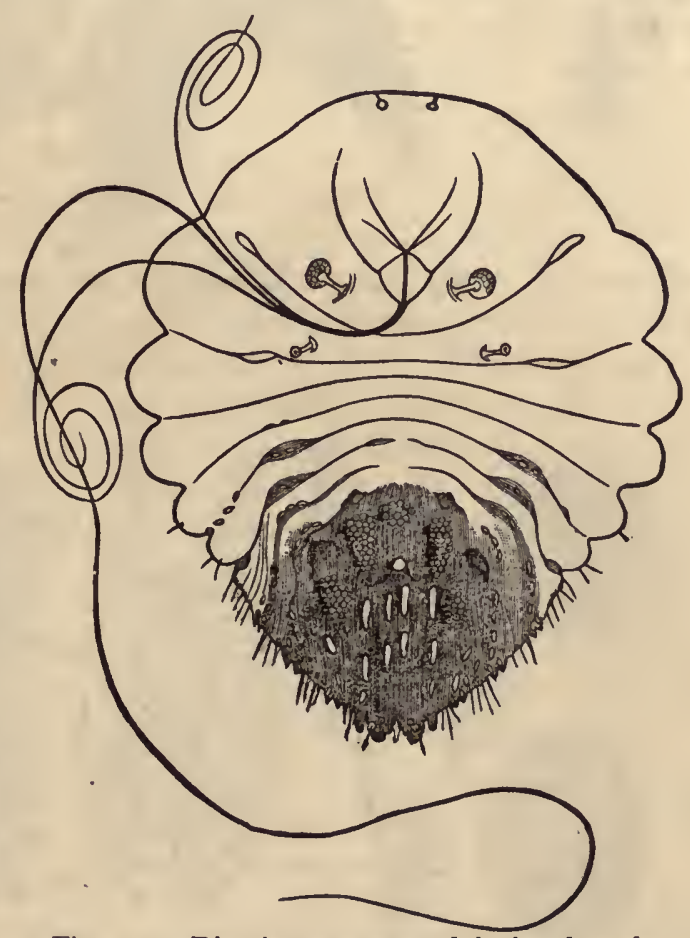

Fig. 144-Diaspis pentagona, adult female scale removed. (Author's illustration.) 


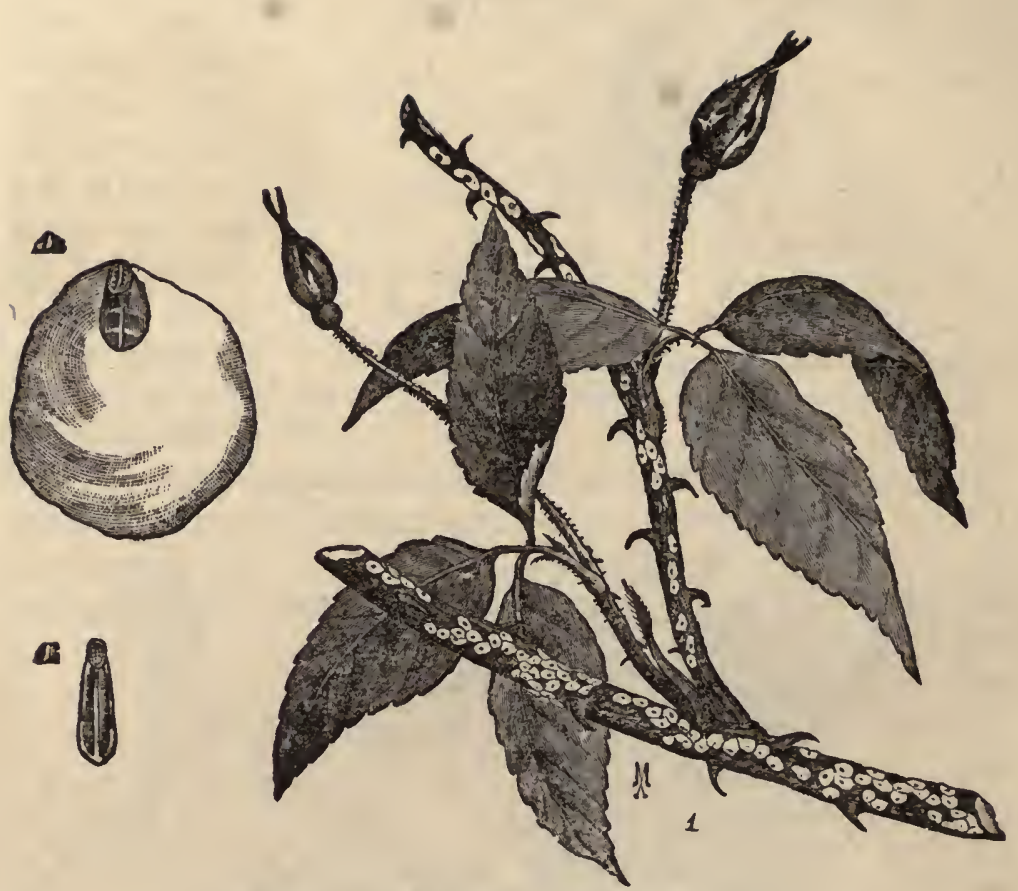

Fig. 145.-Diaspis rosæ. (After Comstock.)

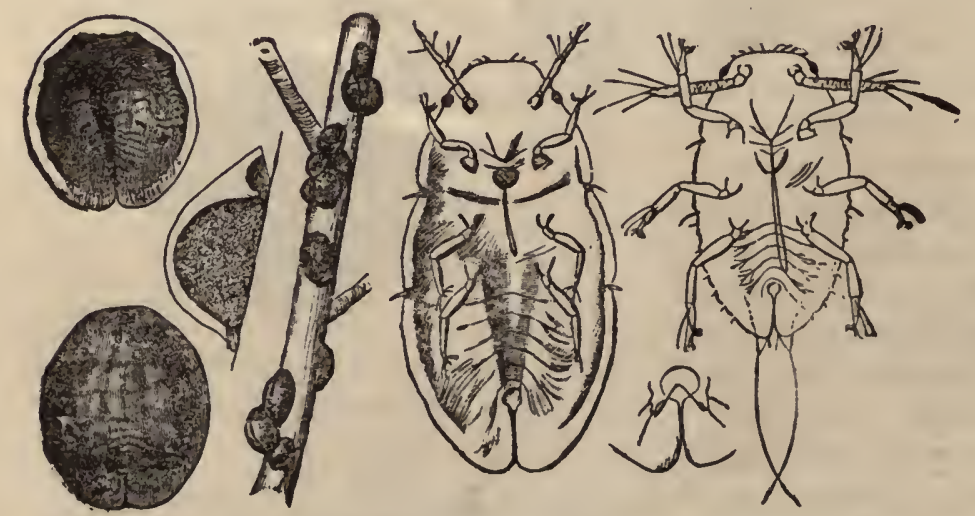

Fig. 146.-Lecanium nigrofasciatum. (Author's illustration.) 
out life. The adult female insect then is a wingless, motionless, degraded, and for all practical purposes legless and eyeless creature. She seems simply an animated drop of protoplasm enclosed in a skin. In the armored scales she is absolutely legless and eyeless. The mouth-parts through which she derives nourishment remain functional and become enlarged from molt to molt. Her body becomes swollen with eggs or

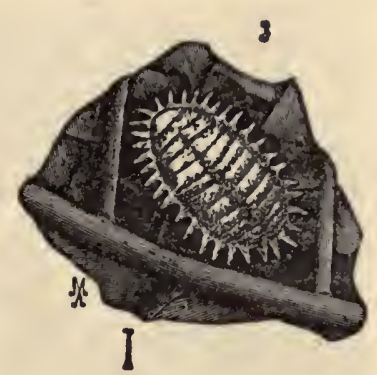

Fig. 147.-Common hot-house mealy-bug, Dactylopius citri. (After Comstock.) young and as soon as these are laid or born she dies.

The life of the male differs radically from that of the female. Up to the second molt the development remains practically parallel in the two sexes, but after this molt the male larva transforms to a pupa in which the organs of the perfectly developed fledged insect become apparent. This change may be undergone in a cocoon or under a male scale. The adult male, which issues at about the time when the female becomes full grown, is an active and rather highly organized creature with two broad functional wings and long vibrating antennæ clothed with hairs. The legs are also long and stout. The hind wings are absent but are replaced by rather long tubercles to the end of which is

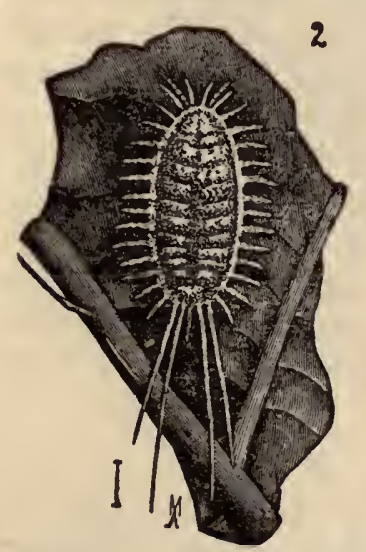

Fig. 148.- Long-talled mealybug, Dactylopius longifilis. (After Comstock.) articulated a strong bristle hooked at the tip and fitted into a pocket on the hind margin of the wings. The eyes of the adult male are very large and strongly facetted. The mouth-parts are absent and curiously enough their place is taken by supplementary eye spots or simple eyes (ocelli). The function of the male seems simply to find the female, to fertilize her and then die.

The number of generations in scale insects varies greatly and no general statement can be made.

The scale insects found in the United States belong to three large groups, the most important and the 


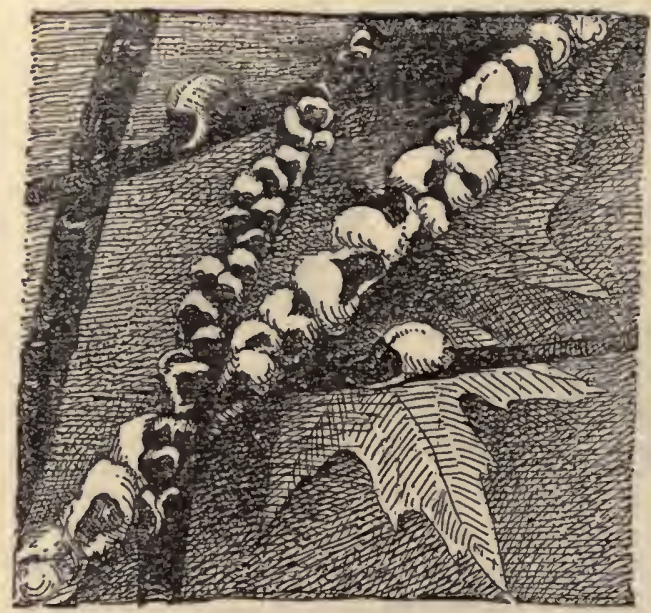

Fig. 149.-Cottony Maple Scale, Pulvinaria innumerabilis. (Author's illustration.) most abundant in species of which is the group known as the armored scales (subfamily Diaspinæ), so termed because the insect soon after settling begins the secretion of a scale by means of threads of wax exuding from pores in the body which eventually blend together and form an impervious covering separated from the insect's body. The shape and character of this scale is of importance in the classification of the group but the most important characters are found in the anal plate of the body of the female insect. A second large group well represented in the United States is the group of naked barklice, known as the subfamily Lecaniinæ. In this group no true scale is formed and the body is usually well arched so as to become almost hemispherical. The third group (subfamily Coccinæ) comprises those forms known as mealy-bugs and related forms. These insects have no differentiated scale but are all covered with a white waxy secretion, some of them having conspicuous waxy egg sacs at the end of the body of the female.

The majority of species of scale insects at present found in the United States are not indigenous to this country, but have been introduced from abroad, most of them from European regions, on plants and young trees and on fruit carried to this country in the course of commercial interchange. 


\section{Life History of the Oyster-Shell Bark-Louse of the Apple.}

(Mytilaspis pomorum Bouché.)

This insect is probably the commonest and most widespread, and consequently the best-known, of any of the orchard scales. It is found all over the world. It was probably an European insect originally - at all events, it was known in Europe during the last century-and was probably imported into this country on nursery stock by the early settlers. It is found in the United States practically wherever apples and pears are grown, more abundantly at the north than at the south, and has often received treatment at the hands of writers on injurious insects. It was

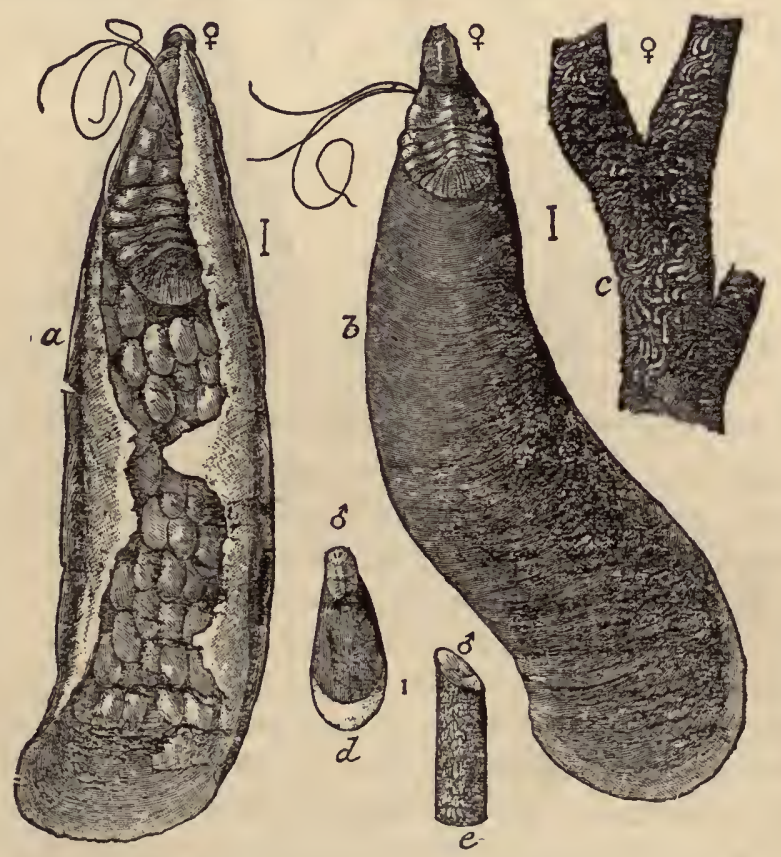

Fig. 150.-Mytilaspis pomorum. (Author's allustration.)

certainly known in this country as early as 1794 , and it unquestionably followed apple culture as it progressed to the west. It was known in the districts bordering along Lake Michigan in 1840 , and in 1858 it invaded lowa and northern Missouri. To- 
day it is present even in California. It is by no means confined to apple and pear, but is also found upon quince, hawthorn, buckthorn, rarely upon raspberry and currant, but also upon linden, hop tree, horse chestnut, maple, water locust, honey-

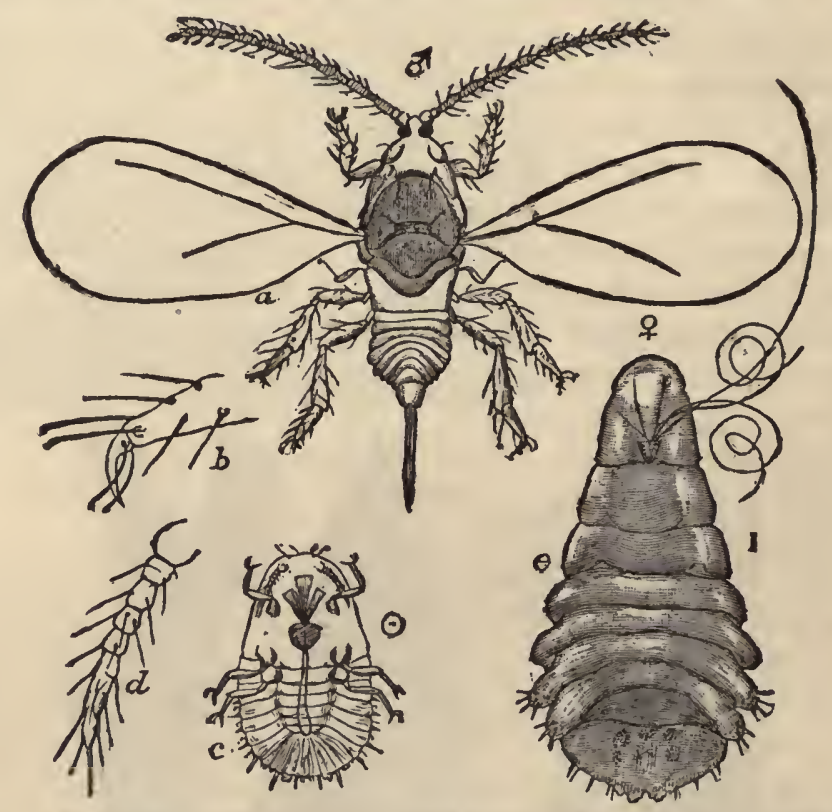

Fig. 151.-Mytilaspis pomorum : adult male and female. (Author's illustration.)

suckle, ash, elm, hickory, cottonwood, willow, poplar, wild grape, rose, fig, bitter-sweet, red maple, black ash, white ash. white birch, red birch, and very abundantly upon the lilac, so that it will be an easy form to collect and to study. In the winter time, if one of the oyster-shell shaped scales is lifted gently with the point of a needle, it will be found to contain at the narrow front end the shriveled body of the female with from 50 to 100 yellowish white eggs packed closely together behind the body. Sometimes the eggs will be found to be very few in number, but then the larva or pupa of a little chalcidid parasite will be found under the scale, which will account for the destruction of the eggs. In most of the northeastern states the young hatch from these eggs during the latter part of May or early in June (at an earlier date farther south), and wander out upon the twigs and settle at once. The young twigs are the only parts of 256 


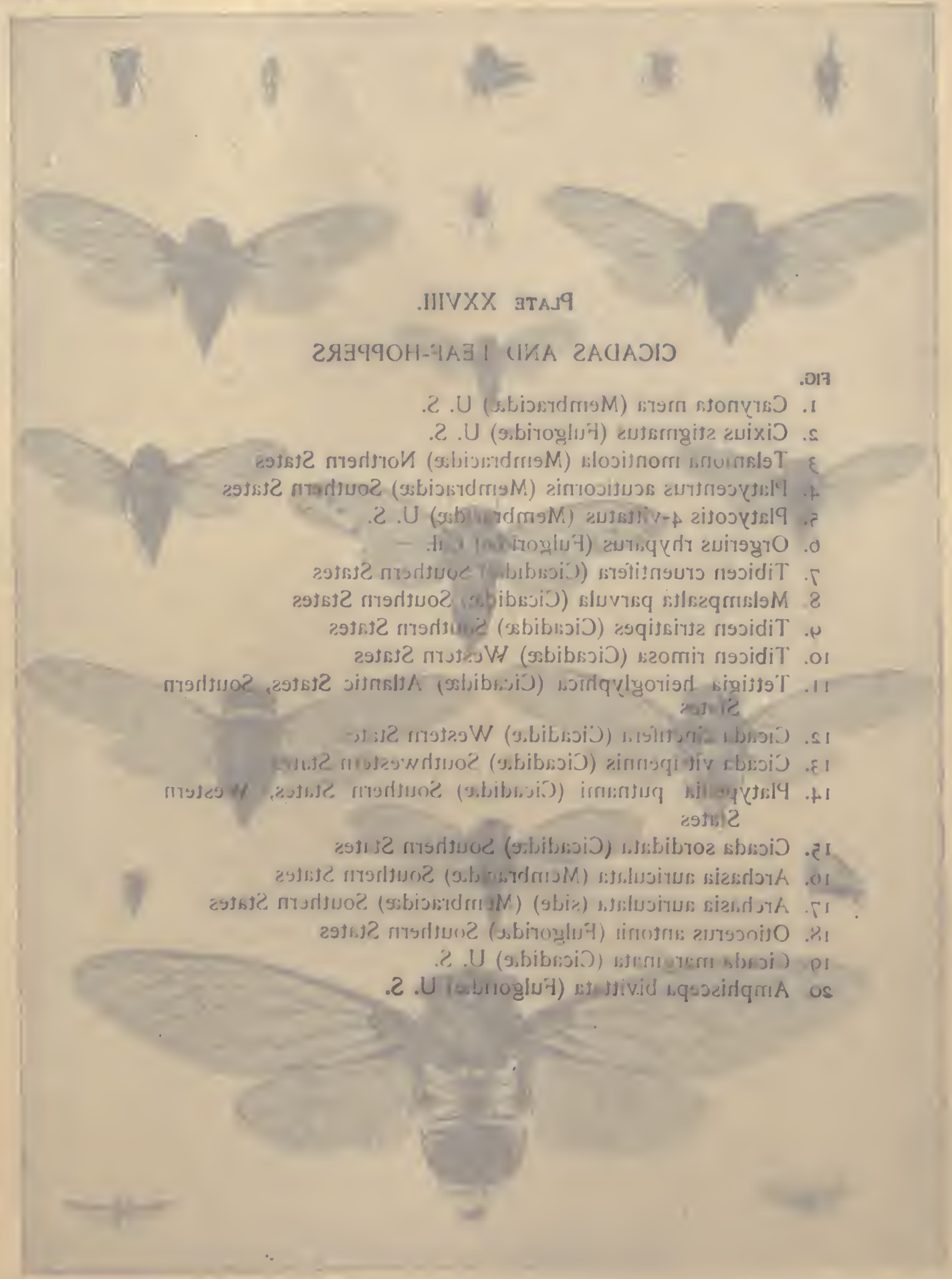


FIG.

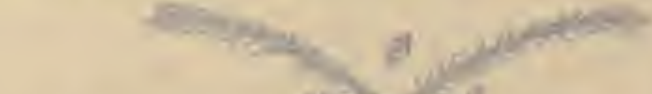

1. Carynota mera (Membracidæ) U.S.

2. Cixius stigmatus (Fulgoridæ) U. S.

3. Telamona monticola (Membracidæ) Northern States

4. Platycentrus acuticornis (Membracidæ) Southern States

5. Platycotis 4-vittatus (Membracidæ) U.S.

6. Orgerius rhyparus (Fulgoridæ) Cal.

7. Tibicen cruentifera (Cicadidæ) Southern States

8. Melampsalta parvula (Cicadidæ) Southern States

9. Tibicen striatipes (Cicadidæ) Southern States

10. Tibicen rimosa (Cicadidæ) Western States

11. Tettigia heiroglyphica (Cicadidæ) Atlantic States, Southern States

12. Cicada cinctifera (Cicadidæ) Western States

13. Cicada vitripennis (Cicadidæ) Southwestern States

14. Platypedia putnami (Cicadidæ) Southern States, Western States

15. Cicada sordidata (Cicadidæ) Southern States

16. Archasia auriculata (Membracidæ) Southern States

17. Archasia auriculata (side) (Membracidæ) Southern States

18. Otiocerus antonii (Fulgoridæ) Southern States

19. Cicada marginata (Cicadidæ) U.S.

20. Amphiscepa bivittata (Fulgoridæ) U. S. 


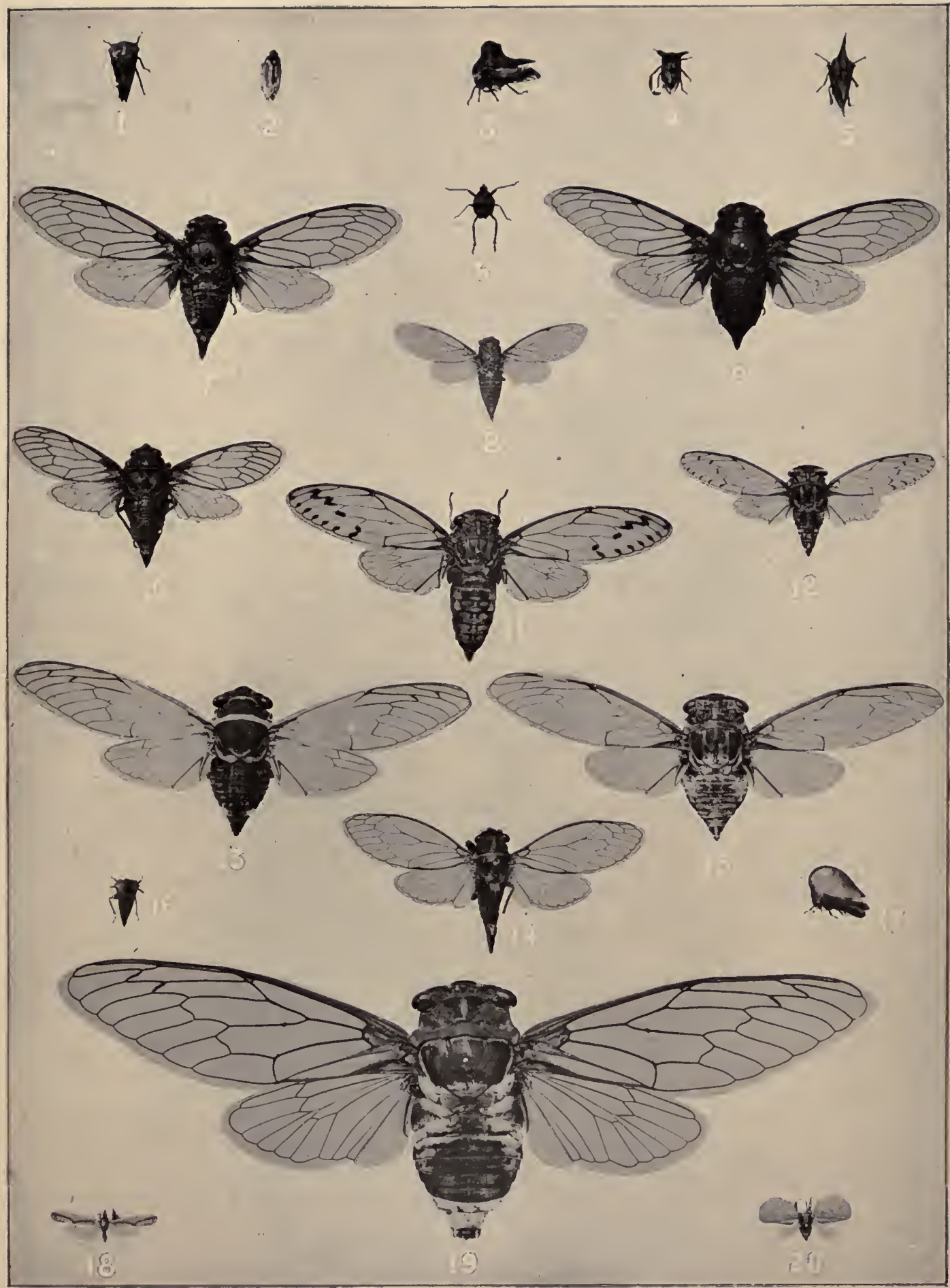


the tree which seem to be seriously affected. Older twigs, however are also attacked, and many specimens of the insect may be found upon the trunk. As soon as the young insect finds a suitable position it gradually inserts its beak and commences to grow through the influence of the healthy food sap which it pumps up. Almost immediately, also, the secretion of scale begins. This is first noticed in the form of a white, waxy powder which first is seen in the form of threads, but which soon becomes homogeneous. In a few days the first molt takes place, not as in the ordinary manner with insects by a series of contractions and extensions which work the old skin to the end of the body, from which it is finally freed, but by a sort of loosening and shrinking of the body underneath, all the parts except the proboscis being shed and abandoned with the skin. Strengthened by the secretions from the body, this skin forms the first scale. Presently the skin is shed a second time and mingles with the second secretion, which forms the second scale, which may be noticed at the anterior end of the completed scale of the old individual. As growth continues this second scale becomes too small and is

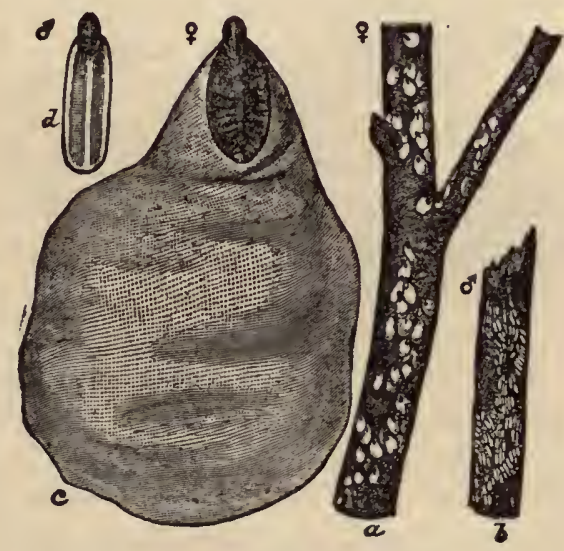

Fig. 152.-The scurfy bark-louse of the apple, Chionaspis furfurus. (Author's illustration.)

lifted up into the third portion, while the shield proper is secreted by a series of increments, more being constantly added on behind as the insect beneath grows. When full grown the female is ready for reproduction. The male scale is a perfectly distinct 
object, as indicated in the accompanying figure, and the adult male, which makes its appearance at the time when the females are almost ready for oviposition, is shown at Figure 151. There is but one annual generation in the northern states, and, owing to this fact, the leaves are not attacked, for if the insect were to go on the leaves it would be lost when they fall in the autumn. Upon the fruit it is almost equally rare, although occasionally a specimen is found in such a location. In the south, however, the insect is two-brooded, and the adults of the first generation are found upon the fruit and leaves without danger to the perpetuation of the species, since their offspring crawl back to the permanent portions of the plant before autumn. As a matter of fact, however, even in the south the insect is very seldom seen upon either the leaves or the fruit.

The insect is subject to the attacks of many natural enemies in the course of its growth. The little ladybirds, as the beetles of the family Coccinellidæ are termed, both as larvæ and adults feed upon these and other scales. There are five distinct species of chalcidid parasites which lay their eggs in the maturing barklice, and while the lice are young and before they have formed a protective scale they are avidly destroyed by the larvæ of the syrphus flies, of the lace-winged flies, and by certain small predatory bugs. The most efficient of their natural enemies, however, are probably the ladybirds, since the writer has determined that the internal chalcidid parasites rarely destroy all of the eggs in the over-wintering scales. A large number of scales were examined in the late winter and early spring of 1894 , with the result that when parasites were found from two to eighteen eggs were found to have escaped destruction, the average number of eggs in uninfested scales being from sixty-five to seventy-five. In two cases, where a parasite had issued late in the fall (and the small round hole of issuing is readily perceived in the scale), eleven and five eggs, respectively, were found. The ladybird, however, eats everything. 


\section{THE JUMPING PLANT-LICE OR FLEA-LICE \\ (Family Psyllida.)}

These insects have two-jointed tarsi, antennæ eight-or-ninejointed, and the hind legs with somewhat swollen thighs. Their

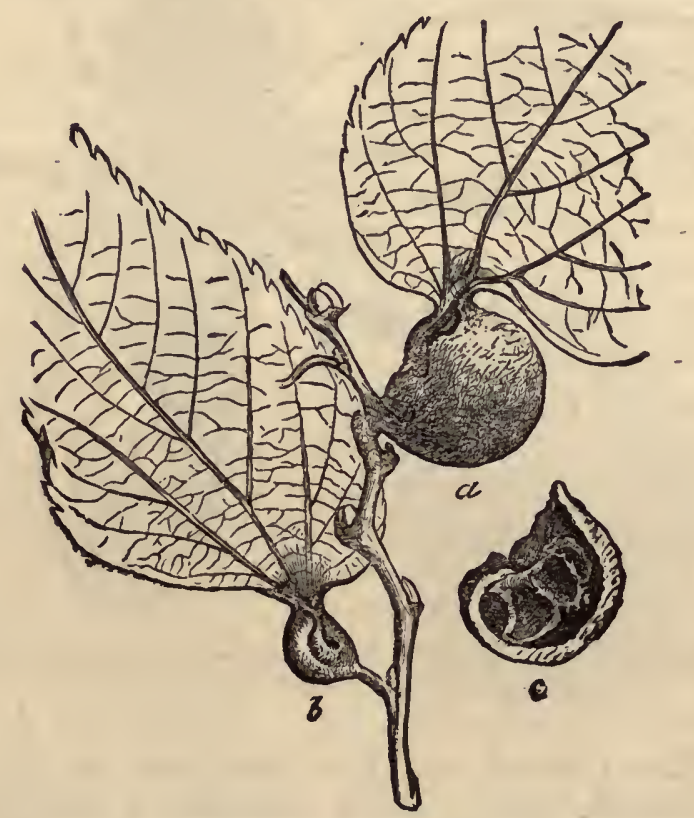

Fig. 153-Galls of Pachypsylla venusta O. S. (Atter Riley)

jumping habit distinguishes them from the plant-lice as indicated in the popular name. Certain species exude quantities of the sweet liquid known as honey-dew, which is also abundantly secreted by the plant-lice and by some of the tree-hoppers and leaf-hoppers. Many forms live in galls and there are several species which produce galls of different kinds upon the trees of the genus Celtis, commonly known as "hackberry trees." 
The Jumping Plant-Lice or Flea-Lice

\section{Life History of the Pear-Tree Psylla (Psylla pyricola.)}

This insect is the commonest and the most destructive flea louse in the United States. It is common throughout the north-

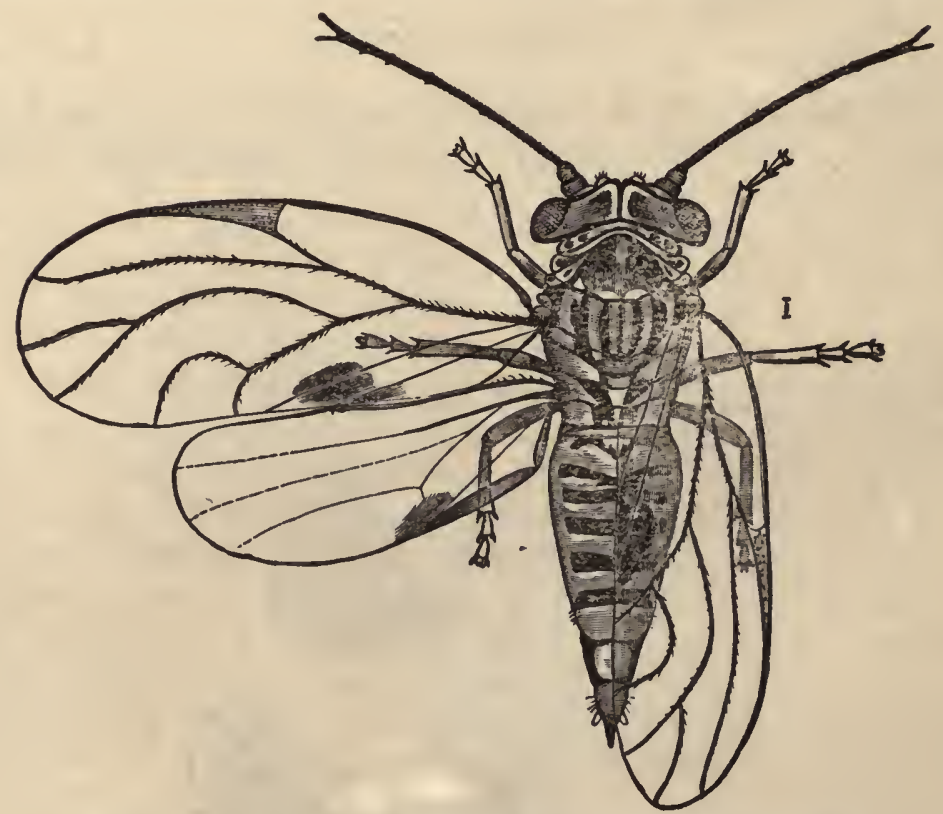

Fig. 154.-Pear-tree Psylla: adult female-natural size indicated by side line. (After Marlatt.)

eastern United States and from Maryland on the south to Michigan on the west. It was originally a European species and is supposed to have been imported into this country about 1832, making its first appearance in Connecticut. The egg is orange yellow in color and very minute. It is attached to the leaf by a short arm and has a long hair-like stalk projecting from its end. The newly hatched larva is somewhat larger than the egg and yellow in color with crimson eyes. It passes through several molts and when nearing the nymphal condition, which corresponds to the pupa stage in insects which have complete metamorphoses, it is readily distinguished by 
the large wing pads. Its color is then dark reddish brown.

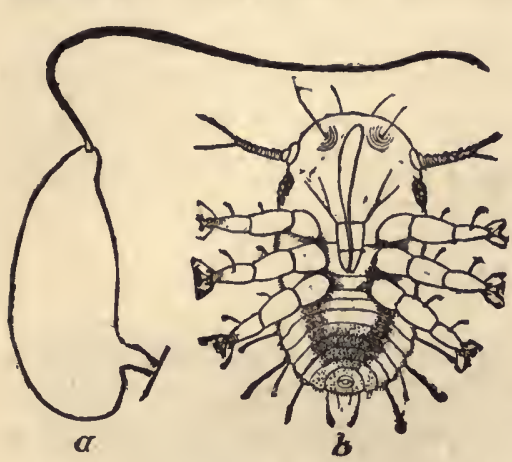

Fig. 155--Pear-tree Psylla: $a$, egg; $b$, larva-both greatly enlarged. (After Marlatt.) In all the early stages the insect is broad-oval and very much flattened, resembling more nearly some scale insect rather than a perfect flea-louse. It is also sluggish in these early stages. When the nymph casts its last skin the adult insect emerges. It resembles much more closely a minute cicada or harvest-fly than any other homopterous insect. It hibernates in the adult stage in crevices in the bark of pear-trees and emerges with the first warm spring days, beginning with the laying of the eggs on the leaves before they have fully expanded or even placing them in cracks in the bark on the twigs. The larvæ hatch in ten to seventeen days and station themselves on the surface of the leaves or on the leaf petioles. There are four or five generations each summer in Maryland but fewer farther north.

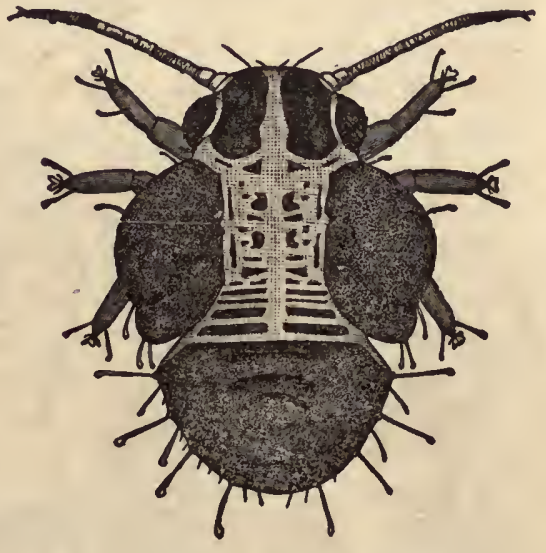

Fig. 156.-Pear-tree Psylla : pupa. (After Marlatt.) 


\section{PLANT-LICE \\ (Family Aphidida.)}

The plant-lice are very numerous not only in point of numbers of individuals but also of numbers of species. In many respects these insects are abnormal, especially in their method of development, and they have attracted great attention from naturalists since Bonnet discovered, 150 years ago, the peculiar

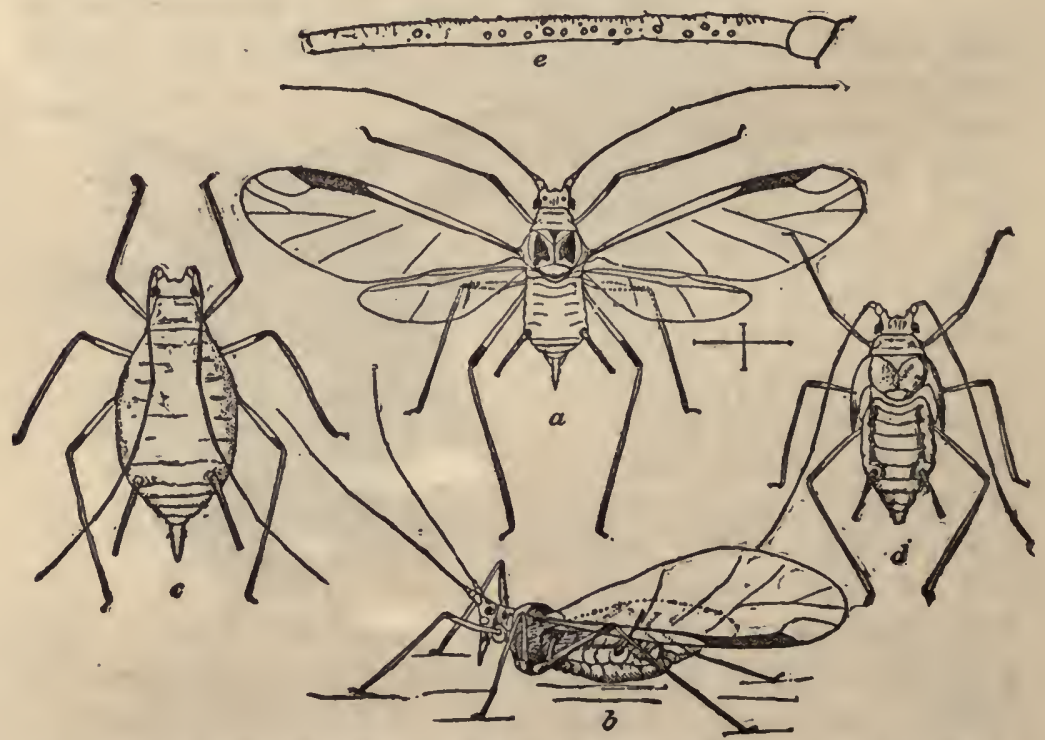

Fig. 157-Nectarophora pisum: the green-pea plant-louse. (After Chittenden.)

phenomenon known as parthenogenesis, which is almost invariably the rule amongst these creatures. Their life history is very surprising and their relations with other insects, especially with ants, are most interesting. They are very destructive insects, preying upon practically all cultivated plants, and their rate of increase is so enormous that if it were not for their innumerable 
natural enemies they would probably annihilate the greater part of plant life. The classic computation of Huxley that the uninterrupted breeding of ten generations of plant-lice from a single ancestor would produce a mass of organic matter equivalent to the bulk of five hundred millions of human beings (about the

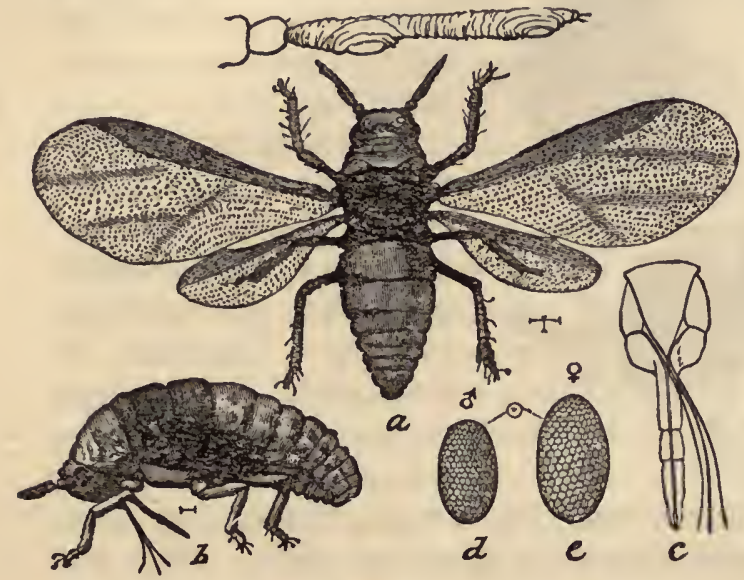

Fig. 158.-.-Phylloxera vastatrix. (After Marlatt.) population of the Chinese Empire) is by no means an over-estimate, but if anything an under-estimate. This rapidity in breeding is not due to extreme prolificacy since the number of offspring of a single female is rather small, but rather to the early age at which the offspring begin themselves to reproduce. Parthenogenesis, which means the virgin birth, $i$. e., the birth of individuals from a virgin female, and the fact that with most species and during a large part of the year the young are born alive, account for this rapidity. Generation after generation is produced in this way but in all cases sooner or later there comes a true sexual generation composed of both males and females which pair and these females as a rule lay eggs instead of giving birth to living young. In many cases it is in this egg stage that plant-

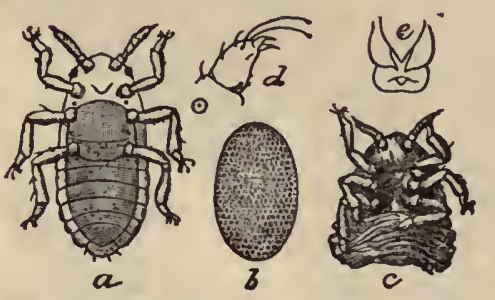

Fig. I 59.-Phylloxera vastatrix: egg and young. (After Marlatt.)

lice pass the winter. Thus it will be seen that true males make their appearance only a single time in a number of generations. Another curious feature in the life of plant-lice is the fact that while the majority of the generations in the course of a summer are composed of wingless females there comes once or twice 263 
during each season a generation of winged females, thus providing for the dispersal of the species and not only for the dispersal of the species but for the return to a perennial plant in the

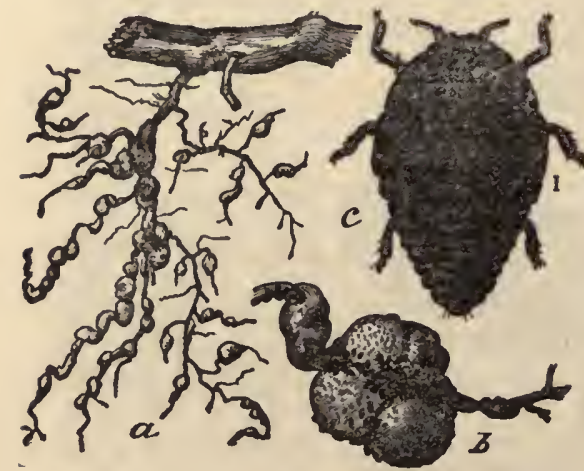

Fig. 160.-Phylloxera vastatrix : root form. (After Marlatt.) autumn from the weeds, grasses and other annual plants upon which the summer generations may have fed.

Plant-lice are attacked by a host of natural enemies. The little Braconid parasites of the subfamily Aphidiinæ are practically exclusively parasites of the plant-lice. Their eggs are laid in the body of the louse, the young live within the body until they reach full growth, and the little fourwinged parasite eventually emerges as an adult. Plant-lice

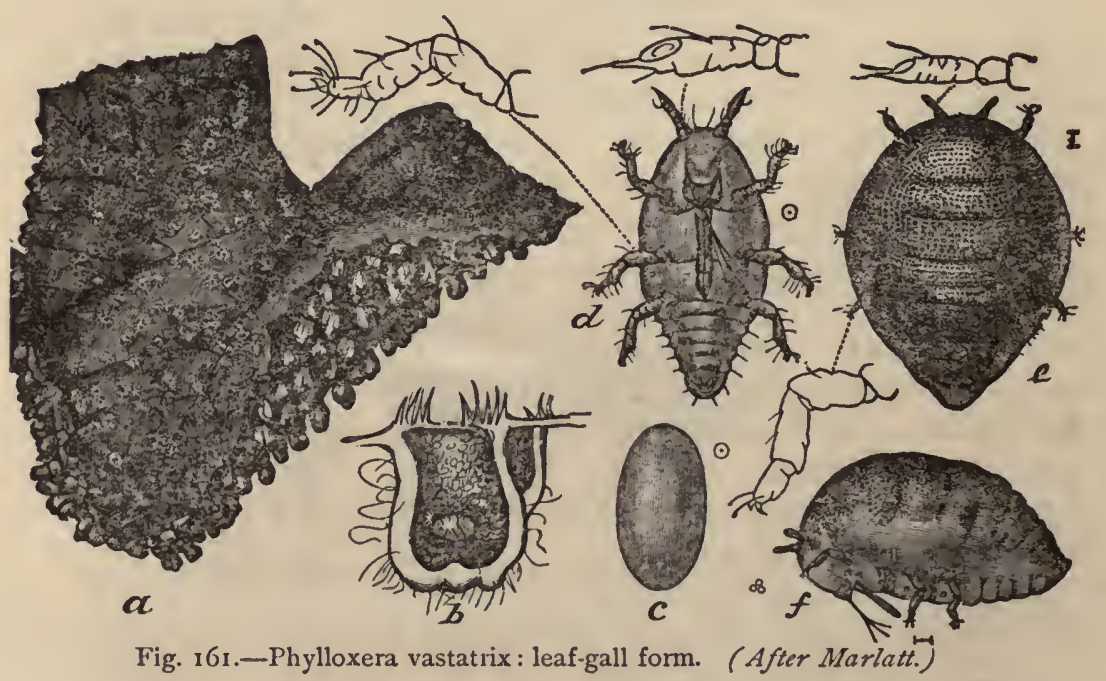

parasitized in this way become swollen and dark in color and can readily be distinguished. These parasites themselves breed with extraordinary rapidity and are frequently responsible for the 
practical extermination of the hosts of lice which are frequently found in the wheat fields in the spring. The lady-birds and the larvæ of the syrphus flies and the golden-eyed lace-wing tlies as well as the maggots of certain midges of the genus Diplosis and others breed upon plant-lice and in fact derive the greater part of their food from these creatures. Extreme prolificacy is the means which nature adopts to continue the existence of many otherwise unprotected and much harassed species. In this instance, however, it has taken the form of extreme rapidity of development instead of great prolificacy.

The relationship between plant-lice and ants has often been described and is one of the most fascinating topics in the whole field of nature study. The honey dew which is secreted by plant-lice both from the anus and from two tubes upon the back of the abdomen is greatly enjoyed by ants which in a surprisingly intelligent way care for the plant-lice, drive away their natural enemies, carry them bodily to better feeding grounds, recognize the necessity for migrations at times and assist in these migrations and actually prepare locations in advance of transportation. The term which is frequently applied to Aphids, viz, "the milch cows of the ants," is a very appropriate one.

Probably the most famous of the plant-lice in the economic sense are the grape-vine Phylloxera (Phylloxera vastatrix), a species which is said to have cost the French nation more than the indemnity paid to the Germans after the Franco-Prussian war, the woolly root-louse of the apple (Shizoneura lanigera) erroneously known in most parts of the world as the American blight, and the hop-plant louse (Phorodon humuli Schrank), a species which is fast becoming cosmopolitan and which for years has been the greatest enemy to the hop-growing industry in England and parts of this country.

\section{Life History of the Hop-Plant Louse (Phorodon humuli Schrank.)}

This insect which we have just mentioned as an extremely injurious species is commonly known as the hop-plant louse and sometimes as the hop blight insect. It is a native of Europe, is a great drawback to the success of hop-growing in England, was 
for many years known in the hop plantations in central New York and in southern Wisconsin and has within the last ten years made its appearance in the extensive hop-growing regions in Washington, Oregon and northern California. All through the Middle and Southern States occasionally hop plants are grown

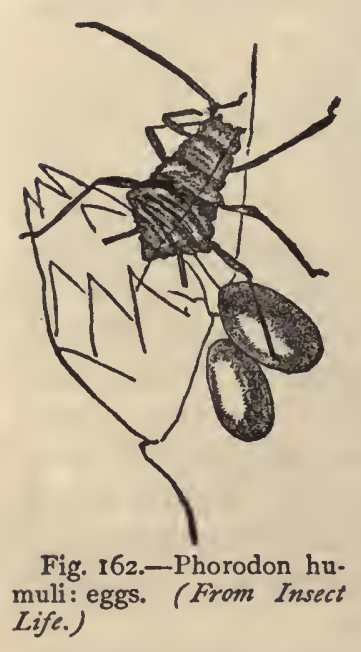
in door-yards and this plant-louse is found practically every season upon these plants. The hop is an annual plant, dying down to the ground with the first frost in the autumn. It is obvious, therefore, that the plant-louse is to be found upon some other plant during the late fall, winter, and early spring. This alternate food plant as it is called is the plum. Just why plum trees are nearly always found in the immediate vicinity of hop yards is a mystery. The winter egg of the louse is found upon the plum tree usually at the base of the buds and sometimes under the scales of a bud. From these eggs in the spring hatches the first generation which is composed entirely of virgin females and the individuals of this generation are known as the stemmothers. In two or three days after hatching, having migrated to the minute leaves bursting from the buds, they begin to give birth to living young, these also all being females. Every day of her existence the stemmother gives birth to several young varying in number from two to seven or eight. Each of these after reaching the age of about eight days begins in its turn to give birth to living young, so that the stem-mother may live to see her grandchildren of the fourth or fifth generation. The third generation acquires wings, although all are still females. By the time the winged generation makes.its appearance the

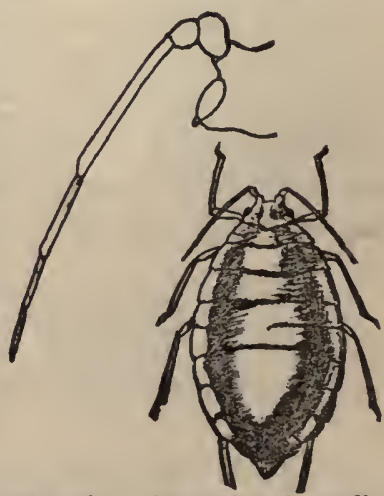

Fig. 163. - Phorodon humuli: stem-mother. (From Insect Life.) hops will have begun to come up in the fields and the lice 266 


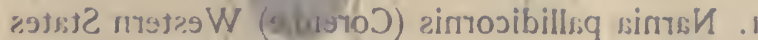

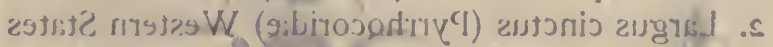

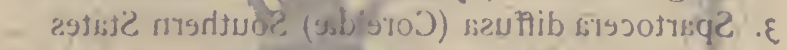

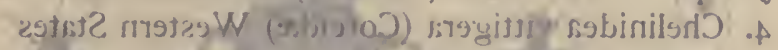

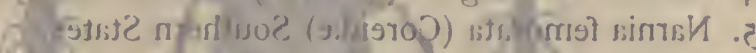

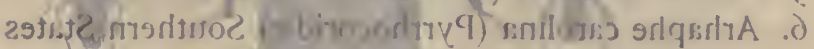

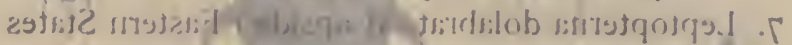

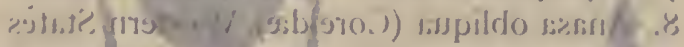

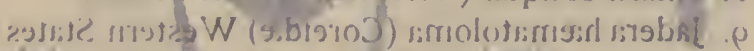

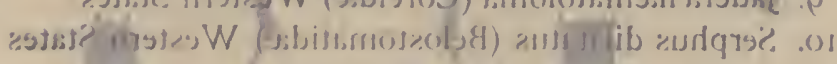

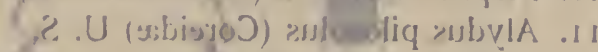

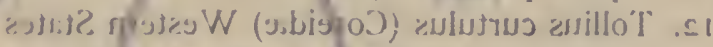

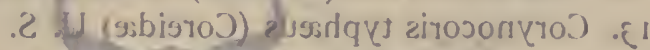

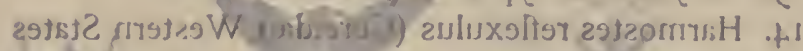

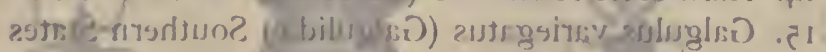

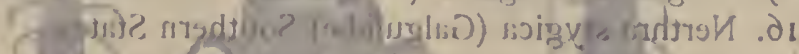

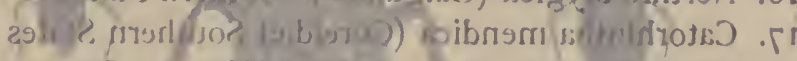

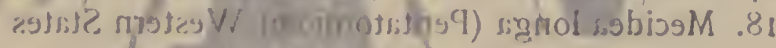

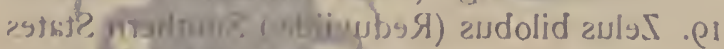

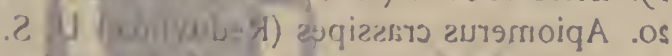

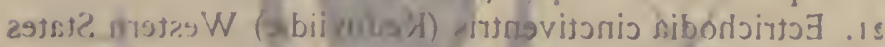

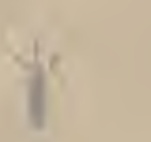

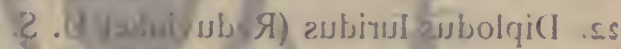

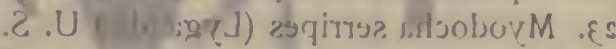

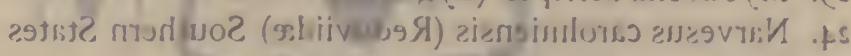

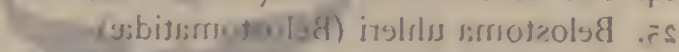

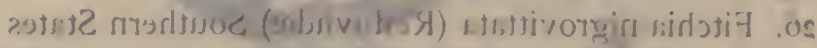

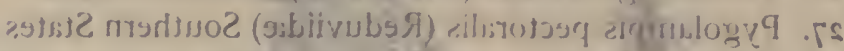

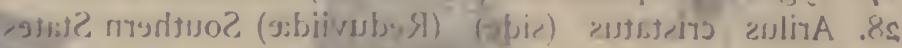

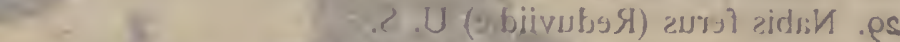

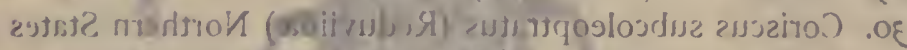

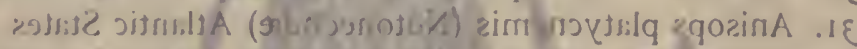

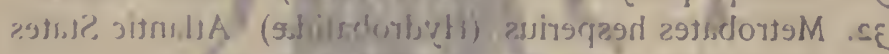

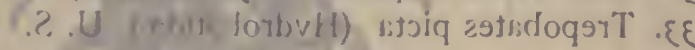

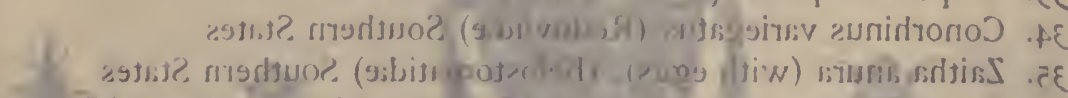

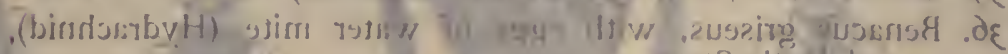

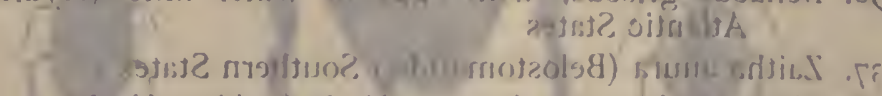

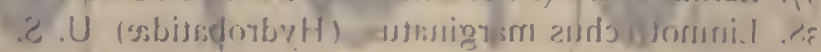


PLATE XXIX

FIG.

\section{TRUE BUGS}

I. Narnia pallidicornis (Coreidx) Western States

2. Largus cinctus (Pyrrhocoridæ) Western States

3. Spartocera diffusa (Coreidx) Southern States

4. Chelinidea vittigera (Coreidæ) Western States

5. Narnia femorata (Coreidx) Southern States

6. Arhaphe carolina (Pyrrhocoridx) Southern States

7. Leptopternal dolabratil (Capsidx) Eastern States

8. Anasa obliqua (Coreidx) Western States

9. Jadera hæinitoloma (Coreidæ) Western States

10. Serphus dilatitus (Belostomatida) Western States

11. Alydus pilosulus (Coreidie) U. S.

12. Tollius curtulus (Coreidx) Western States

13. Corynocoris typhæus (Coreidæ) U. S.

14. Harmostes reflexulus (Coreidæ) Western States

15. Galgulus variegatus (Galgulidx) Southern States

16. Nerthra stygica (Galgulidæ) Southern States

17. Catorhintha mendica (Coreidx) Southern States

18. Mecidea longa (Pentatomidæ) Western States

19. Zelus bilobus (Reduviidx) Southern States

20. Apiomerus crassipes (Reduviidie) U. S.

21. Ectrichodia cinctiventris (Reduviidx) Western States

22. Diplodus luridus (Reduviidx) U. S.

23. Myodocha serripes (Lygæidæ) U. S.

24. Narvesus caroliniensis (Reduviidx) Southern States

25. Belostoma uhleri (Belostomatidx)

26. Fitchia nigrovittatil (Reduviidæ) Southern States

27. Pygolampis pectoralis (Reduviidx) Southern States

28. Arilus cristatus (side) (Reduviidæ) Southern States

29. Nabis ferus (Reduviidæ) U. S.

30. Coriscus subcoleoptratus (Reduviida) Northern States

31. Anisops platycnemis (Notonectidx) Atlantic States

32. Metrobates hesperius (Hydrobatidx) Atlantic States

33. Trepobates picta (Hydrobatidx) U.S.

34. Conorhinus variegatus (Reduviidx) Southern States

35. Zaitha anura (with eggs), (Belostomatidx) Southern States

36. Benacus griseus, with eggs of water mite (Hydrachnid), Atlantic States

37. Zaitha anura (Belostomatidæ) Southern States

38. Limnotrechus marginatus (Hydrobatidæ) U.S. 


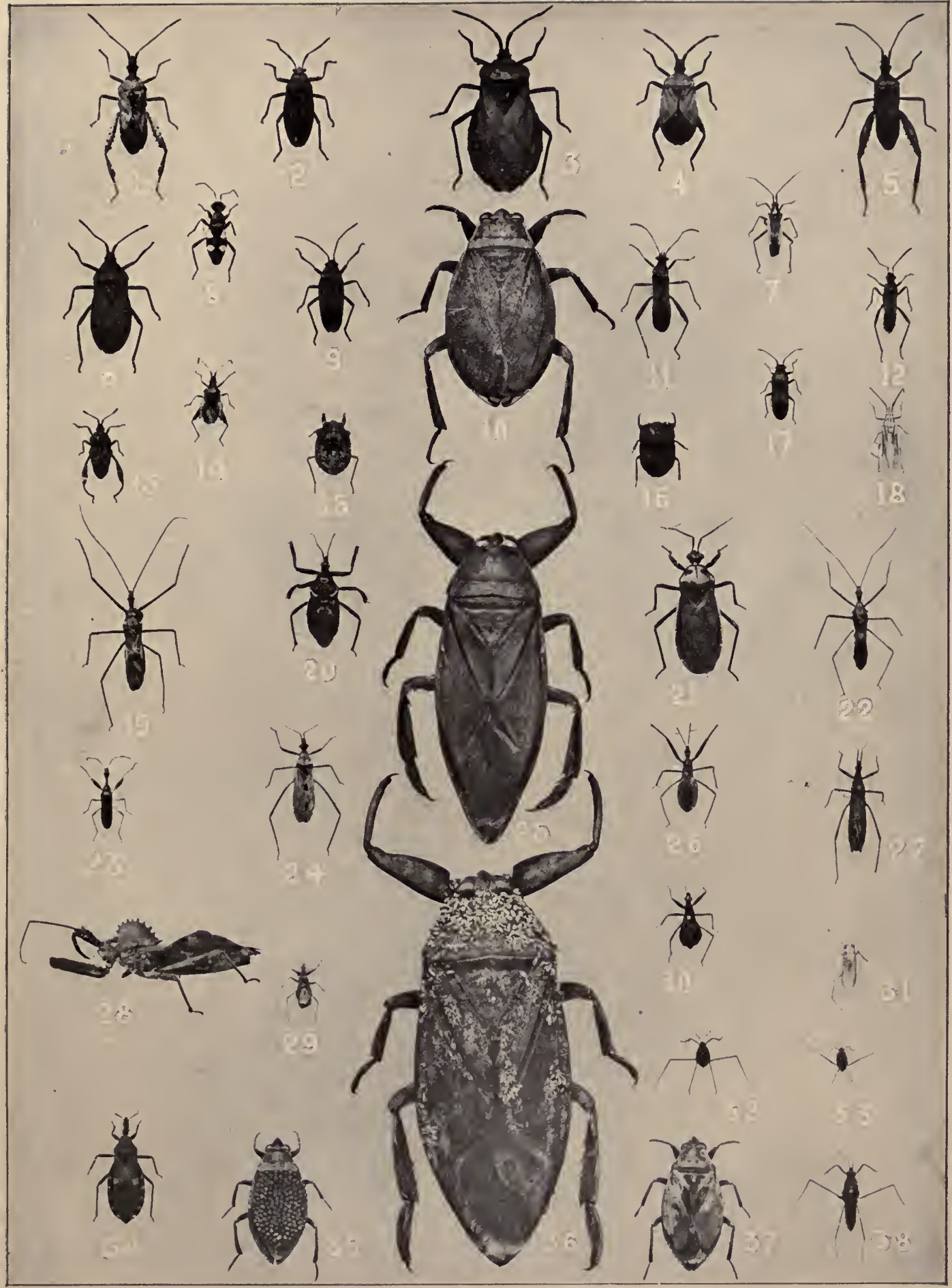



fly to the hops, settle upon the leaves, and begin to give birth to the fourth generation which is composed like the second of wingless parthenogenetic females and the same process is repeated until possibly eleven or twelve generations in all have been produced. By the time the twelfth generation makes its appearance the month of September has come and hop-picking is well along. All of the lice at this time acquire wings. Some of them may be of the twelfth generation, others through the fact that their ancestors have been late born through a series of generations may be only of the fifth generation. The first to acquire wings in the autumn are always females and these fly back to the

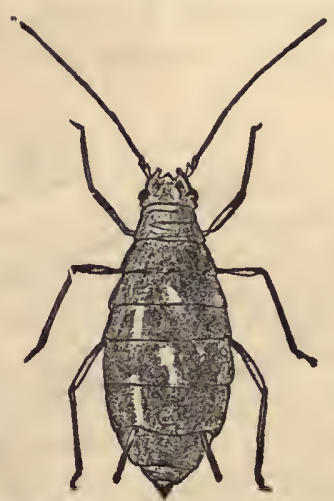

Fig. 164. - Phorodon humuli : egg-laying female. (From Insect Life.) neighboring plum trees. Later individuals of this generation and frequently all of the individuals of an additional generation

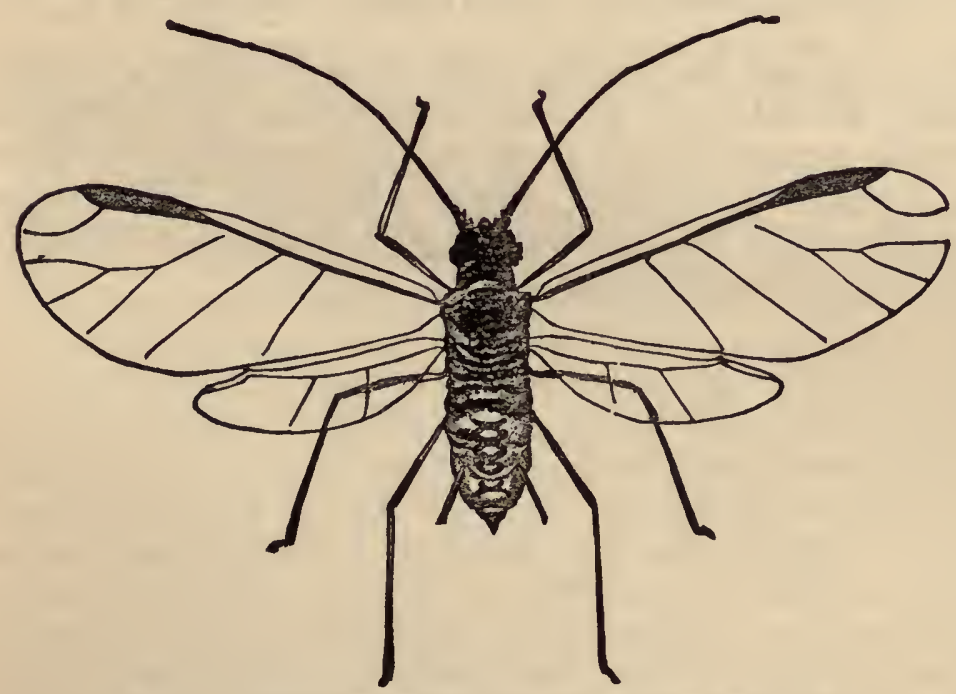

Fig. 165.--Phorodon humuli : migrant. (From Insect Life.)

on the hop are true males, the male thus making its appearance for the first and only time in the life round of the species. By 267 


\section{Plant-Lice}

the time they have developed the first issuing females will have settled upon the plum trees and will have given birth parthenogenetically as before to a generation of wingless individuals which comprise the true females-not the virgin females as

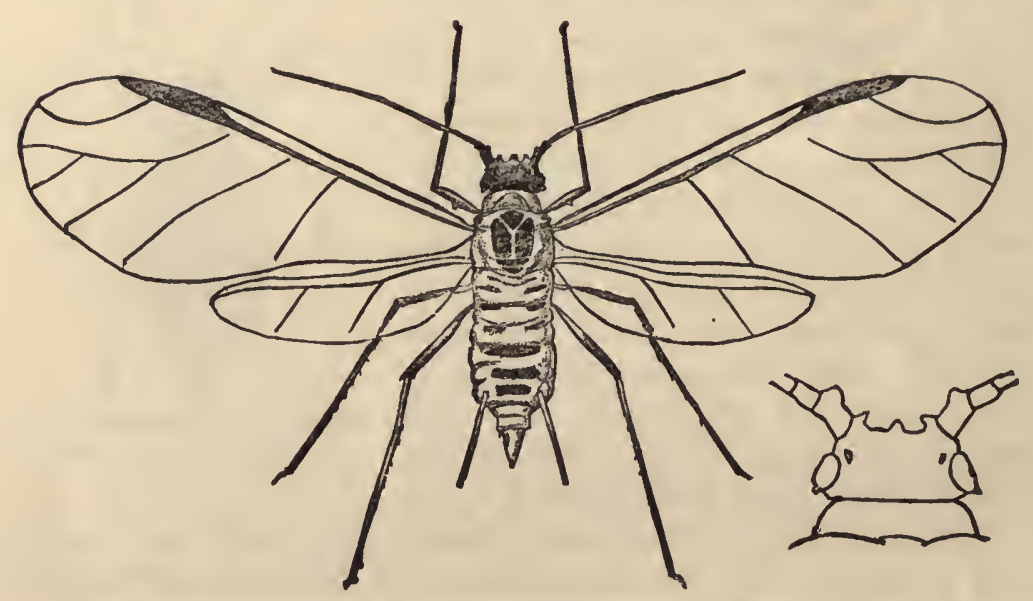

Fig. 166.-Phorodon humuli : retum migrant. (From Insect Life.)

before-but the true females which must be fertilized by the males. So that, by the time the winged males have developed from the hop and fly back to the plum we have this generation of wingless sexual or true females awaiting them. Impregnation then takes place, the males die, and these wingless sexual females give birth to the winter eggs. 


\section{THE TRUE BUGS}

\section{(Suborder Heteroptera.)}

The true bugs belong to this group and the common squashbug may he taken as a typical example. In all, the metamorphoses are incomplete and the mouth-parts are formed into a beak fitted for sucking either the juices of plants or of insects or the blood of fishes, birds or mammals. The wings, when present, differ radically from those of the preceding order in that the front wings or wing covers, or elytra, or hemielytra, as they are variously termed are horny at the basal half and membranous for the end portion. When they are folded the membranous portions overlap, that of the right wing covering that of the left, but there are many exceptions to this rule, and even in the same species, while most specimens will be found with the right wing uppermost, there will be some in which the membrane of the left wing is on top.

The order is a very large one, but has not been studied with the same assiduity which has characterized the study of other groups. There are not more than half a dozen entomologists or collectors in the United States who specialize in the true bugs. Yet these insects are easily captured and are as readily preserved as beetles and the studying of their varying habits offers a most attractive field. Probably twelve thousand species have been described in the whole world of which only about one thousand six hundred inhabit the United States. This number could be more than quadrupled by careful collecting and, indeed, our most learned authority on the group, Professur P. R. Uhler, of Baltimore, informs me that he infers that we have five thousand species in the United States, of which not more than three thousand species have been brought together in collections, but the number is being added to every month. He thinks that fifty thousand, as an estimate of the existing species in the whole world, would be a very insufficient supposition. 
In food habits the Heteroptera vary greatly. Some of them live strictly on the sap of plants, while others are carnivorous, sucking the blood of other insects, and even the blood of vertebrate animals, while still others seem to feed indifferently upon plants and animals. Still others seem to require no other nourishment than the moisture of decaying wood and fungi. Many forms are truly aquatic, others travel about with ease upon the surface, while others seem confined to the shores of streams and ponds and to the sea beach. The majority, however, live inland under the most diverse conditions on trees, plants and shrubs.

The peculiar odor possessed by many of the true bugs is by no means characteristic of all. The disagreeable and characteristic odor of the bed-bug is approximated by that of the chinchbug of western wheatfields and by certain Pentatomids. Others smell like very ripe or over-ripe fruit, especially pears, while in some Coreidæ the odor is aromatic and in others it is spicy like cinnamon. This odor is that of a very volatile oil which is secreted, as a method of defense, from certain specialized glands situated in different parts of the body.

It will especially be noticed that there is very much yet to be learned about the individual life histories of the true bugs. ln very few of the families has a single species been studied with sufficient care to enable the writer to give a good typical life history. There is probably no one of the great groups of insects which offers so good an opportunity for the collector, the systematic worker, or the true student of nature who wishes to learn how insects live, to learn so many original and absolutely novel facts as in collecting and studying the Heteroptera. For many years Professor P. R. Uhler has worked practically alone in this country on this easily collected, easily preserved and easily studied group, and although Professor H. E. Summers, and Mr. O. Heidemann have recently taken up this interesting study, an enormous field is open for scores of workers.

\section{TABLE OF FAMILIES *}

Antennæ shorter than the head and nearly or quite concealed in a cavity beneath the eyes.................

* For the greater part of this table, which, however, has been rearranged, the writer is indebted to H. E. Summers' Bull. 3, Vol. iv, Agric. Expt. Station of the Univ. Tenn., I 891 . 
Antennæ at least as long as the head, usually free, rarely (in Phymatidx) lying in a groove along the side of the pronotum .............................

I-Hind tarsi without claws $\ldots \ldots \ldots \ldots \ldots \ldots \ldots \ldots \ldots$

Hind tarsi with two claws $\ldots \ldots \ldots \ldots \ldots \ldots \ldots \ldots . . . \ldots$

2-Fore tarsi flattened, ciliated on edge, without claws; head overlapping prothorax ................. Corixida

Fore tarsi not flattened, with two claws; head inserted into

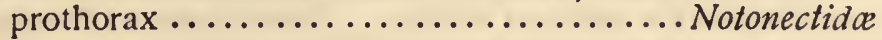

3-Abdomen with two grooved filaments at tip, forming together a respiratory tube which is not retractile, Nepidae

Abdomen without respiratory tube.

Legs formed for swimming; tip of abdomen with two retractile strap-like appendages......... Belostomatidoe

Legs formed for walking; abdomen with no such appendages.

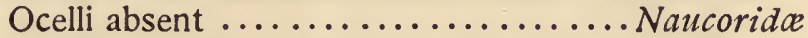

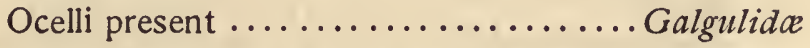

4-Antennæ with their bases visible from above, usually fourjointed; rarely five-jointed, (not counting the minute intermediate segments sometimes present.)

Scutellum less than half as long as abdomen.........5

Antennæ with their bases not visible from above, five-jointed.

Scutellum more than half as long as abdomen........ 14

5-Beak three-jointed, sometimes four-jointed, with basal segment very short and inconspicuous ............ 6

Beak four-jointed, with plain basal segment...........

6-Body very slender; head as long as thorax .. Hydrometrida

Body of various shapes, but when slender, head shorter than thorax.

Last segment of tarsi more or less bifid, with the claws inserted before the tip................... drobatidae

Last segment of tarsi entire, claws at tip.

Hemelytra usually well developed and without cuneus.

When Hemelytra is absent ocelli are present......7

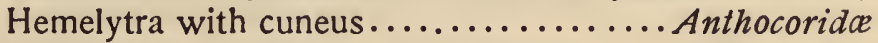
Hemelytra rudimentary, ocelli absent........ Cimicida

7-Hind tarsi with three segments...............

Hind tarsi with two segments ................. 
8-Beak long and slender.................... Saldida

Beak short and stout.

Head globulous behind the eyes....... Henicocephalida

Head not so formed................... Reduviida

9-Ocelli present. Fore-thighs greatly widened.... Phymatida

Ocelli absent. Fore-thighs not greatly widened.

Hemelytra shorter than abdomen............Aradida

Hemelytra longer than abdomen........... Tingitida

10-Hemelytra without cuneus. Membrane with longitudinal veins which are sometimes indistinct............1

Hemelytra with cuneus. Membrane with one or two cells at base, but otherwise veinless.............. Capsida

I 1 -Membrane either with four or five simple longitudinal veins, in which case ocelli are usually present, or with about eight forked veins, in which case ocelli are absent....12

Membrane with many, usually forked, longitudinal veins which are sometimes difficult to see.......... Coreida

12-Membrane with four or five simple longitudinal veins....13

Membrane with about eight forked longitudinal veins. Ocelli lacking ........................ Pyrrhocorida

13-Head with transverse incision in front of ocelli which are always present.....................Berytida

Head without transverse incision. Ocelli usually present, rarely lacking $\ldots \ldots \ldots \ldots \ldots \ldots \ldots \ldots \ldots$ Lygaida

14-Five-jointed antennæ with hidden bases. Scutellum more than half the length of the abdomen, sometimes flat, sometimes very convex and covering nearly the whole abdomen..................... Pentatomida 


\section{THE WATER BOATMEN}

\section{(Family Corixide.**)}

The little bugs of this family and of the five families which immediately follow are all aquatic in their habits and form the series known to most writers as the Cryptocerata from the fact that they appear to have no antennæ, since these organs are hidden below the head, sometimes in pockets. From their aquatic habits they are called Hydrocorise or Hydrocores in some of the older works, though there are two other families, the Hebrida and Hydrobatidae which have obvious antennæ and yet live on the surface of the water and in damp places.

The Corixidæ are known as "water boatmen." They are mottled bugs of oval shape which are found commonly swimming on the surface of ponds and streams in all parts of the United States. They are flattened below and swim with the back upwards. They can descend below the surface and remain there for a long time since they carry down with them a film of air held by the fine hairs which cover the body. They are true air breathers. When cold weather comes on,

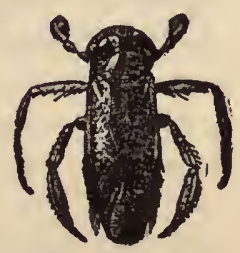

Fig. I67.-Curixa interrupta Say. (After Uhler.) the water boatman, as do other aquatic bugs as well, swims down to the bottom and buries itself in the mud where it remains during the winter and specimens captured in spring are frequently coated with mud. The eggs are laid under water and are attached in numbers to the stems of aquatic plants. The eggs of two Mexican species (Corixa mercenaria and C. femorata) are laid in enormous numbers in lakes near the city of Mexico, and are made into cakes with meal and are eaten by the Indians and half-breeds. They are said to have an agreeable acid flavor. I

* Usually printed in the books Corisida, and the type genus as Corisa; but the change from the older Corixide and Corixa was not justified by the nomenclature rules now in force. 
ate some once, but it was a stale museum specimen and had anything but a pleasant taste. These Mexican species are imported into England by the ton as food for game and song birds, poultry and fish. Kirkaldy has computed that one ton contains $25,000,000$ of these insects.

According to Miall, Schmidt-Schwedt says that Corixa uses its fore legs to play a tune on its snout, the note being tolerably loud and sustained. They swim rapidly, their hind legs being oar-like, and they are predatory in their habits, feeding upon other aquatic animals. The beak is strong and sharp and they can pierce the tough skin of one's finger.

Active as these insects are in water they are slow and clumsy on land but when their pools dry up they fly inland in search of other water and are sometimes attracted to light at night. About forty species occur in the United States, all belonging to the genus Corixa. The full life history of none is known, and an easily made aquarium study of any one of our common species is greatly to be desired.

Uhler says: "Few insects are more sprightly and the aquarium acquires a new interest by the introduction of these easily obtainable creatures." 


\section{THE BACK SWIMMERS}

\section{(Family Notonectida.)}

These water bugs known as the "back swimmers" much resemble the water boatmen, but are very convex on the back and always swim with the belly upwards. This, in fact, distinguishes them from all other water bugs. In their habits they are much like the water boatmen. They are predaceous, and feed upon other water insects and even fish. They are strong

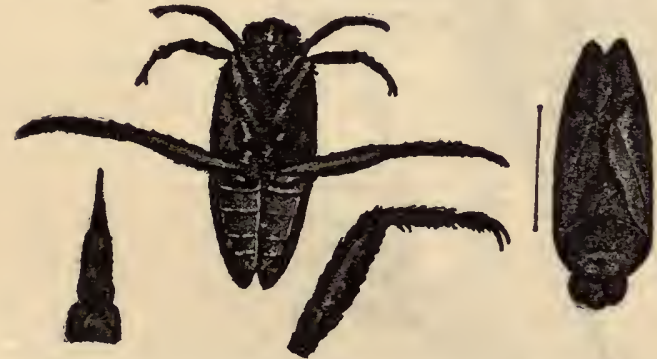

Fig. 168.-Notonecta undulata Say: upper and lower side, beak and leg. (After Lugger.) enough to master a good-sized minnow, and a prick from their beak is as painful as a bee sting. They carry below with them a greater air film than do the others, and have to hold fast with their fore legs to some stone or

water plant to prevent themselves from popping up to the surface. They are most active insects, and most interesting creatures for the aquarium. They hibernate in the mud at the bottom of streams, pools and ponds. The eggs are laid in the stems of water plants, which are pierced by the sharp ovipositor of the female. About two-thirds of the egg are pushed into the incision, and the remaining third is left extruding.

About a dozen species are known to inhabit the United States, and these are distributed in the genera Nolonecta, Anisops and Plea.

A good life history of one of our common species such as Notonecta undulata, widely distributed in North America, is still to be written, but could be made out in any school aquarium. 


\section{THE WATER SCORPIONS}

\section{(Family Nepida.)}

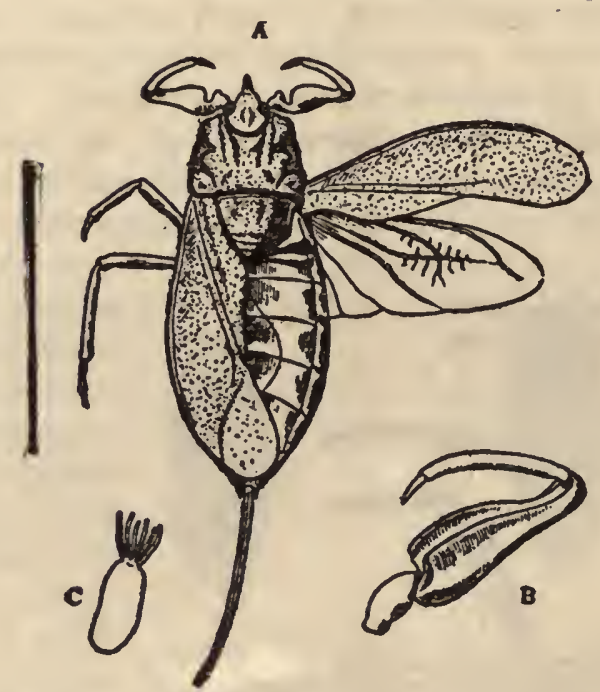

Fig. $169 .-$ Nepa cinerea Linn : $a$, adult; $b$, front leg, showing groove to receive rest of limb; c, egg. (After Miall.)

The Nepids have been called "water scorpions" because their fore legs are swollen and fitted for grasping, and rather distantly resemble the cheliceres of a scorpion. The anal end of the body bears two long half-tubes which, when united, form a tube to convey air to the insect when the rest of the body is under water. The water scorpions are either flat and oval or they are long and thin. Those of the former shape belong to the genus Nepa, and of the latter to the genus Ranatra. As with the water boatmen and the back swimmers, these insects are predatory, and a large share of their food is the eggs of fish, but they also attack small fish and other water insects. 
The eggs are laid in the stems of plants in much the same manner as are those of the back swimmers, but the egg itself is pushed entirely within the slit made in the plant by the insects'

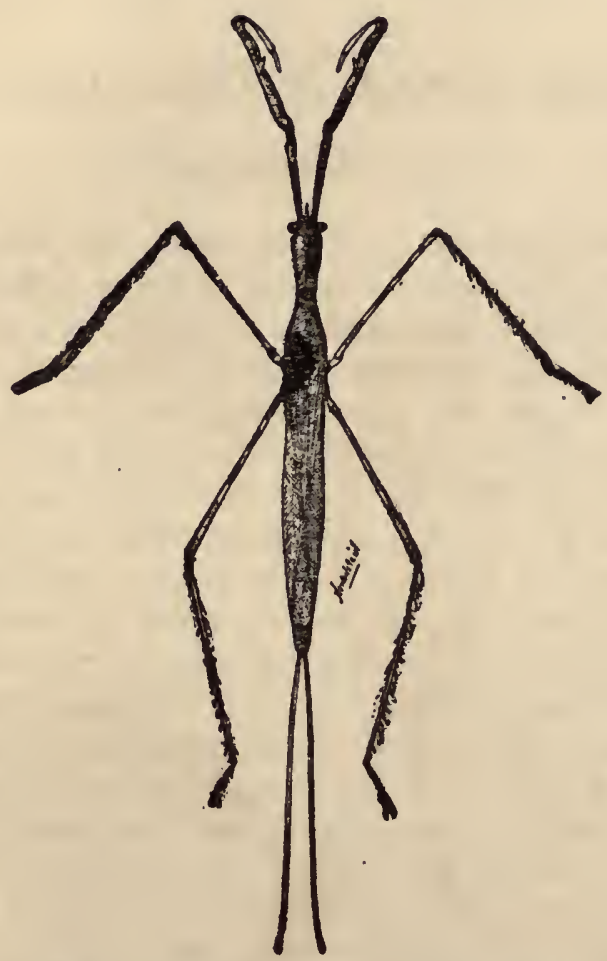

Fig. 170.-Ranatra fusca. (After Lugger.)

ovipositor, while there protrude several long filaments (seven. in Nepa and two in Ranatra) which are supposed to be pneumatic in function.

The eggs of no American species have been described, and a full life history of any American species is greatly desired. 


\section{THE GIANT WATER BUGS}

\section{(Family Belostomatida.)}

The remarkable insects of this family have long attracted attention. They include the largest of living bugs, are strictly aquatic in their early stages and are predatory in habits, living at the bottom of ponds and feeding upon other aquatic animals including fish. Their fore legs are fitted for grasping their prey and their hind legs for swimming. When full grown, however, their wings are developed and they fly strongly and for great distances. They have been found in the midst of great cities far from ponds and are attracted to electric lights on the tops of high buildings. So attractive are electric lights to these great bugs that they congregate about them in extraordinary numbers and thousands of them which have fallen to the ground beneath such lights are crushed beneath the feet of passers by. They have in fact become generally known as "electric light bugs." While such hosts of them are destroyed in this way, their numbers do not seem to be reduced, but it is bad policy to have electric lights near fish breeding establishments or artificial fish ponds. The fish ponds in Washington, since the advent of the electric light have become so greatly stocked with these bugs that they are a serious detriment in fish raising. The two most abundant and the largest of our native species are Belostoma americanum Leidy and Benacus griseus Say. Both are very large, flat, grayish or brownish bugs and were long confused. The Belostoma has a double groove on the underside of its fore thighs which is lacking on the thighs of the Benacus. The eggs are large and spherical and are attached to the stems of water plants or to some other convenient object. Of Benacus griseus Uhler says: "It is the facile master of the ponds and estuaries of the tidal creeks and rivers of the Atlantic States. Developing in the quiet pools, secreting itself beneath stones or rubbish, it watches the approach of a Pomotis, mud-minnow, frog or other small-sized tenant of 278 


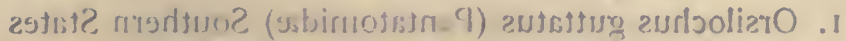

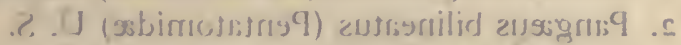

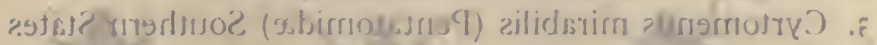

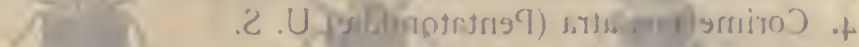

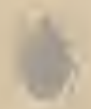

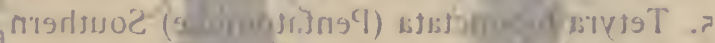

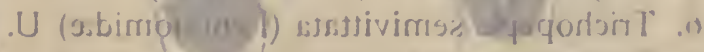

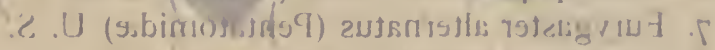

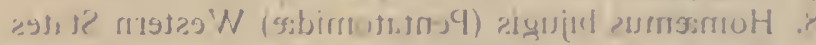

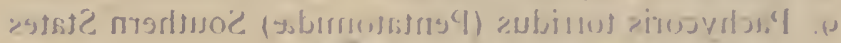

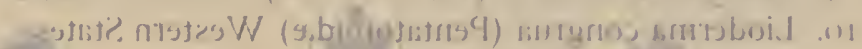

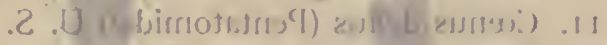

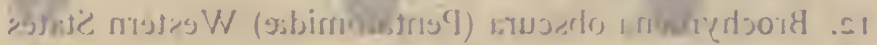

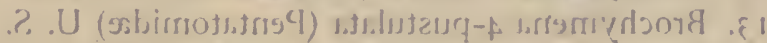

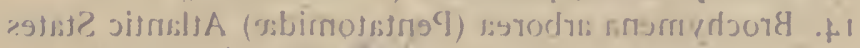

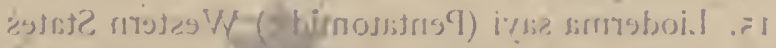

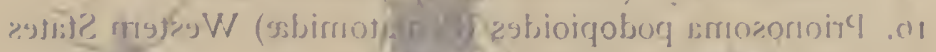

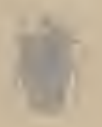

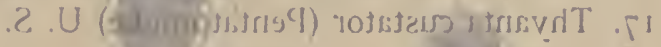

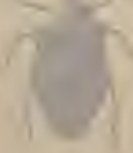

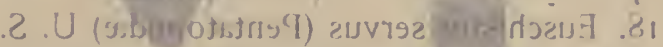

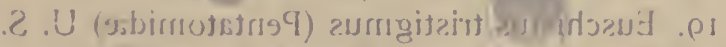

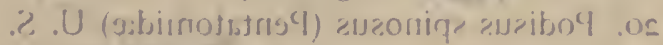

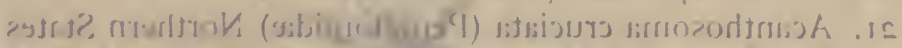

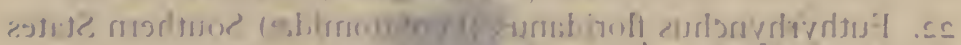

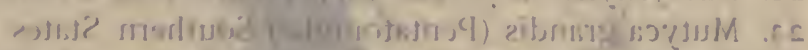

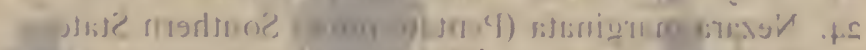

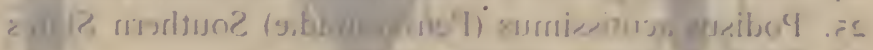

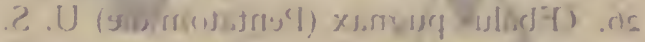

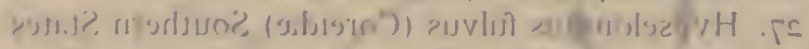

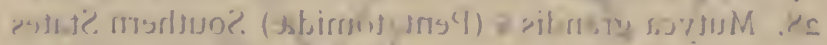

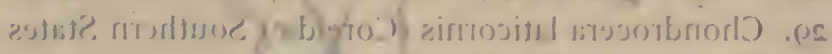

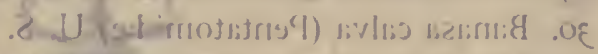

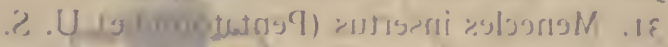
zofiat? (n)

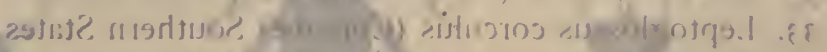

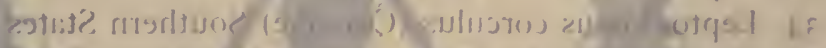

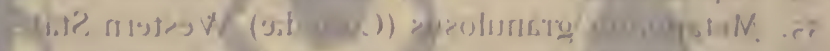

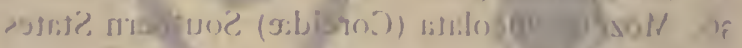

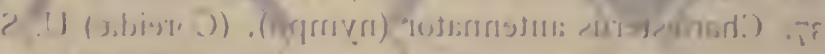


Plati: XXX.

FIG.

TRUE BUGS

1. Orsilochus guttatus (Pentatomidx) Southern States

2. Pangæus bilineatus (Pentatomidx) U.S.

3. Cyrtomenus mirabilis (Pentatomidx) Southern States

4. Corimelæna atra (Pentatomidæ) U. S.

5. Tetyra bipunctata (Pentatomidx) Southern States

6. Trichopepla semivittata (Pentatomidx) U. S.

7. Eurygaster alternatus (Pentatomida) U.S.

8. Homæmus bijugis (Pentatomidæ) Western States

9. Pachycoris torridus (Pentatomidie) Southern States

10. Lioderma congrua (Pentatomidæ) Western States

11. Coenus delius (Pentatomidx) U. S.

12. Brochymena obscura (Pentatomidx) Western States

13. Brochymena 4-pustulata (Pentatomidx) U. S.

14. Brochymena arborea (Pentatomidæ) Atlantic States

15. Lioderma sayi (Pentatomidæ) Western States

16. Prionosoma podopioides (Pentatomidæ) Western States

17. Thyanta custator (Pentatomidx) U. S.

18. Euschistus servus (Pentatomidæ) U. S.

19. Euschistus tristigmus (Pentatomidæ) U.S.

20. Podisus spinosus (Pentatomidx) U. S.

21. Acanthosoma cruciata (Pentatomidx) Northern States

22. Euthyrhynchus floridanus (Pentatomidæ) Southern States

23. Mutyca grandis (Pentatomidx) Southern States

24. Nezara marginata (Pentatomidx) Southern States

25. Podisus acutissimus (Pentatomidx) Southern States

26. CEbalus pugnax (Pentatomidx) U. S.

27. Hypselonotus fulvus (Coreidx) Southern States

28. Mutyca grandis (Pentatomidæ) Southern States

29. Chondrocera laticornis (Coreidx) Southern States

30. Banasa calva (Pentatomidre) U. S.

31. Menecles insertus (Pentatomidæ) U. S.

32. Nezarat viridula (Pentatomidx) Southern States

33. Leptoglossus corculis (Coreidx) Southern States

34. Leptoglossus corculus (Coreidx) Southern States

35. Metapodius granulosus (Coreidx) Western States

36. Mozena lineolata (Coreida) Southern States

37. Chariesterus antennator (nymph), (C. reidie) U. S. 


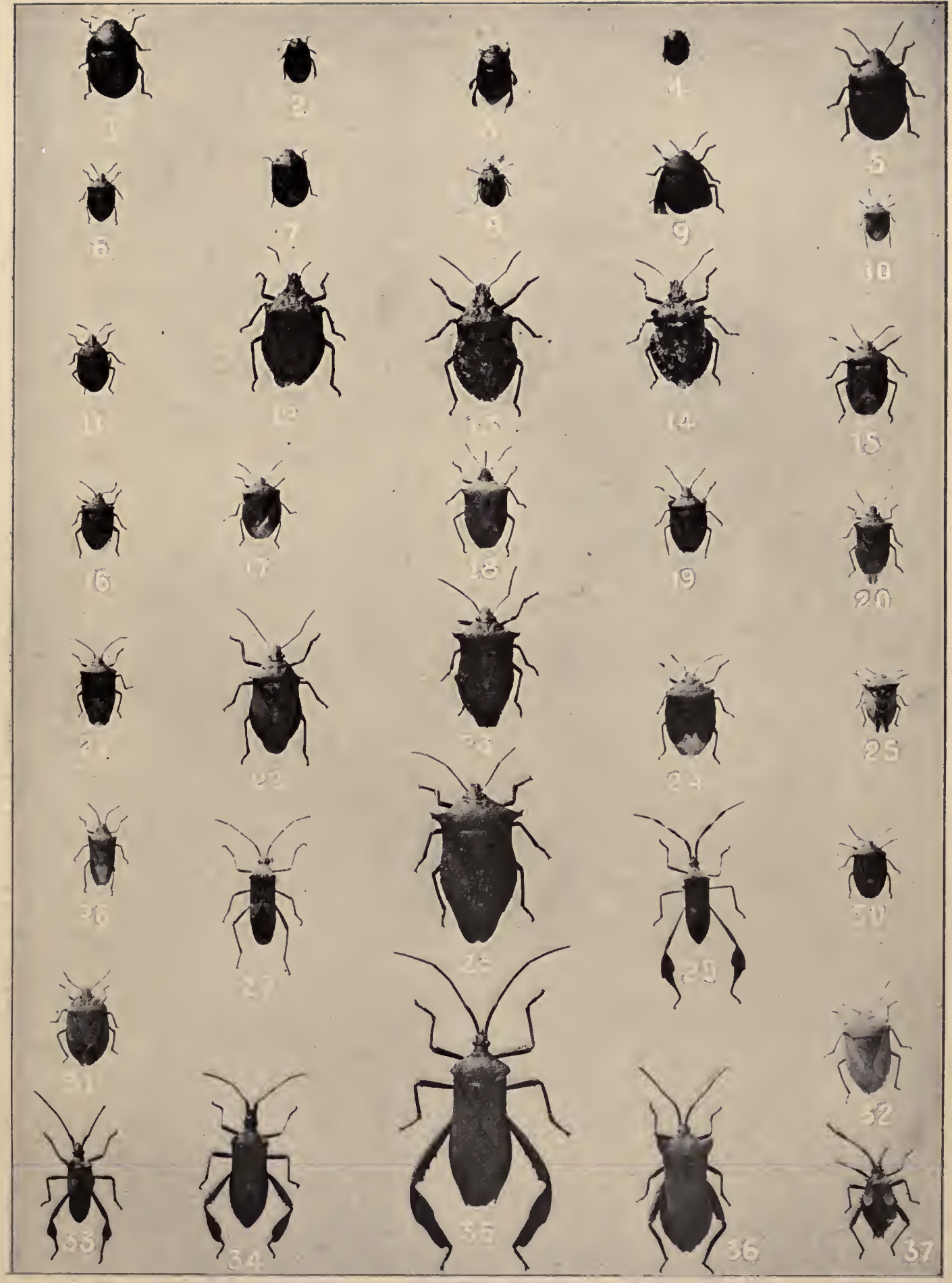


the water, when it darts with sudden rapidity upon its unprepared victim, grasps the creature with its strong, clasping fore legs, plunges its deadly beak deep into the flesh, and proceeds with the utmost coolness to leisurely suck its blood. A copious supply of saliva is poured into the wound, and no doubt aids in producing the paralysis which so speedily follows its puncture in small creatures."

The genus Zaitha contains similar water bugs of smaller size which have frequently been mentioned and figured from the curious habit of carrying the eggs plastered in a group on the back of the adult insect. For a long time it was supposed that the female sticks her eggs to her own back and the case was supposed to parallel, in a way, that of the famous Surinam toad. A German observer, Schmidt, however, found that many males carried eggs, but the method and purpose of attachment remained a mystery until it was cleared up by aquarium observations made by an American, Miss Slater, who found that the female, vis et armis, customarily lays them on the back of the unwilling male. Sometimes she has to struggle for hours to accomplish her fell purpose, but she does accomplish it in the end and her spouse is converted into an animated baby carriage. Says Miss Slater: "That the male chafes under the burden is unmistakable; in fact my suspicions as to the sex of the egg-carrier were first aroused by watching one in an aquarium which was trying to free itself from its load of eggs, an exhibition of a lack of maternal interest not to be expected in a female carrying her own eggs. Generally the Zaithas are very active, darting about with great rapidity; but an egg bearer remains quietly clinging to a leaf with the end of the abdomen just out of the water. If attacked, he meekly received the blows, seemingly preferring death, which in several cases was the result, to the indignity of carrying and caring for the eggs."

The full life history of none of these giant water bugs has been properly described in this country. The young Belostomas are said to have two tarsal claws instead of one as when adult, but their growth has not been followed. About fifty species of the family are known, of which about one-half inhabit the United States. 


\section{THE CREEPING WATER BUGS}

\section{(Family Naucorida.) .}

These insects are few in number and small in size. They are aquatic and predaceous, flat-bodied and oval. About thirty species are known, and only seven are found in the United States. The commonest of these, Pelocoris femorata Beauv., is widely distributed in this country and is found in waters in which

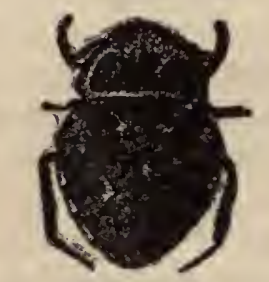

Fig. 171.-A mbrysus signoretti Stal.

(After Uhler.)

there is abundant vegetation, on which it creeps and about which it swims in its search for prey. It may be found near the margin of a pool with a grassy bank, feeding on little land insects which have accidentally fallen into the water. It's life history should be studied. 


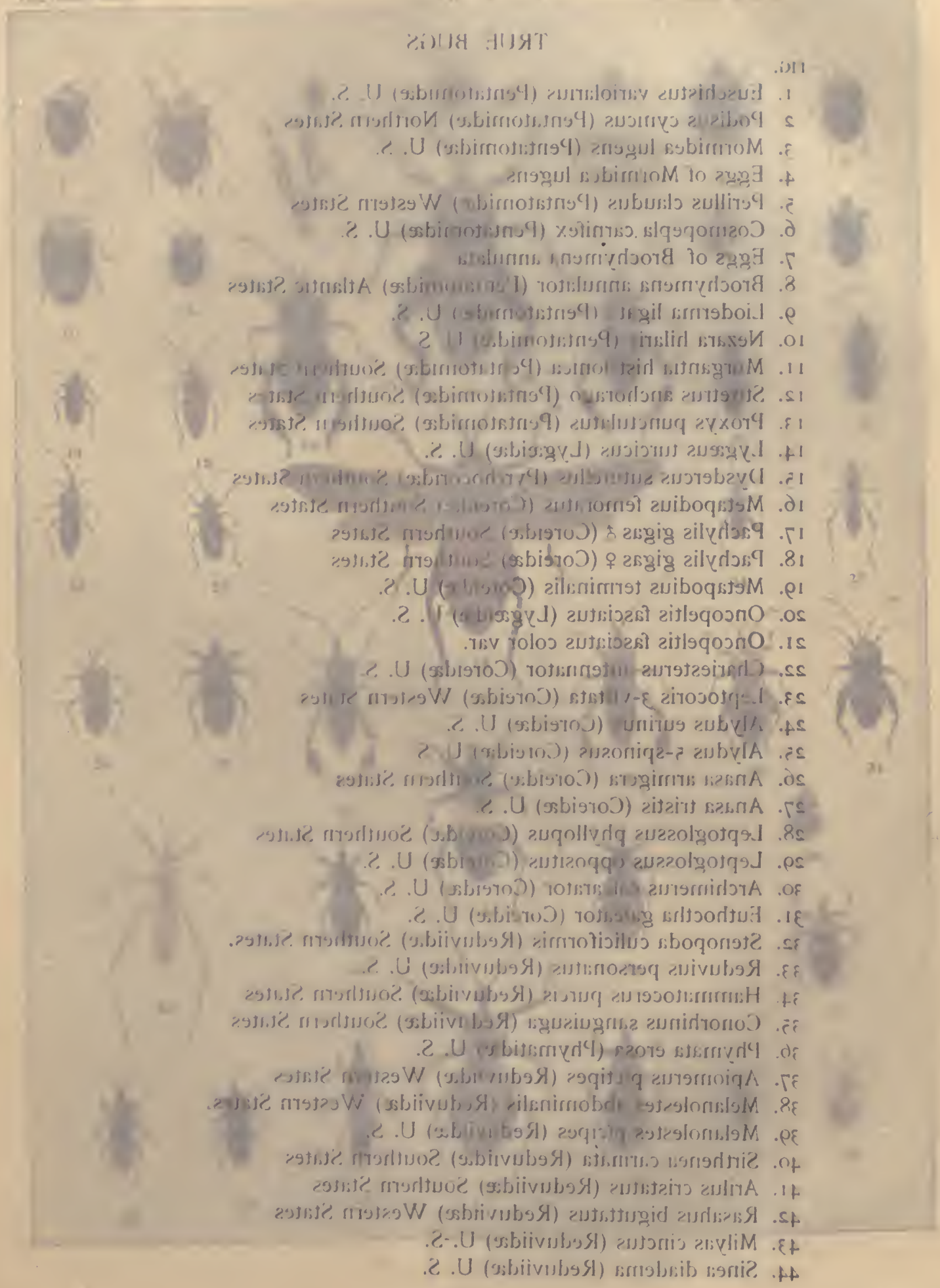




\section{TRUE BUGS}

FIG.

1. Euschistus variolarius (Pentatomidæ) U. S.

2 Podisus cynicus (Pentatomidæ) Northern States

3. Mormidea lugens (Pentatomidæ) U. S.

4. Eggs of Mormidea lugens

5. Perillus claudus (Pentatomidæ) Western States

6. Cosmopepla carnifex (Pentatomidx) U. S.

7. Eggs of Brochymena annulata

8. Brochymena annulator (Pentatomidx) Atlantic States

9. Lioderma ligata (Pentatomidæ) U.S.

10. Nezara hilaris (Pentatomidx) U.S.

11. Murgantia histrionica (Pentatomidæ) Southern States

12. Stiretrus anchorago (Pentatomidx) Southern States

13. Proxys punctulatus (Pentatomidæ) Southern States

14. Lygæus turcicus (Lygæidæ) U. S.

15. Dysdercus suturellus (Pyrrhocoridæ) Southern States

16. Metapodius femoratus (Coreidæ) Southern States

17. Pachylis gigas ô (Coreidæ) Southern States

18. Pachylis gigas $\&$ (Coreidx) Southern States

19. Metapodius terminalis (Coreidæ) U. S.

20. Oncopeltis fasciatus (Lygæidæ) U. S.

21. Oncopeltis fasciatus color var.

22. Chariesterus antennator (Coreidæ) U. S.

23. Leptocoris 3-vittata (Coreidæ) Western States

24. Alydus eurinus (Coreidæ) U. S.

25. Alydus 5-spinosus (Coreidx) U. S.

26. Anasa armigera (Coreidæ) Southern States

27. Anasa tristis (Coreidæ) U. S. Wand. Il a ife history should be28. Leptoglossus phyllopus (Coreidæ) Southern States

29. Leptoglossus oppositus (Coreidæ) U. S.

30. Archimerus calcarator (Coreidæ) U. S.

31. Euthoctha galeator (Coreidx) U. S.

32. Stenopoda culiciformis (Reduviidæ) Southern States.

33. Reduvius personatus (Reduviidx) U. S.

34. Hammatocerus purcis (Reduviidx) Southern States

35. Conorhinus sanguisuga (Reduviidx) Southern States

36. Phymata erosa (Phymatidæ) U. S.

37. Apiomerus pictipes (Reduviidx) Western States

38. Melanolestes abdominalis (Reduviidæ) Western States.

39. Melanolestes picipes (Reduviidx) U. S.

40. Sirthenea carinata (Reduviidæ) Southern States

41. Arilus cristatus (Reduviidx) Southern States

42. Rasahus biguttatus (Reduviidæ) Western States

43. Milyas cinctus (Reduviidæ) U. S.

44. Sinea diadema (Reduviidæ) U. S. 


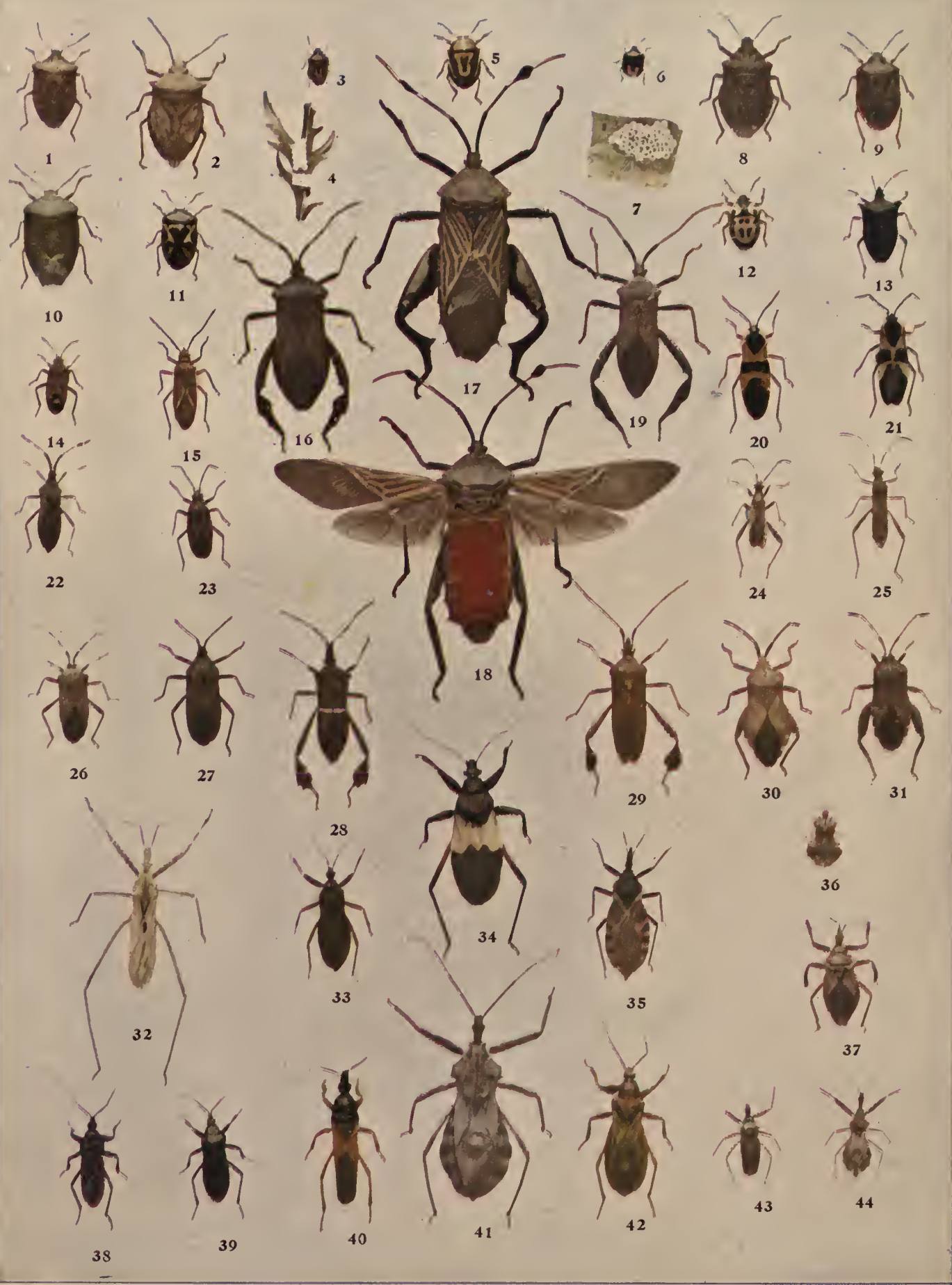


$+4$

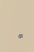

$-$ 


\section{THE TOAD BUGS}

\section{(Family Galgulida.)}

The odd and ugly little insects of this group have been appropriately termed the "toad-shaped bugs." The short, broad body and the projecting eyes, as well as the dull mottled colors, are toad-like. They are not true water bugs, but live in moist places along the banks of streams and ponds. Unlike the

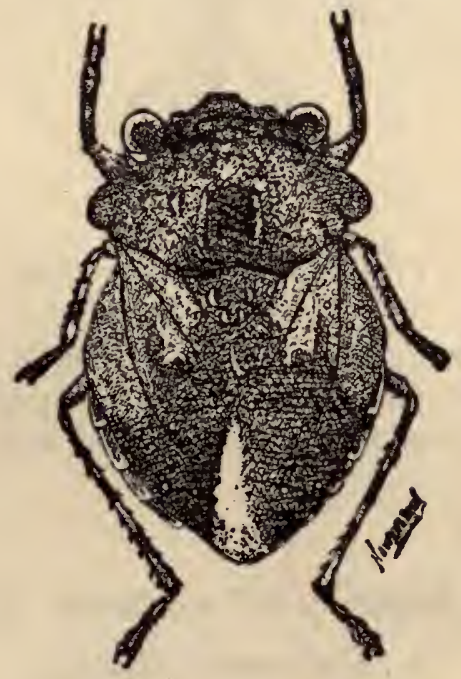

Fig. 172.-Galgulus oculatus Fab. Greatly enlarged.

(After Lugger.)

true water bugs, they have no ocelli, and are in other ways quite different structurally. It is not a large family, and only twenty species are known, of which three inhabit the United States. Galgulus oculatus Fab. is a common species, and its life history should be thoroughly studied. 


\section{THE MARSH TREADERS}

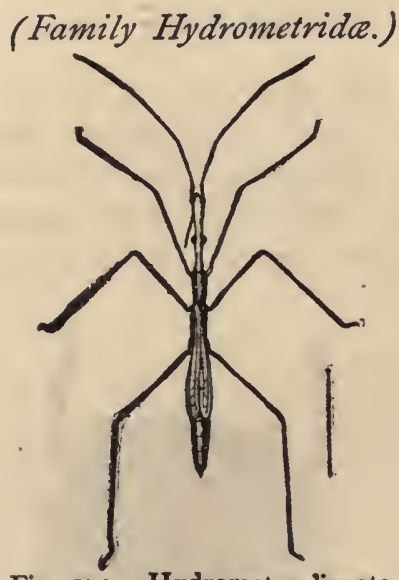

Fig. 173.-Hydrometra lineata.

(After Comstock.)

These are very slender aquatic bugs with a greatly prolonged head. We have only one species, Limnobates lineata Say, which crawls around on soft mud or on water, preferring stagnant pools.

\section{Life History of a Marsh Treader (Hydrometra lineata.)}

This rather common form is frequently to be found among the aquatic vegetation at the borders of ponds and slow streams. Its life history has been studied and admirably portrayed in the Canadian Entomologist for March, 1900, by Mr. J. O. Martin, of Cornell University. The elongated body of the insect is borne on hair-like legs and resembles a bit of twig or grass. There are several generations during the summer, and the insect hibernates as an adult under the rubbish along the banks and lays its eggs early in May. The eggs are laid singly and are 
glued to the stems of grasses along the stream. They are about two $\mathrm{mm}$. long and are spindle-shaped. The number of eggs must be small, since they are so large that four or five would fill the abdomen of a female. They are covered with a horny coating which has longitudinal ribs, and are marked with a hexagonal pattern. In seventeen days the young insect emerges from the egg and molts five times before becoming adult. It feeds upon the juices of insects which fall into the water, and, of course, there are many of these along the grassy borders of ponds. Mr. Martin has seen ten of these little water bugs surround a single insect, all of their heads in the direction of common interest, and their bodies radiating outward. The body and legs of the bug are covered with minute hairs which prevents the creature from becoming wet, and it is constantly engaged in lifting its legs into the air and drying them, for if they become wet they sink through the surface film of the water. 


\section{THE WATER STRIDERS}

(Family Hydrobatide.)

In this group belong most of the curious, slender, longlegged creatures known as water striders, which dart about on the surface of the water with such rapidity that it is very difficult to capture them. It is a large group and contains many different forms which are included in several subfamilies. They are

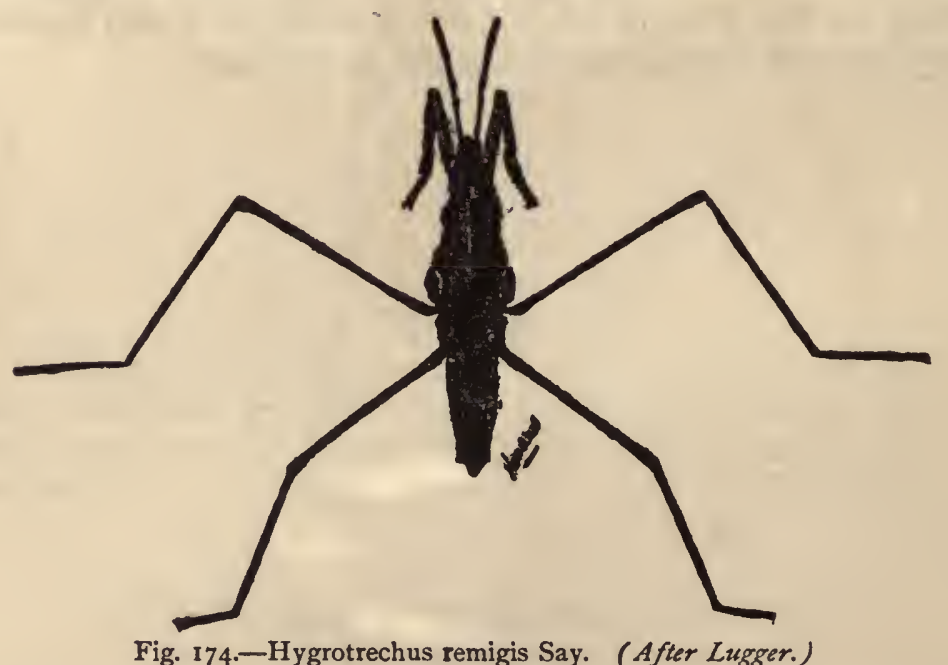

found upon salt as well as upon fresh water. They have prominent eyes, a stout beak, long antennæ, and a usually tapering abdomen. Two different forms of the adult occur with most species, the one winged and the other wingless. The Oceanic forms are most abundant in the Sargasso Sea, resting upon and breeding among the great mass of accumulated seaweed. When storms break up this great island of vegetation portions of it are carried far and wide, and some of the Oceanic water bugs are therefore brought to our shores. 
One of the commonest water striders of the United States is Hygrotrechus remigis Say. It is about a half-inch long, darkbrown in color, and moderately stout. It is everywhere seen skimming about on the surface of mill-ponds or similar bodies of water. It uses its slender, rather hairy hind legs as oars, practically rowing itself, and frequently congregates in groups with others of its kind in quiet places as though to talk over old times. Full-grown specimens are seen towards the end of summer, and

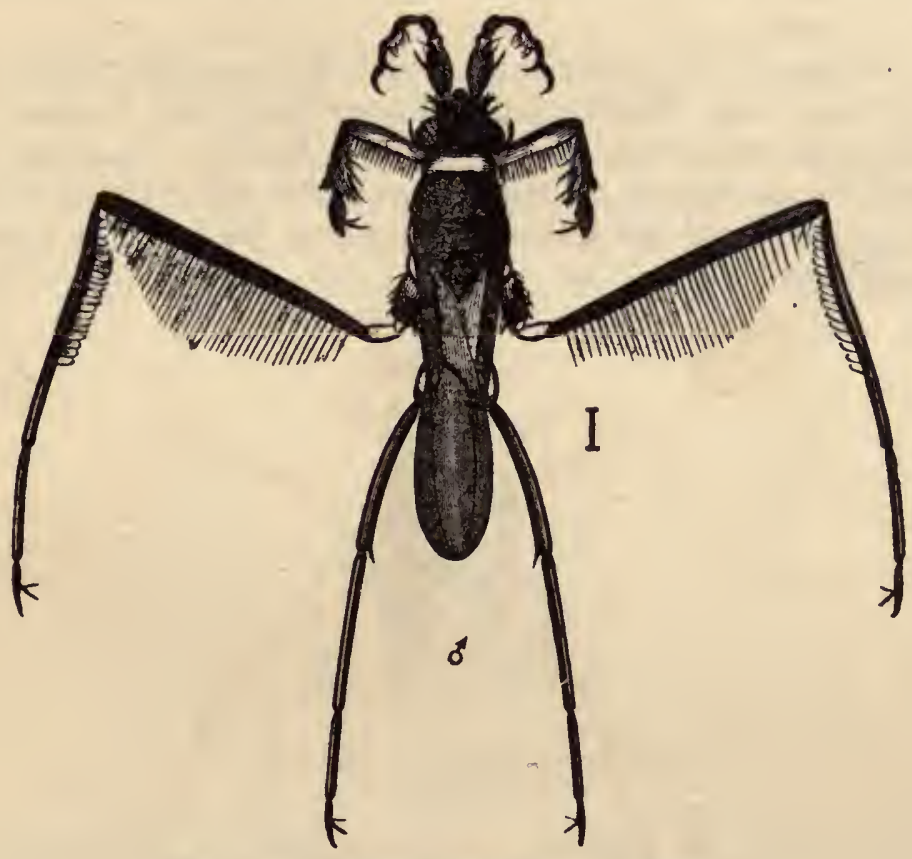

Fig. 175.-Rheumatobates rileyi. (Original.)

at the approach of cold weather they hide away under the banks of streams in mud or beneath leaves, or at the bottom of the water under stones, and wait until spring. As the weather grows warmer they bob up to the surface of the water and prepare for egg-laying. The eggs are whitish, translucent, and are long, nearly cylindrical, and blunter at one end than at the other. They are stuck on the leaves and stems of the water plants. The young strider does not issue from the egg by pushing off a cap at the end as do other water bugs, but by 285 
bursting through a slit which opens a little below the blunt end of the egg. The duration of the egg stage is about two weeks.

An extraordinary water-strider, known as Rheumatobates rileyi, was found near Washington, D. C., several years ago by Mr. Otto Heidemann, and has since been proved to be rather widely distributed. It is so extraordinary an insect in its general appearance that it has been adopted for the seal of the Entomological Society of Washington. It is found on still waters, such as canals, and is carnivorous in its habits like the other members of the family.

Although the water striders are truly aquatic, they are structurally more closely allied to the land bugs than to most of of the other water bugs, and especially in that they have free and conspicuous antennæ, the water bugs of the group Cryptocerata having, as stated elsewhere, the antennæ hidden in a pocket beneath the head. 


\section{THE FLOWER BUGS}

\section{(Family Anthocoride.)}

These insects are all small and are distinguished from those of the bed-bug family by the possession of ocelli and wing covers. The latter are usually well developed but are occasionally abbreviated. The head is prolonged. Less than 200 species are known of which only twenty-two are known to inhabit North America. Some of them, however, are very abundant, as the little Triphleps insidiosus Say, and are frequently found

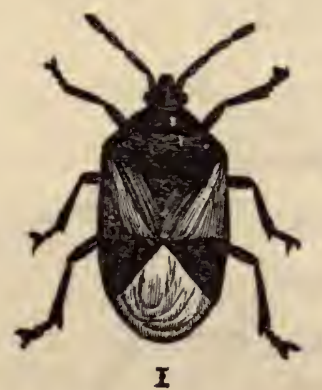

Fig. 176.-Triphleps insidiosus.

$$
\text { (After Riley.) }
$$

in the flowers of different plants. Probably all of the Anthocoridæ are carnivorous, feeding on other insects and the little Triphleps just mentioned is a voracious enemy of plant-lice, lace-bugs and other small tender insects. Some forms have been found in ants' nests. The life history of none of them has been worked out in this country and Triphleps insidiosus offers a good opportunity for investigation. 


\section{THE BED-BUG FAMILY}

\section{(Family Cimicida.)}

By more recent authors the family is called Acanthiidx, but the present name is preferable. Only twelve species are known

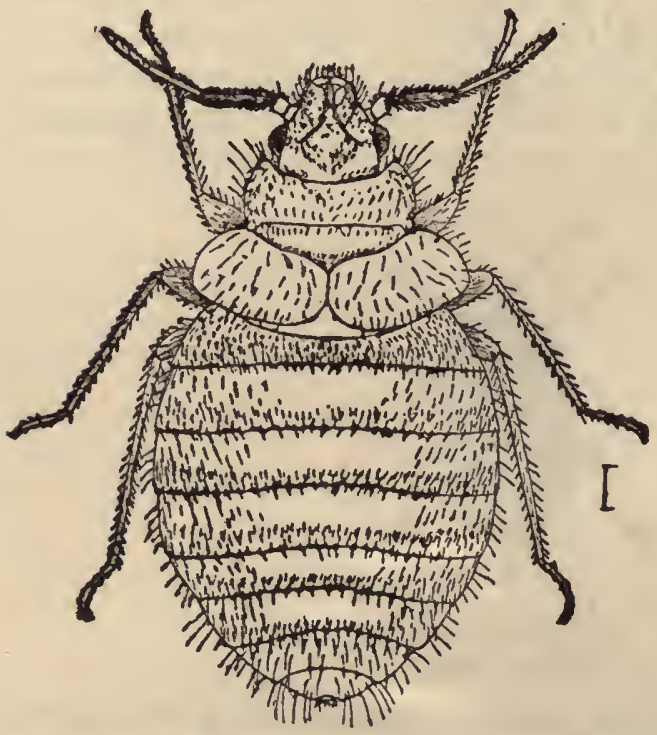

Fig. 177.- Eciacus hirundinis. (After Osborn.) but the family is notorious because it contains the disgusting parasite of human habitations. The other species are all found in the nests of birds and act and much resemble the true bed-bug. In this group the insects do not possess wings and only rudimentary wingcovers are to be seen. They are flatbodied, the ocelli are absent and the beak rests in a groove beneath the head. Aciacus hirundinis Jenyns is common to Europe and North America and frequently occurs in this country in great numbers in the nests of the common barn swallow. It closely resembles the form found in houses, but is darker in color and has shorter antennæ. 


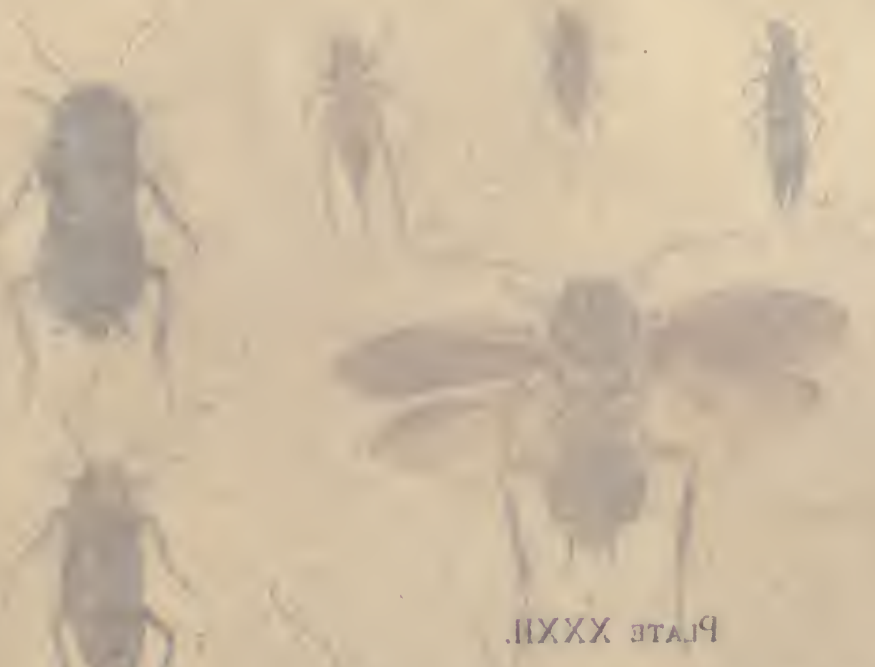

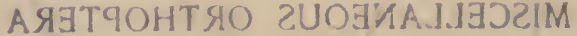

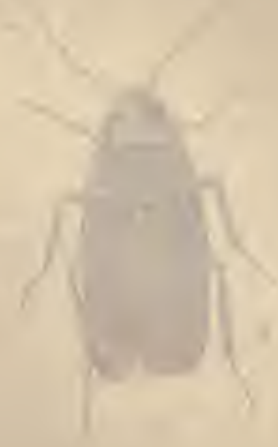

.ำ

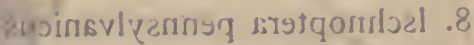
zilegrod s.qulstollprya) .e

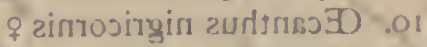
2imositgint asdtrus? .11 eibristy zulindyontus .s.

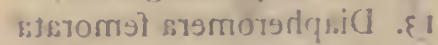
ingem s.lotzvilosid it

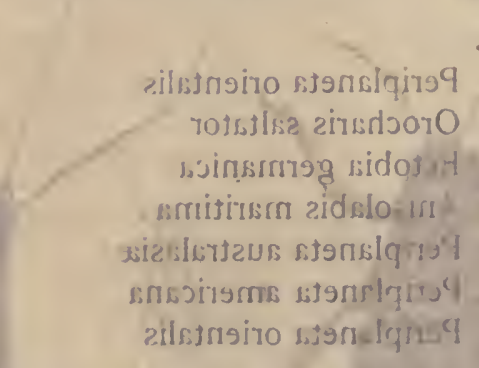

.

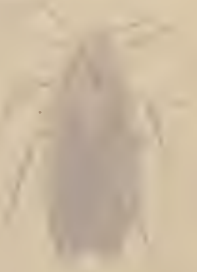




\section{THE AED-BUG FAMIC.

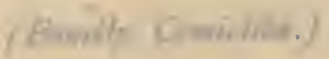

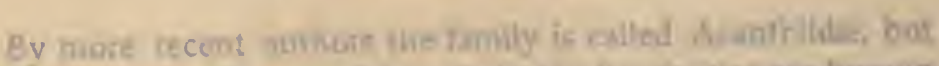

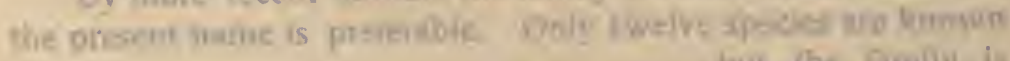

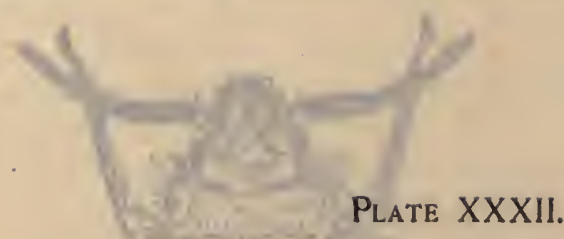

but the nomily is

nowrious howe If cankian ifie dile

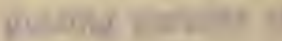

Plate XXXII.

MISCELLANEOUS ORTHOPTERA bidr ind

FIG.

1. Periplaneta orientalis

2. Orocharis saltator

3. Ectobia germanica

4. Anisolabis maritima

5. Periplaneta australasiæ

6. Periplaneta americana

7. Periplaneta orientalis
F1G.

8. Ischnoptera pennsylvanicus

9. Gryllotalpa borealis

10. EEcanthus nigricornis $q$

11. Ecanthus nigricornis 8

12. Ceuthophilus grandis

13. Diapheromera femorata

14. Brachystola magna 


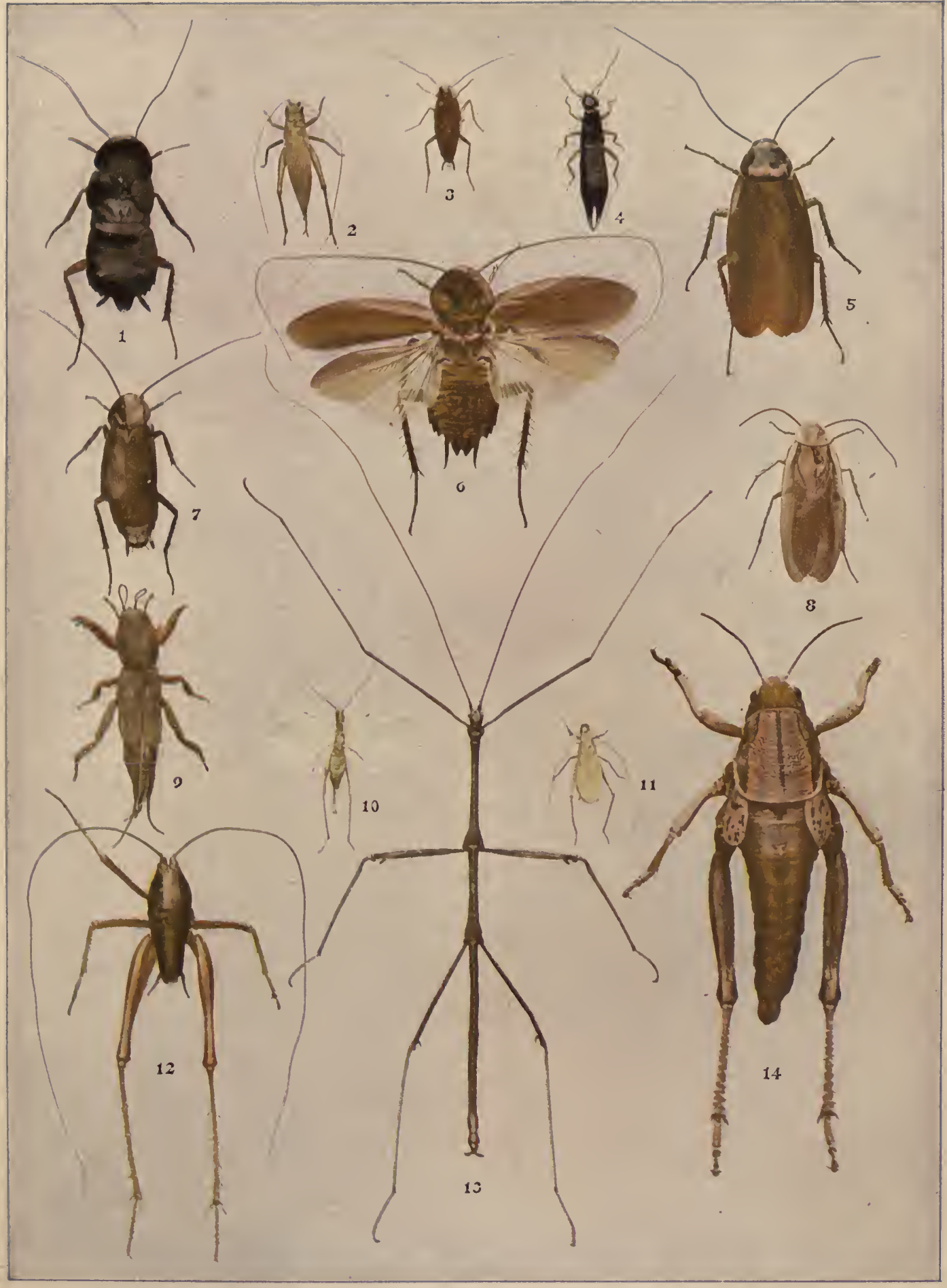





\section{Life History of the Bed-Bug (Cimex lectularius Linn.)}

Slovenly man has carried this abominable bug to all parts of the civilized world. "Tot. orbis" is the laconic expression of its geographic range given by Lethierry and Severin. It has become a true domestic animal and has accommodated itself well to the environment of human habitations. It has lost its wings, but has acquired a flat body which enables it to hide in the narrowest cracks of beds and walls. It has gained the power of subsisting almost indefinitely without food, waiting for its meals with a patience far surpassing that of Job.

The eggs of the bed-bug are minute white oval objects each having a frojecting rim around one end. They are laid in clusters in such crevices as are used by the mature bugs for concealment, and each cluster contains from six to fifty eggs. The eggs hatch in about eight days and the young bug pushes off the lid enclosed within the projecting rim at the end of the egg. At first the new-born insect is yellowish-white and nearly transparent, but becomes darker after it feeds and grows until the color of the mature and well-fed insect is brown. The skin is shed

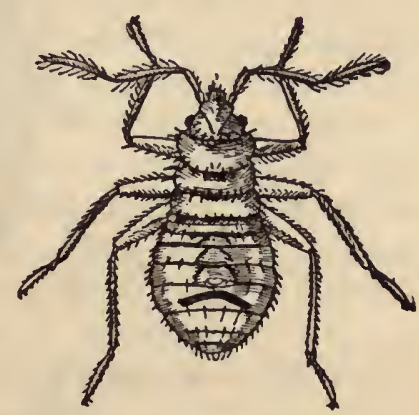

Fig. 178.-Cimex lectularius: young.

(Redrawn from Marlatt.) five times and with the last molt the wing pads characteristic of the adult become apparent. The period of growth from egg to adult varies greatly with the temperature and the food supply. Marlatt has reared them under favorable conditions (feeding them upon the healthy and abundant blood of a complaisant assistant) in seven weeks, but without food they may remain unchanged for many weeks. Ordinarily but one meal is taken between molts, so that at least five full meals must be taken before maturity and at least one more by the female before she is ready for egg laying. Each female is supposed to lay several batches of eggs.

The pronounced odor of this insect is also possessed by certain plant bugs and is produced by certain glands opening on the back of the abdomen with young bugs and on the underside in 
the metasternum with the adult. With plant bugs this odor evidently protects them by rendering them nauseous to their bird and other vertebrate enemies. It persists with the bedbug; but here it is detrimental to the species since it reveals its presence to its greatest enemy-man.

The belief that bed-bugs breed under the bark of certain trees and that houses built of the wood of such trees will be

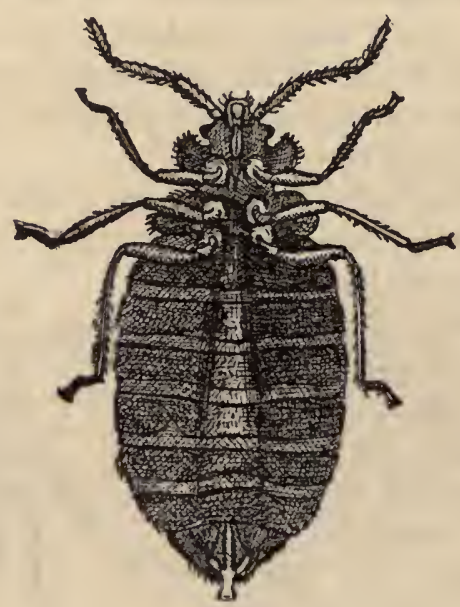

Fig. 179.-Cimex lectularius; adult. (Redrazon from Marlatt.)

infested with bugs, is due only to the resemblance which certain other bugs, especially the Aradidæ, which normally live under tree bark, have to the bed-bug. And then, too, from the ability which the bed-bug has of undergoing prolonged fasts, it may be found alive not only in houses which have been deserted for a long time, but about old deserted camps in the woods. 


\section{THE SHORE BUGS}

\section{(Family Saldida.)}

The active little bugs of this family which have been dubbed "shore bugs" by Comstock for the reason that they are always found upon the sea beach or the shores of fresh-water ponds or lakes are not numerous in species, although individuals are plentiful. Ninety-seven species have been described and about thirty occur in this country. Their color is usually black, brown or drab with whitish markings, the head is free and the eyes prominent. They are carnivorous and feed upon other beach inhabiting creatures, being frequently seen with the beak thrust into the body of some drowned insect. Every sea beach from Cape Cod to the Florida Keys has some kind of these shy little bugs which resemble tiger beetles in their habits. Some of them burrow under ground. The life history of none of them is well known, yet they offer an apparently easy field for investigation.

One swift and strong form from Java has been given the generic name Velocipeda by Bergroth. 


\section{THE THIN-WINGED BUGS}

(Family Henicocephalida.)

This is a remarkable family of which only twelve species are known, of which two inhabit the United States. It is allied to the Reduviidx, but the front wings are wholly membranous, with a distinct venation resembling those of certain saw-flies. The

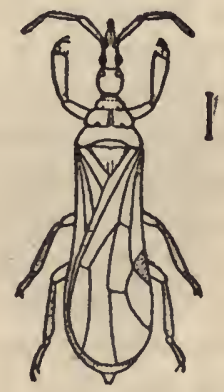

Fig. I79a.-Henicocephalus culicis. Enlarged. (Original.)

front legs are greatly swollen. The American species are Henicocephalus culicis Uhl. and H. formicinis Uhl. The former was found by Mr. E. A. Schwarz under stones on the shores of the Great Salt Lake, Utah, and later on the shores of the Potomac River near Washington. 


\section{ASSASSIN BUGS}

\section{(Family Reduviida.)}

This is a large and important family of bugs comprising more than two thousand species of which more than one hundred

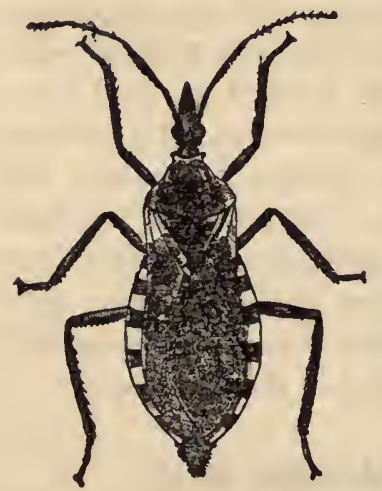

Fig 180.-Conorhinus sanguisuga. (Redrawn from Marlatt.) and fifty inhabit the United States. Its forms vary much in structure and have been divided among thirteen subfamilies and three hundred and thirty-six genera. All are predatory in their habits and feed on other insects which they pierce and whose blood they suck by means of their strong, sharp beaks. From this food some of the subfamilies are known as "cannibal bugs" or "pirate bugs." Comstock calls them the "assassin bugs.". With many species the beak is so strong as to readily pierce the skins of human beings, and one species, known as the "blood-

sucking cone-nose" (Conorhinus sanguisuga) so often frequents houses, especially in the southwest, and is so fierce a biter that it is often referred to as "the gigantic bed-bug." It seems, according to Schwarz, to normally inhabit the nests of field mice. Other species, especially Melanolestes picipes and Reduvius personatus, were especially abundant in the eastern states in the summer of 1898 , and their bites were responsible for the extraordinary so-called "kissing bug"

scare which was greatly advertised by Fig. 181.-Reduvius personthe newspapers. A western species, atus. (Author'sillustration.) Rasahus binotatus is also a severe biter. Of these "kissing 293
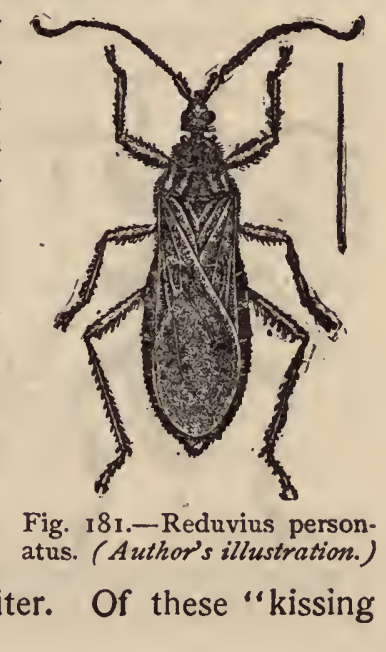
bugs," Reduvius personatus, is a cosmopolitan form which, in the northern states, is found in basements and cellars of dirty houses and preys upon bed-bugs and cockroaches. When immature

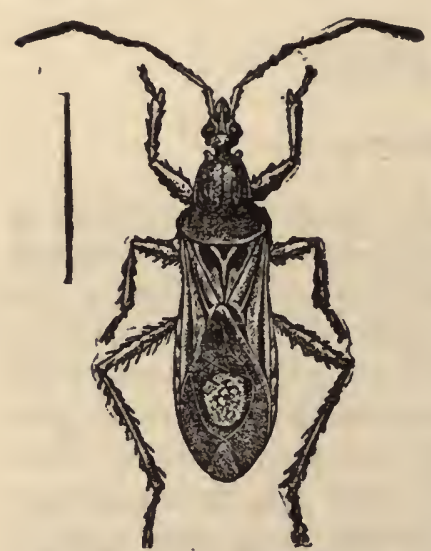

Fig. 182,-Rasahus biguttatus. (Author's illustration.) it covers itself with dust and presents a very odd appearance.

Some very odd species are found in the subfamily Emesida, which have been called "thread-legged bugs." Their legs are excessively long and they have a peculiar habit of swinging the body up and down. One of them frequents spiders' webs and robs the spiders of their prey.

The eggs of nearly all Reduviids are of very strange appearance and are frequently distinguished by some form of protective resemblance. None of these predatory bugs seem to possess the strong and frequently disagreeable odor so characteristic of many of the plant bugs.

\section{Life History of the Wheel Bug (Arilus cristatus L.)}

This is a large predatory bug common all through our southern states and Mexico and which extends up into southern

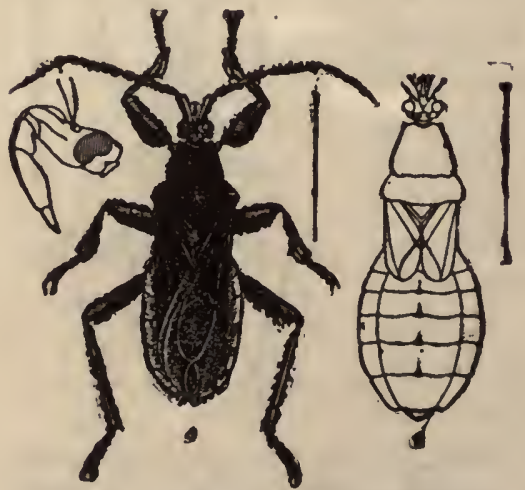

Fig. 183.-Melanolestes abdominalis. (Author's illustration.)

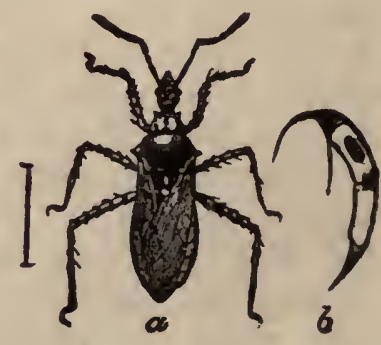

Fig. 184.-Milyas cinctus. (After Riley.) 
Illinois and New Jersey and even to Long Island and Rhode Island. It is popularly known as the "wheel bug" and sometimes by the negroes as the "devil's riding horse" and is referred to in the older books as Reduvius novenarius and Prionotus or Prionidus cristatus.

The eggs of the wheel bug look like miniature leather bottles standing on end and in hexagonal clusters, seventy or more in a group, and attached to the bark of trees, on fence rails, or whereever the female chances to be. In this stage the insect passes the winter. In the late spring the cap of the bottle is pushed off and the young bug emerges. The young insect has a blood-red

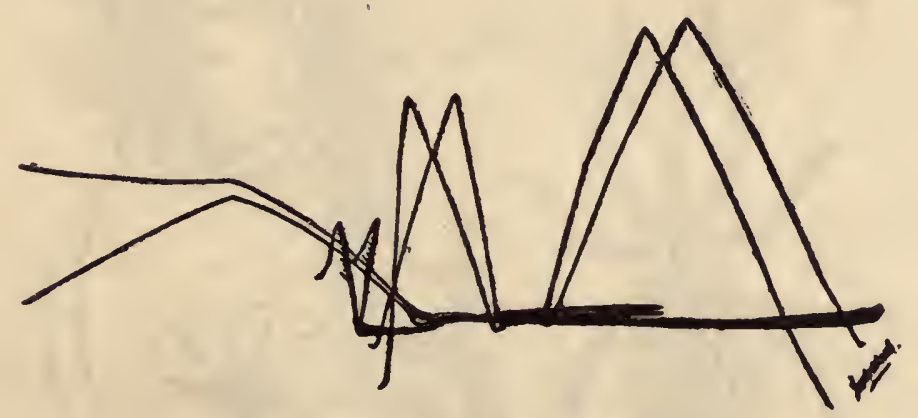

Fig. 185.-Emesa longipes. (After Lugger.)

abdomen and its thorax is marked with black. In walking it frequently elevates the abdomen, curving it over forwards. It feeds upon soft-bodied insects, its attacks, while young, being confined mainly to such weak, delicate species as plant-lice. As they grow larger they attack larger insects and when full-grown destroy large caterpillars. They seem to inject a poison into the wound made by the beak and Glover tells of a bite on his thumb which was severely poisoned and gave him great trouble. After four molts the peculiar crest on the thorax appears which has given this insect its specific scientific name cristatus (crested) and its popular name "wheel bug." This is a semicircular longitudinal crest bearing nine teeth, prongs or cogs like a cog-wheel.

The full grown bug is sordid black in color. It captures its prey not by agility but by stealth. Its coloration is protective and it slowly crawls up to some caterpillar or other insect, ad- 
vancing one leg after another with a movement so slow as almost to be imperceptible. When once within striking distance, however, the beak is thrust into the victim which is at the same time grasped with the front legs with a movement which is quite the reverse of slow.

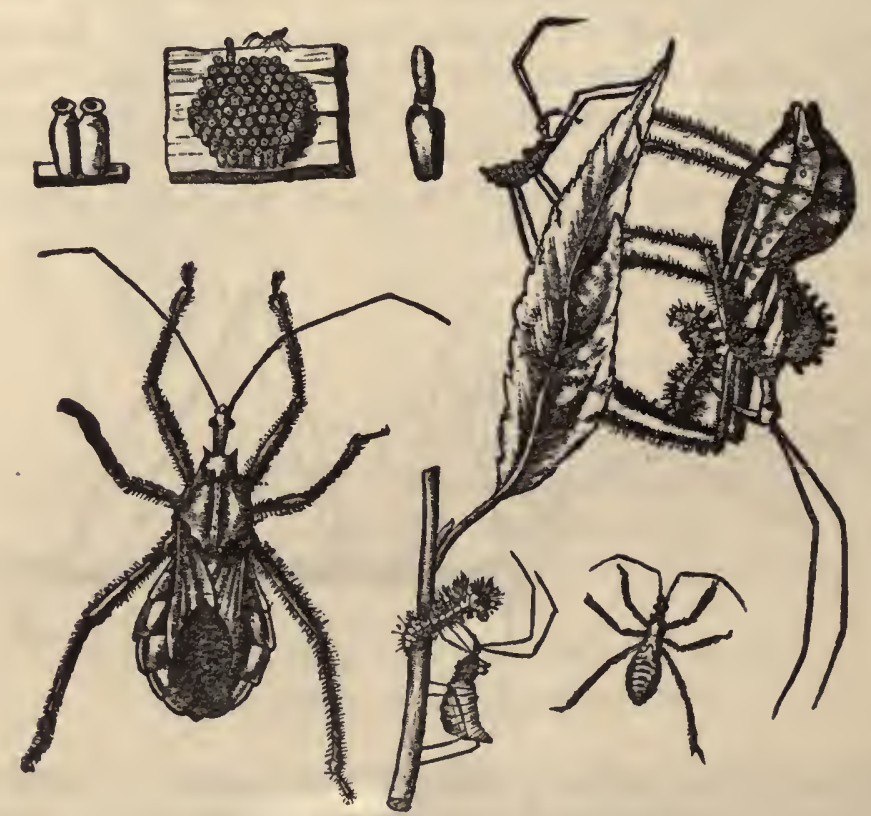

Fig. 186.-Arilus cristatus. (After Glover.)

The wheel bug is a very beneficial insect. It is a common inhabitant of southern cities and in such places as Baltimore and Washington is an important factor in the destruction of the numerous caterpillars which defoliate shade trees. 


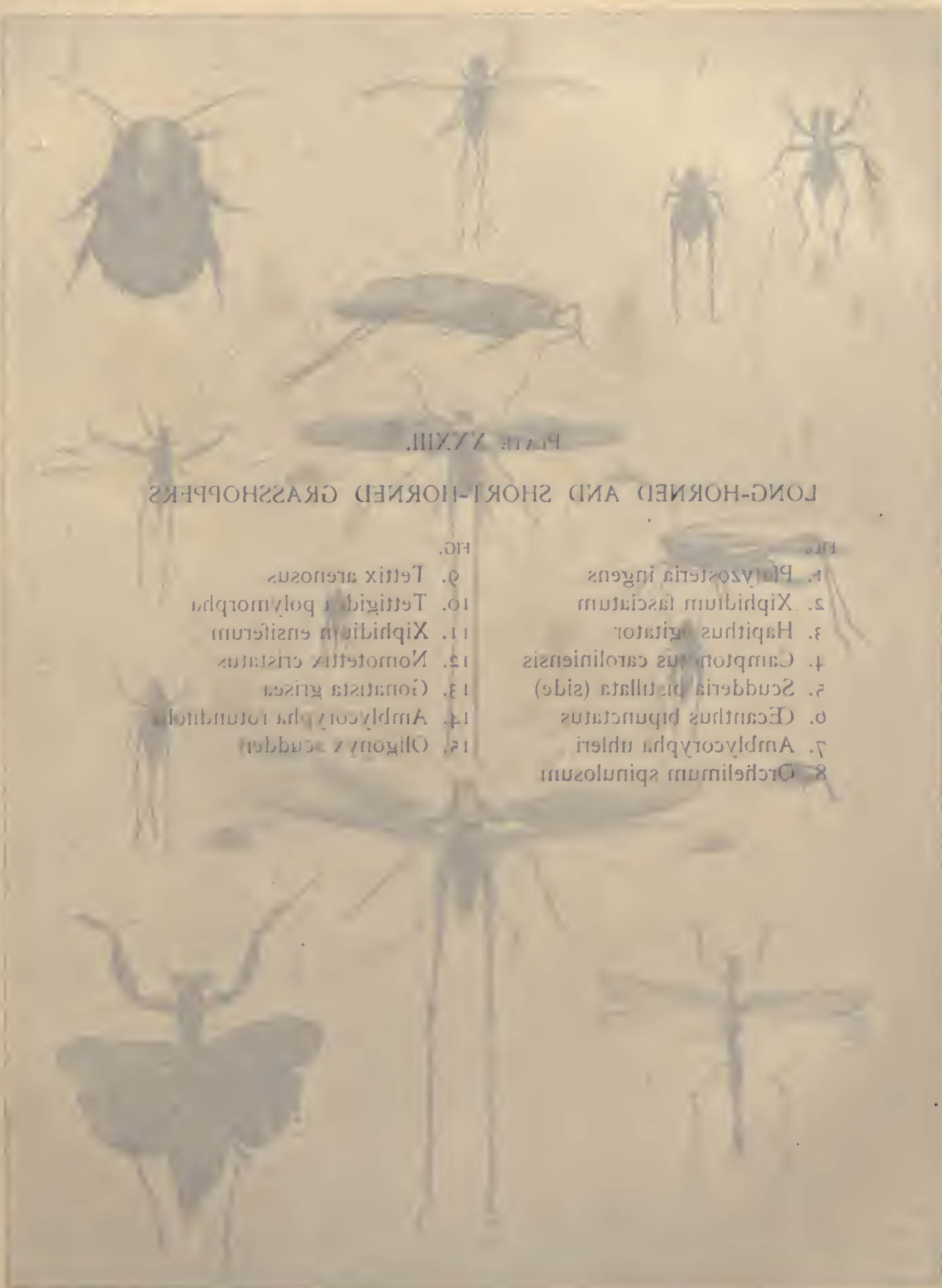




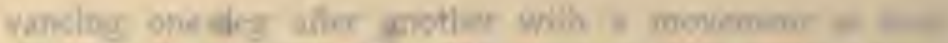

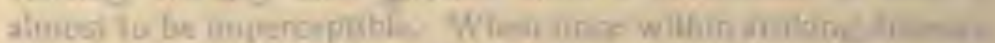

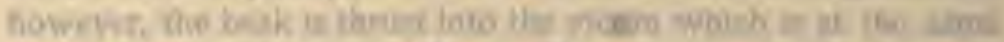

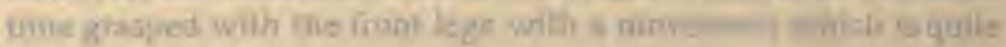 the reviases of a.ow.}

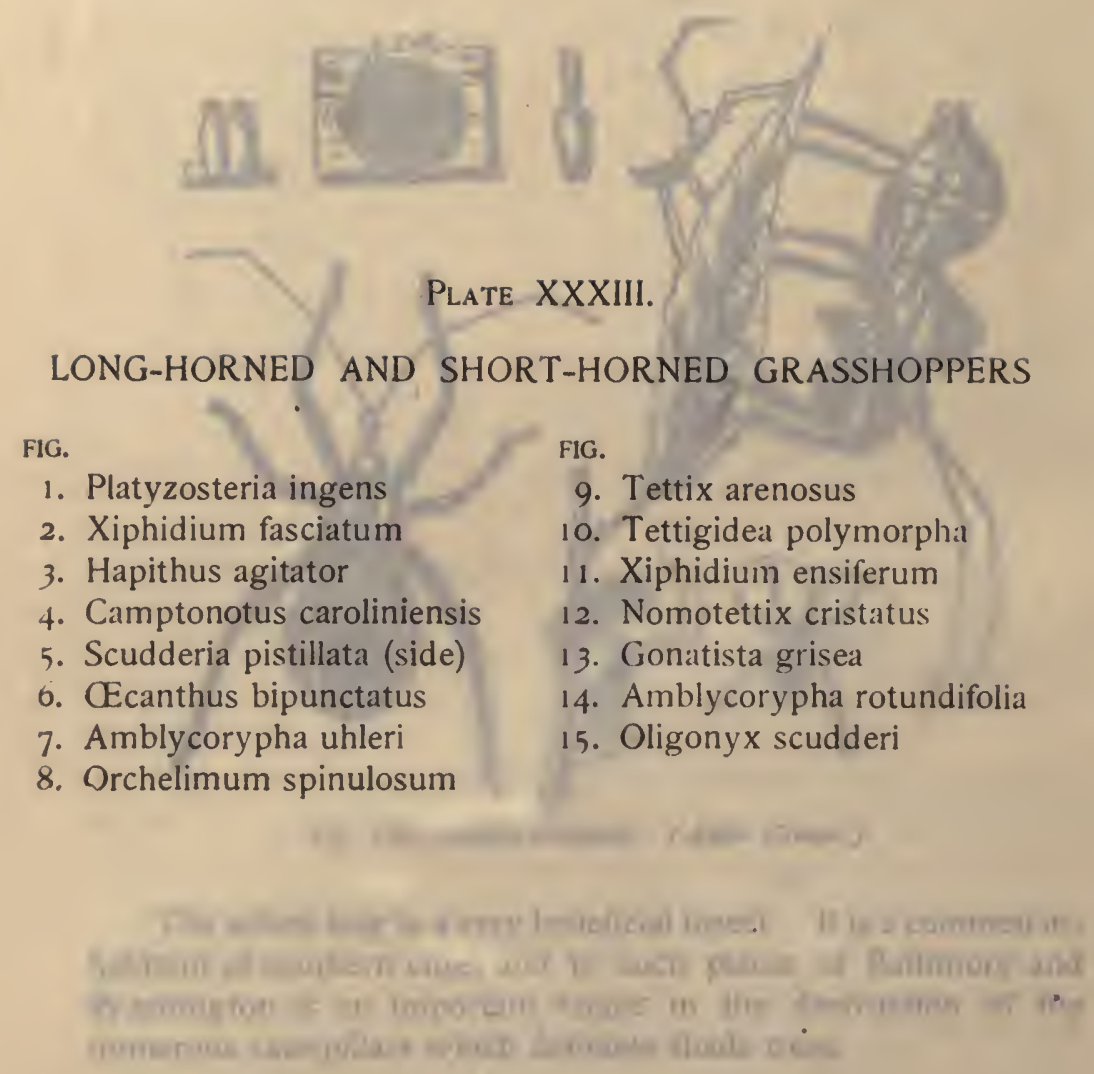




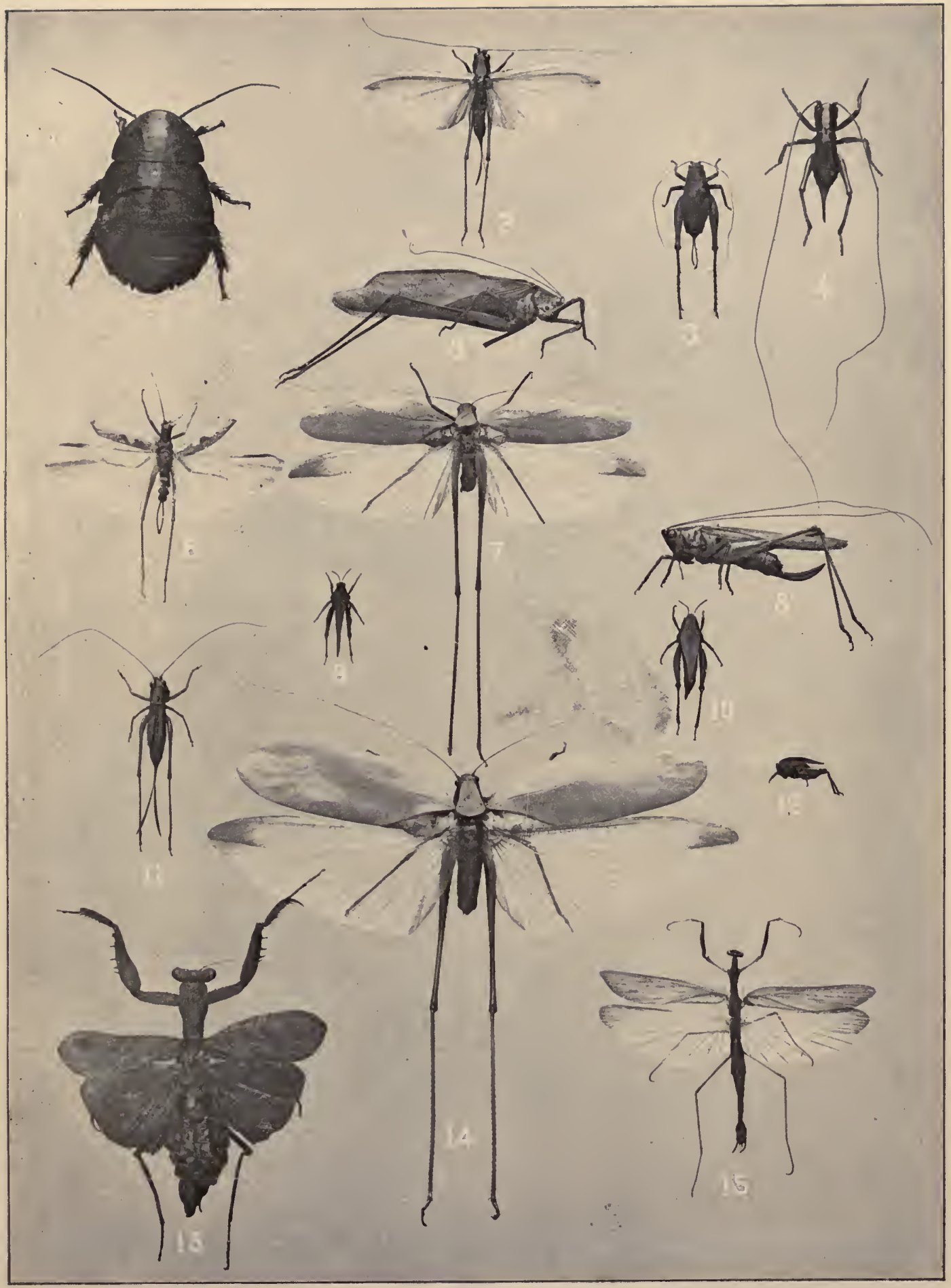





\section{THE AMBUSH BUGS}

\section{(Family.Phymatida.)}

The strong and ferocious predatory bugs of this group number only forty-three described species, of which but five live in the United States, yet it is structurally and economically an important family. The head is shaped like that of the Aradidx, the front legs are enlarged and fitted for grasping, frequently lacking

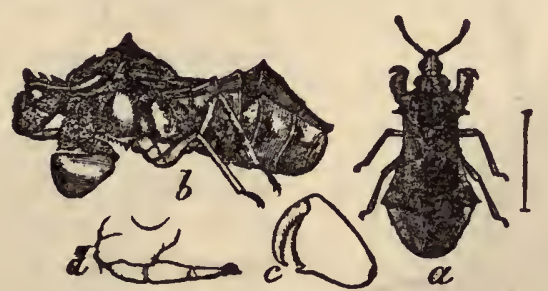

Fig. 187,-Phymati wolffi.

(From U.S. Dept. Agr.)

the tarsi, and its beak and general appearance ally it to the Reduviidæ. These insects are tough and horny, and in the tropics are apt to be armed with spines. Phymata wolffi Stal., our commonest species, is yellowish-green in color, with a brown or blackish band across its abdomen. It frequents yellowish flowers like the ox-eye daisy, with which its color harmonizes, disguising its presence from the insects which visit such flowers, and upon which it preys. From this fact Comstock has called these insects "the ambush bugs," and this insect affords our best exponent of what Professor Poulton calls "specific aggressive resemblance" - that is, the resemblance of a predatory species to some special object to facilitate the capture of its prey. The full life history of none of the Phymatids is known, and $P$. wolffii should be followed through its life round by some careful observer. 


\section{THE FLAT BARK-BUGS \\ (Family Aradida.)}

These are small, strangely-formed bugs found commonly under the bark of trees, where they feed upon fungus growths. They are all extremely flat, and look, as Comstock says, as if they had been stepped upon. It is these insects which are often

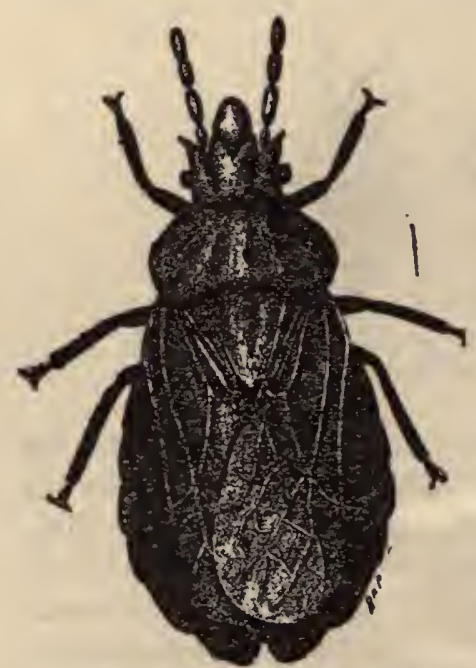

Fig. 188.-A radus robustus Uhl. (After Lugger.) mistaken for bed-bugs and that give rise to the idea that the household pest breeds naturally in such situations. The abdomen is broader than the wings, and frequently encloses them like a frame. It is not a large family, less than three hundred species being known, of which about thirty occur in the United States. The prevailing color of these insects is brown, sometimes varied with reddish or pale markings. Aradus crenatus Say is the largest of the species found in this country, reaching nearly half an inch in length, and Aradus similis Say and Neuroctenus simplex Uhl. are the commonest species in the northeastern states. Mr. Heidemann has found the eggs of the last-named species. They very closely resemble the eggs of the bed-bug, having the same size, markings, and the same whitish color. The life history of both these last-mentioned species should be carefully worked out, as they represent different subfamilies. 


\section{THE LACE BUGS}

\section{(Family Tingitida.)}

The curious little bugs of this family have rather aptly been termed "lace bugs" by Comstock from the fact that the wing veins are thickened and form a lace-like pattern in most of the species. These insects are all small, have two-jointed feet and usually knobbed antennæ. They are all plant-feeders, and

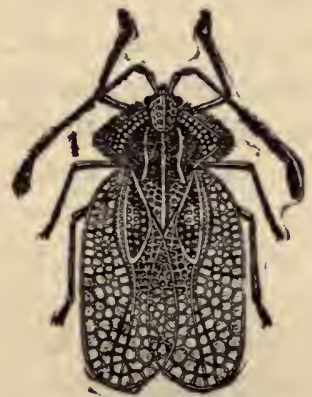

Fig. 189.-Gargaphia angulata.

(After Chittenden.)

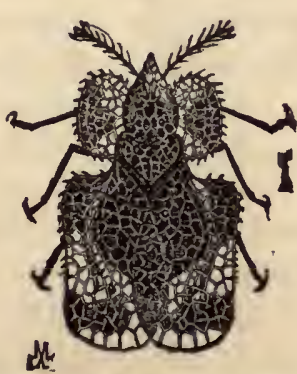

Fig. 190.-Corythuca arcuata.

(After Comstock.)

the brown, rusty appearance which the leaves of certain trees, notably sycamores, acquire in summer is due to their attacks. Rather more than three hundred and fifty species are known of which twenty-five inhabit the United States, but there are, undoubtedly, many unnamed and undeveloped forms. As a rule the eggs are laid in leaves and young twigs and the whole life of the insect is spent in sucking sap. They usually overwinter as adults hidden away in bark crevices. There are two subfamilies and the members of one, Piesmince, are not so lace-like as are the others, the Tingitinoe. 


\section{Life History of the Hawthorn Lace Bug (Corythuca arcuata Say.)}

More than twenty years ago 1 saw most of the leaves of a Hawthorn tree at Washington turning brown and rusty and on examining them found the beautiful little Tingitid, shown at Fig. 190, present in all stages of development. Projecting from the leaf surface in groups of from ten to thirty along both sides of the prominent leaf veins were certain minute brown funnelshaped objects which were found to be the eggs. Each egg is laid on end and is covered with a brown sticky substance which rapidly hardens and holds it to the leaf surface. This brown gum adheres so strongly to the egg that it is impossible to remove it without crushing the egg, and it is more copious near the base so as to give the appearance of an actual insertion into the leaf tissue. The top of the funnel has a porous cap which the insect removes in emerging. The newly hatched bug grows rather rapidly and casts it skin five times before becoming full grown. While yet immature it is of the same dirty-brown color

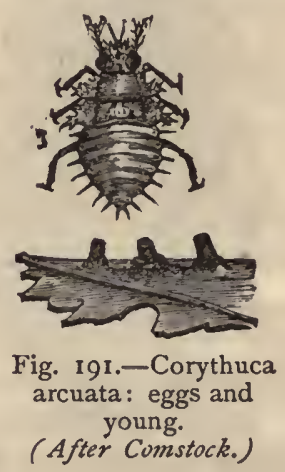

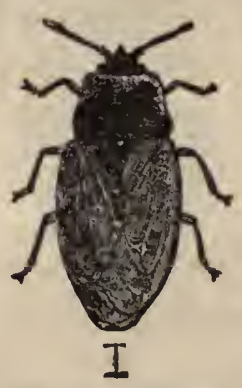

Fig. 192.-Piesma cinerea.
(After Riley.)

as the substance covering the egg and but little darker than the withering leaf. It is of a broad, flat, oval shape, and spines seem to project from almost every portion of its body. It looks, under the microscope, more like a lobe of prickly cactus than anything else. A sticky honey dew is excreted by these bugs and their cast-off skins adhere to the leaf and make it appear as if there were many more insects present than is actually the case.

During the winter the dead leaves under the trees were found to contain living and healthy eggs, but the insect customarily hibernates as a full-grown and winged bug. 


\section{THE LEAF-BUGS}

\section{(Family Capsida.)}

The usually rather slender and delicate bugs known as "leafbugs" or "true plant bugs," having two cells in the wing membrane, belong to this family. More than one thousand species are known, and of these more than two hundred and fifty inhabit the United States. It is undoubtedly the largest group of Heteroptera, and thousands of species are as yet undescribed. Mr. O. Heidemann tells me that he has in his collection more than two hundred undescribed species from the United States. They are not all true plant feeders, and very few of them occur in sufficient numbers to become important crop enemies. Some of them habitually prey on other insects, and I have seen Camptobrochis grandis sucking the eggs of the imported elm-leaf beetle (Galerucella luteola), while Mr. Heidemann states that Lopidea media Say once alighted on the back of his hand, and that (with a true scientific interest) he watched it pierce the skin and suck his blood for some minutes. A common species in the east, Oncognathus binotatus Fabr., frequents the heads of timothy grass. Fulvius anthocoroides Uhl. is found commonly on lichens on old stumps. Lygus pratensis, known as the "tarnished plant bug," is present in all flower and vegetable gardens, and causes what is called the "buttoning" of strawberries. The natural egg place of this common insect is not known, but the rest of its life has been well worked out by Woodworth, although there is probably one more molt than he has observed, $i$. e., five instead of four. Halticus uhleri Giard, known as the "garden flea-hopper," is common in gardens and is injurious to flowers and vegetables. 
The Leaf-Bug

\section{Typical Life History of a Leaf-Bug (Pacilocapsus lineatus Fabr.)}

This insect, known as the four-lined leaf-bug, is found all over the United States east of the Rocky Mountains, and is a common garden pest, sucking the sap of gooseberry bushes, currants, dahlias and many other plants. The insect passes the winter in the egg stage. The eggs are inserted in slits cut

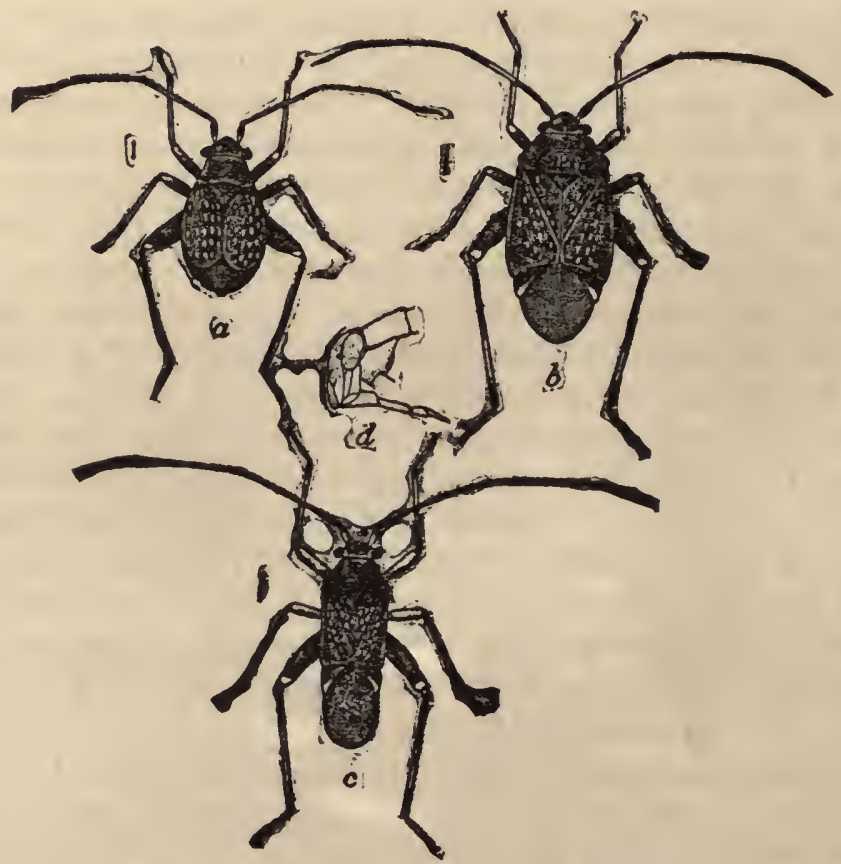

Fig, 193.-Halticus uhleri. (After Chittenden.)

lengthwise into the stems of plants extending through the bark and wood nearly half way to the pith. The slits may be an eighth of inch in length, and into each of them is pushed from two to fourteen eggs. These are crowded side by side, are about $1.6 \mathrm{~mm}$. long, smooth, cylindrical, slightly curved, lightyellow in color, and with the outer third capped with a white striate portion. From these eggs the young hatch in the spring -the latter part of May in central New York-and feed upon the 
tender new growth of leaves for from two to three weeks, undergoing five molts. The adult bugs appear early in June, and often spread to the different surrounding plants. Egg-laying begins in the latter part of June ; the adults disappear in July, and, as above stated, the insect hibernates in the egg stage. There is only one generation each year in New York, but in the southern states there are more. The young insect when first hatched from the egg is of a shining vermilion color, marked with large blackish spots on the thorax. The antennæ and legs
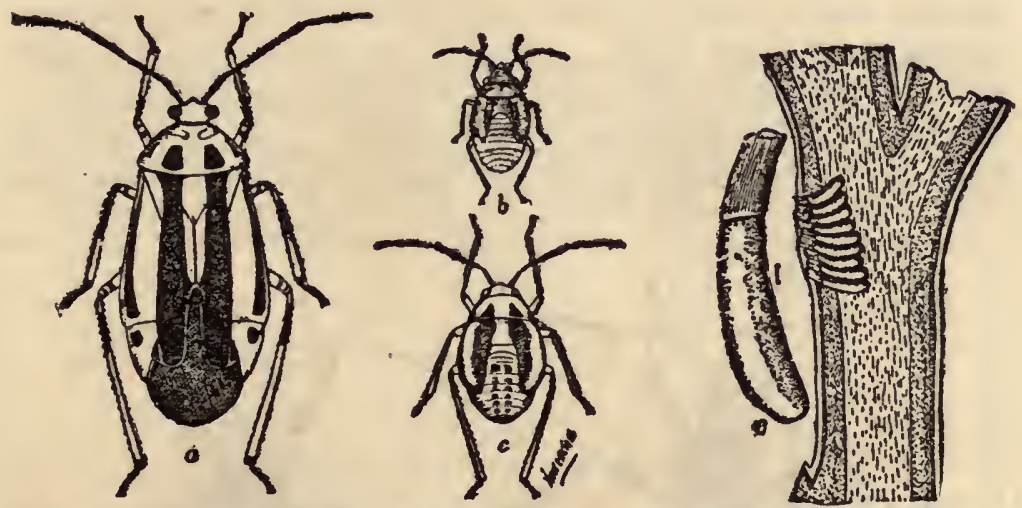

Fig. 194.-Pœcilocapsus lineatus Fab.: $a$, adult ; $b, c$, immature. (After Lugger.) Eggs. (After Slingerland.)

are of a greenish-black color. The red color is retained until the last stage before the adult is reached, then the large black spots on the thorax seem to mark the beginning of wing pads, which have gradually become more and more apparent after each molt. In the adult insect a radical change in color is found. The general color is bright orange-yellow; the legs and the wing covers are of dark apple-green, but the wing covers and the thorax are marked with four black stripes.

This life history was first worked out by Professor Slingerland, of Cornell University. 


\section{THE SQUASH-BUG AND ITS ALLIES}

\section{(Family Coreida.)}

This is a large and important family, divided into many subfamilies and containing about 1,500 species of which nearly 200 inhabit the United States. The group has no popular name although these insects, in common with the members of several allied families are known as "plant bugs." Comstock calls the Coreidæ "the squash-bug family" after its best-known represen-

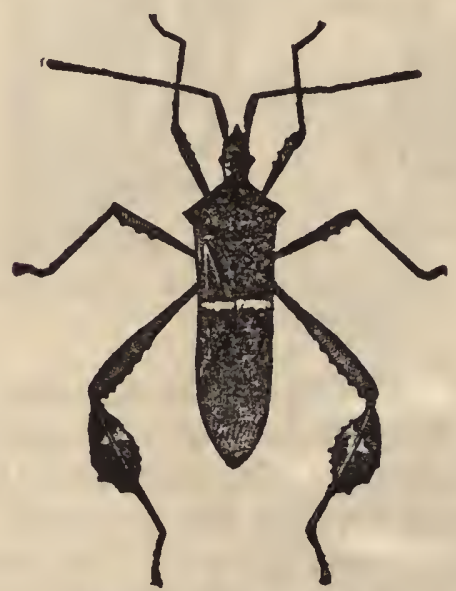

Fig. 195.-Leptoglossus phyllopus

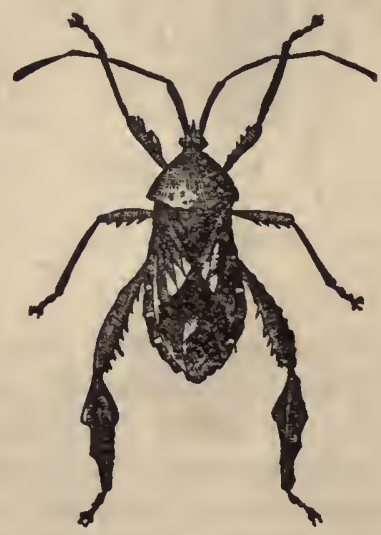

Fig. 196.-Metapodius femoratus

tative, but of course this is not a distinctive name, nor does it seem possible to coin one. The Coreidæ are very diverse in shape and structure, some being broad and clumsy and others thin. Some have curiously modified legs like the leaf-footed plant bug (Leptoglossus phyllopus) and the thick-thighed Metapodius (Metapodius femoratus) while others have slender normal legs. All of these bugs feed on the juices of plants and some of 
them are well-known enemies of crops. A curious tropical genus-Phyllomorpha-carries its eggs upon its back. A common species in the western United States known as the boxelder plant bug (Leptocoris trivittatus) frequently does much damage to the box-elder trees which from their rapid growth are commonly planted on western tree claims.

\section{Life History of the Squash-Bug (Anasa tristis De Geer.)}

The common "squash-bug," as this insect is called, is found all over the United States as well as in Central America. It is a serious enemy to garden plants of the pumpkin family (Cucurbitacece), but does not damage other vegetation. The egg is 1.5 $\mathrm{mm}$. long, stout, somewhat flattened on three sides and is of a

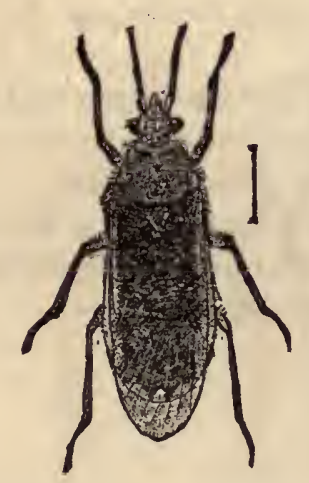

Fig. 197.-Corizus hyalinus. (From U. S. Dept. Agr.)

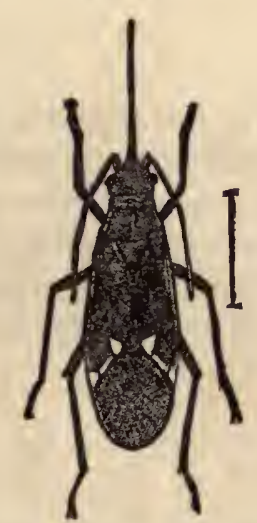

Fig. 198.-Leptocoris trivittata. (From U. S. Dept. Agr.)

yellowish-brown or dark bronze color. From twenty to forty eggs are laid in a group, each one rather well separated from the others and placed either on the under or upper surface of a leaf, or on a stem. When first hatched the little bug is light green in color with beautiful rose-colored legs, antennæ and beak. Later the head and thorax become black and the abdomen gray. There are five distinct molts and the full grown bug is the dark, sordid, ugly 
and ill-smelling creature commonly noticed in vegetable'gardens. The adult insect hibernates, thrusting itself into some protected crevice and lays its eggs in the late spring or early summer. These hatch in about two weeks and the insect may become full

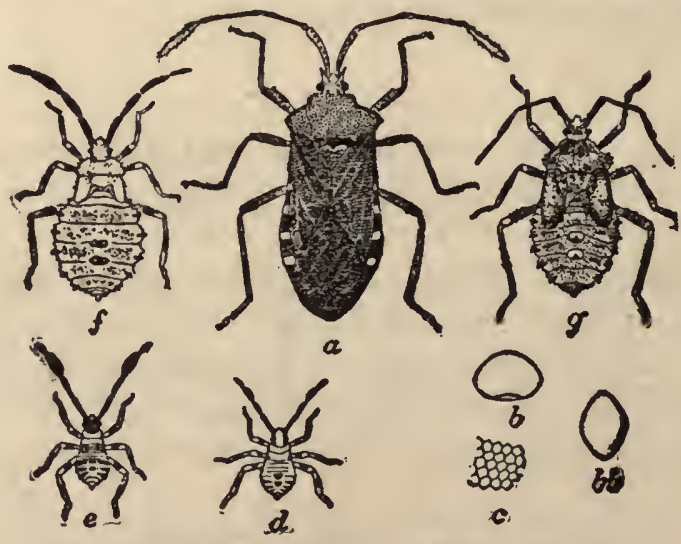

Fig. 199.-Anasa armigera. (After Chittenden.)

grown in less than a month. There is no evidence that there is more than one generation annually from the District of Columbia northward, but further south there are probably more.

Observers need not be surprised at the failure of the eggs to hatch as they are frequently parasitized by two minute eggparasites, Hadronotus anasce and Ooncyrtus anase. 


\section{THE COTTON STAINER AND ITS ALLIES}

\section{(Family Pyrrhocorida.)}

This is not a large family. It comprises less than three hundred species, and only about twenty-five are known in the United States. Most of the species are tropical or sub-tropical. They are distinguished from the Lygæids by the absence of ocelli. As a rule, they are stout, moderately large bugs, and

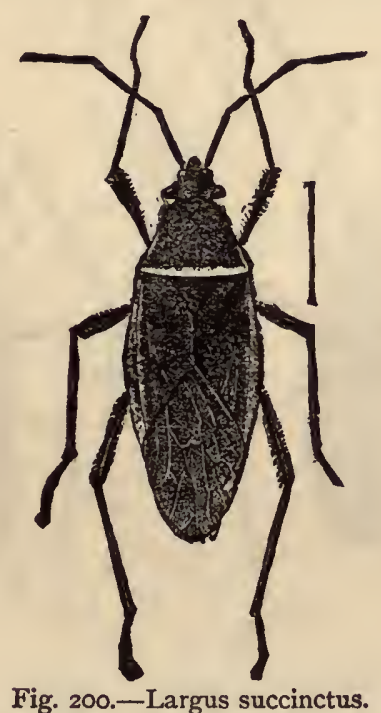

Fig. 200.-Largus succinctus
(From U.S. Dept. Agr.)

are frequently marked with red. The commonest of our native species is Largus succinctus, an insect of very wide distribution, since it occurs from New Jersey to Mexico. It is a brownishblack species with the sides of the thorax margined with orange or red. It is commonly found along the borders of oak woods, and the adults appear in July and August. The young stages are of a brilliant steel-blue color, with reddish legs and a bright red spot at the base of the abdomen.

The full life history of this species should be worked up. 


\section{Life History of the Cotton Stainer (Dysdercus suturellus H.-Schf.)}

This insect, which is found exclusively in our Southern States, is known popularly by the name of the "cotton stainer." It is found also in the West Indies. Its natural food is probably a rose-mallow (Hibiscus), but it feeds upon the bolls of the cotton plant and also sucks the juices of oranges. It is marked with red and is a very beautiful insect, and derives its popular name from the fact that it stains the cotton in the bursting bolls

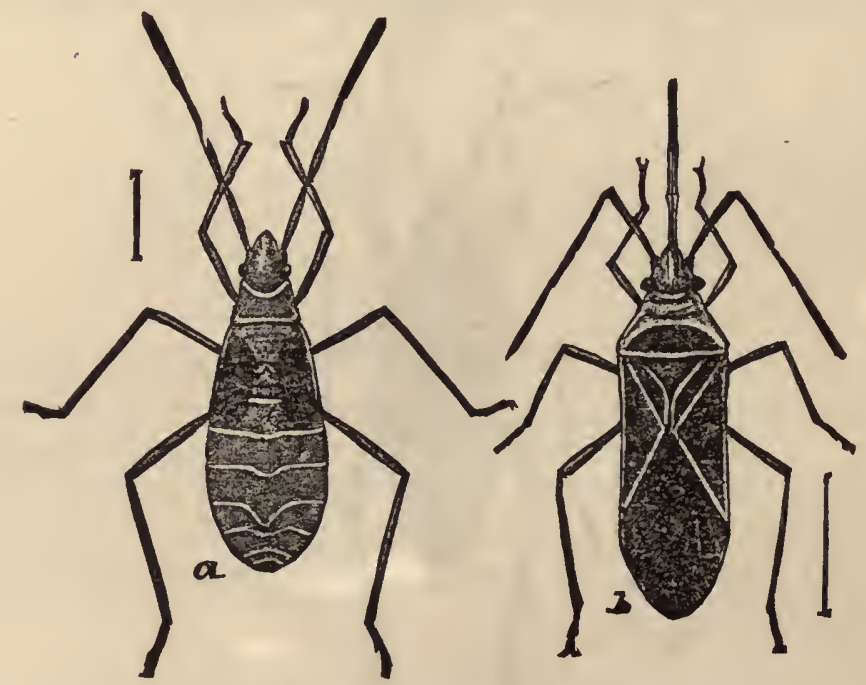

Fig. 201.-Dysdercus suturellus. (From Insect Life.)

by its excretions, which are of a yellowish color. Experiments have been made with this insect looking toward its use as a dye, and the whole substance of the insect can be converted into a rich orange-yellow dye, which can readily be fixed on woolens or silk by the alum mordant liquor. The eggs, to the number of twenty or thirty, are deposited upon the leaves or stalks of the cotton plant, and are also loosely dropped in the sand. The insect molts five times and breeds apparently steadily all through the year, so that there are several generations. Careful observations on the eggs and the first stage are needed. 


\section{THE STILT BUGS}

(Family Berytida.)

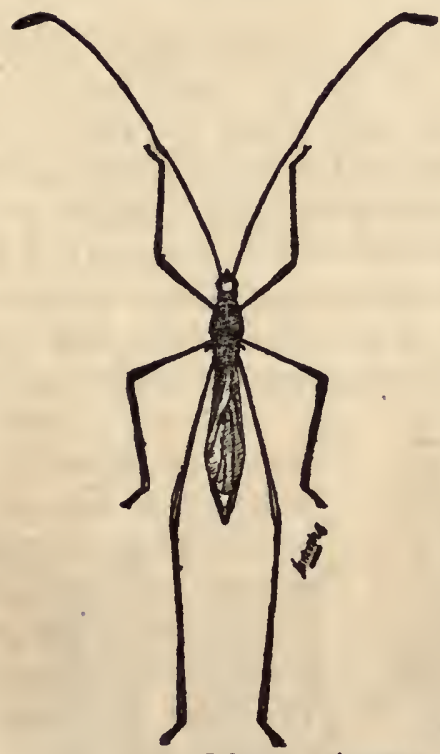

Fig. 2ora.-Jalysus spinosus

(After Lugger.)

This group, rather closely allied to the Coreidæ, is of much smaller extent. It includes slender plant bugs which have the thighs thickened at the tip. Some of them are very slender and have long, thin legs, from which fact they have been termed "stilt bugs." Only six species are known to occur in the United States and the life history of none of them has been carefully worked out. Jalysus spinosus, our commonest species, a sluggish little insect which is to be found on the undergrowth in oak woods, all through the summer, from Maine to Georgia and westward to Texas and Arizona, would be a good species to study carefully. 


\section{THE CHINCH-BUG FAMILY}

\section{(Family Lygaida.)}

This is one of the large families of plant bugs, comprising rather more than 1,300 species, distributed in thirteen subfamilies and 208 genera. Of these about 175 species are known in the United States. No good popular name has been proposed for this group. Comstock calls it the " chinch-bug family" from its most famous representative, but of course this is not a distinctive name. The Lygæids are distinguished from other bugs chiefly by the membrane of the front wing, which has four or five simple veins, and by the antennæ, which are inserted low down

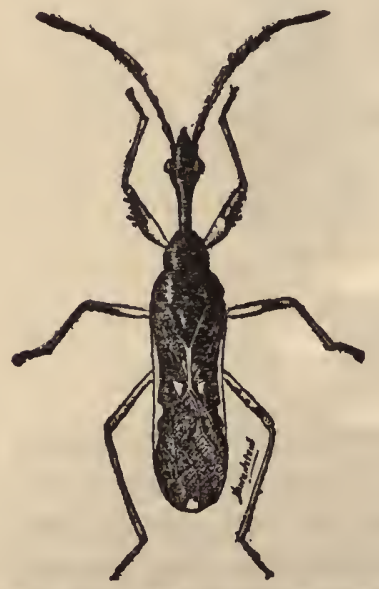

Fig. 202.-Myodocha serripes

Oliv. (After Lugger.)

on the side of the head. Many of these bugs, when full grown, have the wings either long or aborted, so that in the same species there are both longwinged and short-winged forms. All live on the juices of plants, and the family contains many injurious forms. The most prominent of these is the chinch-bug (Blissus leucopterus), a little bug which occurs in Central America and the West Indies and all over the United States and north into Canada. It feeds on Indian corn and on wheat and other small grains and grasses, puncturing the stalks, and causing them to wilt. Its great notoriety as a crop destroyer arises from the incalculable numbers in which it appears in dry seasons. The average annual loss which this insect causes to the United States cannot be less than $\$ 20,000,000$.

Another very common and destructive insect belonging to this family is the so-called "false chinch-bug" (Nyzius 
angustatus Uhl.) which although it belongs to a different subfamily is frequently mistaken by farmers for the true chinch-bug. It damages grapevines, strawberry plants and many garden vegetables; puncturing the leaves with its beak and causing them to wilt. The life history of this bug should be worked up. We do not know its eggs, the number of molts or the number of generations. One of these bugs, known as Belonochilus numideus Say, according to Heidemann, feeds on sycamore leaves and passes the winter in the half-grown condition thrust down in the crevices of the "button balls."

\section{Life History of the Chinch-Bug (Blissus leucopterus Say.)}

The chinch-bug is a small, dark colored insect with white wings. It is only $3 \mathrm{~mm}$. long and is rather slender. It passes the winter as a full-grown bug, hidden away in clumps of old

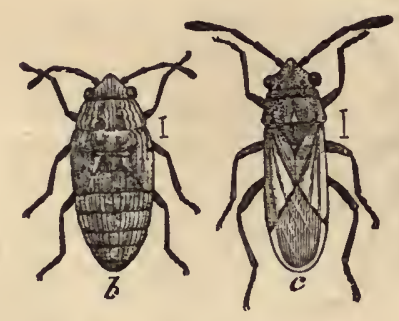

Fig. 203.-Nysius angustatus.

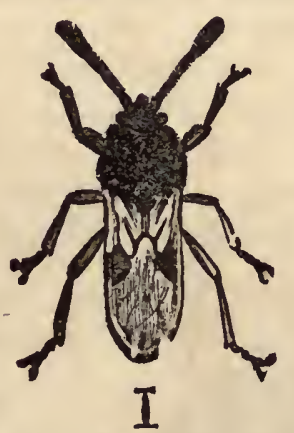

Fig. 204.-Blissus leucopterus. After Riley.)

grasses or in other protected spots. The egg is nearly $1 \mathrm{~mm}$. long, elongate-oval, and of an amber color. About five hundred are laid by each female and are thrust into grass sheaths near the ground, or upon the stem at or under the surface of the ground. They are laid in the spring and the young hatch soon afterwards. The newly hatched bugs are pale yellow at first but grow red. They molt four times before becoming adult and grow darker in color and the adult is dark gray or nearly black. Over most 
of the United States there are two generations, the eggs for the second generation being laid in late July or early August. In all stages the chinch-bug is gregarious and clusters upon grains and grasses in such numbers as to quickly destroy them.

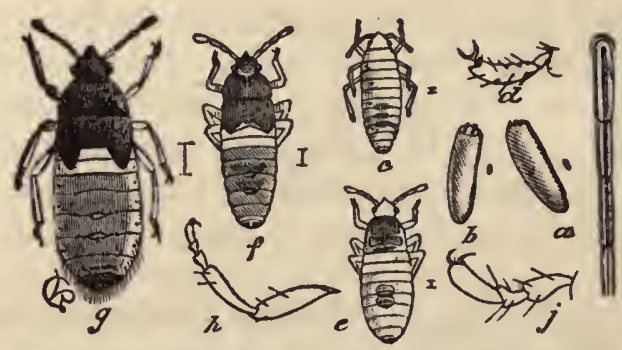

Fig. 205.-Blissus leucopterus. (After Riley.)

They migrate in search of food and after wheat harvest they usually travel to the nearest cornfield and the second generation is developed on this crop. Many of the adults have only half developed wings and this form, which is called "micropterous"

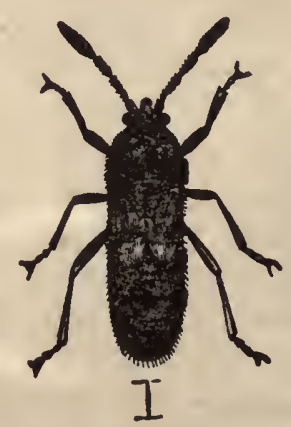

Fig. 206.-Blissus leucopterus.

(After Riley.)

is apparently more abundant near the sea-coast than elsewhere. A fungus disease is very prevalent in wet weather and efforts have been made to propagate this disease and (with some measure of success) artificially introduce it into infested fields. 


\section{THE STINK-BUGS AND THEIR ALLIES}

\section{(Family Pentatomida.)}

In this large family of bugs, which comprises nearly four thousand species, of which about three hundred inhabit the United States, we find a curious difference in habit in that while

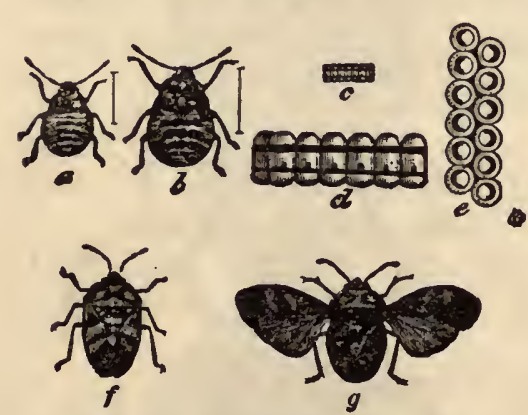

Fig. 207.-Murgantia histrionica. some of them are exclusively plant feeders others feed both upon plants and upon other insects. This differentiation in habit corresponds in a measure with the subfamily grouping. As a rule these insects are flat and broad, and the antennæ are five-jointed. The scutellum is enlarged and in some (the Scutellerinæ) covers the whole abdomen.

Many species possess an extremely bad odor and taste, which has led Comstock to term the group "the stink-bug family." Very many wellknown and common insects belong to this group. The harlequin cabbage bug (Murgantia histrionica Hahn.) is a wellknown species in cabtage fields south of New Jersey. It is a serious enemy to cruciferous vegetables.

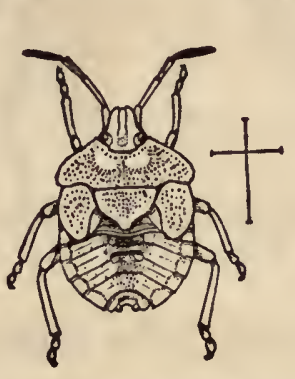

Fig. 208. - Euschistus variolarius.

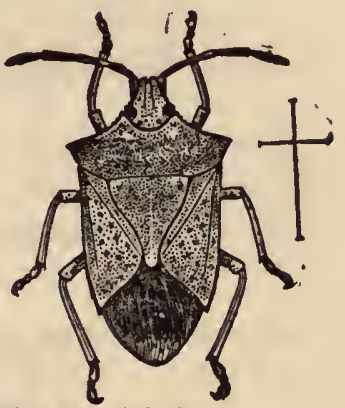

(Author's illustration.)

In parts of Georgia it is still known as the "Abe Lincoln bug," and in Texas as the "third-party bug." The eggs are very 
beautiful banded objects, laid in clusters on the leaves of cabbage, and the full-grown bug is beautifully mottled with black and red. The so-called spined soldier bug (Podisus spinosus) is a plantfeeder, and also preys upon insects, especially caterpillars. The

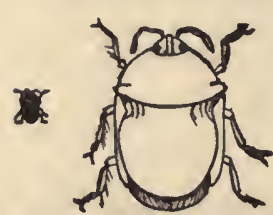

Fig.209.-Corimelæna pulicaria. (After Riley.) beautiful bug known as Stiretrus anchorago is largely predatory, and feeds upon many different kinds of insects. The green soldier bug (Nezara hilaris Say) and the common species known as Euschistus servus are both plant and animal feeders.

The eggs of nearly all of these insects are laid in clusters on leaves or other objects, and vary greatly in color and sculpturing. Many of them are parasitized by the little Proctotrypid flies of the genus Teleas.

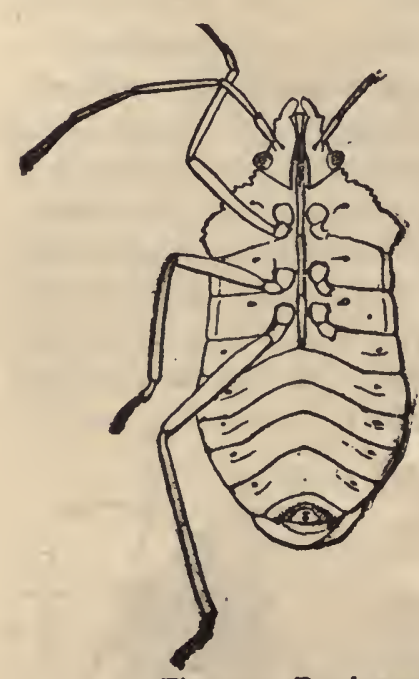

Fig. 210.-Brochymena annulata.

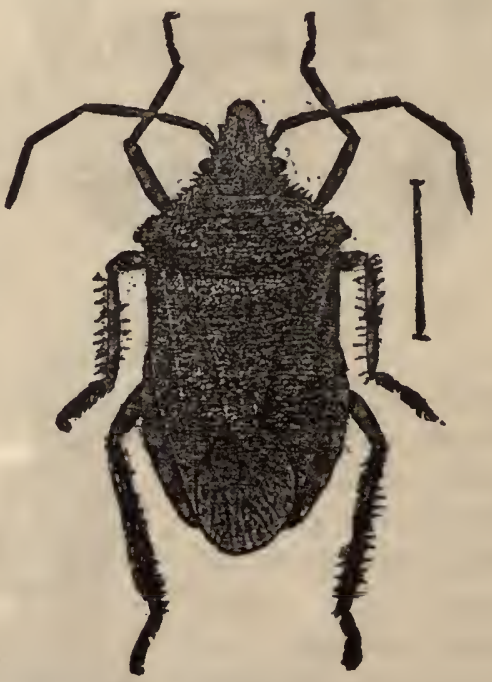

(From Insect Life.)

\section{Typical Life History}

(Podisus serieventris Uhl.)

This species which is not uncommon in the northern states lays its eggs in small clusters of from ten to thirty each on the bark of trees or on leaves or other objects. They are bronze in 
color growing darker up to the hatching period. They are nearly circular in shape, and are furnished with a well-defined circular cap. The upper part of the egg is covered by irregular rows of minute short spines, while around the edge of the cap is a row of long, curved, knobbed spines. They hatch in eight days, and the insect passes through five molts, growing gradually, and
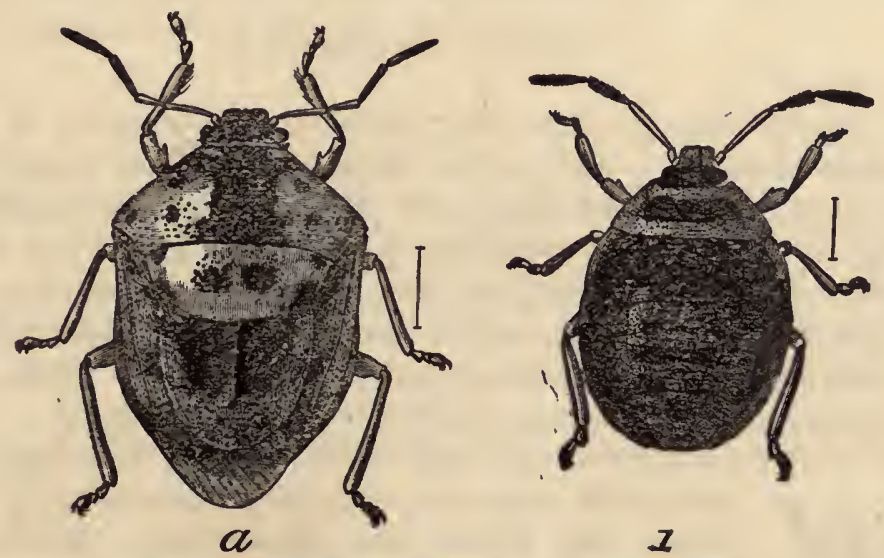

1

Fig. 211.-Stiretrus anchorago. (After Chittenden.)

changing in color from yellowish-red to brownish-yellow. There are three generations in the course of the summer, and the insect hibernates in the adult condition under the rough bark of trees, and in similar protected situations. When young they feed upon very small insects and their eggs, but when full-grown will attack any insect however large, even full-grown cutworms and. the larvæ of the Gypsy moth.

Mr. A. H. Kirkland was the first observer to work out the complete life history, and from his full account as published in the report of the Massachusetts Board of Agriculture on the Gypsy moth (1896) these facts have been drawn. 


\section{THE TRUE LICE}

\section{(Suborder Anoplura.)}

The true lice are generally referred to in the books as the suborder Parasita. They are all wingless, degraded creatures, possessing to a marked degree the degradational characteristics which result from a parasitic form of life. They have a thin skin the feet are armed with a single long claw, and the mouth-parts consist of a short tube furnished with hooks, from which may be protruded a delicate sucking tube. They are not numerous in species and are all parasitic on warm-blooded animals. The lice which are so commonly found on birds belong to a different

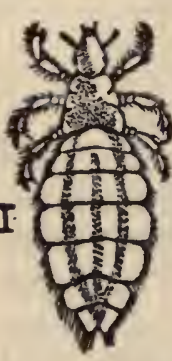

Fig. 21 2.-Ped. iculus capitis.

group and are structurally quite different from Anoplura. Six genera and about forty species of Anoplura are known. They are found upon many mammalia, even upon those which live in the water. A curious genus, for example, is found upon seals. The lice of domestic animals and those which are found upon uncleanly individuals of the human race are well known. Three species are found upon human beings in different parts of the world, and are more or less specifically attached to this host. The conditions of modern civilization, however, are gradually causing these insects to become rare, except in the lowest quarters. Fortunately it would no longer be appropriate, or even possible, in the dawn of the twentieth century, for a poet of distinction to write lines comparable to those which Robert Burns once composed in the Scottish church.

The eggs of most species are attached to the hairs of the host animal, and the young lice, after hatching, begin immediately to attack the skin. The rate of growth is not recorded, and the embryological and morphological development of the group is not well known. Here is an opportunity for some enthusiastic student, who can overcome the natural distaste for these dis- 
agreeable parasites, to do some good original work. The old Dutch naturalist, Leeuwenhoek, once started an experimental investigation of Pediculus vestimenti, using his own person as the breeding ground, but, beyond the conclusion that the species is very prolific, he reached no results of particular value. Mercurial ointment is a sovereign remedy for the species which attack human beings, while different oily mixtures are used with success on domestic animals. 


\section{THRIPS}

\section{(Order Physopoda.)}

The very minute insects known as "thrips" belong to this order, which is a very well differentiated group and has apparently no very close relatives among the insects. It is unfortunate that in this country the name thrips has been applied largely by vinegrowers to some of the little leaf-hoppers of the family Jassidæ $(q . v$.$) , but the name was long preoccupied, both popularly and$ scientifically, by the physopod insects, which, by the way, are

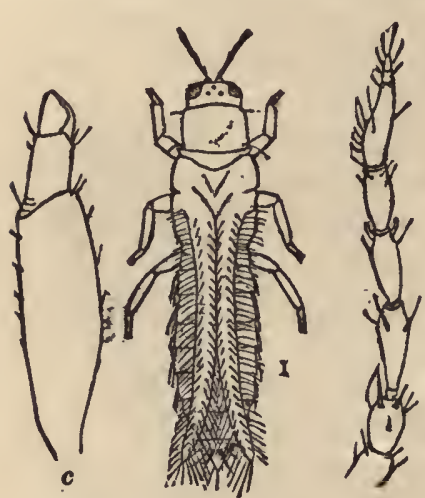

Fig. 213.-Thrips tritici. also sometimes called Thysanoptera. They are very minute, slender insects, with four wings which are also very slender and very short, perfectly transparent and practically without veins. They are fringed, however, with long delicate hairs and lie along the back of the abdomen when at rest. The metamorphosis is incomplete and the mouthparts are of very curious shape, but probably function in sucking. They are really intermediate between true biting and true sucking mouthparts. A striking peculiarity of the mouth-parts is that they frequently differ on the two sides. In other words, they are asymmetrical. Although the metamorphosis is incomplete, what may be called the pupa is not active. The larvæ, however, are not in the least worm-like and resemble the adults, except for the lack of wings. The feet are curiously constructed and have a little bladder-like vesicle at the tip, from which fact the name of the order was derived.

The thrips are found in the greatest numbers in the flowers of flowering plants and there can be little doubt that they do $3^{18}$ 
considerable damage by injury to the essential organs of flowers. Although the statement has been made that they sometimes feed upon other insects, the evidence is not good. An interesting form in this country lives in the sheaths of timothy grass and sometimes causes the dying of the heads of the grass. Sometimes they are found under bark and in fungi, and in Australia some of them form galls on the leaves of acacias. In the United States, however, they are most abundantly found in flowers and frequently in the heads of wheat. In greenhouses thrips are especially noticeable. Dracænas are said to suffer especially from their attacks. They are commonly found on chrysanthemums, on hydrangias, in orange blossoms, and many other flowers. Probably the most injurious species in this country, however, is the so-called onion thrips which causes the disease known as the white blast of onions. The same species is found on leaves of cabbage and cauliflower, squash, turnips, nasturtiums, and many other plants. It is also found in Europe where it occurs on tobacco as well as upon garden plants. It is known as Thrips tabaci Lind.

It does not seem to be generally known that parthenogensis has been found to occur with thrips. Less than one hundred and fifty species are known, but almost no one has taken the trouble to collect these little creatures in out-of-the-way places, and it is reasonable to suppose that the order will be found to be quite numerous in species. 


\section{GRASSHOPPERS, KATYDIDS, CRICKETS, ETC.}

\section{(Order Orthoptera.)}

This is a large and important group of insects which comprises those forms which are known as the straight-winged insects and includes the grasshoppers, or true locusts, the longhorned grasshoppers (including the katydids), the crickets, cockroaches, walking sticks and leaf insects, and the praying mantids or rearhorses. In all these insects the mouth-parts are fitted for biting and the metamorphoses are incomplete, the young when hatching from the eggs resembling the adult except for the lack of wings. The eggs are comparatively few in number and are laid in specialized egg cases. The fore wings are somewhat thickened and rather tough and horny as a rule, though not so much so as the elytra of beetles and at rest lie closed on the back of the insect so as to protect it and the hind wings. They are called tegmina. The hind wings are much more delicate and are the important ones in flight. They are furnished with radiating veins somewhat like the sticks of a fan and have short cross-veins forming a sort of network. In repose they fold like a fan and are more or less covered by the fore wings. While the order is not such an extensive one in number of species, it is one of very great economic importance, largely through the ravages which the migratory locusts, or short-horned grasshoppers, make upon agricultural crops in various parts of the world and the numbers in which not only these insects but certain other forms occur, while their comparatively large size and frequently conspicuous appearance, make the group a noted one.

As to size, the Orthoptera probably include the largest of living insects and this is particularly the case in tropical countries. Even in this country, however, it is doubtful whether any insect exceeds in actual bulk the large lubber grasshoppers of our South- 
eastern and Southwestern States. It is estimated that probably ten thousand species of Orthoptera exist in the world, but this estimate is probably a small one, since, as in the other groups, the smaller and more inconspicuous species have not been collected in out-of-the-way places. The average traveller who picks up specimens, and even the average collector, when he goes to some rarely visited corner of the world, will always collect the large and conspicuous things and neglect the smaller and more insignificant specimens. From this habit, it results that in the large museums, like the British Museum, the Berlin Museum and the Vienna Museum, and our own National Museum, large, exotic forms from most portions of the world are well represented, but there are comparatively few of the little dull-colored ones.

The order Orthoptera affords a peculiar interest to the student of the phenomena of protective and aggressive resemblances. The family Phasmidæ includes those remarkable creatures which are so much like twigs and leaves that they have been called walking sticks and leaf insects. It also includes the great group of praying mantids which feed upon other insects and which, though slow movers, are enabled to capture their prey by means of their perfect disguise which, in temperate regions, makes them resemble twigs and in tropical regions brings about an extraordinary resemblance to flowering vegetation, some of them being most highly colored, as the flower mantids, which resemble the most conspicuous orchids.

Another fact which renders this group of especial interest is that many of them are so musical. One often hears of the "song" of the katydid, but as a matter of fact, these insects are not vocalists but instrumentalists. Portions of the body are so modified as to produce musical sounds by the rubbing of one part upon another. In the crickets it is the rubbing of the upper wings upon the hind wings, the membrane being veined in such a way as to produce a chirping sound. In some of the grasshoppers the sound is brought about by the rubbing of the hind thighs against the edge of the fore-wings, or "tegmina." These musical powers are confined to the male sex and the tunes which they play are, while songs without words, always love songs.

Many of the Orthoptera are great jumpers, their hind thighs being thickened so as to errable them to make great leaps. 'The common name grasshopper is based upon their facility in this 
Grasshoppers, Katydids, Crickets, etc.

direction. This reminds me of the little girl, who, being told that the beetles were Coleoptera and that the butterflies were Lepidoptera, remarked that the grasshoppers must be the "Grasshoptera." Many of the Orthoptera fly well and strongly. The migratory grasshoppers frequently fly for hundreds of miles with daily rests for food, sometimes in such enormous swarms as to darken the face of the sun.

\section{TABLE OF FAMILIES}

Hind thighs stouter, or longer, or both, than the other thighs; head vertical; ovipositor generally extruded; generally singers or chirpers (stridulators) ............... I

Hind thighs like the other thighs; head usually bent under; ovipositor concealed ; mute................. 3

I-Antennæ much longer than the body, delicately tapering; sound-producing organs at the inner base of the fore wings (tegmina); ovipositor usually prolonged into a blade or needle ......................... 2

Antennæ much shorter than the body, not delicately tapering; sound-producing organs on the hind thighs and outer edge of the fore wings; ovipositor composed of a double pair of short plates which diverge at tip. Family Acridiidae

2-Feet (tarsi) four-jointed, nearly similar in structure on all legs; ovipositor (unless, as rarely, concealed) forming a strongly compressed, generally sword-shaped blade, valves not expanded at tip ................... Family Locustidoe

Tarsi three-jointed, those of the fore or hind legs differing from the others in structure; ovipositor (unless, as rarely, concealed) forming a nearly cylindrical, straight, or occasionally upcurved needle; valves expanded at tip. .......................... Family Gryllida

3-Body oval, flattened; head nearly horizontal; rapid runners. .............................. Family Blattid $x$

Body long, narrow; head free; slow movers......... 4 4-Head oblique, generally three-cornered; front legs fitted for grasping ...................... Family Mantida

Head nearly horizontal, generally four-cornered; front legs like the other legs................. Family Phasmida 


\section{THE WALKING STICKS}

\section{(Family Phasmida.)}

The insects of this family present some of the most striking forms known among the Hexapoda. They consist of the so-called "walking sticks." This name is given to them from the remarkable development of protective resemblance which has brought all of the species to a close imitation of the twigs of different plants. The family reaches its highest development in the tropics, but one species is common in the Northern States. The family constitutes the section of Orthopterous insects known to the old naturalists as Gressoria or walkers, as contrasted with the runners, jumpers, and graspers (Cursoria, Saltatoria and Raptoria). The body is long and slender, the head is exserted, the legs are long and slender and generally similar. They generally have no wings although some of the tropical species have short or long wings. The eggs have a very curious structure and frequently resemble seeds in appearance. They possess the power of reproducing lost limbs, the new limb being weaker than the old one and generally curved. Certain of the tropical forms in this family are curiously modified so as to resemble leaves instead of twigs. Leaf insects in the tropics frequently bear so close a resemblance to vegetation as to deceive a keen observer.

\section{Life History of a common Walking Stick (Diapheromera femorata Say.)}

This is the common "walking stick" of the northern United States and is distributed over the greater part of the country. It has been given the popular name of the "thick-thighed walking stick" owing to the fact that the femora of the middle legs are somewhat swollen. The eggs, of which each female lays about one hundred, are a little less than $3 \mathrm{~mm}$. long, oval in shape, 
The Walking Sticks

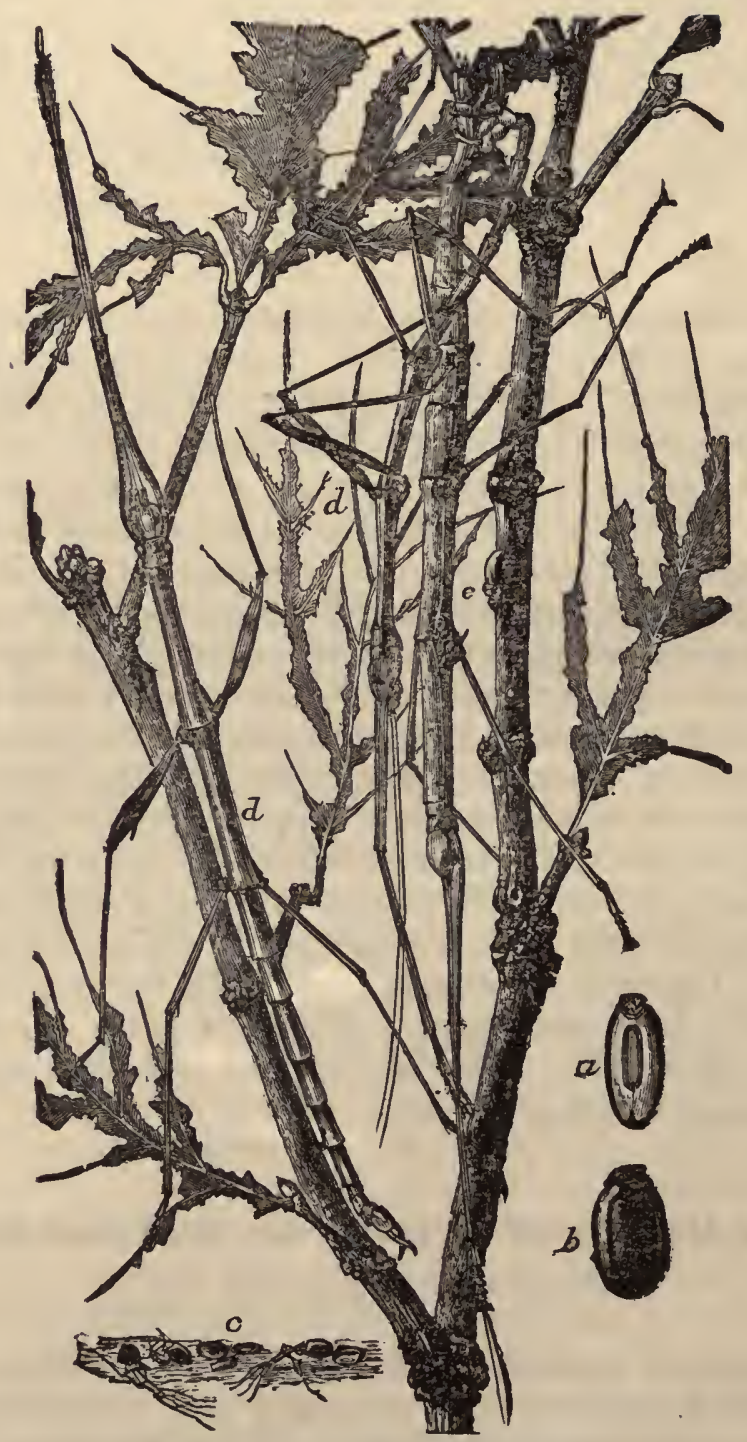

Fig. 214.-Diapheromera femorata. (After Riley.) 
slightly compressed at the sides, and of a polished black color with a whitish stripe on one side. They resemble the small plump seeds of some leguminous plant. They are not laid in clusters or fastened to the plant but are dropped loosely on the ground where they remain through the winter and hatch the following May. Some of them are retarded in their hatching and young walking sticks may be found throughout the summer. In hatching the top of the egg lifts up like the lid of a vessel. The young when first hatched are $4.5 \mathrm{~mm}$. long, and of a uniform pale yellowish-green color. They live, as a rule, near the ground and drop readily when disturbed. They molt but twice, retaining the same color until maturity, and develop rapidly, averaging, under favorable circumstances, about six weeks from birth to maturity. When adult the green color becomes gray and brown. This change in color is protective since in the early summer while vegetation is green, the insects are also green; when the foliage turns in the autumn they change color to correspond to a certain extent, and when the foliage is stripped they closely resemble the twigs upon which they rest. The front legs of the insect are stretched out straight in front so as to increase the twig-like appearance. The males are smaller than the females and frequently retain the green color in the mature condition, following the rule which holds more or less throughout nature, that the male sex is not so well protected as the female, since upon the latter depends the all-important function of reproduction. There is but one generation annually and, as before stated, the insect hibernates in the egg state on the surface of the ground. In spite of the protection afforded by form and color the insect seldom becomes sufficiently abundant as to be ranked as injurious. although it feeds voraciously upon the leaves of plants during all stages of growth after hatching. In the few instances where it has become sufficiently abundant to do noticeable damage it has been easy to reduce its numbers to a minimum by burning over the leaves on the ground during the winter time, thus destroying the hibernating eggs. In 1898 this insect appeared in extraordinary numbers in a black-walnut forest in western New York, so that in the autumn the dropping of the eggs on the leaf-covered earth sounded like a heavy shower of rain. 


\section{THE REARHORSES, OR PRAYING MANTIDS}

\section{(Family Mantide.)}

The insects of this family formed the old Orthopterous group, known as Raptoria, or graspers. They are predatory insects, and are characterized by having a long, slender prothorax, with the first pair of legs fitted for grasping their prey. They are like the Phasmidx, much more abundant in tropical regions than elsewhere, and, while many forms, by their shape and color, exhibit striking instances of protective resemblance, in others are seen in its highest development the phenomenon of aggressive

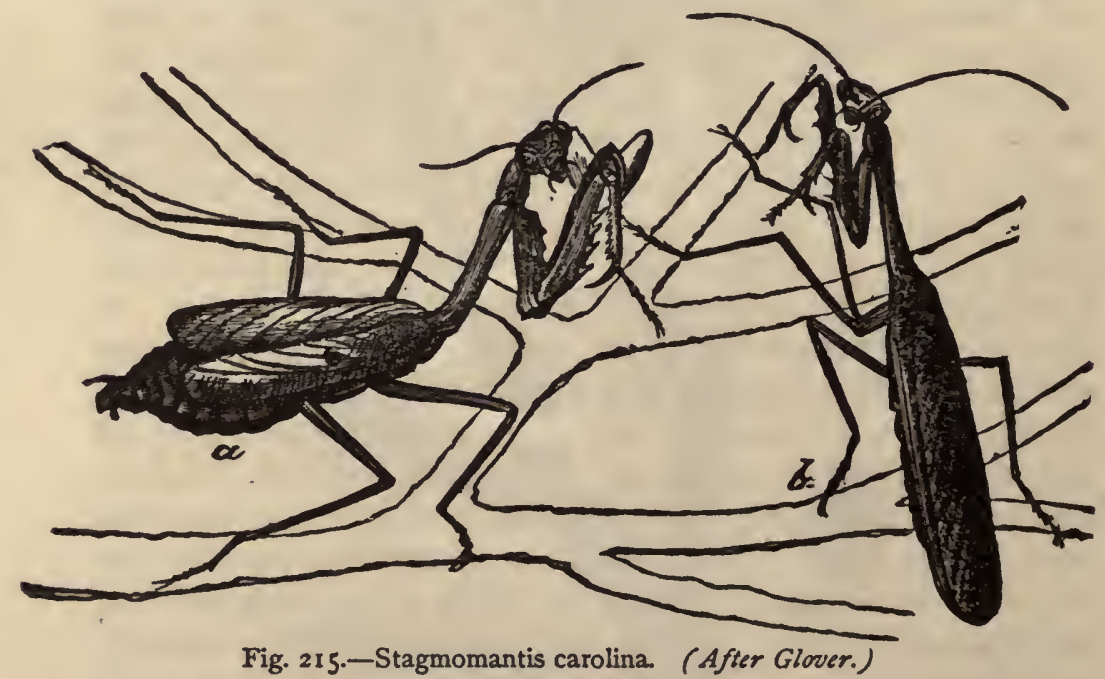

resemblance. The so-called flower mantids in tropical countries closely resemble the flowers of certain plants, especially brilliant orchids, and in these flowers they lurk awaiting the visits of insects, which they capture. They have various popular names, 326 
being known in England as "sooth-sayers," or "praying insects," from the attitude which they assume when at rest or when waiting to grasp another insect. The knees are bent, and the front legs are held as though supporting a prayer-book. In our Southern States they are known as "mule-killers," from the curious superstition that the brownish liquor which they exude from the mouth is fatal to mules. They are more commonly known, however, in the south, as "rearhorses," from the rearing attitude assumed when about to grasp another insect. The eggs of the Mantidæ are laid in a curiously-formed egg case which is secreted by the female. They capture their prey by stealth, crawling upon them so slowly that the motion is hardly observable, but when within reaching distance the front legs are thrown out with incredible rapidity. They are cannibalistic in a high degree, and the female often, if not usually, devours the male while in the act of conjugation.

Like so many other predatory insects, they have the most voracious appetites. Colic and bilious headaches seem unknown to them. Slingerland has brought together some interesting instances of this voracity in his account of the recent accidental introduction and establishment of the European Mantis religiosa in New York State. His correspondent, Mr. Atwood, writes : "One Sunday a green mantis ate three grasshoppers, each seveneighths of an inch long, a daddy-long-legs, and then tackled another mantis, and I was obliged to interfere between them." It is probable that this common European insect was introduced into northern New York in the egg stage on nursery stock. Another foreign mantid has also recently become acclimatized in this country. This is Tenodera sinensis Sauss., of Japan. This large and striking form made its appearance about Philadelphia in 1896 , and in 1900 was quite numerous.

\section{Life History of a Rearhorse}

\section{(Stagmomantis carolina.)}

This species, which is common throughout the southem United States, extends as far north as New Jersey. It is an austral form, but does not reach the northern limits of the socalled upper austral life zone. The eggs are laid in tough cases 
about an inch long which are attached to the twigs of trees. The case is tough and horny, and the eggs are laid in parallel rows, perhaps forty in a row, issuing

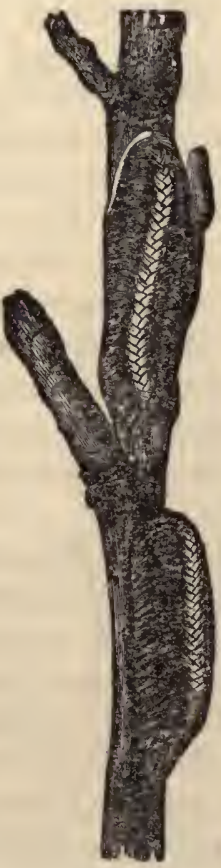

Fig. 216.-Stagmomantis carolina : egg cases. (After Riley.) from a common longitudinal middle line. All of the eggs stand on end and are inclined somewhat toward the central channel. A cluster of eggs has a braided appearance, but consists simply of a continuous ribbon of mucous folded in close fluting and having an egg deposited in the bight or angle of each fold. The eggs are deposited simultaneously with the deposition of this ribbon by the mother insect, and the whole mass is at first soft and flexible, but rapidly hardens by exposure to the air. The newlyhatched insect is light yellowish-brown, but after the second molt many of them become green. The number of molts has not been recorded, but there are certainly more than three. At full growth, however, most of the females are green, while the males become brown or gray. There is but one generation each year. The young hatch in the early summer, but complete their growth in the latter part of the season, and the insect hibernates in the egg stage. The eggs are frequently parasitized by a very peculiar chalcis fly, Podagrion mantis, which penetrates the tough egg mass with its long ovipositor, and whose larvæ feed upon the eggs. Thus egg masses taken by the observer in the winter and kept for the hatching of the young will frequently in the spring give out these parasites instead of the young mantids. 


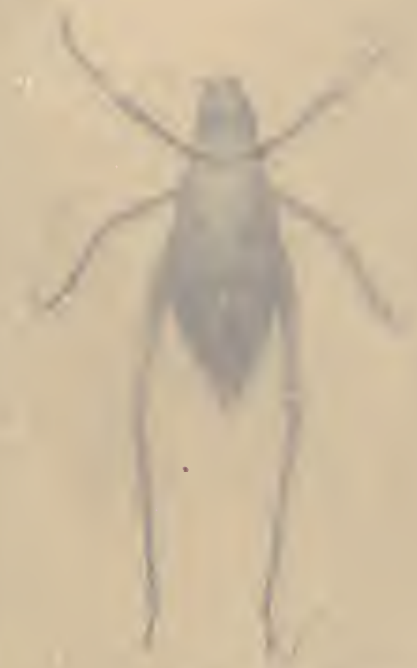

$.61 \times \times \times 118.14$

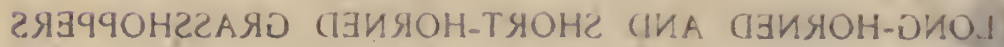

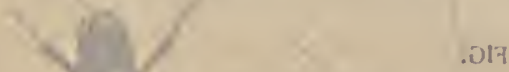

sibizoft spXoris . musjiq musolvjisal do

19h:0s prqued sidqmomozirat. if

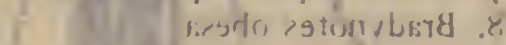

17<smiles></smiles>

(n)

mavriznos rnullydquessild .1 zufrsiciso zulliost friulidun robyqood

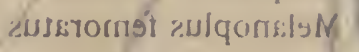




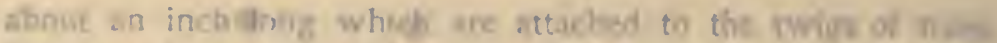
The case is tough and horns, and the eges are lild is aacles

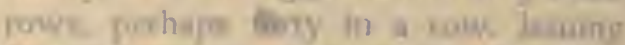
fiom a soirmon lungitudius in lable dise Bil of the reço aland on rend sogt ine inclienert same what tow twe the commi

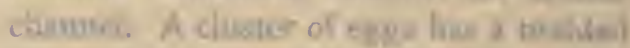
apprainace bus corsists simply of a come

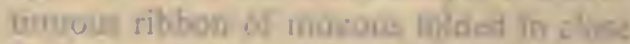

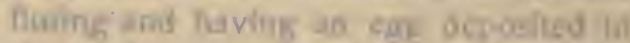
the bight of angle of cacti inde. the egist are deposiled slenumencouds wifh the depounion af this alhborr Ly the

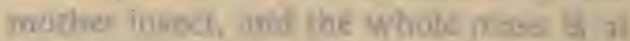

PLATE XXXIV. Alewihle, bur wafidiy nero.

\section{LONG-HORNED AND SHORT-HORNED GRASSHOPPERS}

FIG.

1. Platyphyllum concavum

2. Bacillus carinatus

3. Boopedon nubilum

4. Melanoplus femoratus

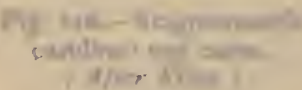

FIG.

5. Paroxya florida

6. Dactylotum pictum

7. Anisomorpha buprestoides

8. Bradvriotes ohesa

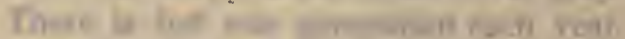

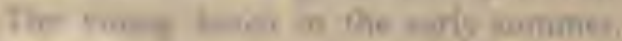

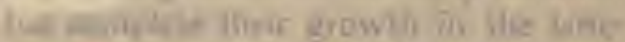

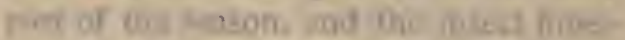

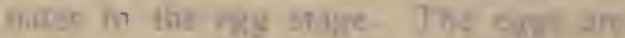

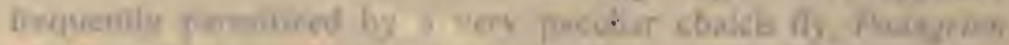

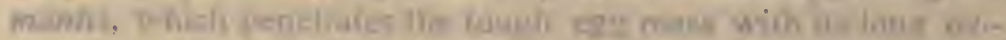

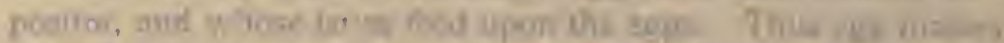

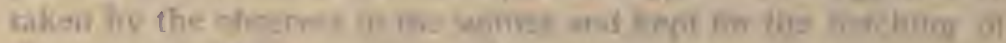

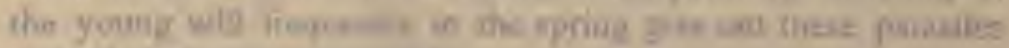
insicad sh the rours. 


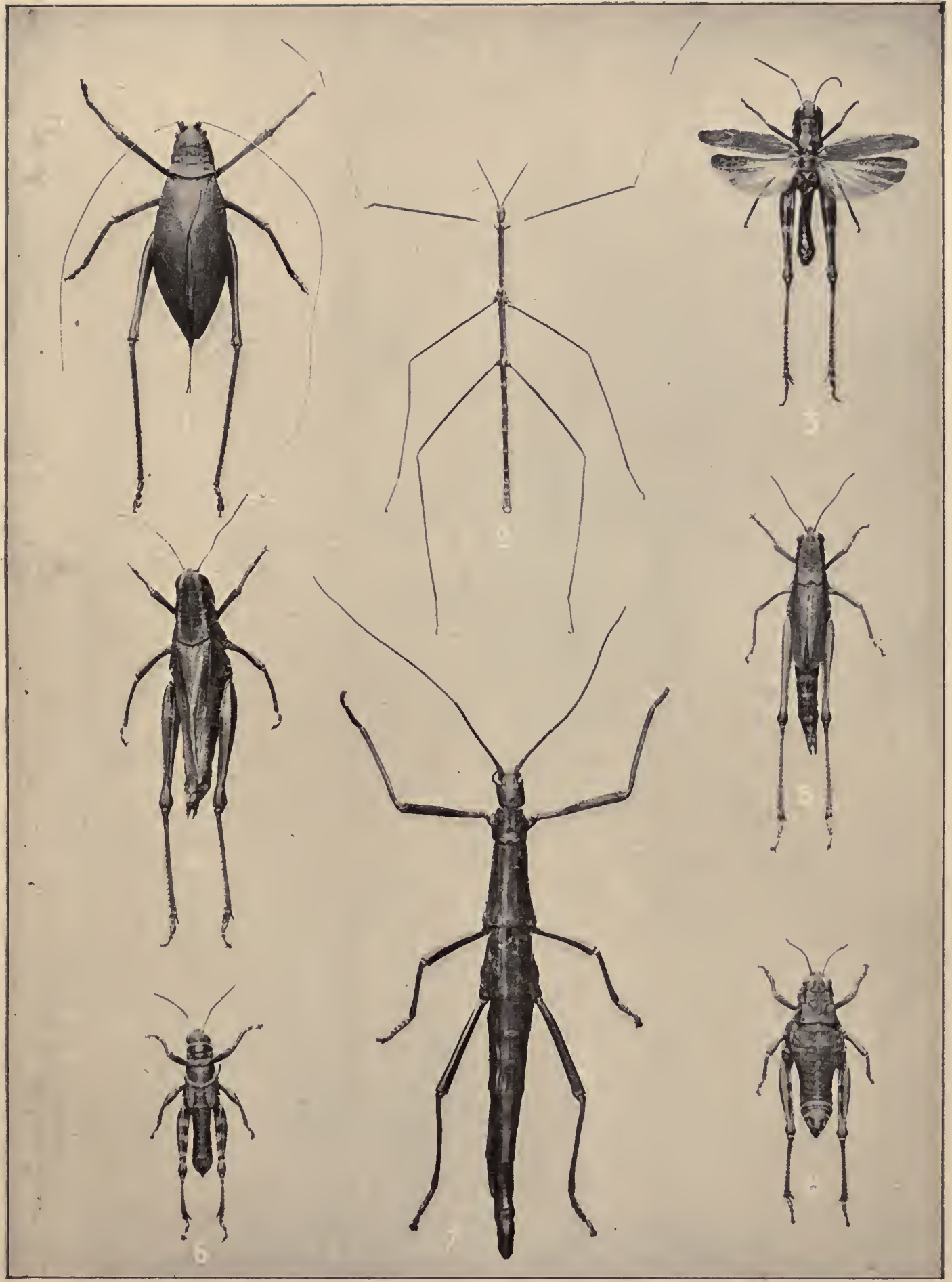





\section{COCKROACHES}

\section{(Family Blattida.)}

The insects of this family, known commonly as cockroaches, form the old group Cursoria, or runners. The body as a rule is oval and flat, all the legs being similar in form. The head is deflexed or bent under and generally concealed by the prothorax. The hind wings are slightly folded. The insects of this group are very abundant in the tropics but several species have become domesticated and are very abundant in the colder parts of the world. The cockroach type is a very persistent one, and insects of this family existed in great numbers in geologic periods prior to the tertiary. They are found in considerable number in carboniferous rocks and one form has been found in Silurian sandstone.

The eggs are laid in egg cases as with

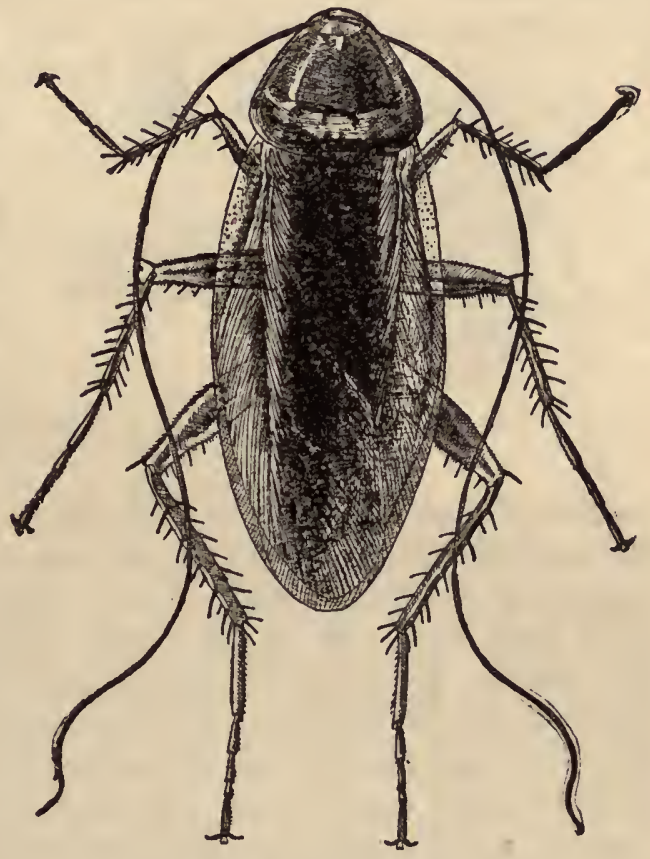

Fig. 217.-Periplaneta americana. (Redrazun from Marlatt.)

the Mantidæ but the subsequent life history is little known, It is supposed that they grow very slowly. Most of them are nocturnal in their habits. They feed on a great variety of 
substances, especially those forms which inhabit houses, but it is supposed that their natural food is dead animal matter. Dr. Sharp estimates that there are five thousand species in existence. The species found in American houses are the American cockroach (Periplaneta americana), the German cockroach or croton bug (Ectobia germanica), the European cockroach or "black beetle" as it is known in England (Periplaneta orientalis) and the Australian cockroach (Periplaneta australasice). The egg cases of the German cockroach is shown in accompanying illustrations.

The female carries the egg case with her until she finds a proper place to leave it or until the eggs are nearly ready to hatch. The young roaches grow slowly and pass through a variable
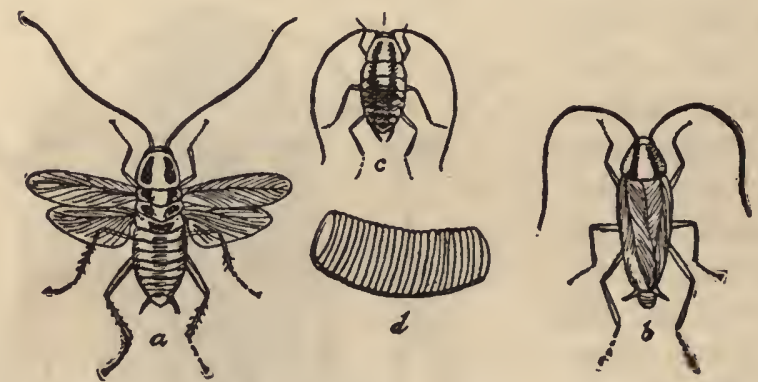

Fig. 218.-Ectobia germanica. (Redrawn from Insect Life.)

number of molts, sometimes as many as seven. The time required for the development from the egg to the adult may be prolonged by absence of food or low temperature. Four or five years have been said to have been occupied in this growth. The German cockroach has been shown to reach full-growth in from four and one-half to six months and the American cockroach has been raised from the egg to the adult in about twelve months. No sufficiently careful observations on the life history of the common species appear to have been made, hence the "Typical Life History" must be omitted with the insects of this family. The anatomy of Periplaneta orientalis has been carefully studied by Miall and Denny.* and the American household cockroaches have been treated at some length by Marlatt.**

* The Anatomy of the Cockroach.

** Bull. 4, N. S., Div. Entomology, U. S. Dept. Agric., pp. 84-95. 
The cockroaches which have just been mentioned are practically domesticated animals in so far as they have accommodated themselves to the environments of civilization. They appear to eat almost everything, whether animal or vegetable in its nature, and they are household pests of the highest rank. They are also all of them cosmopolitan, or practically so, and have been carried in ships to almost all parts of the world. Our native cockroaches are, most of them, out-door feeders and are exceptionally cleanly insects. In fact, any one of the domestic cockroaches, if watched, will be seen constantly to make efforts to beautify its person, licking its legs and its antennæ in much the same manner in which a cat washes its paws. A curious observation which the writer once made indicates that it is possible for cockroaches to acquire the tobacco habit. A croton bug of the usual inquisitive turn of mind inhabited my office desk, and as soon as I laid down my cigar upon the edge of the drawer the little fellow invariably came out of his hiding place and worked vigorously at the moist end. At first he was after the moisture but later the tobacco taste grew and he became as much addicted to the habit as the most inveterate human tobacco user. It may be worth mentioning that it seemed to have no appreciable effect on its health.

Cockroaches are fond of darkness.

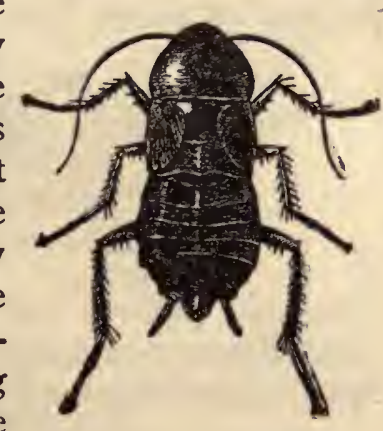

Fig. 219.-Periplaneta orientalis.

They roam about houses at night, and new houses become stocked with roaches through migrations at night time from over-supplied adjoining establishments. On a dark day in Washington I once saw a migrating army of cockroaches, incalculable in number, crossing the street from a dirty restaurant toward buildings opposite. The majority of the individuals composing the army were females carrying egg cases, and the observation thus became one of psychological interest since the migratory instinct seemed to have been developed by an appreciation of the fact that while the restaurant might support the mothers there would not be food enough for the coming children. 


\section{THE SHORT-HORNED GRASSHOPPERS OR TRUE LOCUSTS}

\section{(Family Acridiida.)}

The insects of this family are everywhere abundant both in number of species and individuals. They comprise some of the most destructive insects known and the migratory species have devastated the crops of many countries, more especially Russia. portions of South Europe, Algeria, India, Cape Colony, the

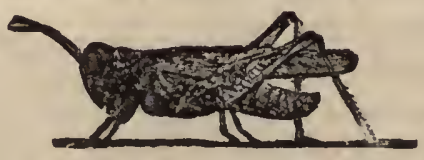

Fig. 220.-Melanoplus devastator. (After Riley.)

Argentine Republic and in former years some of the western United States. In the insects of this family the antennæ are short, much shorter than the body, the ovipositor of the female is short

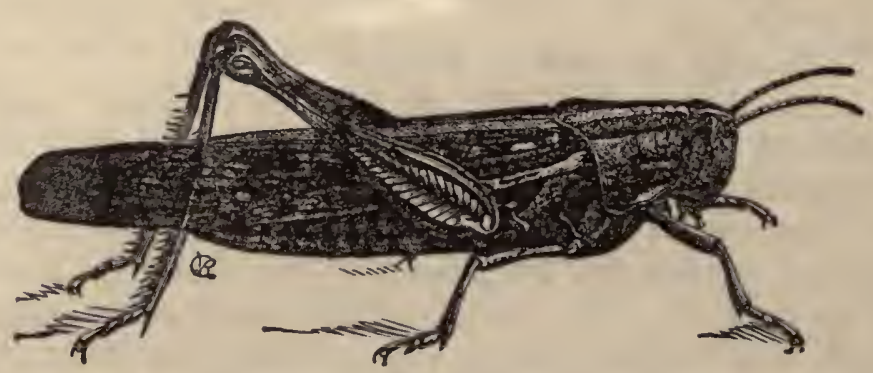

Fig. 221.-Schistocerca americana. (After Riley.)

and composed of four separate plates and the tarsi are threejointed. The hind legs are the longest and usually have stout femora, especially near the base. Among the most abundant and injurious species occurring in this country are the western 
grasshopper or migratory locust (Melanoplus spretus), an insect which damaged western agriculture, especially in the States of Kansas, Colorado, Nebraska and Missouri, in the years $1874-1876$, to the extent of more than $\$ 200,000,000$, and which was the subject of an investigation by a special governmental commission lasting through several years; the common red-legged locust (Melanoplus femur-rubrum), a species closely resembling the foregoing but having shorter wings; the two-striped locust (Melanoplus bivittatus), a widespread form which is abundant almost every year; the Carolina locust (Dissosteira carolina), the common light-brown species seen so frequently along dusty roads; the American locust (Schistocerca americana), more abundant in our Southern States where it occasionally becomes

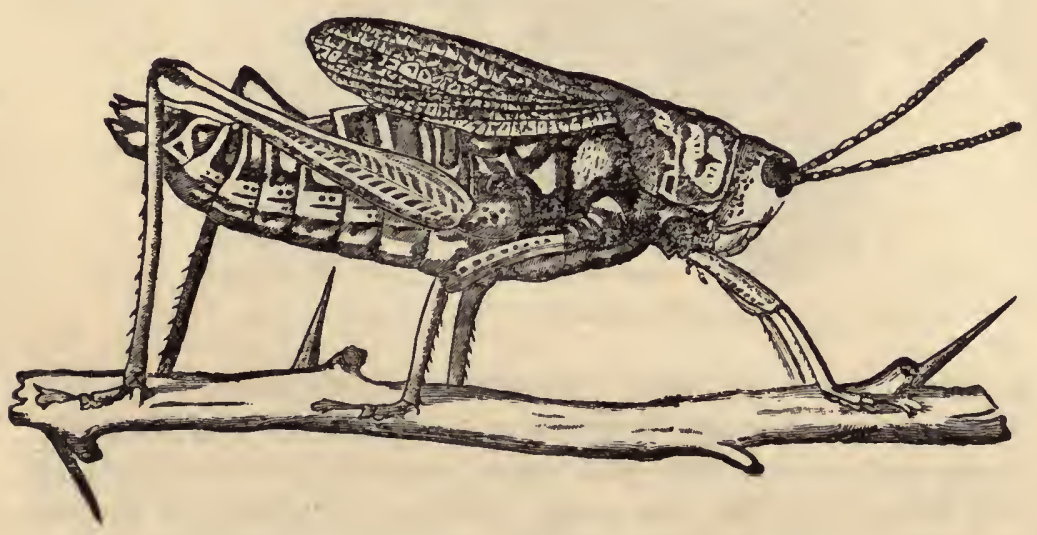

Fig. 222.-Dictyophorus reticulatus. (After Glover.)

very injurious; and the differential locust (Melanoplus differentialis), a species which has recently done great damage to cotton plantations in Mississippi. The lubber grasshopper of Florida and Georgia is known as Dictyophorus reticulatus. It varies in color from green to black and has very short wings. It occurs frequently in enormous numbers in the rice-fields near the mouth of the Savannah River, and is an extremely disagreeable object on which to step; in fact, it reminds one of Thackeray's famous remark when he swallowed his first saddle-rock oyster. The corresponding lubber grasshopper of the Southwest is (Brachystola magna, and is a large greenish species. 
With the short-horned grasshoppers we come to the first of the Orthoptera which are musical. Almost everyone who walks in the fields knows the rattling or crackling sound produced by certain grasshoppers in their flight. It appears to be under the control of the insect. It can produce it or not, just as it pleases. Some give distinct snapping sounds, or separate, loud snaps. Still other grasshoppers play upon their instruments not during flight but while at rest. Professor A. P. Morse tells how ho

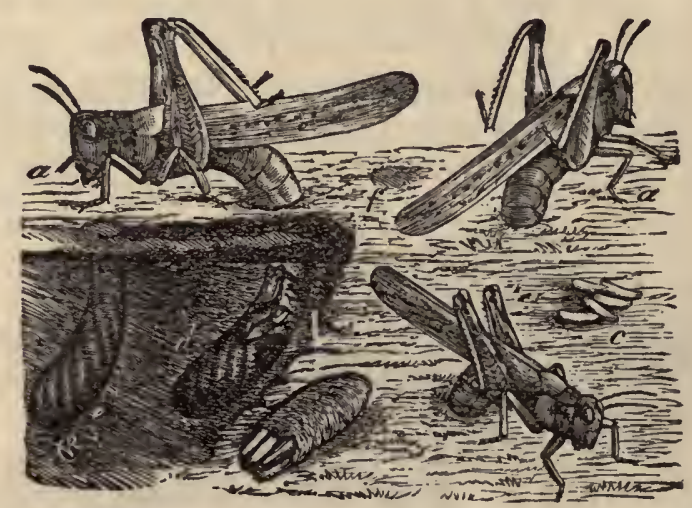

Fig. 223--Melanoplus spretus: laying its eggs. (After Riley.)

watched some of them (Circotettix verruculatus) on Mt. Washington sunning themselves, occasionally elevating the hinder part of the body and rapidly moving the hind thighs up and down against the wing covers, "producing a distinct 'scritching' sound clearly audible at a distance of three or four feet. This act was repeated several times at intervals of a few seconds."

\section{Life History of a Grasshopper (Melanoplus atlanis Riley.)}

This insect, which is known as the lesser migratory locust, is a close relative of the common red-legged locust and the western grasshopper. It occurs commonly throughout the northern United States and has for many years made occasional injurious outbreaks in a restricted region in New Hampshire where local conditions seem to favor its undue increase. The 
eggs are laid beneath the surface of the ground in an egg pod in shape something like a bent flask, the eggs in each pod averaging from twenty-four to thirty-six in number. Each female in the course of her life usually deposits two of these egg pods although three and even four have been laid by the same female. The insect passes the winter in the egg state and the young locust or grasshopper hatches in the spring. The period between hatching and maturity averages eighty to ninety days and the grasshopper passes through four to five molts, the young grasshoppers attaining their full wings only after the last molt. In about one week after reaching full growth the insects pair and soon commence ovipositing. There is but one annual generation in New England, but two in Missouri. Egg-laying commences late in July and some of the earlier eggs may hatch in the autumn in New England, showing a tendency towards a second generation. 


\section{THE LONG-HORNED GRASSHOPPERS \\ (Family Locustida.)}

These insects, known as the long-horned grasshoppers, or green grasshoppers, comprise those species having very long antennæ, longer than the body, having tarsi with four joints instead of three, as with the Acridiidæ, and possessing in the female sex a long saw-shaped ovipositor which is composed of six pieces instead of four, as with the Acridiidæ. They are delicate insects, much more fragile than the short-horned grasshoppers, and are great singers. The males are usually provided
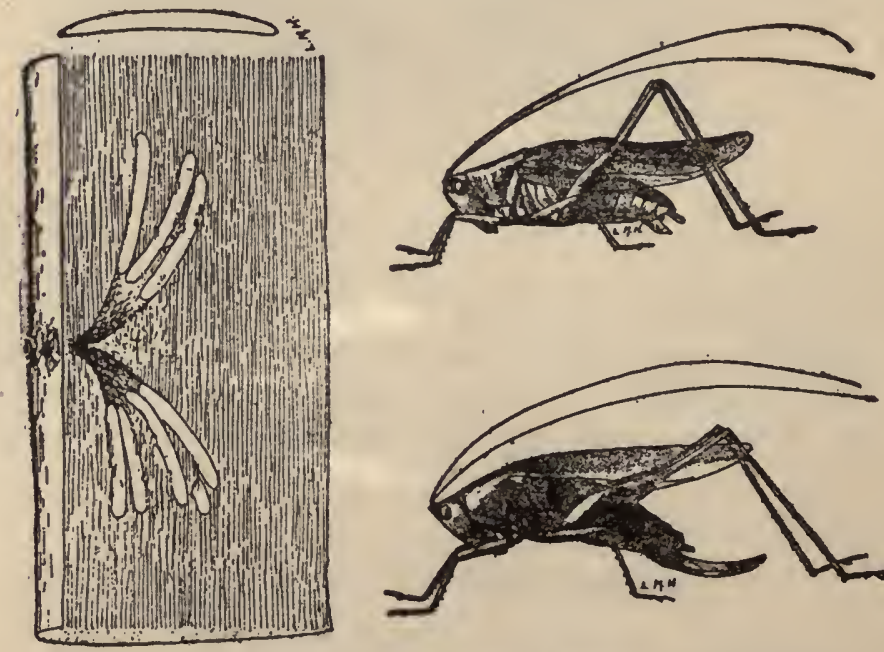

Fig. 224.-Orchelimum vulgare; and its eggs. (After Forbes.)

with a musical apparatus consisting of a curious development of the veins and membrane at the base of the wing cover. A curved ovipositor permits many forms to insert their eggs into pithy plants or into the earth. Nearly all of the species are strict vegetable feeders although some of them are said to be carnivo- 

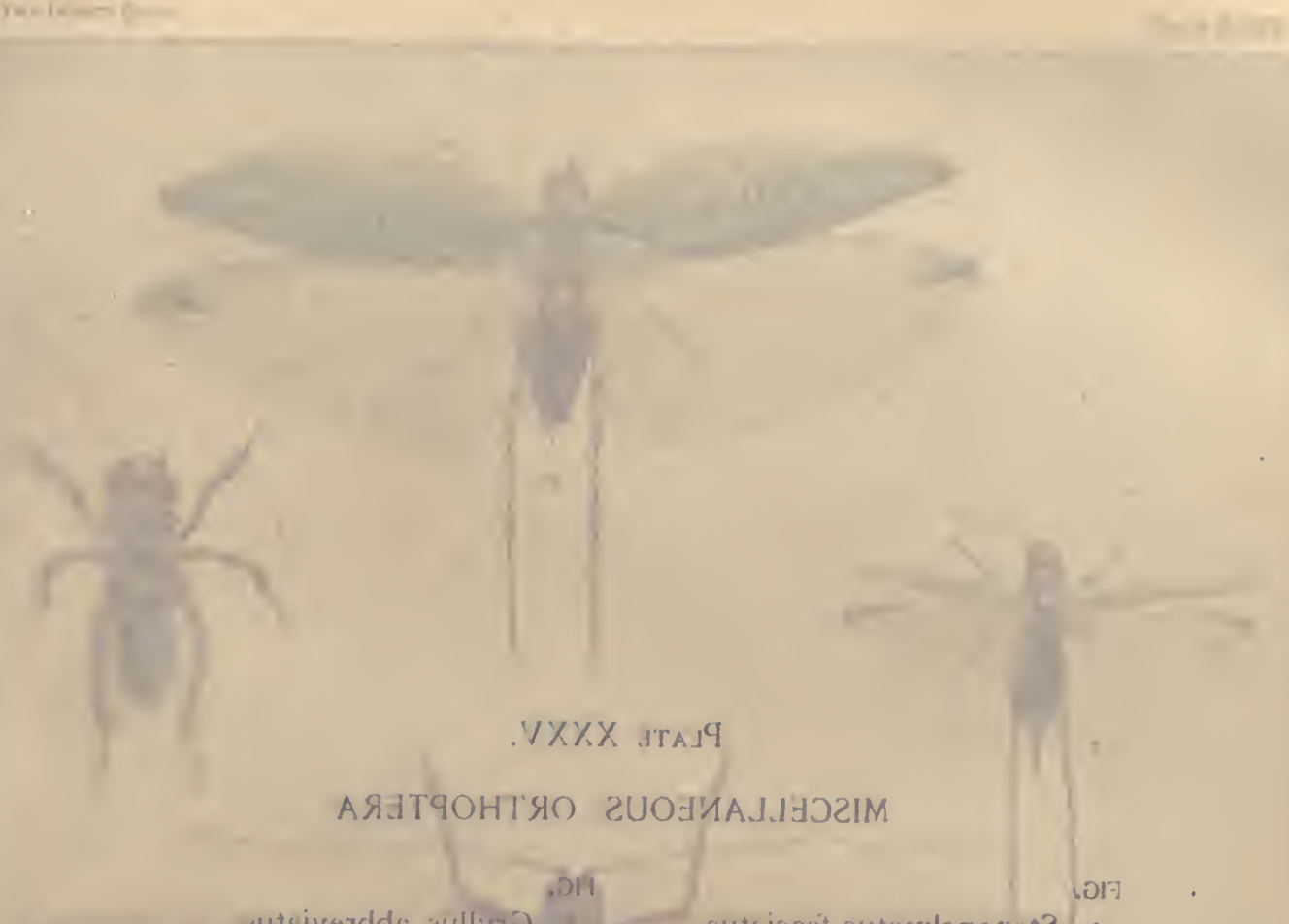

- enteivstdds zullvio .r 2utrijorit zusumloqonst? . I

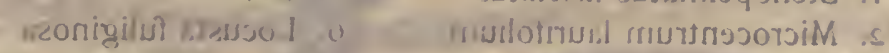

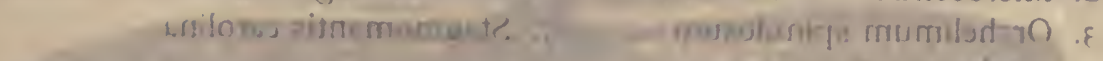




\section{THE LONTE-MORNEO GRASSHOPPERS}

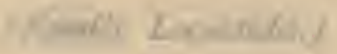

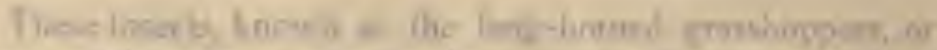

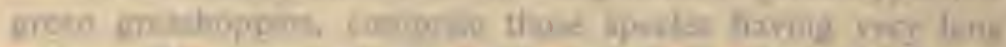

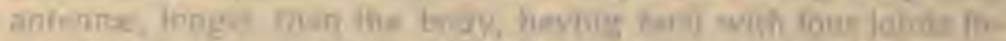

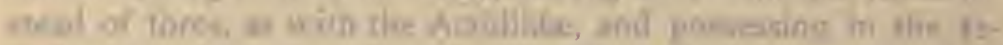

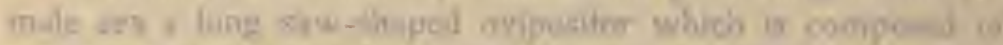

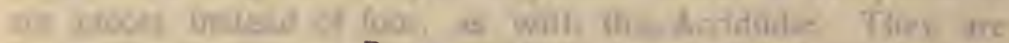

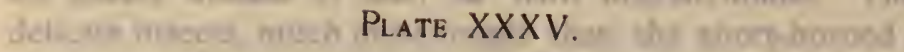
MISPGELLANEOUS ORTHOPTERA

FIG.

1. Stenopelmatus fasciatus

2. Microcentrum laurifolium

3. Orchelimum spinulosum

4. Anabrus purpurascens
FIG.

5. Gryllus abbreviatus

6. Locusta fuliginosa

7. Stagmomantis carolina

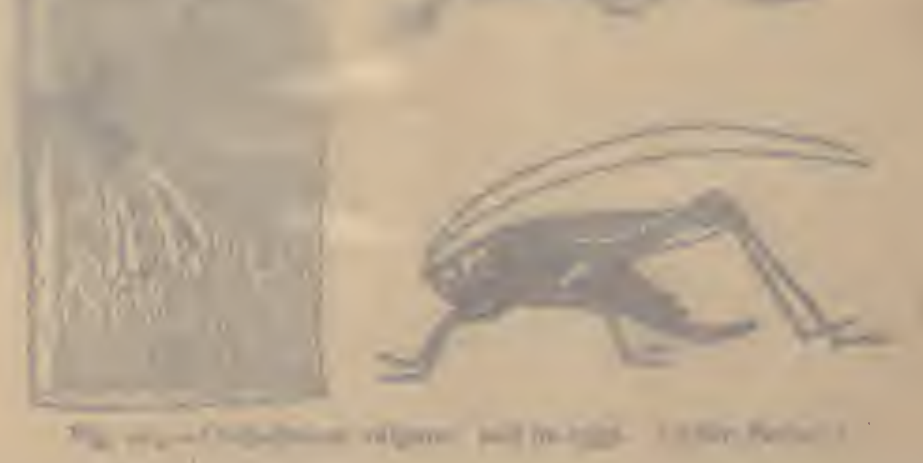

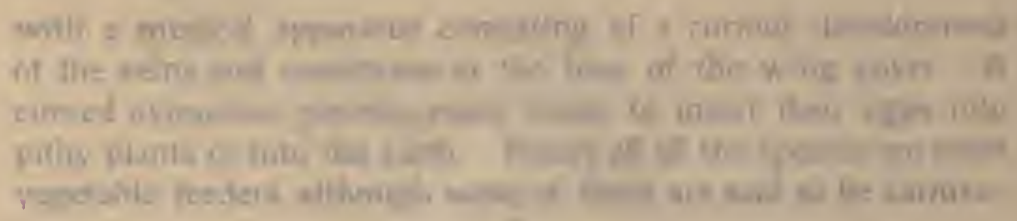




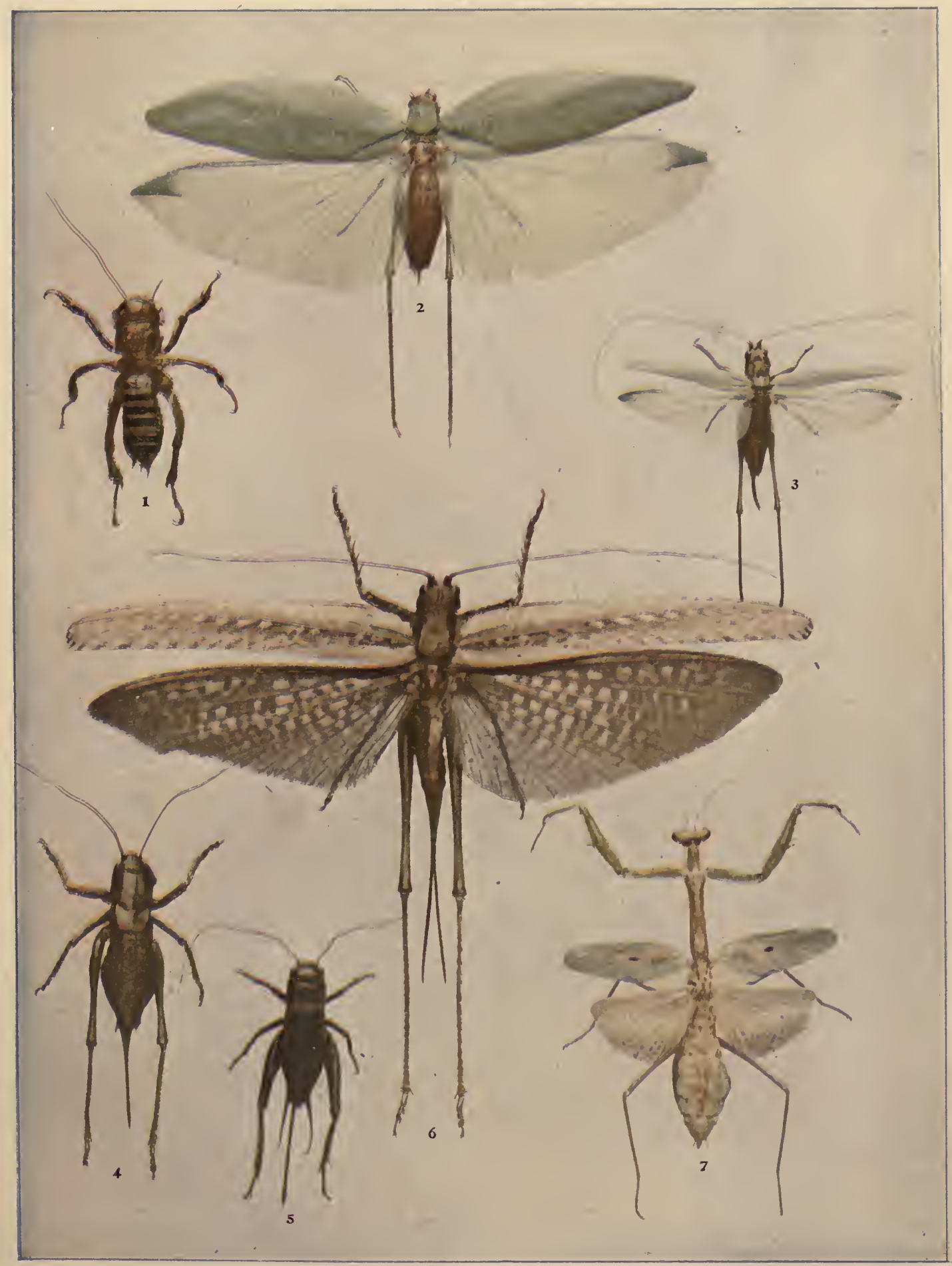



rous. The commoner forms have been called the meadow grasshoppers. They are the long, slender, delicate species found on grass and low-growing plants. A common representative of this group is Orchelimum vulgare. Others are known as the katydids from the resemblance of the male call to the word "katydid," while others somewhat resemble crickets and are found under stones and rubbish in the woods and in caves. The so-called western crickets (Anabrus purpurascens and $A$. simplex) belong to this group, as also do the ferocious looking creatures of the genus Stenopelmatus, found in the arid regions of the West and which are erroneously considered as poisonous.

The long-horned grasshoppers, or green grasshoppers, are among the most musical of our orthopterous insects. Everyone knows the call of the katydid, and everyone knows Holmes' beautiful poem about this interesting creature. Our commonest katydids ordinarily call "Katy," or say "She did," rather than "Katy did." That is to say, they rasp their fore wings twice oftener than three times. "These two notes," says Scudder, "are of equal (and extraordinary) emphasis, the latter about onequarter longer than the former; or, if three notes are given, the first and second are alike, and a little shorter than the last. The notes are repeated at the rate of two hundred per minute, and while the interval between two series of notes varies to a certain degree, it is seldom greater than two and one-third seconds or less than a second and a quarter." This is Mr. Scudder's attempt to reduce this note to a scale:

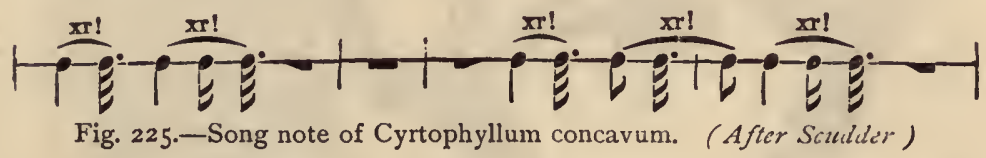

It is a noticeable thing with these insects that the diay note differs from the night note, and, unlike the katydids, one of the long-horned grasshoppers, known as Scudderia curvicauda, is noisier by night than by day. The day tune is played only in the sunshine, and the night tune after dark or in cloudy weather. Scudder was once watching one of these little creatures in the sunshine. "As a cloud passed over the sun he suddenly changed his note to one with which I was already familiar but without knowing to what insect it belonged. At the same time all the 


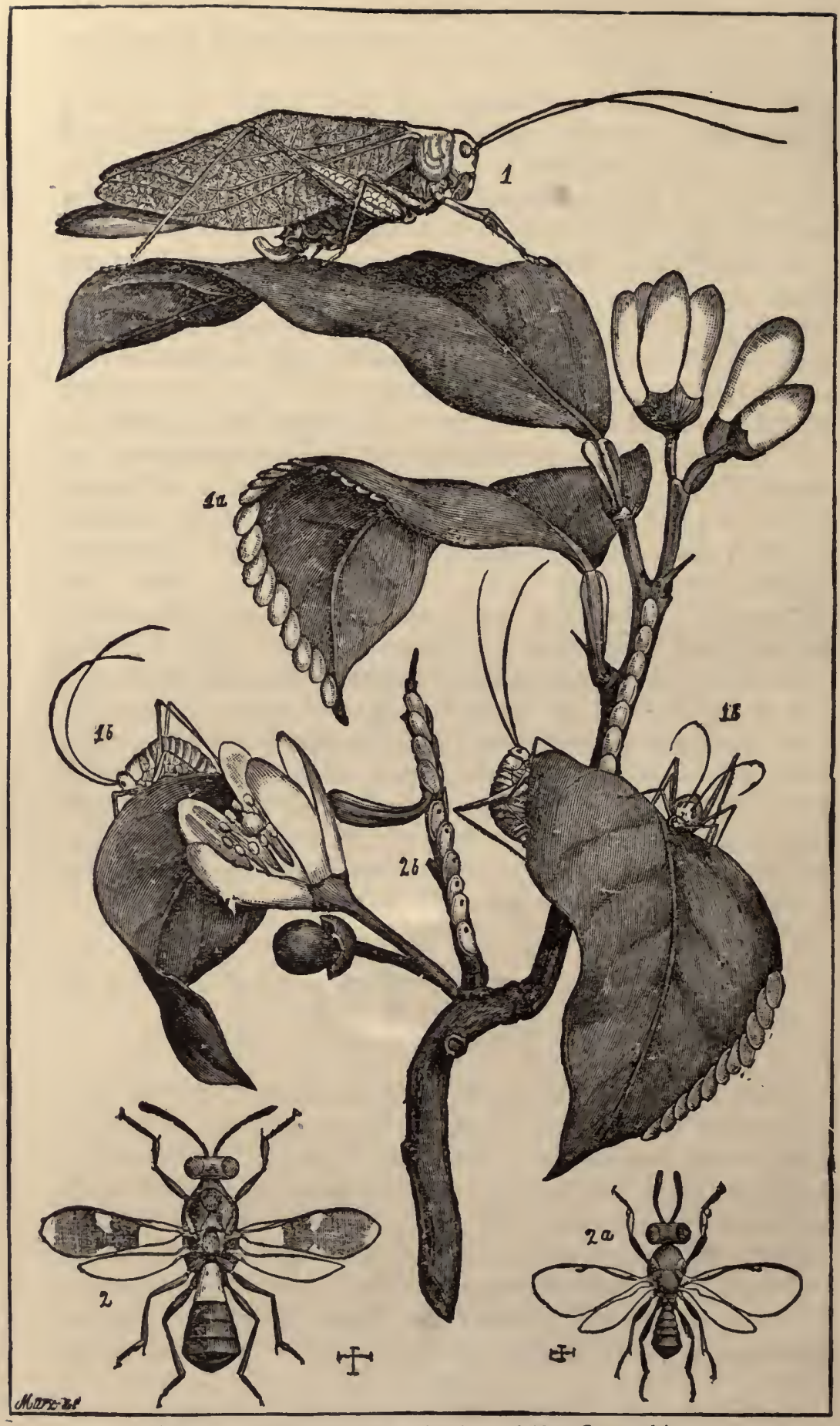

Fig. 226.-Microcentrum retinerivs. (After Comstock.) 
individuals around, whose similar day song 1 had heard, began to respond with the night cry. The cloud passed away, and the original note was resumed on all sides. The day song is reduced to scale by Scudder as follows :

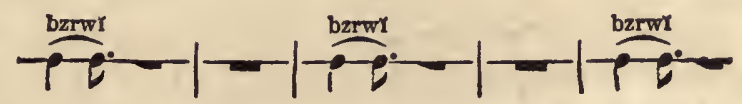

Fig. 227.-Day song of Scudderia curvicauda. (After Scudder.)

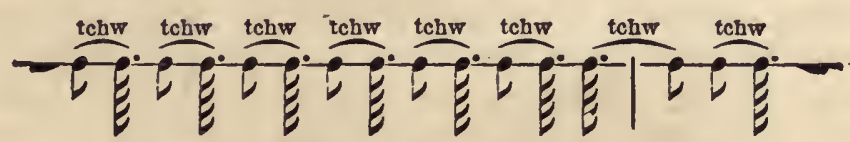

Fig. 227a.-Night song of same. (After Scudder.)

\section{Typical Life History of a Katydid}

\section{(Microcentrum retinervis Say.)}

This insect, commonly known as the angular-winged katydid, is a common species throughout the more southern portions of the United States, extending as far north as New Jersey on the Atlantic Coast. This insect hibernates in the egg stage. The eggs are flattened, oval, of a slate-brown color, about four $\mathrm{mm}$., in length, and are laid in a curious double overlapping row on twigs of trees and in other situations. In the south, where the insect has two generations annually they are even laid on the edges of leaves, in which case one row will be found on one side of the leaf and the other row on the other side. They are sometimes also laid in peculiar situations, as on the edge of a fence board, and the writer once received a batch from a western correspondent which was found on the edge of a freshly laundried collar which had laid for some time in a bureau drawer. Riley records oviposition on the edge of a piano cover and on a long piece of cord. The females begin to oviposit in the early fall and continue to lay at intervals until killed by frost. The surface of the twig is first roughened by the jaws and then the ovipositor is moved up and the eggs are laid one after another, the successive ones being pushed for a short distance under the edge of the one immediately preceding, the number varying from two to thirty 
in a bunch. Each female lays from 100 to 150 eggs. In the spring the egg splits along its top edge and the young katydid, very. pale in color, emerges. In Missouri the skin is cast five times and the perfect insect appears from July to August, the songs being most commonly heard in the latter month. Mr. Scudder, who has studied the notes of crickets and grasshoppers from the musical standpoint, states that the day song of the katydid differs from the night song. In its northern range the insect is single brooded but in the far southern States there are two generations annually. The eggs of the angular-winged katydid are stung by the curious chalcidid parasite known as Eupelmus mirabilis Walsh, called by its describer the "back-rolling wonder" from the fact that the abdomen is frequently turned backwards and upwards until it nearly reaches the head, the hind legs being turned in the same direction so thai the insect almost forms a ball.

This parasite, male and female, appears at the bottom of Fig. 226. 


\section{THE CRICKETS}

\section{(Family Gryllida.)}

These insects, commonly known as crickets, have long antennæ, longer than the body, as in the Locustidæ, but the tarsi are three-jointed and the ovipositor, when exserted, is spearshaped. The hind legs are long, and the femora are swollen. Many species are wingless, but with those which have wings the tegmina, or upper wings, are deflexed on the outer edge so that they fit closely to the sides of the body. In the male sex the upper wings are frequently curiously modified so as to permit an even more elaborate musical apparatus than is the case with the Locustidx. The insects of this family are not numerous from the point of num-

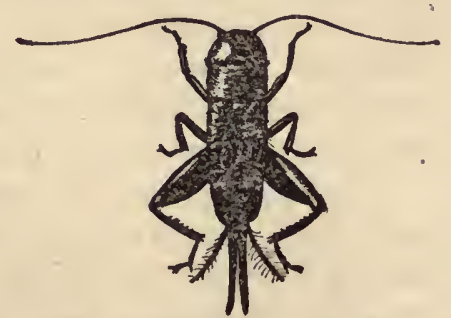

Fig. 228.-Gryllus assimilis. (Redrawn from Marlatt.) ber of specis, and but three distinct types are found in the group. These are the true crickets, typified by the common field cricket;

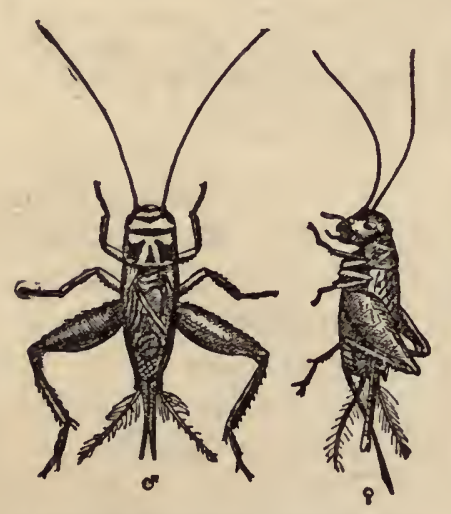

Fig. 229.-Gryllus domesticus. (After Marlatt.) the mole crickets, forms with very short wings, which are sometimes entirely absent, and with modified front legs, which superficially resemble those of a mole, and which live during their entire lives underground; and third, the so-called tree crickets, pale-colored nocturnal forms which lay their eggs in the twigs of different plants, and which sometimes are so abundant that by their egg-laying alone they do considerable damage to vineyards and to raspberry and blackberry planta- 
tions. The house cricket, or hearth cricket, Gryllus domesticus, of Europe, is not common on this continent except in Canada, but two or three species of field crickets are occasionally found in houses in this country. The common black cricket, found in

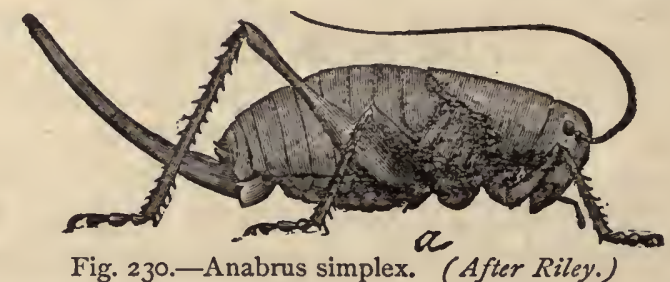

grassy pasture lands or fields, lives in burrows under the ground, issues sometimes in the day, but more usually at night to feed, and takes blades of grass back into its burrow. The eggs are laid in the autumn, usually in the ground, and are hatched the following summer. The mole crickets live always under the ground and feed upon the tender roots of forage plants, while the tree crickets are, as their name suggests, arboreal in their habits.

The crickets are the most musical of all insects. Even the male mole cricket consoles himself by fiddling, and warms the heart of his mate by playing a tune which is not cheerful enough for a household ditty, but, to our ears, uneducated in the orthopteran musical culture, sounds more like a lament of his sad subterranean fate. It has been reduced to scale by Scudder as follows :

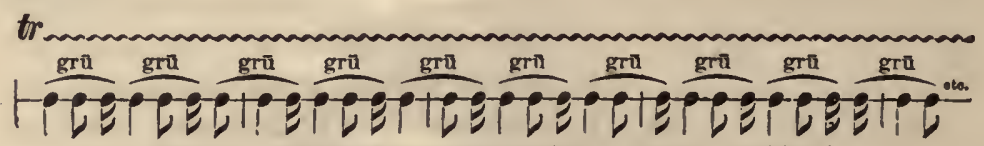

Fig. 231.-Song of the mole cricket. (Ajter Scudder.)

The house cricket, or the cricket of the hearth, plays a more cheerful tune, or, at all events, it is supposed to mean comfort and a warm fireside and a steaming kettle. It is thus not the music but the association of ideas which produces the pleasing effect. Cowper expressed it perfectly when he wrote :

"Sounds inharmonious in themselves and harsh, Yet, heard in scenes where peace forever reigns, And only there, please highly for their sake."

The name cricket comes from this sound, and is derived from the imitative French popular name, "cricri," and similat 
, :
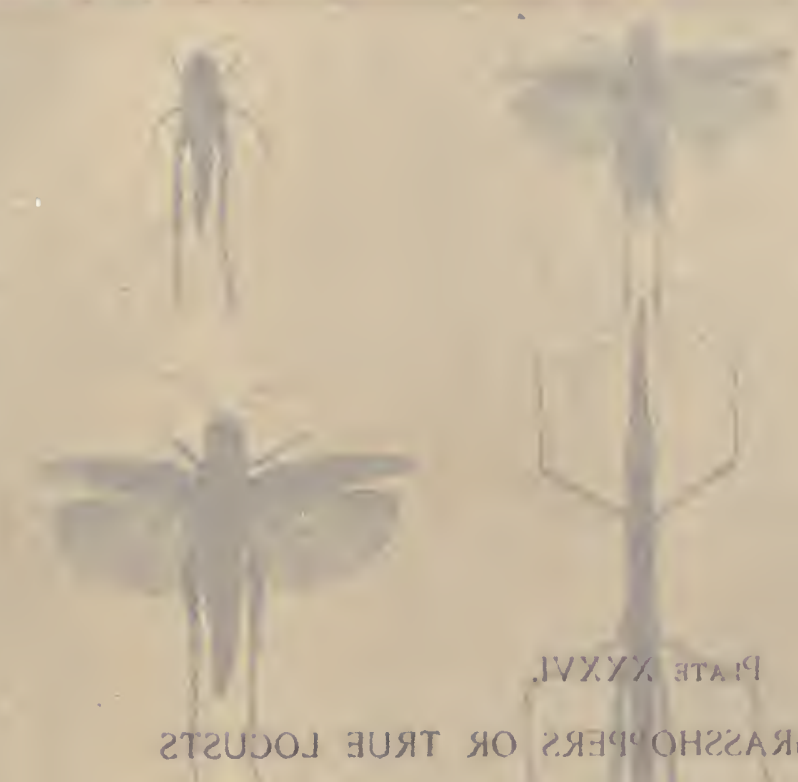

IVXYY ATA!
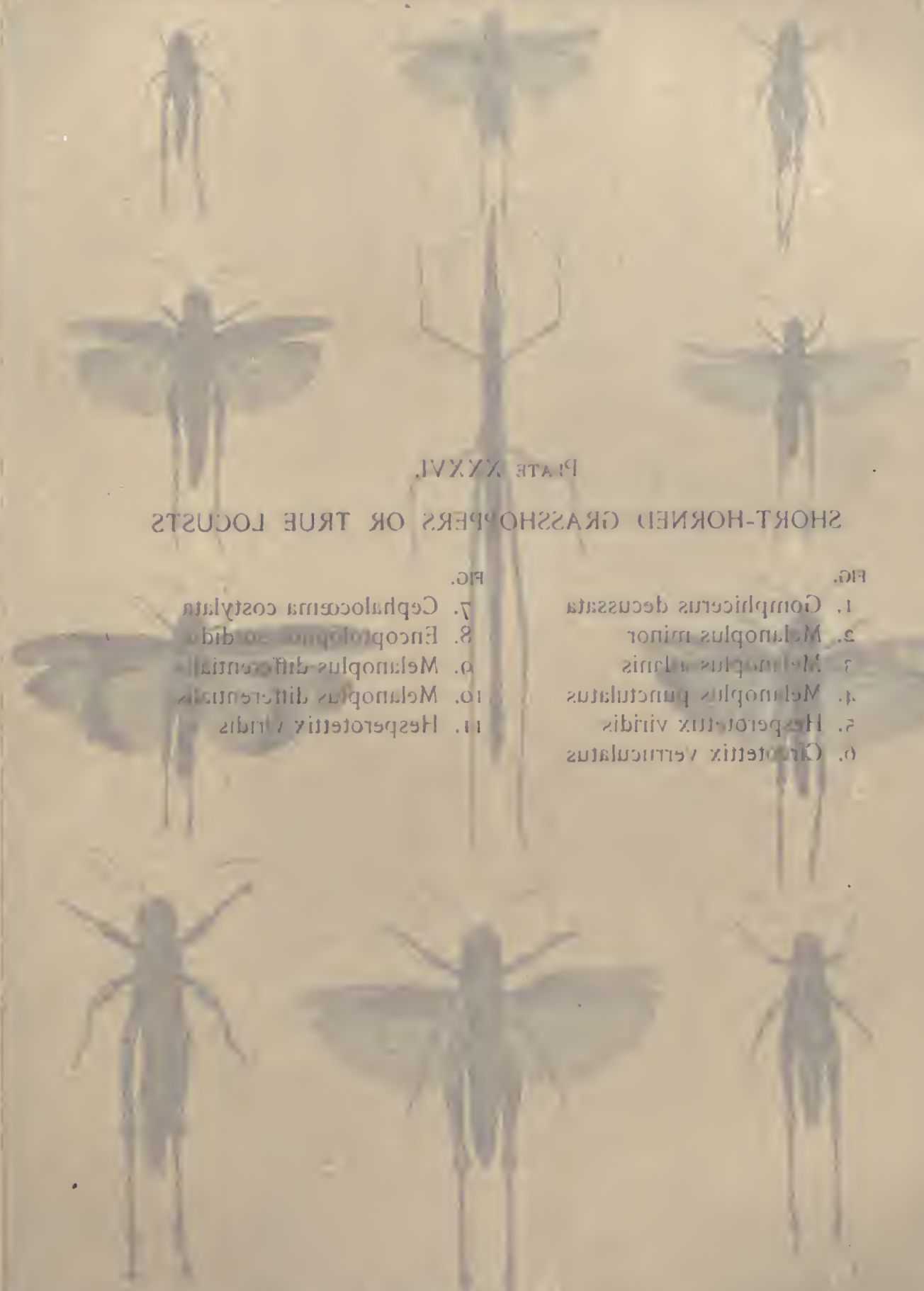

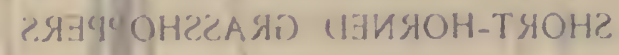

.019

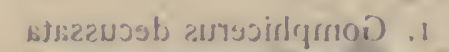
ronirs zulqqoru. S.M.s

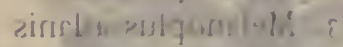
z.nstilusorma dulqgormlon . .

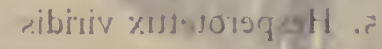

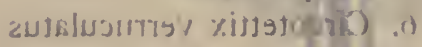




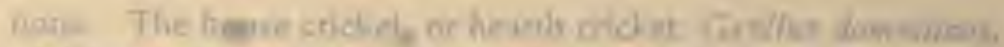

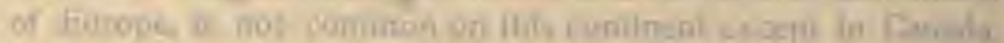

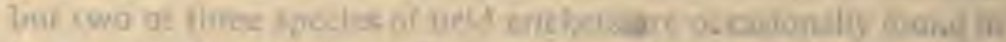

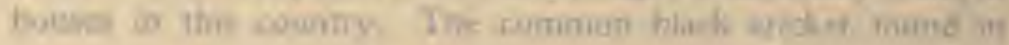

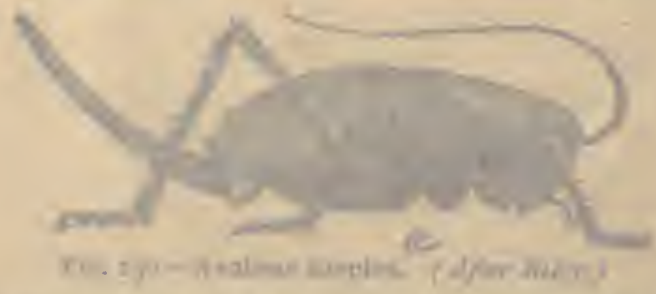

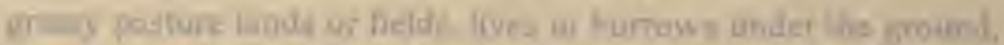

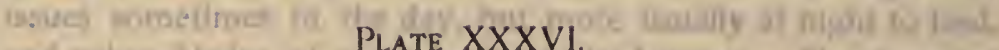

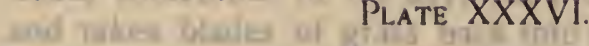

\section{SHORT-HORNED GRASSHOPPERS OR TRUE LOCUSTS}

FIG.

I. Gomphicerus decussata

2. Melanoplus minor

3. Melanoplus atlanis

4. Melanoplus punctulatus

5. Hesperotettix viridis

6. Circotettix verruculatus
FIG.

7. Cephalocœma costylata

8. Encoptolophus sordidus

9. Melanoplus differentialis

10. Melanoplus differentialis

II. Hesperotettix viridis

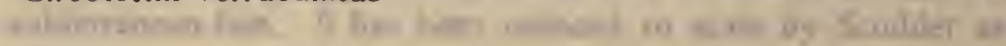
Natess

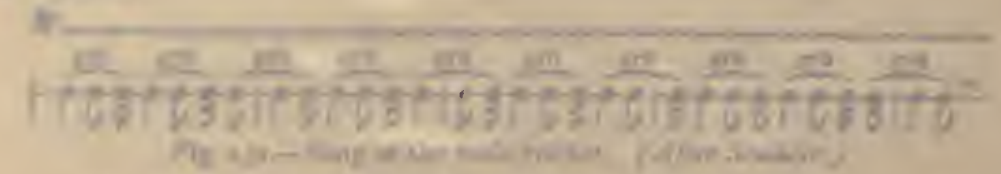

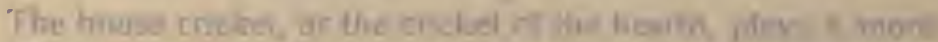

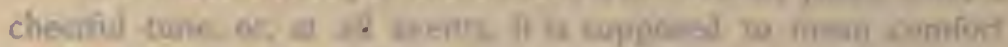

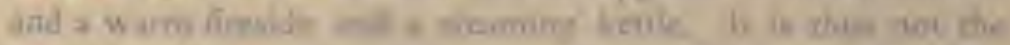

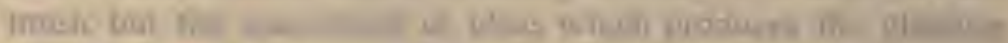
aboce-

05

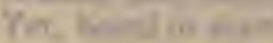

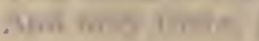

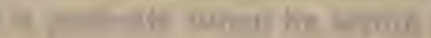

Tho oxm oncod ons

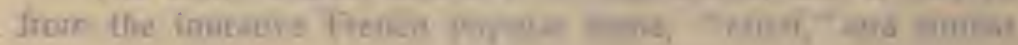




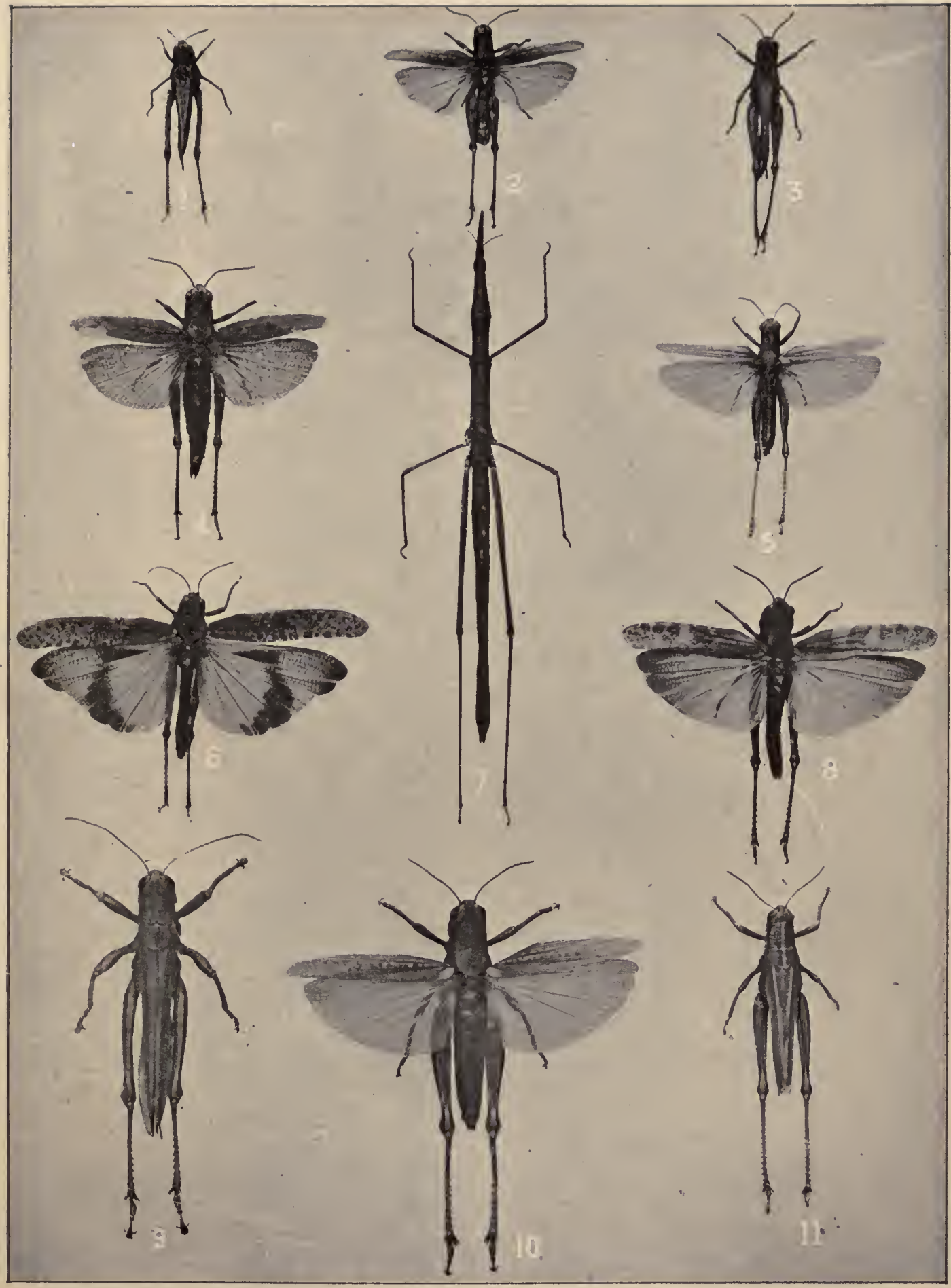



descriptive names are applied to it in many foreign tongues. The common field crickets (Gryllus neglectus, for example) are often very musical at night. Scudder says that sometimes the notes are produced as slowly as two per second, but that they may be twice as rapid. The note is a shrill one, and is said to be pitched at $e$ natural, two octaves above middle $c$. It is recorded as follows :

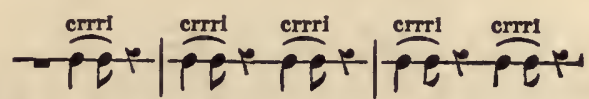

Fig. 232.-Song of the field cricket. (After Scudder.)

Perhaps the commonest night song, however, is that of the snowy tree cricket (Ecanthus niveus et al). The notes of our three or four species of snowy tree crickets vary much in intensity. There is a distinct relation between the temperature and the number of notes per minute. Professor Dolbear has reduced this to a mathematical formula. He says:

Let $\mathrm{T}=$ temperature in degrees Fahrenheit; $\mathrm{N}=$ number of chirps per minute. Then $T=50+N_{4}-^{\circ}$. This would give 100 chirps for 65 degrees Fahrenheit.

This formula has been tested in Massachusetts by Dr. Robert Edes and Mr. Walter Faxon, who find that from actual records the temperature is about 63 degrees to 100 chirps, with an error of variation of one degree or less in four-fifths of the cases. The day song is annotated by Mr. Scudder as follows, and he states that it is a nearly uniform, equally-sustained trill lasting from two or three seconds to a minute or two. The insect, however, "often begins its note at a different pitch from the normal one-fourth $f$ above middle $c$-as if it required a little practice to attain it."
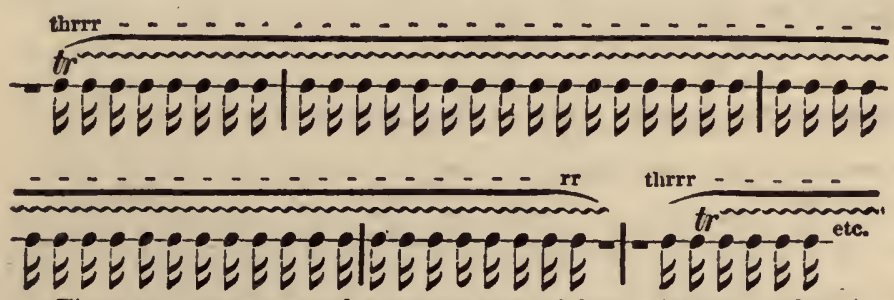

Fig. 233.-Day song of a snowy tree cricket. (After Scudder.)

The song of Ecanthus niveus is by far the most familiar one. Riley gave the best description of it when he said that it "is intermittent, resembling a shrill 're-teat, re-teat, 
re-teat,' with a slight pause between each." Scudder reminds us that Burroughs has called this noise a "rhythmic beat;" that Thoreau called it "slumbrous breathing," and that Hawthorne describes it as "audible stillness," and that he says, "if moonlight could be heard it would sound like that." Fitch says that the noise made by these crickets is an invitation to "treat-treat -treat."

Harrington has watched one of these concerts closely and says, "An interesting feature of its concerts is one of which I have not been able to find any mention in books accessible. While the male is energetically shuffling together his wings, raised almost vertically, the female may be seen standing just behind him, and with her head applied to the base of the wings evidently eager to get the full benefit of every note produced."

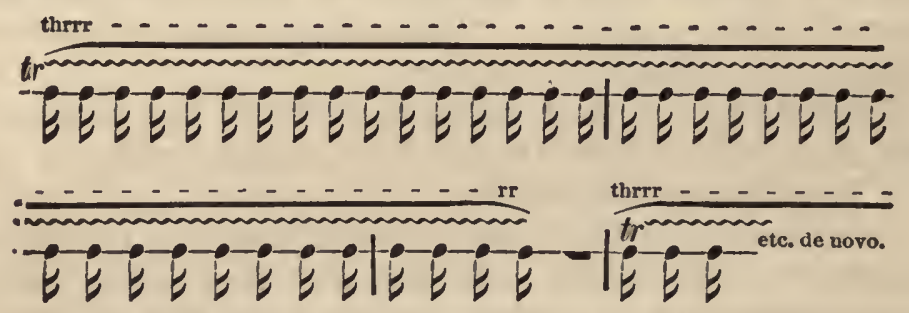

Fig. 234--Night song of the snowy tree cricket. (After Scudder.)

Even the curious cave crickets of the genus Ceuthophilus have a song. But they sing only by night and in cloudy weather. C. ensiger makes five notes per second and these have been recorded by Scudder as follows:

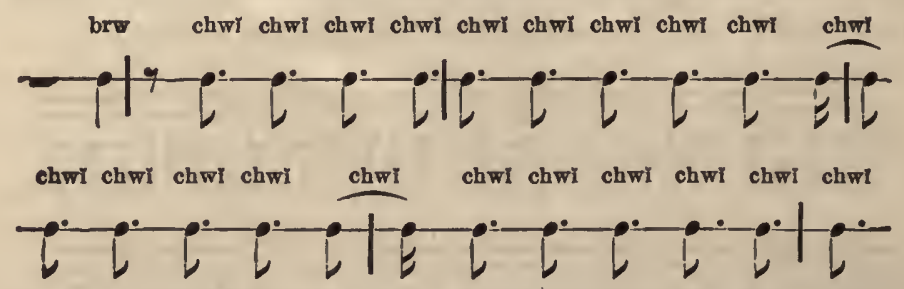

Fig. 235.-Song of the cave cricket Ceuthophilus ensiger. (After Scudder.)

Why has no one ever worked up a full life history, with all of its interesting details, of one of our commonest crickets ? It is earnestly to be hoped that some good observer will answer this conundrum with the following words: "Because it has been left for me to do, and I purpose to do it as soon as possible." 


\section{EARWIGS}

\section{(Order Euplexoptera.)}

These are the insects which are properly known by the vernacular name, earwigs. They are so distinct in structure from all other insects that they are now placed in an order by themselves, although formerly they were considered as belonging to the Orthoptera. They apparently have four wings, but the first pair are horny and small and resemble somewhat the elytra of beetles. The second pair are very curiously folded, but when expanded are almost circular in shape and possess veins which radiate from a common center. The mouth-parts are for biting and the metamorphoses are incomplete. The most peculiar structure of the earwigs, however, is the pair of forceps at the end of the abdomen. These forceps are sometimes very large and when opened give the insect a somewhat terrifying appearance. They are not used, however, as weapons of offense although with some of the earwigs which have wings (by no means all of them are winged) one of the forceps is used to assist in folding the hind wing, with the wingless species no use for these forceps has been discovered. Why they should have been evolved is a mystery. The

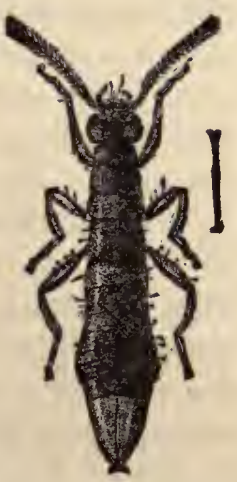

Fig. 236. - Forficula sp. (From U.S. Dept.Agr.) name earwig is derived from the general idea amongst uneducated people that these insects seek to enter the ears of human beings, causing injury to the sense of hearing. This idea is a very old one and, of course, is totally unfounded, for the earwigs are perfectly harmless. The antiquity of this superstition and the widespread belief in it are evidenced by the fact that these insects have practically the same name in many languages. Thr Dutch, German, Swedish, Danish, French, Portugese and Spanish all give it a name with practically this same meaning. Our own 
use of it comes from the Anglo-Saxon earwicga. In this country especially in the South the same name is applied to the common house centipede. An early advocate of the doctrine of similia similibus curantur anticipated Hahneman by prescribing earwigs, dried, pulverized and mixed with the urine of a hare, as a remedy for deafness.

There are very few earwigs in the Northern States. Some, however, appear in the South and along the Pacific slope, but no damage has been reported from these insects in this country. In Europe, however, and particularly in England, earwigs are said to be injurious and are said to nibble the petals of flowers. There is considerable doubt, however, as to the accuracy of this inference, which seems to have been made by gardeners. The entomologists who have studied the question of the food of the earwigs have been unable to find that they do anything of the sort. They are really carnivorous, living upon dead insects, upon small snails, and upon small living caterpillars. It is suggested that the gardeners have held the earwigs responsible for damage which was really done by other insects, perhaps even the very ones upon which the earwigs have preyed. A curious habit which earwigs are said to possess is that the females brood over the eggs. They take the greatest care of them, collect them when scattered and move them from place to place in an endeavor to secure the best position for their development. When the eggs are hatched, however, the female does not care for her young. From this fact it would seem that the female earwig is not as good a mother as the female Psocus, which as we shall show, keeps her young by her after hatching and in fact seems to show a decided appreciation of family ties. All of the earwigs are contained in the single family Forficulidx. 


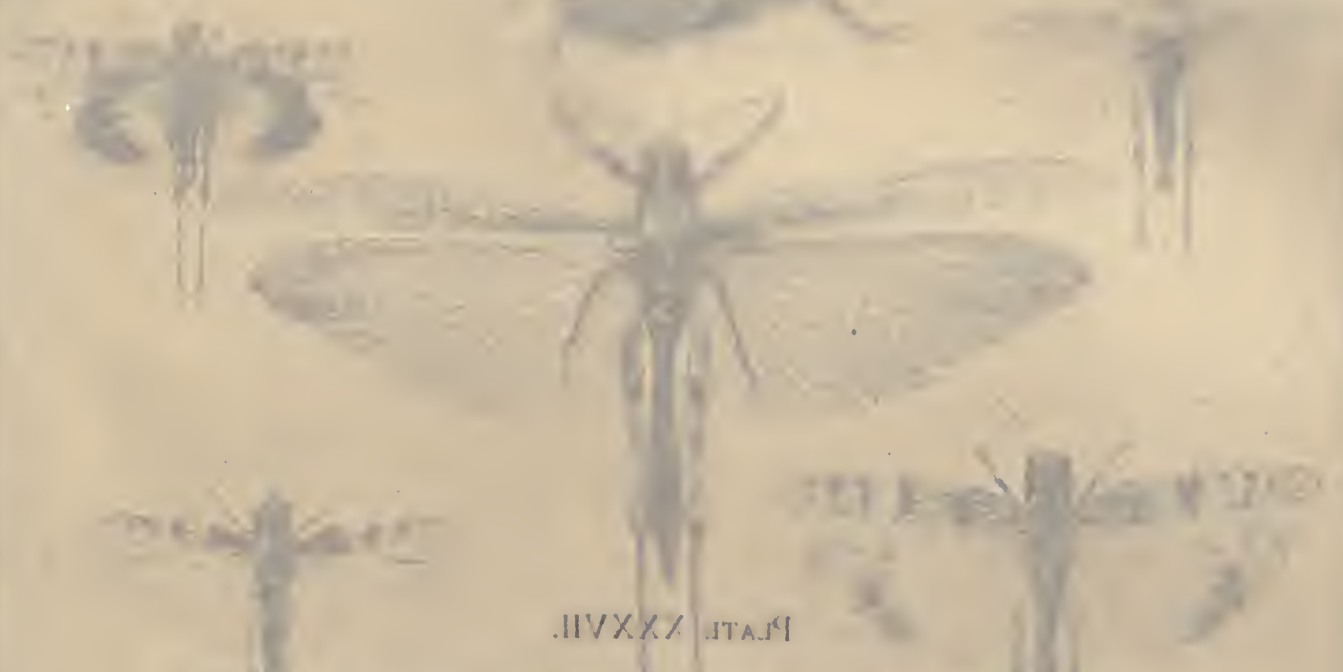

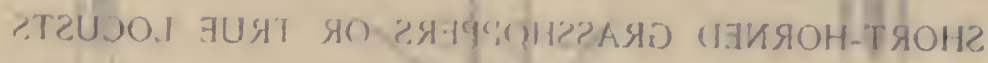

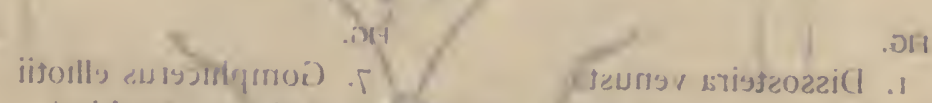

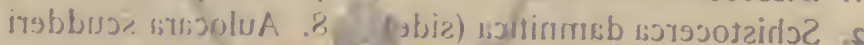

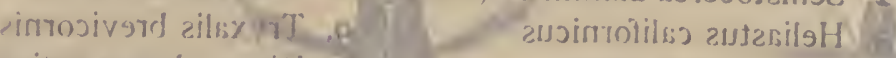

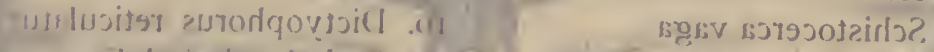

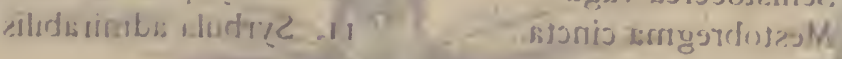
1 


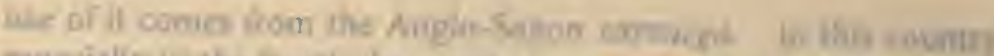

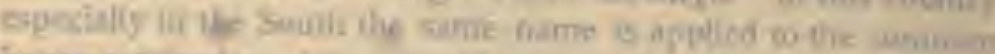

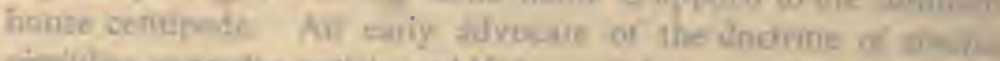

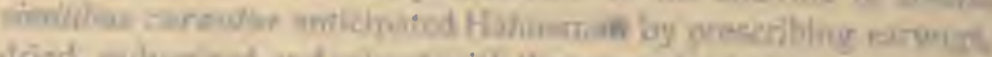

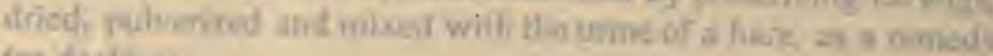
for dealhes:

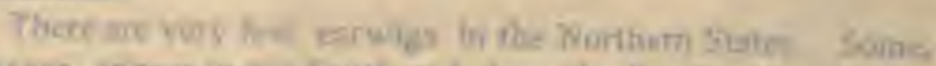

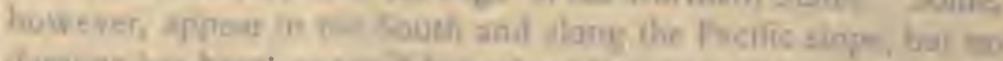

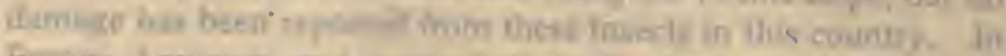

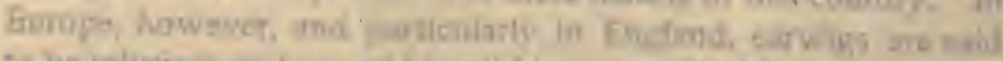

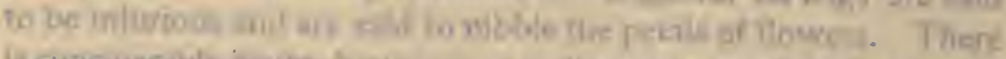

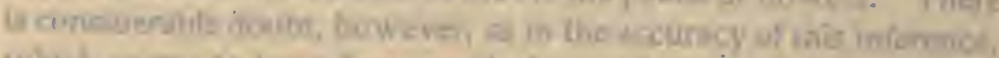

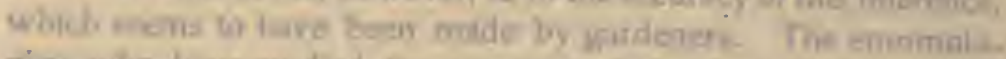

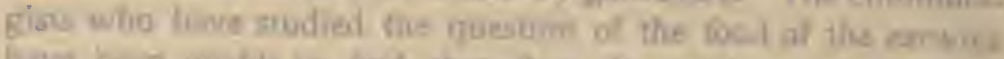

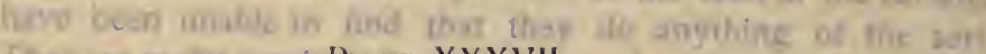
Ther ge vemyycoif PLATE XXXVII.

\title{
SHORT-HORNED GRASSHO'PPERS OR TRUE LOCUSTS
}

FIG.

Whan aIG.

1. Dissosteira venusta

2. Schistocerca damnifica (side)

3. Heliastus californicus

4. Schistocerca vaga

5. Mestobregma cincta

6. Dissosteira spurcata
7. Gomphicerus elliotii

8. Aulocara scudderi

9. Tryxalis brevicornis

10. Dictyophorus reticulatus

11. Syrbula admirabilis

the

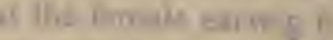

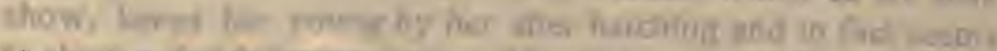

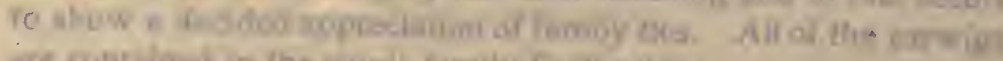

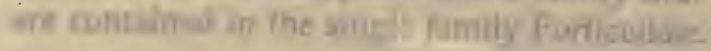




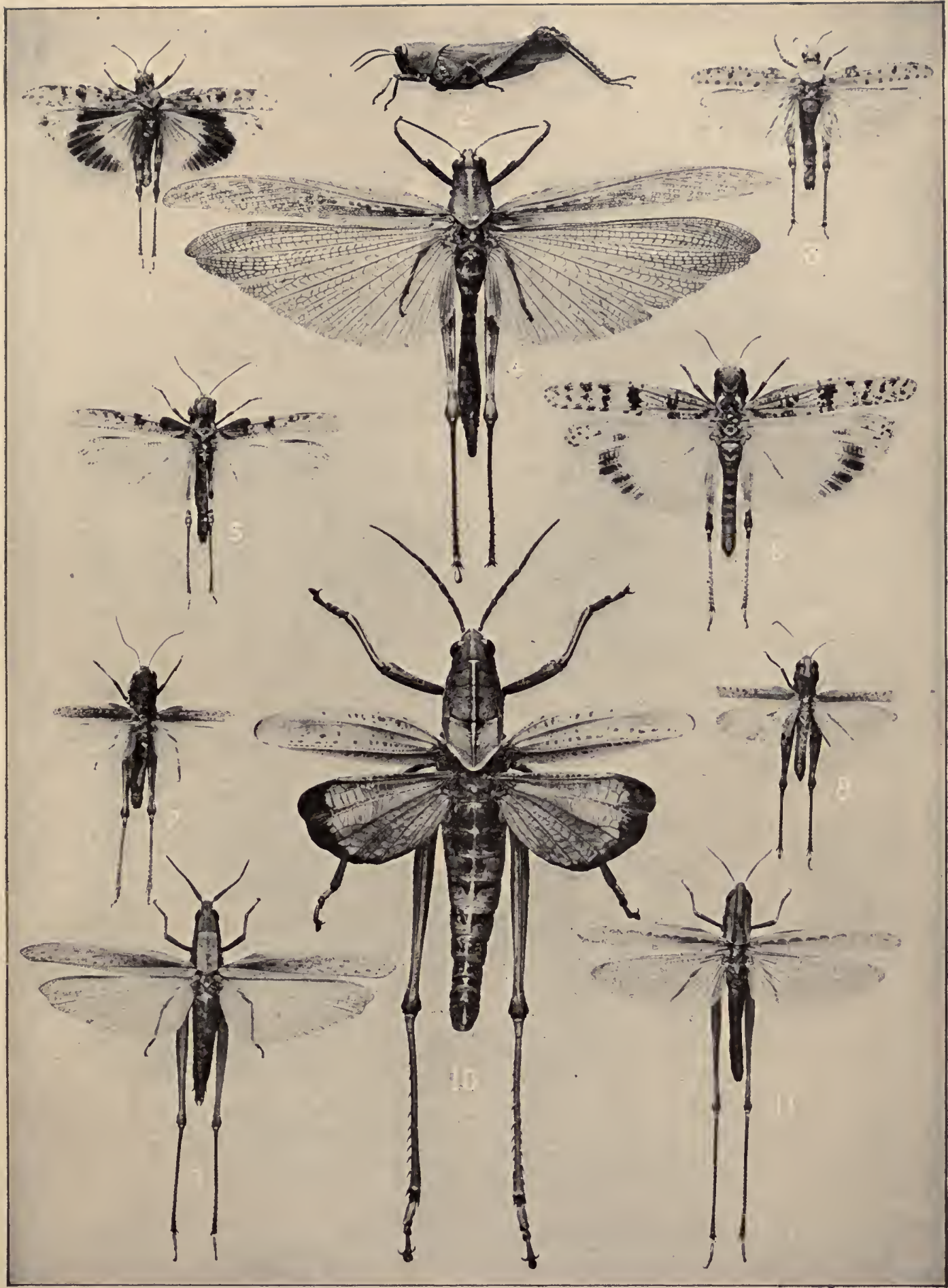





\section{THE BIRD-LICE}

\section{(Order Mallophaga.)}

The very strange parasitic insects which belong to this order are generally known by the name bird-lice. They differ widely from true lice of the order Heteroptera, suborder Anoplura, and in spite of the fact that they are known as bird-lice some of them occur on mammals. From this fact it is evident that the popular name birdlice is a misnomer, and it will be well to adopt Sharp's suggestion and call the Mallophaga "biting lice" as opposed to the sucking lice of the suborder Anoplura.

They are very small and have no wings, and the principal characteristic which distinguishes them from the true lice is that instead of having apparently sucking mouth-parts they have biting mouth-parts. They do not suck the blood as do the true lice, but feed upon the feathers or hair of the birds or mammals upon which they are found.

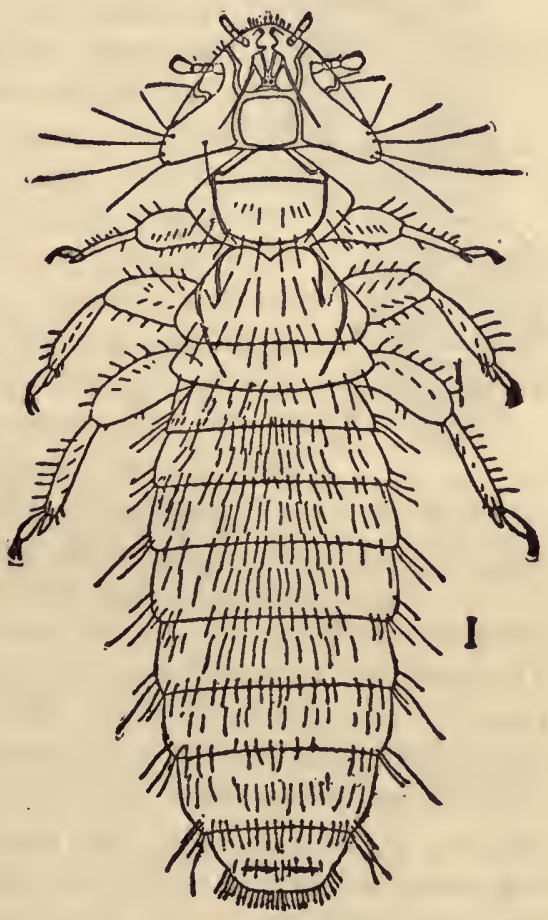

Fig. 237.-Menopon biseriatum (After Osborn.)

Their metamorphosis is incomplete. The body is very greatly flattened, and generally hard; the head is large and flat; the antennæ are short, and three to five jointed; the eyes are simple; the 
jaws are usually toothed and pointed; the legs are strong, and, curiously enough, the front legs are short and are used only in carrying food to the mouth. When at rest, they project forward beneath the head. The whole body is usually rather hairy.

The eggs are elongate oval and are fastened singly to the feathers or hairs of the host. The young issue by breaking off a circular lid at the larger free end of the egg. The duration of the egg stage is not known.

The young lice when first hatched look much like the full grown lice, except that the head is comparatively larger, and the markings of the body are absent or dull. Just before the last molt some individuals are quite as large as the adult specimens.

The question as to whether they really draw blood has been carefully studied. There will frequently be seen a large dark

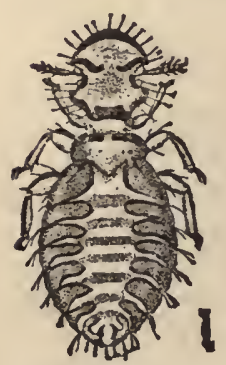

Fig. 238.-Goniocotes abdominalis.

(After Denny:) blotch indicating some opaque contents to the stomach, but a careful examination on dissection has shown that this blotch is composed of bits of feathers. One species is said by Kellogg to live in the pouch of a pelican, where, of course, there is no hair, and about the portion of the mernbrane to which the lice cling the surface is raw and bloody, but here Kellogg thinks that the food is simply the epidermal scales of the inner wall of the pouch.

Such of these bird-lice as occur upon domestic fowls, while not serious pests, undoubtedly cause poultry considerable annoyance simply by the irritation of the skin by the sharp feet of the parasites. After a hen affected with bird-lice dies, the insects either die or attempt to leave her body by crawling slowly toward the head. Considering that they do not feed upon the blood, but simply upon the feathers, it is curious that they should die after the death of the hen. Kellogg suggests that their death is probably due to the lack of animal heat to which they have been accustomed during the life of the host.

Aquatic birds are affected with bird-lice quite as abundantly as those which never enter the water, and it would not be strange if in the lice affecting such birds should be found some modification of the breathing apparatus, but there is no such modification and they are doubtless protected by the close feathers, so that 
they always have a sufficient supply of air even when the bird or a portion of its body remains under the water for some time.

It is very rare that bird-lice ever leave the body of the host, but they do migrate from one bird to another whenever two birds come in contact, as during the nesting season or among birds of gregarious habits.

In many cases a given species of Mallophaga will be found to be confined to a given species of bird or mammal, but in other cases one species of parasite will be found upon two or more species of birds. Curiously enough, some of these parasites are found in Europe on birds which differ from those upon which identically the same species of parasite is found in North America. Several species may occur upon the same bird; for example, at least five species belonging to three distinct genera have been found upon the common fowl. Nearly all of these are cosmopolitan insects and have been carried upon fowls to all parts of the world. Chickens hatched in an incubator should be absolutely free from lice and remain so

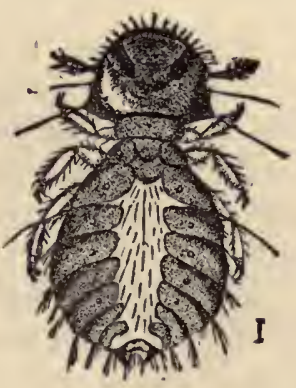

Fig. 239.-Goniocotes dissimilis.

(After Denny.) until they join company with older fowls. There is little doubt that the habit which hens have of bathing themselves in dust is an effort on their part to get rid of the irritation caused by these creatures.

\section{TABLE OF FAMILIES}

Antennæ filiform with three or five joints; no labial palpi.. I Antennæ clubbed or knobbed and with four joints; four-jointed labial palpi ...........................

1-Antennæ three-jointed; tarsi with one claw; found on mammais..................... Family Trichodectidae

Antennæ five-jointed; tarsi with two claws; found on birds 2-Tarsi ......................... Family Philopteride Tarsi with two claws; found on birds....... Family Liotheidae

Any detailed consideration of the habits of these families will be unnecessary, as they do not differ in a sufficiently marked manner to necessitate such treatment. 


\section{THE BOOK-LICE AND THEIR ALLIES (Order Corrodentia.)}

The curious little wingless insects known as book-lice, which are found frequently in numbers among old, dusty books in damp places, and the interesting little bark-inhabiting creatures known as Psocids are structurally so different from all other insects that they have been brought together in the order Corrodentia.

Those which are winged have four wings with prominent veins but very few cross veins. The fore wings are larger than the hind wings, and both are held in a roof-shaped manner over the back when not in use. The mouth-parts are formed for biting, and all of these insects have very incomplete metamorphoses.

The true Psocidx ( 1 regret that there is no popular name for these insects, for they are very interesting, and always attract

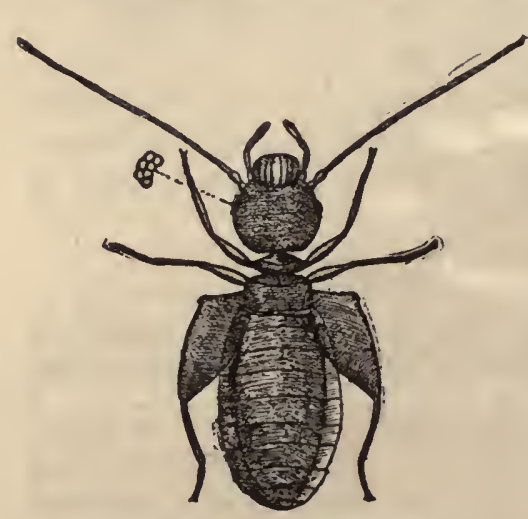

Fig. 240.-A tropos divinatoria. (Redrawn from Marlatt.) attention when seen) live together in curious little colonies on the bark of trees, especially old trees covered with a growth of lichens, or even upon the surface of old fence boards. They possess the power of spinning a certain amount of silk, and each colony is generally covered with a delicate silken web. The eggs are laid together in clusters, and the development of individuals is rather rapid.

Psocus venosus is a common form in most parts of the country, and its habits have been described by Hubbard, who has studied it in its southern range upon the trunks of orange trees in Florida. It is small and 
smoky-brown in color, and is seen upon the trunks of trees in flocks numbering from a dozen to forty or fifty individuals. They feed in companies and browse upon the lichens, which they cleanly remove from the bark, leaving a clear space behind them. The colonies consist of one or more families, and include individuals of all ages, the wingless young herding with the adult insects. The adults, although winged, do not readily take flight. When alarmed the whole troop huddles together apparently for mutual protection like sheep, but when seized with a sudden panic they scatter in every direction and run rapidly over the bark, their color harmonizing so closely with that of the bark that they are not easily distinguished. Soon after they reassemble and begin to eat the lichens.

The eggs are oval, glistening white, and are laid upon the bark in batches of fifteen to thirty, deposited on end in several rows, and each cluster is protected by an oval, convex shield of gnawed-up wood which adheres closely to the eggs. The females brood over the eggs, see that they are not disturbed, and, when they hatch, lead the young ones forth to pasture.

This insect is fond of shade and moisture, and is most often seen in densely shaded groves and old gardens. The adults, according to Hubbard, hibernate, and begin breeding early in the spring.

Hubbard has also studied another species, Psocus citricola, which is probably a Southern form. With this species the eggs are laid in hollows upon orange leaves in little clusters covered with a shield of black excrementitious matter. Over this is stretched a slight silken web. The embryo is plainly seen through the shell, and when ready to hatch air bubbles are seen which pass in rapid succession between the mouth-parts and collect in a larger bubble within the head. From time to time this larger bubble passes down into the body cavity. The head swells-elongates-distends the eggshell at the end until it bursts, and then the young insect protrudes its body. Air continues to pass through the neck into the abdomen, which becomes greatly distended and elongated, and this distention causes, probably, the bursting of the first larval skin. The process of hatching occupies several days.

This species lives upon the leaves of plants associated in small flocks, and passes the greater part of its life hiding under 
the canopies of webs spun over the egg clusters. Here the mother awaits the appearance of her brood, and here the young insects cluster, sallying forth from time to time with the mother in search of food.

The book-lice belong to another family, the Atropidæ. They are very small and some of them have been supposed to make a ticking noise which in olden times caused them to be known as "death watches."

These little insects are widely distributed, and are commonly seen on library shelves and in old records in closets. They are omnivorous, feeding on any animal or vegetable matter, and are especially fond of the starch paste used in book bindings or under wall paper. They feed on flour and meal, and are often found in natural history collections, living on the specimens. They are sometimes found in straw beds and in the straw coverings of wine bottles. A case has been recorded in Insect Life in which they bred so extensively in a mattress of hair and corn husks that "a pin point could not have been put down without touching one or more of the bugs." They swarmed over the sheets and the walls of the room; bureau draws were swarming with them, and the mattress no doubt contained them by the millions. 


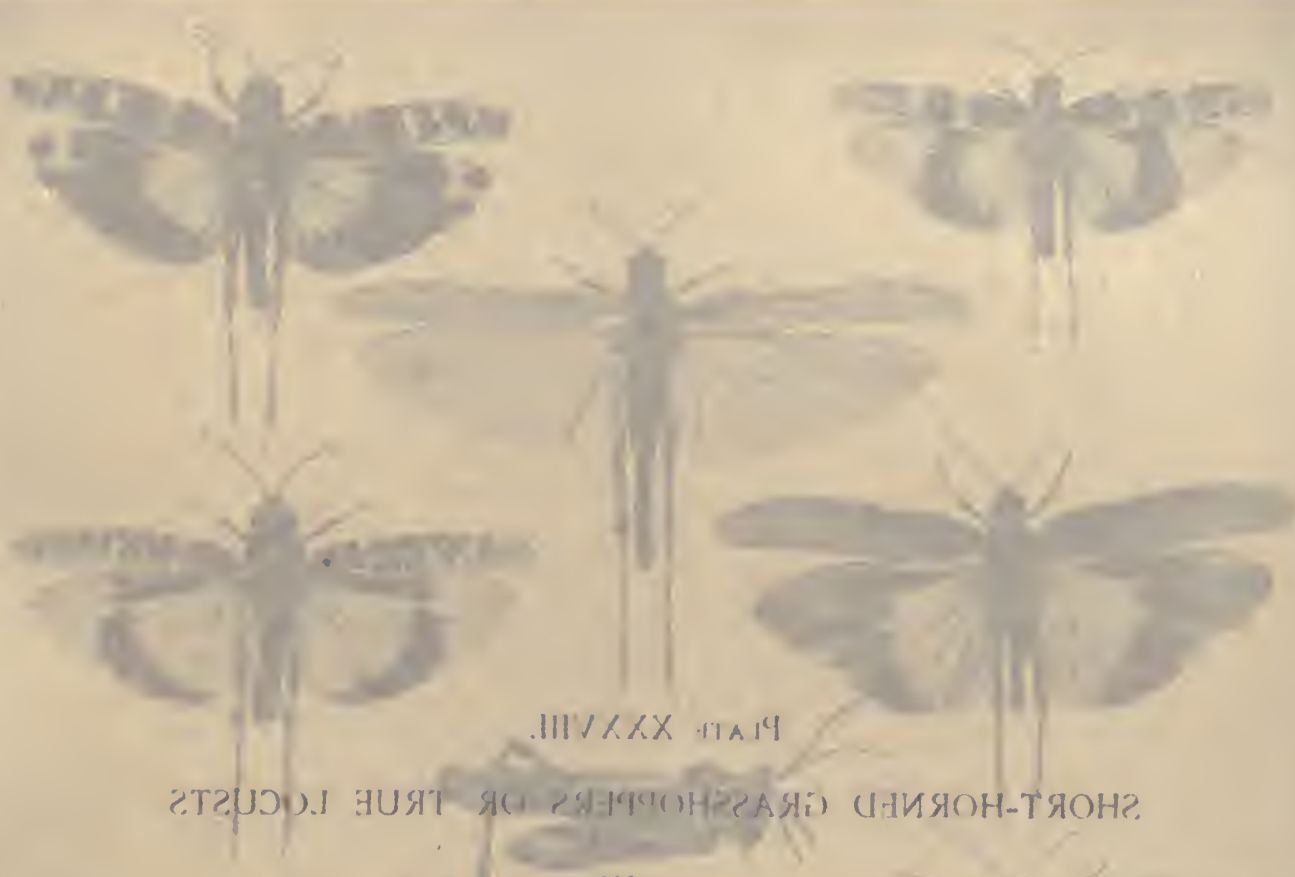

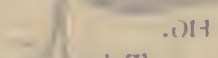

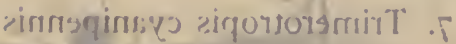

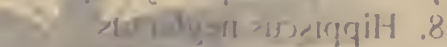
insiniles xisfgsostia . squscirl estritgolorsh .or

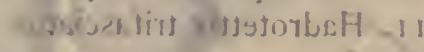

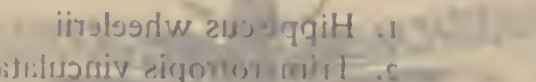

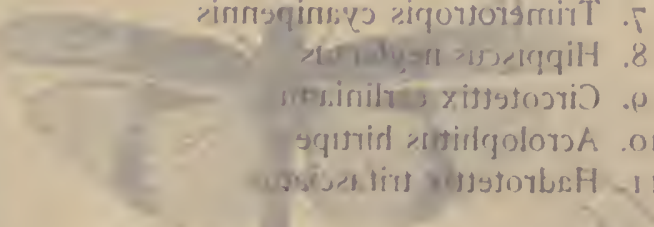

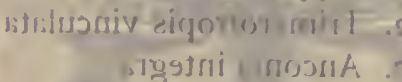
ma moblsas 2us igqiH 1.2แคน

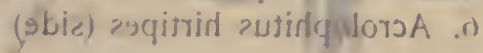

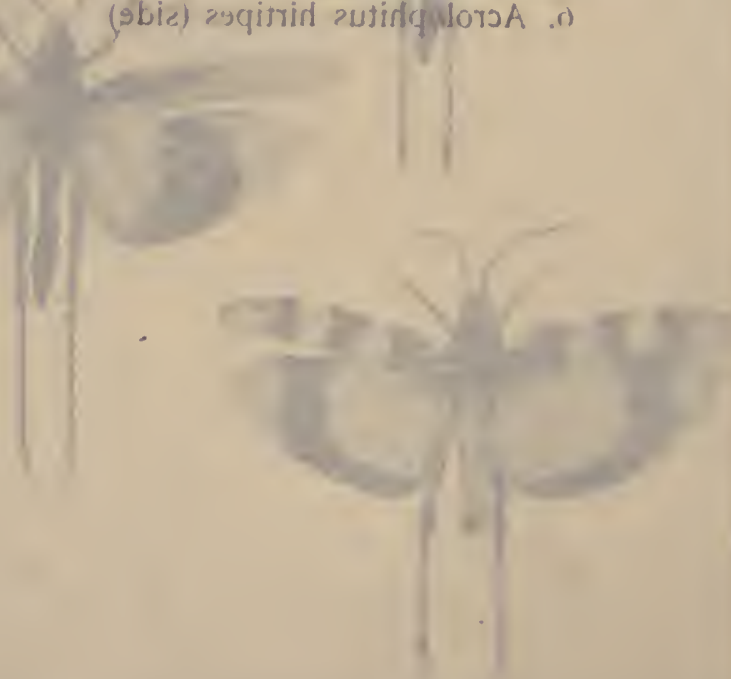




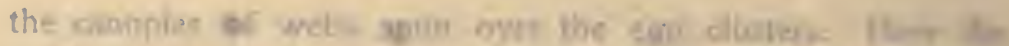
moifir awant dre appoaranoe of her lmod, and hare the nos.

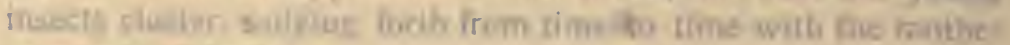
in sared or food.

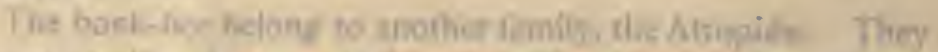

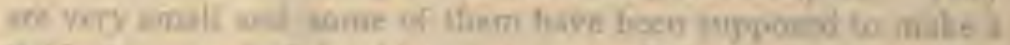

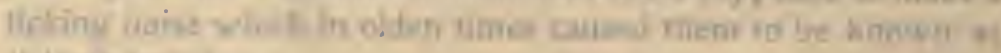
thion Wawie.

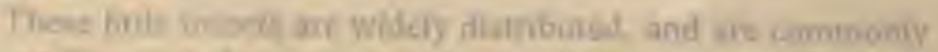
ken on liwary dhetis and if cid re ond In cloced They are

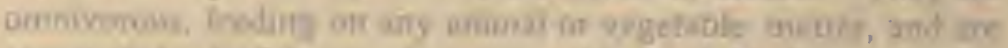

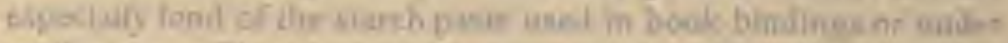

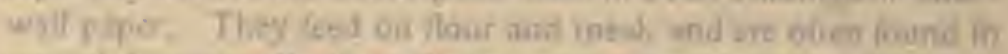

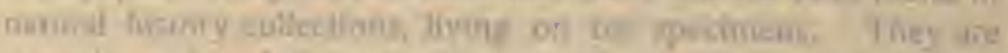

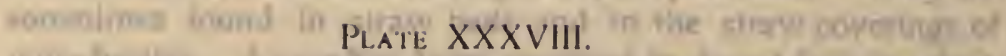

SHORT-HORNED GRASSHOPPERS OR TRUE LOCUSTS

FIG.

1. Hippiscus wheelerii

2. Trimerotropis vinculata

3. Anconia integra

4. Hippiscus haldemanni

5. Trimerotropis suffusa

6. Acrolophitus hirtipes (side)
FIG.

7. Trimerotropis cyanipennis

8. Hippiscus neglectus

9. Circotettix carlinianus

10. Acrolophitus hirtipes

11. Hadrotettix trifasciatus 


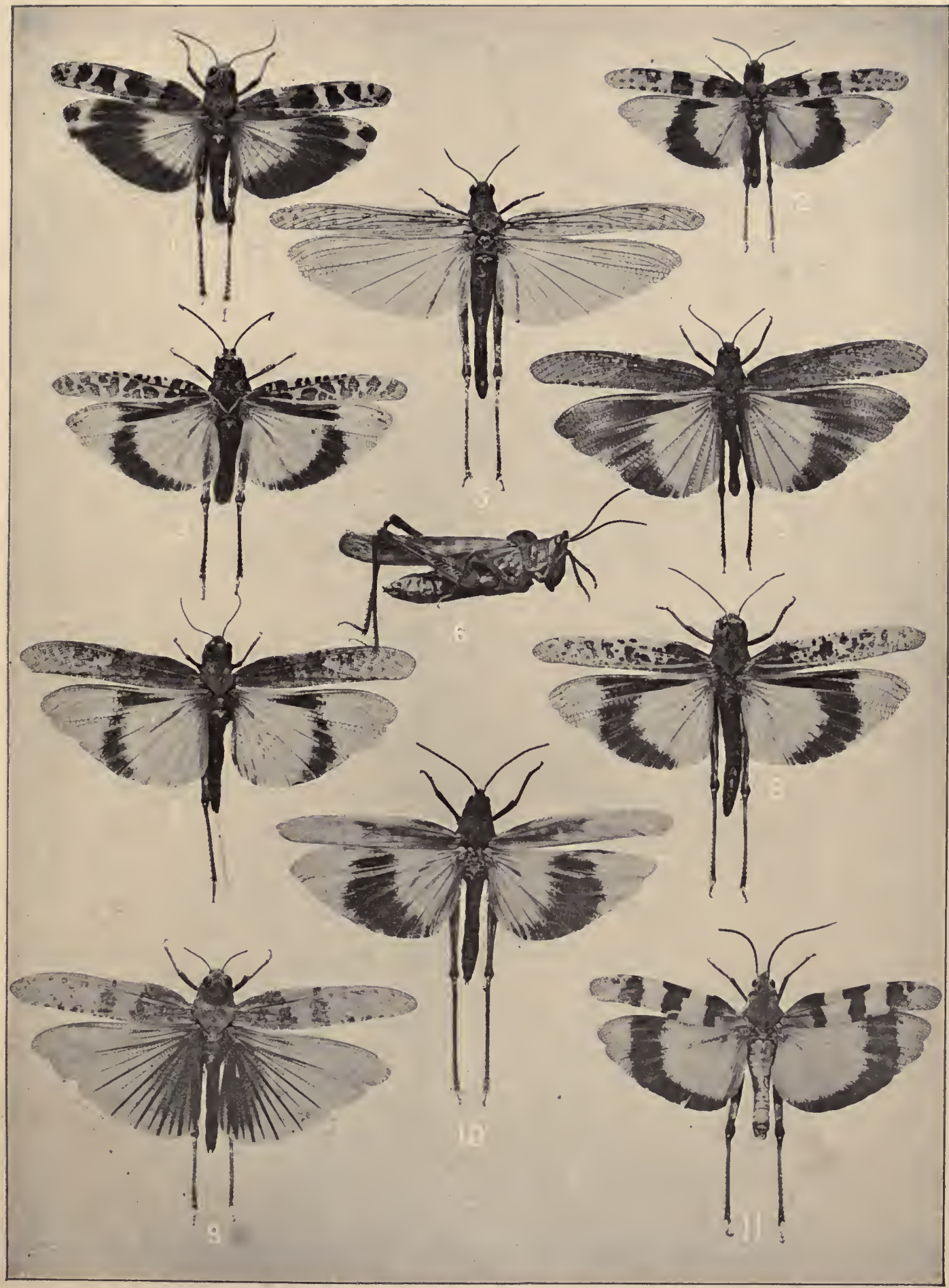


$-2$

- 


\section{WHITE ANTS}

\section{(Order Isopiera.)}

Although from their peculiarities of structure the insects of this group form a distinct order, there are not many genera or species, and there is in fact but a single family, namely, the Termitidæ (unless the curious family Embiidæ be included here, which would not seem to be justified). All isopterous insects are known popularly as white ants. As the late Dr. George Marx once remarked jocularly to the writer, "they are called white ants because they are not ants and because they are not white."
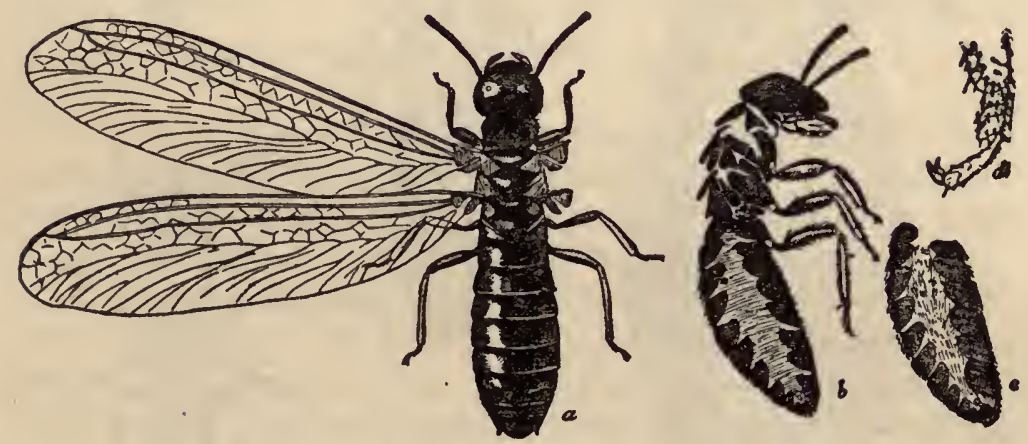

Fig. 241.-Termes flavipes : adult male. (After Marlatt.)

At this late date it is almost hopeless to attempt to change a popular term so thoroughly grafted upon the literature and upon the popular mind, but if people would only call them termites, a short and easy word to pronounce, instead of keeping up the bald misnomer-white ants-the cause of accuracy and truth would gain. Perhaps there is a slight superficial resemblance between these insects and ants, but they are structurally radically different. They belong at the opposite end of the insect series and are more closely allied to the stone-flies, the May-flies and even the dragon- 
flies, than they are to ants. Perhaps, after all, it is not so much the resemblance of the individual termite to an ant which gave it this name as it was the fact that all termites live together in communities containing different castes and that thus their social economy is in a way ant-like.

The Isoptera undergo practically no transformation, that is to say, they have very incomplete metamorphoses. The young ter-
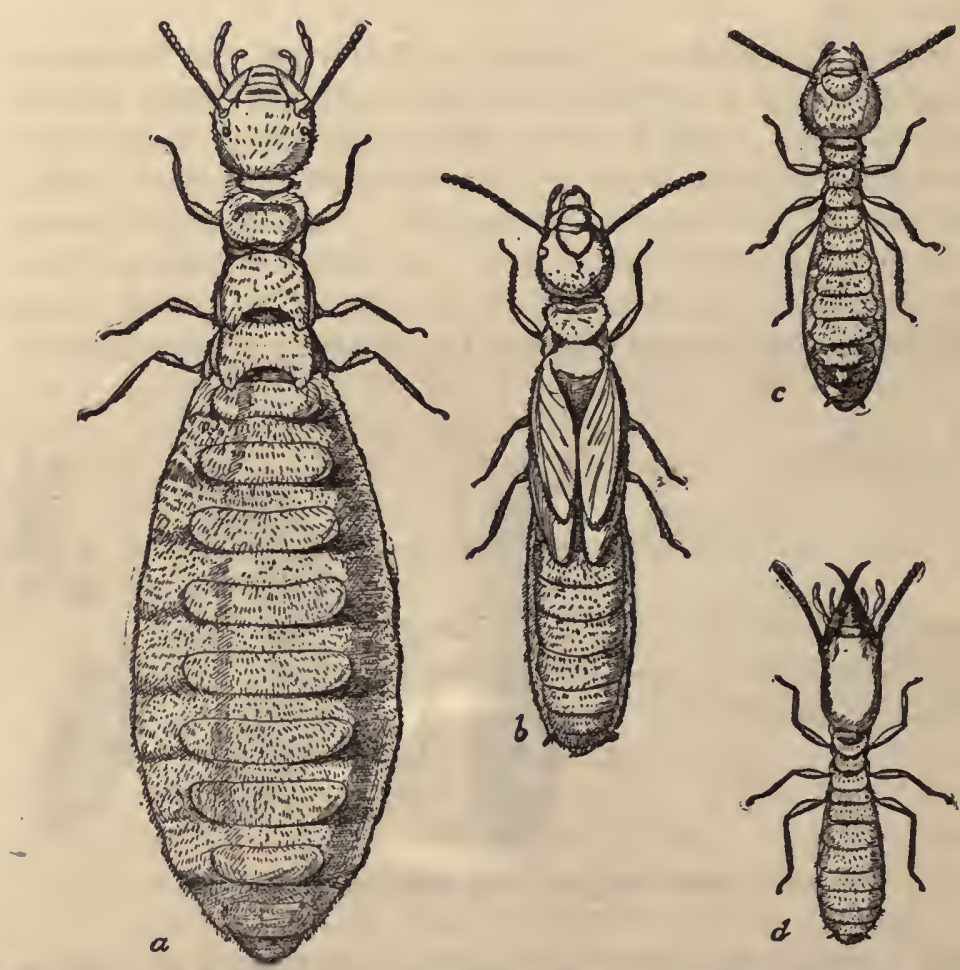

Fig. 242.-Termes flavipes: $a$, supplementary queen; $b$, nymph of winged female; $c$, worker ; $d$, soldier. (After Marlatt.)

mite, when it hatches from the egg is an active, crawling, sixlegged creature. It much resembles the adult, except in size, whereas with the ants, it will be remembered, the larva is a footless grub which looks no more like an adult than a garter snake resembles a chipmunk. All species, as just stated, are social and the communities consist of both wingless and winged individuals. 
The four wings are very long and when in repose are laid flat along the back, extending far beyond the tip of the abdomen. They are membranous and most of the veins are longitudinal. The hind wings are of almost precisely the same shape and size as the front wings, and across near the base of each wing is a line of weakness along which the wing breaks off after the so-called nuptial flight. The wingless individuals in each colony are, with most species, excessively numerous and as a rule they are divided into two castes, namely, the ordinary workers and the soldiers. The so-called soldiers also exist with the true ants but they have not in these creatures become such a structurally well differentiated caste as with the termites. In the latter the jaws have become enormously developed and in some cases the soldier is five times the size of a worker. Then, in some species a certain portion of the workers have become changed in form particularly by the elongation of the head into a long, nose-like process at the tip of which is a hole through which is exuded a fluid which is used in making or mending the walls of the habitation. This caste is known as the nasuti, or nosed ones, a term which must at once remind the admirers of Sienkiewicz of the Polish warrior, Kharlamp.

The order Isoptera reaches its highest development in tropical regions, and the reading world has been familiar with the main details of the economy of the extraordinary species which build the great ant-mounds in Africa since the days when Smeathman the English traveler, described them in print more than a hundred years ago. The females, or queens, of some of these African species grow to be of enormous size. The abdomen, swollen with eggs, sometimes becomes as big as a potato, or 20,000 or 30,000 times the bulk of a worker. The rate at which the eggs are laid is extraordinary and it is stated at sixty a minute, or 80,000 and upwards in a day. Listening to an account of this extraordinary egg-laying, which was given before the Biological Society of Washington by Mr. O. F. Cook, a friend remarked to the writer in a whisper, "What a fortune that would mean with eggs at twenty-five cents a dozen!"

In the United States there exist comparatively few species, and only one which thas a northward range into the territory occupied by most of the readers of this book. This is Termes flavipes Koll. It is probably a true American species but was 
accidentally introduced into Europe many years ago.. It destroyed the imperial greenhouses at Schönbron, near Vienna, so that they were replaced by houses with iron frames. Another species which is widely distributed in the United States, but which does not seem to be especially common, is also found in Europe and is one of the most abundant and destructive termites found there. This is Termes lucifugus Rossi. It has not yet been definitely determined whether this insect is a native of Europe or of America. It occurs in all of the Mediterranean countries in Europe and is found in Texas, Kansas, Colorado and Southern California, and perhaps elsewhere. Another species, known as Termes tubiformans Buckley, is a form of curious habits occurring in Texas, in the spring, beneath and within patches of cow-dung, and after midsummer making tubes around grass stems and the stems of other plants, nesting probably deep in the ground. Still another Texas form, known as Eutermes nigriceps Haldeman, is a small species which constructs nests, apparently of cow dung, which are attached to the trunks of trees. Buckley wrote of this form, "lt was about sunset on the $22 \mathrm{~d}$ of October, 1860, when I first saw this species in a field, where both workers and nasuti were carrying home seeds of grasses and weeds. They marched in dense columns along pathways leading to a hole near the base of a stump, into which they entered. $* * *$ They dwell in the ground where they have rooms, seldom more than one to two inches long, connected by tunnels. $* * *$ After rains-which are of rare occurrence in that climate-they make semi-cylindrical tubes, which lie on the ground with a length of from three to six inches. These arched ways sometimes intercept each other, being connected with chambers; but they rarely work by day above the surface and never in bright sunshine."

Of the commonest of our species, Termes flavipes, it is greatly to be regretted that no thoroughly good account of its life history has been published. The true queen, in fact, has never been found, unless it should turn out that a large queen found two or three years ago by Mr. H. G. Hubbard in the mountains in southern Arizona should belong to this species. In the Northern States its nests are to be found under almost any decaying log, and, although many entomologists have examined these nests, they have never found the queen. From Baltimore southward, 
and perhaps even a little farther north, this insect becomes a serious pest in houses, particularly in old houses which are rather damp. They make their nests in old beams, such as the main floor joists, and construct innumerable tunnels, running usually with the grain, so that, although a great deal of the substance of the wood is devoured, the main longitudinal fibers support the building structure for a long time; in fact, their presence in many cases would not be noticed except for the spring flight of the winged males and females. Quite recently a handsome private residence in the city of Baltimore was found to have its timbers on the first floor reduced almost to shells by the workers of this insect. Further south, not only the buildings, but even furniture is destroyed by them in the same way. They seem especially fond of paper, and Forbes has recorded the fact that a collection of books and papers of the state of lllinois was completely ruined by them. A school library in South Carolina, which had been left closed for the summer, was found, on being opened in the autumn, to be completely eaten out and rendered valueless. The work of these insects was brought home strongly to the writer on one occasion when a lot of records and documents stored in a vault in the Department of Agriculture was found to be mined and ruined by them; and again, the floor of one of the largest sections of the United States National Museum. was annually undermined and weakened until it was torn up and replaced with cement. Whenever an old beam is found to have been hollowed out, even if no insects are present, it can readily be identified as the work of termites by the fact that all of the galleries are plastered with a brownish, mortar-like substance composed of excrement, from which, apparently, all nourishing food has been taken. In Florida this insect is often the cause of great damage to orange trees, working around the crown and in the roots of trees, and altogether it is a thoroughly bad character.

In the most general terms the life of a termite colony is about as follows: After the so-called nuptial flight (which is made usually at a certain time of the year, and with Termes flavipes it is generally in the spring) composed of winged individuals of both sexes, male and female, and which always, except when it occurs in houses, attracts birds and other insect-eating creatures so that most of the individuals are destroyed, the wings of the 
survivors break off and they either pair and attempt to start a new colony or they drop in such a situation that workers from some old colony find them, join forces with them, and thus start a new community. The body of the true female, or queen, begins to swell with eggs, grows enormously, and egg-laying commences. Unlike the true ants or any of the other social Hymenoptera, the young require very little care from the workers. They are quite active and very soon feed themselves to some extent. The food of the termites is variable. It consists of wood fiber, or their own cast skins, or their excrement, or the contents of the stomach regurgitated by other individuals, or, in the case of the soldiers, they may eat dying or even healthy workers. The enlarged head and great jaws of the soldiers unfit them, in fact, for any other kind of food. They can not gnaw wood very well, and, as Sharp has expressed it, "their condition may be considered to be that of permanent hunger, only to be allayed by carnivorous proceedings." When the nest is disturbed and the soldiers get excited they dash their jaws around and frequently kill their fellows, but of course this is more or less accidental, since they have no eyes. When a Callotermes wishes food, according to Grassi, it strokes the posterior part of the body of another individual with its antennæ and by some sort of a reflex action the contents of the alimentary canal of the individual stroked issue from the anus and are devoured by the stroker. The habitations of all termites are very cleanly, which is accounted for by the fact that they eat everything, the contents of the alimentary canal being eaten again and again until all nourishment has been taken out of it. Hubbard, in Jamaica, found that the young feed upon prepared food which is stored up in the form of very hard and tough round masses, some nests containing many pounds' weight. This material is softened by saliva before it can be eaten. The true queens can be distin. guished at once by the stumps of their old wings as well as, later, by their enlarged abdomens; but there are in most colonies individuals known as supplementary queens, which are capable of reproduction up to a certain point and undoubtedly help to carry the colony on in case of the death of the true queen. These supplementary queens are undoubtedly female workers which have been fed in a certain way and which develop up to a certain point, although not to the point of becoming winged. 


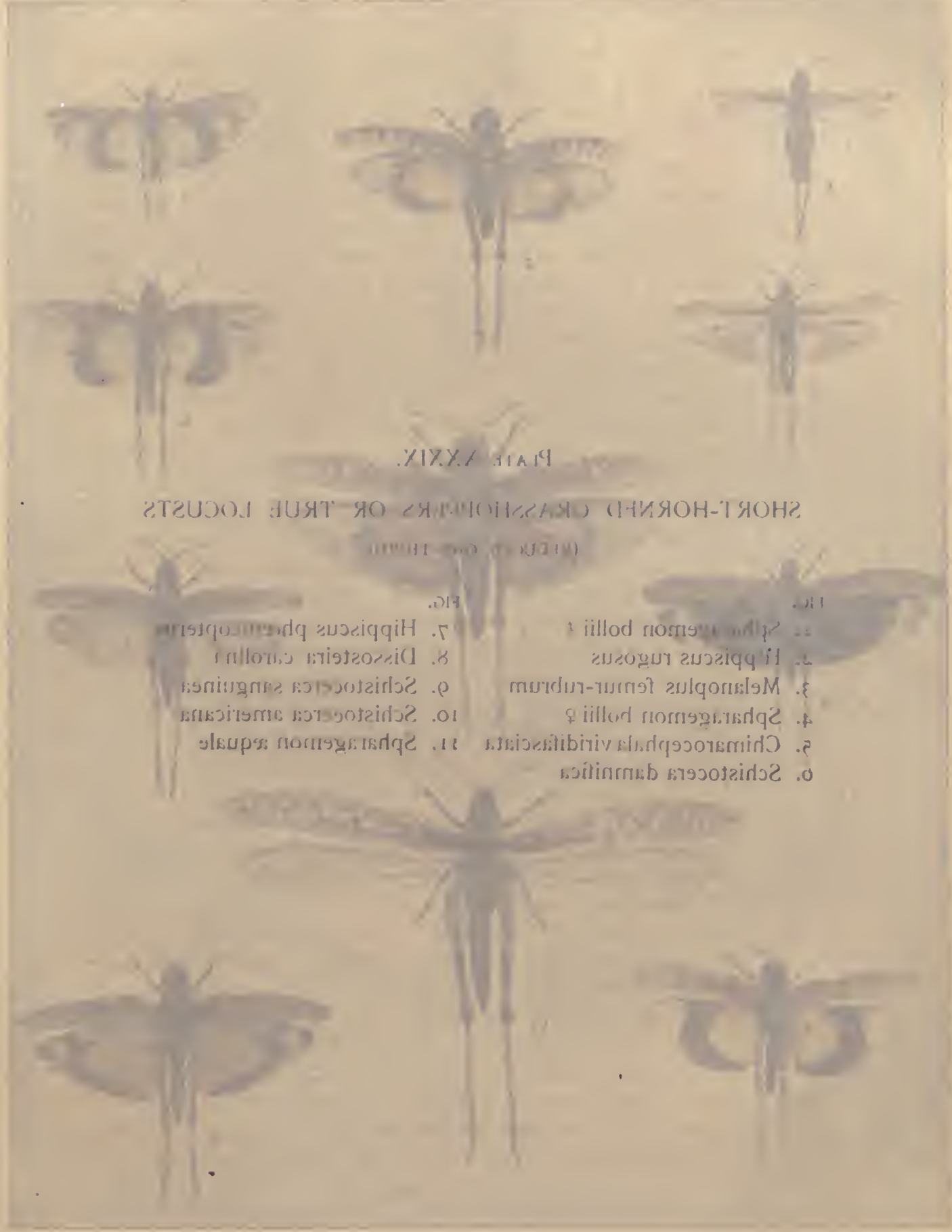




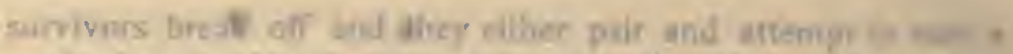
mow colony or they dnop 16 noch a atuallas Lnt warkers 1

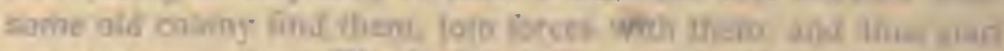

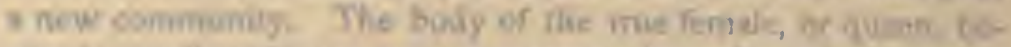

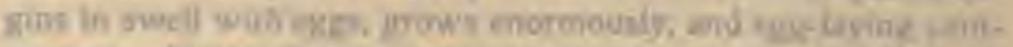

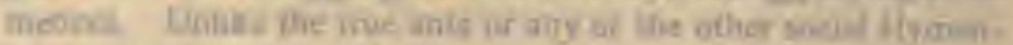

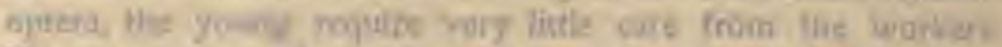

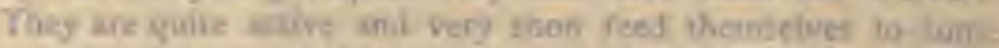

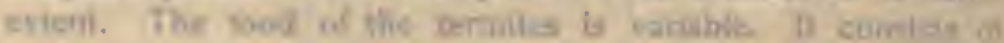

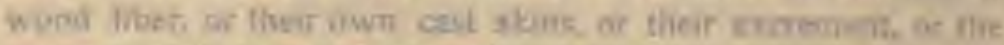

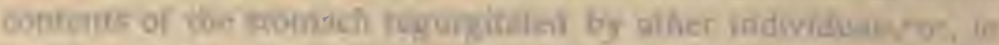

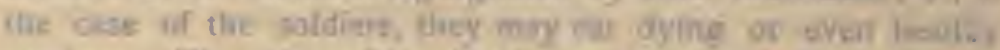

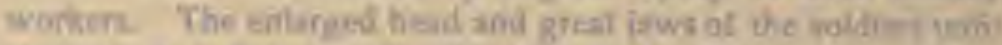

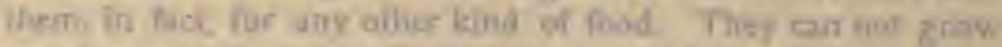

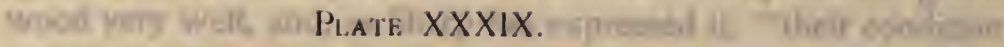

\section{SHORT-HORNED GRASSHOPPERS OR TRUE LOCUSTS}

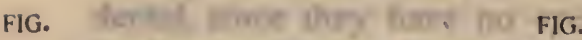

\section{(REDUCED ONE-THIRD)}

1. Spharagemon bollii of Gras, it 7 . Hippiscus phoenicopterus

2. Hippiscus rugosus indivitual 8 . Dissosteira carolina

3. Melanoplus femur-rubrum 9. Schistocerca sanguinea

4. Spharagemon bollii o

10. Schistocerca americana

5. Chimarocephala viridifasciata

11. Spharagemon xquale

6. Schistocera damnifica

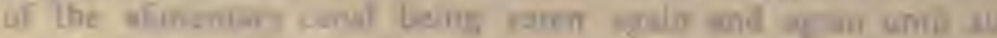

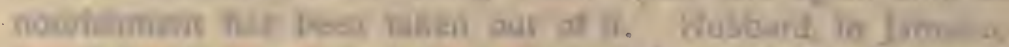

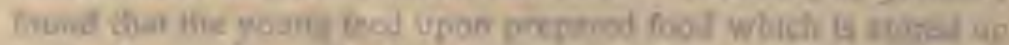

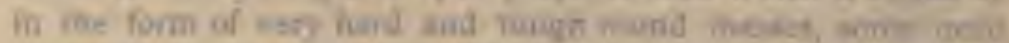

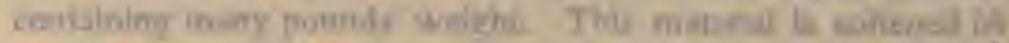

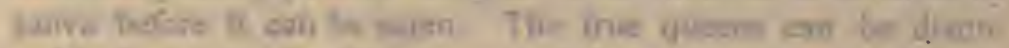

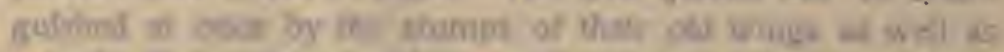

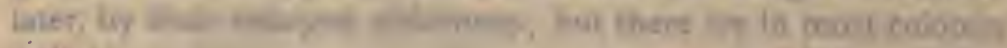

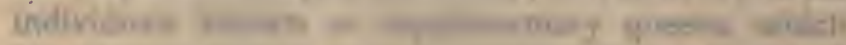
Kie al wh

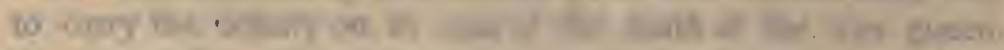

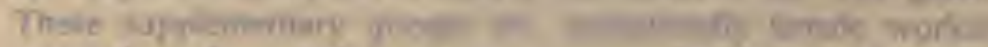

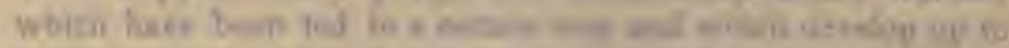

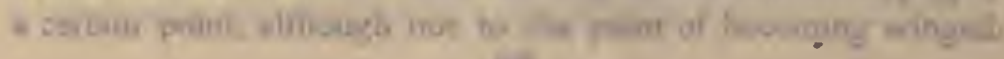




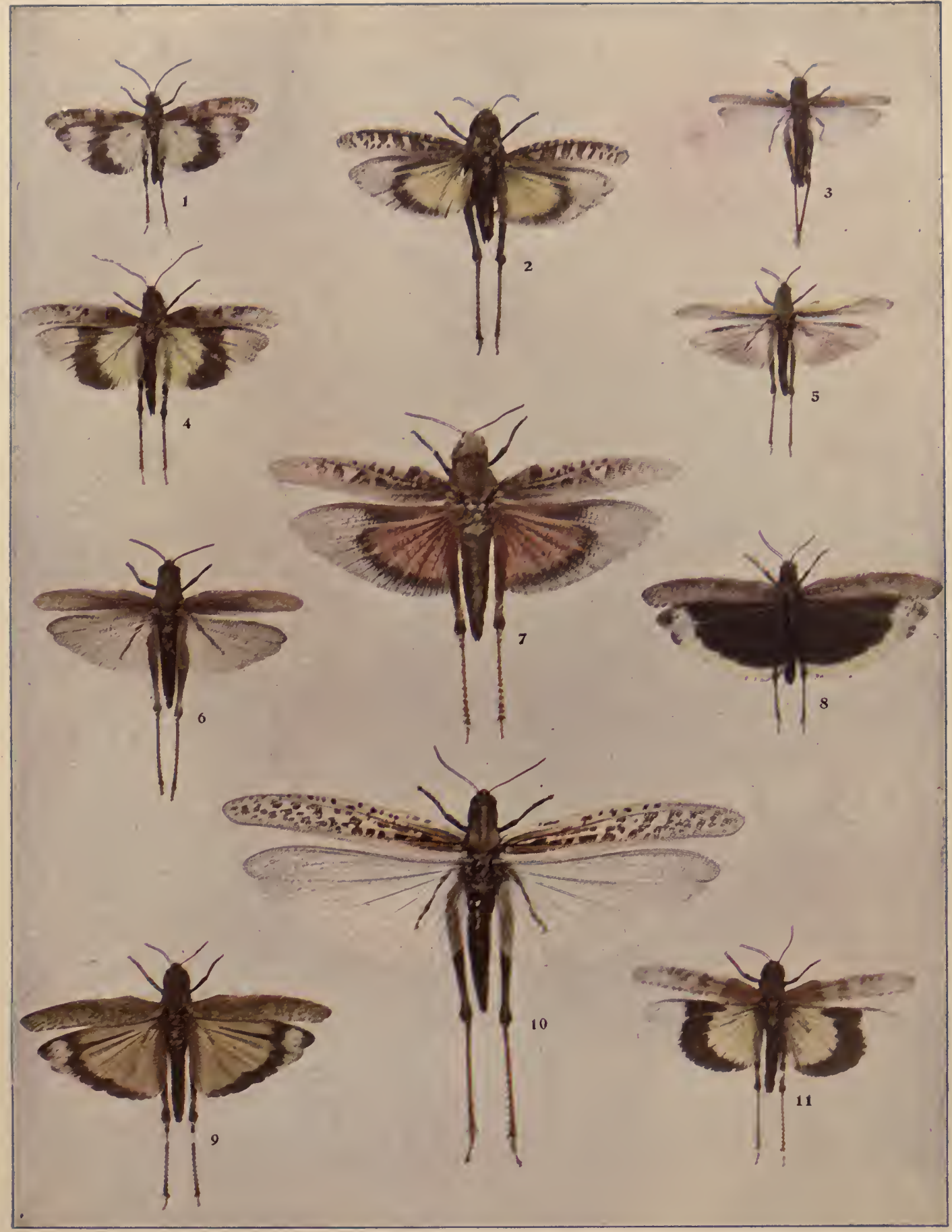


One of these, found by Hubbard in the nests of Termes flavipes in Florida, is shown at Fig. 242.

In America Termes lucifugus has not been studied, but in Europe its history is rather well known. It burrows in wood of different kinds, makes excavations and builds galleries so that it can move from one point to another without being exposed. This suggests that we have as yet omitted to state that all termites shun the light, except during the nuptial flight; in fact, the workers and soldiers are almost invariably blind, although with certain African species of the genus Hodotermes facetted eyes occur in these castes and they issue from holes in the ground during the heat of the day and cut grass. There seems to be some question, however, whether these creatures really belong to this group. It is supposed also that these galleries keep the right degree of moisture, since in dry air these creatures die. Many thousands compose a community. The period of development apparently occupies from eighteen to twenty-three months.

Probably in the whole range of insects treated in this book there is no species which offers a better and more convenient field of study than the common Termes flavipes. I feel sure that what we know about it is but a small fraction of what remains to be learned, and it is everywhere so abundant that the earnest observer need never be without material.

Just as with the ants, and also with some of the social bees, so that we may, in fact, say just as with all social insects, in the habitations of termites will be found many guest insects. Such insects in ants' nests are known as Myrmecophilous; in termites' nests they are known as Termitophilous insects, and the study of these insects, in the United States, offers an almost unexplored field. Mr. E. A. Schwarz has paid some attention to them, and in the Proceedings of the Entomological Society of Washington (Vol. 1, pp. 160, 161) has given a list of nine species of beetles found living in termites' nests and has published some very interesting notes about them. No true hymenopterous parasites of termites are known, unless the curious, big-headed chalcis flies of the genus Caratom is shculd prove to be parasitic upun them.

The damage done by termites in tropical regions is very great. In Central America it seems almost impossible to erect wooden telegraph poles which will last for any length of time, since they are tunneled by these creatures and weakened to their 
fall in an incredibly short time. Accounts of damage done in houses, both in Tropical America and in Africa, as well as in British India, occur commonly in the literature. A striking account, however, of damage in Rhodesia occurs in the Zambesi Mission Record for Januury, 1901, written by the Rev. A. Lebœuf, and which is quoted in Nature. "It is no uncommon thing' says the writer 'for the colonist, on returning from his day's labor, to find the coat he left hanging on a nail on his cottage wall and the books on the table absolutely destroyed by these tiny marauders.' Nor is this all. ' On awakening next morning,' writes Mr. Lebœuf, 'you are astonished to see in the dim light a cone-shaped object rising from the brick floor a short distance from your bed, with two holes on the top like the crater of a miniature volcano. Upon closer examination you discover that the holes have just the size and shape of the inside of your boots, which you incautiously left on the brick floor the night before. They have given form and proportion to an ant heap, and nothing is left of them except the nails, eyelets and, maybe, part of the heels."

There are certain insects which belong to the family Embiidx which seem to have a relationship to the termites but their detailed consideration may well be omitted from this work, since but a single species is known in North America, namely, Oligotoma hubbardi Hagen, and which occurs rarely in Florida. 


\title{
THE STONE-FLIES
}

\author{
(Order Plecoptera.)
}

This order is not a large one and contains only the single family Perlidæ, of which thirteen genera are represented in North America and less than a hundred species. The stone-flies have mouth-parts formed for biting; the body is long and soft and flat; the wings are four in number and are membranous, the hind wings being much larger than the fore wings, folded in plates, and lie upon the abdomen when at rest. The antennæ are long and thread-like. The larvæ are aquatic and are usually found under stones in running water. The flies are commonly seen about water courses in the first warm days of spring, and the cast skins of the nymphs, or pupæ, sticking to stones and logs on the banks of streams, are very common objects. The eggs are produced in enormous numbers. They are small and are probably dropped on the surface of the water, as with the May-flies, but some of them, even after they issue from the abdomen enclosed in a kind of capsule, are carried about by the female. One female may deposit 5,000 or 6,000 eggs. The larvæ when hatched are very active and are carnivorous in habits, feeding upon the young of the May-flies and other soft-bodied aquatic animals. They are as a rule very flat in lorm, which enables them to crawl under heavy stones at the bottom of swift running streams. The head is large and flat and the eyes are large and compound. They resemble the adults in general structure except that they lack the wings. There are as a rule two long protruding filaments at the anal end of the body, and they breathe by means of tracheal gills. The legs are flattened and are fringed with hairs, fitting the insect admirably for swimming. The long antennæ are present in the larvæ also and when the larva is hidden beneath a stone frequently the antennæ curve around upwards, apparently to give it warning of the approach of prey. The jaws are strong and toothed but are hidden by the 
upper lip. The full-grown nymph is not at all pupa-like and is active.

The enormous number of eggs laid by stone-flies indicates that the chances of successful larval growth are rather small and as a matter of fact these larvæ are extensively eaten by fishes. It makes no difference to the average fish whether he eats a carnivorous stone-fly larva or a vegetable-feeding May-fly larva. If there were economic entomologists among the fishes these would devote themselves to the destruction of the stone-fly larvæ in order that the general food supply of May-nies might be left undisturbed for fish food!

We have said that the larvæ breathe by means of tracheal gills. As a matter of fact, however, with some species there are no such gills and no spiracles. These larvæ must take their oxygen from the water through the skin, the ultimate tracheæ being especially numerous in the spots where the spiracles would be if there were any and the skin at this point is especially thin. This method of breathing has been already mentioned in our accounts of the larvæ of the Chironomidæ and of the larvæ of the internal feeding parasitic Hymenoptera.

An aquarium student with an aquarium so constructed as to maintain a constant current of water will do good service in fully elaborating the life history of any of our common species. 


\title{
DRAGON-FLIES
}

\author{
(Order Odonata.)
}

Excepting the butterflies, there are few more attractive and graceful insects than the "dragon-flies," as the members of this order are generally termed. They are insects which have always attracted attention, and which are known by a variety of vernacular names, of which dragon-fly is the commonest English

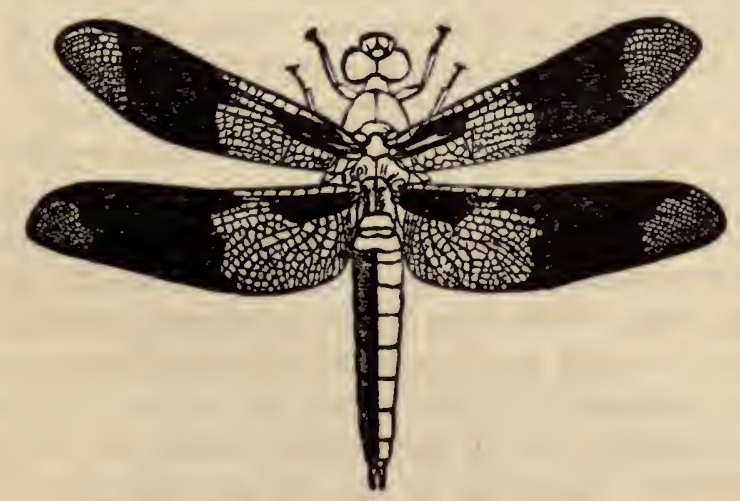

Fig 243-A dragon-fly: Plathemis lydia.

term. They are known in some parts of the country as "devil's darning needles;" elsewhere as "snake feeders" or "snake doctors;" in Scotland as "flying adders," and in some parts of England as " horse stingers." Although the insects are perfectly harmless, these names well indicate the existence of numerous popular superstitions. Some believe that they will sew up the ears of bad boys; others that they sting horses; still others that they act as feeders and physicians to snakes, especially to water snakes.

The Odonata are slender insects with a very large head which moves most easily upon its slender neck, even rotating to a 363 
considerable extent. The eyes are very large, but the antennæ are small and short. The wings are elongate, nearly equal in size, and have many veins, both longitudinal and transverse, so that the entire surface of the wing is cut up into many small cells. The legs are placed near the front of the thorax, and all curve forward and are used for grasping the prey of the dragonny, and never for walking. In fact, the legs are unfitted for walking, although they are used to grasp the twig or other object upon which the dragon-fly may rest. All of the dragonflies are aquatic in their early stages. The metamorphosis is complete in so far that the larvæ differ radically in appearance from the adults, but the pupa is not quiescent at any time. It is very active, and feeds up to the moment when the final metamorphosis begins. The jaws in all stages are strong, and both larvæ and adults are extremely active and are among the strongest and most graceful flyers of all insects. Their flight is so perfect that it has been seriously suggested that flying machines should be modeled after the flight mechanism of these insects.

A very peculiar feature of the adult is the curious separation in the male of the intromittent organs from the opening of the ejaculatory duct. The former are placed on the under side of the second abdominal segment, while the latter are on the next to the last ventral plate. Therefore, before copulation, the male curves his abdomen around beneath, so that the ninth segment of the abdomen is brought into contact with the second, thus transferring the fertilizing fluid to the intromittent organ. The tip of the abdomen of the female is bent around and joins with the under side of the second segment of the male's abdomen, the male frequently grasping the female around the neck with certain appendages at the extremity of his abdomen. He retains this hold after fertilization, and frequently during the entire process of egg-laying. Even with such species as descend under the surface of the water to lay their eggs the male has been observed to still retain his grasp of the female's neck, and to be carried down under the water with her.

Dragon-flies capture their prey on the wing, and feed upon almost all flying insects, especially the small ones-that is, the gnats and midges. They alter their direction with perfect facility, and dart here and theie, unerringly capturing their prey. Possibly some of the smallest are seized with the jaws, but the larger 

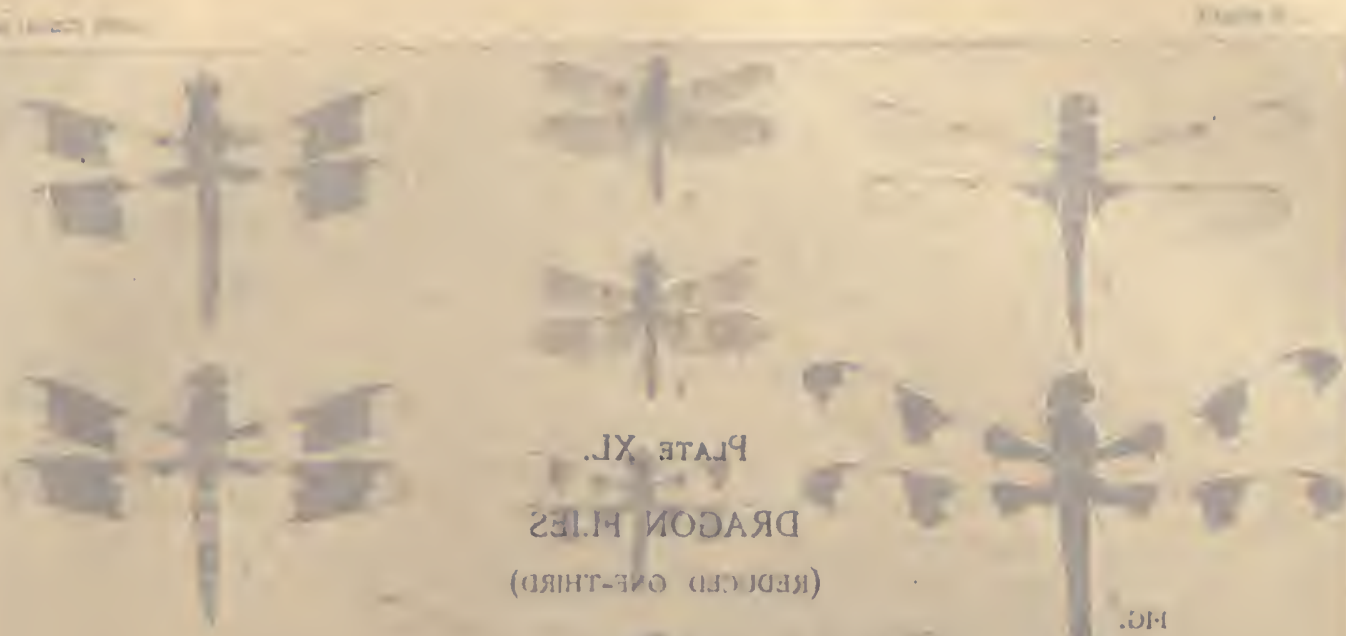

2. UHobilulladi.J) \& sibul zimghts/9 .I

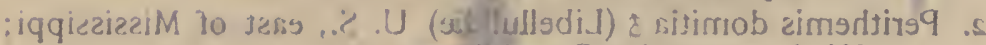

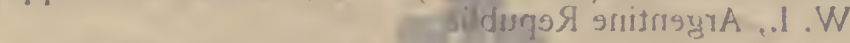

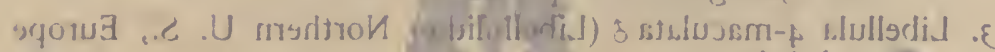
tiizA bri

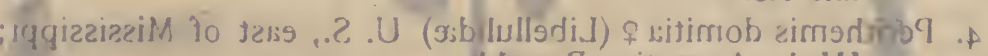

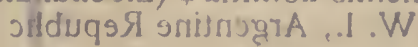

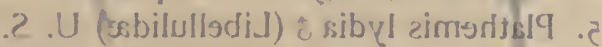

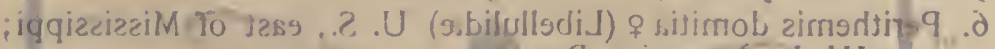

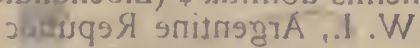

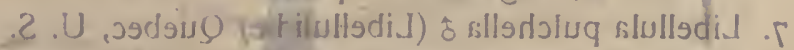

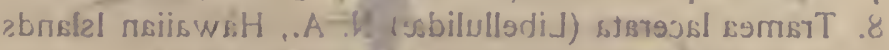

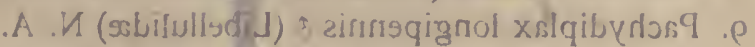

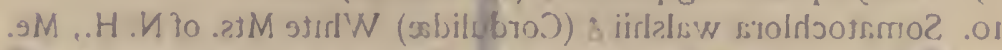

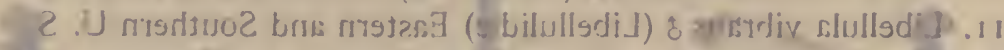

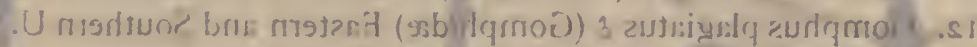

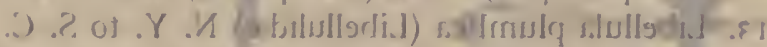

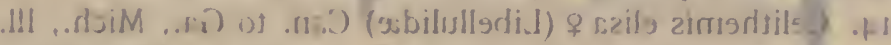

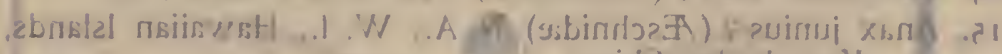

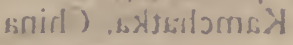

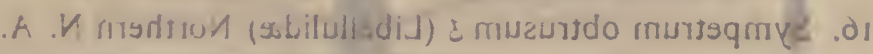
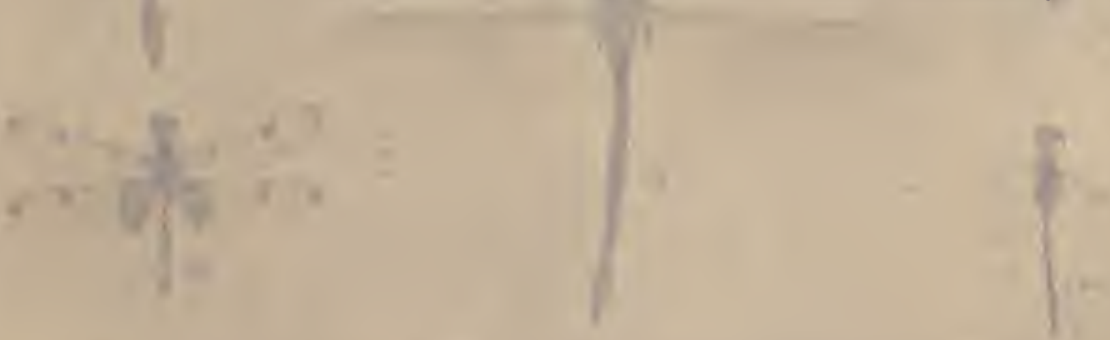


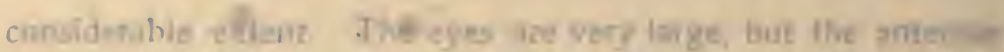

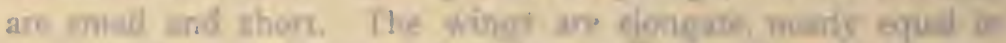
size añ

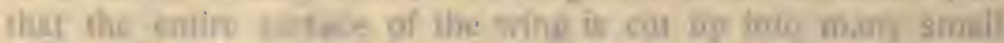

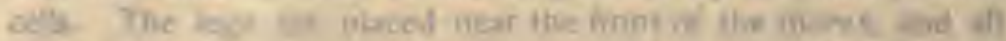

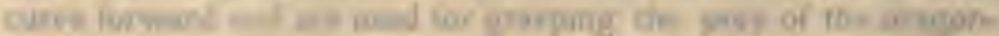
Ay. sid nere waxlio, acti oblect unoo we

Plate XL.

hizi nate aquath DRAGON FLIES

FIG.

complate if in-

frum the = (REDUCED ONE-THIRD)

1. Plathemis lydia o (Libellulidæ) U.S.

2. Perithemis domitia ơ (Libellulidæ) U. S., east of Mississippi ; W. 1., Argentine Republic

3. Libellula 4-maculata ô (Libellulidæ) Northern U. S., Europe and Asia

4. Perithemis domitia + (Libellulidæ) U. S., east of Mississippi; W. 1., Argentine Republic

5. Plathemis lydia of (Libellulidæ) U. S.

6. Perithemis domitia o (Libellulidæ) U. S., east of Mississippi; W. I., Argentine Republic

7. Libellula pulchella ơ (Libellulidæ) Quebec, U. S.

8. Tramea lacerata (Libellulidæ) N. A., Hawaiian lslands

9. Pachydiplax longipennis ô (Libellulidx) N. A.

I0. Somatochlora walshii ô (Cordulidæ) White Mts. of N. H., Me.

11. Libellula vibrans ô (Libellulidæ) Eastern and Southern U. S.

12. Gomphus plagiatus of (Gomphidæ) Eastern and Southern U.S.

13. Libellula plumbea (Libellulidæ) N. Y. to S. C.

14. Celithemis elisa $q$ (Libellulidæ) Can. to Ga., Mich., 111 .

15. Anax junius \& (Æschnidæ) N. A., W. I., Hawaiian Islands, Kamchatka, China

16. Sympetrum obtrusum $\$$ (Libellulidæ) Northern N. A.

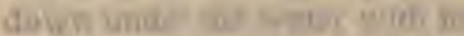

IJit row

alinem alf for

annosind mider

and dant kere and thes

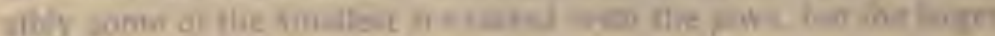




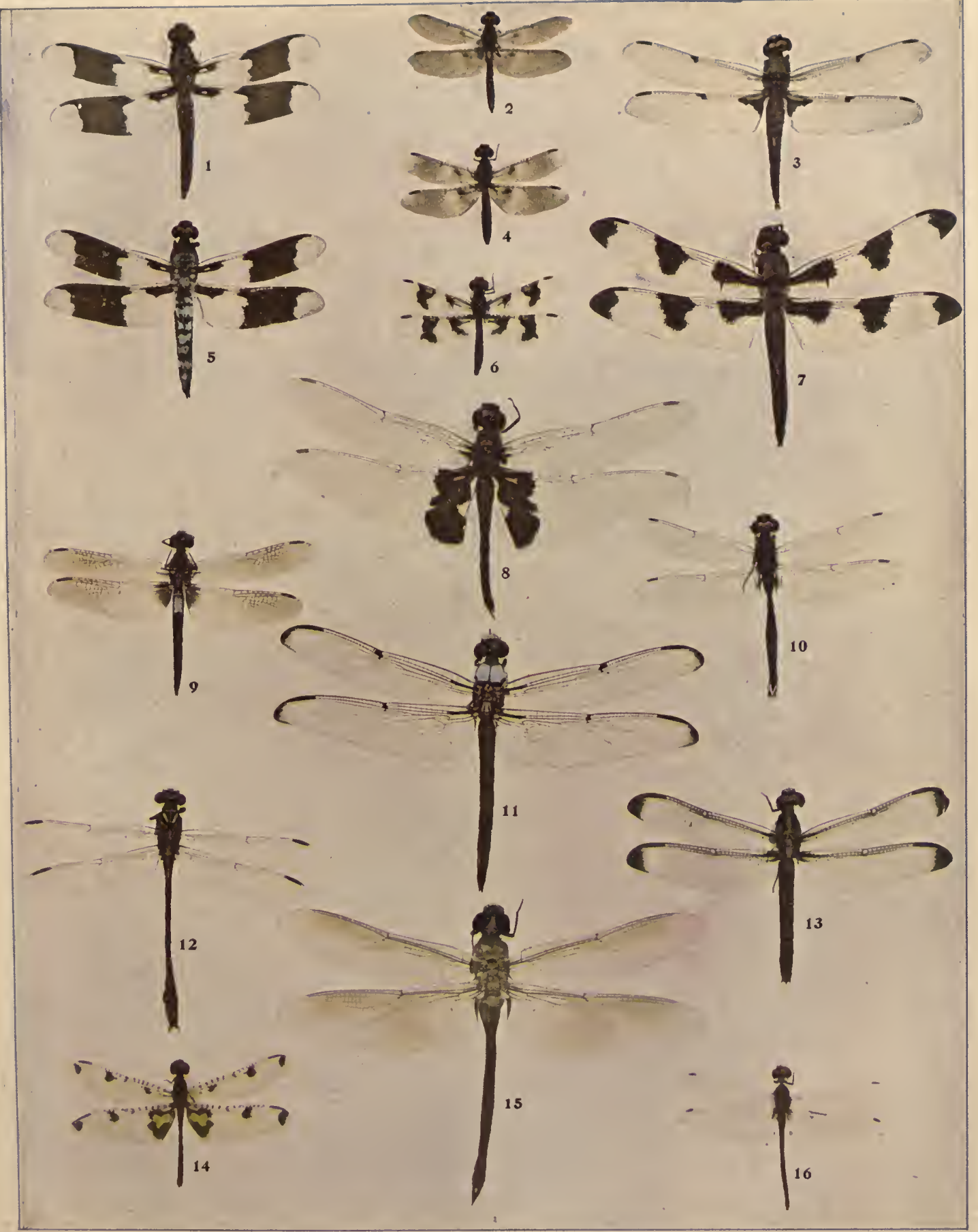



ones are undoubtedly captured by the legs, and are consumed during flight, and so rapidly is all this done that it is practically impossible to see the operation. The only way, in fact, that one can know that an insect has been captured is, as Dr. Needham expresses it, to see that the place that once knew them knows them no more.

Flies seem to be their commonest food, but large dragon-flies will eat small ones. Leaf-hoppers and even small butterflies and moths are captured by them. Some forms will occasionally pick up a moth from a weed or a grass stem on which it is resting, and even one of the large swallow-tailed butterflies has been seen captured by a dragon-fly, while Williamson states that he once saw one holding a large wasp in its jaws. The voracity of a large dragon-fly may easily be tested by capturing one and holding it by its wings folded together over its back, and then feeding it live house-flies. I should hesitate to say how many it will accept and devour, as 1 never tried one to the limit of its capacity. Beutenmüller found that one of the large ones would eat forty house-flies inside of two hours, while a smaller one ate twentyfive in the same time. It is an odd fact that a dragon-fly will eat its own body when offered to him. Even when insufficiently chloroformed and pinned, if one revives, it will cease all efforts to escape if fed with house-flies, the satisfying of its appetite making it apparently oblivious to the discomfort or possible pain of a big pin through its thorax. There is one record to the effect that a dragon-fly has been observed feeding upon the flesh of a dead reptile.

Although dragon-flies are frequently very abundant in swampy regions and about ponds, there are times when they swarm in enormous numbers. Koppen, a German entomologist, has published a chronological account of the records of dragonfly migrations, from 1494 to 1868 . Such migrating swarms seem to have been more frequently noticed in Europe than in this country, but several have been noticed in the United States. For example, Mr. A. H. Mundt, of Fairbury, lllino1s, says that between the hours of 5 and 7 P. M., August 13, 188I, "the air for miles around seemed literally alive with these dragon-flies (Aschna heros) from a foot above ground to as far as the eye could reach, all flying in the same direction, a southwesterly course, and the few that would occasionally cross the track of 365 
the majority could all the more easily be noticed from the very regular and swift course they generally pursued; but even these few stray ones would soon fall in with the rest again. Very few were seen alighting, and all carefully avoided any movable obstacles." This migration was probably caused by the very dry season which had resulted in the drying up of ponds and swamps, and it is probable that other similar recorded migrations have arisen from the same cause.

Among the insects killed by dragon-flies there must be, of course, some mosquitoes, although the beneficial work of these insects in this direction is greater in the larval stage than in the adult. Dragon-flies are day flyers, but in cloudy weather and toward evening many mosquitoes are undoubtedly killed by them. Dr. E. A. Mearns, U.S. A., (quoted by Beutenmüller) states that at Fort Snelling, Minn., mosquitoes appeared in vast swarms, and were soon followed by large numbers of dragon-flies after which the mosquitoes were considerably reduced in numbers. Dr. Robert H. Lamborn, noticing in the Lake Superior region the activity of dragon-flies in this regard, years later offered a prize for the best essay on the artificial multiplication of dragon-flies for the destruction of mosquitoes and house-flies. The prize essays by Mrs. Carrie B. Aaron, Mr. Archibald C. Weeks, and Mr. William Beutenmüller were published in 1890 in a very readable and valuable book, but as might have been foreseen the practical value of Dr. Lamborn's suggestion was not substantiated.

The eggs are laid either in the water or are inserted in the stem of some aquatic plant.

In the dragon-flies of two families there is no apparatus for the insertion of eggs into plant stems, and they are therefore either dropped loosely in the water or attached to submerged objects by means of a mucilaginous substance which surrounds them. With others, however, there is a curious modification of the end of the body. The sides of the vulva are pointed or roughened, and cut into plant tissue so that the eggs may be pushed into the cuts. Here the female gradually crawls down the stem of a water plant until she is often completely submerged. She is always incased with an air film so that she can continue to breathe under water to a certain extent. The number of eggs is variable, but is usually large. Some very curious Hymenopterous parasites live in the eggs of dragon-flies. 
When the eggs hatch the young immediately begin an active, predatory life under the water, feeding upon other aquatic insects. This food habit is continued throughout their larval or nymphal existence, and as they grow larger they are able to overpower larger and larger insects and even small fish and other aquatic animals. They will kill others of their own kind, and nymphal dragon-flies have been seen to catch and destroy adults in which the wings were not yet expanded. They molt probably a number of times, but the exact number has not been recorded for any species, so far as I know. The most peculiar feature of the larva or nymph is the strange modification of the mouth. There has been a backward growth of the lower lip and this has become hinged so as to form a long, hinged apparatus with sharp teeth at its extremity. It can be folded to cover the lower face like a mask. The structure has been called a mask, and when it is folded the head of a dragon-fly larva seen from the front looks like that of a bulldog. It is more innocent looking than that of a bulldog simply because we know what a bulldog can do, but the moment that the larva approaches near enough to its prey the innocent looking mask is unfolded and darted out, and the probably unsuspecting aquatic insect or small fish is seized by the teeth at the extremity and drawn back into the mouth.

Dragon-fly larvæ breathe in a peculiar way modified to some extent with the members of the different families. The rectum is furnished with very many tracheal branches, forming numerous loops and even penetrating the walls of the intestine. Water is sucked into the rectum, and these "rectal gills," as they are termed, derive their oxygen from this water. This same feature affords with some species a means of locomotion, for this water which is sucked in for breathing purposes may be ejected violently, the effect of which is to send the larva ahead. This same principle has been used in certain mechanical toys, and applications have even been made for patents on a similar method of propulsion for vessels. With some there are external abdominal gills, both lateral and caudal, while when the nymph becomes full grown and is ready to leave the water breathing is taken up by certain obscure spiracles. There is still some doubt as to the exact method by which they begin to breathe air after leaving the water, and it is a subject which will bear much further investigation. 
When the nymph becomes full grown, it has changed its form from a rather slender creature to a broad and flattened one, not resembling the slender bodied adults in the least. It crawls out of the water on the bank upon the stems of water plants or upon the rocks, and later its skin splits down the back, and the adult dragon-fly emerges. Empty skins of these nymphs are very common objects about watercourses.

Rather more than two thousand species of dragon-flies have been described, and of these something less than three hundred inhabit the United States, of which about two hundred and twenty-five species are peculiar to this country. According to Kellicott, about one hundred species are found in the State of Ohio, and Williamson thinks that even more are to be found in Indiana. In many places dragon-flies are disappearing, owing to the drainage of their breeding places.

On account of the beauty of the adults and the interest attaching to their habits, they are becoming favorite subjects for collections, and there are now a number of earnest students of the Odonata in this country. The recent death of the great master of dragon-fly science, Baron de Selys-Longchamps, of Belgium, December 11,1900, has called renewed attention to this fascinating group.

The nymph dragon-flies are well adapted to aquarium study. They are easily collected and easily kept. The debris at the bottom of ponds can be brought up with a rake, and the nymphs thus collected placed in a bucket and carried home to the aquarium, which should be furnished with sand and aquatic plants. The best time for collecting them is in the spring and early summer.

\section{TABLE OF FAMILIES}

Wings alike, held vertically in repose; eyes constricted at base, peduncled......................... I

Front wings dissimilar from hind wings, held horizontally in repose; eyes not peduncled.................. 2 


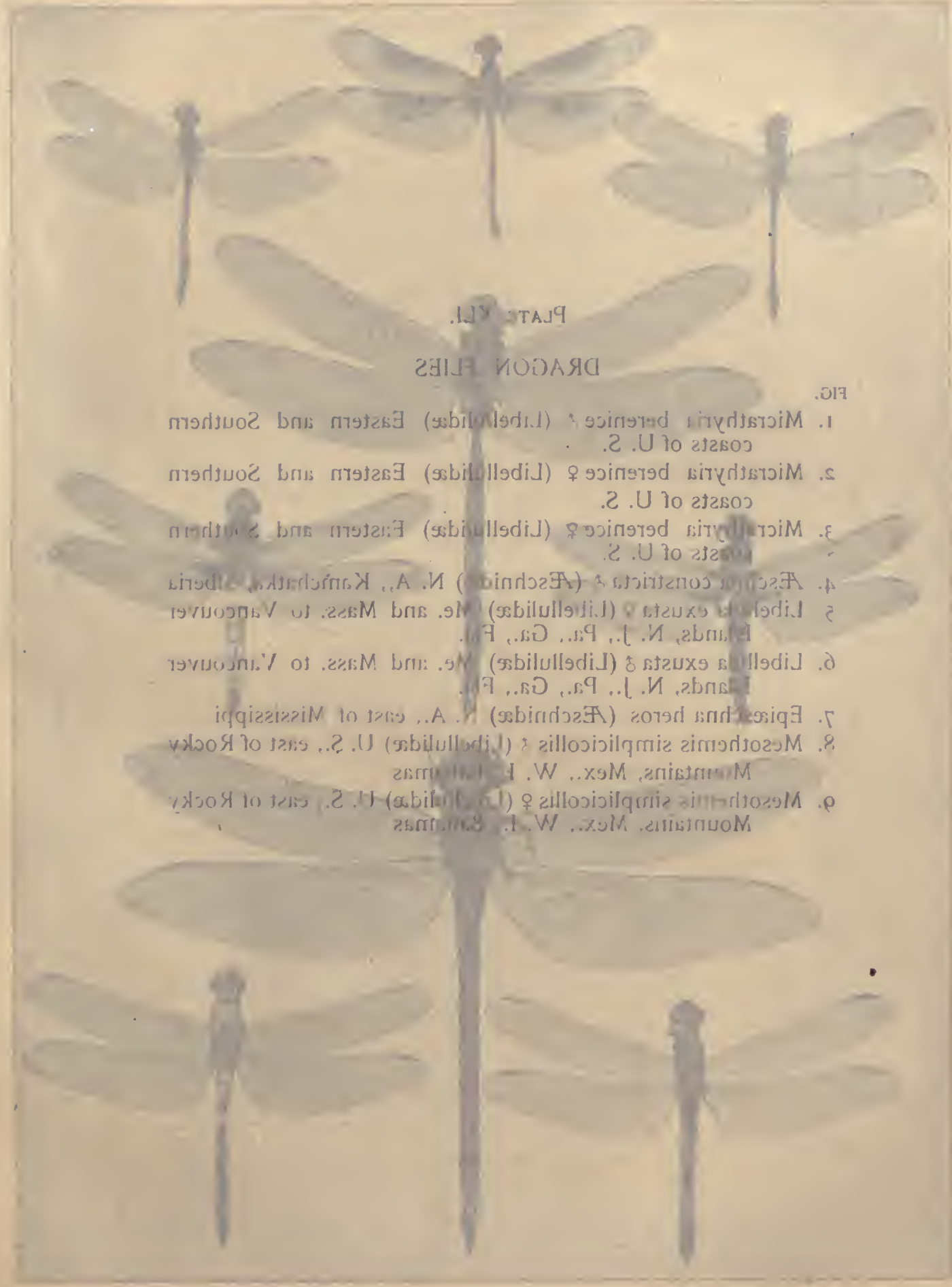


Wher the nisigh becomes folt grown it kat kam th

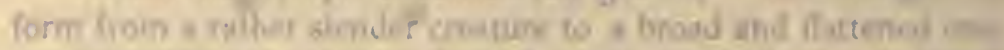
nol moeutiting the slerider bodicd adulis in the leusi It cries.

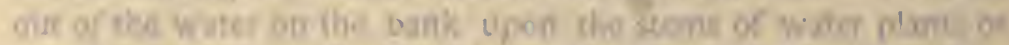

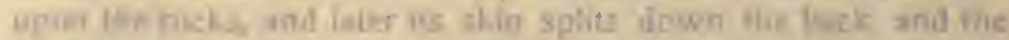

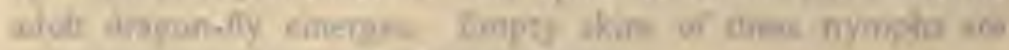
verj catromith

\section{Rasit} Extonosics.

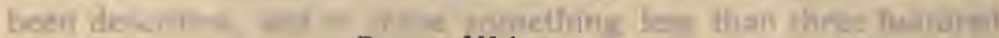

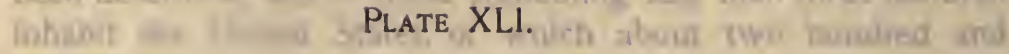
FIG.

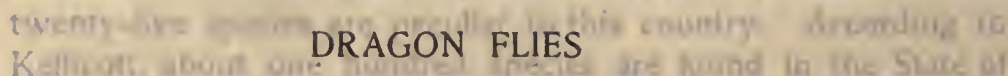

1. Micrathyria berenice of (Libellulidæ) Eastern and Southern coasts of U. S.

2. Micrathyria berenice $q$ (Libellulidæ) Eastern and Southern

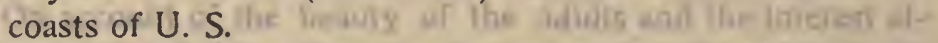

3. Micrathyria berenice $q$ (Libellulidx) Eastern and Southern coasts of U. S.

4. Æschna constricta ô (Æschnidæ) N. A, Kamchatka, Siberia

5. Libellula exusta o (Libellulidx) Me. and Mass. to Vancouver Islands, N. J., Pa., Ga., Fla.

6. Libellula exusta ô (Libellulidx) Me. and Mass. to Vancouver Islands, N. J., Pa., Ga., Fla.

7. Epirschna heros (Eschnidæ) N. A., east of Mississippi

8. Mesothemis simplicicollis o (Libellulidæ) U. S., east of Rocky Mountains, Mex., W. I., Bahamas

9. Mesothemis simplicicollis o (Libellulidæ) U. S., east of Rocky Mountains, Mex., W. l., Bahamas 


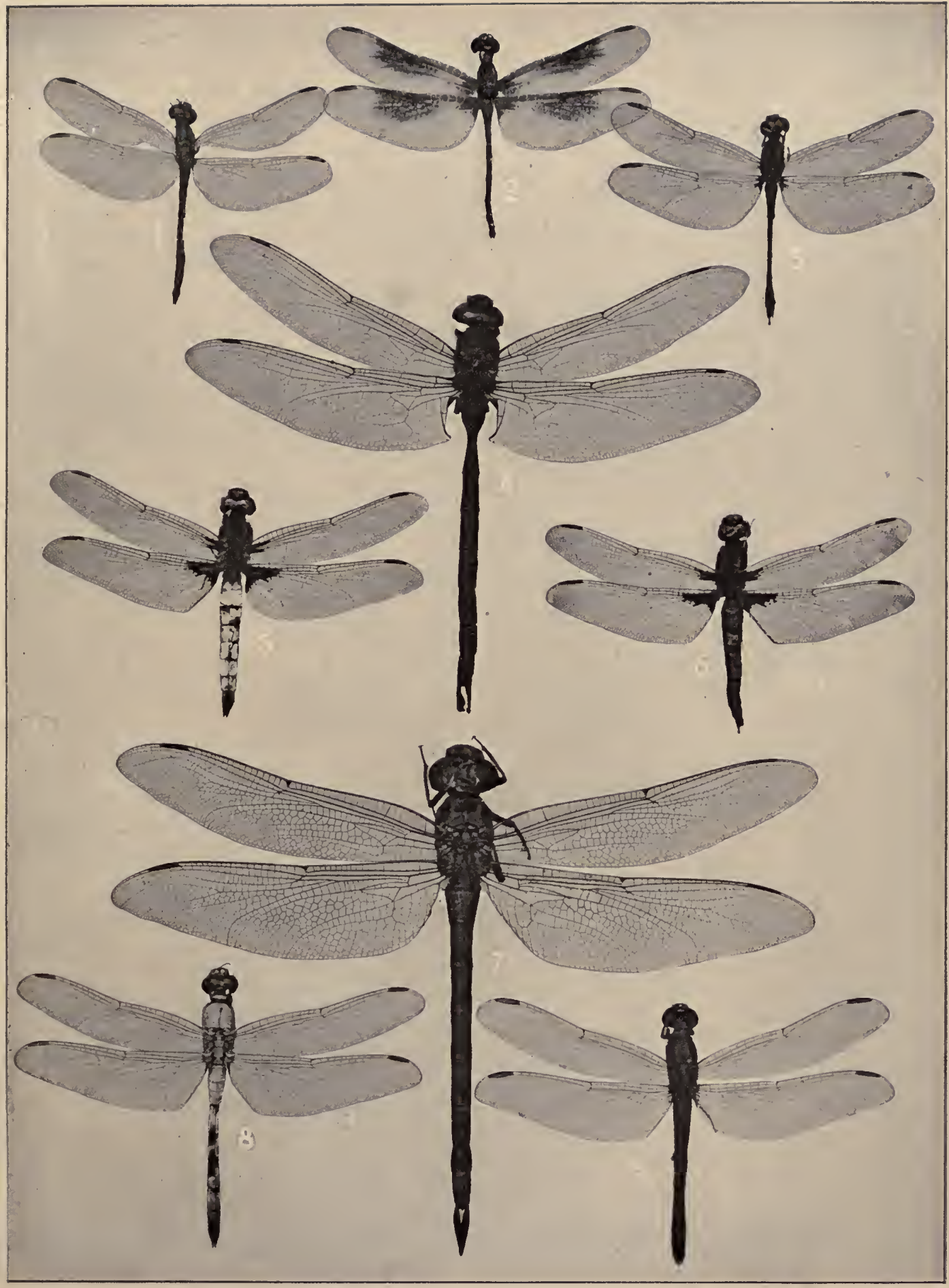



1-Wings with at least five cross veins between the first and second longitudinal veins and before the first break in the wing (antecubitals) ............. Family Calopterygida

Wings with but two such cross veins..... Family Agrionida

2-Antecubitals of the first and second rows not meeting except

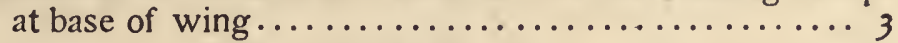

Antecubitals of first and second rows running into each other........................... 4

3-Eyes wide apart.................. Family Gomphida

Eyes touching at a single point..... Family Cordulegasterida

Eyes touching for some distance.......... Family Aschnida

4-Eyes with tubercles behind............ Family Cordulida

Eyes not tubercled behind............ Family Libellulida 


\section{DAMSEL-FLIES}

\section{(Family Calopterygida.)}

This family and the following, the Agrionidæ, are by some late authors grouped together, the Calopterygidæ being considered simply of subfamily rank and called Calopteryginæ. Both groups, as pointed out in the table, hold their wings vertically in repose; that is to say folded together over the back, instead of spread out horizontally. They are called by some authors damsel-flies.

The species of this family, and especially those of the genus Calopteryx, seem to live preferably in wooded places along the banks of running streams. Their wings are frequently so dark as to appear almost black, and they have also something of a metallic lustre. The body is strikingly metallic, and of an iridescent green and blue. The large pop eyes, which seem almost stalked like those of a crab, are characteristic and distinctive of this and the following group. The flight is not strong, and they are seldom found far from the banks of the stream or pond where they were born and where they lay their eggs.

We have but two genera in this family, namely Calopteryx and Hetærina. The Hetærinas have clear wings which however, sometimes bear spots near the tip, and in the males have a brilliant red area near the base of each wing. The Hetærinas are not woodland species like Calopteryx, but are found near running water in the open. 


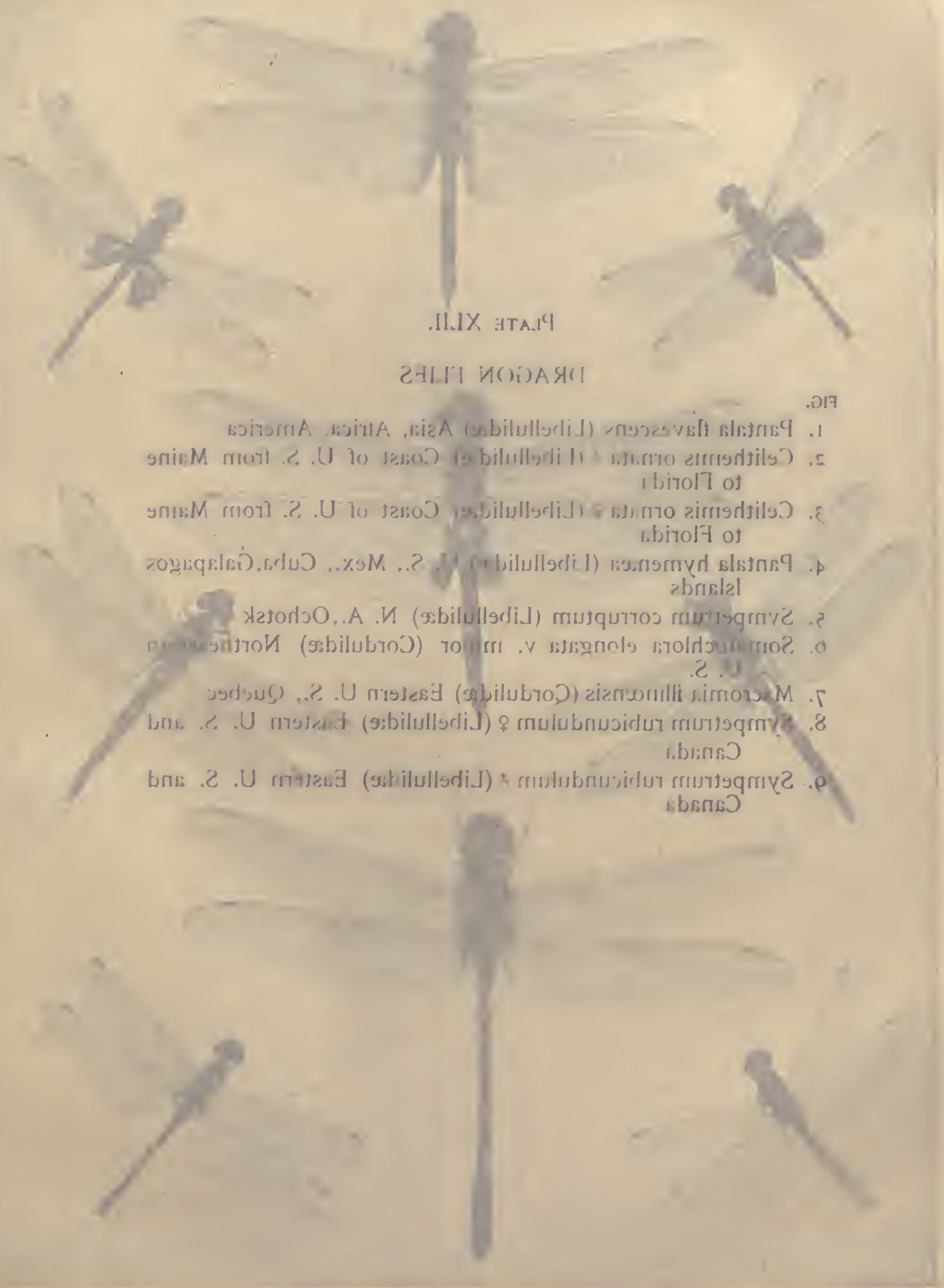




\section{DAMSEL-RLES}

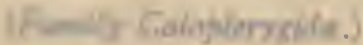

Thía fantily PLATE XLII.

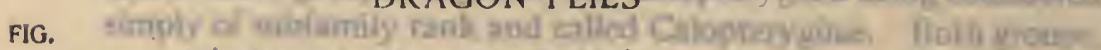

1. Pantala flavescens (Libellulidæ) Asia, Africa, America

2. Celithemis ornata 3 (Libellulidx) Coast of U. S. from Maine ho to Florida

3. Celithemis ornata \& (Libellulidæ) Coast of U. S. from Maıne Q to Florida

4. Pantala hymenæa (Libellulidæ) U. S., Mex., Cuba, Galapagos Islands

5. Sympetrum corruptum (Libellulidæ) N. A., Ochotsk

6. Somatochlora elongata v. minor (Cordulidx) Northeastern U. S.

7. Macromia illinœnsis (Cordulidæ) Eastern U. S., Quebec

8. Sympetrum rubicundulum $q$ (Libellulidæ) Eastern U. S. and Canada

9. Sympetrum rubicundulum f (Libellulidæ) Eastern U. S. and Canada

and The ere

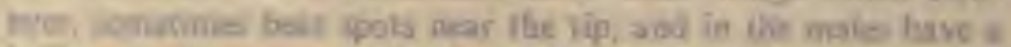

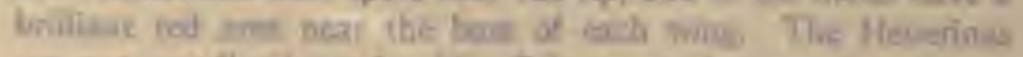

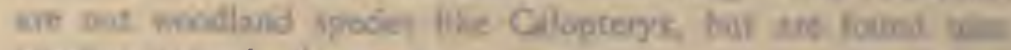
huaning wive in the opso. 


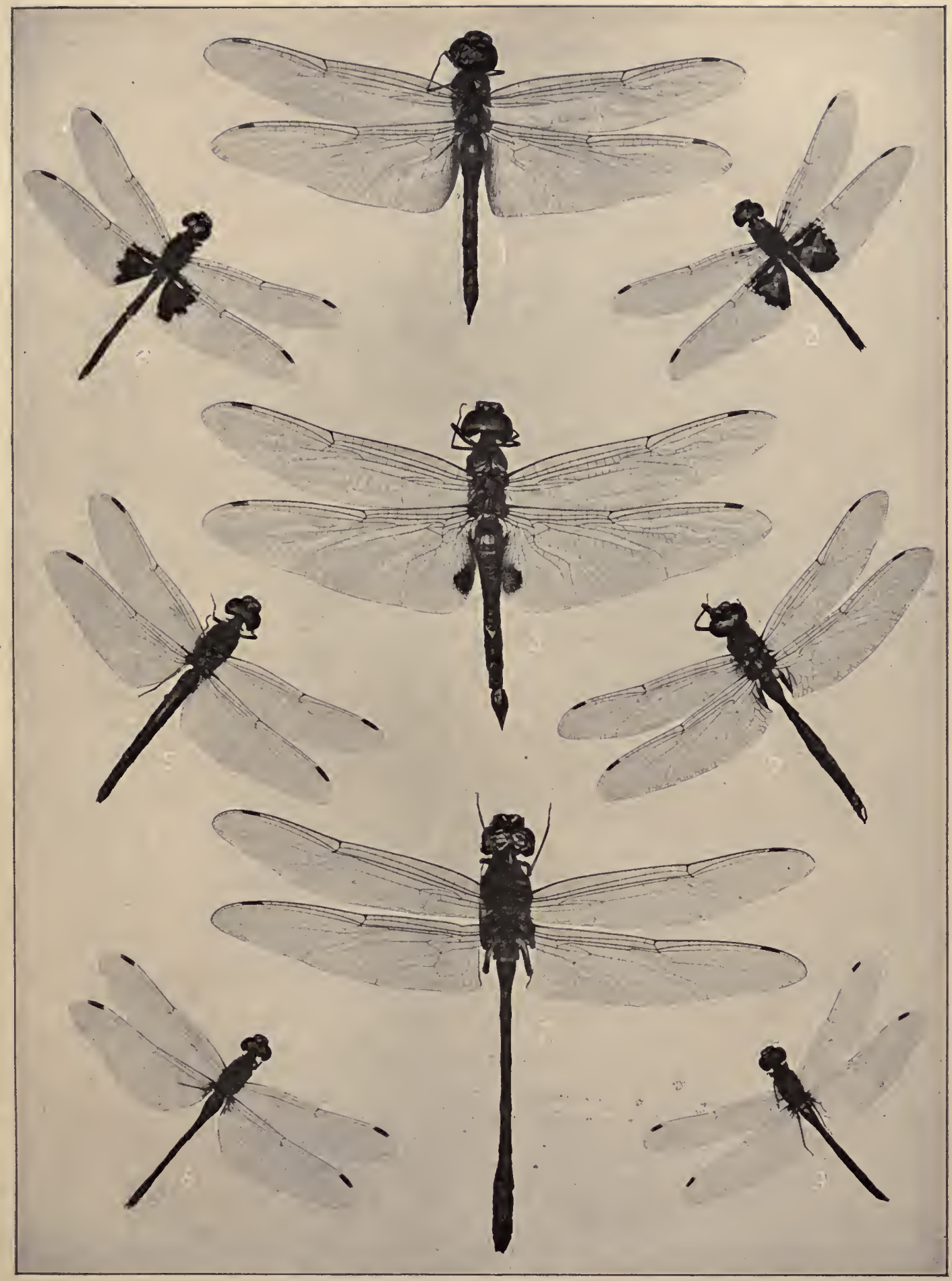




\section{FAMILY AGRIONID AE}

These are the true damsel flies, and are the small, graceful species with extremely slender bodies and narrow, clear wings, which are very commonly found flying over large bodies of still water, and with which every one who has ever rowed a boat on a fresh water lake must be perfectly familiar. They are found in great numbers in the reedy borders of the fresh water ponds and lakes over the entire country. All of our North American species are small, but in tropical regions they grow to large size, and some South American forms are among the largest species of the order Odonata. They do not fly high in the air, but frequent low-growing aquatic vegetation. The colors as a rule are rather dull, but the slender bodies of some are brilliantly blue, green or even yellow, and sometimes red.

The family is a large one, and about seventy-five species are known in this country. Lestes and Enallagma are the largest genera. 


\section{TRUE DRAGON-FLIES}

\section{(Family Gomphida.)}

In this family and the following ones the wings are held horizontally when the insects are in repose; also the eyes are not pop eyes. This group is also by late authors considered a subfamily of the Æschnidæ, and is then called Gomphinæ. They are separated from their nearest allies from the fact that their eyes are widely separated. The species are rather large, and with certain forms the end of the abdomen appears much swollen, especially in the male; as, for example, in the interesting form known as Gomphus vastus Walsh.

Kellicott says of these dragon-flies: "Their habits are various. Some are found only about the rapid streams or wave-tossed lakes; others by reedy pools; while others haunt sloughs mantled by lily pads. They do not fly about in apparent sportiveness, as do the Libellulas. The females rest among the adjacent foliage or on the ground in some nearby pathway, repairing at intervals to the water's edge or skimming the roughened surface of the rapid stream or disturbed lake for oviposition. The males rest nearer the water, skirt the bordering aquates, or explore the water far from shore in search of the ovipositing females. Copulation is at rest in low herbage or high up in trees. The female oviposits unattended by the male, and the eggs are washed from the tip of the abdomen by repeated dips into the water either in some quiet nook among the weeds or in other species far out on the rough surface of swift stream or wind-disturbed lake. Most species fly in early summer, some in mid, and a few late in summer." 


\section{FAMILY CORDULEGASTERIDAE}

This group is also considered by recent authors to be simply a subfamily of the Æschnidæ. They resemble the species of the foregoing group, but the eyes touch at a single point on the top of the head. They are all large insects, and there are comparatively few of them in the United States. None of them are common. The colors are not metallic, but their bodies are usually banded with brown and yellow, the wings for the most part being nearly clear.

Needham says: "The imagos are strong of flight, and are oftenest seen coursing back and forth over some small stream, flying on a regular beat, and passing and repassing the same point at intervals of a few minutes. The collector may take advantage of this habit and so station himself that he may reach the specimen as it passes and capture it if dexterous enough with the net. The nymphs live on the bottom in shallow water, buried in clean sand or in vegetable silt. Though buried, they do not burrow, but descend by raking the sand from beneath them by sweeping lateral movements of the legs. When deep enough, they kick the sand up over the back till only the elevated tips of the eyes and the respiratory aperture at the tip of the abdomen are exposed. By placing a live nymph in a dish of sand and water, and watching, its method may be observed in a very few minutes. The whole comical performance reminds one strongly of the descent of an old hen in a dust bath." The same authority says that, when once placed, the nymph will remain for weeks without changing position, but when some little insect comes near it throws out its jaws and captures it. One species was seen in the nymph stage to capture and eat young brook trout as long as the nymphs themselves. 


\section{FAMILY ASCHNIDAE}

This is one of the largest groups of dragon-flies, and comprises many of our largest forms. The eyes meet on top of the head. In coloration and general appearance they are much like the preceding families but with the majority of them the wings are generally clear with only apical brown spots and sometimes they are a little smoky. These large dragon-flies are abundantly found all through the summer. They are among the first to appear in spring and among the last to disappear in the autumn. Their flight is very strong, and the large species are most ferociouslooking creatures. In fact, the largest and most powerful dragonfly in the North American fauna is Epioeschna heros Fabr. One of the commonest forms which may be seen in many parts of the country is Anax junius Drury. On account of the strong flight of these insects they are frequently found far away from the place of their birth seeking their prey in the fields and about open places in the woods, busying themselves continually in the capture of flies and even larger insects. The male and female of Anax junius paired are common objects flying over the water. The female seems to prefer to lay her eggs in stagnant pools or in ponds where the surface is covered with duckweed and other aquatic plants. The female submerges her abdomen in laying her eggs. According to Williamson, this species appears in large and compact flocks, some of them numbering several hundred individuals, and they pass back and forth frequently near the ground as twilight comes on, seeking especially swarms of midges.

Six genera are represented in this country, mostly the species belonging to the typical genus Æschna. 


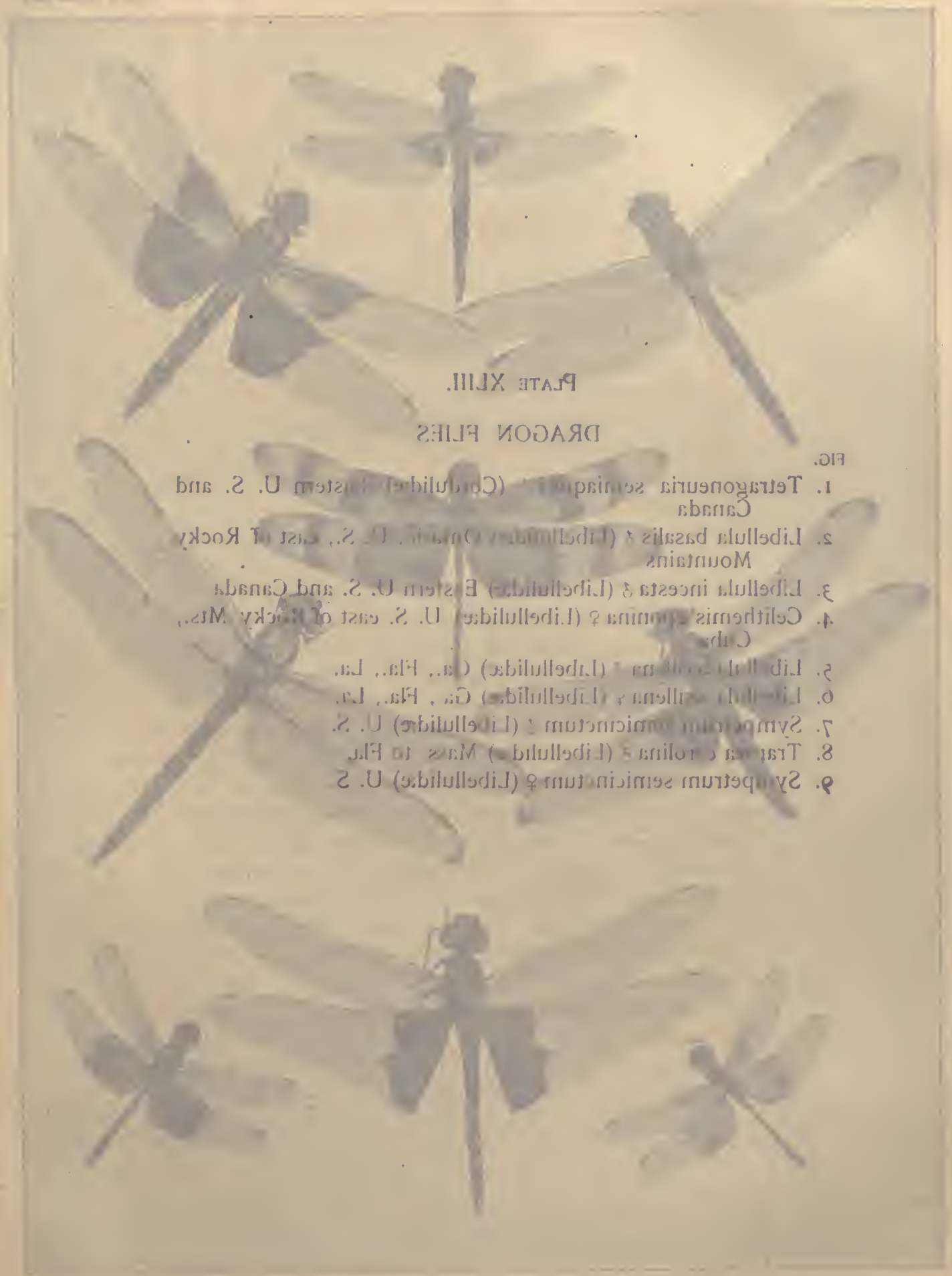




\section{FAmiY ABCMNDAA}

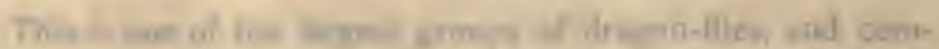

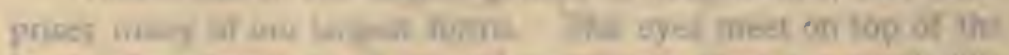

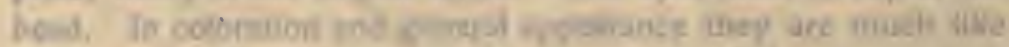

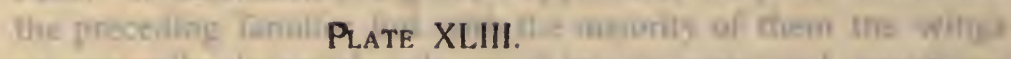

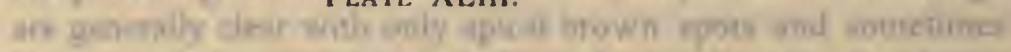

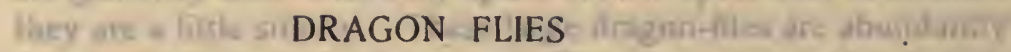

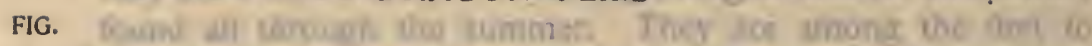

1. Tetragoneuria semiaquea of (Cordulidæ) Eastern U. S. and Canada

2. Libellula basalis $\tilde{f}$ (Libellulidæ) Ontario, U. S., east of Rocky Mountains

3. Libellula incesta $\delta$ (Libellulidx) Eastern U. S. and Canada

4. Celithemis eponina 9 (Libellulidæ) U. S. east of Rocky Mts., Cuba

5. Libellula axillena $\delta$ (Libellulidæ) Ga., Fla., La.

6. Libellula axillena $\&$ (Libellulidx) $\mathrm{G} a$, Fla., La.

7. Sympetrum semicinctum ơ (Libellulidx) U. S.

8. Tramea carolina of (Libellulidx) Mass. to Fla.

9. Sympetrum semicinctum o (Libellulidx) U.S.

Sympetrum semicinctum 9 (Libellulidee U. Sa

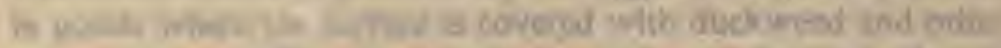

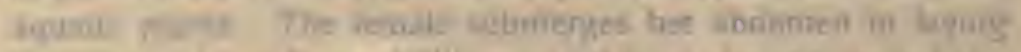

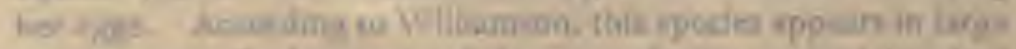

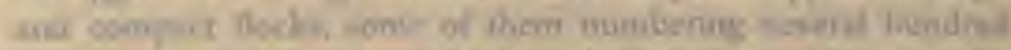

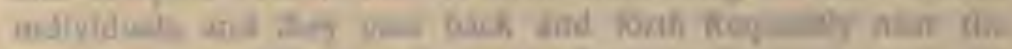

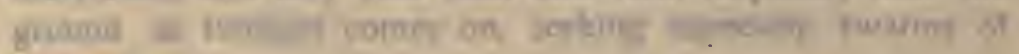
widse

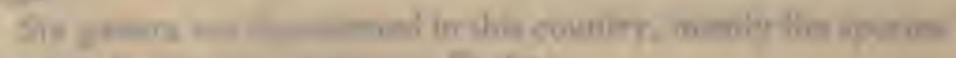

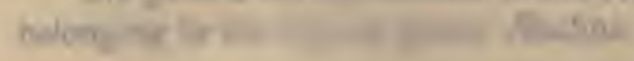




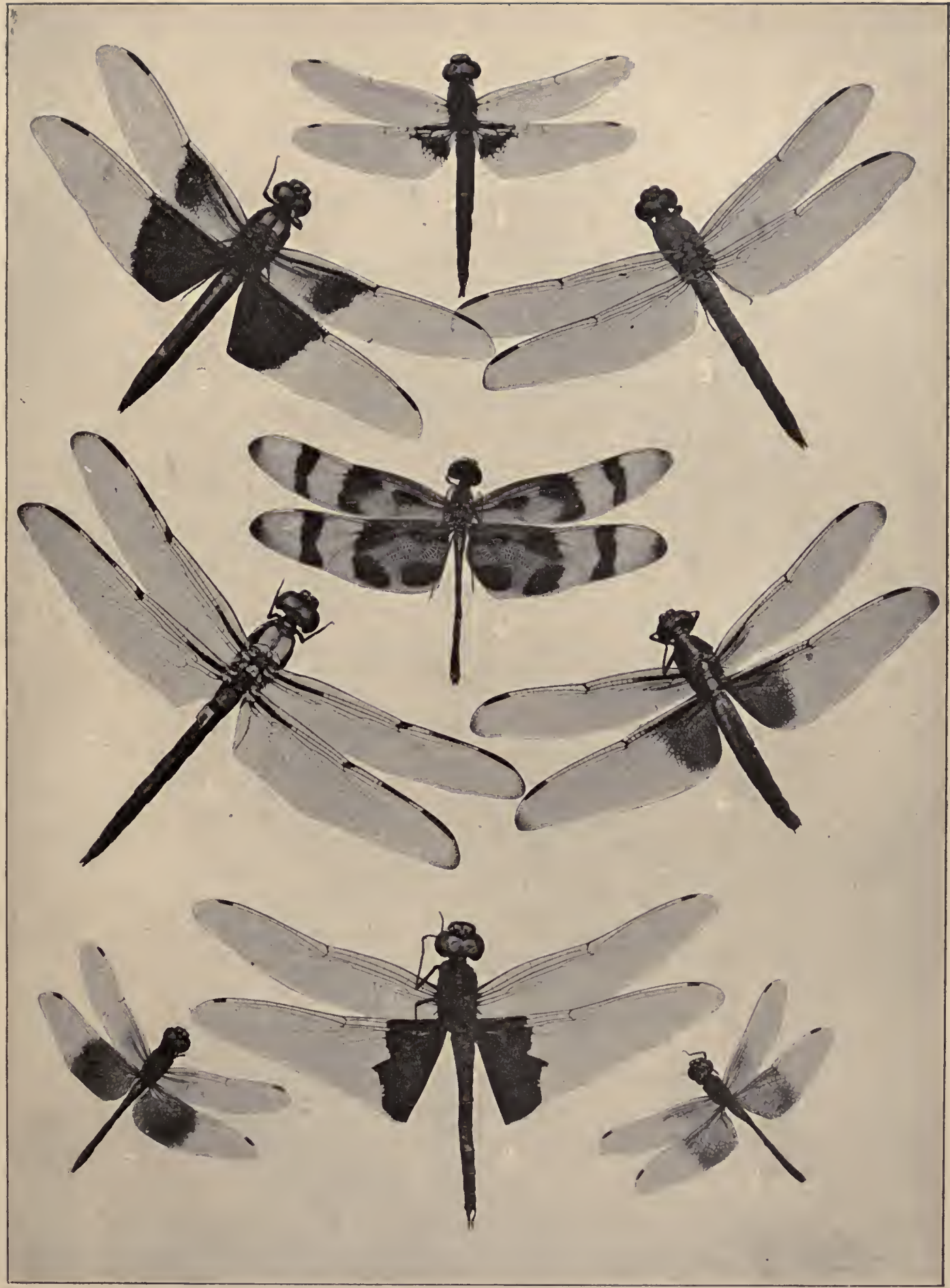


1

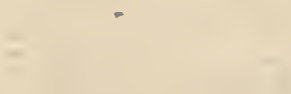




\section{FAMILY CORDULIDAE}

With this group we approach the large family Libellulidæ, the Cordulidæ being distinguished by possessing a single tubercle on the hind border of each eye, and in fact these insects are by most recent authors considered to be simply a subfamily of the Libellulidæ, which they resemble in most respects. They are medium sized, or large dragon-flies in which the wings are frequently banded with brown, although in some forms the dark markings occur only at the base of the wings, and some are entirely clear. The body colors may be metallic or sordid. These insects, according to Kellicott, oviposit by flying close to the surface of the water striking the water occasionally with the tip of the abdomen to wash off the eggs. 


\section{FAMILY LIBELLULIDAE}

This is one of the largest dragon-fly groups in the United States, and comprises some of the most beautiful species. With many forms the wings are beautifully banded with brown, either in a series of cross bands or with large blotches which sometimes cover the basal half of the wings. The abdomens of some species are covered with a whitish powder-like substance which is not seen when the insects first emerge from the nymph, but which, when they grow old is sometimes so abundant as to make the abdomen appear perfectly white. A characteristic feature of these forms, especially those of the typical genus Libellula is that the abdomen assumes the shape of a prism, with a strong sharp longitudinal ridge above the flat sides and a flat underside. In some forms the wing markings are not dull brown, but become yellowish and in the very handsome and common Libellula pulchella, of Drury, the brown spots alternate with milk-white spots. They are very abundant about stagnant ponds and such pools as harbor water-lilies and rushes. They are favorite food of the king bird.

The females poise themselves close to the surface of the water, remaining almost motionless and striking the water with the tip of the abdomen in the act of laying their eggs.

With the exception of the Agrionidæ these are the most numerous dragon-flies in this country.

Needham says that the nymphs are sprawlers upon the bottom, mainly in shallow water, or clamber over fallen plant stems, and are protectively colored.

A single egg-mass of one of these dragon-flies has been observed by Needham to contain 110,000 eggs.

Williamson has shown that one of the species has the habit of resting on the top of a rush, each one being, apparently, proprietor of a certain territory. When another one encroaches, "he is quickly hustled away by the rightful and irate owner." 


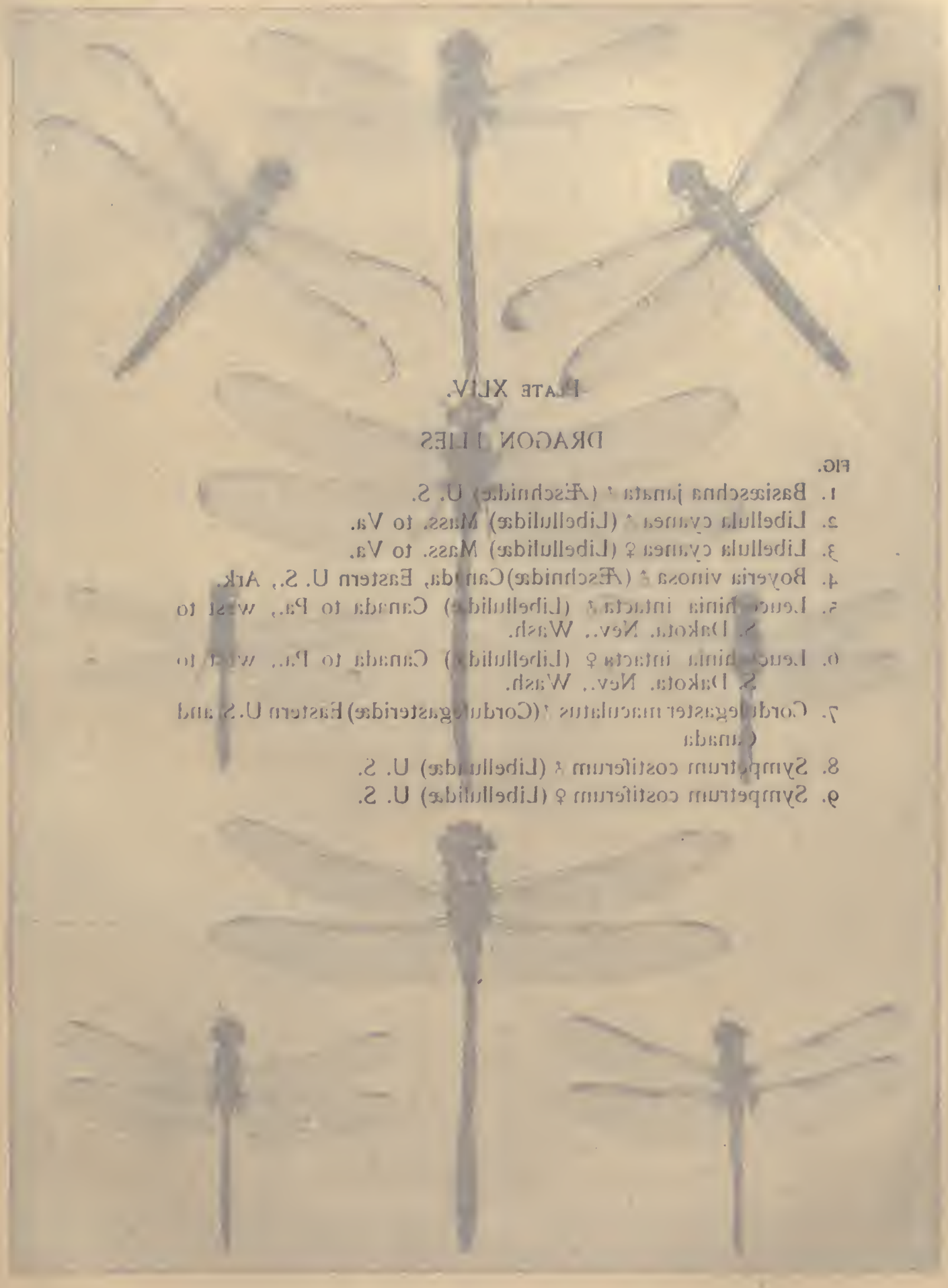




\section{FANILY LIBELLULIOA}

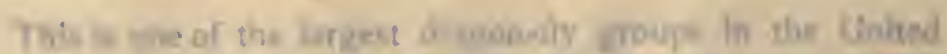

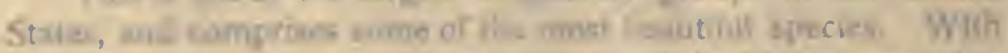
meny foone dia wi PLATE XLIV.

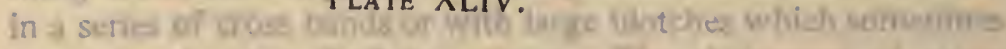

FIG. seccles are coverea with a w FLIES

1. Basiæschna janata of (Aschnidæ) U. S, engt firom the nympth, het

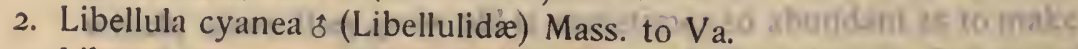

3. Libellula cyanea of (Libellulidæ) Mass. to Va. nast in fownes of

4. Boyeria vinosa of (Æschnidæ) Canada, Eastern U. S., Ark.

5. Leucorhinia intacta of (Libellulidæ) Canada to Pa., west to

S. Dakota, Nev., Wash.

6. Leucorhinia intacta o (Libellulidæ) Canada to Pat, west to

S. Dakota, Nev., Wash.

7. Cordulegaster maculatus $\delta($ Cordulegasteridæ) Eastern U.S. and

Canada

8. Sympetrum costiferum $\delta$ (Libellulidæ) U. S.

9. Sympetrum costiferum o (Libellulidæ) U. S.

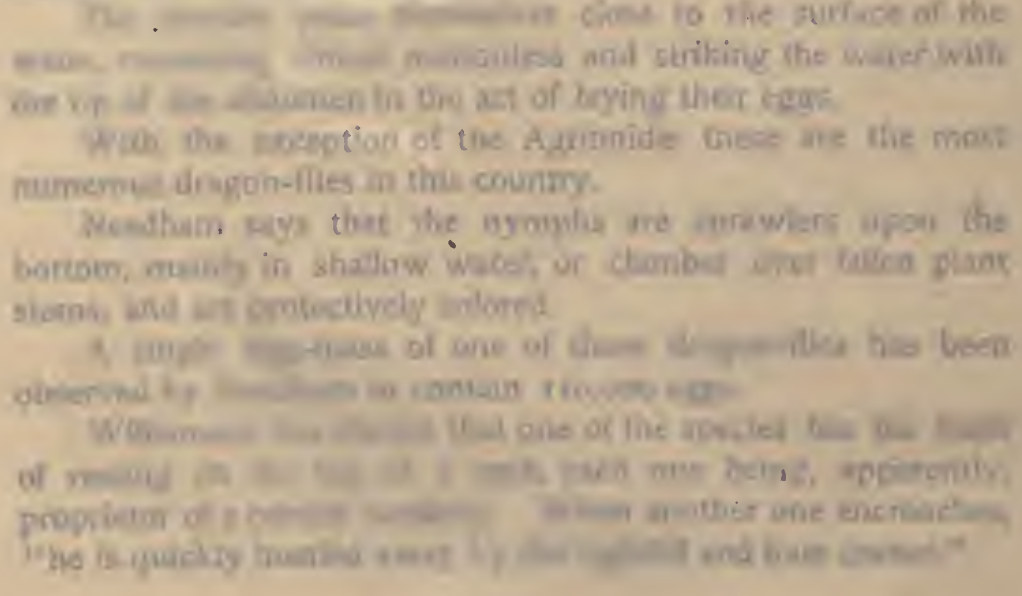




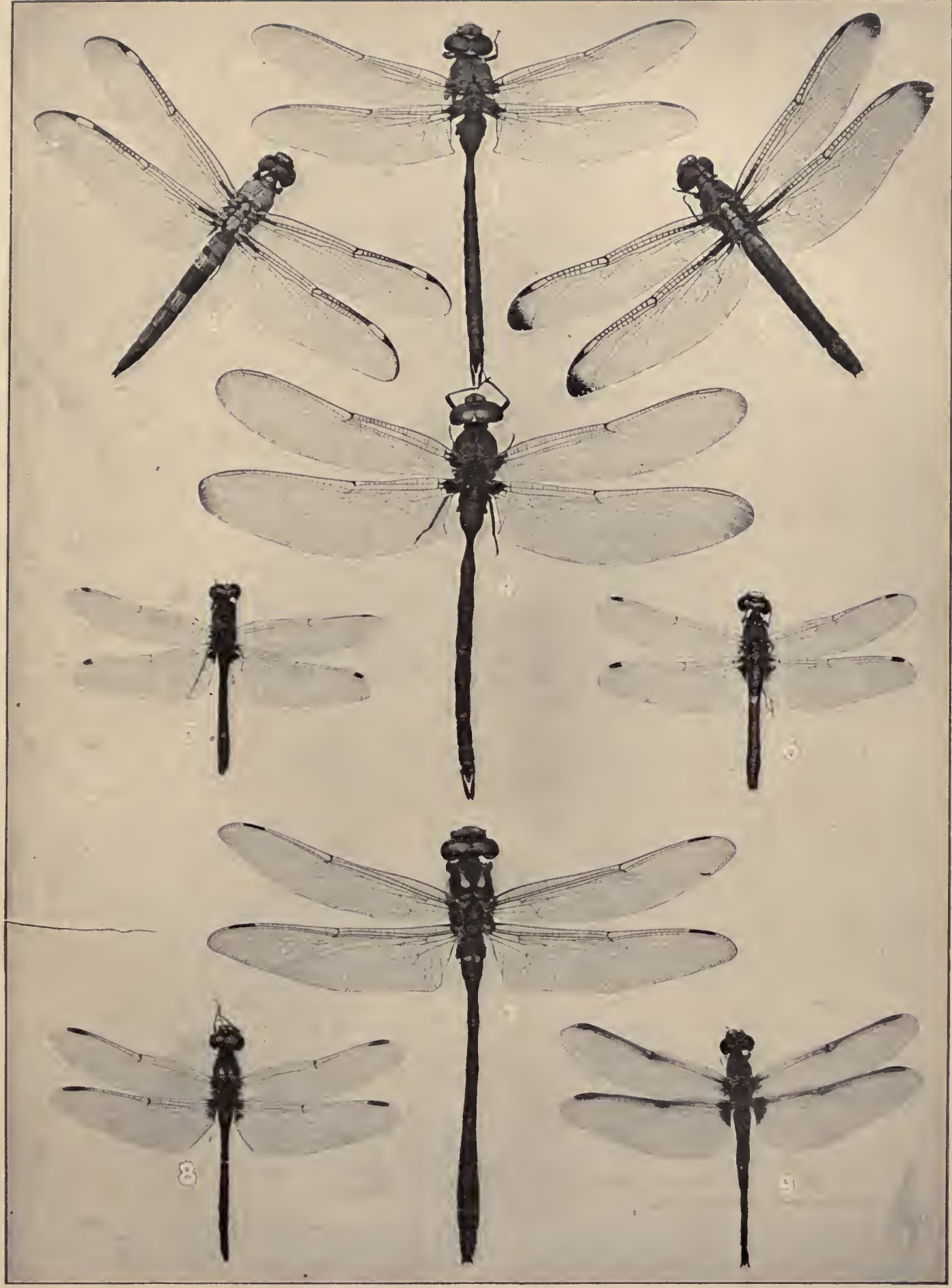





\title{
THE MAY-FLIES OR SHAD-FLIES
}

\author{
(Order Ephemerida.)
}

The so-called May-flies, or shad-flies, are the insects which constitute this order. They are known by one name or the other by almost every one who has seen them swarming about the electric lights during the summer or who lives in the vicinity of some large watercourse in which these insects breed in incalculable numbers. Structurally speaking, the adult insects are very interesting creatures. They are distinguished from other insects by their short antennæ, their extremely large front wings as compared with the very small hind wings, the absolutely atrophied mouth-parts and the long, slender filaments, two or three in number, at the end of the abdomen. The transformations are complete and the early stages are always passed in the water.

The larvæ are active creatures with long, strong legs, and breathe by means of tracheal gills. They both swim and crawl and feed very largely upon vegetable matter, diatoms and confervæ being found in their stomachs. They may be found under stones in running streams or swimming among water plants in quiet waters, or they may live at the bottom more or less covered with slime or mud. Some forms burrow into the sand-banks of rivers. The pupa or nymph is also active and feeds. It has small wing pads, and, when ready to transform, it floats upon the water, and the skin of the back opens and the winged insect flies out. The emergence is extremely rapid and the insect flies away almost immediately after the skin cracks. A very curious phenomenon occurs with these insects which is not found with any other insect, and that is that there is a molt after the fly issues from the nymph. It flies away to the shores in the condition called the sub-imago stage and again the skin splits and the true-imago, or adult, issues. This shedding of the sub-imago skin is said sometimes to take place while the insect is flying in the air.

The life of the adult is short; in fact, these insects were named after the Ephemerides of the Greek mythology, creatures which lived but a day, and from this root comes our common 
word, ephemeral. But they live longer than a day. They do not eat, since, as we have stated, the mouth-parts are atrophied and the alimentary canal is not fitted for the digestion of food; but it has been shown that where the air is not too dry some of them can live for several days. It is stated that Curtis kept one alive for three weeks; but in general they die within three or four days, and frequently in a few hours, or even less time. The males are readily distinguished from the females from the fact that with the males the hind legs only are atrophied or feeble, while with most females the fore legs as well as the hind legs are too feeble to support the body. When at rest the front legs are generally extended straight in front of the head, and frequently very close together, the anal setæ usually slanting upwards. As a rule they remain quiet during the day, limiting their flight to the cooler hours of sunlight or extending it later in the evening, just after sunset. Where there is a strong artificial light they will fly until late in the night. The numbers in which these creatures swarm are often extraordinary. I drove through a dense cloud of them once on the banks of the St. Lawrence River in the month of June when both the air and the ground and our clothes looked as though the heaviest kind of a snow-storm were raging. Along the shores of the Great Lakes their bodies are frequently massed in great windrows miles in length and of a very considerable thickness.

Most of them couple during flight, the male undermost. Egg-laying is usually performed in fresh water, though one exotic species lays in brackish water. The females of some species discharge the contents of their ovaries at once in the form of a pair of egg-clusters. These upon reaching the water rapidly disintegrate, and the eggs sink to the bed of the river or stream. Others drop their eggs gradually, a few at a time, the female either alighting on the surface of the water at intervals to wash off the eggs that have issued, or she creeps down into the water, enclosed within a film of air, to lay her eggs on the under side of stones, after which she floats up to the surface and either flies away or is drowned. In one case a female has been seen to deposit living larvæ.

These insects can readily be bred in fresh water aquaria, but Eaton says that it is important not to grow Ranunculus in the aquaria, because the sap exuding from its broken stems appears 

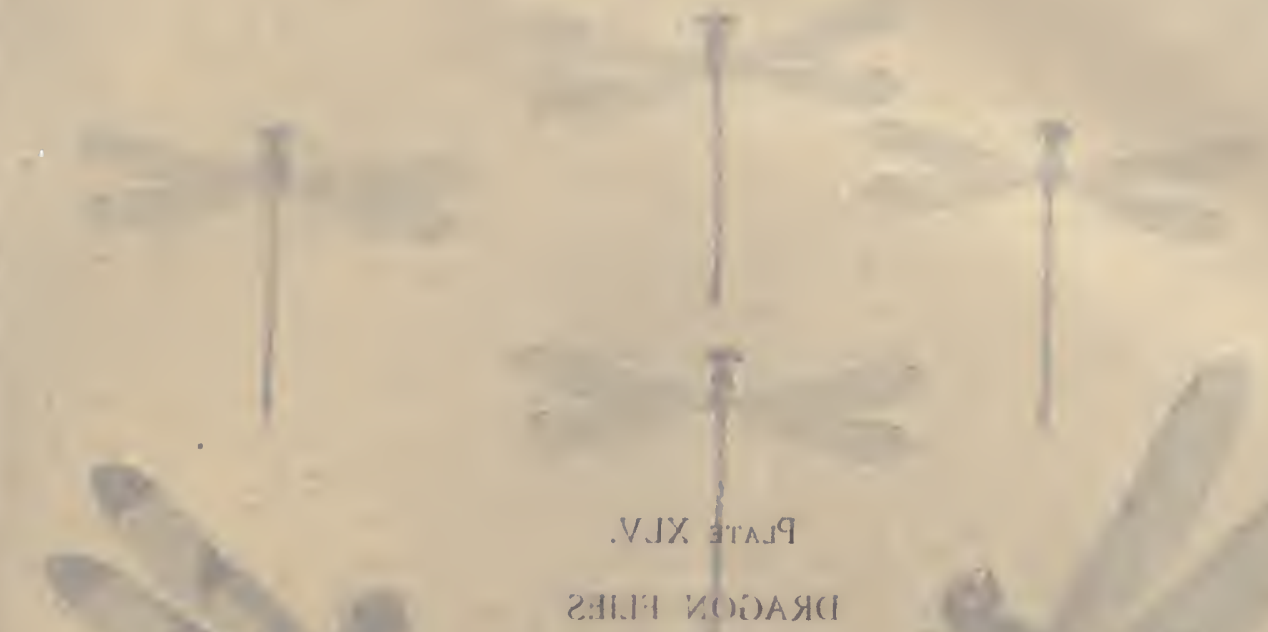

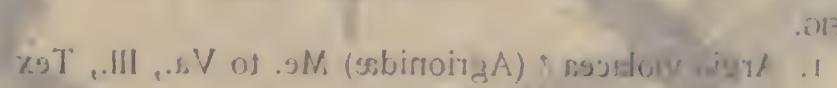

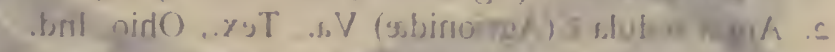

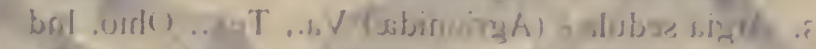

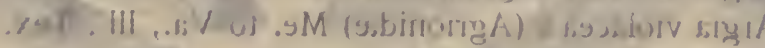

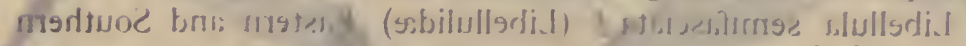

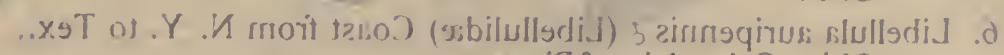
zagi to glel idis , oido

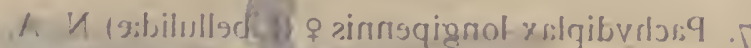

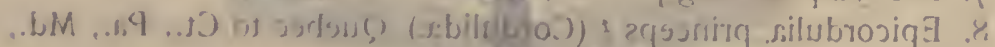
.xsT , III , Hoim, ..nis)

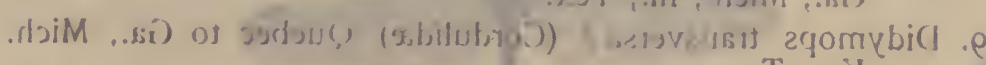
. $.5 T$ T. $Y$ त्र 


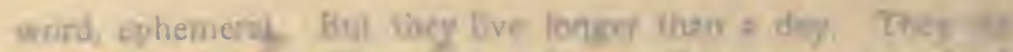
aot ear, siacs is winavestated. the mouth para are atcuphis

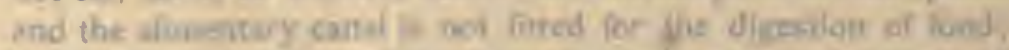

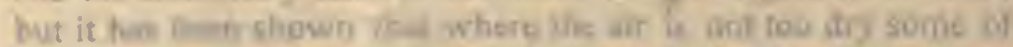

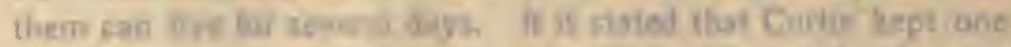

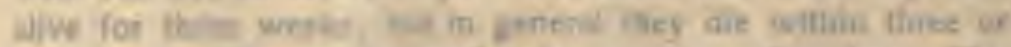

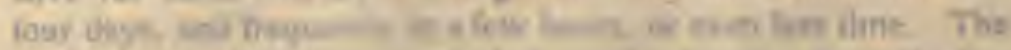

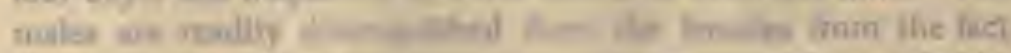

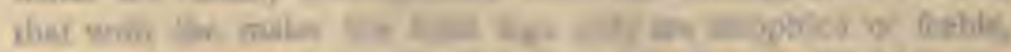
While wah mow ton

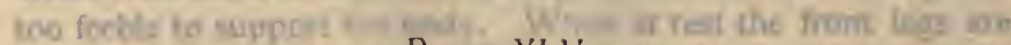

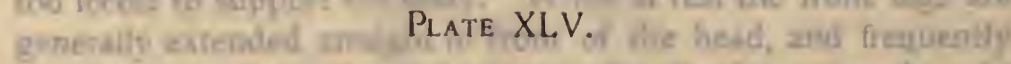

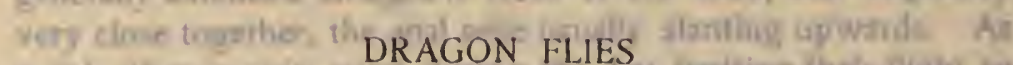

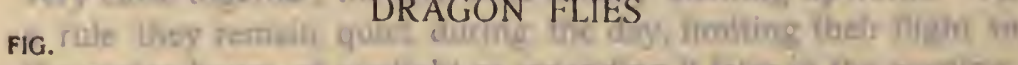

1. Argia violacea of (Agrionidx) Me. to Va., Ill., Tex.

2. Argia seduli $q$ (Agrionidx) Va.. Tex., Ohio, Ind.

3. Argia sedula of (Agrionidx) Va., Tex., Ohio, Ind.

4. Argia violacea + (Agrionidx) Me. to Va., Ill., Tex.

5. Libellula semifasciata of (Libellulidæ) Eastern and Southern U. S.

6. Libellula auripennis $\hat{o}$ (Libellulidx) Coast from N. Y. to Tex., Ohio, Cuba, Isle of Pines

7. Pachydiplax longipennis $\$$ (Libellulidæ) N. A.

8. Epicordulia princeps ô (Cordulidæ) Quebec to Ct., Pa., Md., Ga., Mich., Ill., Tex.

9. Didymops transversa ô (Cordulidæ) Quebec to Ga., Mich. Ky., Tex.

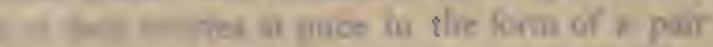

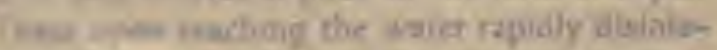

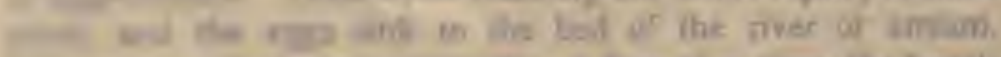

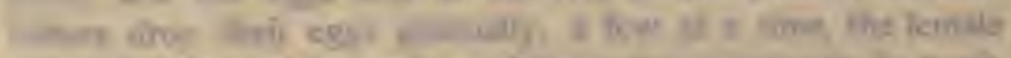

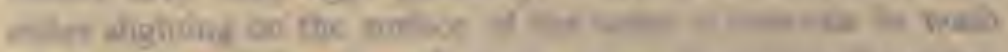

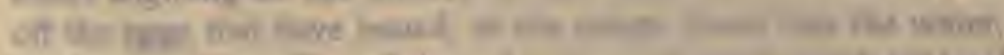

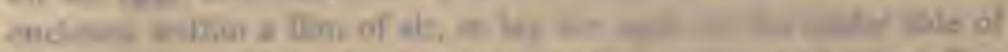

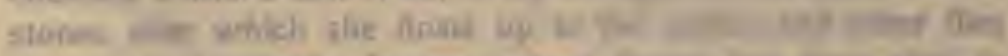

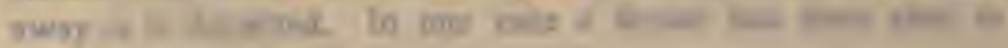

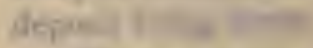

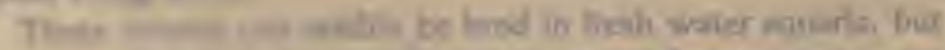

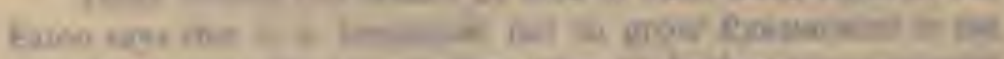

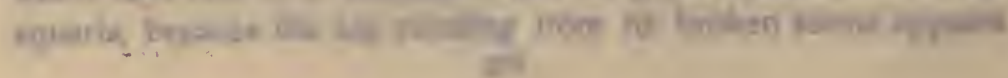




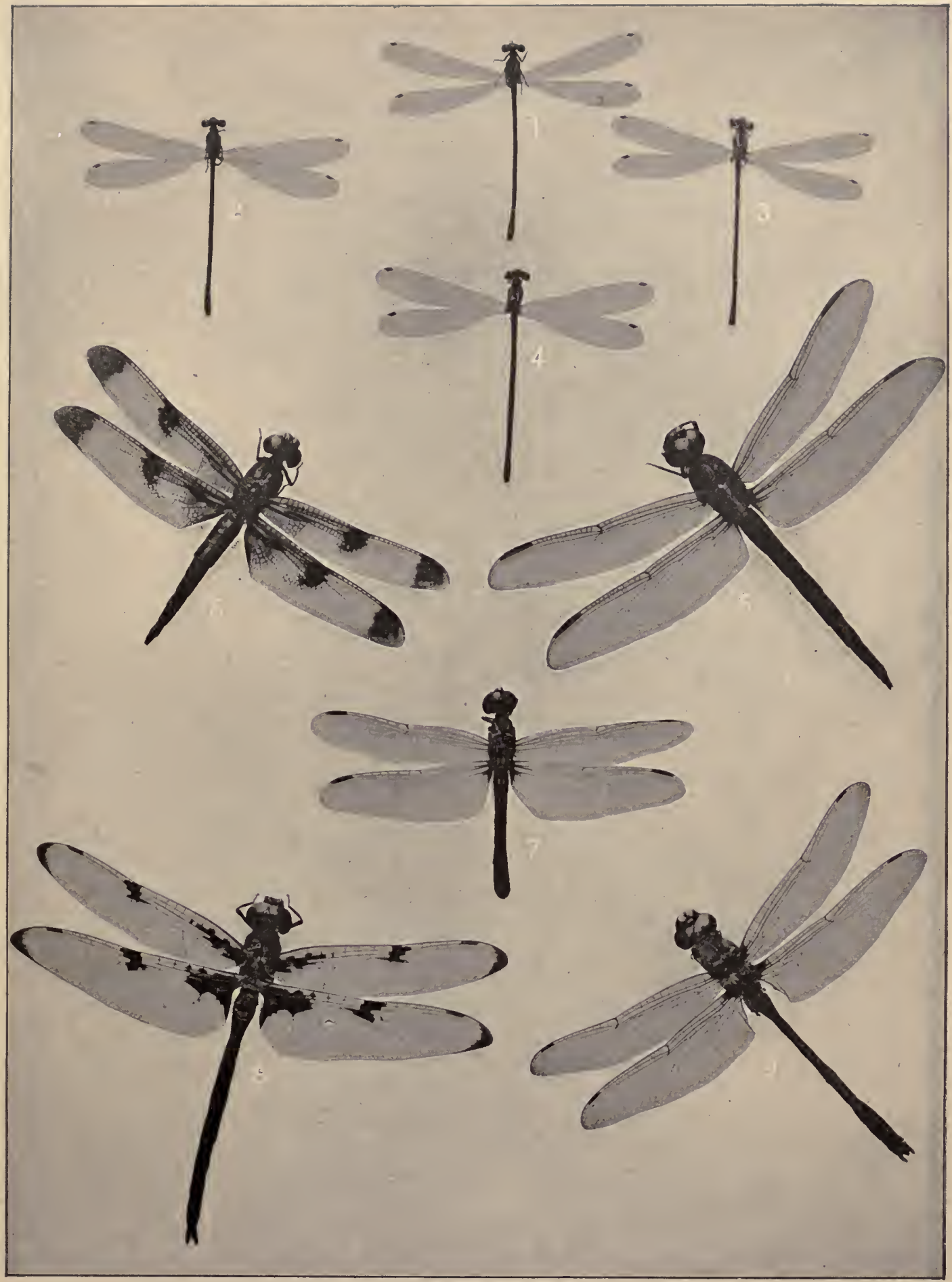


to be poisonous to the larvæ. After the eggs hatch the larvæ live upon mud or the small vegetation which grows on stones and the stems of large water-plants. Some of them are apparently predaceous. They cast their skins several times during the first few days after their birth.

These larvæ, or nymphs, as all of the early stages of the Mayflies are called, are very important fish food. Forbes has found them to be the most important food of the white bass, the toothed herring, the shovel-fish and the croppies, while the rock bass, the common perch, the striped bass, the darters, the catfish, the suckers, and many other freshwater fish feed upon them very largely. The writer has been appealed to quite recently on the subject of the possible extermination of these insects along the St. Lawrence River, where they cause so much annoyance by their swarming flight, but their value as food for fish would make such an extermination extremely undesirable. The St. Lawrence is noted for its fine fish and the fishing possibilities attract so many summer visitors to its shores that the tem. porary annoyance of the shad-flies should joyfully be borne.

The larval life is a long one, lasting from one to three years, and the number of molts is very large. There may be as man'y as twenty. The adults, as well as the larvæ, are favorite fist. food. Of the swarms that issue, many meet their ultimate resting place in the water, or more strictly speaking, in the stomachs of fishes. Fishes are so well acquainted with them that imitation shad-flies afford the best bait in certain regions. In England the so-called flies known as duns, drakes, and spinners are all imitations of Ephemerids. Although so enormously numerous in individuals, the Ephemerida is not a large group in number of species, and only about three hundred have been described. There must be very many more, however, and possibly the difficulty with which these insects are preserved in collections accounts for the fact that comparatively few have been named. If pinned they shrivel up and dry into such queer shapes that the coloration and structural characters become obscure. Good aquarium studies for any of our North American species will be found to be interesting and will be of valuable record.

A very good table for determining the nymphs of May-flies has been prepared by Needham, and will be found in Bulletin 48 of the New York State Museum of Natural History, Albany, Igol. 


\section{THE SPRINGTAILS AND FISHMOTHS}

\section{(Order Thysanura.)}

The insects of this order are usually of very small size, and are wingless and have practically no metamorphoses. They comprise the little insects known as springtails, bristletails, fishmoths or slickers. They have three pairs of legs, the mouth-parts, often hidden, are formed for biting, and the skin is delicate. The order is supposed to comprise the most generalized or simplest forms of insect life and although there is some reason for considering that they are degenerate insects the consensus of opinion is that they are living representations of primordial insects. Some of them possess a very remarkable leaping arrangement in the shape of a spring-like process on the under side of the abdomen, which enables them to jump in an extraordinary way, some of them have long abdominal appendages or processes at the end of the body, and still others have short leg-like processes on the under surface of the abdomen. The order as at present understood comprises two suborders, namely the Cinura and the Collembola. Formerly some curious creatures belonging to the genus Scolopendrella were considered as belonging to this order and were placed in a suborder by themselves-the Symphyla-but it is thought now that these little creatures are more closely related to the Myriopoda than to the true Insecta.

The two remaining suborders may be separated as follows: With bristle-like and many-jointed appendages or forceps at the end of the abdomen, which is composed of ten segments and does not possess a sucker on the ventral side............

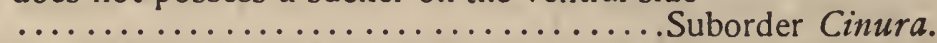

With a forked sucker on the under side of the first abdominal segment, and the abdomen, which is composed of not more than six segments, furnished with a spring-like apparatus near the tip, or without appendages...Suborder Collembola. 


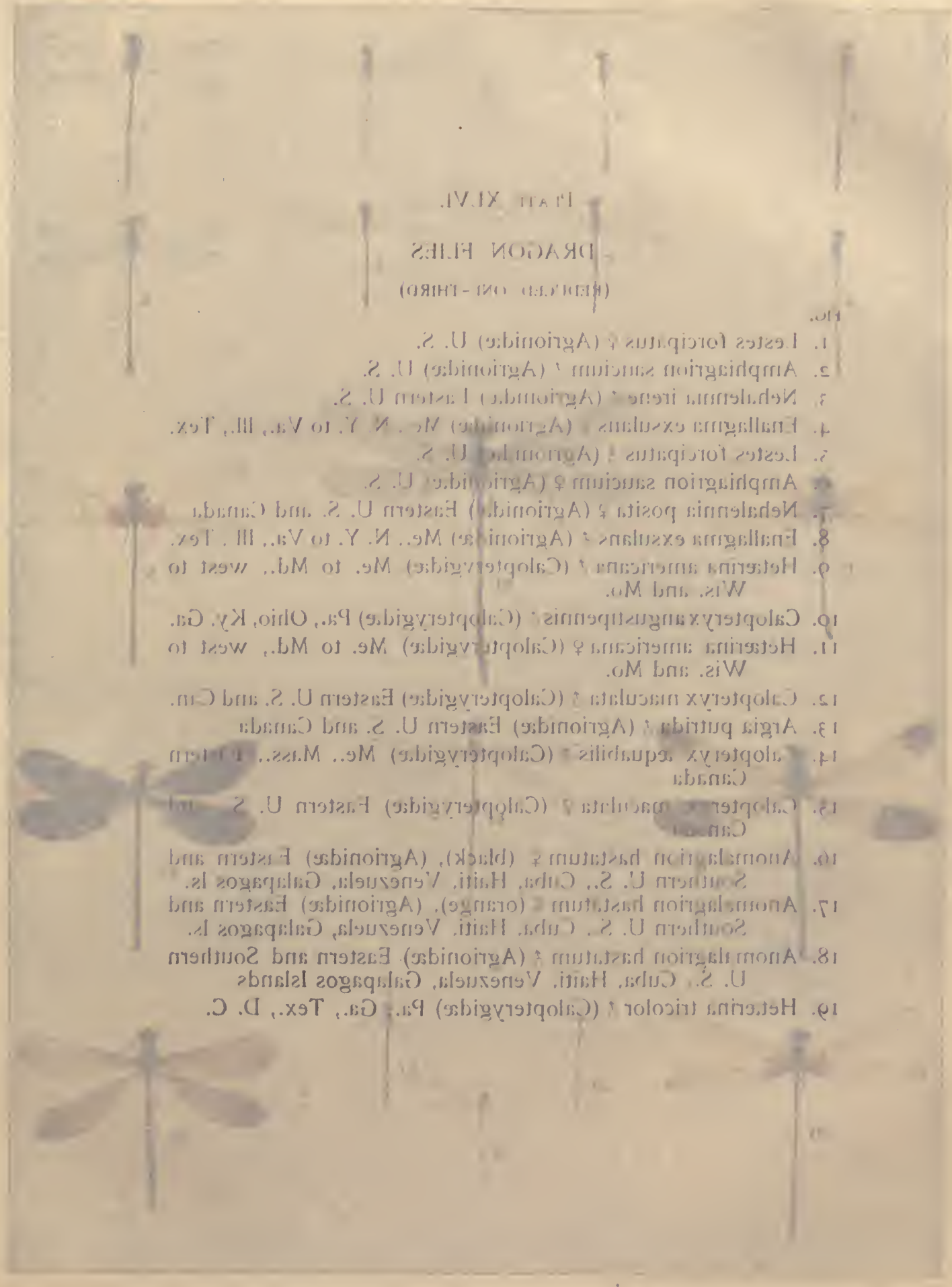




\section{THE SPIRIN PLATE XI.VI. AND FISEIMOTHS DRAGON FIJIES \\ (REDHCHII ONI-THIRD)}

FIG.

1. Lestes forcipatus of (Agrionidie) U. S.

2. Amphiagrion saucium of (Agrionidx) U.S.

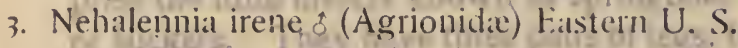

4. Fnallagma exsulans o (Agrionide) Me., N.Y. to Va., Ill., Fex.

5. Lestes forcipatus $\$$ (Agrionide) U.S.

6. Amphiagrion saucium o (Agrionidx) U. S.

7. Nehalennia posita o (Agrionidæ) Eastern U. S. and Canada

8. Enallagma exsulans \& (Agrionidx) Me., N. Y. to Va.. III.. Tex.

9. Hetærina americana of (Caloptervgidæ) Me. to Md., west to Wis, and Mo.

10. Calopteryxangustipennis ô (Calopterygidie) Pa., Ohio, Ky. Ga.

11. Hetærina americana o (Calopterygidæ) Me. to Md., west to Wis. and Mo.

12. Caloptery $x$ maculata $\delta$ (Calopterygidæ) Eastern U. S. and Can.

13. Argia putrida $\delta$ (Agrionidæ) Eastern U. S. and Canada

14. Calopteryx æquabilis of (Calopterygidæ) Me., Mass., Eastern rol Canada

15. Calopteryx maculata $q$ (Calopterygidæ) Eastern U.' S., and Canada

16. Anomalagrion hastatum ol (black), (Agrionidæ) Eastern and betic Southern U. S., Cuba, Haiti, Venezuela, Galapagos Is.

17. Anomalagrion hastatum o (orange), (Agrionidæ) Eastern and Southern U. S., Cuba, Haiti, Venezuela, Galapagos Is.

18. Anomalagrion hastatum ô (Agrionidx) Eastern and Southern U. S., Cuba, Haiti, Venezuela, Galapagos Islands

19. Hetærina tricolor ô (Calopterygidæ) Pa., Ga., Tex., D. C. 


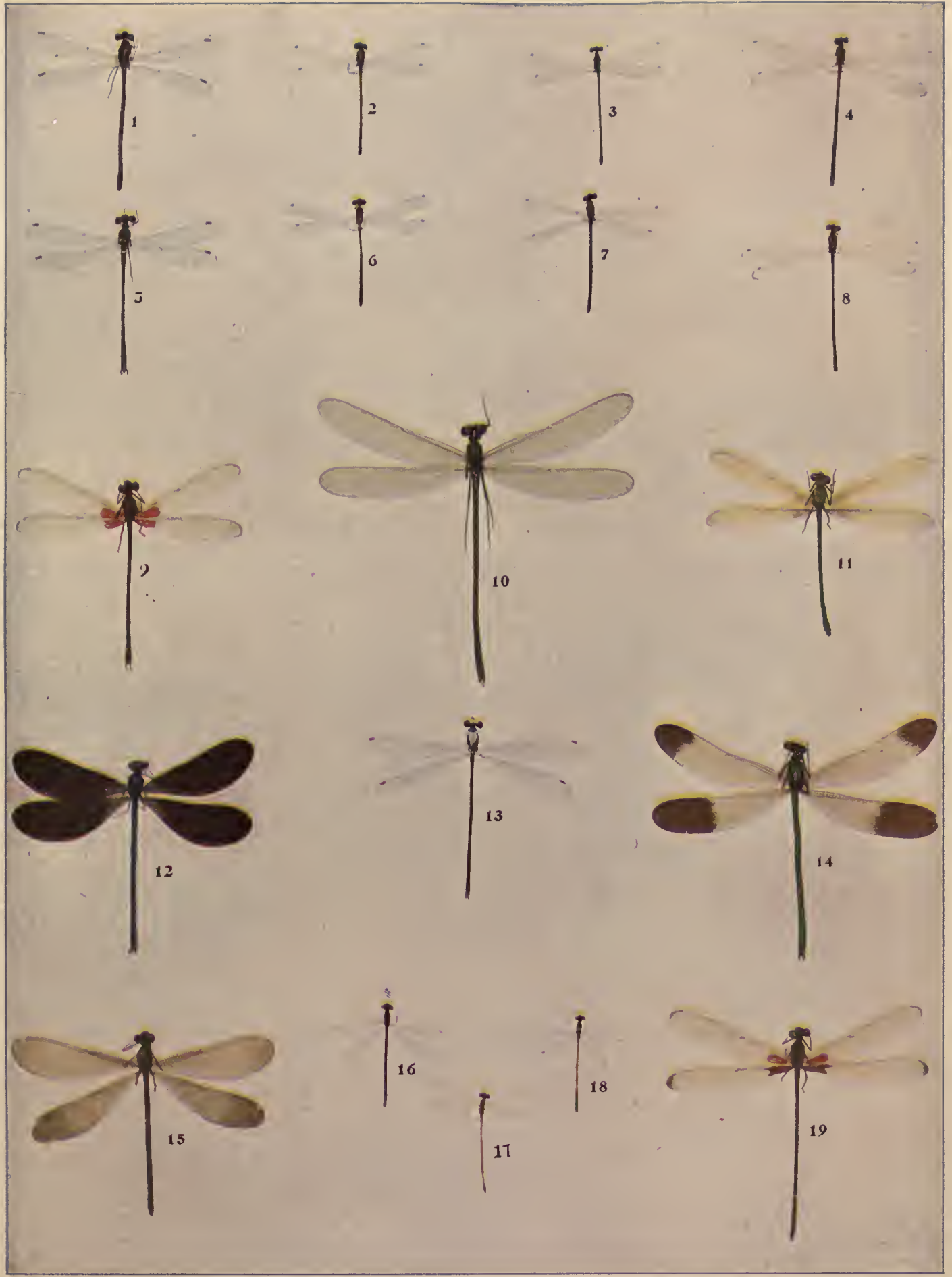




\section{SUBORDER CINURA}

There will be no necessity for generalizations regarding this suborder, aside from the mention of the characters by which it is separated from the Collembola. In this country it is represented by species belonging to three distinct families, which may be separated as follows:

Mouth-parts buried in the head.................

Mouth-parts not buried.............. Family Lepismatidoe

I-Anal end of the body with a pair of forceps.. Family Japygidae Anal end of body with long antenna-like processes......... 


\section{FAMILY LEPISMATIDAE}

The little insects which are known to housekeepers, particularly in the Southern States, as the silver fish, or fishmoths, or slickers, belong to this family. They are covered with scales, usually of a silvery appearance, and have three long antenna-like

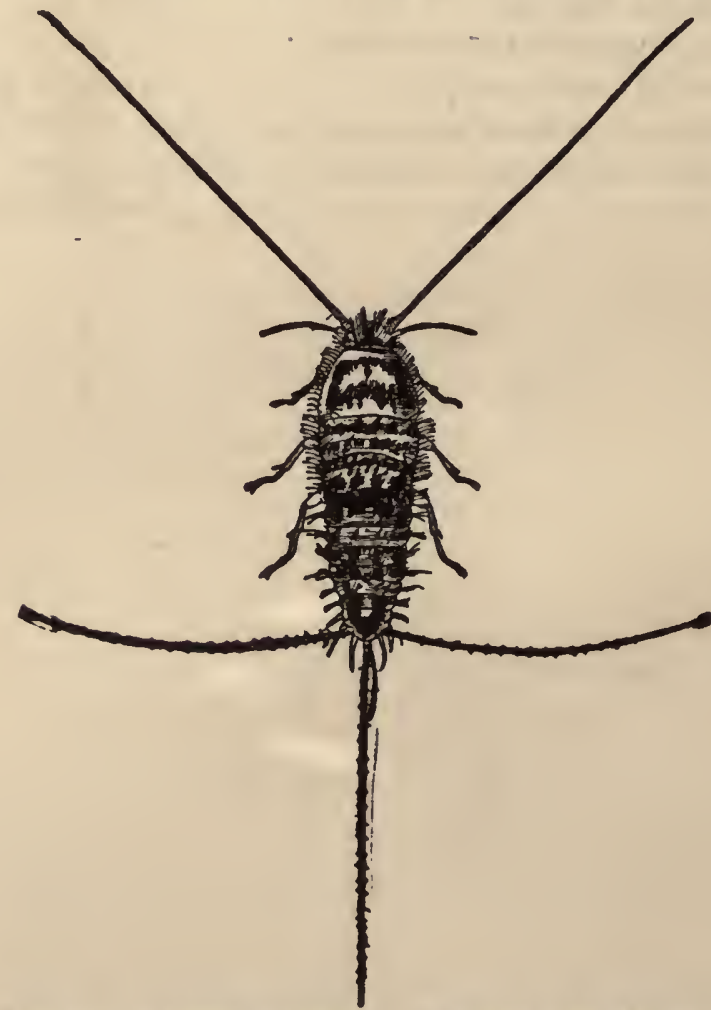

Fig. 244-Lepisma domestica. (Redrawn from Narlatt.)

processes issuing from the end of the abdomen. These insects are often very troublesome household enemies of books, papers, starched clothing, and occasionally stored foods. They also 382 
damage the card labels in museums. They move very rapidly, and make active efforts to conceal themselves. They shun the light, and slip from the fingers with ease, the silvery scales coming off and, the insect escapes at the expense of its clothing. In damaging the cloth bindings of books, it is really trying to feed upon the paste with which the cloth is stuck to the boards. Heavily glazed paper is attractive to them, and they will eat the glaze from drafting linen. They are found commonly in old houses in rather damp places, but one of our species seems to prefer the vicinity of fireplaces, crawling rapidly over hot bricks and metal and showing most surprising immunity from the effects of high temperature. They are readily destroyed by a free use of pyrethrum powder.

Nothing is known about their life history. Their eggs have not

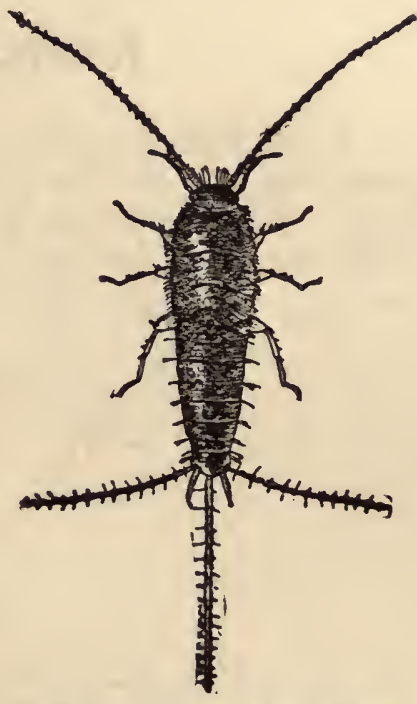

Fig. 245.-Lepisma saccharina. (Redrawn from Marlatt.) been described, and of the number of molts and the rapidity of development we are absolutely ignorant. None of these points ought to be especially difficult to ascertain.

Ten or more species occur in the United States, and those which are not found in houses are generally found in decaying wood. 


\section{FAMILY JAPYGIDAE}

These little creatures differ from the other Cinurans in the possession of a peculiar forceps-like structure at the end of the body. They are slender in form, and are found in moss or in shady places at the edges of woods. They look like young earwigs. Nothing is known of their development or life history.

\section{FAMILY CAMPODEIDA}

These little insects have elongate and cylindrical bodies, and the first seven of the abdominal segments bear each a pair of appendages on the under surface. We have only three species in this country. They are found in loose, damp earth in which there is much vegetable mold. 


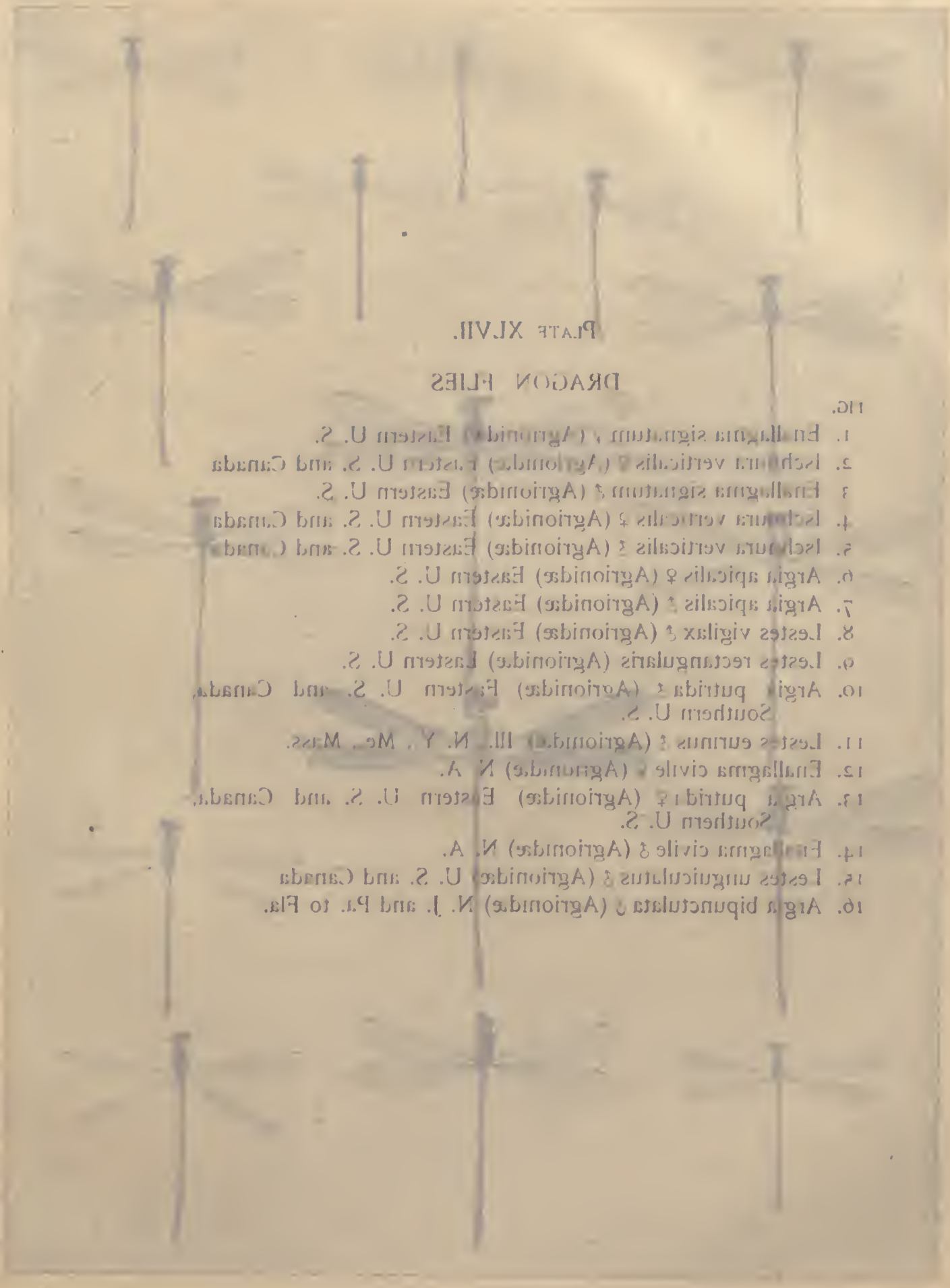




\section{FAMU Y PAPYGIDA6}

FIG.

\section{Plate XlVII.}

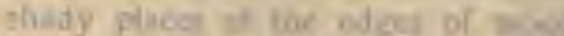 \\ DRAGON FLIES}

1. Enallagma signatum $q$ (Agrionidx) Eastern U. S.

2. Ischnura verticalis $q$ (Agrionidæ) Eastern U. S. and Canada

3. Enallagma signatum ô (Agrionidæ) Eastern U. S.

4. Ischnura verticalis \& (Agrionidæ) Eastern U. S. and Canada

5. Ischnura verticalis ô (Agrionidæ) Eastern U. S. and Canada

6. Argia apicalis $q$ (Agrionidæ) Eastern U. S.

7. Argia apicalis of (Agrionidæ) Eastern U. S.

8. Lestes vigilax of (Agrionidæ) Eastern U. S.

9. Lestes rectangularis (Agrionidæ) Eastern U. S.

10. Argia putrida $f$ (Agrionidx) Eastern U. S. and Canada, Southel'n U. S.

11. Lestes eurinus ô (Agrionidæ) Ill., N. Y., Me., Mass.

12. Enallagma civile $q$ (Agrionid $x)$ N. A.

13. Argia putrida o (Agrionidx) Eastern U. S. and Canada, Southern U. S.

14. Enallagma civile of (Agrionidæ) N. A.

15. Lestes unguiculatus of (Agrionidx) U. S. and Canada

16. Argia bipunctulata of (Agrionidx) N. J. and Pa. to Fla. 


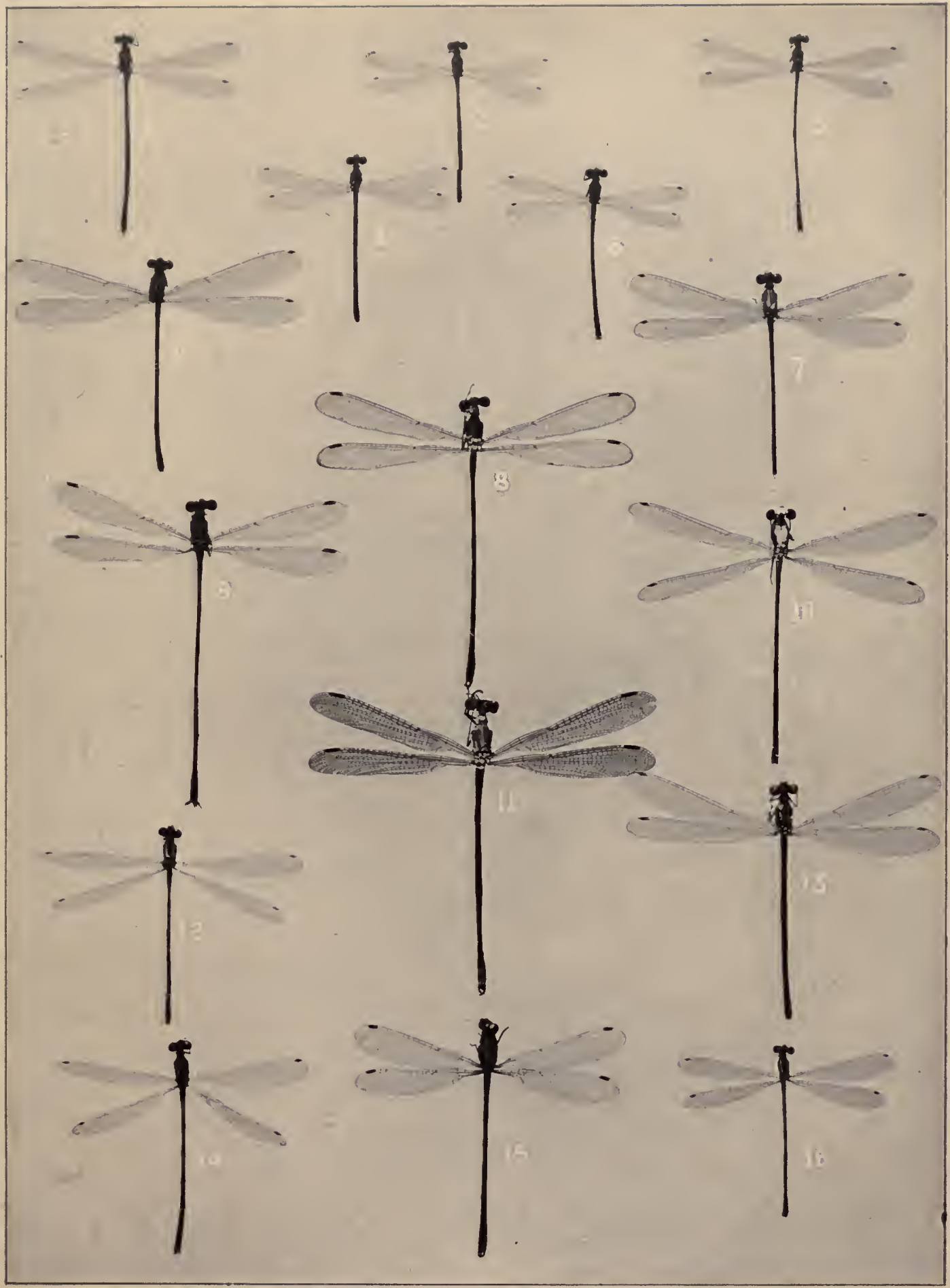




-




\section{SUBORDER COLLEMBOLA}

This suborder is composed of very minute insects which possess the faculty of springing suddenly, and which when alarmed make use of this means of escaping. They are found in the spring in the Northern States on bright sunny days when the snow is thawing, frequently in great numbers on the surface of the snow. They are also found on the surface of water, in old wells, and even at considerable distances under the surface of the ground feeding apparently. upon vegetable mold.

Five families are represented in the United States, which may be distinguished by the following table:

A ventral spring below the abdomen.............. I

No ventral spring below the abdomen.... Family Aphorurida I-Ventral spring on the second from last abdominal segment.... . Family Podurida

Ventral spring on the next to the last abdominal segment.. 2 2-Abdomen elongate, cylindrical, much longer than broad..... .......................... Family Entomobryidae

Abdomen globular, but little longer than broad......... 3

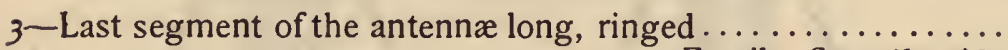
......................... Family Smynthurida

Last antennal segment short, with a whorl of hairs........ ............................ Family Papiriida 


\section{FAMILY APHORURIDAE}

This group is composed of small insects which have no ventral spring. They are soft-bodied, and move slowly, and are very seldom noticed although not uncommon.

\section{FAMILY PODURIDAE}

The Podurids are among the most abundant of insects, although on account of their excessively small size they do not attract much attention.

We have something more than a half dozen species in this country and one of them, Achorutes nivicola, is the form, as one might know from its name, which is commonly found in the late spring upon the surface of snow.
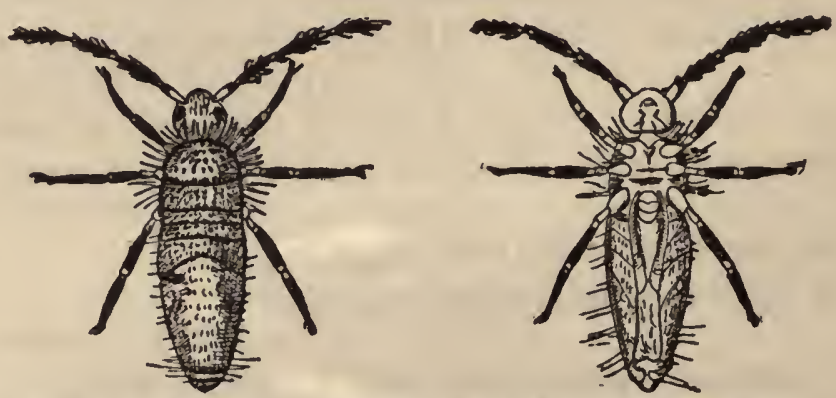

Fig. 246.-Lepidocyrtus americanus. (Redrawn from Marlatt.)

They are commonly found in deep soil which contains more or less soil humus, and have been taken in a stiff clay subsoil at a depth of six feet, but they had probably penetrated to this depth by following the path of rootlets. They are found upon the surface of water, on mushrooms, and are common among dead leaves in the woods.

The eggs of one species have been observed. They were fifteen in number, spherical, white, and one one-hundred and eightieth of an inch in diameter. 


\section{FAMILY ENTOMOBRYIDAE}

The forms belonging to this family are found in the earth, in caves, in greenhouses, and in hothouses, on the bark of old trees,

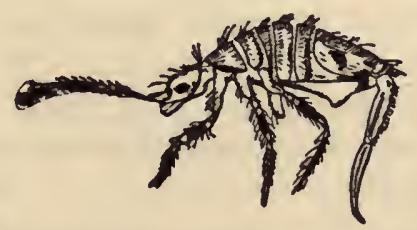

Fig. 247.-Lepidocyrtus americanus. (After Marlatt.)

in cellars, under logs, and in similar localities. One species, Lepidocyrtus americanus Marlatt, is commonly observed in houses in situations similar to those where one finds the silverfish or slickers. It is shown in the accompanying figures.

The development of none of these insects is understood, although the eggs of one European species have been recorded as being laid in the spring. 


\section{FAMILY SMYNTHURIDAE}

These are globular-bodied with long four-jointed antennæ. The ventral spring is composed of a basal portion and two arms. We have a half dozen or more described species in the United States. They occur in vegetable mold, upon decaying wood, and feed upon the spores and mycelium of fungi. Some are found upon aquatic plants, and some under stones in woods. Lubbock, writing of one of these minute insects, Smynthurus luteus, says: "It is very amusing to see these little creatures coquetting together. The male, which is smaller than the female, runs around her and they butt one another, standing face to face and moving backwards and forwards like two playful lambs. Then the female pretends to run away, and the male runs after her, with a queer appearance of anger, gets in front and stands facing her again; then she turns 'round, but he, quicker and more active, scuttles around too and seems to whip her with his antennæ; then for a bit they stand face to face, play with their antennæ, and seem to be all in all to one another."

\section{FAMILY PAPIRIIDAE}

These little creatures are found in moss, and do not seem to be common, only four species having been recognized in the United States 


\section{.IIIV.IX aTA.J9}

\section{टझा.न ИОВАЯด}

. .19

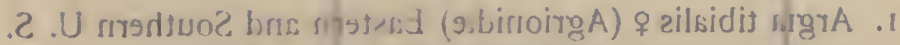

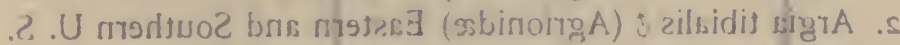

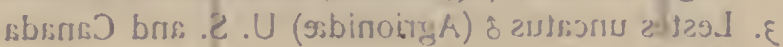

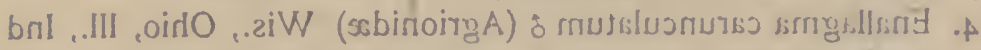

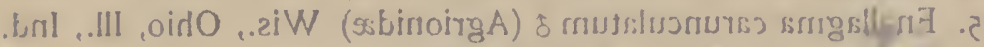

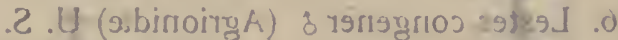

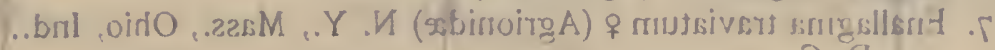

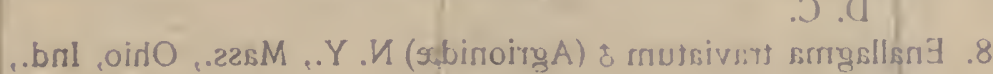

.$j .0$

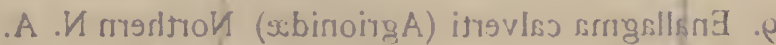

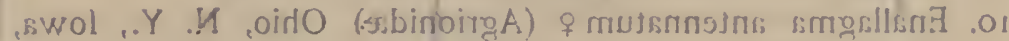
.bol ..lll

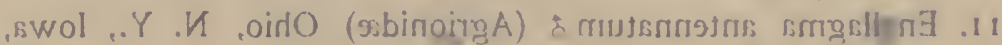
.bril ,. III

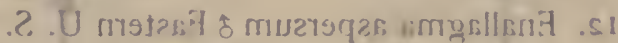

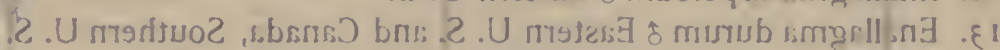

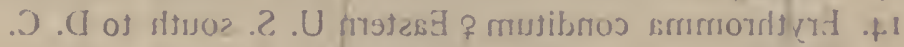

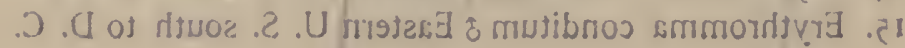




\section{PAMEY SMYNTHUEROAL}

We heve of The PLATE XLVIII.

FIG.

\section{Silien Tlingy DRAGON FLIES}

1. Argia tibialis $q$ (Agrionidæ) Eastern and Southern U. S.

2. Argia tibialis $f$ (Agrionidx) Eastern and Southern U. S.

3. Lestes uncatus ô (Agrionidæ) U. S. and Canada

4. Enallagma carunculatum ô (Agrionidæ) Wis., Ohio, III., Ind.

5. Enaliagma carunculatum ô (Agrionidæ) Wis., Ohio, Ill., Ind.

6. Lestes congener $\hat{o}$ (Agrionidx) U. S.

7. Enallagma traviatum $q$ (Agrionidæ) N. Y., Mass., Ohio, Ind., D. C.

8. Enallagma traviatum ơ (Agrionidæ) N. Y., Mass., Ohio, Ind., D. C.

9. Enallagma calverti (Agrionidæ) Northern N. A.

10. Enallagma antennatum $q$ (Agrionidæ) Ohio, N. Y., lowa, III., Ind.

11. Enallagma antennatum of (Agrionidæ) Ohio, N. Y., lowa, III., Ind.

12. Enallagma aspersum ô Eastern U. S.

13. Enallagma durum $\delta$ Eastern U. S. and Canada, Southern U.S.

14. Erythromma conditum $q$ Eastern U. S. south to D. C.

15. Erythromma conditum of Eastern U. S. south to D. C.

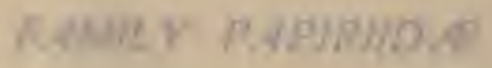




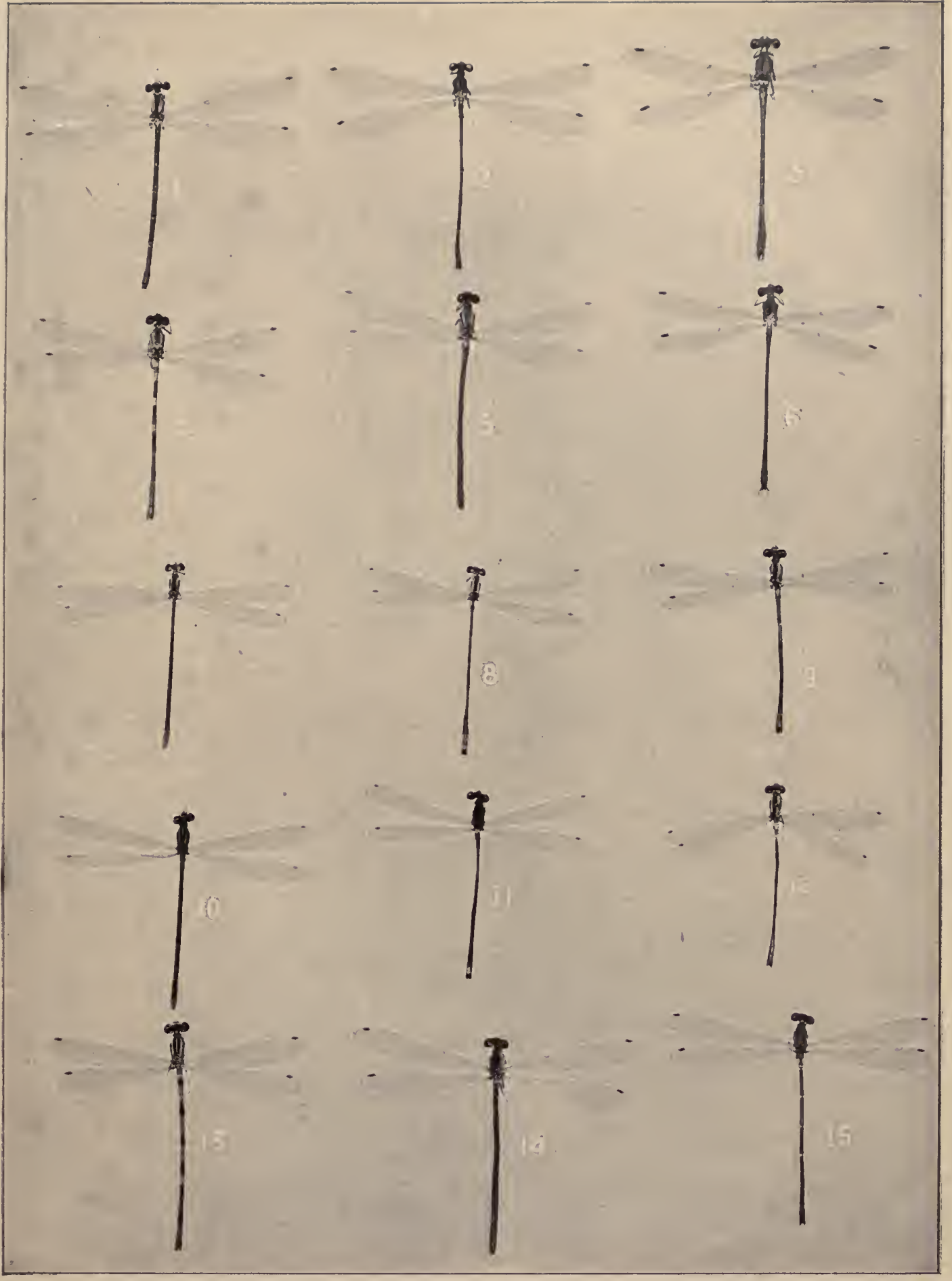


11

w 


\section{COLLECTING AND PRESERVING INSECTS .}

\section{COLLECTING APPARATUS}

The old-fashioned entomologist used to go out armed simply with a net, and pin his captures to the top or brim of his hat. Some of the modern entomologists go into the field laden down with all sorts of apparatus-a large haversack filled with boxes and bottles, two or three different kinds of nets, and with pockets bulging with hatchet, trowel, saw, forceps, knives and other small things. It is just as bad for an entomologist to go out laden down in this way as it is for soldiers to take long marches with unnecessary impedimenta. As a rule one should go out after one class of objects, prepared, however, to capture other interesting specimens, and he should take with him as prime necessities one net (and a proper sweeping net is the most useful), one or two cyanide bottles for killing specimens, a few small pill boxes and a few assorted vials containing dilute alcohol or formalin, and that is really all that is necessary, unless he is after aquatic insects or those which live in old logs or in trunks or branches of trees, in which case a water net or a hatchet will be necessary. Most collecting apparatus can be purchased from dealers in such things. The following firms issue price lists which may be had on application, viz: Queen \& Co., Inc., roro Chestnut St., Philadelphia, Pa.; A. Smith \& Sons, Fulton Street, New York City; John Akhurst, 78 Ashland Place, Brooklyn, N. Y.; The Kny-Scheerer Co., 225 Fourth Ave., New York City; American Entomological Co., 1040 DeKalb Avenue, Brooklyn, N. Y.; Noyes Bros. and Cutler, 396 Sibley St., St. Paul, Minn.

The Net.-There are three main kinds of nets-the light butterfly net, the strong beating or sweeping net and the water net. The butterfly net, which is a very handy one for catching $3^{89}$ 
flies, dragon-flies, ant-lions, scorpion-flies and similar insects with more or less fragile wings, is made in a number of different ways

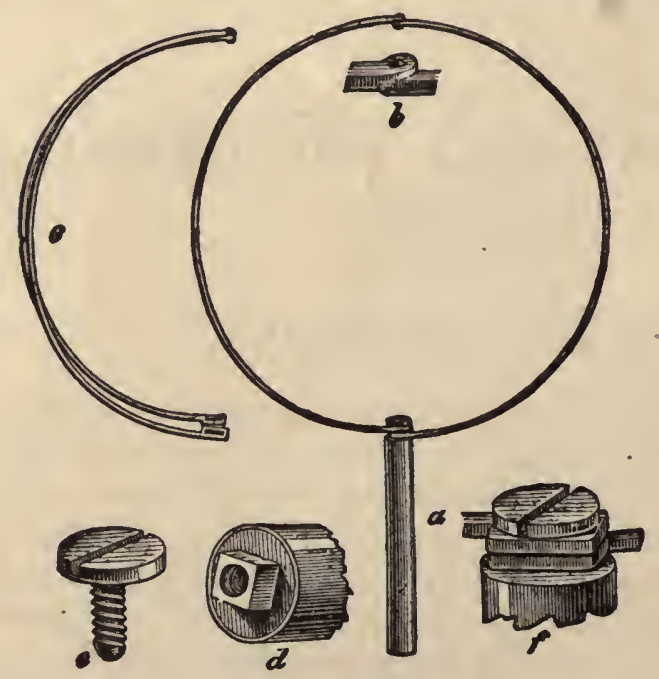

and several excellent ones are for sale by dealers above mentioned. A fairly satisfactory one can be made at home in the following manner: Bend a strong piece of iron wire into circular shape, the ends being abruptly bent

Fig. 248. - The butterfly net frame.

(After Riley.)
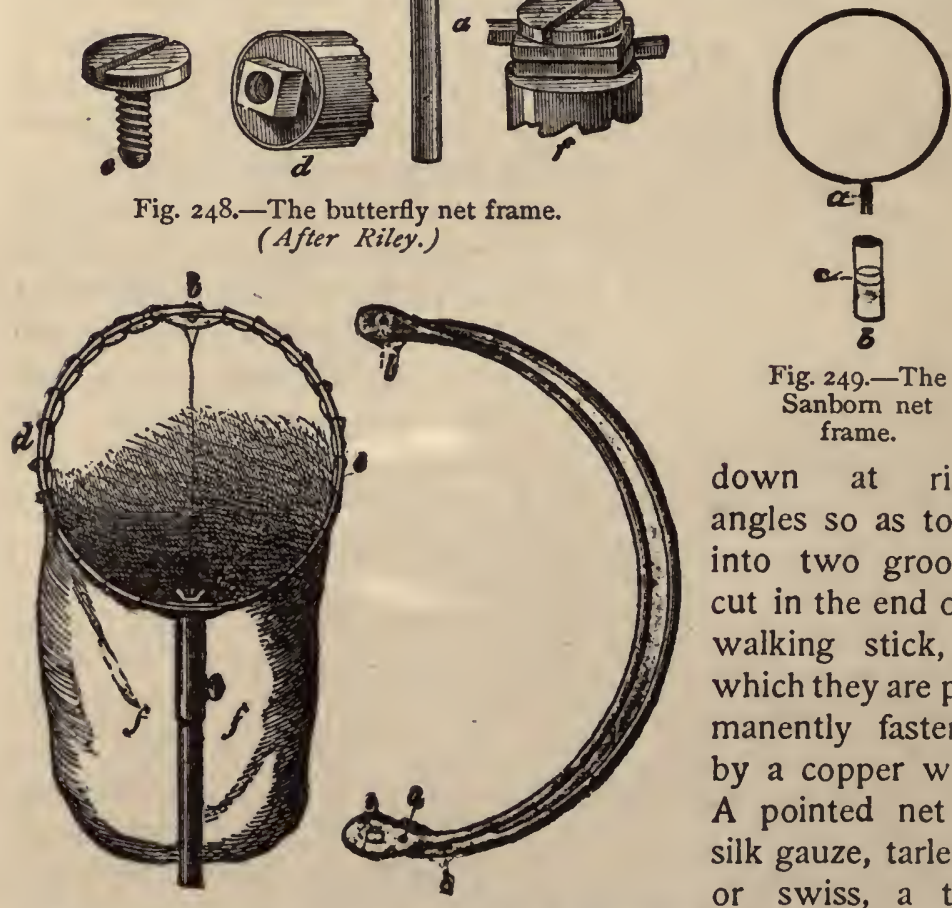

Fig. 249.-The Sanborn net frame.

down at right angles so as to fit into two grooves cut in the end of a walking stick, to which they are permanently fastened by a copper wire. A pointed net of silk gauze, tarleton or swiss, a thin

Fig. 250.-Beating net, opened and attached to handle, light quality being with frame of same folded. (After Kiesenzvetter.) used, is then sewn around the wire frame which should previously be covered with some heavier cloth. 
The Sweeping or Beating Net.-Very many insects feed or rest upon grasses and low plants, and the beating net, which is made on the same principle as the butterfly net, is a most useful instrument with which to collect these forms. It should have a strong frame and the cloth of which it is composed should be light in color and strong like cheese cloth. The beating net is not necessarily pointed but may be rounded at the bottom. The collector passes the net several times quickly over the low shrubbery or grass and then sits down to examine his captures and remove them to the cyanide bottle. The ring of the beating net should be especially strong, either of brass or iron and of one or two pieces and should be fastened rigidly to the handle either by means of a special device, by clamps, nuts and screws, or by copper wire as

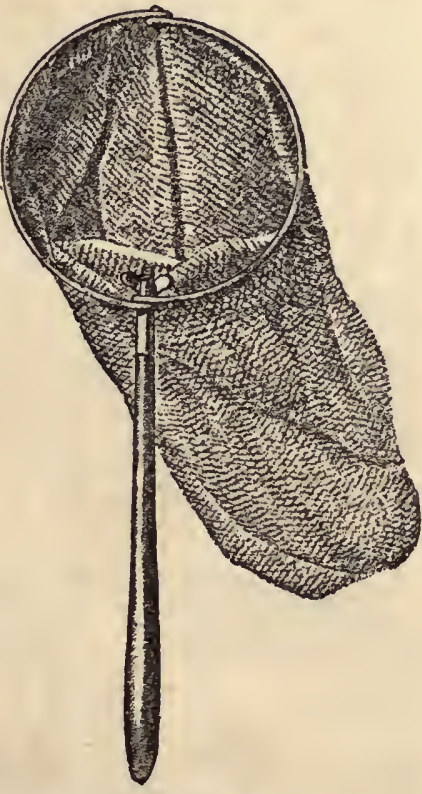

Fig. 251.-A good hand net. above mentioned. The reason for this special strength is that sometimes it is desirable to sweep tough bushes or the low branches of trees.

The Water Net.-The water net may be a simple sag net

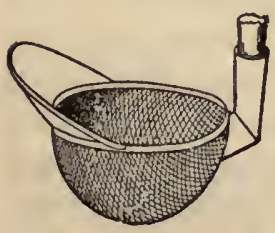

Fig. 252.-Small water dip net. (After Riley.) with a short handle, the frame being oblong and the net or bag being of some very coarse material like grass cloth or millinet. A sieve net with sides of galvanized iron and bottom of galvanized wire screen is desirable where one is scraping up mud and sand from the bottom of pools for the purpose of sifting out aquatic insects.

The Sieve.-A sieve with cloth șides is an excellent bit of apparatus for sifting out earth, moss, materials of ants nests, etc., the size of the wire meshes at the bottom being larger when it is desired to sift the 


\section{Collecting and Preserving Insects}

fragments of old decayed trees and smaller when sifting ants nests and ordinary earth.

Chisel and Trowel.-A small stout chisel for securing insects which hide under the bark of dead or dying trees is a useful instrument. A stout pocket knife will sometimes do the work but something stronger and better adapted to the purpose is desirable. When one is studying underground insects a small trowel is a necessity.

Collecting Forceps.-The entomologist skilled in the use of his fingers and who does not mind an occasional sting or bite does not need forceps, yet a small delicate pair made of steel or brass, very pliable and with rounded tips, is useful in picking up specimens and transferring them into vials and boxes. A little dodge which is used by many entomologists in picking up small insects is to slightly moisten the fore finger and touch it to the insect which will adhere long enough so that it can be dropped

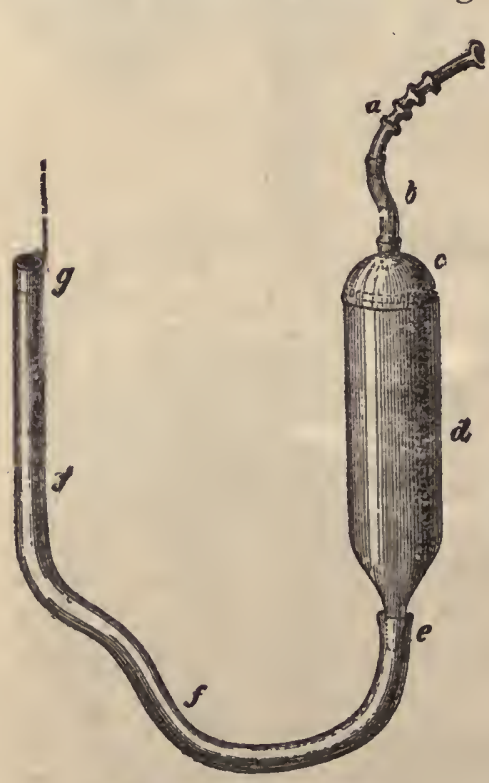

Fig. 253.-The fumigator. (After Kiesenwetter.) into the cyanide bottle, vial or pill box. A camel's-hair brush is sometimes used for the same purpose.

Fumigator. - This is a bit of apparatus used by European collectors and to some extent by those in this country. It is used for smoking out specimens which hide in cracks in the ground or holes in hard wood, etc. The accompanying figure shows the common form. A smoking-pipe mouth-piece (a) with flexible rubber-joint $(b)$ is attached to the cover $(c)$ of a very large smoking pipe head (d). To the mouth $(e)$ of the latter a rubber hose $(f)$ is attached, which has a convenient discharge at its end $(g)$. The pipe is filled with tobacco, the latter ignited, the cover screwed on and the smoke blown through the mouth-piece in any desired direction. A puff of tobacco smoke blown gently over the 


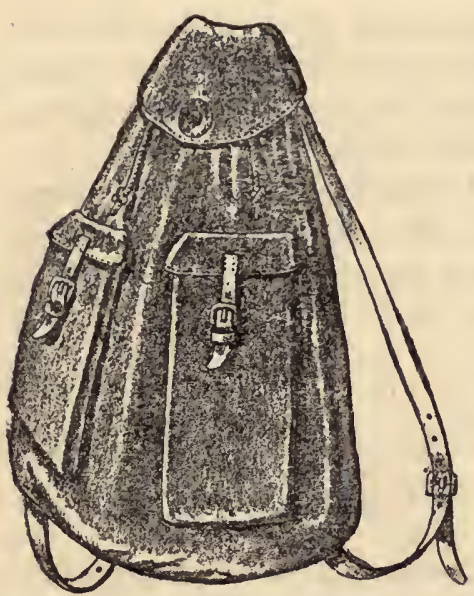

Fig. 254-An entomological haversack.

debris on the collecting cloth will often make many specimens move which otherwise play possum.

Haversack.-A haversack of water-proof cloth is convenient but by no means indispensable. It should contain various compartments of different sizes for storing away nets, sieve, larger implements, boxes and vials.

Hand Lens. - A hand lens is quite necessary for field work with the smaller forms. Excellent hand lenses are now on the market and can be purchased from any dealer in microscope supplies.

Umbrella.
The umbrella is
one of the most
useful imple-
ments to the
collector since
he can collect
with it insects
which live upon
the branches of
trees and large
bushes. Umbrel-
las constructed
especially for en-
tomological pur-
poses have the
inside lined with
white linen and
the handle has
a joint near the
middle so that it
can be more con-
veniently held

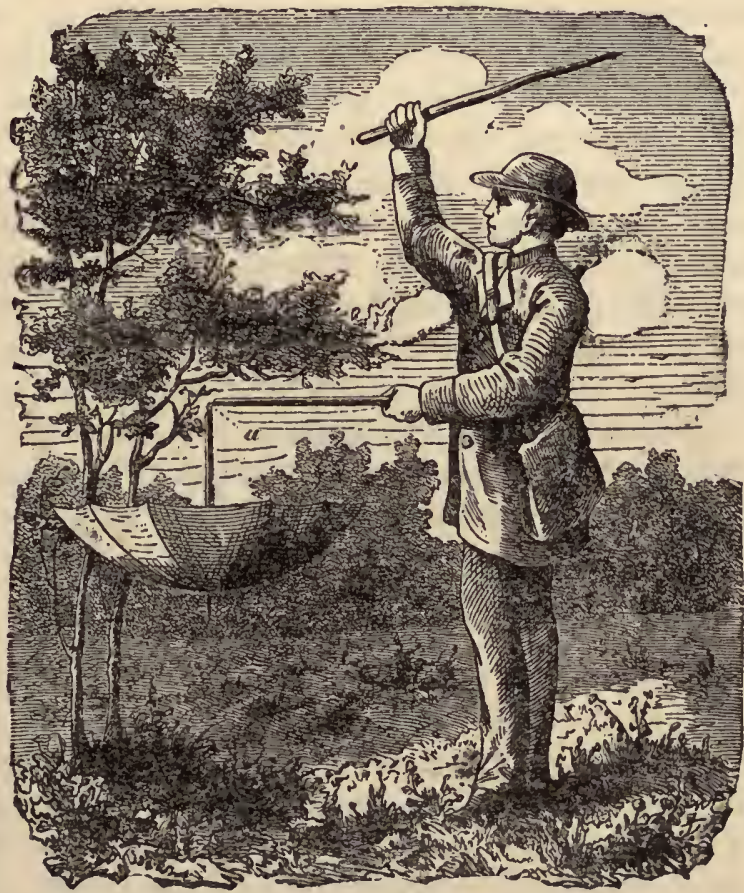

Fig. 255.-The umbrella and its mode of use. (After Kiesenwetter.) 
and more conveniently packed away. The opened and inverted umbrella is held with the left hand under the branch and with the right hand the collector beats the branch, jarring the insects into the convex umbrella cover.

Collecting Shears. - These are often used, the blades being composed of flat, net-like frames looking. something like minute tennis rackets. They are useful for picking up delicate insects which would be apt to be damaged by the fingers or tweezers.

\section{SOME POINTS ON METHODS OF COLLECTING DIFFERENT ORDERS}

Hymenoptera.-Many Hymenoptera, such as the bees, some of the wasps and many parasitic forms, can readily be collected by means of the beating net or sweeping net from flowering plants. The removal of the stinging species from the net is sometimes rather dangerous. The callous collector will pick them up with his thumb and fore finger, never minding the sting, especially as after a few stings his hand becomes practically inoculated, but a good idea is to have an opening "in the bottom of the net which should be kept tied with a string. When enough insects are caught they are driven to the bottom by swinging the net rapidly through the air, then holding it tightly together with the hand just above the bottom, untieing the string and shaking the insects into a wide-mouthed cyanide bottle. After they are stupefied the contents of the bottle may be emptied out and the desirable specimens selected. The gallflies and the parasites are best collected by breeding. The galls of the gall-flies should be collected when mature and kept in closed jars, the jars being occasionally moistened by putting a sheet of damp blotting paper over the mouth.

Hemiptera.-The beating net is used with these insects and they are found to some extent under logs and stones and are also captured in the collecting umbrella. Plant-lice should be collected in connection with their food plants and at different seasons of the year in order to obtain different generations. One should also collect both winged and wingless forms. Bark-lice or scale insects should be preserved dry in situ on the plants. The collector should have a series of small envelopes or flat card boxes 
in which to place these specimens, writing the date, locality, name of plant, collector, and any other remarks that may seem desirable. Nothing air-tight, such as tin boxes or closed tubes, should be used for fresh material as it nearly always molds. Pillboxes are sometimes used but are too small to contain a good quantity of material. A good-sized twig or several leaves should be collected for each species.

Diptera.-Most flies frequent flowers and may be collected with the sweeping net. So many of them are very delicate that the greatest care must be exercised both in collecting and handling. A light sweep net is the best implement and the contents should frequently be emptied into cyanide bottles with plenty of blotting paper to absorb the excess of moisture. Collecting shears are successfully used with these insects.

Orthoptera.-These insects are best collected by using the sweeping net.

Collecting Aquatic Insects.-For collecting forms which live upon the bottom of ponds and streams, Dr. Needham advises the use of the common garden rake. With it the debris may be drawn ashore and the insects picked out by hand. Withdrawn from the water they generally make themselves evident by their active efforts to get back. The rake is especially useful in the spring while there is as yet no new growth of well-rooted water weeds to interfere with hauling it. The sieve net previously described is used for bringing ashore mud and sand from the bottom. Those specimens which live above the bottom in still or slowly running water or which crawl among the submerged branches or erect aquatic plants are most of them easily taken by sweeping the plants with any of the forms of water nets. Some of the little ones which cling closely to the water plants can only be discovered by taking the plants out of the water and examining them, a small bunch at a time, in a white dish of clean water. Those forms which live in rapids can be had by picking up the stones and examining them. Some may be taken with a water net. Some are captured by wading into the rapids holding the water net with the left hand and lifting the stones in advance with the rake, the disloged insects floating into the water net.

In carrying home a day's catch a large quantity of water is not necessary. Needham says that it is well to have a pail and to 
place within it a few smaller receptacles containing a little water and pack ordinary water weed between these. The smaller nymphs taken may be distributed among these receptacles so as to diminish the chances of having them eaten by the larger and stouter ones which may be stowed away in the weed. The latter does not need to be submerged unless left long uncovered in the sun.

\section{REARING DIFFERENT KINDS OF INSECTS}

Even the collector of insects who cares little about habits and life histories desires often to rear his specimens, since they are then in the best condition for the collection; and then, too, it is

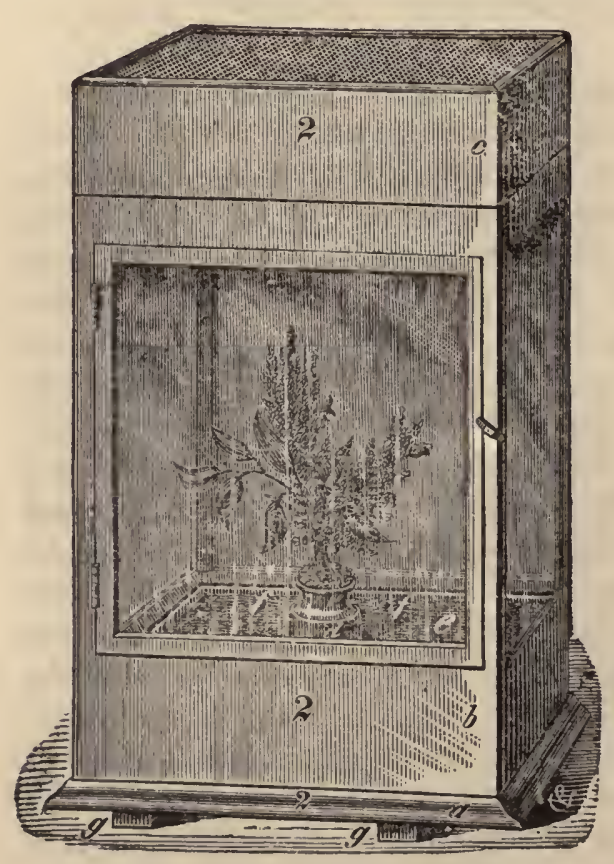

Fig. 256.--Riley insect breeding cage or vivarium. (After Riley.) very difficult sometimes to capture some kinds of insects, or they can be obtained only in this way. The methods of rearing caterpillars in order to obtain the adult butterflies or moths has been admirably treated by Dr. Holland in his "Butterfly Book," and the breeding cages recommended by him may be used equally well for many of the insects described in this volume. The simplest form of such cage is frequently the best, and, as Dr. Holland says, with some species the best method is simply to pot a plant on which the insect is

known to feed and place it in a box over which some mosquito netting is tied. Glass cylinders or even lamp chimneys placed over small plants growing in pots, the top being covered with 396 
gauze, are frequently used to advantage in this work, and glass jars-from the small test-tube to the large morphine bottles and fruit jars and up to the large 'battery jars-all may be used in rearing different kinds of insects. The large, so-called Riley breeding cage, shown at Figure 256, is a good one, especially if

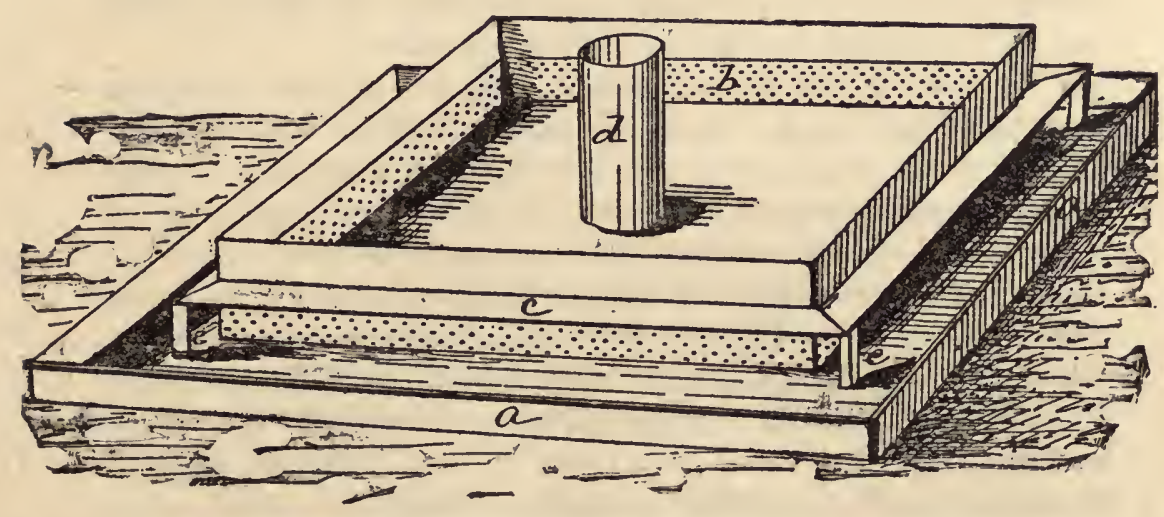

Fig. 257-Comstock improved base for breeding cage. (After Riley.)

it is used with the improved base invented by Professor Comstock, shown. at Figure 257. Some very good breeding jars are sold by the dealers in entomological supplies, but most workers prefer to construct their own cages.

All earth used in rearing insects in the cages or in the bottles should be sterilized and sifted. This is necessary in order to destroy disease. germs, in order subsequently to regulate the amount of moisture, and in order to destroy predaceous mites and other insects which might be the cause of damage or confusio1. In my office we prepare earth readily and in bulk in a galvanized iron oven $2 \frac{1}{2} \times 1 \frac{1}{2} \times 1$ foot. The cover is roofshaped, and lifts off by a central handle. There is a circular orifice in this cover to emit steam and facilitate drying. The oven stands on legs and is heated by a single gas jet from a Bunsen burner placed beneath. After two hours' heating the moisture becomes dissipated, and the earth becomes dry and is readily sifted. It is then passed through a sieve, and is in proper condition to use either in large boxes for underground insects or in the ordinary breeding jars and cages. 
Professor Comstock has invented and described a root-cage in order to study underground insects. This is a metal cage with glass sides, made narrow, and with galvanized iron additional sides which can be slipped down over the glass ones so as to keep the cage dark when not under observation. Plants and insects are placed in earth between the two glass sides, and the whole apparatus is then placed in the ground. It can be pulled up and the insects watched through the glass.

For insects feeding upon grasses it is well to make a wooden box two feet deep with bottom perforated with a few auger holes covered with wire netting and containing a good supply of growing grass. The box should be of good size, say $2 \times 2 \times 2$ feet. Little upright posts or sticks or laths six inches high should be nailed to the corners of the box, and gauze mosquito netting or something finer tacked over the whole. This kind of a box is of good service in rearing grasshoppers, which are the most difficult insects to rear. Confined in a small breeding cage they feed little, and are apt to fatally exhaust themselves in futile efforts to escape. Boxes for these insects should be about three feet square, and in the earth should be growing not only grasses but also weeds of various kinds. The long-horned grasshoppers (Locustidæ) are very easy to rear in confinement, and need only be given an occasional supply of fresh food. This is the case also with the walking-sticks, and mantids, the latter requiring no moisture whatever beyond that which they get from the bodies of their victims.

That reminds me that one of the difficulties encountered in the rearing of insects is the proper maintenance of the right degree of moisture. Galls of all kinds are apt to be left either to dry, in which case the issuing of the insect is delayed far beyond the normal time, or too moist, in which case they become covered with mildew and spoil. If the jar containing them be left open they dry no matter how frequently sprinkled. If it be closed mildew frequently puts in its appearance. This difficulty is obviated by keeping them in a series of jars of the same height, the mouths of the jars being covered with gauze to prevent the escape of the insects or parasites. Over the whole series is laid a large sheet of blotting paper which is moistened daily and the insects seem to thrive under this treatment. In rearing Hymenopterous parasites, the breeding jar should be tightly closed and 398 
an occasional strip of moistened blotting paper inserted or they may be enclosed in glass tubes with tight absorbent stoppers the latter being occasionally moistened. Bees need very little moisture and give very little trouble in rearing. Wood-boring insects of all kinds may as a rule be kept perfectly dry or only moistened every two or three weeks. Plant-bugs need simply plenty of fresh food and take care of themselves with comparative indifference as to their surroundings.

Of all larvæ none are more difficult to rear than those of the the saw-flies. Their mouth-parts seem to dry unless constantly lubricated by the saliva produced by mastication and once dried the larva usually dies. Fresh food must constantly be supplied and if possible they must not be allowed to descend to the surface of the sand; the latter must be carefully covered with paper, for if they once close their prolegs on a grain of sand they hold it convulsively and it is almost impossible to dislodge it so that they are practically unfitted for again clasping a twig.

The study of scale insects is a simple one. The food plants should be grown in pots and the insects colonized upon it. Most of the species remain stationary or nearly so and their location recorded, the exact situation of each individual under observation being circumscribed by a ring of ink marked with a pen upon the leaf.

The Aquarium.-Almost any of the different styles of aquaria which may be purchased will answer a good purpose. A very good one is shown in the accompanying illustration. Where it is desired to go rather thoroughly into the rearing of aquatic insects and where one is able to spend some money in preparations, the apparatus in use in my office is rather better than anything which I have seen. Two glass aquaria each $2 \frac{1}{2} \times 1 \frac{1}{2} \times I^{1} / 2$ are placed end to end, the one elevated on a three inch base so as to make it that much higher than the other. The water connections from the one to the other are so arranged that each may be independent of the other, and the details are simply arranged. In each is a V-shaped inclined glass septum with a broad, deflexed lip, and beneath this lip has been constructed an artificial rock-work grotto. The water enters the first aquarium through a $\mathrm{T}$ sprinkler with six pipette orifices. It drops a distance of six or eight inches into the V-shaped septum and its force is 
easily graduated by stop cocks. Rising to the height of the deflexed lip it pours in a broad cascade into the main compartment, impinging on the top of the rock-work grotto. The second or lower aquarium is at present similarly arranged, and derives its supply of water either from the overflow of the first or independently from an overhead pipe, so that its water may be kept either still or running at will. Thus we have arrangements in a small

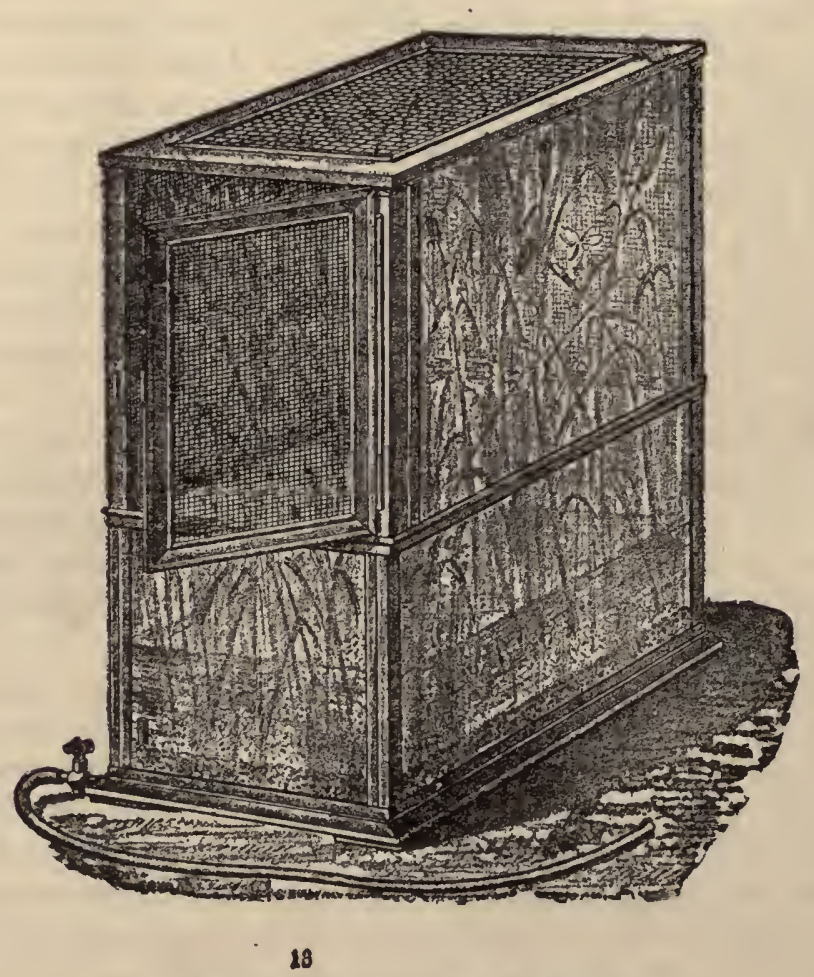

Fig. 258. -A good simple aquarium

space for the rearing of all kinds of aquatic insects. The sliding stream upon the artificial rockwork is particularly adapted for such forms as Simulium, and opportunity is also offered for such species as have the habit of crawling out either on rocks or earth, as the case may be. 


\section{KILLING AND PRESERVING INSECTS}

The use of alchohol or formalin is the most satisfactory method of killing most soft-bodied insects. Those with harder bodies should be dropped into a cyanide bottle or they may be killed with chloroform.

The Cyanide Bottle.-The cyanide bottle is prepared by taking a large quinine bottle or morphine bottle or one of the stout roundbottomed neckless tubes, putting into it a few small lumps of cyanide of potassium and pouring over them a semi-fluid mixture of plaster of paris and water. The bottle is then left open for a few hours until the plaster of paris thoroughly dries. The purpose of the plaster is to prevent the moisture from the deliquescing cyanide from reaching the insects and it is well also to put a piece of blotting paper over the plaster. When one is collecting insects it would be well to cut into strips some soft absorbent paper and stick the slips into the bottle in such a way that the insects' bodies will not rattle about too much.

Preparing Insects for the Cabinet.-In mounting insects for the cabinet no pins should be used except those made especially for mounting specimens. The long German pins are much to be preferred to the short English ones. The best are the Klæger pins, the Carlsbad pins and the Vienna pins, all of which can be purchased from the dealer in

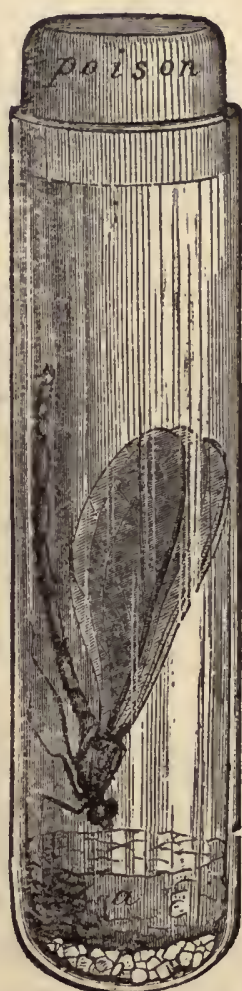

Fig. 259. - Pocket cyanide bottle. (After Riley.) entomological supplies. The Japanned black pins are the best for most insects since they are not ruined by the verdigris which issues from the bodies of many insects. Specimens should be prepared for the collection as soon after death as possible. If they have been collected in the forenoon they should be mounted the same evening-where possible. Most of the insects which we consider in this book should be pinned through the thorax. Grasshoppers and locusts should have one pair of wings spread. Dragon-flies and most other Neuropterous insects 
should have both pairs of wings spread. For this purpose a

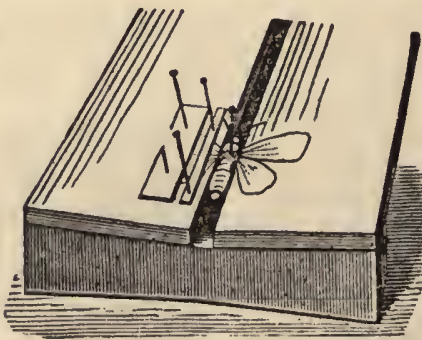

Fig. 260.-Spreading board for Lepidoptera. (After Riley.) spreading board is necessary. Excellent spreading boards are for sale by the dealers but very good ones can readily be made. The spreading board in use for Lepidoptera will answer admirably for any of these insects. One is shown at Fig. 260 and needs no extended description except to state that the central grove in which the body of the insect rests should be bottomed with cork or some soft substance into which the pin can be inserted. While spreading, the time required for drying must be determined by experiment for a given locality and given time of the year since it depends upon the dryness of the atmosphere.

Insects which are too small to pin are preferably mounted upon little triangular cardboard tags. They are glued to the tip of the triangle, the pin being thrust through the base. White shellac or yellow shellac are good substances to use for the glueing. Most of those minute

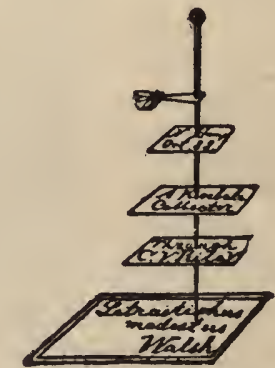

Fig. 261.-Insect mounted on card. board triangle. (After Riley.) insects may be mounted to advantage on the side with the

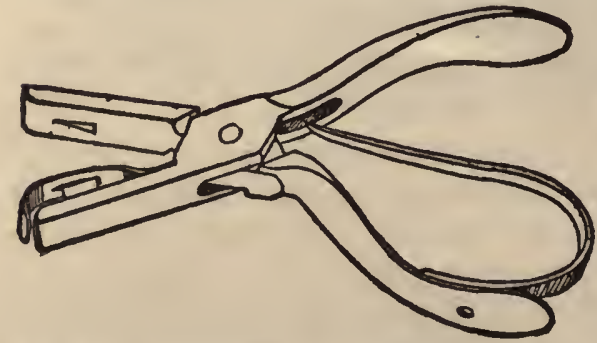

Fig. 262.-Insect punch for cutting triangles or points. (After Riley.)

back away from the pin, and it is generally advisable to mount them with the side uppermost. It must be remembered that while an insect has one back and one belly it has two sides. Punches for cutting tags for this purpose may be purchased from the dealers. After the insect is pinned and dried great care should be taken with the labelling. In all cases the date and 
the actual locality should be entered upon the label, and, if the locality is such that there is some doubt that the elevation can in future be ascertained with ease, the elevation should be also placed upon the label. The name of the collector should be stuck on the same pin, and the name of the insect upon another label on the same pin. That will make three labels, one with the name, one for the collector, and one for the exact locality and date. All labels should be as small as possible, and should be

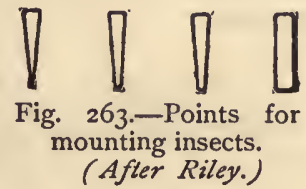
printed in diamond type. After the labelling is done the specimens are ready for the cabinet.

The Cabinet.-In the matter of a cabinet there is considerable room for the judgment of a collector. The so-called Schmidt insect box is an excellent box for a more or less temporary collection, and, in fact, there are many specimens in the museums which have been preserved in these boxes for many years. They are of small and convenient size, book form, cork-lined, tightly constructed, and close very tightly. An insect cabinet

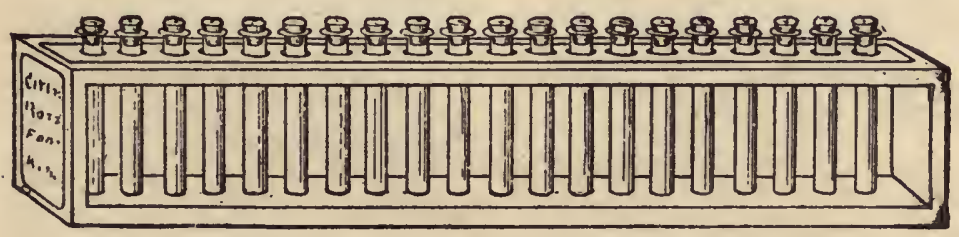

Fig. 264:-The Marx tray for alcohol specimens. (After Riley.)

with sliding drawers, glass-covered, can be made by any good carpenter, but great care should be taken to make the joints of the drawers absolutely air-tight. When a collection becomes infested with museum pests or mites or Psocids, it can easily be disinfected by pouring into the box bisulphide of carbon. Great care must be used in the handling of this substance, however, as it is inflammable. After the drawer has become disinfected, a teaspoonful, more or less, of naphthaline will act as a deterrent against the entrance of other insect pests. For soft-bodied insects which must be kept in liquid, either alcohol or formalin, a permanent arrangement is a very difficult matter. A vial-tray in use by some collectors is a good idea. The one invented and 
used by Dr. George Marx is shown in the accompanying figure. In mounting insects for the microscope Canada balsam is the best medium for most of them, but it must be remembered that with soft-bodied forms fresh mounts will cloud unless the water has been extracted by passing through successive strengths of alcohol. 


\section{BIBLIOGRAPHY}

\section{HYMENOPTERA}

\section{I.--CATALOGUES}

E. T. Cresson.-Catalogue of the described species of North American Hymenoptera. species of North American Hymenoptera.

E. T. Cresson.-Cata!ogue of species and bibliography. Part II of Symopsis of the Hymenoptera of America, north of Mexico. Synopsis and Catalozue. Price, \$3. Transactions of the Am. Entom. Soc., Supplementary volume, 1887. Philadelphia, 1887 .

C. G. DE DAlla Torre.-Catalogus Hymenopterorum. Io vols. Leipzic, 1893-1900.

Vol. 1, Tenthredinidie; 1I, Cyniplda: III, Ichneumonllie, etc.: IV, Braconldx; V, Chal cididx and Proctotrupidre; VI, Chrysididre V1I, Formicidie: VIII, Fossores: IX, Ves pidre: X. Aplile. Each volume can be purchased separately.

\section{II. - GENERAL WORKS ON CLASSI-} FICATION

E. T. Crzsson.-Synopsis of the families and genera of the Hymenoptera, north of Mexico, together with a catalogue of the described species and bibliography. Transactions Am. Entom. Soc., Supplementary volume, Part I, 1887 .

he second part contains the Catalogue of Species and Bibliography.

W. H. AshmeAD. - Classification of the horntails and sawflies, or the suborder Phytophaga. $<$ Can. Entom., r 898, 7 parts.

W. H. Asнmва D.-Classification of the bees, or the superfamily Apoidea. <Trans. Amer. Entom. Soc., 1809 , pp. $49-100$.

W. H. Ashmzad.-Superfamilies in the Hymenoptera and generic synopses of the families Thynnidx, Myrmosidx, and Mutillidx. $<$ Journ. N. Y. Entom. Soc., March, 1899 , pp. $45-60$

W. H. Asrimzad.-Classification of the entomophilous wasps, or the superfamily Sphegoidea. $<$ Can. Entom., 1809,7 parts.

W. H. Asнмва D.-Classification of the fossorial, predaceous and parasitic wasps, or the superfamily Vespoidea. <Can. Entom., 1900, pp. $145-155,185-188$, etc.

W. J. Fox.-A proposed classification of the fossorial Hymenoptera of North America. <Proc. Acad. Nat. Sci. Phila., 1894, pp. 292-307.

\section{III.-MONOGRAPHS AND SYNOPSES}

E. T. Cresson.-A list of the North American species of the genus Anthophora, with descriptions of new species. <Trans. Amer. Entom. Soc., Vol. II, 1868-69, pp. 289-293.

E. T. Cresson.-Catalogue of North American A pida. <Trans. Amer. Entom. Soc., Vol. VII, I 878-79, pp. 21 5-232. A synonymical reference list of the species.
W. H. PA TtON.-Generic arrangement of the Bees allied to Melissodes and Anthophora. <Bul. U. S. Geolog. and Geogr. Survey, Vol. V, No. 3,1879 , pp. $471-479$.

E. T. Crrsson.-On the North American species of the genus Nomada. <Proc. Entom. Soc. Phila., Vol. II, 1863, pp. 280-3 I2.

E. T. Cresson.-On the North American species of several genera of Apida. <Proc. Entom. Soc. Phila., Vol. II, 1864, pp. 373-411.

E. T. Cresson,-List of the North American species of Bombus and Apathus. <Proc. Entom. Soc. Phila., Vol. II, pp. $83^{-116}, 1863$.

E. T. Cresson.-On the North American species of the genus Osmia. <Proc. Entom. Soc. Phila., Vol. II I, 1864 , pp. $17-43$.

E. T. Cresson.-Descriptions of new North American Hymenoptera in the collection of the American Entomological Society. Family Apid.e. <Trans. Amer. Entom. Soc., Vol. VII, $1878-79$, pp. $61-136,201-214$.

C. Robertson.-North American bees. Descriptious and Synonyms. <Trans. Acad. Sci., St. Louis, Vol. VII, pp. 315-356. 1897.

C. Roвzktson. - Synopsis of the North American species of the genus Oxybelus. <Trans. Amer. Entom. Soc., 1889, pp. $77^{-85}$.

C. ROBERTSON,-Descriptions of new species of North American bees. < Trans. Amer. Entom. Soc., 1891 , pp. $49-66$.

T. D. A. CockzrzLl.-On some Panurgine and other bees. <Trans. Amer. Entom. Soc., 1898, pp. 185-198.

Table of Calliopsis and Parurginus.

E. T. Cresson.-Synoptic table of the North American species of Sapyga. <Trans. Amer. Entom. Soc., Vol. VIII, I88o, pp. 20-2I.

E. T. Cresson,-Notes on the Pompilida of North America, with descriptions of new species. <'Trans. Amer. Entom. Soc., Vol. I, 1867 , pp. $85-150$.

W. J. Fox.-The species of Pepsis inhabiting America, north of Mexico. <Proc. Entom. Soc. Wash., Vol. IV, pp. 140-148. 1897 .

W. J. Fox.-The North American species of Ceropales. <Trans. Amer. Entom. Soc., r 892 , pp. $49-63$.

W. H. PAtTon.-Some characters useful in the study of Sphecidz. <Proc. Boston Soc. Nat. Hist., Vol. XX, 1880 , pp. $37^{8-38}$

F. F. KонL.-Die Hymenopterengruppe der Sphecinen. <Ann. k. k. Naturh. Hofmuseums, Wien, Vol. V, 1890, Part I, pp. 77-194; Part II, pp. 317-462.

H. PAtton,-The American Bembecida: Tribe Stizini. <Bul. U. S. Geolog, and Geogr. Survey, Vol. V, No. 3, 1879, pp.

W. J4. Fox.-Synopsis of the Stizini of Boreal America. <Proc. Acad. Nat. Sci. Phila., 1895, pp. $264-268$. 
W. J. Fox.-Synopsis of the Bembicini of Boreal America. < Proc. Acad. Nat. Sci. Phila., I895, pp. 351-374.

A. Handerksch,-Monographie der mit Nysson und Bembex verwandten Grabwespen. 7 parts. <Stzber. K. Akad. d. Wissensch., Wien, $1887-93,1,150$ pp., 23 pls.

A. S. PACKARD.-Revision of the Fossorial Hymenoptera of North America. I. Crabronidx and Nyssonidx. <Proc. Entom. Soc. Phila., Vol. VI, 1866, pp. 39-114 and $353^{-444}$.

Thls work includes revislons of the following amilies: Larridae, Bembecidie, Philanthidae Mimesidx, M

W. H. PA tron.-List of North American Larridx. < Proc. Boston Soc. Nat. Hist., Vol. XX, r88o, pp. $3^{8} 5-397$.

W. J. Fox.-Monograph of the North American species of Tachytes. <Trans. Amer. Entom. Soc., 1892 , pp. 234-252.

W. J. Fox.-The North American Larridz. <Proc. Acad. Nat. Sci. Phila., 1894, pp. 467-551.

E. T. Cresson.-Descriptions of the species belonging to the genus Nysson, inhabiting North America. <Trans. Amer. Entom. Soc., Vol. IX, 1881-82, pp. 273-284

W. J. Fox.-Synopsis of the species of Nysson inhabiting America, north of Mexico. <Jour. N. Y. Entom. Soc., March, r8g6, pp. 10-16.

W. J. Fox.-Synopsis of the North American Gorytes. <Proc. Acad. Nat. Sci. Phila., 1895, pp. 517-539.

E. T. Con the Philanthida of North America. <Proc. Entom. Soc. Phila., Vol. V, 1865, pp. $85^{-132}$.

W. H. Patron.-Notes on the Philanthinx. <Proc. Boston Soc. Nat. Hist., Vol. XX, 1880; pp. 397-405

E. T. Cresson.-Table of the North American species of the genus Fucerceris. < Trans. Amer. Entom. Soc., Vol. X, $188_{2}-83$, pp. 5-8.

S. N. DuNNiNG.-Monograph of the species of Aphilanthops inhabiting Boreal America. $<$ Trans. Amer. Entom. Soc., r898, pp. 19-26.

W. J. Fox.-The species of Psen inhabiting America, north of Mexico. <Trans. Amer. Entom. Soc., I 88 , pp. I-18.

W. J. Fox.-Studies among the fossorial Hymenoptera. <Entom. News, 1894, pp. 86-89; $126-128 ; 201-203$.

Synopses of Alyson, Didineis and Mellinus.

W. J. Fox.-The North American Pemphredonidz. <Trans. Amer. Entom. Soc., I892,

W. J. Fox.-The Crabroninx of Boreal America. $<$ Trans. Amer. Entom. Soc., 1895, pp. $129^{-226 .}$

W. J. Fox.-On the species of Trypoxylon inhabiting America, north of Mexico. <Trans. Amer. Entom. Soc., 1891, pp. 136-148.

HRNRI DE SAUSSURE.-Svnopsis of American Wasps. Solitary Wasps. <Smithsonian Miscellaneous Collections, 254, Washington, 1875 . This work monographs the Anerican Masarida work monograph

HenR1 de SAussure.-Etudes sur la famille des Vespides. Monographie des guêpes sociales ou de la tribu des Vespiens. Paris, $18_{53}$. 8 vo., pp. 256 . [Separate work.]

HENRI DE SAussurg.-Bemerkungen liber die Gattung Vespa, besonders über die amerikanischen Arten. <Stettiner Entom. Zeit., Vol. XVIII 1857, pp. II 4-1I7.

HeNR1 DE SAUSSURE. - Note sur les Polistes américains. <Ann. Soc. Entom. France, 1857 , pp. $309-314$.
H. W. Lrwis.-Vespinæ of the United States and Canada. <Trans. Amer. Entom. Soc., 1897 pp. $16 g^{-1} g^{2}$.

EDWARD Norton.-On the Chrysides of North America. <Trans. Amer. Entom. Soc., Vol. V II , 1878-79, pp. 233-242.

II, $1878-79$, pp. $233^{-242}$.
Glves tables of genera and species.

S. Frank Aaron.-The North American Chrysididx. <Trans. Amer. Entom. Soc., Vol. XII, 1885 , pp. $209^{-24} 8$, pls. 6-Io.

A. MocsA 12y.-Monographia Chrysididarum orbis terrarum universi. Budapest, r889, p. 643 .

CH. A. Blake.-Synopsis of the Mutillidz of North America. <Trans. Amer. Entom. Soc., Vol. II I, 1870-71, pp. $217-265$; Additions and Corrections, Vol. IV, $1872-73$, pp. $71-76$.

Cн. A. Braks, - Catalogue of the Mutillidx of North America, with descriptions of new species. <Trans. Amer. Entom. Soc., Vol. VII, $1878-79$, pp. 243-254.

CH. A. BLAKE. - Monograph of the Mutillidx of North America. <Trans. Amer. Entom. Soc., Vol. XIII, r886, pp. $179^{-2} 86$. ol. XIII, r886, pp. $179-286$.

W. J. Fox.-The North American Mutillidx. <Trans. Amer. Entom. Soc., 1898 , pp. $219-292$.

H. DE SAussure and J. Sichel.-Catalogus specierum generis Scolia, Geneva, 1864. 8 vo., p. 352,2 pls.

G. L. MAYR.-Die Formiciden der Vereinigten Staaten von Nordamerika. <Verh. zool.-bot. Ges. in Wien, 18S6, pp. $419-464$.

C. EMRRY.-Beiträge zur Kenntniss der nordamerikanischen Ameisenfauna. <Part I, Zool. Jahrb., A bth. f. Syst., Vol. VII, pp. 633-682, I894; Part II, Ibid., Vol. VIII, pp. 257-360,

C. R. Ostran SACKen.-On the Cynipidx of the North American oaks and their galls. <Proc. Entom. Soc. Phila., Vol. I, 1861-63, pp. $47-72$; additions and corrections, 1. c., pp. $241-259$.

C. R. OStren SACKen.-Contributions to the natural history of the Cynipidæ of the United States. < Proc. Entom. Soc. Phila., Vol. II, 1863-1864, pp. 33-49; Vol. IV, I865, pp. 33 I380 ; Trans. Amer. Entom. Soc., Vol. III, 1870-187 $\mathrm{r}$, pp. 54-64.

Continuation of the foregoing paper, both contain Ing valuable contributions to the classification of genera and species.

B. D. WALSH. - On Dimorphism in the Hymenopterous genus Cynips; with an Appendix, containing hints for a new classification of Cynipidx, including descriptions of several new species inhabiting the oak galls of Illinois. species inhabiting the oak galls of Illinois. 64 , pp. $443-500$.

Gustav Mayr.-Die Genera der gallenbewohnenden Cynipiden. < zoter Jahresbericht der Communal-Oberrealschule im I. Bezirk. Wien, I88I.

W. H. AshmeAd.-A bibliographical and synonymical catalogue of the North American Cynipida, with description of new species. $<$ Trans. Amer. Entom. Soc., Vol. XII, $188_{5}$,

W. H. Asmanad.-Synopsis of the North American subfamilies and genera of Cynipidz. <Trans. Amer. Entom. Soc., Vol. XIII, 1886,

W. H. Ashmean.-On the cynipidous galls of Florida, with descriptions of new species and synopses of the described species of North America. <Trans. Amer. Entom. Soc., Vol. America. <Trans. Amer. Ent

C. P. Gilletir.-A monograph of the genus Synergus. <Trans. Amer. Entom. Soc., 1806 , pp. $85-100$. 
L. O. HowARD-A generic synopsis of the Hymenopterous family Proctotrupidx. <Trans. Amer. Entom. Soc. Vol. XIII, 1886, pp. $169^{-1} 7^{2}$.

W. II. AsHmis D.-A monograph of the North American Proctotrypidæ. Bul. No. 45 , U. S. Nat. Museum, 1893,463 pp., 18 pls.

A. Foerster.-Synoptische Uebersicht der Familien und Gattungen in den beiden Gruppen der Chalcidize Spin. und Proctotrupil Latr. $<$ Jahresber. d. höheren Bürgerschule in Aachen, 1856.

E. T. Cresson.-Synopsis of the North American species belonging to the genera Leucospis, Smicra and Chalcis. <Trans. Amer. Entom. Soc., Vol. IV, $187^{2-73}$, pp. 29-60.

L. O. How ARD-Descriptions of North American Chalcidid $x$ from the collections of the U.S. Department of Agriculture and of Dr. C. V. Riley, with biological notes [first paper], together with a list of the described North American species of the family. <Bul. No. 5 , Div. Entom., U.S. Dept. Agric., Washington, 1885 .

L. O. HowARD.-A generic synoysis of the Hymenopterous family Chalcididx. <Entom. Amer., Vol. I, 1885-86, pp. $197^{-199}$ and 215219 ; Vol. II, pp. 33-38.

I. O. How A RD.-Revision of the Aphelininze of North America. <Technical series, No. I, Div. Entom., U. S. Dept. of Agric., 1895, pp. 44 .

L. O. HotwARD. - On the Pothriothoracine insects of the United States. < Proc. U.S. Nat. Mus., Vol. XVII, Pp. $605-61_{3}, 1896$.

L. O. How RD.-On some American phytophagic Eurytominx. < Technical series, No. 2, Div. Entom., U. S. Dept. Agric., 1866.

W. A synopsis of Isosoma and allies: table of the Chalcidinæ. <Entom. Amer., 888, pp. 87-88.

W. H. AshmeA D.-Classification of the old family Chalcididx. <Proc. Entom. Soc. Wash., Vol. IV, 1899 , pp, 242-249.

W. H. Ashmea D.-On the genera of the chalcidflies belonging to the subfamily Encyrtinx. <Proc. U. S. Nat. Mus., Vol. XXII, pp. 323-412, 1900 .

W. H. Ashmead.-On the Chalcideous tribe Chiropachides. < Can. Entom., 1888, pp. $17^{2-176 .}$

W. H. Asнmвad.-On the genera of the Cleonymidx. <Proc. Entom. Soc. Wash., Vol. IV, 1899, pp. 200-206.

W. H. AshmbaD,-On the genera of the Eucharidæ. <Proc. Entom. Soc. Wash., Vol IV, 1899 , pp. 235-242.

W. H. Ashmend. - A revised generic table of the Eurytominx, with descriptions of new species. $<$ Entom. Amer., 1888, pp. 41-43.

W. H. AshmBAD.-On the genera of the Eupelminæ. < Proc. Entom. Soc. Wash., Vol. IV, 1896 , pp. $4^{-20}$.

W. H. Ashimend.-A synopsis of the Spalanginze of North America. <Proc. Entom. Soc. Wash., Vol. III, 1894, pp. 27-37.

A. SCHLETTERER.-Die Hymenopteren-Gruppe der Evaniiden. <Ann. k. k. Naturh. Hofmuseums, Wien, Vol. IV, 1839, Part I, pp. 107-180; Part II, pp. 289-338; Part III, pp. 373-546.

EDWARD Norton.-Catalogue of our species of Ophion, Anomalon, Paniscus and Campoplex. $<$ Proc. Entom. Soc. Phila., Vol. I, I863, pp. $357-368$.

ynoptlc arrangement of the North American genera and species of the subfamily Or-
phionina.
E. T. Cresson-Descriptions of North American Hymenopter in the collection of the Entomo. logical Society of Philadelphia. < Proc. Entom. Soc. Phila., Vol. III, 1864, Pp. $131-196$

Consists chiefly of a synopsis of the North American species of the genus Ichneumon.

E. T. Cresson.-A list of the Ichneumonidx of NorthAmerica, with descriptions of new species. <Trans. Amer. Entom. Soc., Vol. I, I867, Pp. 289-312; Vol. II, 1868-69, pp. 89-114.

E. T. Cresson.-Descriptions of new species belonging to the subfamily Pimplarize found in America, north of Mexico. <Trans. Amer. Entom. Soc., Vol. II I, 1870-71, pp. 143-172. Tabulates the genera Pimpla, Polysphincta, Glypta, Arenetra, Lampronota, Xylonomus,
Odontomerus, with a list of all specles.

B. D. WALSH.-Descriptions of North American Hymenoptera, with notes by E. T. Cresson. $<$ Trans. St. Louis Acad. Sci., Vol. III, 1873, pp. $65-166$.

E. T. Cresson,-Notes on the species belonging to the subfamily Irhneumonides found in America, north of Mexico. <Trans. Amer. Entom. Soc., Vol. VI, 1877, pp. 129-212.

A synopsis of the genera and specles of the subsynopsis of the genera
family Ichneumoninx.

G. C. Davis.-A review of the Ichneumonid sub. family Tryphoninz. <Trans. Amer. Entom. Soc., 1897, pp. 193-348.

G. C. DAvis. A monograph of the tribe Bassini. <Trans. Amer. Entom. Soc., 1895, pp. 17-30.

G. C. Davis-Two new species of Clistopyga. $<$ Entom. News, 1895 , pp. 198-199.

W. H. AsHMrA D.Classification of the Ichneumon flies, or the superfamily Ichneumonoidea. $<$ Proc. U. S. Natl. Mus., 1900.

E. T. Cresson,-List of the North American species of the genus Aleiodes, Wesmael. <Trans. Amer. Entom. Soc., Vol. II, 1868-69, pp. 377-382.

C. V. RILEY.-On North American Microgasters, with descriptions of new species. <Trans. St. Louis Acad. Sci. Vol. IV, No. 2, $188 \mathrm{r}$.

T. A. Marshall. -Monograph of the British Braconidx. Part I. < Trans. Entom. Soc. London, 1885 , pp. 1-28o, pls. $1-4$.

Mrstiall's classification is that reproduced by Cresson in lis Synopsis.

W. $\mathrm{H}$. AsHMzAD-Synopsis of the Hormina of North America. <'Trans. Amer. Entom. Soc., 1893 , pp. $39^{-44}$.

EDWARD NORTON.-Catalogue of the described Tenthredinid $x$ and Uroceridæ of North America. <Trans. Amer. Entom. Soc., Vol. I, 1867, pp. 31-84 and 193-280; Vol. II, $1868-69$, pp. $211-242$ and $321-367$.

Gives synoptic tables of genera and species of both fainilies: the Uroceridxe are treated in

Vol. 11, pp. $349-367$.
E. T. Cresson.-Catalogue of the Tenthredinidæ and Uroceridxe of North America. <Trans. Amer. Entom. Soc., Vol. VIII, 1880, pp. 53-68.

A synonymical reference list of the species; the Urocerida a re trented on pp. $66-67$.

Prter Cameron.-Monograph of the British Phytophagous Hymenoptera. 2 vols. London, 1882-1885.

Contains an arrangement of the sublamllies and genera of Tenthredinide, which has been re-
produced iy Cresson in his generai work of produced iny

C. I. MARLATT-Revision of the Nematinx of North America, a subfamily of leaf-feeding Hymenoptera of the family Tenthredinidx. <Technical Series No. 3, Div. Entom., U. S. Dept. Agric., 1896, pp. 135

A. D. MacGillivray.-New species of Ten. thredinidæ, with table of species of Strongylogaster and Monoctenus. <Can. Entom., I894, Pp. 324-328. 


\section{DIPTERA}

\section{1.-Catalogues}

C. R. Ostren SACken.-Catalogue of the described Diptera of North America. Washing ton, Smithsonian Institution, 1858 . <Smith sonian Miscellaneous Collections, Vol. III.

C. R. Ostren SACKEN.-Catalogue of the de scribed Diptera of North America. Second edition. Washington, Smithsonian Institution, 1878 . <Smithsonian Miscellaneous Collections, 270.

This completely supersedes the first edition and ence list of the North American Diptera.

\section{II.-GENERAL WORKS ON CLASSI-} FICATION

S. W. Williston.-Manual of the families and genera of North American Diptera. New Haven, Conn., 1806 .

S. W. WILLISTON.-Bibliography of North American Dipterology ; 1878-1895. <Kans. Univ. Quart., Vol. IV, $1896, \mathrm{pp}$. 129-144.
A list of articles since Osten Sacken's catalogue.

F. W. MrIGrs.-Systematische Beschreibung der bekannten europäischen zweifligigeligen Insecten. 7 vols. Aachen und Hamm, 1818-1838. Aithough only dealing with the European faun and now antiquated and superseded in many parts, this work is still the foun

C. R. W. WIEDEMANN.-Aussereuropäische zweifliggelige Insecten. 2 vols. Hamm, 18281830 , with plates.

A continuatlon of Melgen's work, and containing descriptions of many genera and species belonging to the North Amerlcan fauna.

J. MACQUART.-Diptères exotiques nouveaux ou peu connus. 2 vols., in 5 parts and 5 supplements. Paris, 1838-55. < Extr. Mém. Soc. Sci. Arts, Lille.

Contains descriptions of many North American genera and species.

J. R. Schivrs - Fauna Austriaca. Die Fliegen (Diptera). Nach der analytischen Methode bearbeitet, mit der Characteristik sämmtlicher europäischer Gattungen, der Beschreibung aller in Deutschland vorkommenden Arten und der Aufzählung aller bishner beschriebenen europäischen Arten. 2 vols. Wien, 1862-64.

Although dealing with the Furopean fauna, this work is very useful on accoun

H. Lorw and C. R. OSTEN SACKEn.-Monographs of the Diptera of North America. 4 parts. Washington, Smithsonian Institution, 1862-72. < Smithsonian Miscellaneous Collections.

The several monographs will be found under the respective families

H. LoBw.-Diptera Americæ septentrionalis indigena. 2 parts. Berlin, $1861-72$. Originally published in ro centuriæ in the Berliner Entomol. Zeitschrift.

Descriptions of 1,000 North American Diptera, but without of 1,000 North America

C. R. OSTrN SACKrN_-Western Diptera : Descriptions of new genera and species of Diptera from the region west of the Mississippi, and especially from Califomia. <Bul. U.S. Geolog, and Geogr. Survey of the Territories, Vol. III, 1877, Pp. 180-354.

Fr BrAUER,-Die Zweiflügler des Kaiserlichen Museums zu Wien. Parts I-III. Wien, 1880$188_{3}$

Important contributions to the classification of the Diptera.

C. H. T. Townsend.-The North American genera of Nemocerous Diptera. <Trans. Amer. Entom. Soc., I892, Pp. 144-160.

\section{MONOGRAPHS AND SYNOPSES}

C. R. OStra SACKEN.-New genera and species of North American Tipulidæ with short palpi. with an attempt at a new classification of the tribe. 2 pls. < Proc. Acad. Nat. Sci. Phila., 1859, Pp. 197-256.

C. R. Ostre SACKen.-On the North American Tipulidx, Part I. <Monographs of the Diptera of North America, Part IV, 1860 . A monographi and the sections Cylindrotomina and Ptychopterina.

C. R. Osten SACken.-Studies on Tipulidx. Part I, Tipulidæ longipalpi. <Berl. Ent. Zeitschr., 1886, pp. 153-188. Part II, Tipulidx brevipalpi. <Ibid, 1887, Pp. 183-242.

H. Losw.-Table for determining the North American species of the genus Pachyrrhina. $<$ Verh. zool.-bot. Ges. Wien, 1879, Pp 513-516.

D. W. Coovillett.-Synoptic tables of the North America mosquitoes. <Cir. No. 40 , second series, Div. Entom., U. S. Dept. Agric., 1900, Pp. 4-7.

N. BAnks.-Some Psychodidæ from Long Island, N. Y. <Can. Entom, 1894 , pp. 329-333.

T. Kincaid.-The Psychodida of the Paciflc coast. <Entom. News, 1899 , pp. 30-37.

J. WiNNERTz.-Beitrag zu einer Monographie der Gallmücken. <Linnæa Entomologica, Vol. VIII, 1853,4 pls.

C. R. OsTrN SACKEN-On the North American Cecidomyidz. <Monographs of the Diptera of North America, by $\mathrm{H}$. Loew and C. R. Osten Sacken, Part I, No. 5, I 862, Pp. 173-205.

B. D. W ALSH.-On the insects, Coleopterous, Hymenopterous and Dipterous, inhabiting the galls of certain species of Willow. Diptera. <Proc. Entom. Soc. Phila.; Vol. III, 1864 pp. 543-644; Vol. VI, 1866, pp. 223-229.

$\mathrm{J}$. voN BERGRNSTAMM and PAUL Lorw.-Synopsis Cecidomyidanum. <Verh. k. k. zool.bot. Ges. in Wien, Vol. XXVI, 1876, pp. 1-104. A synopsis of all tlie literature of the family.

J. Winnertz.-Beitrag zu einer Monographie der Pilzmücken. <Verh. k. k. zool.-bot. Ges. in Wien, 1863 , pp. $637-694$.

Useful for determination of genera; no American species are described

J. WiNNERTz. - Beitrag zu einer Monographie der Sciarinen. Wien, 1867 , pp. 187.

D. W. CopuinletT.- The buffalo gnats or black flies of the United States. A synopsis of the Dipterous family Simuliidæ. <Bul. ro, new series, Div. Entom., U. S. Dept. Agric., 1898 , Pp. 66-69.

H. Losw. - Revision der Blepharoceridæ. <Schles. Zeitschr. f. Entom., neue Folge, Heft VI, Breslau, 1877 .

S. W. WILIISTON.-On the classification of North American Diptera. Second paper. <Entom.

A mer. Vol. 1, $1885, \mathrm{Pp}, \mathrm{ro}^{-13}$.
Table of the genera of North American Leptida.

D. W. CopuiLlE TT.-Synopsis of the Dipterous genus Symphoromyia. <Joum. N. Y. Entom. Soc. 1894, Pp. 53-56.

FR. BraURR.-Versuch einer Characteristik der Gattungen der Notacanthen (Ltr.), mit Rücksicht auf die im Kaiserlichen Museum befindlichen von Dr. J. R. Schiner aufgestellten neuen Gattungen. <Die $Z$ weiflügler des Kais. Museums zu Wien, Vol. II, 1882, Pp. 3-35. The Notacantha Latreiile comprlse the family

S. W. WiLListon.-On the classification of North American Diptera. Third paper. < Entom. Amer. Vol. I, 1885, Pp. 114-116.

Tabies for dlstinguishing the families Stratiomyl. dxe and.Leptidxe and osciliant genera. 
L. T, DAY.-The species of Odontomyia found in the United States. <Proc. Acad. Nat. Sci. Phila., 1882, Pp. 14-88.

C. W. Johnson.-A review of the Stratiomyix and Odontomyix of North America. <Trans. Am. Entom. Soc., 1895, pp. 227-278.

C. R. Osten SACKen.-Prodrome of a monograph of the Tabanidx of the United States. $<$ Memoirs of the Boston Soc. of Nat. Hist., Vol. II, $1875^{-7} 8$.

Part 1. The genera Pangonla, Chrysops, Silvius, Hremotopota, Diabasis (1. c., pp. 365-397) Part II. The genus Tabanus, with an Appen dix and Index (i. c., pp. 421-479). Suppie ment (1. c., pp. 555-560).

S. W. Williston.-On the classification of North American Diptera. Second paper. <Entom. Amer., Vol. I, 1885 , pp. 10-13.

Contains a synopsis of the genera of Tabanidx. pp. I0-1x.

S. W. WILLISTON.-Notes and descriptions of North American Tabanidx. <Trans. Kans. Acad. Sci., Vol. X, 1888, pp. 129-142.

S. W. WILliston.-The North American species of Nemestrinidx. <Can. Entom., Vol, XV, 1883 , Pp. $69-72$.

A. GRRSTARCKRR. - Systematische Uebersicht der bis jetzt bekannt gewordenen Mydaiden. $<$ Stettiner Ent. Zeit., 1868, pp. 65-103.

S. W. WILliston.-Notes and descriptions of Mydaidæ. <Trans. Kans. Acad. Sci., Vol. $\mathrm{XV}, \mathrm{pp} .53-58,1898$.

C. R. OSTHN SACKEN.-Western Diptera, etc. $<$ Bul. U. S. Geolog. and Georgr. Survey of the Territories, Vol. III, No. 2,1877 .

Analytical table of the North American genera of Bombyliidæe, pp. 228 ; Tables of the species of Exoprosopa, p. 230; Anthrax, p. 238; Argyramoeba, p. 241; Bombylius (species fron the Atlantic States), p. 247: Ploas (California species), p. 260 ; Toxophora, p. 265 ; Epibates.

D. W. COQuilletr. - Monograph of the Lomatina of North America. <Can. Entom., Vol. XVIII, 1886, Pp. 8I-87.

The Lomatina comprise the genera Eucessla, Leptochilus, Aphoebantus and Oncodocera.

D. W. Copuill etr. - The North American genera of Anthracina. <Can, Entom., Vol. XVIII, 1886, Pp. $157^{-159}$.

tabular arrangement of the genera composing the subfamily Anthracina.

D. W. CooviLLETT,-Monograph of the species belonging to the genus Anthrax from America, north of Mexico. < Trans. Ainer. Entom. Soc., Vol. XIV, 1887 , No. 2, pp. 159-182.

D. W. COQuilLETT.-Revision of the species of Anthrax from America, north of Mexico. <Trans. Amer. Entom. Soc., 1892, Pp. 168-187.

D. W. CoQuilLETt. - Notes and descriptions of North American Bombyliidx. <Trans. Amer. Entom. Soc., 1894, pp. 89-112.

D, W. Copurllett.-Revision of the Bombylid genus Epacmus. <Can. Entom., 1892, pp.

$\mathrm{q}^{-11}$.

D. W. Coquillett.-Revision of the Bombylid genus Aphoebantus. <West American Scientist, 1891 , Pp. 254-264.

D. W. CoquilletT.-Synopsis of the Dipterous genus Thereva. <Can. Entom., 1893, Pp.

197-201.

W. Coquriletrt.-Synopsis of the Dipterous genus Psilocephala. <Can. Entom., 1893, pp. 222-229.

D. W. Copurnemtr.-Revision of the Dipterous family Therevidæ. <Journ; N. Y. Entom. Soc., September, 1894, pp. 97-101.

C. R. Osten SACKEN.-Western Diptera, etc. <Bul. U.S. Geolog. and Geogr. Survey of the Territories, Vol. III, No. 2,1877 .

Synoptical and analytleal table of the Western species of Cyrtopogon, pp. 294-309.
S. W. Wrulston.-On the North American Asil idx-Dasypogoninx, Laphrinz-with a new genus of Syrphidx. <Trans. Amer. Entom. Soc., Vol. Xr, 1883, pp. I-35, Pls. 1, 2.

Tabulates the genera of the subfamilles Dasypothe species.

S. W. Wruliston.- On the North American Asilida, Part II. <Trans. Amer. Entom. Soc., Vol. XII, I885, pp. 53-76.

Tabulates the species of Laphrla and revises the genera and specles of the subfanily A silinze, excepting the genus Asilus.

W. A. SNow.-List of Asilidx supplementary to Osten Sacken's catalogue of North American Diptera. <Kans. Univ. Quart., Vol. IV, 1896, pp. $173-190$.

D. W. CoQUILLETT.-Brief tables of several genera have been published in the Can. Entom. 1893 , pp. $20,33,80,118$ and 175 .

D. W. Coqunletr.-Ospriocerus, <Entom. News, 1898, p. 37.

D. W. Cocunletr--Revision of the North American Empidz. <Proc. U. S. Nat. Mus., Vol. XVII, pp. 387-440. 1806 .

H. Losw.-On the North American Dolichopodidæ. <Monographs of the Diptera of North America Part II, I864.

J. M. ALDRICH.-A revision of the genera Dolichopus and Hygroceleuthus. <Kans. Univ. Quart., Vol. II, 1893, pp. 1-26.

W. M. WheEler. - New species of Dolichopodida from the United States. $<$ Proc. Calif. Acad. Sci. 3 ser., Vol. II, Zool. No. 1, pp. I-77. 1899.

Tabies for the species of fifteen genera.

J. M. AlDrich.-New species of Phora. < Can. Entom., 1892 , pp. 142-146.

D. W. Coquilletr. - Synopsis of the Dipterous genus Phora. <Can. Entom., 1895, pp. 103II0.

G, DE N. Hougr.-The Pipunculidx of the United States. < Proc. Bost. Soc. Nat. Hist., Vol. XXIX, pp. $77^{-86}$. 1899 .

W. A. SNow.-American Platypezida. <Kans. Univ. Quart., Vol. III, Part I, 1894, PP. 143-152; Part II, 1895, pp. 205-207.

S. W. WILLISTON.-Contribution to a monograph of the North American Syrphidx. <Proc. Amer. Philos. Soc., Vol. XX, 1882, pp.

S. W. WiLListon.-Synopsis of the North American Syrphidx. Bul. U. S. National Museum, No. 31,1886 .

This work supersedes the previsus publications on

W. A. SNow.-Supplementary list of North American Syrphidæ. <Kans. Univ. Quart., Vol. III, pp. 249-262. 1895.

W. D. HUNTER. - A summary of the members of the genus Chilosia Meig. in North America, with descriptions of new species. <Can. Entom., 1896, Pp. 227-233.

S. W. WILLISTON.-The North American species of Conops. <Trans. Conn. Acad., Vol. IV, 1882, pp. 325-342.

S. W. WILliston.-North American Conopida: Stylogaster, Dalmannia, Oncomyia. <Trans. Conn. Acad., Vol. VI, 1883 , pp. 5-12.

Fr. Brauer.-Monographie der Oestriden. Wien, 1863.

Four supplements, by the same author, are published in Wiener Entom. Zeit., Vol. V, 1886,

S. W. WIL.1STON. -North American Tachinidx. Gonia. <Can. Entom., Vol. XIX, 1887, pp. 6-12.

A revision of the species of Gonia. 


\section{Bibliography}

Fr. Braurr and J. E. Brrgenstamm-Die Zweiflügler des Kaiserlichen Museums zu Wien. Parts IV-VII, 1889-94.

These parts contain a prodrome to a monograph of the Muscaria Schizometopa (excl. Anthomyid $x$ ).

C. H. T. Townsend.-The North American genera of Calyptrate Muscida. Paper II. <Trans. Amer. Entom. Soc., 1892, pp. 133-144.

D. W. Coqurlnetr.-Revision of the Tachinidze of America, north of Mexico. <Technical series, No. 7, Div. Entom., U. S. Dept. Agric., 1897 .

C. H. T. Townsrnd.-The North American genera of Calyptrate Muscidz. Paper III. $<$ Trans. Amer. Entom. Soc., 1892, pp. 273278 .

Table of the genera of Dexidx.

H. A. HAGEN.--List of North American Sarcophagidx, examined by R. H. Meade, Esq., Bradford, England. <Can. Entom., I88I, Vol. XIII, pp. 146-150.

C. H. T. Tow NSEND.-The North American genera of Calyptrate Musicdx. Paper IV. $<$ Trans. Amer. Entom. Soc., I892, pp. 279284

Tables of the genera of Sarcophagidæ and Muscl-

G. DE N. Hovgr.-Synopsis of the Calliphorinz of the United States. <Zool. Bul. II, I899, pp. $28_{3}-220$.

G. DB N. HovgH.-Some Muscinze of North America. <Biol. Bul. I, 1899, pp. 19-33.

H. A. HAGRN.-List of North American Anthomyidæ, examined by R. H. Meade, Esq., Bradford, England. <Can. Entom., Vol.XIII, 1881, pp. 43-51.

P. Strin. - Nordamerikanische Anthomyiden. <Berl. Entom. Zeitsch., I897, pp. 161-288.

D. W. Coquilert - On the Dipterous family Scatophagida. <Joum. N. Y. Entom. Soc., September, 1898 , pp. 160-165:

H. Lozw.-On the North American Sciomyzidx. $<$ Monographs of the Diptera of North America, Part I, 1862, Pp. I03-128.

S. W. Williston.-The American genera of Sapromyzidz. <Entom. News, Vol. V, I894, pp. 1 g6-197.

H. LoEw. - The family Ortalidx, < Monographs of the Diptera of North America, Part III, 1873 , Pp. $1-209$.

H. Lozw.-On the North American Trypetida. $<$ Monographs of the Diptera of North America, Part 1, 1862, pp. 49-102.

H. Lozw.-Review of the North American Trypetina. <Monographs of the Diptera of North America, Part III, 1873, pp. $211-347$.

D. W. Coquilzrt - Notes and descriptions of Trypetida. <Journ. N. Y. Entom. Soc., 1899 , pp. $259-268$

H. Lozw.-On the North American Ephydrinida. <Monographs of the Diptera of North America, Part I, 1862, pp. 120-172.

W. M. WheELER. - The genus Ochthera. <Entom. News, 1886, pp. 121-123.

D. W. Coquilzett.-Notes and descriptions of Oscinida. < Journ. N. Y. Entom. Soc., March, 1898, pp. 44-49.

D. W. CoquilletT. - New genera and species of Nycteribidx and Hippoboscidx. < Can. Entom., 1899. pp. 333-336.

\section{SIPHONAPTERA}

O. Taschennerg.-Die Flöhe. Die Arten der Insektenordnung Suctoria nach ihrem Chitinskelet monographisch dargestellt. Halle, 1880.
P. Megnin.-Les parasites et les maladies para. sitaires chez l'homme, les animaux domestiques et les animaux sauvages avec lesquels ils peuvent être en contact. Insectes, Arachnides, Crustacés. Paris, 1880

The Pulicidae (Aphanipteres) are treated of on

C. F. BAKRR. - Preliminary studies in Siphonaptera. <Can. Entom., 1895, pp. 19-22;63-66; 108-11 I; 130-132; 162-165; 186-191; 221-222.

\section{TRICHOPTERA}

R. MCLACHLAN,-A monographic revision and synopsis of the Trichoptera of the European

Extremely valuable for the study of genera.
Eana. London, $1874^{-1} 880$.

F. A. Kolenati.-Genera et species Trichopterorum. 2 parts. Part 1 , Prague, 1848; part 2, Moscow, 1859 .

R. Mclachlan.-Notes on North American Phryganidze, with especial reference to those contained in the collection of the British Museum. < Entom. Annual for 1863, pp. 155Mus.

H. Contains a list of North American Phryganids. A. HAGEN.-Phryganidarum Synopsis synonymica. KVerh. k. k. zool.-bot. Ges. in Wien,

. A. HAGEN.-Beiträe zur Kenntniss der Phryganiden. < Verh. k. k. zool.-bot. Ges. in Wien, Vol. XXIII, 1873 , pp. $377-452$.

H. A. Hagen,-On the Phryganida. <Proc Boston Soc. Nat. H ist., Vol. XV, 1873, pp. $384^{-}$ 385 .

A. E. EATON, On the Hydroptilidx, a family of the Trichoptera. LTrans. Entom. Soc. London, 1873 , pp. 125-151.

secies, and synopsis of genera. BAN KS.-Descriptions of new North American Neuropteroid Insects. <Trans. Amer. Entom. Soc., I898, pp. $109-218$. Contains a table of the genera of Leptocerida.

\section{MECOPTERA}

J. O. Westwood.-Monograph of the genus Panorpa. <Trans. Entom. Soc. London, Vol. IV,

p. I. S. Hine.-The North American species of the Soc., Vol. XIII, 1899, pp. Ir, 2 pls.

J. S. Hink-A review of the Panorpidze of America north of Mexico. Ohio State University, University Bulletin, series V, No. 7 : Contribu. tions from the Department of Zoology and Entomology, No. 4. Reprinted from Bul Sci. En University, Vol. XI Art X February, University, February, 1901, pp. $241-264$, pls. LIX-LXI inc.

\section{NEUROPTERA}

\section{I.-CATAlogues}

N. BANKS.-A synopsis, catalogue, and bibliography of the Neuropteroid insects of temperate North America. <Trans. Amer. Entom. Soc., 1892, pp. 328-373.

\section{II.-GENERAL WORKS ON CLASSI-}

\section{FICATION}

Hermann Purmeister.-Handbuch der Entomologie. Berlin, 1832-1835.

In Vol. II, Part I

P. RAmDUR.-Historie naturelle des Netroptères. Suites a Buffon. Paris, 1842 .

HermanN HAGEN.-Synopsis of the Neuroptera of North America, with a list of the South American species. Prepared for the Smithsonian Institution. <Smithsonian Miscellaneous Collections, Washington, 186r. 
M. Rostock.-Neuroptera Germanica. Lwickau, 1888,200 pp. 10 pls.

appendix, an European genera, and, as an appendix, an elaborat
Psocidie by $\mathrm{H}$. Kolbe.

Fr. Braugr. - Verzeichnis der bis jetzt bekannten Neuropteren im Sinne Linné's. < Verh. zool.bot. Ges. Wien., 1868, pp. 359-416; 711-742.

N. BANKs, - New genera and species of Nearctic Neuropteroid Insects. < Trans. Amer. Entom. Soc., $1899-1900$, pp. $239-259$.

oc, $1899-1900, \mathrm{pp} .230^{-2} 59$. and tables of Callibietis and Trienodes.

H. Albarda.-Révision des Raphidides. <Tijd. voor Entom., 1891, pp. 65-184.

H. A. H AGEN.-Stray notes on the Myrmeleonidx. $<$ Can. Entom., $1887-1888$. Continued in severl numbers.

N. BAN KS.-A classification of the North American Myrmeleonidx. <Can. Entom., 1899, pp. 67-71.

G. TH. SCHNEIDER.-Symbola ad monographiam

H. A. HAGBN.-Hemerobidanum synopis synonymica. < Stettiner Entom. Zeit., 1866, pp. 369

H. A62. HAGEN - Monograph of the Hemerobidx. Part I, Proc. Boston Soc. Nat. Hist., Vol. XXIII, 1886, pp. 250-269: Part II, l. c., pp. 276-292.
Never completed.

\section{HEMIPTERA}

\section{1.-CATALOGUES AND CHECK-LISTS}

F. A. Dohrn.-Catalogus Hemipterorum. Stet-

Philip R. UnLrR. - Check-List of the HemipteraHeteroptera of North America. Published by the Brooklyn Entom. Soc., 1886

L. LethibrRY et G. Severin, - - Catalogue général des Hémiptères. 3 vols. 1893-1896. <Musée royal d'histoire naturelle de Belgique.

These include all the Hleteroptera except the Capsidæ and the Cryptocerata.

\section{II.-GENERAL WORKS ON CLASSI- FICATION.}

C. W. Hahn und G. A. W. Herrich-SChatpFER.-Die wanzenartigen Insecten. ro vols.

C. Nuernberg, 1831-1853. B. AMYot et J. G. AUD1NET-SERV1LLE.Hémiptères. Suites à Buffon. Histoire Naturelle des Insectes. Paris, 1843 .

C. ST ur. - Analecta hemipterologica. Berlin, 18661860. 3 parts. Originally published in the Berlin, Entom. Zeitschr.

C. StaL.-Hemiptera Fabriciana, secundum exempla Musei Hafniensis et Kieliensis descripta. 2 parts. <Kongl. Svensk. Vet.-Akad. Handl. $1868-1860$.

J. G. SCH1OEdtв.-Einige neue Hauptsätze der Morphologie und Systematik der Rhynchoten. $<$ Naturh. Tidskr., 1860, p. $237 \mathrm{ff}$.

P. R. UHLER.-List of Hemiptera of the region west of the Mississippi River, including those collected during the Hayden explorations of 1873. <Bul. U..S. Geolog. and Geogr. Survey of the Territories, Vol. I, 1875, pp. 267-36r, pls.

P. ${ }^{10-2 I}$.

RHLER.-Report upon the insects collected by P. R. Uhler during the exploration of 1875 including monographs of the families Cydnida and Saldidx, and the Hemiptera collected by A. S. Packard, M.D. SU.S. Geolog. and 355-475.

C. STAL.-Enumeratio Hemipterorum. Bidrag till en förteckning öfver alla hitills kända Hemiptera (or: Index specierum omnium hucusque cognitarum cum observationibus systematicis). K Kongl. Svensk. Vet.-Akad. Handl., 18701877,5 parts.

C. STAL.-Bidrag till Hemipterenas Systematik. Ofver. k. Vet.-Akad. Förh., 1867, pp. 491-560.
HërRert Osborn.-Classification of Hemiptera. $<$ Entomologica Amer., Vol, I, 1885, pp. 21-27. Short characterization of the who
tables of suborders and families.

H. E. Summers, - The true bugs, or Heteroptera, of Tennessee. <Bul. Tenn. Agr. Exp. Sta., Vol. IV, No. 3, July, 1891, pp. $75-96$. Contains a table of the families, tables of genera of all aquatic forns, of the Emesidx, Nabida, Cydnidie.

III.-MONOGRAPHS AND SYNOPSES

Charlas WIIL1AM WoOdworth,-Synopsis of 1888, pp. $67-68$

P. R. U HLER.-Preliminary survey of the Cicadidx of the United States, Antilles, and Mexico. Trans. Maryland Acad.Sci., 1892, pp. 175-179.

A. D. MACG1LL1VRAY.-Cicadidz. American genera and species. <Can. Entom., March, $1901, \mathrm{pp} .74-84$.

J. O. WESTwOOD. - On the family Fulgoridx, with a monograph of the genus Fulgora of Linnaus. <Trans. Linn. Soc. London, Vol. XVIII, 1839, pp. 133-238, I pl

C. STAL.-Die amerikanischen Fulgoriden-Gattungen synoptisch beschrieben. < Stettiner Entom. Zeit., Vol. XXXI, 1870, pp. 255-258.

W. H. AsHMEAD. - A generic synopsis of the Fulgoridz. <Entom. Amer., 1888, pp. 1-6, $21-28$. North American Delphacidæ. < Bul. Buffalo Soc. Nat. Sci., Vol. V, 1897, pp. 225-261.

E. P. VAN DuzER. - Observations on some northern Derbidx. <Can. Entom., 1889, pp. 359 and 176 .

P. R. UHLER.-Aids to a recognition of some North American genera and species of the old family Fulgoridæ. <Trans. Maryland Acad. Sci. 1900 , pp. $401-408$.

C. STAL. - Bidrag till Membracidernas Kännedom. Ofver. af Kongl. Vet.-Akad. Förhandl., I869.

F. W. GodivG.-Bibliographical and synonymical catalogue of the described Membracidz of Hist., Vol. III, 1894, pp. 391-482.

F. W. Goding. - $A$ synopsis of the subfamilies and genera of the Membracidæ of North America. CTrans. Amer. Entom. Soc., 1892, pp. ica. $<3<$.

V. SIGNORET.-Revue critique du groupe des Tettigonides et de la tribu des Cercopides. $<\mathrm{Re}$ vue et Mag. de Zool., Vol. V, 1853, pp. 173-184

F. Wue et Mag. de Zool., Vol. V, 1853, pp. 173-184. W. GoD1NG.- Synopsis of the subfamilies and genera of the North American Cercopida, with a bibliographical catalogue of the described species. $<$ Bul. Ill. State
Vol. III, I895, pp. $483-501$.

E. D. BALL.-A study of the genus Clastoptera. <Proc. Iowa Acad. Sci., Vol. III, 1896, pp. 182-193, 4 pls.

E. P. VAN DUzer. - A catalogue of the described Jassoidea of North America. <Trans. Amer. Entom. Soc., 1894, pp. 245-316.

E. P. V AN DuzkB.-A synoptical arrangement of the genera of the North American Jassidx, etc. Trans. Amer. Entom. Soc., 1892, pp. 295-307.

v. SignoRet. - Revue iconographique des Tettigonides. - Ann. Soc. Entom. de France, tigonides. SAnn. Soc. Ent

V. 1853-1855, with colored plates. et plus particulièrement sur les Acocéphalides Puton. <Ann. Soc. Entom. de France, 1879

1880.
ChaRLES WILLIAM WoOdWorth.-Jassidz of Illinois, Part I. <Bul. Ill. State Lab. Nat. Hist., Vol. III, 1887 , pp. 9-33.

H. OsBorN and E. D. BALL. - Studies of North American Jassoidea. < Proc. Davenport Acad. Sci. Vol. VII, 1898 , pp. $45-100$.

H. OsBorN and E. D. BALL.-Contributions to the Hemipterous fauna of lowa. < Proc. Iowa Acad. Sci., Vol, IV, 1897, pp, 172-234. 
H. Osborn and E. D. BALl. - The genus Pediopsis; a review of the North American species.
Proc. Davenport Acad. Nat. Sci., Vol. VII, $1900, \mathrm{pp}$. $111-123$.

H. Ostorn and E. D. BAll. $-A$ review of the North Anierican species of Idiocerus. < Proc. Davenport Acad. Nat. Sci., Vol. VII, rgoo, pp. $124^{-1} 38$.

Charles William Womivorth. - On the genus Cicadula. < Psyche, Vol. V, is 89 , pp. 75-76.

E. P. VAN DuzBr, -Review of the North American species of Pediopsis. < Entom. Amer. 889 , pp. 165-174.

E. P. VAN DuzEk. $\rightarrow$ A revision of the North American species of Phlepsius. <Trans. Amer. Entom. Soc., 1392 , pp. 63-82.

J. SPANBERG.-Species Gyponæ Generis Homopterorum. < Bihang till k. Svenska Vet,-Akad. Handl., 1878 .

C. F. BAKRR.-The Noril American species of Gnathodus. Can. Entom., $18 y 6$, pp. 35-42.

W. H. Ashmen D. $\rightarrow$ A gelleric synopsis of the Bythoscopide. Entum. Amer., 1889, Dp. 125-126.

P. VAN Duzer,-Review of the North American species of Eythoscopus. < Entom. Amer. 890 , pp. $221-229$.

Craph W can Typhlocybini. < Psyche, Vol. V, 1889, pp.

C. P. GILLETTB.-American leaf hoppers of the subfamily Typhlocybinz. <Proc. U.S. Nat Mus., Vol. XX, 1898, pp. 709773

H. OSBORN.-The genus Scaphoideus. < Journ. Cin. Soc. Nat. Hist., Vol. XIX, 1900, pp. 187 209, 2 pls.

A. L. Quaintance.-Contributions toward a monograph of the American Aleurodidx. $<$ Bul. No. 8, Technical series, Div. Entom. U. S. Dept. Agric., 1900, pp. 1-6.

V. Signoret,-Essai sur les Cochenilles. <Ann. Soc. Entom de France, 1868-1876.

J. H. Comstock.-Report on scale insects. <Annual Report of the Commissioner of Agriculture for the year 1880, Washington, 1881, pp. 276for the

J. $\mathrm{H}^{349}$. Comstock.-Second Report on scale insects, including a monograph of the subfamily Diaspinæ of the family Coccidæ and a list, with notes, of the other species of scale insects found in North America. - S Second Report of the Cornell University Experiment Station, 1882 83 , I thaca, N.Y., I883, PP. 47 143, pls. 1-4.

W. H. A SHMEAD.-A generic synopsis of the Coccidx. <Trans. Amer. Entom. Soc., 1891, Pp.

T. D. A. CoCKERELL. - Tables for the determination of the genera of Coccidx. <Can. Entom. 1899, PP. 273-279; 330-333.

T. D. A. CocKerell. - A check-list of the Coccidx. <Bul. Ill. St. Lab. Nat. Hist., Vol. IV 1896, Pp. $318-339$

T. D. A. CoCKERrLL.-First supplement to the check-list of the Coccidx. <Bul. Ill. St. Lab. Nat. Hist., Vol. V, 1809 , pp. 389-308.

T. D. A. Cockerel. -A check-list of the Nearctic Coccidx. \& Can. Entom., 1894, PP. 31-36.

T. D. A. Cockerrel.-Table of North America Kermes, based on external characters. $<$ Psyche,

W. Nel. IX, 1900 , Pp. $4^{-45}$. the subgenera Diaspidiotus and Hemiberlesia, of the genus Aspidiotus. <Contrib. Dept. Zool. Entom., Iowa St. Coll. Agric, and Mech.

R. Arts, No. 3, August, 1899 . and Hemichionaspis. <Spec. Bul. Mass. Agric. Exp. Station, August, 1809 , pp. 58 , 9 pls.

Agric. Exp. Station, Aukust, 1899 , $\mathrm{B}$. ica. < Psyche, July, 1900, pp. 78-84.

Fra. Verh.d. k. k. Zool.-Bot., Ges. in Wien, 1878 , Pp. $585-610$.

the European sub. famllles and genera. Supersedes all prevlous classifications.
W. H, Ashmen D. - On the Aphididx of Florida, with descriptions of new species. Family Pp. 220225

ives $\mathrm{a}$ list of the North American specles, with descriptions of several new ones.

C. V. RILEY. $\rightarrow$ Notes on North American Psyllidx. <Proc. Biolog. Soc. Wash., Vol. II, 184, PP. 67-79.

classlfied llst of the Vorth American Psyllld hitherto clescribe:t, $\mathrm{w}$ lth short cliaracteristics of the sulvfamilies, and diescriptions of sume new genera all is species.

C. W. Mally.-Psyllida found at Ames. < Proc. Iowa Acad. Sci., Voi. 11 , $1894, \mathrm{pp}, 152-171,3$ pls.
A list of the describerl specles, witlia lew additions.

Benjamin D. Walsh.-On the genera of Aphidx found in the United States. CProc. Entom. Soc. Phila., Vol. 1, 1861-1863, Pp. 294310.

Cyrus Thomas. - Notes of the Plant-lice found in the United States. <Trans. Ill. Hortic. Soc. 877, PP. 137-212.

review of the family, inclurling the Psyllidxe: reproduces the descriptions of earlier authors,

Crrus Tromas, $-A$ list of the species of the tribe Aphidini, family Aphida, found in the United States, which have been heretofore named, with descriptions of some new species. <Bul. No.

C. V. RILEY and J. MONELL.-Notes on the Aphididx of the United States, with descriptions of species occurring west ot the Mississippi, $<$ Bul. L.S. Geolog, and Geogr. Survey of the Territories, Vol. V, No. 1, 1879 , pp. 1-32, 2 pls. Pey glies tlie biolugy and ces ription of severa
Pemphigine: Monell, descriptions. with oc Pemphiginze Monell, desriptions. with
casional tables, of a number of Aphidlnie.

Crrus Tromas.- Eighth Report of the State Entomologist on the noxious and beneficial insects of the State of Illinois. CThird Annual Report,

by Cyrus Thomas, Springfield, 1879 . report treats wholly on the Aphidida of the
United States and is an enlargement of the author's paper in the Trans. III. Hortic. Soc, 1877 .

Georgr B. Buckton.-Monograph of the British Aphides. 4 vols. Ray Society, London, $1875^{-}$ 1883

Thls is the latest European work on thls famlly, containing tables for the determination of the genera.

J. Lichtenstrin.- Les Pucerons. Premiere partie. Genera (all published.) Paris, 1885, pp. 185 .

ontains a bibllography, synopsis of genera, and lists of specles of the entire world to date.

O. W. Onstrund.-Synopsis of the Aphidida of Minnesota. < Bul. No. 4, Geolog. and Nat. Hist. Survey of Minn., St. Paul, 1887 .

W. H. Asmmend.-A generic synopsis of the A phidida. < Entom. Amer., I889, Pp. 185-189. ican A phididz. Spec. Bul. No, 1, Univ. Nebr. Dept. Intom., $180 \mathrm{r}$.

F. X. FIRBER,-Species generis Corisa monographice disposita. <Abhandl. kön. böhm. Ges. der Wiss. Prag, Ser. 5, Vol. VII, 18\$2, Pp. 213-

260.

X. FIEBER.-Rhynchotographien, drei mono graphische Abhandlungen. Sciocoridx, Oxycarenus, Notonecta. $<$ Abhandl. kön. bohm. Ges. 88 .

G. $\mathbb{W}^{25}$. KIRKALDV, - Revision of the Notonectidx, Part I. LTrans. Entom. Soc. London, 1897 pp. $393-426$

JOSEPH LE1DY.-History, and anatomy of the Hemipterousgenus Belostoma. < Journ. Acad Sci. Phila., Ser. 2, Vol. I, 1847, pp. $57-6$, pl. I.

LEon Dupour, - Essai monographique sur les Bélostomides. <Ann. Soc, Entom. de France,
1863 , pp. 373-400. G. MAYR, - Die Belostomiden, Monographisch Wien, 1871 , pp. 399-440. 
A. I. Montandon--Hemipteres-Heteropteres exotiques, notes et descriptions, II. Fam.
Belostomidæ. <Ann. Soc. Entom. Belg. 1896, pD. 508520 .

F. X. FIEBER.-Genera Hydrocoridum secundum ordinem naturalem in familias disposita. $<\mathrm{Ab}$ handl. kön. bühm. Ges, der Wiss Prag, Vol. VII. 1852, pp. 181-212, 4 pls.

O. M. RzUter.-Acanthiidæ Ainericanæ. <Öfver.

k. Vet.-Akad. Forh., 1871, pp. 557567.

M REUTER - Monographia Anthocoridarum orbis terrestris. <Act. Soc. Fenn., Vol. XIV, I 886 , PP. $555-758$.

P. R. Uhler, - Family Saldida. Report upon the insects collected by $P$. R. Uhler during the explorations of 1875 . Bul. U.S. Geolog. and Geogr. Survey, Vol. III, No. 2, 1877, Pp. 429452.

C. StAL.-Monographie der Gattung Conorhinus und Verwand ten. Berliner Entom. Zeitschr., Vol. III, 1859, PP. 312-328.

C. Stal. - Bidrag tili Reduviidernas kännedomen. CÖfver, k. Vet.-Akad, Förh., 1866, Pp. 235-302.

O. M. REUTER, - Nabidæ novæ et minus cognitæ. <Öfver. k. Vet.-Akad. Förh., Vol, XXIX, 1872-1873, pp. $79-96$.

F. A. DонкN-Beiträge zu einer monographischen Bearbeitung der Familie der Emesina, < Linnaa Entom., Vol. XIV, 1860, PP. 206-355, Table I.

A. HANDlirsch, -Monographie der Phymatiden. <Ann. k. k. Naturh. Hofmuseums, Wien., 1897, Vol. XII, PP. 127-230.

A. N. CAUdell. - The genus Sinea of Amyot and Serville. <Journ. N. Y. Ent. Soc., March, 1901, pp. 1-11, 2 pls.

E. BERGROTH.-Notes on the Nearctic Aradidæ. $<$ Proc. Entom. Soc. Wash., Vol, II, Pp. 332$33^{3}, 1892$.

ATK1NSON.-Catalogue of the Capsidre. Suppl., Journ. Asiatic Soc. Bengal, Vol. LVIII, Part II, 1889 , pp. 200 .

O. MeUtrin-Capsine ex Asids of th Museo Holmiensi asservatæ. <Öfver, k, Vet.• A kad. Förh., 1875, Pp. 59-92.

O. M. REUTER,-Hemiptera Gymnocerata Europæ. Helsingfors, Vol. I, 1878 ; Vol. II, 1879 Vol. III, 1883 ; Vol. IV, 1891 ; Vol. V, 1806.

$\mathrm{H}, \mathrm{E}$. Summers.-A generic synopsis of the $\mathrm{Ne}$ arctic Pentatomida. < Proc. Iowa Acad. Sci., $1898-1899$.

E, F, GrRMar. - Beiträge zu einer Monographie der Schildwanzen. < Germar's Zeitsclir, f. Entom., Vol. I, 1830 pp. 1-46.

Now greatly antiquated; treats of the Scuteiieridx and Corimelaenidx.

A. L. Montandon.-Notes on American Hemip. tera-Heteroptera. < Proc. U. S. Natl. Mus., Vol, XVI, pp, 45-52, 803 . Contains Table to Cosmopepia, and review of

P. R. UHLER, - Summary of the Cydnidx of North America in report upon the insects collected by P. R. Uhler, etc. < Bul. U.S. Geolog.Survey, Vol. III, 1877, pp. 366-396.

V. SiGNORET. - Révision du groupe des Cydnides de la famille des Pentatomides. CAnnales de la Société Entom. de France, 1881, and subse-

quent volumes to 1884 .

H. Densw.-Monographia Anoplurorum Britannix, or an essay on the British species of parasitic insects. London, 1842,26 pls.

C. G. A. G1Ebel.-Insecta epizoa. Die auf Saügethieren und Vögeln schmarotzenden Insekten Nach Zeichnungen von C. L. Nitzsch. Leipzig

1874, 20 pls.
ANDREW MURRAY.-Economic Entomology. Aptera. South Kensington Museum Science Handbooks. London and New York, 1877.
The Pediculidxe are treated on pp. 384-400.
P. Mḱgnin.-Les Parasites et les maladies parasitaires chez l'homme, les animaux domestiques et les animaux sauvages avec lesquels ils peuven être en contact. Insectes, Arachnides, Crustacés. Paris, 1880 .

The Pediculidix are treated on pp. 7z-79.

E. Pingrt.-Les Pediculines. Description de toutes les espèces observées, enrichie d'especces nouvelles. Leyden, 1880, 56 pls.; Supplement, 1885,17 pls.

\section{PHYSAPODA}

A. H. Haliday, - An Epitome of the British genera in the Order Thysanoptera, with indica tions of a few of the species. < Entom. Mag. Vol. III, 1836, PP, $439^{-4} 41$.

Francis WALKER.- List of specimens of Homop terous Insects in the collection of the Britisl Museum. 5 vols. and i vol. Supplement, London, $1850-1858$

he Physapoda, compiied from Haiiday's manuscripts, are treated in the supplement.

A, M, BEACH,-Contributions to a knowledge o the "Thripida of Iowa, < Proc. Iowa Acad Sci., Vol. III, 1896, Pp. $214-227$.

H. UzzL.-Monographie der Ordnung Thysanoptera. Königgrätz, 1895, 4to, $472 \mathrm{Pp}$., 10 pls.

\section{ORTHOPTERA}

\section{r.-CATALogues}

Samuel H. Scudner. - Catalogue of the described Orthoptera of the United States and Canada. <Proc. Davenport Acad. Nat. Sci., Vol. VIII, 1900.

SAmuel H. Scunder,-A catalogue of the Orthoptera of North America described previous to 1867 . < Smithsonian Institution Miscellaneous Collections 189,1868 .

An alphabetical, not synonymicai, ist of the Orthoptera described from North America contains also a full bibliography up to 1867 .

\section{II.-LOCAL LISTS}

J. Sidney Smith.-Orthoptera of the State of Maine. < Proc. Portland Soc. Nat. Hist. 1868, Pp. 143-151.

A synonymical catalogue of the Orthoptera found in Maine, with notes on habits and distribu-

Cyrus Thomas. A A list of the Orthoptera of Illinois. Bul. Ills. Mus. Nat. Hist. No. 1,1876 Pp. $59-69$.

A synonimicai ist of the Orthoptera found in

c. H. FERnLand.-The Orthoptera of New England. < Ann. Rept. Mass. Agric. Col. 1888, Pp. 6r.

W. Beutenmuller.-Descriptive catalogue of the Orthoptera found within fifty miles of New York City. <Bul. Amer. Mus. Nat. Hist. Vol. VI, pp. 253-316. 1894.

\section{III.-GENERAL WORKS ON CLASSI-}

\section{FICATION}

S. H. SCUDDRR.-Guide to the genera and classification of the North American Orthoptesa. Cambridge, Mass., 1897 .

C. BRUNNER von WATTINWYL.-Révision du système des Orthoptères, et description des especes rapportées par M. Leonardo Fea de Birmamie. <Ann. Mus. Civ. Stor. Nat. Genova, XIII, 1893, Pp. 1-230.

J. G. Audinet-SkRviLLE.- Histoire naturelle des Insectes Orthoptères. Paris, $1839,776 \mathrm{pp}$. 14 pls.

thral history of the order up to date, with bibilography and ist of species describod. 
HenR1 de SAUSSURr, -Orthoptera nova Americana [Diagnoses prxliminares]. Series I-III. Revu et Mag. de Zool., 1859-6r. Contains Synopticaí tables of species, besides
descriptions ot numerous North American Orthoptera.

Samuer, H. Scudder.-Materials for a monograph of the North American Orthoptera. < Boston Journal of Nat. Hist., Vol. VII, 1862, pp. $409-480$

Contains synoptical tabies and a review of the system used for classification.

SAMURL H. Scudder.-Remarks upon the arrangement of the families of Orthoptera. < Proc. Boston Soc. Nat. Hist., Vol. XII, 1868-69 also separate under the title: Entomologica Notes, Vol. II, pp. 7-14.

Samurz H. Scudder. - Synoptical table for determining North American insects. Orthoptera. <Psyche, Vol. I, 1876, pp. 169-171.

Synopsis of the families of Orthoptera; aiso a ist of usefui works in the study of North Americas Orthoptera.

S. H. SCUDDER.-A list of the Orthoptera of New England. <Psyche, Sept., rgoo, pp. 99-106.

\section{IV.-MONOGRAPHS AND SYNOPSES}

SAMUel H. SCUDDER.-Summary of the U.S. Phasmidz. <Can. Entom., 1895, pp. 20-30

Grorge R. Gray.-Synopsis of the species of in sects belonging to the family of Phasmidz. London, 1835 .

J. O. Westwoon.-A catalogue of the Orthopterous insects in the British Museum. Part I, Phasmidæ. London, 1859 .

C. Stal.-Recensio Orthopterorum. Revue critique des Orthoptères décrits par Linné, De Greer et Thunberg. Part III. Stockholm, 1875 Synoptical tables of the genera of Phasmida, with

AMUEL H. ScUD many species. mera (Phasmidx) found in U. S. and Canada. <Psyche, Vol. IX, No. 300, pp. 187-189. April, 190x.

Samurl H. Scudder. - Index to the Mantida of North America, north of Mexico. <Can. Entom., 18g6, pp. 207-215.

HeNRI DE SAUSSURE.-Essai d'un système des Mantides. <Mittheil. d. Schweiz, Entom. Ges., Vol. III, 1869, pp. 49-73.

Classification of the Mantida. Part II contain descriptions of North American species.

Henri de Saussure.-Additions au systeme des Mantides. Geneva, 187 .

Synoptic table of genera and species of North Synoptic table of gener.

Henri dE SAussure.-Mantides Américains. $<$ Mém. Hist. Nat. Méx., II, 1. Geneva, 1871 , 186 pp., 2 pls.

J. O. WESTWOOD.-Revisio Insectorum Famila Mantidarum, Speciebus novis aut minus cognitis descriptis et delineatis. London, $188 \mathrm{~g}$.

HENR1 DE SAUSSURr.-Orthoptera nova Ámericana (Diagnoses praliminares). Ser. III. $<$ Revue et Mag. de Zool., 1862. Contains description of new Blattidee, with synop-
tical arrangement.

C. BRUNner voN WATtrewrt.-Nouveau système des Blattaires. Vienna, 1865, $426 \mathrm{pp}$. 13 pls.

noptical arrangement of aii described species, with descriptions of many new ones; aiso

HENRI DE SAussure.-Mélanges Orthoptérolo giques. 6 fascicules. Genova, $1863_{3}-1878$.

W. I. BLATCHLEY. - The Locustidx and Blattidx of Indiana. <Proc. Ind. Acad. Sci., 1892 pp. $92-163$.
C. Stal.-Recensio Orthopterorum. Revue critique des Orthoptères décrits par Linné, De Geer et Thunberg. Part I. Acrididæ. Stock. holm, 1873, 154 pp.

A synoptical arrangement of the genera of the family, with descriptions of new genera and species.

Cyrus Thomas.-Synopsis of North American Acridida. < Report U. S. Geolog. Survey, Vol. V, Part I, 1873 .

A systematical arrangement of the described spe. cies of North Ainerican locusts: Part $I$, Species of the United States; Part II, Species
from other parts of North America.

Samuer, H. Scudder.-Spharagemon, a genus of CEdipodidre; with a revision of the species. <Proc. Boston Soc. Nat. Hist., Vol. XVII, 1875 , pp. $467-471$. Separate, under the title Entom. Notes, IV, pp. 66-70.

A synopsis of the genus, with descriptions of new species.

Samuel H. Scudder.-A revision of two American genera of CEdipodidx. < Proc. Boston Soc. Nat. Hist., Vol. XVII, 1875, pp. 478 485. Separate, under the title: Entom Notes, IV, pp. 77-84.

A synopsis of the genera Encoptoiophus and Tragocephola.

Cyrus Thomas.-Manual of economic entomology. Part III. The Acrididæ of Illinois. $<$ Ninth report of the State Entomologist ... of the State of Illinois, r88o, pp. 73-140.

Contains a synoptical table or key to the families of Orthoptera, a key to the subfamilies an genera, and a key to the Illinois species of Acrididx.

LAWRENCr BrUner.-North American Acrididx, north of Mexico. < Third Report U. S. Entom. Commission, $188_{3}$, pp. $55^{-6} \mathrm{r}$.

Entom. Commission, 1883 , pp. $55-6 \mathrm{r}$. systematical list

Henri de SAussure. - Prodromus CEdipodiorum Insectorum ex ordine Orthopterorum. $<$ Mém. Soc. Phys. Hist. Nat. Geneva, 1884. 4to, $254 \mathrm{pp}$.

A synoptical monograph of the subfamily Edipo dine of ali countries, with descriptions of new species.

C. Sra . - Systema Acrideorum. <Bih. Svensk. Vet. Akad. Handl., 1878 , pp. 100.

Samurl H. Scudder.-Revision of the Orthopteran group Melanopli (Acrididx,) with special reference to North American forms. <Proc U. S. Nat. Mus., Vol. XX, pp.01-421. 1897.

Samuri H. Scudpre. - The Orthopteran genus Hippiscus. <Psyche, Vol. VI, 18g2. [Com tinued in several numbers.]

Samurl H. Scudder. - The North American species of Orphulella. <Can. Entom., 18g9, pp.

$177^{-188 .}$
SAMULL H. Scudder.-The species of the Or. thopteran genus Derotmerna. <Proc. Amer. Acad. Arts and Sci., Vol. XXXV, No. 19, March, 1900, pp. 387-395.

Samuel H. Scudder.-Some genera of CEdipodidx rescued from the Tryxalidz. <Psyche 1890 , pp. $433-442$

SAMUEL H. SCUDDER, - Supplement to a revision of the Melanopli. <Proc. Davenport Acad. Nat. Sci. Vol. VII, pp. 157-205, 3 pls. 1890

Samuel H. Scudder.-The Orthopteran genus Schistocerca. <Proc. Amer. Acad. Arts and Sci., Vol. XXXIV, 1899, pp. $441-476$

A. P. Morse.-Revision of the species of Spharagemon. <Psyche, Vol. VII, 1895, pp. $287 \sim 299$

J. McNellt.-Revision of the Truxalina of North Amcrica. <Proc. Davenport Acad. Nat. Sci., Vol. VI, 1S97, pp. 179-274.

J. MCNeILL. - The Orthopteran genus Trimero tropis. <Psyche, Vol. IX, pp. 27-36. rgoo. 
A. P. Morse - Notes on the Acrididx of New England. <Psyche, I, r894, Pp. 147-167 ; II, 1896 , pp. 323-327, 342-344, 382-384, 402-403, 407-411, 419-422, 443-445; III, 1897, Pp. 6-8, $35-37,50-51,64-66,80-82,87-89,111-114$; IV, 1898 , pp. $247^{-248}, 255^{-260}, 269^{-273}, 279^{-282}$, 292-296.

Samurl H. Scuddrr. - The species of Hadrotettix, a genus of Edipodinx. <Psyche, 1900, Pp. 67-69.

I. Bolivar.-Essai sur les Acridiens de la tribu des Tettigidæ. <Ann. Soc. Entom. Belg., 1887, Pp. 175-313

J. L. HANCOCK.-The species of the new genus Neotettix with a key to the genera of North American Tettigix. <Entom. News, 1898 , pp. $137^{-141 .}$

J. L. HANCOCK.-Synopsis of subfamilies and genera of North American Tettigidæ. <Psyche, Vol. IX, pp. 6-7. Igoo.

S. H. Scunder. - The species of Circotettix, a North American genus of CEdipodinz. $<$ Psyche, Dec. 1900, pp. 135-141.

J. MCNEIL, ., - Revision of the Orthopteran genus Trimeroptropis. <Proc. U. S. Natl. Mus., Vol. XXIII, pp. 393-449, roor.

C. STAL_-Recensio Orthopteroruin. Revue critique des Orthoptères décrits par Linné De Geer et Thunberg. < Part II. Stockholm, 1874 , 121 Pp.

Contains synoptlcal tables of the genera.

C. Brunner von WattenWyL. - Monographie der Phaneropteriden. <Wien, $1878,402 \mathrm{pp}$., 8 pls.

A synoptical monograph of the Katydids of the world, with full blbllography and full synony-

GNAC:O BOLlvar.-A Arthropodos del viage al Pacifico, verificado de $1862-1865$ por una comision de naturalistas enviada por el Gobierno Español. Insectes Neuropteros y Ortopteros. <Madrid, 1884,114 Pp., 3 pls.

Contains a synoptical table of the genus Conocephalus, with descriptions of new species.

C. BRUNNer VON WATtenwyL.-Monographie der Pseudophylliden. <Verh. Zool. Bot. Ges. Wien, 1895, pp. 28..

J. Rentenbacher.-Monographie der Conocephaliden. < Verh. Zool. Bot. Ges. Wien, 1891, pp. 315-562.

Samurz. H. ScudDrR. - The North American Ceuthophili. < Proc. Amer. Acad. Arts and Sci., Vol. XXX, 1894, pp. 17-113.

Samuer H. Scunder.-The Orthopteran group Scudderix. <Proc. Amer. Acad. Arts and Sci. Vol. XXXIII, 1898, pp. 271-29o.

Samuel H. Scuddrk.-A preliminary review of the North American Decticidæ. < Can. Entom., 1894, Pp. 177-184.

SAMURL H. ScuDDER. The described species of Xiplidium in the United States and Canada. $<$ Can. Entom., 18g8, Pp. $183^{-1} 8_{4}$.

J. McNeill. - Orchelimum Serv. <Can. Entom., 1900, pp. 77-83.

Samure H. SCUdder. - The Stenopelmatinæ of the Pacific Coast. <Can. Entom., 1899, pp. I: 3 -121.

W. L. Bratchley.-The Locustidæe and Blattidæ of Indiana. < Proc. Ind. Acad. Sci. 1892, pp. $92-163$.

SAMUEL H. ScunDER.-Revision of the large, stylated, fossorial crickets. <Memoirs of the Peabody Academy of Sciences, Vol. I, No. $x$, 1869 .

Description of the species of Scapteriscus and Gryllotalpa

HzNRI DE SAussuRE,-Mélanges Orthoptérologiques. Gryllides. Two parts. Geneva, $1877-78$.

monograph of the family, contalning synoptical tables of the genera and species.
C. A. HART-On the species of Ecanthus <Entom. News, 1892, Pp. 33-34.

SamurL H. Scudorr. -The species of Nemobius found in Nortl America. < Psyche, Vol. VII, $1896, \mathrm{pp} .43 \mathrm{I}-434$.

W. S. BLAtchlEY.-The Gryllidæ of Indiana.

<Proc. Ind. Acad. Sci., 18gr, pp. 126-144.

\section{EUPLEXOPTERA}

H. DoнRN.-Versuch einer Monographie der Dermapteren. <Stettiner Entom. Zeit., Vols. XXIV-XXVI, $1863^{-65}$.

A monograph of the Forficulidx of the whole world.

Samurl H. Scudper,-Synoptical tables for determining North American insects. Orthoptera. U. S. Forficulariz. <Pysche, Vol. I, 1876 , Pp. $177-178$.

Tabulates thirteen specles and gives a list of books useful for the study of the family.

Samuel H. Scudper.-Brief Symopsis of North American Earwigs, with an appendix on the fossil species. <Bul. U.S. Geolog. and Geogr. Survey of the Territories, Vol. II, No. 3,1876 , Pp. $249-260$.

Samuez H. Scudper.-Critical and historical notes on Forficulariæ, including descriptions of new generic forms and an alphabetical synonymic list of the described species. <Proc. Bost. Soc. Nat. Hist., July-October, 1876 ,

W. Fol. KIRBY, A revision of the Forficulidx, with descriptions of new species in the British Museum. <Journ. Linn. Soc. London, Zool., XXIII, 1800 , pp. 502-531.

A. DE BORMANS und H. KRAUSS, - Forficulidæe und Hemimeridæ. <Das Tierreich, 1 I Lieferung. 1900, pp. $x^{-1} 4^{2}, 41$ figs.

\section{MALLOPHAGA}

H. Dennyy.-Monographia Añoplurorum Britannix. <London, $1842,26 \mathrm{pls}$.

C. G. A. G1ebeL,-Insecta enizoa. Die auf Säugethieren und Vögeln schmarotzenden Insekten. < Nach Zeichnungen von C. L. Nitzsch. Leipzig, 1874,20 pls.

ANDREW MURRAY. - Economic Entomology. Aptera. <South Kensington Museum Science Handbooks. London and New York, 1877. The Mallophaga (Anoplura) are treated on pp. 375-384.

P. Mrgnin,-Les Parasites et les maladies parasitaires chez l'honme, les animaux domestiques et les animaux sauvages avec lesquels ils peuvent être en contact. <Insectes, Arachnides, Crustacés. Paris, 1880 .

E. Piaget.-Les Pédiculines. Description de toutes les espèces observées, enrichie d'espèces nouvelles. <Leyden, 1880,56 pls.; Supplement, 1885,17 pls.

O. TAschenserg.-Die Mallophagen mit besonderer Berücksichtigung der von Meyer gesammelten Arten. Halle, 1882.

V. L. KeLLOGG.-A list of the biting lice (Mallophaga) taken from birds and mammals of North America. <Proc. U. S. Nat. Mus., Vol. XXII, pp, 39-100. 1899 . Contains a bililiography and table to genera.|

\section{CORRODENTIA}

H. A. HAgen.-Beiträge zur Monographie der Psociden. <Stettiner Entom. Zeit., Vols. XLIII and XLIV, 1882-83.

\section{ISOPTERA}

H. A. HAgen.-Monographie der Termiten. $<$ Linnzea Entom., Vols. X, XII and XIV, $1855^{-60}$. 


\section{Bibliography}

H. A. HAGEN.-Monograph of the Embidina. $<$ Can. Entom., Vol. XVII, 1885.

Only one species of this family has hilherto been Only one species of this famley
found in the Unlted States.

\section{PLECOPTERA}

F. J. Prcter.-Histoire naturelle générale et particulhère des insectes Neuroptères. Première monographie: Famille des Perlides. Geneva, 1841-42.

\section{ODONATA}

W. F. Kirby, - A synonymic catalogue of Neit roptera Odonata, or dragon-fies. <London 1800, pp. 202.

E. DE Setys LnNGChamps et H. Hagen-Monographie des Caloptérygines. <Bul. Acad. Belg.. Brussels. 1854.

E. Dh Sezys Longchamps bt $\boldsymbol{H}$. Hagen.-Mon ographie des Gomphines. <Bul. Acad. Belg., Brussels, $185^{8}$.

E. DE SzIYS Longchamps.-Synopsis des Agrionines. ' Six parts. < Bul. Acad. Belg. Brussels, $1860-78$.

E. DF SELys Longchamrs. - Synopsis des Cordulines. < Bul. Acad. Belg., Brussels, 1871.

H. A. HAGEN.-Synopsis of the Odonata of America. < Proc. Boston Soc. Nat. Hist., Vol. XVIII 1875 , PP. $20-96$.

E. DE SELyS LONGCHAMPS-Synopsis d'ÆschDE SElys LoNGCHAMPS.-Synop
nines. < Bul. Acad. Belg., $188_{3}$.

E. DE SElys Longch amps.-Révision du Synopsis des A rrionines. <Bul. Acad. Belg., 1886.

H. A. HAGRN.-Synopsis of the Odonat genus Leucorhinia. <Trans. Amer. Entom. Soc., 1800 , PP. 229-236.

H. A. H AGRN.-Synopsis of the Odonata of North America. <Psyche, Vol. V, 188,-9o. No. 1 , pp. 241-2 50, Calopteryx; No. 2, pp. 303-308, Anax.

P. P. CALVRRT-Catalogue of the Odonata (Dragon-flies) of the vicinity of Philadelphia. $<$ Trans. Amer. Entom. Soc., 1893, Pp. 152272,2 pls.

D. S. KELLICOTt. - The Odonata of Ohio. <Ohio Acad. Sci. Special Paper No. 2, 1899 , Pp. 114, 3 pls.

E. ${ }^{3}$. Williamson. - The Dragon-flies of Indiana. <Indiana Geolog. Rept. f. $1899-1900$, pp. 229-333, 7 pls.

\section{EPHEMERID $A$}

F. J. P1CтвT.-Histoire naturelle générale et particulière des insectes Neuroptères. Seconde monographie : Famille des Ephémérines. Geneva, 1843-45.
Benjamin D. Walsh.-List of the Pseudoneuroptera of Illinois contained in the cabinet of the writer, with descriptions of over forty new species, and notes on their structural affinities. <Proc. Acad. Nat. Sci. Phila., 1862, pp. $361-402$.

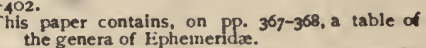

BENJAMIN D. WALSh.-Observations on certain North American Neuroptera, by H. Hagen M.D., of Koenigsberg, Prussia ; translated from the original French MS., and published by permission of the author, with notes and descriptions of about twenty new North American species of Pseudoneuroptera. <Proc. Entom. Soc. Phila., Vol. II, 1863-64, Pp. $167-272$

Contains a modification of the table of genera of Ephemeridx, pp. 195-196: a table of the subgener of Coinphus, p. 253, and a "Synoptica! table of the subfamilies of the family Odonata,

A. E. EATON.-A monograph on the Ephemeridze. Part I. The nomenclature of the Ephemeridx. <Trans. Entom. Soc. London, 1871, pp. 1-164, 6 pls.

A. E. EATon,-A Revisional Monograph of Recent Ephemeridx, or May-flies. <Trans. Linn. Soc. London; $188_{3}-86,6$ parts.

\section{THYSANURA}

K. W. v. DAlla Torrr.-Die Gattungen und Arten der Apterygogenea. < 46 Program k.k. Staats-Gymnasium, Innsbruck, PP. 23, 1895 A cataingue of the known species.

A. D. MacGillivray.-A catalogue of the Thysanura of North America. <Can. Entom., I891, Pp. 267-276.

A. S. PACKARD.-Synopsis of the Thysanura of Essex County, Mass., with descriptions of a few extralimital forms. <Fifth Annual Report of the Trustees of the Peabody Academy of Science for the year 1872 . Salem, 1873, pp.

23-51.
ЈонN LUввоск. - Monograph of the Collembola and Thysanura. <London, Ray Society, 1873 . The introduction gives the full bibliography up to

A. D. MacGillivray - North American Thysanura. III. <Can. Entom., 1893, PP. 218-220.

A. D. MacGillivray - North American Thy sanura. IV. <Can. Entom., 1893, Pp. 313318.

A. sanura. V. <Can. Entom., 1894, PP. $105^{-110}$.

Synopses of Entomolryidx and Sinynthuridx.

A. D. MacGillivray.-The American species of Isoloma. <Can. Entom., 1896, Pp. 47-58. 


\section{INDEX}

Aaron, Carrie B., 366

Abe Lincoln bug, 313

Acalypteræ 90

Acanthiidæ, 288

Acanthomeridæ, 87, 130

Achorutes nivicola, 386

acknowledgments, xi

Acridiidæ, 322, 332, 341

Acroceridä, 134

Aculeat Hymenoptera, The Habits of the, 20

Adela, 203

Adler, 55

Æciacus hirundinis, 288

Aedes, 101, 102

Æschna, 374

heros, 365

Eschnidæ, 369, 372, 373, 374

Agallia sanguinolenta, 244

aggressive mimicry, 142

agricultural ant of Texas, The, 46

Agrionidæ, 369, 370, 371, 376

Agromyzidæ, 92, 187

alder flies, 211

Aldrich, 144, 145

Aleuronia, 218

westwoodii, 218

Aleyrodes, 247

citri, 247

Aleyrodicus, 247

Aleyrodidæ, 230, 246, 247

ambush bug, The, 297

American cockroach, 330

locust, 333

saw-fly, 75

Ammophila, 20

Ampulex, 20

Ampulex ruficornis, 20

Anabrus purpurascens, 337

Anabrus simplex, 337

Anasa tristis De Geer, 305

Anatomy of the Blow-Fly, 164

Anatomy of the Cockroach, The, by Miall and Denny, 330

Anax junius, 374
Andrena vicina, 12

angular-winged katydid, 339

Anisops, 275

Anopheles, 101, 102 claviger-maculipennis-quadrimaculatus, 101

crucians, IOI

punctipennis, 101

Anoplura, 82, 227, 316,347

ant, black, 46

black carpenter, 43

ant-decapitating fly, life history of, 147

ant-lions, 126, 127, 219

ant pavement, 43

red, 43,46

Anthocoridx, 271, 287

Anthomyia Flies, The, I7!

Anthomyiidæ, 90, 17 I

Anthophoridæ, 6, 7

anthrax, 8I, I3I

ants, 37

Ants, Bees and Wasps, Lubbock, 43

Ants, honey, 45

nests, 128

solitary, 32

stinging, 39

stingless, 39

typical life history of, 48

ants, white, 353

Apathus, 15

Aphididx, 230, 262

Aphis-lions, The, 221

Aphoruridæ, 385,386

Aphrophorinæ, 24I

Apidæ, 6

Apioceridæ, 87, 136

A pocephalus pergandei Coq, 147

Apoidea, Superfamily, 3, 4

apparatus, collecting, 389

aquarium, the, 399

aquatic insects, collecting, 395

Aradidæ, 272, 290, 298

Aradus crenatus Say, 298

Aradus similis Say, 298

Archytas, 158 


\section{Index}

Arilus cristatus L., 294

armored scales, 254

army worm, 159

Ashmead, W. H., xi, 2, 12, 20, 31, 32, $33,49,56,59,73$

Asilidæ, 88, 136, 141

Asiloidea, Super-family, 88

Asilus sericeus, 143

Asindulum montanum, 117

assassin bugs, 293

Aster, 114

Atherix, 126

Atropidx, 352

Atwood, 327

Australian cockroach, 330

Axima zabriskii, 8

Baccha, 150

back-rolling wonder, 340

back swimmers, The, 275

Bæus, 51

Bailey, W. W., 212

Banks, Nathan, xi, 218

bark lice, 113, 250

bat ticks, 190

beating net, 391

bedbug, 82

bed-bug family, the, 288

bed-bug, Life history of, 289

bee, bumble, 6

common carpenter, to

cuckoo, 7

bee-flies, 137

bee-fly, typical life-history of, 138

bee hives, 128

honey, 6

large carpenter, 9

mason, 10, 11 small carpenter, 8

bees, blunt-tongued burrowing, 12 leaf-cutting, 10 obtuse-tongued carpenter, 12 parasitic, i1

potter, 11

sharp-tongued burrowing, 12

the true, 4

belostoma americanum, 278

Belostomatidx, 271, 278

Benacus griseus Say, 278

Berytidæ, 272, 309

Bethe, Albrecht, 41

Bethylidæ, 25, 33

Beutenmüller W., 365, 366

Bibio albipennis, 119

Bibionidx, 86, 119

Bibionidea, Super-family, 85,86

bibliography, 405

big-eyed flies, 149

bird lice, 82,347

bird ticks, 188,189 biting lice, 347

Bittacomorpha, 95

clavipes Fab., 95

Bittacus, 207

black ant, 46

black beetle, 330

black carpenter ant, 43

black cricket, 342

black flies and buffalo gnats, 120

black fly, 80

black horse fly, 132

Biepharocera capitata Loew, 125

Blattidæ, 322, 329

Blepharoceridæ, 86, 124

Blissus leucopterus Say, 3 10, 3 II

blood-su cking cone-nose, 293

blow-fly, 164

blue-bottle flies, 164, 166

Boisduval, 49

Bombidx, 6

Bombus borealis, 14

fervidus Fabr., 12, 14

Bombyliidæ, 87, 88, 134, 137

Bonnet, 262

book-lice and their allies, The, 35

Borboridæ, 92, 187

Boreus, 207

bot-flies, 155

bot-flies, typical life history of, 155

Bothriothorax, 57

bottle, the cyanide, 401

box elder plant bug, 305

Brachycera, 84, 86

Brachydeutera argentata, 182

Brachypeplus magnus, 333

Brauer, L., 207, 217

Brewer, W. A., 182

bristletails, 380

Buckley, 356

buffalo gnats, 120 tree hopper, life history of the, 239

Bugonia Myth, 153

bugs, the true, 226,269

bumblebee, 6

life history of, 12

Burns, Robert, 316

Burroughs John, 344

burrowing bees, 12

Busck, August, 33

Butterflies of the Eastern United States and Canada, The, by Scudder, 61

Butterfly Book, The, W. J. Holland, Ix

button bolls of sycamore, $3 \mathrm{It}$

cabinet, preparing insects for the, 401

cabinet, The, 403

Caddis flies, 195, 196

Cænis, 79

Calliphora erythrocephala, 164 


\section{Callotermes, 358}

Calopterygidæe, 369, 370

Calopteryginæ 370

Calopteryx, 370

Calypteratæ, Group, 89, 90

Campodeidæ, 381, 384

Camponotidæ, 39

Camponotus pennsylvanicus, 147

Camptobrochis grandis, 301

Camptoneura picta, 176

Canadian Entomologist, 285

cannibal bugs, 203

Capsidæ, 272, 301

Caratomus, 359

Carolina locust, 333

carpenter bees, $8,9,10,12$

cat and dog flea, life history of, 193

Catalpa speciosa, 184

Cecidom yia destructor Say, II 3

larvæ, 118

legumenicola Lint., II5

Cecidomyiid galls, II 4

Cecidomyiid $æ, 53,86$, I13

Celtis, 259

Cephidx, 69

Cephus pygmæus, 69

Ceratina dupla, 8

Ceratinidæ, 6, 7

Ceratitis capitata, 178

Ceratopogon, III

Ceratosmia (Osmia) lignivora, to

Cercopidæ, 229, 24 I

Ceresa bubalus, 239

Chætopsis ænea, 176

Chalcidid parasite, 256, 257

Chalcidoidea, 3

Chalcidoidea, Super-family, $5 \epsilon$

chalcis flies, 49, 53,56 parasite on lace-winged fly, 224

chalcis fly, life history of, 57

Chalybion cœeruleum, 22

de Charmoy. D'Emmerez, 20

Chauliodes, 2 I I, 2 I2

Chauliodes, lunatus, 211 pectinicornis L., 2 II

cheese skipper, 179

chicken flea, I93

chigger, 193

chigoe, 193

chinch-bug, 3 I0

chinch-bug family, the, 3 to

chinch bug, life history of, 3 II

Chionea, 95

Chironomidx, 85, 1 ro, 362

Chironomus, III, II2

minutus, III

plumosus, I Io

chisel, 392

Chittenden, F. H., XI, 140
Chlorochroa conica, 236

Chlorops assimilis, 183

graminea, 183

Chrysididæ, 25, 32, 33

Chrysis, 32

cœrulans, 32

Chrysopa oculata Say, 224

Chrysopidx, 210, 222

Chrysops, I32, I37

Chrysopsis, II4

cicada, annual, 22

Cicada emarginata, 232

cicada, large dog-day, 22

Cicada septendecim L., 233

Cicadas, 231

Cicadidæ, 229, 23I

Cimbex americana, 75

Cimicidæ, 27I, 288

Cinura, 380, 381, 384

Circotettix verruculatus, 334

Clemens, Samuel L. (Mark Twain), 4I

Cleptes, 32

Climacia, 22r

Clisiocampa americana, 64

Clisiocampa disstria, 64

Cloeon, 79

clover seed midge, II 5

Coccidæ, 230, 246, 250

Coccinæ, 254

Coccinellidæ, 258

cockroach, American, 330

Australian, 330

domestic, 20

European, 330

German, 330

cockroaches, 329, 33 I

Coenomyidæ, 126

Coleoptera, 79

collecting and preserving insects, 389

collecting apparatus, $3^{8} 9$

collecting aquatic insects, 395

collecting different orders, 394

col'ecting forceps, 392

shears, 394

Collembola, 380,385

Colletidæ, 6

comb-horned fish-fly, 211

Comstock, J. H., I24, I28, 134, I39, $145,147,149,197,199,216,237$, 293, 297, 298, 304, 31 3, 398

cone-nose, blood-sucking, 293

Coniopterygidæ, 210, 218

Coniopteryx vicina, 218

Conocephalus, 344 ensiger, 344

Conopidæ, 89, 154

Conorhinus sanguisuga, 293

Cook, O. F., 355

Copidosoma, 57

Coquillett, D W., xi, 83, 97, 560, 161 
Cordulegasteridæe, 369, 373

Cordulidæ, 369, 375

Coreid $x, 270,272,304$

Corisidæ, 273

Corixa, 273, 274

femorata, 273

mercenaria, 273

Corixidæ, 271, 273

Corrodentia, 350

Corydalis cornuta $\mathrm{L} ., 2 \mathrm{I}_{4}$

Corythuca arcuata Say, 300

cotton stainer, 308

cotton stainer and its allies, The, 307

cotton stainer, life history of, 308

cottony cushion scale, 218

Coville, F. V., 14, 15

Cowper, W., $34^{2}$

Crabronidx, 19

crane flies, 94

crane fly, life history of, 95

creeping water bugs, The, 280

crickets, 341

western, 337

croton bug, 330

Cryptocerata, 273

Ctenophora, 95

cuckoo bee, 7

flies, 32

flies, so called, 25

Culex, ror, 102

pungens Wiedemann, I04

Culicidæ, 85,98

currant worm, imported, 74

Currie, Rolla P., xi

Cursoria, 323, 329

Curtice, Cooper, 157

Curtis, John, 378

Cuterebra, 155

cyanide bottle, 401

Cyclops, 5 I

Cyclorhapha, Section, 84, 89

Cynipoidea, 3, 49, 53

Cynipoids, 54

Cyrtidx, 134

daddy-long-legs, 94

damsel-flies, 370

dance-flies, 144

larve of, 145

Davidson, A., 32

death watches, 352

deer flies, 13I, ${ }_{32}$

Delphacinæ, 235

Deltocephalus inimicus, 245

Dermatobia cyaniventris, 155

Deromyia annulata Bigot, 142

devil's darning needles, 363

devil's riding horse, 295

Dexia, 162

Dexiidx, 90,162
Diamorus zabriskii Cres., 8

Diapheromera femorata Say, 323

Diaspin $x, 254$

Diedrocephala, 244

mollipes, 244

differential locust, 333

digger wasp, life history of, 22

Diopsid $x, 92,179,180$

Diplosis, I 13, 265

Diptera, xi, 79, 80, 81, 108, 158, 189 methods of collecting, 395 table of the higher groups, 83

Dissosteira carolina, 333

Dixa, 97

Dixidx, 85, 97

dobson and its family, the, 211

dobson, life history of, 212

dog-day cicada, 22

dog-day harvest fly, 232

Dolichopodidæ, 88, 144, 145

Dysdercus suturellus, 308

dragon-flies, 363

table of families, 368

true, 372

drone-fly, I 52

Drosophila ampelophila, 185 flaveola Meig., 186

Drosophilidæe, 92, 185

dung flies, 173

dusty-wings, The, 218

earwigs, 345

Eaton, 378

Ectobia germanica, 330

Edes, Robert, 343

Elachistinæ, 58

electric light bugs, 278

Embiidæ, 353

Emerton, J. H., 8, it

Emesinæ, 294

Empidre, 88

Empididæ, 144

Empis, 144

Enallagma, 371

Enchenopa binotata, 233

Encyrtus egg, 50

Entilia sinuata, 238

Entomobryidæ, 385, 387

Ephemerida, 377, 379

Ephydridæ, 82, 92, 182

Epixschna heros, 374

Epidapus scabiei, 118

Eproboscidea, Suborder, 83, 93

ergatoids, 38

Eriocampoides limacina, 76

Eristalis tenax, I 52

Erythroneura vitis, 244

Euantha liturata, 162

Eumenes fraterna, 32

Eumenidæ, 30 
Euplemus mirabilis, 340

Euplectrus comstockii, 57

Euplexoptera, 345

European cockroach, 330

Euschistus servus, 314

Eutermes nigriceps, 356

Euvanessa antiopa, 51

Fabre, J., 21

false chinch bug, 310

false crane flies, 125

ialse rear-horses, 217

Faxon, Walter, 343

Feh, E. P., xi, 207

Fernald, C. H., 160, 241

field cricket, 343

fish flies, 211

fish-fly, comb-horned, 211

fishmoths, 380,382

Fitch, A., 141, 344

flat bark-bugs, The, 298

flat-footed flies, 149

Flata, 236

Flatinæ, 235, 236

flea-lice, 259

flea, life history of the cat and dog, 193

fleas, I 19

flesh-flies, The, 163

flies, 82

alder, 211

bee, 137

dance, and long-legged, 144

flat-footed, and big-eyed, 149

fish, 211

fruit and gall, 177

gad or horse, 131

harvest, 231

little house, 171

robber, 141

small-headed, and tangle-veined, 134

stone, 361

syrphus, 150, 151

the anthomyia, 171

the bot, 155

the caddis, 195

the dung,

the flesh, 163

the golden-eyed lace-winged, 222

the grass stem, 183

the hump-backed, 147

the little fruit flies, 185

the nimble, 162

the salt-water, 182

the scorpion, 206

the snake, 216

the tachina, 158

the thick-head, 154

the true, 79

window, and stiletto, 139 flower bugs, the, 287

fly, blue-bottle, 164,166

green-bottle, 164

hellgrammite, 212

life history of a scorpion, 207

the house, 166

"flying adders," 363

Forbes, S. A., 52, 186, 245, 357

forceps, collecting, 392

forest fly, 188

Forficulidæ, 346

Formica, 42

Formicoidea, 3

Formicoidea, Super-family, 37

four-lined leaf-bug, 302

Fox, W. H., 147, 148

frit fly, 184

frog-hoppers or spittle insects, 241

frosted lightning hopper, life history of, 236

fruit and gall flies, 177

flies, the little, 185

Fulgoridæ, 229, 235

Fulvius anthorcoroides Uhl, 30 I

fumigator, 392

fungus gnats, 117

gad flies or horse flies, 131

gad-fly, 80

life history of, 132

Galerucella luteola, 301

Galgulidæ, 271, 281

Galgulus oculatus Fab., 28i

gall-gnat, life history of, 115

gall-gnats, 113

gall-flies, 53

guest, 55

parasitic, 55

gangrene, 80

garden flea-hopper, 30 เ

Gastrophilus, 155

Gaurax anchora, 183

Geomyzidæ, 92, 187

German cockroach, 330

giant water bugs, the, 278

Gibson, William Hamilton, 20, 238

gigantic bed bug, the, 293

golden-eye, life history of, 224

golden-yed lace-winged flies, 22 i

golden rod, 114

goldwespen, 32

Gomphidx, 369, 372

Gomphinæ, 372

Gomphus vastus Walsh, 372

Goniozus, 36

grape-vine Phylloxera, 265

grasshopper, life history of, 334

lubber, 333

short-horned, 333

western, 333 
grasshoppers, 320

green, 336, 337

The long-horned, 336, 337

The short-horned, 332

Grassi, B., 192, 358

Grave, Caswell,

green-bottle fly, 164

green flies, 74

grasshoppers, 336,337

soldier bug, 314

Gressoria, 323

grub, 155

grubby cattle, 155

Gryllidx, 322, 341

Gryllus domesticus, 342

neglectus, 343

guest gall-flies, 55

gypsy moth report (18g6), 315

Gyropidæ, 349

habits of the Aculeate Hymenoptera, 20

hackberry trees, 259

Hadronotus anasæ, 306

Hæmatobia serrata, 166

Haldeman, S. S., 212

Halictus, 12

parallelus, 12

Haliday, A. H., 33

Halticus uhleri Giard, 301 '

hand lens, 393

Harrington, W. H., 344

Hart, C. A., 95, 126, $129,132,245$

harvest flies, 231

harvest-fly, 22

dog-day, 232

haversack, 393

hawthorn lace bug, life history of, 300

Hawthorne, Nathaniel, 344

hearth cricket, $34^{2}$

Hebridæ, 273

heel fly, 155,156

Heidemann, O., xi., 270, 284, 298, 301,311

Helicobia, 165

hellgramite fly, 212

hellgrammites, 2 I I

Helomyzidæ, 91, 174

Hemerobiidæ, $210,221,222$

Hemiptera, 226

Hemiptera, some points on methods of collecting, 394

Hemiptera, table of suborders, 227

Henicocephalidæ, 272, 292

Henicocephalus culicis Uhl., 292 formicin is Uhl., 292

Hermetia, 128

illucens, 128

Hessian fly, 80, 113

Hetærina, 370

Heteroneuridæ, 91, 173
Heterophaga, 2

Heteroptera, xi, 227, 269, 270, 347 table of families, 270

Hippelates, 8 I

Hippobosca equina, 188

Hippoboscidæ, 93, 188

Hirmoneura, 134

Hodotermes, 359

Holland, W. J., ix

Holmes, O. W., 337

Holorumsia, 95

grandis, 95

Homoptera, 227, 228

Homoptera, table of families, 229

Homalomyia brevis, 171 canicularis, I 71

honey ants, 45

honey ants and the occident ant, The, 46

honey bee, 6 wasps, 25

hop plant louse, 265 Life history of, 265

Hopkins, A. D., 118

horn-fly, I 66

horn-tail larvæ, parasites of, 68

horn-tail, life history of, 7 I

horn-tails, 69

hornet, bald faced, 27,28

of England and Europe, 29

horse flies, 80,131

horse stingers, 363

house cricket, $34^{2}$

house-fly, 8o, 81, 82

and its Near Relations, The, 166

life history of, 167

Hubbard, H. G., 8, 121, 184, 350, 351, 356,358

hump-backed flies, 147

Huxley, T., 262

Hydrocores, 273

Hydrocorisæ, 273

Hydromet ra lineata, 285

Hydrometridæ, 271, 273, 283

Hydropsychidx, I97, 204

Hydroptilidx, 197, 201

Hygrotechus remigis, 284

Hymenoptera, xi, 1, 69, 79

internal feeding parasitic, 362

parasitic, 51, 55, 67

some points on methods of collecting, 394

Suborders, Table of, 2

Superfamilies, Table of, 2,7

hymenopterous parasites of dragon-fly, 366

Hypoderma bovis, 155

lineata Villers, 155

ichneumon flies, 33,61 
ichneumon fly, life history of, 64

Ichneumonoidea, 3, 61

imported currant worm, 74

insects, collecting and preserving, 389

collecting aquatic, 395

for the cabinet, preparing, 401

killing and preserving, 401 rearing different kinds of, 396

internal parasites, how they live, 49

introduction, vii

Isoptera, 353, 354, 355

Jalysus spinosus, 309

Japygidæ, 381, 384

Jassidæ, 229, 243

Jassoidea, 243

jumping plant-lice, 259

katydid, 337

angular-winged, 339

"song," 321

typical life history of, 339

Katydids, 320

Kellicott, D. S., 368, 372, 375

Kellogg, V. L., 108, 109, 348

killing and preserving insects, 401

Kirkaldy, G. W., 274

Kirkland, A. H., 315

kissing bug, 293

koo-chah-bee, 182

Koppen, F., 365

Kræmer, 55

La Fontaine, 39

Laboulbéne, 192

lace bugs, The, 299

lacewing fly, 79

lace-winged flies the golden-eyed, 222

lace-winged insects, 209

ladybirds, 258

Lxlius trogodermatis Ashm., 34

Lamborn, Robert, H., 366

lantern-flies and their allies, The, 235

Laphria, 142

larch saw-fly, 74

Largus succinctus, 307

Lasius, 42

leaf-bug, typical life history of, 302

leaf bugs, The, 301

leaf-cutting bugs, it

leaf-footed plant bug, 304

leaf-hopper, typical life history of, $\mathbf{2 4 5}$

leaf-hoppers, the, 243

Lebœuf, A., 360

Lecaniinæ, 254

Leeuwenhoek, 317

Leidy, Joseph, 80

lens, hand, 393

Lepidocyrtus americanus, 387

Lepismatidæ, 381, 382
Leptidæ, 87, 126

Leptoceridx, 197, 203

Leptocoris trivittatus, 305

Leptogaster, 142

Leptoglossus phyllopus, 304

Lestes, 371

Lethierry, 289

Leucopis, 187

Libellula pulchella Drury, 376

Libellulas, 372

Libellulidx, $369,375,376$

lice, the true, 316

life History of a bee-fly, typical, 138

bumblebee, 12

Chalcis fly, 57

common walking-stick, 323

crane fly, 95

digger wasp, 22

gad fly, 132

gall-gnat, 115

golden-eye, 224

grasshopper, 334

horn-tail, 71

katydid, typical, 339

leaf-bug, typical, 302

leaf-hopper, typical, 245

midge, III

mosquito, 104

parasitic wasp, 34

pear-tree Psylla, 260

rear-horse, 327

scorpion fly, 207

water-strider, 285

white fly, typical, 247

ichneumon fly, 64

ants, typical, 48

bot-flies, typical, 155

stink bugs, typical, 314

wasps, typical, 33

Life History of the ant-decapitating fly, 147

bed-bug, 289

buffalo tree-hopper, 239

cat and dog flea, 193

chinch-bug, 311

cotton stainer, 308

dobson, 212

frosted lightning hopper, 236

hawthorn lace bug, 300

hop plant louse, 265

house-fly, 187

oyster-shell bark louse, 255

"pear slug," 76

"seventeen-year locust," typical, 233

squash bug, 305

wheel bug, 294

Limnephilidæ, 197, 199

Limnobates lineata Say, 282

Limnobatidæ, 271, 282

Limnobia, 95 


\section{Index}

Limosina, 187

Limosina venalicius, $\mathbf{1 8 7}$

Liotheid $x, 349$

Lipoptena, 189

little house flies, I $7 \mathbf{I}$

locust, 231

American, 333

Carolina, 333

differential, 333

migratory, 333

red-legged, 333

two-striped, 333

typical life history of the "seventeenyear," 233

Locustidæ, 322, 336, 34I

locusts, true, 332

Lonchæa polita, 175

Loncheidæ, 91, 175

Lonchoptera, 146

lutea, 146

Lonchopteridæ, 89,146

long-horned grasshoppers, The, 336, 337

long-legged flies, 144, I45

Lopidea media Say, 301

Lowne's "Anatomy of the Blow-Fly, ${ }^{164}$

lubber grasshopper, 333

Lubbock, Sir John, 43, 44, 146, 388

Lucilia cæsar, I64

Lugger, O., 220

Lygæidæ, 272, 3 10

Lygæids, 307

Lygus pratensis, 301

lyre-man, 22, 232

Macronema zebratum, 205

malignant pustule, $80,1_{3} \mathrm{I}$

Mallophaga, 82, 347

table of families, 349

Mallophora, 142

Mantidx, 322, 326, 329

Mantis religiosa, 327

Mantispa interrupta, 2I7

brunnea 217

Mantispidx, 210, 217

march-flies, II9

Margarodes, 228

Mark Twain, $4 \mathrm{I}$

Mark Twain's "Chamois," 193

Marlatt, C. L., 13, 27, 36, 224, 330

marsh treaders, The, 282

Martin, J. O., 285, 286

Marx, George, 353,404

mason bee, IO, II

Mason, O. T., 3 I

may flies, 79, 361, 362, 377

MeCook, H. C., 46,48

McLachlan, R., 198

Mearns, E. A., 366

Mecoptera, 206
Megachilidæ, 6, 10

Megarbinus, IOI, $\mathrm{IO}_{2}$

Megastigmus, 55

de Meijere, I 46

Melanolestes picipes, 293

Melanoplus atlanis Riley, 334

bivittatus, 333

differentialis, 333

femur-rubrum, 333

spretus, 333

Melophagus ovinus, I 83

Membracidæ, 229, 237, 241

Meromyza americana, 183

Metapodius femoratus, 304

methods of collecting different orders 394

Miall, L. C., viii, 274

Miall and Denny, "The Anatomy of the Cockroach," 330

Miall and Hammond, I I I

Miall and Walker, Trans. Ent. Soc., London, 1895, I08

Microcentrum retinervis, 339

Microdon, I $50, I_{52}$

Micropezidæ, 91, 92, 179

midge, life history of, III

midges, $8 \mathbf{r}$, I ro

migratory locust, 333

mimicry, aggressive, $\mathbf{I} 42$

Monomorium minutum, 46 pharaonis, $43,46,47$

Monostegia rosæ, 74

Morelos orange fruit worm, 178

Morse, A. P., 334

Morse, E. S., $24 \mathrm{I}$

mosquito, life history of, 104

mosquitoes, $80,81,82,98,102,102$

moth-flies, The, 108

mourning-cloak butterfly, 5 I

mud-daubers, 22

mud-minnow, 278

mule killers, 327

Mundt, A. H., 365

Murgantia histrionica Hahn., 313

Murtfeldt, Miss Mary E., 26

Musca domestica, 166, 167

Muscidæ, 90, I66

Muscoidea, Super-family, 89

museum pests (dermestid beetles), 34

Mutillidæ, 25, 32, 33, 37

Mycetophila, II 7

Mycetophilidæ, 86, II 7

Mycetophilids, II 8

Mydaidæe, 87, I 36

Mydas-flies, 136

Mydas fulvipes Walsh, I 36

luteipennis Loew, 136

myiasis, 163

myiasis interna, I 7 I

Mymaridæ, 247 
Myopa, 154

Myriopoda, 380

Myrmeleonidx, 210,219

Myrmicidæ, 39

Mytilaspis pomorum Bouché, 255

Myzinidæ, 3I, 33

Naucoridæ, 27x, 280

Nectarinia, 26

Needham, J. G., xii, 2 I I, 21 2, 22 I, 373 , $376,379,395$

Nematidæ, 73

Nematus erichsonii, 74

ribesii, 74

ventralis Say, 75

Nemestrinidx, 87, I 34

Nemocera, Subsection, 84

Neoprosopis, 12

Nepa, 276, 277

Nepidx, 271,276

net, sweeping or beating, $39 \mathrm{I}$

net, the, 389

net, water, $39 x$

Neuroctenus simplex Uhl., 298

Neuronia, ros

Neuronia semifasciata Say, I $_{9} 8$

Neuroptera, 209

Neuroptera, Table of Families, 2 ro

Neuropteroid series, $x i, 30$

Newport, 7, 49

Nezara hilaris Say, 314

nimble flies, The, I62

Nomadidæ, 6, 7

no-see-um, I I I

Notonecta, 275

Notonecta undulata, 275

Notonectidæ, 271, 275

Nycteribiidæ, 93, Igo

Nyzius angustatus Uhl., 3Io, 3II

Odonata, $363,368,37 \mathrm{I}$

Odontomyia, I 26, I29

cincta, 129

vertebrata, 129

Odynerus, 31, 32

Ccanthus niveus, 343

Estridæ, 90, I55

CEstrus ovis, I 55

Olfersia americana, I 88

Oligotoma hubbardi, 360

Oncognathus binotatus, 30I

onion fly, I 7 I

Oœncyrtus anasæ, 306

ophthalmia, purulent, 8 I

Orchelimum vulgare, 337

orders, some points on mathods of collecting different, 394

Orgyia leucostigma, 64

Ormenis pruinosa, 236

Orphnephila testacea, I 24
Orphnephilidæ, 86, 124

Ortalidæ, 91, I75

Orthoptera, 320, 334

some points on methods of collecting. 395

Orthorhapha, Section, 84

Oryssidæ, 69

Osborn, Herbert, II9, 243

Oscinid $x, 92, I 8_{3}$

Osmia larva, II

Osmiinæ, to

Osten Sacken, R., I 53

ox bot, I 55

ox warble, $\mathrm{I}_{5} 5$

Oxybelidæ, I $9_{9}$

Oxybelus quadrinotatus, I9

oyster-shell bark louse, life history of, 255

Packard, A. S., Io, I 10

Panorpa, 206, 207

Panorpa rufescens Ramb., 207

Panorpidæ, 95, 207

Papiriidæe, 385,388

Parasita, 3 I6

parasitic bees, II

gall flies, 55

Hymenoptera, 5I

wasp, life history of, 34

parasites, how internal, live, 49

parasites of horn-tail larvæ, 68

parasites, proctotrypid, 49

pavement ant, 43

pear slug, life history of, 76

pear-tree Psylla, life history of, 260

Peckham, Geo. W. and Elizabeth G., 18

Peckhams, The, I9, 20, 2I, 30, 33

Pedicia albovittata Walk., 95

Pediculus vestimenti, $3 \mathrm{I}_{7}$

Pegomyia vicina, I 72

Pelecinidæ, 5I

Pelecinus polyturator, 52

Pelocoris femorata, 280

Pelopæus, 22

Pentatomidæ, 272, 3 I $3_{3}$

Pentatomids, 270

Pepsis formosa, I36

Pergande, Theodor, 20, 54, I40, 147, 193

Pericoma californiensis, I08 canescens, 108

Periplaneta americana, 330

australasiæ, 330

orientalis, 330

Perkins, R. C. L., I 2, 20

Perlidae, 36r

Phalangiidæ, 94

Phanurus tabanivorus Ashm., I 33

Phasmidæ, 322, 323, 326

Philænus lineatus, 241

spumarius, 241 


\section{Index}

Phillips, Miss R. O., 121

Philopteridæ, 349

Phorbia brassicx, 172 ceparum, 171

Phoridæ, 89, 147

Phoridea, Super-family 88,89

Phorodon humuli Schrank, 265

Phryganea, 198

Phryganeidæ, 197, 198

Phycodromidx, 91, 174

Phylløcus inteeger Norton, 71

Phyllomorpha, 305

Phylloxera vastatrix, 265

Phymata wolffii Stol, 297

Phymatidx, 272, 297

Physopoda, 318

Phytophaga, 23

Piesminæ, 299

pigeon Tremex, 60

Pimpla, 64, 65, 66, 68

Pimpla inquisitor Say, 64

pink eye, 81,184

Poiphila, 179

casei Linn., 179

Pipunculidæ, 89, 149

pirate bugs, 293

plant bugs, 304

plant-lice, $113,226,228,262$

plant-lice, jumping, 259

Platypezidx, 89, 149

Platyura, 117

Platyura pectoralis Coq., 117

Plea, 275

Plecoptera, 36

Podagrion mantis, 328

Podisus serieventris Uhl., 314

spinosus, 314

Poduridæ, 385,386

Pœcilocapsus lineatus Fabr., 302

points on methods of collecting different orders, some, 394

Polistes, 26, 29

mellifica Say, 25

metricus Say, 142

Polybia, 30

Polygnotus, 51

Pomotis, 278

Pompilidæ, 30

Poneridæ, 39,47

Pontania, 76

Popenoe, E. A., 36

potter bees, II

potter-wasps, 30

Poulton, E. B., 297

Pratt, F. C. xi., 118

praying insects, 327

praying Mantis, 141, 326

preparing insects for the cabinet, 401

preserving insects, collecting and, 389

preserving insects, killing and, 40I
Prionidus cristatus, 295

Prionotus, 136, 295

Proboscidea, Suborder, 83

Proconia, 244

undata, 244

Proctorypid Parasites, 49

Proctotry piodx, 3, 25, 33, 49, 51

Prospopidæ, 12

Psectra, 79

Pseudoneuroptera, 209

Psilidæ, 92, 179

Psilota, 150

Psithyrus, 15

Psocidæ, 350

Psocids, 403

Psocus citricola, 351 venosus, 350

Psorophora, 101, 102

Psychodidx, 85, 108

Psylla pyricola, 260

Psyllidæ, 230, 259

Pterodontia, 134 analis, 134

Pulex avium, 191 irritans, 192, 193 serraticeps, 191

Pulicidæ, 191

Pulvinaria innumerabilis, 218

punkie, 111

purulent ophthalmia, 8I

pustule, malignant, 80

Putnam, F. W., II

Pyrrhocoridæ, 272, 307

Ranatra, 276, 277

Ranunculus poisonous to may-fly larvæ, 378

Raphidiidæ, 210,216

Raptoria, 323

Rasahus binotatus, 293

rat-tailed maggots, 152

Ratzeburg, 49

Reade, Chas., 181

rearhorse, 141

life history of, 327

rear-horses, 326

the false, 217

rearing different kinds of insects, 396

rectal gills of dragon-fly larvæ, 367

red ant, 43,46

red-legged locust, 333

reduviid eggs, 294

Reduviidx, 272, 293

Reduvius novenarius, 295 personatus, 293

Rheumatobates rileyi, 284

Rhomaleum micropterum, 333

Rhyacophilidx, 197, 200

Rhyphidæ, 86, 124, 125

Riley, C. V., 32, 54, 55, 234, 339, 343 
robber-flies, 141, 142

larvæ of, 142

Rocky Mountain Locust, 138

rose chafer, 74

rose slug, 74

Rothney, 20

Royal Dream Book, The, 39

Rutilia, 162

Saldidæ, 272, 291

salt-water flies, 182

Saltatoria, 323

sand flies, 120

Sapromyzidæ, 91, 175

Sapygidæ, 31, 33

Sarcophaga, 164

Sarcophaga carnaria, 164 sarraceniæ, 164

Sarcophagid $x, 90,163$

Sarcophila, 163

Sarcopsylla gallinacea, 193 penetrans, 193

saw-flies, 73

saw-fly, American, 75 larch, 74

scale insects, 226, 228, 250

Scatophagidæ, 91, 173

Scatopse, 119

pulicaria, 119

Sceliphron, 22

Scenopinidæ, 88, 139

Scenopinus fenestralis Linn., 139

Schistocerca americana, 333

Schmidt, 279

Schmidt-Schwedt, 274

Schwarz, E. A., 22, 32, 58, 59, 60, 292, 293, 359

Sciara fraterna, 118 tritici Coq., 118

Sciaras, 118

Sciomyzidæ, 91, 174

Sciophila, 117

Scolia, 31

Scoliidæ, 33

Scolopendrella, 380

scorpion flies, 95, 206

scorpion fly, life history of, 207

Scotridæ, 31

screw-worm fly, 163

Scudder, S. H., 61, 337, 340, 343, 344

Scudderia angustifolia, 337

Scutellerinæ̇, 313

Selys-Longchamps Baron de, 368

Sepsidæ, 91, 92, 179

Sericostomatidæ, 197, 202

Setodes exquisita Walk., 203

Seurat, L., 50

seventeen-year locust, life history of the, 23

Severin, 289 shad-flies, 377

Sharp, D., 20, 226, 330, 347

shears, collecting, 394

sheep tick, 188

Shizoneura lanigera, 265

shore bugs, the, 29 !

short-horned grasshopper, 333

short-horned grasshoppers, the, 332

Sialidæ, 210, 211

Sialis, 211

infumata, 2 II

Sienkiewicz, H., 355

sieve, the, 391

Silvanus surinamensis, 140

silver fish, 382

Simmons, W. J., 192

Simon, 192

Simuliidx, 86, 120

Simulium, 120, 400

pictipes, 121

Siphonaptera, 19!

Siricidæ, 69

Siricoidea, 3, 69

Sisyra, 221

Slater, Miss, 279

slickers, 380, 382

Slingerland, M. V., 303, 327

small-headed flies, 134

Smeathman, 355

Smicra microgaster, 129 rufofemorata, 129 I

Smith, S. 1., 110

Smynthuridæ, 385,388

Smynthurus luteus, 388

snake doctors, 363

snake feeders; 363

snake flies, the, 216

snipe flies, 126

snowy tree-cricket, 343

social wasps and their allies, 25

soldier bugs, 68

flies, 128

solitary ants, 32 wasps, 18,30

some points on methods of collecting different orders, 394

sooth-sayers, 327

spear-winged flies, 146

Sphecius speciosus Say, 22

Sphecoidea, Super-family, 3, 18, 30

sphegid wasp, 22

spined soldier bug, 314

spittle insects, 24 I

springtails, 380

squash bug and its allies, the, 304

life history of, 305

parasites of, 306

stable-fly, 166

Stagmomantis Carolina, 327

Stein, 216 


\section{Index}

Stelidæ, 6, 11

Stelis minuta, I1

Stenopelmatus, 337

Stenoxenidx, 85, 97

Stenoxenus johnsoni, 97

stilet to-flies, 139,140

stilt bugs, The, 309

stinging ants, 39

stingless ants, 39

stink-bugs and their allies, The, 313

typical life history of, 314

stink flies, 222

Stiretrus anchorago, 314

Stomoxys calcitrans, 166

stone-flies, the, 361

Stratiomyia, 129

Stratiomyiid, 126

Stratiomyiidæ, 87, 128, 129

Stylogaster, 154

Summers, H. E., 270

sun-flowers, 114

Surinam toad, 279

Symphyla, 380

Syrphidx, 89, 150

Syrphoidea, Super-family, 89

Syrphus, 265

Syrphus flies, 149, 150

Systoechus oreas, 138

Systrophus, 137

sweeping net, 391

Tabanidæ, 87, 131, 132

Tabanoidea, Super-family, 86

Tabanus americanus, 132

Tabanus atratus Fabr., 132

table of families (of dragon flies), 368

(of Heteroptera), 270

of Mallophaga, 349

Tachina Flies, The, 158

Tachinidæ, 90, 158

Tænia (tape worm), 192

tangle-veined flies, 134

tarantula-killer, 30, 136

tarnished plant bug, 301

Taylor, L. H., 111

Teleas, 314

Telemona monticola, 238

Telenomus, 51

Tenodera sinensis, 327

Tenthredinidæ, 76

Tenthredinoidea, $3,73,76$

Termes flavipes, $355,356,357,359$

lucifugus, 356,359

tubiformans, 356

Termitidæ, 353

Tetramorium cæspitum, 43, 46

Tettigia hieroglyphia, 232

Tettigonidæ, 243

Thalessa atrata, 70

Thalessa lunator, 70
Therevidæ, 88, 139, 140

thick-head flies, 154

thick-thighed metapodius, 304

thick-thighed walking stick, 323

thin-winged bugs, The, 292

third-party bug, 313

Thoreau, 344

thread legged bugs, 294

Thrips, 244, 318 tabaci Lind, 319

Thynnidæ, 31

Thysanoptera, 318

Thysanura, 209

Tibicen pruinosa Say, 22

ticks, the bat, 190

the bird, 188

tineid egg, 50

Tingitidx, 272, 299

Tingitinæ, 299

Tiphia wasps, 31

Tiphiidæ, 31, 33

Tipulas, 95

Tipulidæ, 85, 94, 108

Tipuloidea, Super-family, 84, 85

toad bugs, the 281

toad-shaped bugs, 28,

Tolstoi, 6

Torymus, 57

Tramp Abroad, 41

tree-hoppers, The, 237

Tremex, 70

Tremex columba, 69

Trichacis, 51

Trichodectidæ, 349

Trichoptera, 195

table of families, 197

Trigonalidæ, 33

Triphleps insidiosus Say, 287

trowel, 392

true bees, 4

bugs, 226

bugs, The, 269

dragon-flies, 372

flies, 79

lice, 82,316

locusts, 332

Trypeta fratria Loew, 178

ludens, 178

pomonella, 177

solidaginis, 177

Trypetidx, 53, 91, 177

Trypoxylon, 20, 32

tsetse fly, 81

tussock moth, 34, 64, 66

Typhlocyla vitifex, 244

Twain, Mark, 41

two-striped locust, 333

Uhler, P. R., 24I, 269, 274, 278

umbrella, 393 
Velocipeda, Bergroth, 29t

Vermileo, 126, 127

Vespa, 26, 142

Vespa crabor, 29 cuneata, 29 germanica, 27, 29 maculata, 27, 28

Vespoidea, Superfamily, 3, 25, 33, 49

"vinegar flies," 185

Volucella, 152

walking stick, life history of a common, 323

walking sticks, 323

Walsh, B. D., 31, 32

War and Peace, 6

Wasmann, 42

wasp, digger, life history of, 22 parasitic, life history of, 34

wasps and their allies, the social, 25

wasps, honey, 25

solitary, 30

the solitary, 18

typical life history of, 33

water boatmen, 273

water bugs, the creeping, 280

water bugs, the giant, 278

water net, the, 391

water scorpions, The, 276

water-strider, life history of, 285

water-striders, The, $\mathbf{2 8 3}$

Webster, F. M., 245

Weeks, Archibald C., 366

weeping trees, 244 western crickets, 337

western grasshopper, 138, 332, 333

wheel bug, 295

life history of, 294

Wheeler, William M., 47

white ants, 353

white flies, The, 246

white fly, typical life history, 247

white marked tussock moth, 64

Williamson, $365,368,374$

Williston, S. W., 20, 21, 80, 110, 153, 154

willow slug, The yellow-spotted, 75

window flies, 139

wood-eaters, 69

Woodworth, 301

woolly root louse of the apple, 265

Xiphydriidæ, 69

Xylocopa virginica, 9

Xylocopidæ, 6, 9

Xylocrabro (Crabro) stirpicola, 19

Xylophaga, 69

Xylophagidæ, 126

yellow fever, 81

Yellow Fever Commission, United

States Army, 81

yellow-jackets, smaller, 27, 29

yellow-spotted willow slug, 75

Zabriskie, Rev. J. L., 8

Zaitha, 279

Zambesi Mission Record, 360 
THE COUNTRY INTE PRESS

GARDEN CITY, \&. $\mathbf{y}$. 










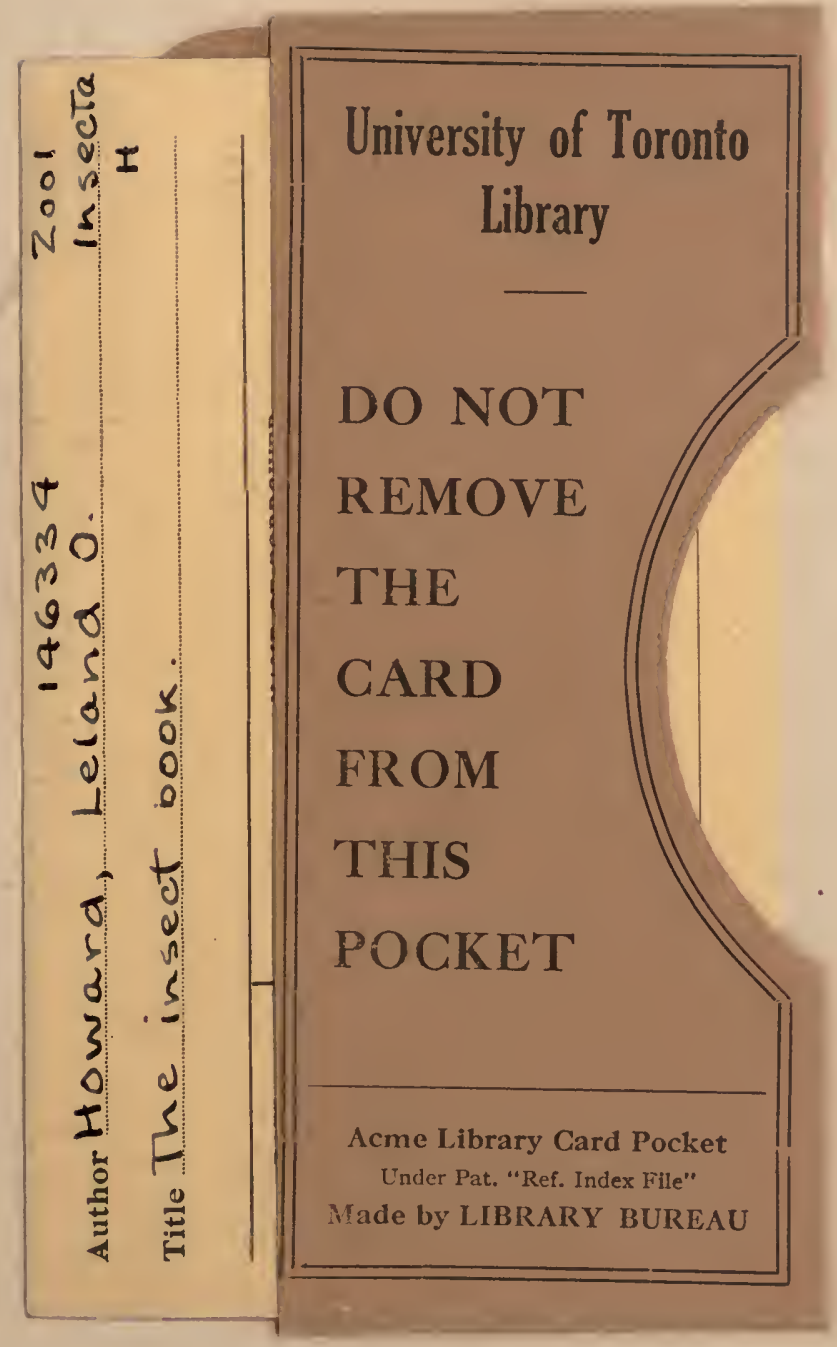


